Florida International University FIU Digital Commons

3-19-2018

\title{
Pennsylvania's Loyalists and Disaffected in the Age of Revolution: Defining the Terrain of Reintegration, 1765-1800
}

Rene J. Silva

Florida International University, rsilv008@fiu.edu

DOI: $10.25148 /$ etd.FIDC006568

Follow this and additional works at: https:// digitalcommons.fiu.edu/etd

Part of the Legal Commons, Public History Commons, and the United States History Commons

\section{Recommended Citation}

Silva, Rene J., "Pennsylvania's Loyalists and Disaffected in the Age of Revolution: Defining the Terrain of Reintegration, 1765-1800" (2018). FIU Electronic Theses and Dissertations. 3670.

https://digitalcommons.fiu.edu/etd/3670 


\section{FLORIDA INTERNATIONAL UNIVERSITY}

Miami, Florida

\section{PENNSYLVANIA'S LOYALISTS AND DISAFFECTED IN THE AGE OF}

REVOLUTION: DEFINING THE TERRAIN OF REINTEGRATION, 1765-1800

A dissertation submitted in partial fulfillment of

the requirements for the degree of

DOCTOR OF PHILOSOPHY

in

HISTORY

by

René José Silva 
To: Dean John F. Stack, Jr.

Steven J. Green School of International and Public Affairs

This dissertation, written by René José Silva, and entitled Pennsylvania's Loyalists and Disaffected in the Age of Revolution: Defining the Terrain of Reintegration, 1765-1800, having been approved in respect to style and intellectual content, is referred to you for judgment.

We have read this dissertation and recommend that it be approved.

$\begin{array}{r}\hline \text { Jenna Gibbs } \\ \hline \text { Victor Uribe } \\ \hline \text { Clement Fatovic } \\ \hline \text { Kirsten Wood, Major Professor }\end{array}$

Date of Defense: March 19, 2018

The dissertation of René José Silva is approved.

Dean John F. Stack, Jr. Steven J. Green School of International and Public Affairs

Andrés G. Gil Vice President for Research and Economic Development and Dean of the University Graduate School

Florida International University, 2018 
(C) Copyright 2018 by René José Silva

All rights reserved. 


\section{DEDICATION}

To Maria 


\section{ACKNOWLEDGMENTS}

I would like to thank my dissertation committee chairperson, Kirsten Wood, for her dedicated guidance. Her clear insights and rigorous scholarship greatly improved the work. Likewise, I would like to thank committee members Jenna Gibbs, Victor Uribe, and Clement Fatovic for their ongoing encouragement and invaluable input which notably enhanced the study. My gratitude to John Stack for his moral support, Micah Oelze for his analysis, and Brett Palfreyman for his aid in the early research. The excellent History faculty at Florida International University whom I had the good fortune to engage during my graduate career deserves recognition for helping to forge this historian, as do the graduate students with whom I shared robust historical debate.

For their outstanding assistance in the investigative stages of this inquiry, I would like to thank James Green and Cornelia King at the Library Company of Philadelphia; David Haugaard, Steve Smith, Sarah Heim, and Wilhelm Echevarria at the Historical Society of Pennsylvania; and Meg McSweeney, Kathie Ludwig, and Brian Graziano at the David Library of the American Revolution. My appreciation to David Maxey for his suggestions in framing several chapters. I am especially grateful to Francisco José Hernández for prompting me to pursue my doctoral degree and making it possible to do so early in the process, and to David and Kathy Naughton whose hospitality in Philadelphia made my research truly enjoyable.

The David Library of the American Revolution Fellowship, the Andrew W. Mellon Foundation Fellowship at the Library Company of Philadelphia and the Historical Society of Pennsylvania, and the Florida International University Dissertation Year Fellowship provided funding and made possible the research for this project. Thank you. 


\begin{abstract}
OF THE DISSERTATION
PENNSYLVANIA'S LOYALISTS AND DISAFFECTED IN THE AGE OF REVOLUTION: DEFINING THE TERRAIN OF REINTEGRATION, 1765-1800
\end{abstract}

\author{
by \\ René José Silva \\ Florida International University, 2018 \\ Miami, Florida \\ Professor Kirsten Wood, Major Professor
}

This study examines the reintegration of loyalists and disaffected residents in Pennsylvania who opposed the American Revolution from the Stamp Act crisis in 1765 through the Age of Federalism in 1790s. The inquiry argues that postwar loyalist reintegration in Pennsylvania succeeded because of the attitudes, behavior, actions and contributions of both disaffected residents and patriot citizens. The focus is chiefly on the legal battle over citizenship, especially the responses of the disaffected to patriot legislative measures such as treason, oaths of allegiance, attainders, confiscation, and militia service laws that revolutionaries employed to sanction dissent in the state.

Loyalists and the disaffected contributed to their own successful reintegration in three ways. First, the departure of loyalist militants at the British evacuation of occupied Philadelphia in June 1778 and later substantially lessened internal political tensions associated with the rebellion. Second, the overwhelming majority of the disaffected who stayed in Pennsylvania adopted non-threatening attitudes and behaviors towards republican rule. And third, the disaffected who remained ultimately chose to embrace the new republican form of government they had earlier resisted. 
Patriots contributed to the successful reintegration of the disaffected chiefly through the outcome of the factional struggle for internal political supremacy between revolutionary radicals and moderates. Pennsylvania radicals used the rule of law to deny citizenship to opponents of the Revolution and pushed for their permanent exclusion from the body politic. Moderates favored a reincorporation of those who had not supported the rebellion, utilizing the law to foster inclusion. Moderate electoral victories in the decade of the 1780s led to solid majorities in the state assembly that rescinded all repressive measures against former opponents, in particular the 1789 repeal of the Test Act of 1777.

The analysis stresses the activities of loyalists and the disaffected, exploring elite loyalist militants such as Joseph Galloway and the sons of Chief Justice William Allen; ordinary loyalist militants like John Connolly and the Rankin brothers of York County; Quaker pacifists such as the Pemberton siblings; loyalists whom patriots perceived as defiant, such as the Doan guerrilla gang and British collaborators Abraham Carlisle and John Roberts; and the Penn family proprietors. Each of these protagonists epitomized a particular strain of loyalism or disaffection in Pennsylvania, ranging from armed resistance to pacifism. Reintegration experiences and outcomes are therefore assessed in relation to these Pennsylvanians' conduct before, during, and after the Revolutionary War. 
TABLE OF CONTENTS

CHAPTER $\quad$ PAGE

INTRODUCTION 1

CHAPTER 1 - FROM REVOLUTION TO REINTEGRATION:

PENNSYLVANIA'S RESPONSE TO LOYALISM AND DISAFFECTION 23

THE COLONIAL ORDER UNDER DURESS

(April 1775 - November 1776) 26

QUELLING DISAFFECTION: THE RADICAL VISION

(November 1776 - June 1778) 44

LOYALIST CHOICES \& THE RADICAL ZENITH

(June 1778 - November 1781) 65

REINTEGRATION \& MODERATE ASCENDANCY

(November 1781 - April 1794) 81

CONCLUSION 95

CHAPTER 2 - REINTEGRATION \& DEPARTURE OF

THE ELITE LOYALIST MILITANTS 98

ELITE ANTECEDENTS

\& THE RIGHTS OF ENGLISHMEN (to 1765) 102

COLONIAL RESISTANCE, LOYALIST MILITANCY

\& INDEPENDENCE (1765-76) 110

IN THE SERVICE OF THE KING (1776-1783) 136

THE CHALLENGE OF POSTWAR REINTEGRATION (1783-1838) 156

CONCLUSION 173

CHAPTER 3 - REINTEGRATION \& DEPARTURE OF

THE ORDINARY LOYALIST MILITANTS

175

JOHN CONNOLLY \& MILITANCY ON

PENNSYLVANIA'S WESTERN FRONTIER

PENNAMITES \& LOYALIST MILITANCY ON

THE NORTHEASTERN FRONTIER 195

MILITANT LOYALIST LEADERSHIP IN THE COUNTRYSIDE:

THE RANKINS

LOYALIST MILITANCY IN AND AROUND PHILADELPHIA 224

CONCLUSION

CHAPTER 4 - REFUSING THE OATH:

REINTEGRATION \& THE QUAKER PACIFISTS 245

QUAKER PACIFISM, RELIGIOUS REFORM

\& THE PEMBERTON BROTHERS 248

COLONIAL POLITICS, THE IMPERIAL CRISIS
$\&$ THE EARLY REVOLUTION 
VIRGINIA EXILE \& THE RETURN TO PHILADELPHIA 276

PACIFIST CONVICTION \& REINTEGRATION DURING THE WAR 286

POSTWAR REINTEGRATION, NONJURORS

\& THE TEST ACT REPEAL

REINTEGRATION AFTER THE TEST ACT REPEAL 320

CONCLUSION

CHAPTER 5 - LOYALIST DEFIANCE, THE RULE OF LAW

\& REINTEGRATION

THE EXECUTION OF QUAKERS

ABRAHAM CARLISLE \& JOHN ROBERTS

THE DOAN GUERRILLA GANG

ARMED HOSTILITY \& THE LONG ARM OF

REVOLUTIONARY LAW

356

POSTWAR REINTEGRATION \&

THE CARLISLE/ROBERTS LEGACY

CHAPTER 6 - THE PENNS, REVOLUTIONARY TRANSFORMATION

WILLIAM PENN'S HEIRS \& THE PROPRIETARY REGIME 385

THE ARREST \& EXILE OF JOHN PENN SR.

PROPRIETARY DIVESTMENT: DEFINITIVE END OF AN ERA 399

THE PENNS' QUEST FOR COMPENSATION

406

REINTEGRATIVE TRAJECTORIES

417

CONCLUSION

CLOSING SCENES AND CONCLUSIONS 


\section{PENNSYLVANIA'S LOYALISTS AND DISAFFECTED IN THE AGE OF REVOLUTION: DEFINING THE TERRAIN OF REINTEGRATION, 1765-1800}

\section{INTRODUCTION}

"PHILADELPHIA, July 4 [1778], On Thursday the $18^{\text {th }}$ ult. the British army, under the command of Sir Henry Clinton, compleated their evacuation of this city, after having possession of it about nine months. The indiscriminate destruction of whig and tory property to be seen in the neighbourhood of the city strongly mark the character of those British savages. They have increased the resentment of their old enemies and turned the hearts of their friends: Many who welcomed them into the city and who were deceived and seduced by their specious proclamations, followed them with the bitterest execrations. A few citizens, whose conduct and crimes gave them no reason to hope for mercy from their injured countrymen, went off with the British army."1

In such terms did patriot and printer John Dunlap portray conditions in his native city in the first locally published edition of his newspaper after returning from temporary exile at Lancaster following the British occupation of Philadelphia. Pennsylvania’s Supreme Executive Council and General Assembly, the leading manifestations of insurrectionist power in the province, joined Dunlap in his homecoming from Lancaster. Returning from York, the Continental Congress reassembled at Independence Hall. Revolutionaries had regained control. Fear of rebel retribution induced several thousand loyalists who backed the British Crown to depart with General Clinton's forces. ${ }^{2}$ Unbeknownst to all sides, patriots would never again relinquish their hold over Pennsylvania. The British retreat set in motion the first phase of a protracted and complex process of legal, political and social reintegration for loyalists and disaffected residents who stayed behind or later returned that extended into the next century.

\footnotetext{
${ }^{1}$ The Pennsylvania Packet, Or the General Advertiser, Saturday, July 4, 1778, DLAR.

${ }^{2}$ Estimates of the number of loyalist evacuees from Philadelphia in June 1778 ranged from three to five thousand from a probable city population of about 30,000. Figures are discussed at length in Chapter 1.
} 
This inquiry examines loyalism and disaffection in William Penn's royally chartered colony during the era of the American Revolution from the Stamp Act Crisis in 1765 through the Age of Federalism in the 1790s, with a special emphasis on loyalist reintegration. The crux of the investigation covers the decade-and-a-half from 1775 to 1790. The revolutionary and reintegrative processes are covered from the perspective of both sides of the conflict. In terms of opposition to the Revolution, the study explores the significance of militant loyalists, disaffected pacifists, and post-occupation armed resistance to republican rule. On the reverse side, it examines both vengeful and accommodating rebel reactions to ongoing dissent, as well as the revolutionary policies and developments that refashioned Pennsylvania's future.

For our purposes, pro-British Americans who favored royal rule and opposed republican government are considered loyalists. Those loyalists who were willing to bear arms and fight for the king or serve in the British civil administration during the occupation of Philadelphia are further regarded as militants. Pennsylvanians who disliked revolutionary rule but did not necessarily support the British are defined as disaffected rather than loyalist. Hence, all loyalists are disaffected but not all the disaffected are necessarily loyalists. ${ }^{3}$ Since British defeat and George III's renunciation of sovereignty over the rebellious colonies made the notion of loyalism anachronistic, patriots in the postwar era reclassified ex-loyalists and disaffected residents who stayed in Pennsylvania as nonjurors - that is, unwilling to swear allegiance to the state. I strive to apply the most

\footnotetext{
${ }^{3}$ While contemporaries used the term "disaffected" quite frequently, patriots called those loyal to the British during the war "tories," not loyalists. The latter appellation became more common as the war neared its end and the British began to consider what to do with those who had remained loyal.
} 
precise meaning for the terms loyalist, militant, disaffected, and nonjuror at each point in the chronology, but all converge at the juncture of dissatisfaction with the Revolution.

The essence of this study revolves around the concept of legal and political reintegration, defined as the reacquisition of the full rights of citizenship in the new republic lost during the revolutionary turmoil. Reintegration as employed here concerns possession of the full set of rights available under the system of government in force in Pennsylvania at a given moment. Pre-independence colonials were English subjects and not republican citizens. At that time, later revolutionaries and the disaffected together possessed the same inherent rights of Englishmen under the British Constitution. Both had their rights transformed under republican rule. But one group had their new rights affirmed while the other lost the rights they once had. The idea of reintegration addresses this disparity in treatment, not the transition from British subjecthood to republican citizenship. Although reintegration takes into account important social, economic, religious and cultural features which are intermittently woven into the analysis where applicable, it is the legal and political aspects of reintegration that measure the success or failure of the process here, for it is in that terrain where the critical battles over rights and citizenship took place. Reintegration is understood as successful if and when those legally marginalized by the Revolution recovered their rights as Pennsylvania citizens. It is deemed a failure when legal deterrents such as retaliatory executions, permanent exile, banishment, disenfranchisement, quarantine within exclusionary legal categories and the 
like prohibited loyalists, the disaffected or nonjurors from exercising the basic rights they once enjoyed before the dispute with Great Britain. ${ }^{4}$

Also central to the analysis is the concept of the rule of law, a term laden with multiple meanings often defined by scholarly discipline or legal context. In this study, the rule of law denotes the supremacy of legal principles and constitutional rights sanctioned by the Pennsylvania Constitution of 1776 and later revolutionary acts passed by the state legislature, set against the potentially arbitrary behavior of patriot factions, officials, extralegal forces or individuals prone to violate, misapply, or ignore established law. Here, the rule of law signifies an equal and evenhanded application of revolutionary legal measures and the legal system to all of the province's inhabitants, especially on matters of allegiance. Patriot legal consistency - or lack thereof - is thus measured in relation to the process of reintegration.

Disaffected or nonjuror residents who remained in or returned to the state presented patriots with a grave and potentially dangerous social and political dilemma. That constituency could become a perennially disenfranchised underclass whose discontent would erode faith in the republican experiment. Revolutionaries had to choose between reassimilation or accommodation of former opponents, on the one hand, and ostracism or expulsion on the other.

The problem of the "inimical" or "obnoxious" who either favored the British monarchy or opposed patriot rule, and yet chose to stay behind, was not unique to Pennsylvania. It surfaced each time the British ceded occupied territory. In addition to the Philadelphia withdrawal of June 1778, royal army evacuations took place at Boston in

\footnotetext{
${ }^{4}$ Failed reintegration includes the departed who never sought to reintegrate because the root cause of departure was a fear of patriot reprisals that generated a subsequent absence of an attempt to reintegrate.
} 
March 1776, Newport in October 1779, Wilmington, North Carolina in November 1781, Savannah in July 1782, Charleston in December 1782, and New York in November 1783. At every place and time, the debate over the future of the loyalists and disaffected who remained grew heated. Less than a month before the final British evacuation from New York City - the last imperial stronghold in the colonies - loyal Maryland exile Henry Addison tensely awaited developments. Upon reading published resolutions impugning the right of the disaffected to stay or return, he concluded that "there can be no Peace here for half a century to come." The conundrum of reintegration was arguably the biggest - and certainly the most urgent - challenge that confronted the infant republic at the end of the war. The nation's viability seemed to depend on a palatable resolution of what to do with the sizeable number of disgruntled residents in the new republic's midst who could conceivably develop into an enemy fifth column. While the conclusive peace of 1783 forced all thirteen rebellious colonies to conjointly face the problem of disaffection once and for all, each of the regions that British forces captured and abandoned during the war had already tackled the issue on their own as the conflict marched on.

In Pennsylvania, the process of reintegration began in the summer of 1778 and transpired over three phases. From the British evacuation of 1778 to the war's end, a first phase under radical supremacy favored ostracism in legal, political, social, and economic terms. Legally, disaffection led to the loss of core citizen rights and disenfranchisement. The disaffected could not vote or hold office. Socially, the stigma of infidelity to the

\footnotetext{
${ }^{5}$ Henry Addison to Jonathan Boucher, October 29, 1783, Henry Addison Papers, Clements Library, cited in Judith Van Buskirk, Generous Enemies: Patriots and Loyalists in Revolutionary New York (Philadelphia: University of Pennsylvania Press, 2002), 172.
} 
Revolution often brought the larger community's repudiation and could result in extralegal raptures of violence. Economically, disaffection gave rise to financial penalties for noncompliance with patriot directives on issues such as militia service, as well as the forfeiture of property and personal goods, and in some cases prohibitions on employment in fields like teaching.

The arrival of peace in 1783 inaugurated a second stage of reintegration under patriot moderates. With the reclassification of ex-loyalists and disaffected residents as nonjurors, the new era moved retribution largely into the legal and political spheres. Disenfranchisement and curtailed rights continued and nonjurors still could not vote or be elected to office. But following an initial frenzy in both the press and the streets, set off by treaty terms recommending a restitution of seized loyalist property totally ignored in all thirteen states, social unrest over nonjuror status pointedly died down. Moderate officials authorized no new property confiscations and did not press against pacifist rebuffs of militia service or ban nonjurors the exercise of particular professions. Under moderates, republican society gradually began to reincorporate the formerly disaffected. A decisive moderate majority in the assembly finally repealed the Test Act in 1789, launching the third and closing phase of reintegration. The revocation eliminated all test oaths and restored nonjurors to full citizenship. No legal distinctions remained to detach the newly enfranchised from fellow Pennsylvanians. The present study examines the legal, political, social, economic, religious and ethnic aspects of reintegration, when applicable, in all three historical phases. The spotlight, however, is on the legal battle over the citizenship of former loyalists, the ex-disaffected, and nonjurors as the final arbiter of the reintegration process. 
The conflict over the legal recovery of core rights necessarily encompasses the topic of republican citizenship, for those rights were a critical ingredient of citizenship in the early republic. In Pennsylvania as elsewhere in the rebellious colonies, full citizenship was largely the purview of males of European descent and legally excluded women and people of color. The language of contemporary legislation tied to the privileges and obligations of citizenship - such as militia service or oaths of allegiance - expressly targeted "white males" only. For example, colonial assembly measures only six months after the outbreak of armed hostilities at Lexington specifically urged "all male white persons within this province" to join the Association for armed defense, while the original Test Act put race/gender specifications directly into its title. ${ }^{6}$ Accordingly, this study conforms to the framework established by Pennsylvania's revolutionary authorities and confines analysis of the expansion or restriction of republican citizenship to that domain.

Loyalists and the disaffected manifested their opposition to the Revolution in Pennsylvania in a variety of ways. Scores took up arms for the British, many became what we would today call conscientious objectors, while others threw in the towel, swore allegiance to the new state, and joined the rebels. Patriots too exhibited a range of reactions to the problem of loyalism and disaffection. At times rebels marginalized or expelled suspected enemies. On other occasions they tried to accommodate dissent. In select instances, such as the application of the death penalty to a pair of Quakers who

\footnotetext{
${ }^{6}$ See James T. Mitchell and Henry Flanders, eds., Statutes At Large of Pennsylvania from 1682 to 1801 (hereafter Statutes At Large of Pennsylvania), vol. 8, "Resolves of Assembly, Agreed to November 8, 1775," Appendix XXVIII, 492-493; ibid., vol. 9, "An Act Obliging All White Male Inhabitants of This State to Give Assurances of Allegiance to the Same and for Other Purposes Therein Mentioned," June 13, 1777, Chapter 756, 110.
} 
collaborated with British officials, they exerted the full ferocity of revolutionary retribution to chasten the allegedly blameworthy. The process of reintegration was shaped by what happened at both ends of this dually driven dynamic. Correspondingly, the present analysis argues broadly that postwar loyalist reintegration in Pennsylvania succeeded because of the attitudes, behavior, actions and contributions of both disaffected residents and patriot citizens.

Loyalists and the disaffected contributed to the successful reintegration of many of their own number in three ways. First, the departure of most militant loyalists at the British evacuation of Philadelphia in mid-1778 substantially lessened internal political tensions along the acrimonious loyalist-patriot axis. The subsequent absence of most militant opposition refocused domestic politics on the contrasts between competing patriot factions rather than the need to suppress threats to the Revolution. Second, the overwhelming majority of the disaffected who stayed in Pennsylvania adopted nonthreatening attitudes and behaviors towards republican rule, despite their initial disconformity with its direction. In the postwar era, Pennsylvanians came to understand that legally disenfranchised former loyalists and disaffected residents rebranded as nonjurors were not much different from themselves and deserved an opportunity to reintegrate into society as full citizens. Third, the disaffected who remained ultimately chose to embrace the new republican form of government they had earlier resisted. Some acquiesced during the war, others did so after the peace of 1783 . Their collective willingness to live and work within a republican framework created a climate conducive to a reincorporation of actual or suspected former adversaries. 
For their part, patriots contributed to the successful reintegration of the disaffected chiefly through the outcome of the factional struggle for internal political supremacy. Intense divisions between radical and moderate revolutionaries arose over the state Constitution of 1776 . The radical faction dominated the constitutional convention which not only proposed and approved the new constitution on September 28, 1776 but months earlier successfully steered Pennsylvania onto the path of independence. The moderate faction objected to the new fundamental charter of the land for a variety of reasons. They felt the constitution was illegitimate because the citizenry had been denied the chance to vote for ratification. They feared the virtual omnipotence of the unicameral assembly as there was no upper house and neither the executive branch nor the judiciary had any sort of veto power over acts passed by the legislature. They contested the requirement that a citizen had to subscribe an oath to the new constitution - which they opposed - in order to cast a vote in elections or run for office. And not least, the affluent among moderates viewed the lower and middling radical upstarts with disdain. ${ }^{7}$ Because radicals supported the Constitution of 1776, they became known as Constitutionalists, while the moderates' opposition converted them into Anti-Constitutionalists. Further complicating political identities, radicals formed a Whig Society and then a Constitutionalist Society, while moderates founded a Republican Society. These activities led to additional designations as radical Whigs and moderate Republicans. A person's initial views on the new state constitution could also evolve and sometimes completely reversed. My demarcation of factional lines relies mostly on political groupings in the late 1770s, after the British evacuation of 1778 had cleared the road for radical ascendancy. It is important to

\footnotetext{
${ }^{7}$ Robert L. Brunhouse, The Counter-Revolution in Pennsylvania, 1776-1790 (New York: Octagon Books, 1971; reprint of Pennsylvania Historical Commission's 1942 edition), 15-16.
} 
emphasize that moderates as much as radicals remained committed to republican rule after the Continental Congress passed the Declaration of Independence. Pennsylvania's revolutionary moderates had no monarchist proclivities.

The deep factional divisions over the Constitution of 1776 further manifested themselves in contrary approaches to the treatment of loyalists, the disaffected and nonjurors, generally along an exclusionary-inclusionary fault line constructed on the basis of allegiance. After passage of the 1777 Test Act, radical Constitutionalists or Whigs denied the rights of citizenship to those who did not swear allegiance to the Revolution, demanding their permanent exclusion from the body politic. AntiConstitutionalist or Republican moderates believed all Pennsylvanians, except those convicted of treason, had a right to citizenship regardless of wartime allegiance. When radicals dominated provincial politics, they used the state's legal apparatus to isolate and penalize the disaffected. When moderates controlled state government, they used the legal system to try to reestablish the rights of the disaffected. Consistent moderate wins at the polls in the 1780s culminated in an interpretation and application of the law in which the assembly repealed all tests of allegiance in 1789 , restoring the rights of previously marginalized citizens and promulgating their full legal reintegration. ${ }^{8}$

\footnotetext{
${ }^{8}$ The two designations with the greatest potential for misinterpretation in this study are "radical" and "Republican." Radicals here are not Robespierre Jacobins intent on guillotining all opposition. They are simply advocates of the 1776 Pennsylvania Constitution. While the small-r "republican" refers to a political philosophy based on popular sovereignty, Pennsylvania's "Republicans" are the moderates who opposed radical "Constitutionalists" or "Whigs" during the revolutionary and postwar eras. They should not be confused with the Jeffersonian Republicans or Democratic-Republicans of the forthcoming Federalist age and early nineteenth century. For these, see Lance Banning, The Jeffersonian Persuasion: Evolution of a Party Ideology (Ithaca: Cornell University Press, 1978); Peter S. Onuf \& Leonard J. Sadosky, Jeffersonian America (Malden, MA: Blackwell Publishers, 2002); Eugene Perry Link, The Democratic-Republican Societies, 1790-1800 (New York: Octagon Books, 1973); and Stanley Elkins \& Eric McKitrick, The Age of Federalism (New York: Oxford University Press, 1993), 303-374, 451-460, 549-580, 750-754.
} 
It is difficult to gauge just how many loyalists supported the British during the Revolution. The chief problem lies in defining just who qualifies as a "loyalist." A review of contemporary sources quickly establishes a major division between those proactively committed to the king's cause and those who reactively opposed rebel rule. The two could be one and the same, but often were not. Underlying motives and intentions likewise created distinctions. While loyalist militants willingly picked up the sword to defend the monarchy, pacifists who believed in the God-ordained sanctity of established royal government and opposed the insurgency nonetheless refused to bear arms for the king. Yet radical revolutionaries considered both groups equally loyal to the British.

Chronology also played a role. A decade of political resistance preceded the outbreak of armed hostilities at Lexington in April 1775. During this prelude known as the imperial crisis, virtually all Pennsylvania colonials contested what they perceived as the arbitrary and unjust impositions of Parliament. Provincials considered the few who defended that body's right to legislate for the colonies as tories. Yet in the early years of the Revolution, rebels expanded this label to apply to those who had actively resisted parliamentary intrusions yet would not countenance a final separation from the mother country. The meaning of the nomenclature was therefore subject to a revolutionary timeline. Just how one became a loyalist can also influence classification. Throughout the war, Pennsylvania's radical government targeted suspected loyalists by name with a series of punitive measures. Many of the accused remained in the state and surrendered for trial as ordered, resulting in either discharge or acquittal. In other cases, those who were truly loyal kept their feelings to themselves in private letters, diaries or journals, or 
acted on behalf of the British but were never discovered. All of this tends to muddle a precise calculation of "loyalist" rolls.

In response, the present study draws the boundaries broadly while attending to ambiguities among the purportedly loyal, as well as distinctions within those conditions. Preference in the first instance is for a broad inclusivity. Besides those who clearly supported the Crown such as armed militants or civil officials during the occupation, anyone who self-identified as a loyalist or who patriots suspected of pro-British tendencies is also considered disaffected, as are those individuals who got into trouble with state officials for opposing revolutionary policies. Loyalism was therefore the product of both self-imposed and externally driven factors. Timing or results do not impact categorization. For example, a person who supported colonial resistance during the imperial crisis and early Revolution in Pennsylvania but dove into obscurity for political reasons after the Declaration of Independence is included. In the same way, individuals tallied in the overall tabulation remain on record regardless of discharge, acquittal or conviction in patriot adjudicatory venues. To date, research within these parameters has unearthed 1,858 Pennsylvanians who supported the British or encountered problems with the patriots, a number that continues to grow as new sources are scoured. Since most people hid disaffection to rebel authority in the absence of overt British support, identifiable loyalists were usually an artefact of official revolutionary sanctions or suspicions - which takes us to the issue of distinctions. A division is drawn here between those who were undeniably faithful in their adherence to king and empire and those who disliked republican rule irrespective of their views towards royal governance. The truly devoted to Britain are considered loyalists, the mere malcontents as disaffected. 
While significant for the analysis, this distinction did not matter in the eyes of the radicals who held the reins of power in Pennsylvania into the early 1780s, for they considered equally at fault everyone who did not stand openly on the side of the Revolution. On occasion, I use the term tory as a synonym for diehard loyalists, especially when stressed by contemporary sources. The study strives to sustain the loyalist/disaffected dichotomy for the war years, but all categories are lumped together in the conflict's reintegrative aftermath when revolutionaries legally referred to the disenfranchised as nonjurors.

With these definitions in mind, Paul H. Smith's oft-cited computation of loyalist numbers during the American Revolution merits a look. By examining the known quantity of men who had served in the king's Provincial Service from "a remarkably complete record" in surviving British manuscripts, surveying the household patterns of American loyalist exiles in Canada to reckon extended families, and extrapolating the proportion of recruits in provincial regiments as a percentage of all loyalists in the general white population from evidence in Lorenzo Sabine's compilation of loyalist biographies and Parliament's Royal Claims Commission, Smith concluded that "loyalists comprised about 16 per cent $(513,000$ out of $3,210,000)$ of the total population, or about 19.8 per cent of white Americans. ${ }^{\prime 9}$ When applied to Pennsylvania, Smith's calculations

\footnotetext{
${ }^{9}$ Paul H. Smith, "The American Loyalists: Notes on Their Organization and Numerical Strength," The William and Mary Quarterly, Third Series, Vol. 25, No. 2 (April, 1968), 262, 269. Smith provides details and tables for all of his calculations and does an excellent job of explaining his methodology, including the choices he made along the way regarding the inclusion-exclusion and acceptance-rejection of certain data. Lorenzo Sabine, Biographical Sketches of Loyalists of the American Revolution, with an Historical Essay, 2 volumes (Boston: Little, Brown 1864; Kessinger Legacy Reprints). Loyalist memorials to the Royal Claims Commission and supporting documentation on losses such as property deeds are gathered in bundles in the British Public Record Office (PRO) and designated with an Audit Office (AO) prefix as either AO12 or AO13. Gregory Palmer of the British Library, who updated Sabine's information from sources that $19^{\text {th }}$ century historian did not have access to in his time, provides an excellent explanation of the Royal Claims Commission in his Introduction to the similarly titled Biographical Sketches of Loyalists of the American Revolution (Westport, CT: Meckler Publishing, 1984), vii-xxxvi.
} 
yield a hypothetical estimate of 59,400 loyalists in the state, or $19.8 \%$ of a provincial white population of $300,000 .{ }^{10}$ Using Royal Claims Commission data, Wallace Brown ranked the proportional total of Pennsylvania loyalists fifth among the thirteen colonies. It is likely that disaffection was even greater in Pennsylvania, however, because the large Quaker presence in the colony tended to stay rather than leave, more so than the loyally inclined elsewhere, resulting in fewer compensation claims before the parliamentary commission. ${ }^{11}$ Whatever the actual figure, disaffected Pennsylvanians were no doubt substantial in number.

Although loyalism has received ample treatment in the historical literature of the American Revolution, the scholarship on loyalist reintegration is relatively recent. The middle third of the twentieth century saw explorations on the treatment of Connecticut, New York and Massachusetts loyalists in the aftermath of rebellion and the postwar effects of anti-loyalist property confiscations in Georgia and Massachusetts. ${ }^{12}$ In addition,

\footnotetext{
${ }^{10}$ For Pennsylvania population estimates at the onset of revolution, see Governor John Penn Sr. to the Earl of Dartmouth, "Answers to the Heads of Enquiry on the Condition of the Province," January 30, 1775, Samuel Hazard, ed., Pennsylvania Archives. Selected and Arranged from Original Documents in the Office of the Secretary of the Commonwealth, Conformably to Acts of the General Assembly, February 15, 1851, \& March 1, 1852 (Philadelphia: Joseph Severns \& Co., 1853), First Series, vol. 4, 597 (hereafter Pennsylvania Archives). Governor Penn estimated 300,000 white inhabitants and 2,000 blacks.

${ }^{11}$ For relative compensation claim levels among the states, see Wallace Brown, The King's Friends: The Composition and Motives of the American Loyalist Claims (Providence: Brown University Press, 1965). Brown calculated that Pennsylvanians submitted 206 of the 2,908 loyalist claims he studied $-7.1 \%$ of all claims, ranking fifth among the thirteen colonies. However, New Yorkers presented 1,106 claims, by far and away the largest number. If New York is subtracted from the overall total, Pennsylvanians then represent $11.4 \%$ of the remaining twelve colonies. See Brown's Appendix: Statistical Tables, 289.

${ }^{12}$ Oscar Zeichner, "The Rehabilitation of the Loyalists in Connecticut," The New England Quarterly, vol. 11, no. 2 (June, 1938), 308-330; Oscar Zeichner, "The Loyalist Problem in New York After the Revolution," New York History, vol. 21, no. 3, (July 1940), 284-302; David E. Maas, "The Massachusetts Loyalists and the Problem of Amnesty, 1775-1790," Loyalists and Community in North America, Robert M. Calhoon, Timothy M. Barnes \& George A. Rawlyk, eds. (Westport, CT: Greenwood Press, 1994), 6574; Robert S. Lambert, "The Confiscation of Loyalist Property in Georgia, 1782-1786," The William and Mary Quarterly, Third Series, vol. 20, no. 1 (January, 1963), 80-94; Richard Brown, "The Disposition of
} 
some modern scholars have tentatively probed reintegration in the closing chapters of studies focused on loyalists during the war or explored postwar expatriation. ${ }^{13}$

More comprehensive and targeted inquiries have appeared in the last decade. Aaron Coleman's 2008 dissertation “Loyalists in War, Americans in Peace: The Reintegration of the Loyalists, 1775-1800" looks at reintegration from a broad-based patriot perspective through ideologies of federalism and republicanism, anti-loyalist legislation and jurisprudence, citizenship, rights, allegiance, and networks of families and friends. Coleman argues popular sovereignty drove a national process of reintegration. While popular will advocated legal persecution of loyalists during the war, reintegration efforts succeeded in the postwar era because revolutionaries were able to rein in and reconfigure that same ideology to reincorporate former opponents as new citizens. ${ }^{14}$ Brett Palfreyman's outstanding 2014 dissertation "Peace Process: The Reintegration of the Loyalists in Post-Revolutionary America" tackles the problem of reintegration by examining questions of citizenship through state politics, the law, and legal instruments such as petitions and attainders, as well as culture and memory. Though also national in scope, Palfreyman keys in on specific states for topical in-depth analysis. He uses South Carolina and Virginia to examine the role of petitions, and New York and Pennsylvania

Loyalists' Estates in Suffolk County, Massachusetts," The William and Mary Quarterly, Third Series, vol. 21, no. 4 (October, 1964), 534-550.

${ }^{13}$ Ruma Chopra, Unnatural Rebellion: Loyalists in New York City during the Revolution (Charlottesville: University of Virginia Press, 2011); Van Buskirk, Generous Enemies: Patriots and Loyalists in Revolutionary New York; Maya Jasanoff, Liberty's Exiles: American Loyalists in the Revolutionary World (New York: Alfred A. Knopf, 2011). Chopra and Van Buskirk's final chapters tentatively explore the loyalist experience in the early stages of the postwar period. Jasanoff's work examines in-depth postwar loyalist migrations to Great Britain, Canada, the Caribbean, and the far corners of the British Empire such as Africa and India.

${ }^{14}$ Aaron N. Coleman, "Loyalists in War, Americans in Peace: The Reintegration of the Loyalists, 17751800, , (Ph.D. Dissertation, University of Kentucky, 2008). 
to provide nationwide models for political reintegration. Palfreyman argues that loyalist reintegration was one of the principal reasons that the American Revolution worked and proved durable, succeeding through a peaceful process of demobilization, compromise, and reconciliation in which the winners effectually accommodated the losers. This settlement involved a patriot adaptability that recognized the benefits of reintegration for the nation, grappled with the postwar pragmatic and procedural difficulties of separating loyalists from neutrals and others who did not necessarily support the Revolution yet did not actively oppose it either, and deferred to the inexorable passage of time and eventual death of the loyalist generation. ${ }^{15}$

Two other studies look at reintegration in narrower though no less constructive regional terms. Rebecca Brannon's 2007 inquiry entitled “Reconciling the Revolution: Resolving Conflict and Rebuilding Community in the Wake of Civil War in South Carolina, 1775-1860" explores reintegration in South Carolina, which she argues was a successful example of reconciliation in the wake of a violent civil war. Brannon posits that South Carolinians achieved reintegration because of official government action, influential and persuasive patriot voices that molded public opinion, and strong bottomup support from the lower and middling orders for a reassimilation of most - not all former loyalists. She examines confiscation and anti-loyalist legislation, the culture of petitioning for forgiveness, legislative clemency, the activism of patriots Aedanus Burke and Christopher Gadsden, and the loyalist legacy in the state well into the antebellum

\footnotetext{
${ }^{15}$ Brett Palfreyman, "Peace Process: The Reintegration of the Loyalists in Post-Revolutionary America," (Ph.D. Dissertation, Binghamton University, 2014).
} 
era. ${ }^{16}$ Before these more recent inquiries, David Maas' dissertation “The Return of the Massachusetts Loyalists" was the lone study for over three decades expansively probing loyalist reintegration. Dating from 1972, Maas concentrates on 233 exiled loyalists from the Bay State who decided to return after the war. He argues that the decision to return "was shaped by, almost predetermined" by loyalists' pre-war activity, whether the exile's experience had been favorable or negative, and the application of anti-loyalist legislation to specific individual cases. Maas finds that ordinary loyalists found their way back to Massachusetts far more easily than high ranking tories of Thomas Hutchinson's old guard who encountered far less rebel sympathy. His study has a strong quantitative bent and is replete with tables and graphs, as per the historiography of his era. He digs deep into demographic explanations - political, ideological, military, economic, occupational, regional, religious and ethnic - for both loyalist and patriot actors. ${ }^{17}$

The present study is also the fifth generation in the subfield of Pennsylvania loyalism, following Wilbur Siebert in 1920, Henry James Young in 1955, John Walter High in 1974, and Anne Ousterhout in 1987. Siebert's The Loyalists of Pennsylvania is a descriptive work introducing the loyalist presence in the colony, including the Upper Ohio, the northeast frontier, and the Indian Tract on Lake Erie. The crux of the study portrays patriot repression against loyalists and neutrals before, during, and after the British invasion and occupation of Philadelphia in 1777-1778, and specific issues such as

\footnotetext{
${ }^{16}$ Rebecca Nathan Brannon, "Reconciling the Revolution: Resolving Conflict and Rebuilding Community in the Wake of Civil War in South Carolina, 1775-1860," (Ph.D. Dissertation, University of Michigan, 2007). Brannon's work has recently been published under the title From Revolution to Reunion: The Reintegration of the South Carolina Loyalists (Columbia, SC: University of South Carolina Press, 2016). My references in this study are limited to her dissertation.

${ }^{17}$ David E. Maas, "The Return of the Massachusetts Loyalists," (Ph.D. Dissertation, University of Wisconsin, 1972). Maas later published a biographical index of the loyalists in his study entitled Divided Hearts: Massachusetts Loyalists 1765-1790 (Society of Colonial Wars, 1980).
} 
the pardon of attainted loyalists, the sale of confiscated loyalist property, and postwar loyalist exiles in Great Britain and Canada. ${ }^{18}$ Young's unpublished dissertation entitled "The Treatment of the Loyalists in Pennsylvania" concentrates on patriot military, economic and political pressures against the "static" loyalists, revolutionary punishment of "dynamic" loyalists, and a closing chapter on the rehabilitation of the disaffected following the war. As the title posits, the focus is on patriot measures against the loyally inclined. ${ }^{19}$ High's similarly unpublished dissertation "The Philadelphia Loyalists, 17631783 " limits analysis to the disaffected in the provincial capital through the war. He is one of relatively few scholars, however, to give an active voice to the loyalists themselves. High examines loyalist identity through ideology and religious attitudes, what compelled them to remain loyal to Britain, and their failure to organize or act vigorously in defense of the Crown which rendered their support for imperial aims negligible. ${ }^{20}$ Ousterhout's A State Divided: Opposition in Pennsylvania to the American Revolution is the best and most extensive account of loyalism in Penn's colony. Covering all regions from the imperial crisis through the end of the war in 1783 , she explores in great detail loyalist types and characteristics, how they expressed dissent, the forces that contributed to their disaffection, and revolutionary responses to their loyalism. Her account ends with the peace of 1783. Ousterhout too succeeds in putting loyalist articulations, rather than patriot treatment, front and center. ${ }^{21}$ The emphasis in these

\footnotetext{
${ }^{18}$ Wilbur Henry Siebert, The Loyalists of Pennsylvania (Columbus, OH: The Ohio State University, 1920).

${ }^{19}$ Henry J. Young, “The Treatment of the Loyalists in Pennsylvania," (Ph.D. Dissertation, Johns Hopkins University, 1955).

${ }^{20}$ John Walter High, Jr., “The Philadelphia Loyalists, 1763-1783,” (Ph.D. Dissertation, Temple University, 1974).
} 
Pennsylvania-centric accounts is generally on loyalists during the war, not the process of reintegration, though Siebert guardedly touches upon the postwar era and Young does dedicate a full chapter to loyalist rehabilitation. The present inquiry therefore fills a historiographical void at the essentially unexplored crossroads of reintegration and Pennsylvania loyalism.

The methodology employed here adds a unique dimension to the above intersection. None of the studies on either Pennsylvania loyalism or national/regional reintegration rely on biographical case studies as the driving force of analysis. The detailed personal explorations of the lives, motives and characters of loyal and disaffected Pennsylvanians themselves, rather than a "big picture" thematic approach from above, lends the present study another distinguishing feature. Given these historiographical and methodological factors, my contribution to the overall historical scholarship is threefold: one, to produce the first study of reintegration in Pennsylvania; second, to place loyalist agency as a centerpiece of the state's reintegration drama; and third, to furnish the first intensively biographical work in both the Pennsylvania loyalist and national/regional reintegration fields. It is the emphasis on the critical choices of particular individuals who did not support the rebellion in determining their own destiny - beyond the actions of the revolutionaries - that sets this work apart.

Accordingly, this inquiry is organized around the respective loyalist/disaffected and patriot contributions to reintegration - in the first instance examining loyally inclined militancy, pacifism and defiance, and in the second rebel vengeance, accommodation, and the demand for permanent republican rule. Chapter one emphasizes patriot actions.

\footnotetext{
${ }^{21}$ Anne M. Ousterhout, A State Divided: Opposition in Pennsylvania to the American Revolution (Westport, CT: Greenwood Press, 1987).
} 
Chapters two through four focus on disaffected attitudes and behaviors, while chapters five and six blend both approaches. The radical vs. moderate factional struggle for political supremacy in Pennsylvania provides a common thread through all chapters.

More specifically, the first chapter argues that the political struggle between revolutionary factions in Pennsylvania set the context and helped determine the fate of the disaffected. It examines the legal measures patriots engaged to combat loyalism and disaffection from 1775 to 1794 , according to radical Constitutionalist and moderate AntiConstitutionalist or Republican models for dealing with opponents of rebellion. The analysis surveys disarmament, treason, test oath, attainder, confiscation and militia laws, dividing the legal revolution against the disaffected into four phases. Radicals brandished the law as an exclusionary mechanism to punish loyalist dissent while moderates in most cases sought inclusion. Chapter two argues that the departure of elite loyalist militants significantly diminished internal political friction and created a climate for a smoother reintegration of the disaffected who stayed, while advancing the overthrow and destruction of proprietary government. The focus is on rival colonial elites based in the provincial capital represented by the sons of William Allen Sr. for the Proprietary party and Joseph Galloway for the Quaker party. The probe shows how colonial enmity faded and interests converged with the approach of revolution, why these pre-war foes wound up on the same side, and what their collaboration meant for the reintegration of the disaffected and the new republic.

Chapter three posits that the substantial number of loyalist militants from the lower and middling echelons of society who went into exile likewise lessened internal political tensions and created a favorable climate for reintegration. Class and regional 
considerations during the Revolution drive the analysis, rather than colonial factionalism and Philadelphia elitism. Protagonists include the Rankin brothers of York County, John Connolly in Cumberland County on the western frontier, Pennamites in Northumberland County whose territorial dispute with Connecticut settlers split the two into loyalist and patriot camps, and a broad swath of "ordinary" loyalist militants including locals that served in the provincial regiments organized by the British. The fourth chapter contends that the pacifist Quakers who stayed and refused to take the oath of allegiance personified the non-threatening behavior and eventual acceptance of republican rule that facilitated the postwar reassimilation of the ex-disaffected turned nonjurors. Scrutiny is centered on members of the Society of Friends banished to Virginia as British invaders approached Philadelphia in 1777 - especially Israel, James and John Pemberton. The Pembertons and their fellow antiwar exiles provide an opportunity to investigate the large contingent of reformist Quakers who opposed all violence and armed turmoil, a singular feature of Pennsylvania's Revolution within the national experience. Quaker refusal to submit to the patriot oath of allegiance for religious reasons and their view that rebellion was unholy because God had ordained established government guide the narrative through the 1789 Test Act repeal and into the early nineteenth century.

Chapter five argues that both radical and moderate patriot factions employed the law to quash perceived existential threats to the Revolution, although perceptions of what constituted such a menace differed significantly. The analysis contrasts the vengeful radical-dominant government that pursued and succeeded in legally executing Quakers Abraham Carlisle and John Roberts following the British evacuation with the joint moderate-radical eradication of the Doan guerrilla gang in the postwar era. Whereas both 
moderates and radicals construed armed opposition as an existential threat, radicals further defined that threat as any collaboration with the British. The chapter tracks the reintegration experiences of surviving family members from the Carlisle, Roberts and Doan clans to show how the advent of moderate government in the 1780s led to greater leniency towards onetime opponents. The sixth and final chapter examines the heirs of Pennsylvania founder William Penn. Patriot radicals used the revolutionary legal order to overthrow the Penn proprietorship in Pennsylvania by first destroying their political authority via the new Constitution of 1776 and then stripping the Penn family of most of their property holdings through the Divestment Act of 1779. Radical treatment of the Penn family was fair and comparatively lenient, however; radicals granted compensation for seized properties and allowed the proprietors to retain portions of the lands known as the Manors or Proprietary Tenths. The account follows the reintegration experience of the Penn male heirs - brothers John Sr. and Richard, and their cousin John Penn Jr. - into the postwar era, exploring questions of national identity tied to allegiance as each weighed the merits or disadvantages of American citizenship vs. British subjecthood.

The reintegration saga in Pennsylvania reaches back into the colonial past and extends well into the republican future. This largely ignored drama yields fruitful insights on royal dominion in America, colonial resistance, rebellion, antirevolutionary dissent, popular sovereignty, and the nature and character of the new republic. We begin our trek with a detailed assessment of how Pennsylvania's revolutionaries countered the challenge that disaffection posed to "the glorious cause - the defense of republican freedom.",22

\footnotetext{
${ }^{22}$ Robert Middlekauff, The Glorious Cause: The American Revolution, 1763-1789 (New York: Oxford University Press, 2005) The phrase is attributed to George Washington, 302; quote is on 602.
} 


\section{CHAPTER 1 \\ FROM REVOLUTION TO REINTEGRATION: \\ PENNSYLVANIA'S RESPONSE TO LOYALISM AND DISAFFECTION}

Patriot governance in Pennsylvania encountered opposition to revolt from the outbreak of armed hostilities. Rebel reaction to both overt loyalist support for the British monarchy and internal disaffection with revolutionary trends encompassed legislative and executive measures dealing with militia service, treason, disarmament, allegiance tests, attainders and the confiscation of real and personal property. The breadth, severity and enforcement of these legal instruments evolved over time in accordance with the relative distribution of political power between insurrectionist radical and moderate factions. Despite a great deal of unrest, patriot legal measures effectively checked active loyalism and clamped down on passive disaffection. Hence, in the absence of direct support from the British, local opposition never imperiled the revolutionary enterprise in Pennsylvania.

As a general rule, radicals exerted power more harshly than moderates. ${ }^{1}$ Four discernible phases of the patriot response to disaffection illustrate this pattern. During the first stage, radical Constitutionalists took control of the Revolution and overthrew the reigning colonial government under the Penn proprietorship with encouragement from the Continental Congress sitting at Philadelphia. The radical movement surged with creation of an Association for provincial defense in the summer of 1775 and coalesced with the Declaration of Independence, convocation of a state constitutional convention and passage of the Pennsylvania Constitution of 1776. Radicals consolidated their revolutionary vision during the second phase, a particularly volatile interlude from the first newly constituted general assembly in late 1776 through the British invasion,

\footnotetext{
${ }^{1}$ For definitions of radical Constitutionalist and moderate Anti-Constitutionalist/Republican alignments, see Introduction. In sum, radicals favored the 1776 Pennsylvania Constitution and moderates opposed it.
} 
occupation, and evacuation of Philadelphia from September 1777 to June 1778. This radical moment spawned the crucial treason, test oath and attainder laws which targeted loyalists and the disaffected throughout the War of Independence and its aftermath. The third phase commenced with the return to the capital of Congress and Pennsylvania's patriot government from their respective refuges at York and Lancaster. Radicals at this time reestablished control of state government, punished disaffection, and seized most of the Penn family's extensive public land holdings. While this interval proved to be the zenith of radical power in Pennsylvania, instability characterized much of the political and economic landscape. The period closed with an upswing in support for moderates beginning in the fall elections of 1781. During this lengthy final stage into the Age of Federalism, moderate Anti-Constitutionalist/Republican ascendancy eradicated the remaining vestiges of armed opposition to rebel rule and terminated all legal distinctions between those who had earlier supported the British and those who had stood with the Revolution.

Patriot factional politics greatly impacted the reintegration of the disaffected in Pennsylvania, a process that transpired over the later phases of intrarevolutionary discord. Although unresolved military conflict cast a fog of uncertainty over the future through 1783, the reintegrative struggle actually began with withdrawal of Sir Henry Clinton's army in the summer of 1778 , introducing the peak of radical supremacy, rather than at the war's conclusion and the arrival of peace as in British-occupied New York. ${ }^{2}$ On the

\footnotetext{
${ }^{2}$ General Sir William Howe and Admiral Lord Richard Howe - brothers - captured and occupied New York for the British in the late summer of 1776. William commanded the army and Richard the navy. The British high command used the city as their North American operational headquarters throughout the rest of the war. In accordance with the Definitive Treaty of Peace, British forces evacuated Manhattan - the last royalist stronghold in the thirteen rebellious colonies - on November 25, 1783, in effect ending the war.
} 
thorny issue of disaffection, Pennsylvania patriots clashed over more than a decade on an exclusionary/inclusionary fault line constructed on the basis of allegiance. Allegiance to the rebellion constituted the sine qua non for securing a citizen's rights, the fundamental issue which had originally sparked insurrection. Patriots thus applied the law to defend the rights of those devoted to the Revolution. Both radical and moderate factions accepted this paradigm. But they diverged in their approach to the disaffected who spurned revolutionary fidelity during the war and after the peace.

Radicals demanded permanent exclusion of the "inimical" and "obnoxious" who openly defied or failed to support the rebel movement. In the radical view, citizenship was a privilege earned during the fight for independence. Only those who contributed to the cause of republican liberty deserved to enjoy the advantages of republican rights. Moderates disagreed. They upheld that all Pennsylvania inhabitants - except those who had been found guilty of active treachery - had an intrinsic right to citizenship regardless of their declared revolutionary allegiance, activism, or lack thereof. ${ }^{3}$ Although these competing factions paid meticulous attention to the law in its composition and enforcement, each configured and applied state law with this broader perspective on rights and allegiance in mind. Contemporary anti-loyalist legislation therefore reflected provincial power dynamics as well as the contours of fluctuating patriot interpretations of the permissible, furnishing the framework for the battle over reintegration. When radicals

For the battle and British capture of New York City, see David McCullough, 1776 (New York: Simon and Schuster, 2005). For New York and the surrounding area during the War for Independence, see Ruma Chopra, Unnatural Rebellion; and Judith Van Buskirk, Generous Enemies.

\footnotetext{
${ }^{3}$ The most comprehensive treatment of the factional struggle between radicals and moderates from the beginning of the war through the Pennsylvania Constitution of 1790 is Robert Brunhouse, The CounterRevolution in Pennsylvania, 1776-1790.
} 
dominated provincial politics, the concepts of inherent rights and the rule of law served to isolate and penalize the disaffected. When moderates controlled state government, the defense of citizens' rights and corresponding legal mechanisms opened the door for a reassimilation of the very people that law had once persecuted. Since only the consent of the winners could countenance the full legal and social reincorporation of those once considered toxic adversaries, it was moderate factional victory culminating in the repeal of the Test Act in March of 1789 which ultimately crafted a suitable path for the successful reintegration of the disaffected.

THE COLONIAL ORDER UNDER DURESS (April 1775 - November 1776)

From the advent of armed rebellion onward, radicals worked the law to separate, disempower and punish loyalists and the disaffected, simultaneously reinforcing their own political legitimacy while striving to build a new state. They did so on the basis of allegiance, essentially restricting the rights of citizenship to only those who supported the Revolution. Radical patriots improvised the path to the marginalization of those who did not back the insurgency more so than subscribing to any predetermined design. As conditions changed, radicals reacted. The first stage began spontaneously with the launch of a makeshift military association to defend the Revolution and closed with a repudiation of all allegiance to the British monarch, the overthrow of the colonial proprietary regime, and the elevation of the principle of popular sovereignty as the basis for government.

The factional antagonism which marked the road to reintegration developed long before the onset of armed rebellion. Almost from its founding, Pennsylvania was rife with factional dissonance. Quaker and proprietary "parties" vied for political dominance 
throughout the colonial era. The advent of the imperial crisis created new fissures. From the 1765 Stamp Act forward, a tug-of-war between Pennsylvania's radical and moderate Whigs existed over how to best counter the overextension of parliamentary authority in the colonies. Provincials in Pennsylvania and elsewhere dubbed those who sided with Parliament as "tories" - but committed tories were few and far between in Penn's colony. For nearly a decade, virtually everyone agreed that Parliament's overreach had to be challenged. Just how that should be accomplished became the defining issue. Cautious Philadelphia merchants aligned with popular sentiment to approve nonimportation agreements in response to the Stamp Act, the Townsend Acts, and then the Intolerable Acts that led to the closure of Boston harbor. ${ }^{4}$ The preferred approach among these conservatives was to petition Parliament as colonial Englishmen for a redress of grievances. But merchant will sometimes waned as they bore severe economic losses. ${ }^{5}$

\footnotetext{
${ }^{4}$ For the Stamp Act in Pennsylvania, see Edmund S. Morgan and Helen M. Morgan, The Stamp Act Crisis: Prologue to Revolution (Chapel Hill: University of North Carolina Press, 1953), 160-162, 238-257; James S. Hutson, Pennsylvania Politics 1746-1770 (Princeton University Press, 1972), 192-203; J. Thomas Scharf and Thompson Westcott, History of Philadelphia, 1609-1884 (Philadelphia: L. H. Everts \& Co, 1884), 27173, 279-80; Burton Alva Konkle, Benjamin Chew 1722-1810 (Philadelphia: University of Pennsylvania Press, 1932, Kessinger Legacy Reprint), 106-110; William Allen Benton, Whig-Loyalism: An Aspect of Political Ideology in the American Revolutionary Era (Rutherford, NJ: Farleigh Dickinson University, 1969), 74-77. For the Townsend Acts, Hutson, Pennsylvania Politics, 220-223, 229, 232; Richard Alan Ryerson, The Revolution Is Now Begun: The Radical Committees of Philadelphia, 1765-1776 (Philadelphia: University of Pennsylvania Press, 1978), 28-30; Scharf \& Westcott, History of Philadelphia, 280-84. The literature on the "intolerable" period is extensive and, from the above, includes Ryerson, 3328; and Scharf \& Westcott, 285-90.

${ }^{5}$ An excellent example of the petitioning philosophy is Governor John Penn's address to the assembly just before the outbreak of war with Britain in which he stresses that "any Grievances which his Majesty's Subjects in America apprehend they have reason to complain of, should be humbly represented to His Majesty by the several Assemblies, as the only proper and constitutional mode of obtaining Redress." See John Penn Sr., "To the Assembly concerning the growing difficulties between the Colonies and Great Britain," February 21, 1775, George Edward Reed, ed., Pennsylvania Archives, $4^{\text {th }}$ Series (Harrisburg: State of Pennsylvania, Wm. Stanley Ray, 1900), Papers of the Governors, vol. 3, 505-506 (emphasis mine). On nonimportation, see especially Ryerson, The Revolution Is Now Begun, 43, 55-56, 66, 72, 77, 98-99; and Steven Rosswurm, Arms, Country and Class: The Philadelphia Militia and the "Lower Sort" during the American Revolution (New Brunswick: Rutgers University Press, 1987), 21-22, 39-40. A complete list of
} 
On the more radical margins, popular forces hosted crowd actions on five occasions during the Stamp Act affair and replicated protests on customs issues five more times from 1769 to 1774. In Philadelphia, the triumph of the "Mechanic Ticket" in the unauthorized November 1774 Committee of Inspection and Observation elections heralded a major shift in the on-the-ground power balance from conventional Quaker and proprietary elites often at odds with each other to a novel contingent of "inferior" sorts led by middling artisans. These mechanics set up an unsanctioned Committee of SixtySix, pressing for more aggressive counters to royal intransigence. ${ }^{6}$ The shots fired at Lexington on April 19, 1775 suddenly transformed nonviolent colonial resistance into armed rebellion. When news arrived in Philadelphia five days later, popular reaction was instantaneous. $^{7}$ In a city of thirty thousand inhabitants, eight thousand rallied on April 25 to launch an association for military defense against British aggression. Companies of armed associators formed on the $29^{\text {th }}$. In June, the Committee of Sixty-Six petitioned the colonial assembly for assistance in martial preparations. Two thousand militiamen paraded in review through city center that month. Under bottom-up duress, the colonial assembly hesitantly endorsed the official creation of an Association for defense - in effect, a state militia - under Lockean principles "for the defense of their lives, liberty

the signers of the Stamp Act nonimportation agreement in 1765 is in Scharf \& Westcott, History of Philadelphia, 272-274. Many signers later time became loyalists.

${ }^{6}$ Rosswurm, Arms, Country and Class, 30-34, 45, 52-53; Ryerson, The Revolution Is Now Begun, 94-96, 190-194.

${ }^{7}$ On April 24, Christopher Marshall noted in his diary that an express had arrived from Watertown, Massachusetts, late that afternoon describing the Lexington episode. William Duane, ed., Extracts from the Diary of Christopher Marshall, Kept in Philadelphia and Lancaster, During the American Revolution, 1774-1781, (Albany, NY: Joel Munsell, 1877, Kessinger Legacy Reprint), 17-18. 
and property." ${ }^{\circ}$ Association was an appellation inherited from the unofficial bodies enforcing nonimportation agreements during the imperial crisis. By mid-September of 1775, a popularly elected Committee of Privates pushed to make the Association compulsory for all white male adult citizens. ${ }^{9}$

Throughout the building storm, the Penn proprietary interest and the Quaker party - historical foes - watched the agitation with mounting alarm. Conservatives from both factions controlled the colonial assembly, still legally the final arbiter of local power. There, resistance to radicalization was strong. Legislators were not the only ones wary of the ominous turn of events. In September, a mob carted loyalists Isaac Hunt and Dr. John Kearsley around the city, insulting and threatening to tar-and-feather each in turn. The throng bayoneted the doctor's hand and broke windows in his home after he discharged a pistol into the crowd and insisted on singing "God Save the King." ${ }^{\prime 10}$ In October, Quakers presented the assembly with an address impugning the compulsory nature of the militia association, asserting that "we, as a religious society, have declared to the World that we could not for Conscience Sake bear Arms, nor be concerned in warlike Preparations, either by personal Service or by paying any Fines, Penalties or Assessments, imposed in

\footnotetext{
${ }^{8}$ John Locke's political trinity of life, liberty and property is in his Second Treatise of Government. It was a precursor to Jefferson's "life, liberty and the pursuit of happiness" in the Declaration of Independence.

${ }^{9}$ Statutes At Large of Pennsylvania, vol. 8, "Resolves of Assembly, Agreed to June 30, 1775," Appendix XXVIII, 485-486; Rosswurm, Arms, Country and Class, 49-52 - for the Committee of Privates, Chapter 2, $56-57,66-72$.

${ }^{10}$ Contemporary accounts of the Kearsley-Hunt affair are plentiful. For example, see Isaac Hunt, The Case of Isaac Hunt, Esq. of Philadelphia (London, 1776), LCP; Duane, ed., Diary of Christopher Marshall, September 6, 1775, 41-42; Alexander Graydon, Memoirs of a Life Chiefly Passed in Pennsylvania, Within the Last Sixty Years (Edinburgh: William Blackwood \& T. Cadell, 1822), 122-124. Dr. Kearsley was imprisoned and eventually sent to York, Pennsylvania (some say Lancaster), where he died. See Scharf \& Westcott, History of Philadelphia, 302.
} 
Consideration of our Exemption from such Services." ${ }^{11}$ Other true blue supporters of the king surfaced. Tory clubs toasting His Royal Majesty's health and the victory of imperial arms met secretly in loyal homes, as well as in taverns owned by champions of empire. ${ }^{12}$

As General George Washington and the Continental Army besieged Boston through the winter of 1775-76, Pennsylvania revolutionaries tackled tangible and surreptitious disaffection through militia laws and redoubled pressures on established colonial institutions. Although not designed for that purpose, militia laws introduced the first active measures against loyalism and disaffection in the province. Obligatory militia service enabled the patriot government to distinguish between those committed to the rebel cause and those who were not. To join or not to join - that was the question. The answer told authorities much about where an individual stood. As Douglas Bradburn has observed, "militia service... became both an important arbiter and agent of loyalty.",13 Militia regulations also pursued an equal apportionment of the burden of rebellion. On November 8,1775 , the conservative colonial assembly caved to bottom-up exigencies, adopting militia resolutions they surely would not have approved of their own accord. In this and all future militia deliberations, white males were the sole target for compulsory enlistment, a race/gender alignment which embraced all social classes. Two resolves grappled with the problem of citizens who refused to join the Association. In deference to the substantial Quaker presence in the colony, one allowed exemptions for men between

\footnotetext{
11 "To the Representatives of the Freemen of the Province of Pennsylvania, in General Assembly Met. The Address of the People Called Quakers," signed October 25, 1775, Charles F. Hoban, ed., Pennsylvania Archives, Eighth Series, vol. 8, Votes of the Assembly, 7327.

${ }^{12}$ The Tory clubs continued into 1776. See Scharf \& Westcott, History of Philadelphia, 324.

${ }^{13}$ Douglas Bradburn, The Citizenship Revolution: Politics \& the Creation of the American Union $1774-$ 1804 (Charlottesville: University of Virginia Press, 2009), 58.
} 
sixteen and fifty years "conscientiously scrupulous of bearing arms." Another qualified that statement by adding that those "capable of bearing arms, who shall not associate for the defense of this province, ought to contribute an equivalent to the time spent by the associators in acquiring the military discipline. ${ }^{\prime 14}$

Later that month, the assembly passed a bill entitled "The articles of association in Pennsylvania" defining rules of conduct for associators and regulating their commitment. Significantly, it addressed the issue of non-association. A section of the articles dubbed "Resolutions directing the Mode of Levying Taxes on Non-Associators in Pennsylvania" authorized tax commissioners in each county to list the names of non-associators in order to "charge every such person not associating, over and above the rates and assessments set upon him by virtue of the laws of this province, the sum of two pounds ten shillings." The resolutions made no accommodation for non-associators with religious scruples except in the case of assessors who refused to perform duties for that reason. In just over two weeks, a nebulous "time" equivalency had morphed into a hard cash penalty and pacifists no longer merited special consideration. ${ }^{15}$ Momentum lay with the radicals.

The Continental Congress, not the provincial government, first pushed the crucial issue of treason to the forefront in Pennsylvania. By definition, treason drew lines in the sand over allegiance, affording a mechanism to define who was for self-government and who was against it. The concept claimed a long tradition in English law transplanted

\footnotetext{
${ }^{14}$ Statutes At Large of Pennsylvania, vol. 8, "Resolves of Assembly, Agreed to November 8, 1775," Appendix XXVIII, 492-493. Since the colony's founding in the late $17^{\text {th }}$ century, the colonial assembly historically dominated by pacifist Quakers - rejected appeals to form armed militias for provincial defense, even during the height of the French and Indian War. Significant elements of the 1775 colonial assembly retained this view.

${ }^{15}$ Statutes At Large of Pennsylvania, vol. 8, "Resolutions directing the Mode of Levying Taxes on NonAssociators in Pennsylvania" in the "Resolves of Assembly, Agreed to November 25, 1775," Appendix XXVIII, 514.
} 
adeptly across the Atlantic. Treason was a breach of the sacred and reciprocal trust between ruler and ruled. The ruler provided subjects with protection and justice; subjects had a duty to bestow their allegiance on the sovereign. ${ }^{16}$ Sir William Blackstone, arguably the most respected jurist in eighteenth century England and a legal authority the revolutionaries held in the utmost esteem, defined treason as crimes against "the supreme executive power, or the king and his government; which amount either to a total renunciation of that allegiance, or at the least to criminal neglect of that duty, which is due from every subject to his sovereign.",17

The treason question arose in part as a result of the arrest of John Connolly and his co-conspirators - "persons inimical to the liberties of America" - captured in Maryland in late 1775 en route to inciting a loyalist revolt near Fort Pitt in Cumberland County and sent to Philadelphia for prosecution. ${ }^{18}$ Their case revealed a grave incongruity between law and reality, for all provincials - including rebels - legally remained His Royal Majesty's obedient subjects. The only treason then possible in the thirteen insubordinate colonies was treason against none other than King George III. Although clearly acting in a seditious manner against the American rebellion, Connolly and company had not technically committed treason for there was as yet no revolutionary

\footnotetext{
${ }^{16}$ For English antecedents, see Bradley Chapin, The American Law of Treason: Revolutionary and Early National Origins (Seattle: University of Washington Press, 1964), 3-9, 38. For background on allegiance, see James H. Kettner, The Development of American Citizenship, 1608-1870 (Chapel Hill: University of North Carolina Press, 1978), 13-28, 44-64.

${ }^{17}$ Sir William Blackstone, Knight, Commentaries on the Laws of England, Twelfth Edition, Edward Christian, Esq., ed. (London: A. Strahan \& W. Woodfall, Law-Printers to the King's Most Excellent Majesty, for T. Cadell in the Strand, 1795), Book the Fourth, Chapter 6, 74.

18 "Examination of A. Cameron, Dr. Smith and Jno. Connolly," November 23, 1775, Pennsylvania Archives, First Series, vol. 4, 682-684; Minutes of the Provincial Council of Pennsylvania, from the Organization to the Termination of the Proprietary Government (Harrisburg: Theo. Fenn \& Co., 1852), vol. 10, 444-445 (hereinafter Colonial Records).
} 
law to that effect. The incident became a clarion call for Congress at Philadelphia. Their response on January 2, 1776 became known as the Tory Act. Since there was no central government to speak of at the time, Congress could not compel any single colony to act in a certain way, much less obligate all thirteen at once to comply with their directives. The best it could hope for was voluntary consent. Accordingly, delegates framed the act as a set of proposals. ${ }^{19}$

This congressional resolution nonetheless proved to be a watershed moment for the disaffected. It catapulted those loyal to Great Britain into the limelight; enlarged the scope of cooperation between Congress and Pennsylvania radicals while injecting the problem of political discontent into that collaboration; and most importantly, inaugurated a redefinition of reciprocal allegiance. In the emerging reconfiguration, the ruled were to rule themselves, owing fidelity only to representatives and officials of state and local governments elected by popular sovereignty, as well as the Continental Congress the elected provincial governments had freely joined.

The Tory Act itself was comparatively brief as far as governmental resolves go a single page with two columns, easily printed as a broadside. Divided thematically into three sections, the first part defined its intended targets, the second provided specific measures for its implementation, and the last fused justifications for its enactment with a call for moderation in its application. The opening differentiated the viewpoints of two

\footnotetext{
${ }^{19}$ Congress was deliberately designed as a league of autonomous entities, retaining sovereignty at the local level, a fluid arrangement reflected in contemporaneous references to the United Colonies. The linguistic rite of passage from United Colonies to United States came about as a product of the Declaration of Independence. Regarding the exercise of power, Edmund Cody Burnett noted that "whatever government existed was centered in the revolutionary assemblies, the provincial congresses or assemblies." Power thus lay within each of the thirteen self-governing English provinces. Edmund Cody Burnett, The Continental Congress: A definitive history of the Continental Congress from its inception in 1774 to March, 1789 (New York: W. W. Norton \& Co., 1964), 69.
} 
sets of colonials towards resistance against the Crown. It acknowledged "diverse and well meaning, but uninformed people in these colonies [who] have been deceived and drawn into erroneous opinions, respecting the American cause, and the probable issue of the present contest." Revolutionaries needed to treat these apprehensive souls with "kindness and attention" and construe their errors as "proceeding rather from want of information, than want of virtue or public spirit." To win over the dubious, patriots had to instruct them on the repeated failure of colonial petitions to the king and alert them to "the various arts of administration to ensnare and enslave us" conducted through imperial intrigues. As a remedy, the act suggested that officials widely distribute the proceedings of the First and Second Continental Congresses, along with patriotic pamphlets, papers, and the speeches of colonial allies in Britain's Parliament which "elucidate the merits of the American cause.",20

The resolution then pinpointed the ultimate target of the measure: "unworthy Americans... [who] have taken part with our oppressors... regardless of their duty to their creator, their country, and their posterity." These reprobates were "influenced by the hope or possession of ignominious rewards" and "recommend themselves to the bounty of administration by misrepresenting and traducing the conduct and principles of the friends of American liberty, and opposing every measure formed for its preservation and security." The act proposed remedies to "frustrate the mischievous machinations, and restrain the wicked practices of these men" in rather tentative terms, demonstrating just

\footnotetext{
${ }^{20}$ The Tory Act, Published by Order of the Continental Congress, Philadelphia, January 2, 1776, Evans 15147, LCP; Worthington Chauncey Ford, ed., Journals of the Continental Congress, 1774-1789, Edited from the Original Records in the Library of Congress (Washington: Government Printing Office, 1906), Tuesday, January 2, 1776, vol. 4, 19 (hereafter Journals of the Continental Congress); "Postscript to the Pennsylvania Gazette No. 2455,” The Pennsylvania Gazette, January 10, 1776.
} 
how little power the congressional assembly actually exercised. "And it is the opinion of this Congress", the resolution continued, "that they ought to be disarmed and the more dangerous among them either kept in safe custody, or bound with sufficient sureties to their good behavior." Towards this end, the national assembly disposed the placement of continental troops under provincial authority and called for increasing unity among the rebellious colonies. Finally, Congress advised caution. Despite a litany of "execrable barbarity... on the part of our enemies" including the burning of colonial towns, seizing provincials' property, raining devastation and misery upon them, inducing Indians to attack frontier settlements, jailing the opposition, and exposing the citizens of Boston to the "insolence of the soldiery," it was essential to exert restraint. "Cruelty should find no admission among a free people," counseled delegates. ${ }^{21}$ With this artful formulation, the Continental Congress propelled the issue of allegiance into the revolutionary vanguard. The resolution sent two clear messages: to the undecided, choose a side; to patriots, disarm those who chose wrongly.

Twice more during that spring and summer, Congress resurrected the issues of disarmament and allegiance. Ten weeks after the Tory Act, they exhorted authorities "immediately to cause all persons to be disarmed within their respective colonies, who are notoriously disaffected to the cause of America, or who have not associated, and shall refuse to associate, to defend, by arms, these United Colonies, against the hostile attempts of the British fleets and armies." Stressing the rule of law over indiscriminate seizures, Congress recommended payment for all commandeered arms after an appraisal "by indifferent persons." Provincial governments were to employ seized weapons to arm

${ }^{21}$ The Tory Act, Evans 15147 (emphasis mine), LCP; Journals of the Continental Congress, January 2, 1776, vol. 4, 19-21. 
continental troops, militias and associators. ${ }^{22}$ In June, Congress tackled the nature of allegiance and treason more directly. In response to a report from its Committee on Spies - which in itself speaks volumes about internal strife only two weeks before the Declaration of Independence - delegates "Resolved, That all persons abiding within any of the United Colonies, and deriving protection from the laws of the same, owe allegiance to said laws, and are members of such colony." The resolution declared that those "who shall levy war against any of the said colonies... be adherent to the king of Great Britain, or others the enemies of said colonies... giving to him or them aid and comfort, are guilty of treason against such a colony" and should be punished. Working once again within prescribed jurisdictional limits, Congress suggested that provincial legislatures each determine the extent of that punishment. ${ }^{23}$

Not surprisingly, Pennsylvania's disjointed government stalled at this juncture. Ambiguity towards disarmament, allegiance and treason bared a much larger problem: proprietary rule was on the verge of collapse. Many colonial officials no doubt preferred the stability of monarchy to feared turmoil under popular rule. Structurally, proprietor John Penn Sr. continued as governor and his appointed provincial council remained in place, at least nominally, but that body did not convene after November 25,1775 , when Penn asked a Northumberland County magistrate to reassert Pennsylvania's authority in the frontier controversy with Connecticut. ${ }^{24}$ Meanwhile, the duly elected and much

\footnotetext{
${ }^{22}$ Journals of the Continental Congress, March 14, 1776, vol. 4, 205.

${ }^{23}$ Journals of the Continental Congress, June 24, 1776, vol. 5, 475.

${ }^{24}$ Governor John Penn to William Plunkett, November 25, 1775, Colonial Records, vol. 10, 275. Governor Penn issued a later Memorandum on December 9 for New Castle County in Delaware, then a separate province but under the same proprietor as Pennsylvania. See Colonial Records, vol. 10, 275-276.
} 
conflicted colonial assembly wavered under the decreasing influence of conservatives.

Although the assembly met intermittently through the spring and summer of 1776, it was torn between a traditionalist inclination for the old order and popular demands. The internal battle for control is evident in the legislative agenda. ${ }^{25}$ On the one hand, representatives christened two bills about to expire in April of 1776 under the rubric of "the Eleventh Year of the Reign of His Present Majesty King George the Third." That the assembly did not wish to sever ties with "His Present Majesty" at that late date rings sonorously. On the other hand, the same House approved "sundry alterations" for the military association and penalties for non-associators on April 5 and further disarmament measures the following day. These alterations included an escalation in fines for failure to serve to three pounds ten shillings, fines for masters or mistresses who prevented apprentices from joining the association, and levies against commissioners who refused to perform required duties. An exception was again granted for officials refusing to carry out duties "from conscientious motives. ${ }^{, 26}$ Even the radical Committee of Safety, perhaps

\footnotetext{
${ }^{25}$ The colonial assembly met on and off to conduct legislative business from February 24 to June 14, 1776. For a list of resolves through April 6, see Statutes At Large of Pennsylvania, vol. 8, Appendix XXXIII, 651. For resolves in May and June, ibid., vol. 8, 565-569. The assembly met again as late as September 26 but mostly to finalize pending financial issues such as payment of Governor John Penn Sr.'s salary. See report of Committee on Incidental Expenses, September 26, 1776, Votes of the Assembly, vol. 6, in Pennsylvania Archives, Eighth Series, vol. 8, 7587-7590.

${ }^{26}$ Laws of the Commonwealth of Pennsylvania from the Fourteenth Day of October, One Thousand Seven Hundred, to the Twentieth Day of March, One Thousand Eight Hundred and Ten. Republished under the Authority of the Legislature. With Notes and References. "An Act to continue part of an act, made in the eleventh year of the reign of his present Majesty King George the third, entitled An Act for regulating and continuing the nightly watch, enlightening the streets, lanes and alleys of the city of Philadelphia, and for other purposes therein mentioned, and for making further provision for the better executing the said act," (Philadelphia: John Bioren, 1810), vol. 1, April 6, 1776, Chapter 717, 426-428; Statutes At Large of Pennsylvania, vol. 8, "An Act to Make Perpetual an Act Passed in the Eleventh Year of the Reign of His Present Majesty King George the Third, Entitled 'An Act for the Relief of the Poor,"' April 6, 1776, Chapter 723, 474; ibid., vol. 8, "Resolutions directing the Mode of Levying Taxes on Non-Associators" in the "Resolves of Assembly, Agreed to April 5, 1776," Appendix XXVIII, 538-544. Radicals did not make allowances for conscientious objectors. For the disarmament measures, see ibid., vol. 8, "Resolves of the Assembly, Agreed to April 6 ${ }^{\text {th }}, 1776, "$ 559-561.
} 
still unsure of its footing, ignored the Tory Act recommendations at first. Instead, they turned their attention to organizing military defense for a presumed British assault. Committee Minutes for the ten days immediately following the Tory Act disclose a recurring preoccupation with gunpowder, gun barrels, firelocks, "the manufactory of Salt Petre," munitions, muskets, officer appointments, the raising of regiments, and financial matters related to acquisition and payment of the above. ${ }^{27}$ The sum of these events reveals that disaffection was common even within government and radicals had not yet achieved full control of the insurgency.

Radicals' aspirations to employ the legal system as a weapon against loyalists and the disaffected soon converged with congressional impatience over the state's political impasse. During the spring and summer of 1776, an increasingly militant Continental Congress tilted the balance of power in Pennsylvania. Two decisive measures offered radicals a justification for deposing the existing political regime. Although congressional resolutions were usually national in scope, the first measure targeted Pennsylvania to a large extent. On May 10, Congress "Resolved, That it be recommended to the respective assemblies and conventions of the United Colonies, where no government sufficient to the exigencies of their affairs have been hitherto established, to adopt such government as

\footnotetext{
${ }^{27}$ Minutes of the Council of Safety, January 2-12, 1776, Colonial Records, vol. 10, 442-451. Interestingly, these minutes mention a reimbursement on January 5 for 28 firelocks to Captain William Allen - future Lieutenant Colonel of the Pennsylvania Loyalists under Sir William Howe who is treated extensively in the next chapter. The Committee of Safety officially became the Council of Safety on July 23, 1776, as per the directive of the Pennsylvania constitutional convention. The terminology for the two is often conflated, even in the official Minutes of the Provincial Council. The title page for volume 10 of the Colonial Records states that it contains the "Minutes from the Council of Safety from June 30, 1775," though the entity at that date was known as the Committee of Safety. For the committee to council transition, see John M. Coleman, Thomas McKean: Forgotten Leader of the Revolution (Rockaway, NJ: American Faculty Press, 1975), 171-172; Ryerson, The Revolution Is Now Begun, 241-43. For the creation of the original Committee of Safety, "Votes of the Assembly," June 30, 1775, Pennsylvania Archives, $8^{\text {th }}$ Series, vol. 8, 7247; Ryerson, The Revolution Is Now Begun, 122-24; Rosswurm, Arms, Country and Class, 53, 58.
} 
shall, in the opinion of the representatives of the people, best conduce to the happiness and safety of their constituents in particular, and America in general." Radicals jumped on the bandwagon. On June 8, the colonial assembly dramatically reversed its earlier instructions to Pennsylvania's delegates in the Continental Congress, "removing the restrictions laid upon you" regarding separation from Great Britain and authorizing provincial representatives to "concur with the other delegates in Congress, in forming such compacts between the United Colonies... [as] shall be judged necessary for promoting the liberty, safety and interests of America." The coup de grace came in July when the Declaration of Independence obliterated what little authority the reigning assembly still retained. ${ }^{28}$

Pennsylvania radicals seized upon congressional calls for drastic change by convening a provincial constitutional convention. Convention delegates gathered in Philadelphia in late June and elected representatives to write a new constitution on July 8. Arriving at the realization that they were the lone active political body in the province, delegates adopted responsibilities not within their original mandate. The constitutional convention passed nine ordinances before adjourning in late September. Issues of disarmament, militia burdens and treason figured prominently on the agenda. On July 19, radicals directed militia officers to "collect, receive and take all the arms... in the hands of non-associators in the most expeditious and effectual manner." On September 5, convention delegates approved the first revolutionary treason ordinance. Then on the $14^{\text {th }}$

\footnotetext{
${ }^{28}$ Congress' May resolution for new state governments responded mainly to local elections in Pennsylvania that had returned a conservative majority to the colonial assembly. Journals of the Continental Congress, May 10, 1776, vol. 4, 342; ibid., July 4, 1776, "The unanimous Declaration of the thirteen United States of America," 510-515. For the revised instructions to Pennsylvania's delegates in Congress, Statutes At Large of Pennsylvania, vol. 8, "Resolves of Assembly, June 8" ${ }^{\text {th }}$ 1776," 567-569.
} 
they set fines for non-association at twenty shillings per month and added prorated penalties of four shillings per pound on total estate values for neglect of militia service. Monthly and annual penalties had replaced one-time fines. ${ }^{29}$ A zealous Council of Safety did not lag far behind, exhorting Committees of Inspection to "a Vigorous Exertion of all their Power" to ensure compliance with assembly disarmament orders, then determining that Associators who had not marched to battle outside the state or enrolled in companies for local defense "shall be deemed a Non Associator." ${ }^{30}$ Clearer lines of allegiance were emerging.

With declared independence creating a new political climate, militia penalties and disarmament directives no longer seemed sufficient tools to combat disaffection. The elephant in the room was treason. The convention responded with an ordinance defining and punishing sedition. Grounding its authority on the notion that "government ought at all times to take the most effectual measures for the safety and security of the state," the regulation declared that all inhabitants "do and shall owe and pay allegiance to the state of Pennsylvania," a condition that could not be renounced if a person remained in the province. It established three offenses as high treason: first, to "levy war against this state"; second, to "be adherent to the King of Great Britain or others the enemies of this state or to the enemies of the United States of America"; and third, "giving him or them

\footnotetext{
29 "Pennsylvania Constitution of 1776, History," Pennsylvania Historical and Museum Commission, Record Group 26, Records of the Department of State, Basic Records, online at: http://www.phmc.state.pa.us/portal/communities/documents/1776-1865/pennsylvania-constitution1776.html, last accessed October 18, 2016. Statutes At Large of Pennsylvania, vol. 9, "An Ordinance Respecting the Arms of Non-Associators," July 19, 1776, Chapter 729, 11-12; ibid., "An Ordinance of the State of Pennsylvania Declaring What Shall Be Treason and for Punishing the Same and Other Crimes and Practices Against the State," September 5, 1776, Chapter 732, 18-19; ibid., "An Ordinance for Rendering the Burden of Associators and Non-Associators in the Defense of the State as Nearly Equal as May Be," September 14, 1776, Chapter 735, 22-27.

${ }^{30}$ Council of Safety Minutes, July 12, 1776 \& August 19, 1776, Colonial Records, vol. 10, 643, 691.
} 
aid or assistance within the limits of this state or elsewhere." For such breaches of patriotic trust, an offender was to "forfeit his lands, tenements, goods and chattels to the use of the state" and face imprisonment for "any term not exceeding the duration of the present war with Great Britain." Constitutional convention delegates also defined a less seditious category for those not being traitors themselves who nonetheless knew of the treason of others, concealed it, or assisted the wrongdoers. Misprision of treason carried a reduced penalty forfeiting one-third of property and goods, but bore the same jail time as high treason. Attuned to the public burden such an act might produce, a fourth section stipulated that judges could use proceeds from forfeited estates to support wives and children. Expediently, traitors would pay for the upkeep of their kin. The treason ordinance was provisional, slated to last through the first session of the first assembly under the new constitution. ${ }^{31}$ Radicals wanted to ensure that the new government lived by the rule of law and left the final formulation to the coming legally constituted assembly. Nevertheless, the convention had thrown down the gauntlet. Dissent was to be punished officially with property confiscation and jail.

Unanimity on treason in Pennsylvania apparently did not exist even among fellow patriots. There is a "Proposed Ordinance" published as a broadside, attributed to an imprecise date in 1776 when "the General Convention met," where penalties differed from those of the first ordinance. Traitors were to "suffer death," not prison, as well as forfeiting half of their property and goods. Those convicted of misprision of treason were to "suffer the Forfeiture to Two Thirds" of property and goods and be jailed for no more

\footnotetext{
${ }^{31}$ Statutes At Large of Pennsylvania, vol. 9, "An Ordinance of the State of Pennsylvania Declaring What Shall Be Treason and for Punishing the Same and Other Crimes and Practices Against the State," September 5, 1776, Chapter 732, 18-19.
} 
than a year. ${ }^{32}$ Whether the broadside appeared prior to the convention treason ordinance as part of the civic debate or circulated thereafter to renew that debate is unclear.

The day before the official colonial assembly convened for the last time on September 26, a majority voted to impugn the constitutional convention for "arbitrary and oppressive" fines against non-associators, alleging convention delegates "have derived no Authority from the good People of Pennsylvania to levy Taxes and dispose of their Property." Few listened and the assembly lost its will to fight thereafter. ${ }^{33}$ The next day, conventioneers further tilted the political scales in favor of the radicals, approving a resolution requiring voters under the new republican order take an oath or affirmation to "be faithful and true to the commonwealth of Pennsylvania" and do nothing "prejudicial or injurious to the constitution or government thereof, as established by the convention." This decree eliminated from the voter rolls patriot moderates who did not agree with the convention itself or the direction it had taken, as well as scores of Quakers and other pacifists who, bound by their religious strictures, declined to obey the directive to pledge allegiance. Radicals had stacked the electoral deck. ${ }^{34}$

\section{Congress' May $10^{\text {th }}$ exhortation to set up new governments culminated on} September 28 when the convention ratified the Constitution of 1776 . The cornerstone of the new order was a wholesale transfer of loyalty. Since Pennsylvanians' "heretofore

\footnotetext{
${ }^{32}$ A Proposed Ordinance for the State of Pennsylvania, Declaring What Shall Be Treason, and for Punishing the Same, and other Crimes and Practices against the State. Broadside (Philadelphia: Styner \& Cist, 1776), Evans 14992, LCP.

${ }^{33}$ Votes of the Assembly, September 25, 1776, Pennsylvania Archives, Eighth Series, vol. 8, 7586.

${ }^{34}$ Constitutional Convention Minutes, September 26, 1776, Journals of the House of Representatives of the Commonwealth of Pennsylvania, Beginning the twenty-eight Day of November 1776, and Ending the second Day of October, 1781, with the Proceedings of the Several Committees and Conventions, Before and at the Commencement of the American Revolution (Philadelphia: John Dunlap, 1782), 88.
} 
acknowledged allegiance to the king of Great Britain" had been corrupted and the king had withdrawn his protection and initiated "with unabated vengeance, a most cruel and unjust war," the convention declared that "all allegiance and fealty to the said king and his successors, are dissolved and at an end." Government was now to be "founded on the authority of the people only." The new charter required state judicial, executive, and military officers, but not the common citizenry, to take a two-part oath of allegiance and do nothing "prejudicial or injurious" to the commonwealth. ${ }^{35}$ For those accustomed to colonial authority, it was devastating moment. Politically, the Constitution of 1776 overthrew the proprietary government William Penn had founded nearly a century before.

The General Assembly convened for the first time under the new structure on November 28, 1776, giving birth to a Pennsylvania built according to the vision of the radical Constitutionalists. By then, increasing turbulence and harassment from the lower sorts convinced some conservatives who had resisted parliamentary overextension but opposed separation from Britain that there was no room for them in radical Pennsylvania. Among them were John, Andrew and William Allen Jr., three of the four sons of the former colonial chief justice, and Joseph Galloway, longtime colonial assembly speaker and ex-Quaker party ally of Benjamin Franklin. In late 1776, these elites established contact with General William Howe and joined the British at New York. ${ }^{36}$ Radicalization had generated schism.

\footnotetext{
${ }^{35}$ Constitution of Pennsylvania, September 28, 1776, The Avalon Project, Yale Law School, http://avalon.law.yale.edu/18th century/pa08.asp last accessed on October 20, 2016. The king withdrew his protection and proclaimed the thirteen colonies "in rebellion" on August 23, 1775, thereby authorizing his armies to put down the insurgency. See King George III, A Proclamation for Suppressing Rebellion and Sedition, Massachusetts Historical Society, https://www.masshist.org/revolution/docviewer.php?old=1\&mode=nav\&item id=858 last accessed on November 25, 2016.
} 
QUELLING DISAFFECTION: THE RADICAL VISION (November 1776 - June 1778)

During the second phase of the patriot response to loyalism, radicals defined and codified into law the crucial distinctions grounded on allegiance that served as the basis for isolating, disempowering and penalizing those dissatisfied with the Revolution during the war and after. Radical legal control generated a plethora of treason, test oath, attainder, confiscation and militia measures that denied loyalists and the disaffected the rights of citizenship and exacted stiff penalties for their dissent. The arm of radical rule could not reach those Pennsylvania loyalists who sought the protection of the British during the occupation of Philadelphia and, for a while, these legal instruments seemed insignificant. But once it became apparent that the king's army would evacuate the captive provincial capital, the radical legal program created a climate of fear and disarray in the ranks of the disaffected and resulted in the flight of many.

By the time the new state assembly gathered for the first time in late November 1776, it was impossible to escape the sharpened revolutionary divisions in Pennsylvania. Three distinct blocs emerged. Radical Constitutionalists comprised the vanguard of the Revolution. Their intervention had occasioned the political overthrow of the proprietary

\footnotetext{
${ }^{36}$ The British also tried to compete for the allegiance of the colonists. Sir William Howe and Lord Richard Howe were not only commanders-in-chief of all British land and naval forces respectively but also the king's peace commissioners. They offered pardons to rebellious colonists in separate declarations of July 14 and September 19, 1776. A third pardon was extended at New York on November 30, 1776, and began by citing the previous two. "Proclamation by Lord Howe," American Archives: Documents of the American Revolution Period, 1774-1776, Northern Illinois University Digital Collections and Collaborative Projects, http://amarch.lib.niu.edu/islandora/object/niu-amarch\%3A101937, last accessed on October 19, 2016. Just where allegiance resided on the patriot side and who had authority to enforce it was more complicated. In addition to the states and Congress, General George Washington joined the fray in January 1777 from his army encampment at Morristown, ordering anyone who had complied with Lord Howe's proclamations to deliver up all such documents and take an oath of allegiance to United States or "to withdraw themselves and families within the enemy lines" within 30 days. Transgressors would "be deemed adherents to the King of Great Britain, and treated as common enemies of the American States." By His Excellency George Washington, Esq; General, and Commander-in-Chief, of all the Forces of the United States of America. Proclamation, January 25, 1777. Evans 15632, LCP.
} 
regime and, as their name implies, creation of the new constitutional order. Although an individual's factional affiliation sometimes oscillated or evolved over time, generallyspeaking Presbyterians, German “church people” and Quakers who eschewed that sect's pacifism and favored armed resistance against British injustice formed the radical core. Among important non-Quaker elements within the leadership were Joseph Reed, George Bryan, John Bayard, Charles Thomson, Charles Willson Peale, Thomas McKean and Frederick Augustus Muhlenberg. Thomas Wharton Jr., Timothy Matlack and Christopher Marshall typified the "fighting" Quakers in the group. While radical elements converged on the need for an entirely new system of government, the acrimonious question of independence split colonial conservatives in two. One group concluded that English obstinacy and blindness would never redress colonial grievances. These moderates joined the forces advocating separation from the mother country and often assumed important positions within the revolutionary movement. James Wilson, George Gray, William Moore, George Clymer, Thomas Mifflin, John Dickinson, Robert Morris, Benjamin Rush and Alexander Graydon, among others, personified this penchant. ${ }^{37}$ Another conservative contingent refused to support the emerging governmental structure. Of these, loyalists wished to remain subjects of the king within the empire, while others placed their fear of popular rule and armed rebellion above devotion to the royal standard. Both clusters populate these pages. Whether openly loyal or not, however, patriots considered everyone in this third group as disaffected.

\footnotetext{
${ }^{37}$ As an example of political oscillation/evolution, Ryerson places Dickinson, Mifflin and Clymer among "the radical core" in 1774 that pushed forward the mechanic ticket. These later formed an important contingent among moderates. See Ryerson, The Revolution Is Now Begun, 95. Of those listed here, McKean evolved more than most; over the long haul, he went from the radical to the moderate camp.
} 
The late winter, spring and summer of 1777 proved critical for the destiny of those opposed to revolutionary rule as the remodeled state government launched efforts to establish a framework for curbing disaffection. Since the intent of patriot law was to express the will of the people, Pennsylvania's legal framework paints a portrait of what rebels wanted republican society to look like. Official responses to disaffection evolved in tandem with changing expressions of the popular will, along with military and political conditions in constant flux. The radicals' three-pronged approach anticipated a British assault and toughened treason and militia laws while adding a controversial condition for citizenship: a loyalty test.

On February 11, 1777, the General Assembly under the leadership of John Jacobs of Chester County, the first elected speaker, reformulated the constitutional convention's treason ordinance, increasing the law's severity in "An Act Declaring What Shall Be Treason and What Other Crimes and Practices against the State Shall Be Misprision of Treason., ${ }^{38}$ The reformulated statute enumerated treasonous activities more precisely and strengthened penalties. Reiterating that residents and travelers owed the state allegiance, the new law targeted "internal enemies" for whom the act was to "provide punishments... in order to deter... the perpetration of... horrid and dangerous crimes." Nine offenses not three - now classified as high treason: taking a commission from the British monarch; levying war against Pennsylvania or the United States; aiding enemies at war with the province or the United States; joining the enemy's armies; recruiting for the king's forces; supplying adversaries with ammunition, arms or provisions; "carrying on traitorous correspondence"; conspiring against the state; and managing "to give or send

\footnotetext{
${ }^{38}$ The election of Jacobs as House Speaker on November 28, 1776, at the opening session of the first assembly is in Journals of the House of Representatives of the Commonwealth of Pennsylvania, 97-98.
} 
any intelligence" to the enemy. Procedurally, convictions required two witnesses.

Forfeiture of the perpetrator's estate to the commonwealth remained in place. But now, ominously, the offender was to "suffer death" instead of prison for the war's duration. The harsher broadside published during the convention appears to have won the day. A more rigorous reconstruction also occurred in cases of misprision of treason. Seven instances fell under this category: conveying intelligence to enemies; publicly speaking or writing "against our public defense"; exciting the people to resist the new government; espousing a return to royal rule; dissuading others from enlisting in the state's forces; raising "tumults, disorders or insurrections" for the enemy; and trying to prevent efforts to secure independence. Again, convictions needed two witnesses. The statute maintained the penalty of imprisonment for the duration of the conflict, but set forfeiture of one-half, rather than one-third, of all real and personal property as the confiscatory norm. ${ }^{39}$ Definitions of high treason and misprision of treason apparently could overlap. What was the difference between giving or sending intelligence for high treason and conveying intelligence for misprision? Perhaps this was intended to provide judges latitude in specific cases. Pennsylvania's February 1777 treason law became the bulwark of the allegiance framework that shaped the reintegration experience of the disaffected and the basis for almost all definitions and measures affecting friend or foe during the revolutionary conflict. Subsequent applications of the law against the politically alienated invariably referenced this statute.

\footnotetext{
${ }^{39}$ Statutes At Large of Pennsylvania, vol. 9, "An Act Declaring What Shall Be Treason and What Other Crimes and Practices against the State Shall Be Misprision of Treason," February 11, 1777, Chapter 740, 45-47.
} 
While the treason law defined what made a traitor, it failed to provide a mechanism for identifying turncoats. The problem of allegiance thus turned pragmatic. The remedy came with a test. In addition to identifying traitors, loyalty oaths sought to compel the pusillanimous and skeptical to choose sides. The radical General Assembly approved "An Act Obliging All White Male Inhabitants of This State to Give Assurances of Allegiance to the Same and for Other Purposes Therein Mentioned" four months after the treason law. The legislature justified the regulation on three assumptions. First, some still refused to support the new order: "sordid and mercenary motives" had induced "sundry persons... to withhold their service and allegiance from the commonwealth of Pennsylvania." Two, others who did support the cause carried an unfair load "at the risk of their lives and the hazard of their fortunes." Good and bad were "at this time mixed and in some measure undistinguished from each other, the disaffected deriving undeserved service from the faithful and well affected." Three, citizens had a duty to give, not just receive: "whereas allegiance and protection are reciprocal... those who will not bear the former are not nor ought to be entitled to the benefits of the latter." ${ }^{, 40}$ For Constitutionalists, the protection due to citizens was not automatic. It had to be earned.

Test legislation set up a system obliging white males over eighteen to take an oath before a justice of the peace and promise to uphold four fundamental principles: renounce allegiance to George III; swear to "be faithful and bear true allegiance" to Pennsylvania; and do nothing "prejudicial or injurious to the freedom and independence" of the state. These tenets did not entail any action beyond taking the oath itself. A fourth condition,

\footnotetext{
${ }^{40}$ Statutes At Large of Pennsylvania, vol. 9, "An Act Obliging All White Male Inhabitants of This State to Give Assurances of Allegiance to the Same and for Other Purposes Therein Mentioned," June 13, 1777, Chapter 756, 110-111 (emphasis mine).
} 
however, demanded that oath-takers "discover and make known... all treasons or traitorous conspiracies" against Pennsylvania or any of the United States to a justice of the peace. Citizens now had to be proactive in their patriotic commitment. After avowing fealty, the subscriber received a signed certificate from the presiding justice validating the oath. Other clauses required traveling residents and outsiders, if suspected of noncompliance, to prove they had taken the Pennsylvania oath or a similar one in their own state. Refusal to swear allegiance exacted a series of penalties: the inability to hold office; vote or be elected; serve on juries; sue for collection of debts; buy, sell or bequeath land or other real property; and in a linkage back to the earlier Tory Act, disarmament. Exceptions were made for delegates of Congress, absentees such as war captives and continental troops, and merchants or seamen from friendly powers trading in the ports of Pennsylvania. The Test Act, as it came to be popularly called, proved imperfect, facing revision several times over the next dozen years. ${ }^{41}$

Like the state Constitution of 1776, scores of moderates opposed the act. From Lancaster, patriot John Hubley spoke for many when he prophesied that "you will hear a loud cry against this Tiranical [sic] Oath, that it was intended for naught but to hinder substantial, good disposed People to ellect or be ellected [sic]; depriving them of the rights of Freemen." ${ }^{, 42}$ As an instrument of radical Whig policy, the test served two functions: developing a method for detecting disaffection and fortifying divisions in the

${ }^{41}$ Statutes At Large of Pennsylvania, vol. 9, "An Act Obliging All White Male Inhabitants of This State to Give Assurances of Allegiance to the Same and for Other Purposes Therein Mentioned," June 13, 1777, Chapter 756, 111-114. Just how many times the Test Act was modified depends on how one defines modification. Legislation dealing with the Test Act itself was passed on at least five subsequent occasions. However, key elements of the Test Act were modified in legislation concerned with other issues, primarily security and elections. This study accepts the broader definition of modification.

42 John Hubley to Timothy Matlack, July, 1777, in Brunhouse, The Counter-Revolution in Pennsylvania, 41 (emphasis in original). 
internecine battle among provincial factions that lasted well past the end of the war. For many of the disaffected, especially pacifists, the oaths produced a social stigma during the war and proved to be their greatest barrier to reintegration in the postwar period. ${ }^{43}$

The Test Act cannot be viewed in isolation from revolutionary political and military developments. In June 1777, rumors abounded that Howe's next move from New York was a strike at the rebel capital at Philadelphia. The new law thus bespoke an urgency demanding compliance within three weeks of its passage in all counties except those on the frontier, who had another month. ${ }^{44}$ Patriots needed to know who was with them and who was against. In early July, redcoats and Hessians began embarking at Staten Island for the anticipated assault. Imperial troops landed at Head of Elk on Maryland's Chesapeake Bay in late August and marched east and north towards Philadelphia. ${ }^{45}$ For once, the rumormongers had it right.

Rebels responded to fears of collaboration between the invaders and loyalists with targeted arrests and, in some cases, banishment. The radical council headed by Thomas Wharton Jr. rounded up two stalwarts of the colonial regime, Governor John Penn and Chief Justice Benjamin Chew, and shipped them off to exile in New Jersey. Panicky patriot officials then deported twenty prominent citizens - mostly Quakers like brothers

\footnotetext{
${ }^{43}$ A record of those who swore allegiance to the revolutionary state is available at "Names of Persons Who Took the Oath of Allegiance to the State of Pennsylvania Between the Years 1776 and 1794," Pennsylvania Archives, Second Series, vol. 3, 3-86. A different version is in Thompson Westcott, ed., Names of Persons Who Took the Oath of Allegiance to the State of Pennsylvania, Between the Years 1777 and 1789, With a History of the 'Test Laws' of Pennsylvania (Philadelphia: John Campbell, 1865). A surprising number of disaffected citizens are listed as taking the patriot oath, which naturally questions the measure's efficacy.

${ }^{44}$ July 1 was set for general compliance and August 1 for the frontier counties.

${ }^{45}$ Stephen R. Taaffe, The Philadelphia Campaign, 1777-1778 (Lawrence, KS: University Press of Kansas, 2003), 45; John W. Jackson, With the British Army in Philadelphia 1777-1778 (San Rafael, CA: Presidio Press, 1979), 5-8.
} 
Israel, James and John Pemberton, Thomas Wharton Sr., and Henry Drinker - to Virginia for refusing to sign paroles or take the test oath. More malleable suspects of disaffection such as Provost William Smith, the Reverend Thomas Coombe and Phineas Bond signed paroles promising good behavior, made arrangements to the satisfaction of radicals, or fell through the cracks and avoided expulsion. ${ }^{46}$ As British forces neared the capital, Congress bolted to York. The state government fled to Lancaster. A wave of apprehensive revolutionaries in southeastern Pennsylvania also absconded. After defeating Washington's troops at Brandywine, General Charles Cornwallis entered Philadelphia at the head of His Majesty's army on September 26, 1777, accompanied by a notable entourage of former residents who had embraced royal aims. Crowds lined the streets to welcome the restoration of monarchical rule. When a patriot counterattack at Germantown on October 4 failed to dislodge the British, the captive city became a refuge for loyalists who feared rebel retribution and abuse elsewhere. Travelers crisscrossing to and fro enhanced volatility. ${ }^{47}$

During the subsequent nine-month British occupation, the radical assembly honed the Test Act with two supplements and fine-tuned penalties for non-associators. Most significantly, it added attainders as a new procedural vehicle to legally arrest, detain,

\footnotetext{
${ }^{46}$ These cases are explored in-depth in later chapters. For Congress' recommendation to imprison "late crown and proprietary officers," Journals of the American Congress: From 1774 to 1788. In Four Volumes. (Washington: Way \& Gideon, 1823), vol. 2, July 31, 1777, 210. For the Pennsylvania Supreme Executive Council's orders to detain Penn, Chew, Smith, Coombe, Bond and a host of others, see Warrant to Arrest Certain Persons, Pennsylvania Archives, First Series, vol. 5, August 1, 1777, 478-480. The most comprehensive treatment of the arrest and deportation of the Quakers is Thomas Gilpin, ed., Exiles in Virginia with Observations on the Conduct of the Society of Friends during the Revolutionary War, Comprising the Official Papers of the Government Relating to that Period. 1777-1778. (Philadelphia: Published for the Subscribers, 1848; Kessinger Legacy Reprint). Gilpin bases his text on official council records and supplements it with firsthand diary and journal entries.

${ }^{47}$ Robert Morton, “The Diary of Robert Morton," Pennsylvania Magazine of History and Biography (hereafter PMHB), vol. 1, no. 1 (1877), 7-8; James Allen, "Diary of James Allen, Esq., of Philadelphia, Counsellor-At-Law, 1770-1778," PMHB, vol. 9, no. 3 (October, 1885), 291.
} 
prosecute and punish those suspected of infidelity to the Revolution. When the General Assembly was not in session, the Council of Safety led by Thomas Wharton Jr. exercised provisional powers from its Lancaster exile that included the ability to seize the property of local collaborators who "wickedly joined themselves to our unnatural enemies."48 Legislators revisited the allegiance question in October of 1777 in the midst of military defeat, general chaos, and a territorial reconfiguration dominated by Britishoccupied Philadelphia. The Test Act helped determine who was who but had not proven effective in procuring the fidelity of many. The bill which followed admitted as much, dryly declaring that it had been "found upon experience that the said act does not fully answer all the good purposes by the same act intended." In other words, it had no bite. This corollary to the original hardened penalties and lowered the age of compliance from eighteen to sixteen for white males. A single witness could force those under suspicion for disaffection to present their certificate of allegiance or take the oath. Refusal carried a penalty of prison without bail pending compliance. State residents traveling outside of their city or county of residence merited special attention. Moreover, no one could be admitted as security for the accused unless they too had taken the test. As with voter rolls, radicals only trusted those verifiably patriotic. The doubling-down on penalties for failure to affirm allegiance underscores the importance radicals placed on conformity throughout the war. They refused to recognize any middle ground and used the law to force even the timid to take a stand. Submission by legal coercion - even if insincere - was a lesser evil

\footnotetext{
${ }^{48}$ In Council of Safety, Lancaster, $21^{\text {st }}$ October, 1777 (Lancaster, PA: Francis Bailey, 1777), Early American Imprints, Evans 15529, LCP.
} 
than neutrality or indifference, while refusal to take the oath was interpreted as a surefire sign of disaffection regardless of the underlying reason for denial. ${ }^{49}$

Three weeks after passage of this first supplement to the Test Act, rebels received word that English general John Burgoyne had suffered a catastrophic defeat at Saratoga in New York. ${ }^{50}$ The loss triggered a diplomatic chain of events culminating in the Franco-American alliance of February 1778 and the strategic decision of Lord North's ministry in London to abandon Philadelphia. ${ }^{51}$ In the interim, the General Assembly at Lancaster approved new regulations against the disaffected on April 1 increasing penalties on inheritances, reducing legal rights in court, imposing double taxation, and curtailing participation in select professions. Doctors, merchants, professors, attorneys, schoolteachers and the like under patriot suspicion were "ipso facto adjudged incapable and disabled in law... to have, occupy or enjoy the said preferment or preferments [,] office or offices, employment or employments." Any two justices of the peace could summon suspects to appear before them to take the oath and failure to obey could result in a three-month jail sentence, fines not exceeding ten pounds plus legal costs, and banishment, the forfeiture of goods and chattels to the state, and the immediate bequest of

\footnotetext{
${ }^{49}$ Statutes At Large of Pennsylvania, vol. 9, "A Supplement to the Act, Entitled 'An Act Obliging the Male White Inhabitants of This State to Give Assurances of Allegiance to the Same and for Other Purposes Therein Mentioned,"” October 12, 1777, Chapter 765, 147-149.

50 “The Diary of Robert Morton,” PMHB, vol. 1, no. 1 (1877), 26-27. Residing in Lancaster, James Allen mentioned rumors of Burgoyne's possible disaster as early as October 15, 1777, but he did not receive conclusive proof until November 2, 1777. "Diary of James Allen," PMHB, vol. 9, no. 3 (October, 1885), 295 \& vol. 9, no. 4 (January, 1886), 424.

${ }^{51}$ For terms of the French alliance, see United States Continental Congress, The articles, published by Congress, of a treaty of amity and commerce, and of a treaty of alliance between the crown of France and these United States... (Lancaster, PA: John Dunlap, 1778), Early American Imprints, First Series, Evans 16145, LCP; Treaty of Alliance between the United States and France, February 6, 1778, Avalon Project, Yale University, College of Law, http://avalon.law.yale.edu/18th century/fr1788-2.asp last accessed on January 13, 2015.
} 
real estate to heirs who had taken the oath. Republican citizenship required tested accreditation.

Further sections of the security law dealt with disarmament; the need for travelers to and from British-occupied Philadelphia to obtain passes from authorities to prevent visitors from "giving intelligence to the enemy"; permission for those who wanted to leave and had not been attainted to sell their property within ninety days with consent of the Supreme Executive Council; and a clause asking ex-colonial government officials "who do now hold or exercise any office or offices by commission or commissions under the authority of the said Crown of Great Britain... [to] renounce such commission or commissions by taking the oath of allegiance... [or] be treated as an enemy or enemies of the state." ${ }^{, 52}$ This last provision shows that, two years after independence, allegiance in Pennsylvania remained blurred as a result of earlier imperial commitments.

Militia concerns also resurfaced at this time, especially the state's failure to collect non-associator fines under prior resolutions. Lamenting this administrative breakdown "to the great discouragement and dissatisfaction of the spirited and virtuous associators in this state," legislators set up procedures for enforcing collection of the $£ 3.10$ fine prescribed by the law of April 5, 1776. Judging from a subsequent June statute addressing additional procedural delays, these efforts did not fare well. ${ }^{53}$ Notably, the assembly approved its first comprehensive modification of militia laws in the spring of

\footnotetext{
52 Statutes At Large of Pennsylvania, vol. 9, "An Act for the Further Security of the Government," April 1, 1778, Chapter 796, 238-245.

${ }^{53}$ Statutes At Large of Pennsylvania, vol. 9, “An Act for Directing the Mode of Collecting the Fines Imposed on Persons Who Did Not Meet and Exercise in Order to Learn the Art Military According to the Resolves of the Late Assembly of Pennsylvania," February 14, 1777, Chapter 742, 49-55; ibid., vol. 9, "A Supplement to the Act, Entitled 'An Act Directing the Mode of Collecting the Fines Imposed on Persons Who Did Not Meet and Exercise in Order to Learn the Art Military According to the Resolves of the Late Assembly of Pennsylvania,"' June 18, 1777, Chapter 758, 124-128.
} 
1777. A key clause introduced surrogates as an alternative to personal militia service. Those unwilling or unable "to serve in person" had to "find a sufficient person for a substitute." For the disaffected or indifferent who disregarded service or substitutes, the law authorized militia lieutenants to find replacements on reasonable terms and charge the corresponding amount. Refusal to pay subjected the negligent to the "distress and sale of his goods and chattels, lands and tenements." The new formula had the state procuring a stand-in while the offender's estate financed the effort. If proxies could not be found, officials set fines in the amount of the average cost of a substitute within each battalion. In December, the assembly penalized the estates of non-associators "an additional sum equal to what such person shall be charged in the state tax" - in effect, double taxation. ${ }^{54}$ Over two years, militia penalties had evolved from a vague "time equivalent" with exceptions for religious scruples, to concrete one-time monetary fines and obligatory service for all, to monthly levies and annual estate charges, to compulsory substitutions and double taxation. Radicals clearly expected everyone to carry their fair share of the revolutionary load.

With treason delineated and test oaths furnishing evidence on allegiance, revolutionaries harnessed the concept of attainders to the anti-disaffection cart. Attainders provided a methodology for punitive action against the Crown's devotees. Rooted in a presumption of guilt, this legal tool expedited prosecutions and rapidly became the most implacable of the retaliatory devices employed against the opposition. Attainders called out those suspected of infidelity by name and instructed them to surrender for trial by a

\footnotetext{
${ }^{54}$ Statutes At Large of Pennsylvania, vol. 9, "An Act to Regulate the Militia of the Commonwealth of Pennsylvania," March 17, 1777, Chapter 750, 82-83; ibid., vol. 9, "An Act for Making More Equal the Burden of the Public Defense and for Filling the Quota of Troops To Be Raised in This State," December 26, 1777, Chapter 773, 167.
} 
specified date. Failure to do so automatically validated guilt. In actual practice, the cases of many attainted citizens ended in discharge or acquittal, especially when defendants dared to face officials at a hearing or trial and few witnesses or evidence materialized. For the accused whose absence automatically rendered a guilty verdict, only an official pardon could overturn the tint of sedition, a major obstacle to later reintegration. ${ }^{55}$

Surrender for trial could also result in a conviction, though such cases were actually rare. The individual decision to test revolutionary judicial waters was thus laden with risk. ${ }^{56}$ Philosophically, the negative premise of attainders contradicted the intrinsically affirmative nature of republican rights. Yet as a technique to quash disaffection, the instrument was a logical extension to the budding anti-loyalist apparatus, supplying a workable mechanism for castigating the blameworthy.

Like treason, attainder theory stemmed from English common law. Sir William Blackstone wrote the following in his Commentaries: "For when it is now clear beyond all dispute, that the criminal is no longer fit to live upon this earth, but is to be exterminated as a monster and a bane to human society, the law sets a note of infamy upon him, puts him out of it's [sic] protection, and takes no farther care of him than barely to see him executed. He is then called attaint, attinctus, stained or blackened. He is

\footnotetext{
${ }^{55}$ For a census of pardons both during and after the war, see Henry James Young, "The Treatment of the Loyalists in Pennsylvania," (PhD. Dissertation, Johns Hopkins University, 1955), Appendix XI, "A List of Proclaimed Traitors Who Were Pardoned," 400-401.

${ }^{56}$ Anne Ousterhout has conducted an excellent statistical study on 1,398 legal prosecutions in Pennsylvania against the disaffected. Of the 639 cases of high treason cited (not all of which involved attainders), the revolutionary government attainted 116 who surrendered within the respective attainder proclamation's time limits for trial. Of these, 91 (or 78.4\%) were discharged without a trial. Of the 25 who went to trial, only 3 were found guilty and one of these received a pardon. Thus, the rate of conviction was $2.6 \%$ for attainted 'on-time' surrenders. See Ousterhout, A State Divided, Appendix: Offenses and Punishments of the Disaffected, 319-323. We must keep in mind, however, that those charged with disaffection had no way of knowing what results would be when they made their decision to surrender for trial or to depart.
} 
no longer of any credit or reputation; he cannot be a witness in any court; neither is he capable of performing the functions of another man: for, by an anticipation of his punishment, he is already dead in law." Blackstone clarified that death in law occurred only after judgment, not during the time of indictment, since it was possible that the accused could be found not guilty and thus pardoned. "Upon judgment therefore of death, and not before," he continued, "the attainder of a criminal commences: or upon such circumstances as are equivalent to judgment of death; as outlawry on a capital crime, pronounced for absconding or fleeing from justice, which tacitly confesses the guilt. And therefore either upon judgment for outlawry, or of death, for treason or felony, a man shall be said to be attainted." He concluded by pointing out that forfeiture was one of the principal penalties of attainder.

Blackstone's appraisal encapsulates the fundamentals of Pennsylvania attainder statutes while demonstrating how rebel concern for the rule of law stemmed from the same political tradition as their English adversaries. Revolutionary attainders treated the accused as a pariah who "had a note of infamy upon him" and as "a bane to human society"; and in select execution cases quite literally as a "criminal... no longer fit to live upon this earth." They prohibited the attainted from serving on juries, comparable to the eminent jurist's “cannot be a witness in any court." In turn, not "capable of performing the functions of another man" and "no longer of any credit or reputation" became the state's basis for annulling the rights of citizenship - or becoming "dead in law." English precedent allowed for the forfeiture of real and personal property and permitted pardons, key procedural elements the Pennsylvania General Assembly instituted and the Supreme Executive Council implemented from 1778 onward. Most important of all, an attainder's 
presumed culpability was a replication of the "absconding or fleeing from justice, which tacitly confesses the guilt" phrase in the Commentaries. Such was the interpretation Pennsylvania's radical patriots chose to adopt: guilt was assumed until proven otherwise. It was incumbent on the accused to exculpate himself. ${ }^{57}$

What strikes the modern scholar of attainders most glaringly is the disappearance of such an unyielding concept in American jurisprudence. This lapse is not coincidental. Postwar patriots well understood the paradox of liberty vs. attainders, since they had applied its tenets so admirably during the conflict. A little celebrated but crucial clause of the 1787 Constitution of the United States tersely states "No bill of attainder or ex post facto Law shall be passed." The entry equates attainders with laws that have a retroactive effect. Federal constitutional convention delegates saw both as unfair. Conspicuously, the attainder reference is an integral component of the first of seven articles in the original constitution sent to the states for ratification, not part of the amendments incorporating the Bill of Rights proposed later. The timing suggests it was a high priority item. A similar clause prohibiting the states from passing attainders on their own immediately follows. ${ }^{58}$ The nation's founders knew attainders were inherently antithetical to freedom - and they made sure the nascent republic did not do what they had once done. ${ }^{59}$

\footnotetext{
${ }^{57}$ Blackstone, Commentaries on the Laws of England, Book the Fourth, Chapter 29, 380-381 (emphasis in the original). The gendered reference to "himself" is intentional - only one woman was attainted in Pennsylvania during the war and her case was adjudicated with her husband.

${ }^{58}$ The Constitution of the United States and The Declaration of Independence (Washington, DC: Superintendent of Documents, U.S. Government Printing Office), Article I, Section 9, p. 8. The clause on the states is in Article I, Section 10. For an outstanding conceptual analysis of attainders, see Brett Palfreyman, "Peace Process: The Reintegration of the Loyalists in Post-Revolutionary America," (Ph.D. Dissertation, Binghamton University, 2014), Chapter 5, "Bills of Attainder," 260-292.

${ }^{59}$ According to James Madison, Elbridge Gerry of Massachusetts and James McHenry of Maryland proposed the bills of attainder clause on August 22, 1787. Gerry "urged the necessity of this prohibition"
} 
The radical General Assembly passed the Pennsylvania attainder law on March 6, 1778. In "An Act for the Attainder of Divers Traitors," prominent "subjects and inhabitants of the state of Pennsylvania" who "have most traitorously and wickedly, and contrary to the allegiance they owe to the said state, joined and adhered to and still do adhere to and knowingly and willingly aid and assist the army of the King of Great Britain, now enemies at open war against this state and the United States of America." ${ }^{, 61}$ Most repulsive was the ongoing notoriety of these defectors, for they "yet remain with the said enemies in the city and county of Philadelphia, where they daily commit divers [sic] treasonable acts without any sense of honor, virtue, liberty or fidelity to this state." The passage of such a measure while the king's forces occupied the state's southeastern region was an act of open defiance. Patriots were weeks away from suspecting a mass British evacuation and as yet unaware of the promise of an alliance with France. In this no-news vacuum, the assembly gave the thirteen attainted malefactors until April 20 to report for prosecution. Failure to "abide their legal trial for such their treasons" by the prescribed date would render them "adjudged, and by the authority of this present act be convicted and attainted of high treason," subjecting them

\footnotetext{
because he thought attainders were "to be feared." Gouverneur Morris - a New Yorker representing Pennsylvania - agreed, declaring the precaution "essential." No one else is cited as offering an opinion. The motion on bills of attainder was passed nemine contradicente - without opposition, or literally "no one contradicting." The unanimity and lack of debate suggest a broad consensus existed among convention delegates on the history and magnitude of the issue. See James Madison, Notes of Debates in the Federal Convention of 1787 Reported by James Madison (New York: W. W. Norton \& Co., 1966), 510-511.

${ }^{60}$ The legislative act establishing attainders was itself an attainder, but it then gave the Supreme Executive Council authority to issue subsequent attainder proclamations on their own that did not require additional legislation. The term "attainder" in this study refers to both legislative acts and council proclamations.

${ }^{61}$ The thirteen were Joseph Galloway, Andrew Allen, John Allen, William Allen Jr., James Rankin, Jacob Duché, Gilbert Hicks, Samuel Shoemaker, John Potts, Nathaniel Vernon, Christian Fouts, Reynold Keen and John Biddle.
} 
to the full fury of the law. The "suffer death" penalty in the February 1777 treason law suddenly bore very sharp teeth. ${ }^{62}$

Despite the tailored indictments, radicals did not aim the original attainder bill solely at thirteen obnoxious turncoats. Their larger concerns were twofold: fix the procedural parameters for dealing with current and future traitors; and design a system facilitating the seizure of loyalist property. The bulk of the fifteen-page act responds to these concerns. Procedurally, the legislation attainted commonwealth inhabitants who "knowingly and willingly aid and assist the enemies of this state or of the United States of America by having joined their armies" or who "hereafter shall do the same." Bearing arms against the cause of liberty continued to be a primary motive for prosecution. The bill projected into the future, targeting those who "from and after the publication of this act... willingly and voluntarily serve the King of Great Britain either by land or sea as a civil or military officer, soldier or seaman." The language made clear that treason could be a civil as well as a military activity.

Given later practice, the provisions for seizure of real and personal property proved to be the most significant features of the attainder statute. Forfeiture authorized retribution without the need to resort to bloodletting. Lawmakers considered it "highly reasonable" that the assets of those "engaged in the present most unnatural, unjust, barbarous and execrable war... should be discovered and applied to the use of the

\footnotetext{
${ }^{62}$ Statutes At Large of Pennsylvania, vol. 9, "An Act for the Attainder of Divers Traitors if They Render Not Themselves by a Certain Day, and for Vesting Their Estates in This Commonwealth, and for More Effectually Discovering the Same and for Ascertaining and Satisfying the Lawful Debts and Claims Thereupon," March 6, 1778, Chapter 784, 201-202. News of the French alliance arrived in Philadelphia on May 2, 1778. See Middlekauff, The Glorious Cause, 411.1
} 
state. ${ }^{, 63}$ Confiscation's almost universal application against those found guilty of treason probably spared the lives of many. Because patriots of all views tended to adhere strictly to the limits of the law, real property could be litigated, even after forfeiture, in cases when the law itself was contradictory or not followed correctly. As a result, the confiscation issue stayed in the public eye longer than any other postwar disaffection problem and presented the state with an especially knotty reintegration challenge evident in property restitution proceedings that sometimes extended into the nineteenth century.

As elsewhere, revolutionary justification for forfeiture came from English common law. Here is Sir William Blackstone anew, for whom forfeiture was "twofold; of real and personal estates," a natural outcome of the blemish of attainder. The eighteenth century magistrate underscored that a man attainted of treason "forfeits to the king all his lands and tenements of inheritance... which he had at the time of the offense committed, or at any time afterwards, to be forever vested in the crown. ${ }^{, 64}$ The General Assembly took the essence of this legal theory and traded the word "state" for "crown" and "king," crafting republican innovation from British constitutional tradition.

For those guilty of treason, the March attainder act authorized the seizure of "all and every the lands, tenements, hereditaments, debts or sums of money, or goods or chattels whatsoever, and generally the estates real and personal of what nature or kind soever they be within this state." The law drew July 4, 1776 as the grand fault line

\footnotetext{
${ }^{63}$ Statutes At Large of Pennsylvania, vol. 9, "An Act for the Attainder of Divers Traitors...," March 6, 1778, Chapter 784, 201-203. The last twelve of the act's fifteen pages deal with structuring attainder procedures, 203-215.

${ }^{64}$ Blackstone, Commentaries on the Laws of England, Book the Fourth, Chapter 29, 381.
} 
demarcating the pre and post treason eras. ${ }^{65}$ The Declaration of Independence had erased blurred lines like the "opinions" of delegates to Congress in the Tory Act encouraging loyalist disarmament. For a first-time stab at the myriad possibilities forfeitures entailed, legislators did an excellent job. Rolfe Lyman Allen - who compiled and contrasted the confiscation laws of all the rebellious colonies - noted admiringly that the Pennsylvania assembly approached the issue "with legal skill and attention to administrative details most unusual in the hastily prepared legislation of this troubled era." ${ }^{66}$ Whigs gave ample consideration to complicated issues such as creditors' claims on attainted estates, debts owed by the attainted, tenants on attainted land, prior conveyances of property, state use of unsold lands, methods for gathering information on people and property, incentives for those who "discovered" concealed assets of the accused, documentation of all real and personal property, and the responsibilities of appointed commissioners, the state attorney general, treasurer, and supreme court. Allen's analysis is spot on for the legal structure itself, but early enforcement was not always on par with the law's finer points - often to the benefit of the disaffected.

Forfeited loyalist estates were "to be sold by auction to the best and highest bidder... within twelve months after the debts and claims upon the said estates shall be respectively adjudged." Proceeds went to the state for prosecution of the war: tories were to fund the revolution's success. Provisions also protected infants, wives, and "madmen,

\footnotetext{
${ }^{65}$ Statutes At Large of Pennsylvania, vol. 9, "An Act for the Attainder of Divers Traitors...," March 6, 1778, Chapter 784, 203-204.

${ }^{66}$ Rolfe Lyman Allen, "The Legislation for the Confiscation of British and Loyalist Property during the Revolutionary Era," (Ph.D. Dissertation, University of Maryland, 1937), 79. Chapin comes to a similar comparative conclusion drawn from a loyalist angle, noting "the most drastic was the Pennsylvania [confiscation] law.” Bradley Chapin, The American Law of Treason, 76.
} 
idiots, or lunatics" linked to the disaffected. Sedition was a private offense and penalties could not be extended to heirs or relations. On the other hand, a prescient clause closed potential legal loopholes, stipulating that title transfers to wives, heirs or relations after July 4, 1776 "are hereby declared to be and shall forever hereafter be deemed to be fraudulent and no claim shall hereafter be allowed for the same." The disaffected could not convey property to someone of trust to elude confiscation. ${ }^{67}$ Even so, some would try.

As the main penalty for loyalists found guilty of subversion, patriots saw the attainder's seizure of real and personal property as a coherent corollary to the treason and test oath laws imposed earlier. Each set of measures flowed smoothly and sequentially into the next. Application of forfeiture law completed the series and gave the other precepts a tangible sting. The correlation between property and reintegration later proved crucial for many of the disaffected who had their birthright or lifetimes of industry upended by the stroke of a rebel pen. Those unable to recover lost property or who saw such an enterprise as innately futile often stayed away. Yet obscured within the morass of confiscatory anguish, the legalized seizure of loyalist property had an unexpected upside for the politically marginalized: forfeiture gave authorities a peaceful means to redirect and placate bottom-up revolutionary ardor. If patriots had not applied confiscation as the dominant punitive alternative against the disaffected, it is probable that violence would have escalated and the struggle for independence would have looked a great deal more like later revolutionary upheavals around the globe. ${ }^{68}$ In Pennsylvania, the enticement of property seizures - encased within the constraints of the law - transcended the lust for

\footnotetext{
${ }^{67}$ Statutes At Large of Pennsylvania, vol. 9, "An Act for the Attainder of Divers Traitors...," March 6, 1778, Chapter 784, 205-215.

${ }^{68}$ The violence of the French, Haitian, Russian, Chinese, Cuban, and Cambodian revolutions come to mind.
} 
blood, mollified popular desire for stiffer reprisals, and enhanced long-term reintegration success. Unfortunately, these outcomes offered little comfort to those who suffered the loss of their property. Administratively, the attainder act assigned the Supreme Executive Council the mission of identifying traitors by way of published proclamations configured in set language. Prospective quislings were afforded up to forty days to surrender. ${ }^{69}$

The council under the leadership of radicals Thomas Wharton Jr. and George Bryan quickly proved themselves up to the task, issuing three attainder proclamations during May and June of $1778 .{ }^{70}$ By then, rumors abounded regarding an imminent British evacuation from Philadelphia. The buzz blended with more certain knowledge that Sir William Howe had resigned his command and was heading for England. On May 8, the council attainted 57 loyalists. On May 21, another 75 Pennsylvanians faced similar charges. Between these two dates, the outbound British general received the lavish tribute of subordinates and locals at the notoriously opulent Meschianza feast organized by Major John André, royal officers, and leading loyalists. On the day of the second May attainder proclamation, recently arrived British commander Sir Henry Clinton confessed to Philadelphia loyalist Samuel Shoemaker that his army was indeed leaving, suggesting that the disaffected do what they could to make peace with the rebels. ${ }^{71}$ Elizabeth Drinker's diary contains this entry two day later: "the Army tis thought are going in reality to leave us - to evacuate the City - some hope tis not the case, tho' things look

\footnotetext{
${ }^{69}$ Statutes At Large of Pennsylvania, vol. 9, "An Act for the Attainder of Divers Traitors...," March 6, 1778, Chapter 784, 201-202.

${ }^{70}$ Supreme Executive Council President Thomas Wharton Jr. died in Lancaster on May 22, 1778. He was either 42 or 43 years of age. Council Vice-President George Bryan temporarily assumed the presidency.

${ }^{71}$ Taaffe, The Philadelphia Campaign, 191-192; Jackson, With the British Army in Philadelphia, 251. The May $18^{\text {th }}$ Meschianza has been the object of ongoing fascination and is treated extensively in the literature. For example, Scharf \& Westcott, History of Philadelphia, 377-382.
} 
like it - many of the Inhabitants are preparing to go with them." Only three days before the withdrawal, the Bryan-led radical council attainted 198 more residents. This June 15 proclamation came after fleeing loyalists had boarded British ships and anxiously awaited departure in the Delaware River harbor. In total, state officials formally charged 343 loyalists with high treason before Sir Henry Clinton's army abandoned the city, comprising the peak of attainder proclamations for the full war. ${ }^{72}$

Rebels hurriedly returned to the capital in the evacuation's aftermath. They found substantial devastation and disarray, despite the fact that British commanders had refrained from ordering troops to destroy the city. Radical Whigs reinstituted government swiftly. Since the king's forces would never return to Pennsylvania despite sporadic rumors to the contrary, ${ }^{73}$ from that point forward rebel leadership exercised a free hand over matters of fidelity without fear of repercussions. The radical-dominated government had not only survived military defeat and expulsion but, paradoxically, consolidated its hold on provincial power while it was away.

\section{LOYALIST CHOICES \& THE RADICAL ZENITH (June 1778 - November 1781)}

Enforcing allegiance, upholding the rights of the revolutionary faithful, and implementing the radical Constitutionalist vision of the rule of law characterized the third phase of the patriot response to loyalism and disaffection. As a key component of that

\footnotetext{
${ }^{72}$ Elaine Forman Crane, ed., The Diary of Elizabeth Drinker: The Life Cycle of an Eighteenth-Century Woman (Philadelphia: University of Pennsylvania Press, 2010), May 23, 1778, 77. For the three Supreme Executive Council pre-evacuation attainder proclamations issued from Lancaster, Colonial Records, vol. 11, May 8, 1778, 481-485; May 21, 1778, 493-495; and June 15, 1778, 512-518.

${ }^{73}$ A notable 'return' incident is related in George W. Kyte, “A Projected British Attack upon Philadelphia in 1781," PMHB, vol. 76, no. 4 (October, 1952), 379-393. Rumors circulated each time patriots received intelligence that British troops at New York boarded navy ships. The imperial ministry's southern strategy featured separate post-1778 attacks on Savannah, Charleston, and Wilmington, North Carolina, as well as deployments to the Caribbean. Each occasion triggered fears of a renewed assault on Philadelphia.
} 
vision, radicals expropriated the bulk of the lands still in possession of the Penns and abolished the proprietary encumbrance once and for all. At the same time, the process of reintegration began for disaffected residents who chose to stay in Pennsylvania after the British evacuation. For these, fear and uncertainty marked much of the period. A great deal of patriot effort also went into tightening existing anti-loyalist legislation, in most cases stiffening penalties, restricting rights and further isolating the disaffected. The daily reality of the legal order under the radicals did not live up to expectations, however, as scarcity, disorder and instability plagued revolutionaries and disaffected alike. Radical failures ushered in a new era of growing moderate dominance.

Loyalists and the disaffected faced a critical choice in June 1778: to stay and face patriot ire or to accompany the British army and face an uncertain future. Fear of patriot retaliation headed the list of motives for removal. The hard language of the treason, test and attainder statutes magnified fears. Because of the personalized nature of attainders, the attainted confronted higher risks than those not so charged. The council published all attainder proclamations demanding that defendants surrender for trial and submit to the verdict of a potentially ill-disposed tribunal. To be attainted was thus to be placed in a distinctive and precarious legal category. For the accused, reintegrative alternatives reflected this daunting prospect.

Not surprisingly, many left. Estimates of loyalist evacuees from Philadelphia range from three to five thousand. Hessian Captain Johann Heinrichs projected "about one thousand royally inclined families... willing to leave hearth and home and with their chattels go with the army." The Earl of Carlisle, who headed the king's recently arrived and doomed Peace Commission, referred to "about three thousand of the miserable 
inhabitants embarked on board our ships," while William Eden, also member of the commission, assessed the number of evacuees at five thousand. ${ }^{74}$ York County notables James and John Rankin were among those who departed. So did Richard Hovenden, Jacob James, William Thomas, Thomas Sandford and Alfred Clifton, officers in His Majesty's loyalist regiments recruited during the occupation of Philadelphia. All but Sandford had been attainted prior to the evacuation. So too did ordinary loyalists forsake their homeland, men like laborer Jacob Holder, carpenter Joseph Paxton, tallow chandler Thomas Badge, and farmers Samuel Custard Jr., Hugh Pugh, and Henry Steininger. ${ }^{75}$ Concern for the safety of this civilian mass forced the British commander to alter his original plans for a military evacuation to New York by sea. Instead, General Clinton decided to deploy British shipping primarily for loyalist refugees and march his soldiers north across New Jersey. His decision led to the dramatic engagement with Washington's Continental Army at Monmouth. The loyalist presence thus dictated British strategy. Without the refugee burden, the battle of Monmouth may never have occurred.

For both the departed and those who stayed, imperial withdrawal signaled the opening chapter in the reintegration drama. In Pennsylvania, reestablishment of patriot government and implementation of the Constitutionalist legislative and political agenda

\footnotetext{
${ }^{74}$ Johann Heinrichs, "Extracts from the Letter-Book of Captain Johann Heinrichs of the Hessian Jäger Corps, 1778-1780," PMHB, vol. 22, no. 2, (1898), 145; Carlisle is cited in Wilbur H. Siebert, The Loyalists of Pennsylvania (Columbus: Ohio State University, 1920), 52; William Eden to Alexander Wedderburn in Jackson, With the British Army in Philadelphia, 260. Andrew Jackson O'Shaughnessy aptly refers to the Carlisle Peace Commission as "stillborn" because its members were unaware that the king had already authorized an evacuation, thereby destroying any possibility of successfully negotiating peace with the Continental Congress. See O'Shaughnessy, The Men Who Lost America: British Leadership, the American Revolution, and the Fate of the Empire (New Haven: Yale University Press, 2013), 63. General William Howe's population census of Philadelphia in the fall of 1777 calculated more than 23,000 residents. This number probably increased in subsequent months as loyalists in the vicinity sought refuge from patriot retribution in the surrounding countryside. Assuming a population of 30,000 at evacuation, the exodus implicated at minimum anywhere from $10 \%$ to $17 \%$ of the urban population.

${ }^{75}$ All of these loyalists are treated in later chapters.
} 
took up much of the immediate post-evacuation period. Because speaker John Bayard's radical assembly was more concerned about applying the posited fidelity framework than further elaborating its structure, George Bryan's Supreme Executive Council and the courts played a more prominent role than the legislature through the remainder of 1778 and the years closely following. Radical officials launched a wave of arrests in August as a response to a popular uproar resulting from the destruction caused by the British occupation. Treason trials began in late September and continued into the following spring. Authorities executed two Quakers convicted of high treason in early November. ${ }^{76}$ By year's end, reprisals had satiated popular ardor somewhat and radicals were firmly entrenched in power. Political instability and economic scarcity plagued radical government, though. Benedict Arnold, who George Washington had named commandant of Philadelphia, contributed to this uncertainty. Seeking status and enrichment, Arnold affiliated himself from the onset of his tenure with wealthy citizens of dubious allegiance to the Revolution and quickly garnered local radical displeasure and hostility. ${ }^{77}$ Other factors added fuel to the fire. A dearth of key staples such as flour led to popular ferment. Radicals adopted policies such as price controls which ultimately backfired, provoking discontent among the very sectors they tried to satisfy. Public opinion frequently blamed the disaffected who had chosen to stay for the prevailing insecurity, resulting in a series of violent incidents. Response to these confrontations led to intrarevolutionary clashes

\footnotetext{
${ }^{76}$ The two Quakers were Abraham Carlisle and John Roberts, protagonists of a later chapter.

${ }^{77}$ Arnold entered the merchant trade in Philadelphia and became a business associate of Joseph Stansbury who had a history of suspect loyalty. Arnold also chose to socialize with the circle of Edward Shippen IV, also of questionable loyalty at the time. He courted and soon married Shippen's daughter Margaret (Peggy). See Randolph Shipley Klein, Portrait of an Early American Family: The Shippens of Pennsylvania Across Five Generations (Philadelphia: University of Pennsylvania Press, 1975), 186-189, 304 fn158; Mark Abbott Stern, David Franks: Colonial Merchant (University Park: Pennsylvania State University Press, 2010), 137-140; Scharf \& Westcott, History of Philadelphia, 389-390.
} 
between ruling radicals and disgruntled lower orders. ${ }^{78}$ Despite these events, the radical faction continued to win elections and dominate government for the moment.

Enforcement of the allegiance agenda led the Supreme Executive Council under radicals George Bryan and then Joseph Reed to issue seven attainder proclamations from post-evacuation 1778 to $1781 .{ }^{79}$ An October 1778 attainder coincided with popular frenzy over the treason trials and targeted 64 loyalists. It was the first issued after the English had quit the capital. Attainder numbers successively diminished thereafter, since many royalist sympathizers had headed off with the British. Although these departures clearly lessened internal tensions, suspicions over concealed loyalists and enduring disaffection persisted and officials promulgated four more group attainders between 1779 and 1781 . In June 1779, President Reed's council attainted 30 more Pennsylvanians. A year later, they proclaimed 33 more as seditious. After Benedict Arnold's duplicitous leap to the British in September 1780, two additional Reed proclamations attainted a total of 25 more suspected loyalists. The October 2 attainder that year included Arnold himself as one of ten traitors, while one in March 1781 targeted fifteen people - mostly yeomen from seven separate counties, including the first and only woman. Authorities also issued two attainder proclamations directed exclusively at single individuals - one against exile Frederick Kesselman in May 1779 for joining the king's armies and another in April 1781 against William Rankin who had reputedly organized a force of 1500 loyalists in

\footnotetext{
${ }^{78}$ For example, a mob attacked merchant Levy Hollingsworth for speculating with scarce flour in May 1779. See Brunhouse, The Counter-Revolution in Pennsylvania, 69. Rosswurm notes that average prices between December 1778 and April 1779 rose 462 percent, while that "of common flour, beef, sugar loaf, and molasses was almost 70 percent higher in May than in April" despite an assembly embargo meant to put a stop to inflationary increases. See Rosswurm, Arms, Country and Class, 170, 172.

${ }^{79}$ After Vice-President Bryan served out the deceased Wharton's presidential term, Reed was elected council president on December 1, 1778, and served in that post until late 1781.
} 
the countryside and awaited instructions from the British high command in New York for an armed uprising. The group's “unabated zeal in the Royal Cause was never called into Action," however, and the signal never came. All told, the council attainted 154 suspected loyalists for high treason from the evacuation through $1781 .^{80}$ In combination with those accused during the British occupation of Philadelphia, the General Assembly and the Supreme Executive Council proclaimed 498 instances of attainder for treason during the war. ${ }^{81}$ In perhaps the most revealing piece of evidence differentiating the respective approaches of patriot factions towards disaffection, radical majority government was responsible all of the 498 attainders issued during the war.

The Supreme Executive Council's campaign against disaffection culminating in the seizure and sale of loyalist estates and personal property best illustrates the apex of radical power. While the treason law's "suffer death" penalty remained in place into the Federalist period, patriot citizens who made up trial juries generally avoided the prospect of such severe chastisement. ${ }^{82}$ Moreover, many of the attainted no longer resided in

\footnotetext{
${ }^{80}$ For the seven post-evacuation Supreme Executive Council attainder proclamations issued from Philadelphia, Colonial Records, vol. 11, October 30, 1778, 610-612; ibid., vol. 12, June 22, 1779, 27-29; ibid., October 2, 1780, 495-497; ibid., March 20, 1781, 665-666. For Frederick Kesselman only, ibid., vol. 11, March 5, 1779, 768 For William Rankin only, ibid., vol. 12, April 27, 1781, 710-711. The June 27, 1780 Supreme Executive Council proclamation is the only one not in the Colonial Records - see instead William Henry Egle, ed., Pennsylvania Archives (Harrisburg: Clarence M. Busch, State Printer, 1896), Third Series, vol. 10, 537-539. All ten Supreme Executive Council proclamations are also published in this tenth volume of the Third Series, 519-544. The opening and closing attainders promulgated by the General Assembly in 1778 and 1783 are in the Statutes At Large of Pennsylvania and cited elsewhere. William Rankin testimony before the Royal Claims Commission cited in Wallace Brown, The Good Americans: The Loyalists in the American Revolution (New York: William Morrow \& Co., 1969), 116.

${ }^{81}$ Some citizens were attainted more than once. There is also probable, though unclear, redundancy in a few cases involving the spelling of names. It is therefore more precise to add the number of instances cited per attainder than the overall number of attainted individuals. The number 498 reflects attainder instances.

${ }^{82}$ The Pennsylvania assembly under the moderate Constitution of 1790 abolished the death penalty for treason in 1794. See Statutes At Large of Pennsylvania, vol. 15, "An Act for the Better Preventing of Crimes, and for Abolishing the Punishment of Death in Certain Cases," April 22, 1794, Chapter 1777. The treason portion of statute is on 174-175. For an in-depth study of the juries, see Carlton F. W. Larson, "The
} 
Pennsylvania. Officials could not take them into custody. Over time, the confiscation of real and personal property became the preferred mode for penalizing the culpable. Rebel authorities began applying forfeiture penalties for treason almost immediately after retaking Philadelphia. For example, confiscation agents appraised John Wright's seized personal goods on July 3, 1778, only two weeks after the British withdrew. ${ }^{83}$ Sales began in earnest in 1779 , peaked in the later stages of the war, and continued even after the peace. Real estate by far comprised the most valuable seized assets. Agents sold the real property of exiled loyalists at public auction. Many attainted advocates of the king failed to surrender for trial and thereby "admitted" guilt by default. Proceeds from forfeiture sales went to state coffers to fund the war effort. ${ }^{84}$

While the executive branch of government applied the radical repressive program, the legislature tweaked confiscation policies, militia service requirements, and test oaths. In late March and early April 1779, the general assembly headed by speaker John Bayard passed two measures directed at streamlining the sale of forfeited estates and alleviating the state's financial crunch. A March supplement to the attainder act urged officials to sell forfeited estates "with all convenient speed," expedited claims and stacked the law in favor of buyers by protecting their title and placing responsibility for legal miscues on the

Revolutionary American Jury: A Case Study of the 1778-1779 Philadelphia Treason Trials," Southern Methodist University Law Review, vol. 61, no. 4 (2008).

\footnotetext{
${ }^{83}$ Two full volumes of the Pennsylvania Archives are dedicated entirely to "Forfeited Estates, Inventories and Sales." See Thomas Lynch Montgomery, ed., Pennsylvania Archives, Sixth Series, vols. 12 \& 13 (Harrisburg: Harrisburg Publishing Company, State Printer, 1907). For Wright, "Inventory of the Sundry Confiscated household goods and Chattles [sic] of John Wright Taken this $3^{\mathrm{d}}$ July 1778 of the Township of Hatfield in the County of Philadelphia," ibid., Sixth Series, vol. 12, 749.

${ }^{84}$ Officials often attainted loyalists they knew had already departed Pennsylvania. The goal in such cases was not the surrender or capture of the individual but rather to legalize and facilitate the confiscation and sale of their abandoned property.
} 
state - all to promote sales. Pennsylvania needed money. The stalled forfeiture inventory promised a bonanza. ${ }^{85}$

Five days later, “An Act Declaring Replevins, Attachments, Judgments, and Executions in Certain Cases To Be Erroneous and Void" addressed the administrative bottleneck more directly. Replevin meant the provisional recovery of property by persons claiming to own it until the case could be decided in court. Blackstone defined it thus: "To replevy (replegiare, that is to take back the pledge) is, when a person distreined [sic] upon applies to the sheriff or his officers, and has the distress returned into his own possession; upon giving good security to try the right of taking it in a suit at law." 86 That the assembly felt a need for such a statute presupposes a heavy legal backlog. The replevin act went to the straight and narrow. "To the delay of public justice and to the great vexation of the officers concerned," writs were "preventing a proper inquiry into the justice of the claims and demands of such [creditors] suitors... to the great waste of the estates, accumulation of suits and unnecessary costs.” The act declared all such writs “irregular, erroneous and void" and all judgments "entered by virtue of any warrant of attorney... to be void and of no effect." Speed sacrificed process. ${ }^{87}$ Unfortunately for the disaffected, the provincial government's revised enforcement apparatus proved effective. Not only was Pennsylvania "the first of the large states to undertake a policy of general seizure of the estates of those in opposition to the revolution," but state authorities in due

\footnotetext{
${ }^{85}$ Statutes At Large of Pennsylvania, vol. 9, "A Supplement to an Act, Entitled 'An Act for the Attainder of Divers Traitors if They Render Not Themselves by a Certain Day, and for Vesting Their Estates in This Common-wealth, and for More Effectually Discovering the Same and for Ascertaining and Satisfying the Lawful Debts and Claims Thereupon," March 29, 1779, Chapter 832, 328-329, 330-331.

${ }^{86}$ Blackstone, Commentaries on the Laws of England, Book the Third, Chapter 1, 13.

${ }^{87}$ Statutes At Large of Pennsylvania, vol. 9, “An Act Declaring Replevins, Attachments, Judgments, and Executions in Certain Cases To Be Erroneous and Void," April 3, 1779, Chapter 837, 349-350.
} 
course put together a "relatively flexible and efficient administration... standing in marked contrast to the faulty machinery set up in some states." 88

At this highpoint of radical rule, the portions of militia legislation dealing with disaffection concentrated on two main issues: fines for neglecting to serve and the apprehension of those for whom "there is just reason to suspect he is an enemy to the American cause, or that he hath manifested a general disaffection thereunto." Over the course of eighteen months, speaker Bayard's legislature addressed the link between disaffection and militia service six times. An April 1779 bill increased fines from $£ 40$ to $£ 100$. An October measure increased fines again to a range between $£ 100$ and $£ 1000$ and proposed arrests and jail for the disaffected "until the first sitting of the next assembly." A November act rescinded earlier double-taxation penalties on the estates of those above militia age because it was "found by experience to be burdensome and inconvenient" but extended the October provisions for arrests, fines and prison of those required to serve. The assembly passed a major restructuring of the militia in March 1780, stressing that "a well regulated militia is the only safe and constitutional method of defending a free state." This reorganization repealed all earlier fines and set up a new fine-or-jail dichotomy driven by the forced sale of a perpetrator's seized assets. Four days later, an act extending the executive branch's powers to detain and jail disaffected persons passed. Then a September 1780 supplement set fines and penalties for neglect of militia duty at "the average price of common labor by the day in the city of Philadelphia and counties of this state." 89 This year-and-a-half of militia legislation exposes key deficiencies in radical

\footnotetext{
${ }^{88}$ Rolfe Lyman Allen, "Legislation for the Confiscation of Loyalist Property," 78, 96.
} 
government and foreshadows the moderate upswing starting in 1781. Runaway inflation, severe food and supply shortages, ineffective price-fixing, extralegal violence, and class tensions characterized life under revolutionary radicals. The constant readjustment of militia fines to keep up with inflation reflects this dynamic. Unable to fix the value of penalties with any certainty, radicals threw in the towel and linked amounts to the going elastic rate of daily unskilled wages. ${ }^{90}$ Radical control was slipping.

With implementation of attainders and confiscations dictating the council's agenda, fine tuning tests of allegiance dominated the radical legislature's concerns at this time. From September 1778 to October 1779, speaker Bayard's assembly passed four bills on this subject. Like the April 1778 act, lawmakers couched three of the four in terms of security rather than tests. The first security supplement explicitly linked voting rights to the test of allegiance. No one could vote in any election without a certificate asserting that he had taken the oath. In order to ensure compliance, authorities levied a heavy fine on patriot election officials who ignored or violated the test oath stipulation -

\footnotetext{
${ }^{89}$ Statutes At Large of Pennsylvania, vol. 9, "A Further Supplement to the Act, Entitled 'An Act to regulate the Militia of the Commonwealth of Pennsylvania," April 5, 1779, Chapter 843, 381; ibid., vol. 9, "An Act to Empower the Supreme Executive Council and Justices of the Supreme Court to Apprehend Suspected Persons, and to Increase the Fines to Which Persons Are Liable, for Neglecting to Perform Their Tour of Militia Duty," October 10, 1779, Chapter 865, 441-442; Statutes At Large of Pennsylvania, vol. 10, "An Act to Repeal Part of an Act, Entitled 'An Act for Making More Equal the Burden of the Public Defense and for Filling the Quota of Troops To Be raised by This State,' and to Continue for a Longer Time the Act, Entitled 'An Act to Empower the Supreme Executive Council and Justices of the Supreme Court to Apprehend Suspected Persons, and to Increase the Fines to Which Persons Are Liable, for Neglecting to Perform Their Tour of Militia Duty," November 27, 1779, Chapter, 872, 31; ibid., vol. 10, "An Act for the Regulation of the Militia of the Commonwealth of Pennsylvania," March 20, 1780, Chapter 902, 144, 160, 172; ibid., vol. 10, "An Act Further to Continue Such Parts of an Act Entitled 'An Act to Empower the Supreme Executive Council and Justices of the Supreme Court to Apprehend Suspected Persons, and to Increase the Fines to Which Persons Are Liable, for Neglecting to Perform Their Tour of Militia Duty,"” March 24, 1780, Chapter 906, 182-183; ibid., vol. 10, "A Supplement to the Act Entitled 'An Act for the Regulation of the Militia of the Commonwealth of Pennsylvania,"' September 22, 1780, Chapter 916, 226.

${ }^{90}$ In still another example, Rosswurm cites a later $300 \%$ rise in wholesale prices for staples such as flour, beef, sugar loaf, and molasses from October to December 1779 - Arms, Country and Class, 228.
} 
one hundred pounds "for every such offense." Constitutionalists meant to adhere to the letter of the law. Since the vote decided power in a republic grounded on popular sovereignty, radicals wanted to guarantee that only revolutionaries voted, thus elevating their chances at the ballot box. ${ }^{91}$

Three months later, assembly radicals rewrote the loyalty oath itself in a further supplement. The December 1778 wording reveals two important aspects of the ongoing dispute among Pennsylvania factions. First, the idea of a test oath remained highly contested. Second, attempts to accurately target potential enemies of the state had not been entirely successful. This new supplement recognized that many "faithful subjects" had not taken the oath on account of "sickness, absence, want of information, and other unavoidable causes" and confessed that "doubts have also arisen on the construction of said acts" - that is, it had been misinterpreted and contained omissions. ${ }^{92}$

A comparison of the semantics in the original June 13, 1777 oath and the December 5, 1778 redesigned pledge shows the effects of the political transformation that had occurred in Pennsylvania between the British military incursion and the return of patriot government. While both affirmations obligated the oath-taker to "renounce and refuse all allegiance" to the monarch, the first version cited George III by name and the latter only mentioned the "King or crown." Depersonalization shows His Majesty's hegemony in decline. The second version expanded renunciation and refusal to include not only allegiance but all "subjection and obedience" to the king, improper behaviors

\footnotetext{
${ }^{91}$ Statutes At Large of Pennsylvania, vol. 9, "A Supplement to the Act, Entitled 'An Act for the Further Security of the Government,"” September 10, 1778, Chapter 813, 284-286.

${ }^{92}$ Statutes At Large of Pennsylvania, vol. 9, "A Further Supplement to the Act, Entitled 'An Act for the Further Security of the Government," December 5, 1778, Chapter 822, 303-308.
} 
exhibited by loyalists during the occupation. Both oaths also took into account the shift in devotion to the new state, though the later rendering was much less demanding than the first. The binding commitment of "I will be faithful and bear true allegiance to the commonwealth of Pennsylvania as a free and independent state" transmogrified into a two-part assertion that "Pennsylvania is, and of right ought to be, a free, sovereign, and independent state" - an abstract impersonal acknowledgment - and an avowal that "I will at all times maintain and support the freedom, sovereignty and independence thereof." Notably, the newer version jettisoned the word allegiance outright. To "maintain and support" state sovereignty no longer required pure motives of fidelity.

Verb tenses in the two documents also reveal an accommodation with the political shift. The June 1777 oath focused on future behavior, ensuring active participation in the cause. Besides the "I will be faithful" avowal, it insisted that the pledger avoid anything “prejudicial or injurious" to the state's freedom and independence, while simultaneously requiring the detection of antirevolutionary conspirators. On the other hand, the key clauses in the December 1778 oath dealt with past behavior. Using the Declaration of Independence as a fault line, the new oath-taker had to assert that he had never "aided, assisted, abetted or in any wise countenanced the King of Great Britain, his generals, fleets or armies, or their adherents," while having "demeaned myself as a faithful citizen and subject of this or some one of the United States. ${ }^{.93}$ It is especially striking that the December 1778 further supplement reduced the number of penalties for refusal of the oath to a mere four: inability to vote or be elected to office, serve on juries, and double

${ }^{93}$ Comparative oaths are in Statutes At Large of Pennsylvania, vol. 9, "An Act Obliging All White Male Inhabitants of This State to Give Assurances of Allegiance to the Same and for Other Purposes Therein Mentioned," June 13, 1777, Chapter 756, 111-112; and ibid., vol. 9, "A Further Supplement to the Act, Entitled 'An Act for the Further Security of the Government,"” December 5, 1778, Chapter 822, 304. 
taxation. Otherwise, "all other penalties, incapacities and disabilities imposed by any

former acts of assembly shall from henceforth cease and determine."94 The new

conditions reveal radicals' diminished hopes and a desire to simplify the political

panorama. Having discarded the illusion that all inhabitants would agreeably conform,

revolutionaries now assumed the presence of a core of disaffected or indifferent residents

who begrudgingly obeyed the law or would not swear loyalty to government. Howe's

unhappy sojourn into Pennsylvania had slashed expectations.

The December act's language inadvertently created confusion among patriot officials as to whether or not they had to retake the test oath. Three months later, a further supplement to the supplement for further security cleared up possible misunderstandings, specifying that those who had already professed their allegiance did not have to do so again. Responding to pockets of armed disaffection in southeast Pennsylvania, it also reemphasized the need to disarm those "who shall have not taken the oath or affirmation of allegiance" because "such person is suspected to be disaffected to the independence of this state." The measure gave a detailed inventory of the armaments, implying that those to be neutralized had used weaponry types to challenge seizure of their firearms. ${ }^{95}$

\footnotetext{
${ }^{94}$ Statutes At Large of Pennsylvania, vol. 9, "A Further Supplement to the Act, Entitled 'An Act for the Further Security of the Government," December 5, 1778, Chapter 822, 305.

${ }^{95}$ Statutes At Large of Pennsylvania, vol. 9, “An Act for Repealing Part of an Act, Entitled 'A Further Supplement to the Act, Entitled 'An Act for the Further Security of the Government; and for Disarming Persons Who Shall Not Have Given Attestations of Allegiance and Fidelity to This State or Some Other of the United States," March 31, 1779, Chapter 836, 346-348. The armaments in question included "any cannon, mortar, or other piece of ordinance, or any blunderbuss, wall piece, musket, fusee, carbine or pistols or other fire arms, or any hand gun: and any sword, cutlass, bayonet, pike or other warlike weapon." This was a period of heightened guerrilla activity in the counties surrounding Philadelphia such as Bucks and Chester. The Doan gang was the most prominent of these armed bands. Guerrillas or outlaws often did not distinguish between patriots and loyalists. Self-defense therefore explains why people who did not take the oath still considered retaining their arms as justifiable.
} 
In October 1779, radicals stepped up the pressure on the disaffected once again as speaker Bayard's assembly took up test oaths for the final time during the war. "A Further Supplement to the Test Laws of This State" reiterated prior penalties for refusing the oath and added two new conditions: violators could not teach school except in private homes, minimizing the influence of pacifist Quakers prohibited from taking the oath by their sect's discipline; and non-oathtakers "shall be forever excluded... and deprived of the... benefits of a citizen or citizens who shall have complied with this act." Through the imposition of lifelong disenfranchisement, radicals sought to magnify the burden of infidelity and permanently exclude the disaffected from participation in the polity.

Disparate parts of prior justifications for amending the test law came together cohesively in this act and yield insight into the contemporary radical mindset. First, republican government had a right to "exact a test." Second, the failure of many to take the oath was "reasonably apprehended [to be] from disaffection to our late glorious revolution." Next, it was "unjust, as well as impolitic" that "those who refuse to share in common... the dangers of the present contest" enjoy the "blessings of independence." Furthermore, many "inimical to the liberties of the country" could be "induced to assume the mask of friendship" even as they "endeavor to betray those whom they cannot conquer." Finally, test laws were useful "to make a proper and reasonable distinction between those who step forward in the hour of trial, and those who would enjoy the rewards of victory without having contributed towards it, and to guard against secret and deceitful designs." In other words, substantial numbers of people still contested the propriety of tests, many refused to affirm allegiance despite repeated prompting, and 
patriots had to ferret out two-faced traitors before they took action. In the face of such resistance, radicals encouraged greater severity. ${ }^{96}$

These premises underscore the patriot view that disaffection was alive and well in Pennsylvania only fifteen months after the British evacuation, despite clear radical supremacy. ${ }^{97}$ Meanwhile, strains in the relations between competing revolutionary factions intensified. Three days after the October 1 passage of the test law supplement, a radical militia mob incensed over the exorbitant prices of bare necessities began to round up suspected "Tories." Events quickly spiraled out of control and led to a shootout with patriot moderates at the home of James Wilson. The incident came to be known as the battle of Fort Wilson. Faced with bottom-up violence from his own followers, radical council president Joseph Reed led a cavalry charge to reestablish order. He succeeded but alienated supporters in the process. ${ }^{98}$ "A Further Supplement to the Test Laws" stabilized the allegiance issue in the General Assembly for more than half a decade. No further test law legislation came before the Pennsylvania House while the war lasted. When the issue resurfaced during the Critical Period, concern was over reintegration and repeal, not raising the stakes for the onetime disaffected.

In addition to actively combatting loyalism and disaffection, radicals at this time finished the job of ousting the proprietary regime that had governed Pennsylvania since

\footnotetext{
${ }^{96}$ Statutes At Large of Pennsylvania, vol. 9, "A Further Supplement to the Test Laws of This State," October 1, 1779, Chapter 852, 404-406.

${ }^{97}$ Brunhouse has called this period "the highwater mark of Radical democracy in Pennsylvania during the revolutionary period." See The Counter-Revolution in Pennsylvania, Chapter 3: "The Triumph of Radicalism," 53-87. Quote is on 75.

${ }^{98}$ For the Fort Wilson incident, see Gary B. Nash, The Unknown American Revolution: The Unruly Birth of Democracy and the Struggle to Create America (New York: Penguin Books 2005), 318-319; Rosswurm, Arms, Country and Class, 205-227; Brunhouse, The Counter-Revolution in Pennsylvania, 75-76; Ousterhout, A State Divided, 205-206.
} 
the colony's formation in the seventeenth century. While the state Constitution of 1776 had wrested political power from the Penn proprietors, the family still owned large tracts of undeveloped land in the province, territory granted to the Penn heirs in perpetuity by the original royal charter. In effect, all land not yet purchased by others in Pennsylvania legally belonged to the Penns. Arguing for incompatibility with republican rights, radicals wanted those holdings turned over to the state for sale to citizen settlers or as rewards for patriot soldiers. In November 1779, speaker John Bayard's radicals in the legislature - prodded by like-minded radical President Joseph Reed - struck a death blow at the founder's successors, approving a divestiture act that transferred the vast majority of the remaining proprietary acreage to the commonwealth of Pennsylvania. It was the crowning achievement of radical rule. ${ }^{99}$

Despite these successes, Constitutionalist government proved brittle as economic, political and social instability opened the door for moderates. ${ }^{100}$ Elections in the next few years witnessed steady Republican/Anti-Constitutionalist gains. Conditions favoring accommodation with the disaffected slowly matured as a by-product of these victories. The Franco-American victory at Yorktown in October 1781 coincided with the moderate upsurge and a corresponding decrease in radical support. On November 14, 1781, a more moderate William Moore took his seat as President of Pennsylvania, elected by the new assembly and council to replace radical Joseph Reed. ${ }^{101}$ Although radicals continued as a

\footnotetext{
${ }^{99}$ Statutes at Large of Pennsylvania, vol. 10, "An Act for Vesting the Estates of the Late Proprietaries of Pennsylvania in this Commonwealth," November 27, 1779, Chapter 874, 33-39. The divestiture conflict and the reintegration of the Penn family are covered in-depth in the final chapter.

${ }^{100}$ The moderate rise is described in detail in Rosswurm, Arms, Country and Class, 228-248, a chapter entitled "The Triumph of Common Sense" that follows an in-depth explanation of the radical "retreat."
} 
small majority in the assembly for a while longer, Anti-Constitutionalists took legislative control in late 1783 and remained dominant into the early 1790s, except for a brief radical rebound in the assembly in the mid-eighties. The moderate age had dawned.

\section{REINTEGRATION \& MODERATE ASCENDANCY (November 1781 - April 1794)}

The rise to power of the moderate Anti-Constitutionalists or Republicans reversed radical implacability against onetime opponents of the colonial insurgency and defined the fourth and final stage of patriot reactions to disaffection. Moderates applied the law to lessen restrictions and reinstate the rights of all Pennsylvanians regardless of previous revolutionary commitments. The reintegration of nonjurors became part and parcel of a moderate political program which eventually led to the legal reincorporation of the formerly disaffected and the pardon of many of the attainted.

Unswerving allegiance was not a make-or-break proposition for moderates as it was for radicals. As devoted patriots, Republicans did not permit open hostility against the Revolution. In fact, it was moderate leadership that extinguished the remnants of armed antirevolutionary opposition in Pennsylvania in the postwar era. Even so, patriot moderates bore a greater tolerance for nuanced disaffection, neutrality or indifference to the cause when driven by factors such as religious conviction, contradictory loyalties, human frailty and fear, family ties, economic necessity and sometimes even opportunism. As a result, they opposed test oaths, attainders and repressive rigor. Where radicals only saw black-and-white, moderate Anti-Constitutionalists also pictured shades of gray. It is

\footnotetext{
${ }^{101}$ While William Moore was affiliated earlier with the radical faction, his views evolved towards the moderates over time. His ascent to the presidency took place in the midst of this ideological transition. For Moore's near unanimous rise, see Council Minutes, November 14, 1781, Colonial Records, vol. 13, 111112. Moore had run for the presidency earlier and lost to radical Joseph Reed by a vote of 59-1. See Council Minutes, November 14, 1780, Colonial Records, vol. 12, 540. The failure of radical economic policies turned the political tables during the course of the year.
} 
not surprising, then, that their response to less blatant infidelity, especially after the war, was to forgive and forget. While radicals' exclusionary formula legally ostracized the disaffected, the moderates' inclusionary vision sought their reinstatement as enfranchised Pennsylvanians with all the rights of citizenship. This ideological divide framed factional political battles over the status of former antagonists throughout the $1780 \mathrm{~s} .{ }^{102}$ As the decade went forward, popular support for moderates in the state expanded in conjunction with a national tendency towards the more centralized type of republican government articulated in the Federal Constitution of 1787. By 1789, moderates held the levers of power in both the General Assembly and Supreme Executive Council. That strength allowed them, first, to push for a total repeal of all tests of allegiance and, a year later, to successfully revoke and replace the radical Constitution of 1776 . While state officials continued to entertain pardons for attainted exiles well into the 1790s, the 1789 repeal of the test acts restored formerly disaffected nonjurors to full citizenship and ended once and for all the legal reintegration drama for Pennsylvania residents.

When not using more pejorative terms such as tory, inimical or obnoxious, patriots referred to resident antirevolutionaries as loyalists or the disaffected during the war. This terminology mutated with the achievement of independence, for loyalism disappeared as a viable option when George III renounced all claims over the thirteen rebellious colonies in $1783 .{ }^{103}$ From that point forward, those who stayed in Pennsylvania

\footnotetext{
${ }^{102}$ I am concerned here strictly with viewpoints, not motives, the complexity of which would require a separate study. Both radicals and moderates had a variety of motives for their positions on the disaffected, ranging the full gamut from base self-interest to idealistic altruism.

${ }^{103}$ Official renunciation came in Article $1^{\text {st }}$ of the Definitive Treaty of Peace, as follows: "His Britannic Majesty acknowledges the said United States, viz. [list of states] ...to be free sovereign \& Independent States; that he treats them as such, and for himself his Heirs \& Successors, relinquishes all Claims to the Government Propriety \& Territorial Rights of the same \& every Part thereof." The full treaty is in Richard
} 
and would not or could not swear allegiance to the patriot government metamorphosed into nonjurors - people who had never sworn the oath of allegiance. The exception was those who actively took up arms against republican government. Scattered guerrilla bands such as the Doans who had earlier aided or fought with the British continued their depredations through the war and after the peace. Patriots never accorded these "banditti" nonjuror status. In response to the latent existential crisis the gangs posed, moderatedominant government allied with the radical minority to destroy all armed resistance. Along with a sustained martial effort under the direction of the Supreme Executive Council, the assembly passed a series of legislative measures branding the culprits as outlaws or extending the reach and flexibility of the law which contributed significantly to dismembering these gangs. ${ }^{104}$

But it was the lasting consequences of the battle over citizenship and reintegration of the onetime disaffected which defined the 1780s. Militia, treason, confiscation and attainder laws and procedures affecting nonjurors all played second fiddle to the factional controversy over repeal of the Test Act. Concerns over noncompliance with militia service diminished as the decade wore on. Late-decade moderate legislators led by

B. Morris, The Peace-Makers: The Great Powers \& American Independence (New York: Harper \& Row, 1965), 461-465. Article $1^{\text {st }}$ quote on 462; and in "British American Diplomacy, The Paris Peace Treaty of September 3, 1783," Avalon Project, Yale Law School, http://avalon.law.yale.edu/18th_century/paris.asp last accessed March 26, 2017.

${ }^{104}$ The elimination of the guerrilla threat is covered at length in the Chapter 5. Examples of outlaw legislation are Statutes At Large of Pennsylvania, vol. 11, "An Act to Encourage the Speedy Apprehending and Bringing to Justice Divers, Robbers, Burglars and Felons," September 8, 1783, Chapter 1028, 109-114; ibid., vol. 13, "An Act for Rewarding the Person or Persons Concerned in Apprehending George Sinclaire Attainted by Outlawry," October 4, 1788, Chapter 1379, 163-164. A 1780 act amending the treason statute allowed imposition of the death penalty for robberies committed "in any place or places whatsoever within this commonwealth," overturning prior limits to capital punishment only in cases of highway robbery. In addition, charges of high treason or misprision of treason could be levied with only one witness, rather than two, as long as these cases were treated as misdemeanors. In essence, legislators traded severity for flexibility. See ibid., vol. 10, "An Act for the Amendment of the Law Relative to the Punishment of Treasons, Robberies, Misprisions of Treason and Other Offenses,” March 8, 1780, Chapter 889, 110-112. 
speakers Thomas Mifflin and Richard Peters focused more on preventing abuse in the collection of fines and recruiting soldiers to defend northwestern frontiers than punishing those who neglected to serve. The war's conclusion surely had something to do with this redirection but the influx of Anti-Constitutionalist moderates into state government also contributed meaningfully to the transformation. ${ }^{105}$ A 1788 militia act reducing fines and taking "conscientious scruples" into consideration for "very burthensome" service illustrates this change towards lenience. ${ }^{106}$

\footnotetext{
${ }^{105}$ Moderates controlled the Supreme Executive Council from November 1781 through the entire decade of the eighties. Presidents included William Moore, John Dickinson, Benjamin Franklin and Thomas Mifflin. (Although Franklin was no doubt a Pennsylvania radical in the 1770s, both factions accepted him after his return from Europe in the 1780s.) In the assembly, moderates took control in late 1783 when George Gray ascended as House speaker. After the one-year return of a radical majority in late 1784, moderates Thomas Mifflin and Richard Peters held the speakership in the legislature from October 1785 through the last assembly under the radical Constitution of 1776 which adjourned in late 1790. Speakerships are mentioned at the beginning of each session of the General Assembly in Laws of the Commonwealth of Pennsylvania (Philadelphia: John Bioren, 1810), vol. 2 covering from 1781 to 1790. Election of Supreme Executive Council presidents from 1781 to 1790 are in Colonial Records, vol. 13, 112, 413, 736; ibid., vol. 14, 249, 557; ibid., vol. 15, 110, 308, 584; ibid., vol. 16, 218.
}

${ }^{106}$ Statutes At Large of Pennsylvania, vol. 13, "An Additional Supplement to the Acts for the Regulation of the Militia in the Commonwealth of Pennsylvania," March 22, 1788, Chapter 1339, 41-44. State officials in the moderate governments of the late 1780s discovered that collection agents for militia fines "frequently abuse the power given them" and that their methods were "highly oppressive and grievous." As a result, they halted collection of all militia fines pending an inquiry, then set up an appeals board. The process went to the other extreme and had to be corrected once again as officials exonerated "all delinquent applicants without distinction or exception." See Statutes At Large of Pennsylvania, vol. 13, "An Act to Suspend for a Limited Time the Collection of All Militia Fines Incurred under the Laws Passed Before the TwentySecond Day of March One Thousand Seven Hundred and Eighty-Eight," November 19, 1788, Chapter 1383, 173-174; ibid., vol. 13, "An Act to Establish a Board of Appeal within the Several Counties of this State and to Grant Exonerations in Cases of Militia Fines," March 27, 1789, Chapter 1416, 267-269; ibid., vol. 13, "A Supplement to an Act Entitled 'An Act to Establish a Board of Appeal within the Several Counties of this State and to Grant Exonerations in Cases of Militia Fines," April 5, 1790, Chapter 1513, 507-508. The legislative focus on frontier defense began late in the war and grew in the postwar era when the British refused to abandon their posts in the northwest as required at the peace because they felt Americans had not complied with treaty obligations for the restitution of loyalist property. See Statutes At Large of Pennsylvania, vol. 10, "An Act for the Greater Ease of the Militia and the More Speedy and Effectual Defence of the State," May 26, 1780, Chapter 908, 191-195; ibid., vol. 11, "An Act for Furnishing from the Militia of Pennsylvania the Quota of Troops Required by Congress for the Protection of the Northwestern Frontiers and for Other Purposes," August 11, 1784, Chapter 1104, 354-356; ibid., vol. 11, "An Act or Furnishing the Quota of Troops Required by Congress for the Protection for the North Western Frontiers and for Other Purposes," September 6, 1785, Chapter 1771, 15-16; ibid., vol. 13, "An Act or Furnishing the Quota of Troops Required by Congress for the Protection of [the] Western Frontiers and for Purposes Therein Mentioned," November 10, 1787, Chapter 1326, 5-7. 
The subject of treason followed a similar legislative trajectory, resurfacing in the legislature only twice during the 1780s, even as the arrival of peace and independence in 1783 reignited public debate about what to do with the loyal and disaffected who chose to stay or wished to return. The loyalist articles in the Definitive Treaty of Peace of 1783 magnified the controversy. ${ }^{107}$ Sporadic extralegal committees resolved the stay-or-leave decision for some disaffected residents in favor of the latter option. ${ }^{108}$ The legislature's first intervention on the treason front, however, had nothing to do with disaffection stemming from the war with England. Instead, the assembly under speaker Frederick Augustus Muhlenberg denounced a rumored conspiracy to foment "the most criminal design" of creating a new state within the commonwealth's borders. Legislators made clear that such actions were high treason, underscoring the "suffer death" and forfeiture penalties, and authorizing the Supreme Executive Council under moderate president John Dickinson to call out the militia to "prevent and suppress" threats to the state's integrity. The warnings worked and put a stop to western settlers' machinations. ${ }^{109}$ A subsequent 1785 law checked procedural flaws leading to incarceration in treason cases. If the state did not adjudicate in a timely manner, judges had to free prisoners on bail or discharge them. It was incumbent on the state to adhere to its own procedures and eliminate

\footnotetext{
${ }^{107}$ The loyalists were a particularly thorny sticking point in the negotiations over peace. The Definitive Treaty of Peace signed in Paris in September 1783 contained ten articles, two of which dealt expressly with loyalists and another tangentially on the matter of recovery of pre-war debts. For a detailed study on the treaty's impact, see Roberta Tansman Jacobs, "The Treaty and the Tories," (PhD. Dissertation, Cornell University, 1974). For the loyalist issue in the negotiations, see also Morris, The Peace-Makers, 361-375.

${ }^{108}$ See the incident involving Capt. Thomas Rawlings, Capt. Joseph Crathorne \& Thomas Plunket and another involving five suspected tories in Scharf \& Westcott, History of Philadelphia, 428.

${ }^{109}$ Statutes At Large of Pennsylvania, vol. 11, "An Act to Prevent the Erecting Any New and Independent State Within the Limits of This Commonwealth," December 3, 1782, Chapter 1000, 14-16. The new state was to be called Westsylvania. The conspiracy included frontier settlers in southwestern Pennsylvania, and what is now West Virginia and portions of Kentucky, Maryland, and Virginia.
} 
arbitrariness. Nonjurors now received the benefit of the doubt, a significant reversal of the earlier mentality that had guided radical policy on high treason. As Henry Young has remarked on the prevailing attitude of Pennsylvania officials, "the tendency therefore was to find some excuse for clemency." Conditions continued to evolve towards greater indulgence, favoring successful reintegration. ${ }^{110}$

Moderate views on sedition triumphed definitively in 1794 when legislative action overturned the capital penalty under the 1777 treason law, ordering that "no crime whatsoever, hereafter committed (except murder in the first degree) shall be punished with death in the state of Pennsylvania." The statute eased punishment for high treason from death to "confinement in the gaol and penitentiary house of Philadelphia, for a period not less than six and no more than twelve years, ... at hard labor, or in solitude," while making similar adjustments for arson, counterfeiting, involuntary manslaughter, and rape. ${ }^{111}$ It should be noted that legislators passed this act amid rising internal tensions that crested three months later in the Whiskey Rebellion. Because of a potential for repercussions at the ballot box, lawmakers did not want to face an autochthonous republican rebellion with the same zeal and severity applied during the Revolution. ${ }^{112}$

\footnotetext{
${ }^{110}$ Statutes At Large of Pennsylvania, vol. 11, "An Act for the Better Securing Personal Liberty and Preventing Wrongful Imprisonments," February 18, 1785, Chapter 1132, 427-434. Henry J. Young, "Treason and Its Punishment in Revolutionary Pennsylvania," PMHB, vol. 90, no. 3 (July, 1966), 313.

${ }^{111}$ Statutes At Large of Pennsylvania, vol. 15, "An Act for the Better Preventing of Crimes, and for Abolishing the Punishment of Death in Certain Cases," April 22, 1794, Chapter 1777, 174-175.

${ }^{112}$ Bradley Chapin makes the case that federal authorities wanted to treat the Whiskey Rebellion as treason while Pennsylvania officials sought to find ways to "divert the resistance into less-violent courses." Chapin, American Law of Treason, 86. The classic account of the rebellion is H. M. Brackenridge, History of the Western Insurrection in Western Pennsylvania, Commonly Called the Whiskey Insurrection. 1794. (Pittsburgh: W. S. Haven, 1859). For modern analyses, see Thomas P. Slaughter, The Whiskey Rebellion: Frontier Epilogue to the American Revolution (New York: Oxford University Press, 1986); the various essays in Steven R. Boyd, ed., The Whiskey Rebellion: Past and Present Perspectives (Westport, CT:
} 
Removal of the death penalty closed the circle on the legal journey from radical harshness to moderate clemency in matters of treason. But this belated action had little impact on the disaffected. By then, legal reintegration had been achieved. The 1794 revision lived on till 1860 when its repeal became part of a major overhaul of the state's penal laws. ${ }^{113}$

Confiscatory policy initiatives and sales of forfeited property likewise slowed late in the war and throughout the eighties under moderate political gains. The focus turned instead to unresolved or contested individual cases. For example, the four patriot sons of attainted loyalist Nathaniel Vernon sought to recuperate whatever forfeited property the state had not yet sold, arguing "that they may not be reduced to indigence on account of their father's transgressions." Two of the brothers were officers in the Pennsylvania regiment of the Continental Army. Similarly, the assembly allowed John Abraham De Normandie more time to settle his estate prior to returning to Geneva, Switzerland, his native land. In the cases of merchants Matthias Aspen and Daniel Rundle, legislators extended the deadline for surrendering for trial because they were in Europe and unable to respond when attainted. Albertson Walton also received an attainder extension because he had been "in the power of the enemy, and that though he endeavored, yet he was not

Greenwood Press, 1985); and Stanley Elkins \& Eric McKitrick, The Age of Federalism (New York: Oxford University Press, 1993), 461-488.

${ }^{113}$ For the $19^{\text {th }}$ century changes, see The Penal Laws of Pennsylvania. Passed March 31, 1860. (Harrisburg: A. Boyd Hamilton, State Printer, 1860), 6. Despite the date of the revision for treason as a possible precursor to the upcoming Civil War, two reasons suggest that no relation existed. First, the revision encompassed ten separate and extensive "Titles" dealing with all aspects of state penal law, implying a comprehensive overhaul. Treason was only one - albeit the first and briefest - of these Titles. Second, the 1794 treason penalties were more or less preserved in 1860; they did not increase in anticipation of sectional conflict. After 1860, high treason was punishable by "a fine not exceeding $\$ 2,000$ " and prison "not exceeding twelve years," while the penalty for misprision of treason was not to exceed $\$ 1,000$ and six years in jail. The death sentence was not reintroduced at the time. 
able to escape from them." ${ }^{\prime 14}$ After the war, issues of property relief, restoration, restitution or compensation sometimes rose to the forefront when officials violated seizure procedures or public opinion thought the punishment too rigorous or unjust in retrospect. Most often, though, legal concerns over confiscated property revolved around the rights of heirs, spouses or extended family. Some family members even managed to recover portions of seized estates. The confiscation regime deeply affected reintegration. For those who had lost significant property and fled, reintegration was not a viable option without recovery of at least a portion of their assets to launch life anew.

The attainder as a weapon to combat revolutionary nonconformity equally faded into oblivion under the Anti-Constitutionalists. Council moderates did not emit any attainder proclamations after the decisive patriot victory over Cornwallis at Yorktown in October 1781. The waning radical majority in the assembly passed the final attainder in January 1783, a single-person act levelled at Harry Gordon of Chester County. This law's intent was less to condemn Gordon than to clarify his disputed legal status and that of his seized property in Bedford County. The loyalist was attainted under the name of Henry Gordon on March 20, 1781 as "now or late a military officer in the British service." After state agents confiscated and sold his estate, questions arose about a possible "misnomer," throwing the legality of the sale and deed into question. The new attainder gave Harry

\footnotetext{
${ }^{114}$ Statutes At Large of Pennsylvania, vol. 9, "An Act to Vest the Estate of Nathaniel Vernon, Late of Chester County. In His Four Sons," October 6, 1779, Chapter 854, 409-410; ibid., vol. 9, "An Act to Enable the Supreme Executive Council to Allow Further Time to John Abraham De Normandie, of the County of Bucks, Practitioner in Physic, for the Sale of his Estate, and to Retire Out of the State than is Allowed in an Act of the General Assembly, Entitled 'An Act for the Further Security of Government,"” September 2, 1778, Chapter 807, 270-271; ibid., vol. 10, "An Act to Prevent the Attainder of Daniel Rundle and Matthias Aspden for a Limited Time, on Condition that They Render Themselves to Take Their Trial on or Before a Certain Day Therein Limited and Appointed," March 31, 1780, Chapter 932, 279-281; ibid., vol. 9, "An Act for the Relief of Albertson Walton, Otherwise Called Albinson Walton," November 27, 1778, Chapter 820, 300-301.
} 
a.k.a. Henry until July 24,1783 , to surrender for trial or prior actions would take effect "as if he had been legally and rightly named." 115 In total, the radical Supreme Executive Council issued ten proclamations between the initial attainder law of 1778 and this final bill. Having originated the use of attainders as a repressive mechanism with legislation, the assembly closed the loop with the Gordon act.

Much more than militia, treason, confiscation, and attainder issues, however, it was the factional struggle over repeal of the Test Act which characterized the postwar decade for both the bloc of nonjurors who refused to take the oath and competing patriot factions. Pointedly, the test oath battle was far less between the onetime disaffected and victorious revolutionaries than between these partisan coalitions. Radicals once again demanded exclusion of opponents from the benefits of republican citizenship, while moderates insisted on their inclusion and reincorporation. The lack of civic participation of a sizeable proportion of the populace and the legal nexus between voting rights and wartime allegiance drew attention to a larger issue: to resolve the test oath controversy was also to resolve the broader reintegration question.

After a hiatus of almost six years, radical legislators - yet again under John Bayard's speakership - resurrected allegiance tests during their brief mid-decade resurgence as an assembly majority. On September 13, 1785, Constitutionalists folded the issue into a lengthy electoral law entitled "An Act to Regulate the General Elections of This Commonwealth and to Prevent Frauds Therein." The test oath portions of the act spoke to the renewed public debate triggered a year earlier by moderate Benjamin Rush

115 "By his Excellency Joseph Reed, Esq'r, President, and the Supreme Executive Council of the Commonwealth, A Proclamation," March 20, 1781, Colonial Records, vol. 12, 665-666; Statutes At Large of Pennsylvania, vol. 11, "An Act for the Attainder of Harry Gordon Unless He Surrender Himself and for Other Purposes Therein Mentioned," January 31, 1783, Chapter 1004, 26-29. 
with the publication of his influential pamphlet Considerations upon the Present TestLaw of Pennsylvania. Rush condemned "the exploded doctrine and practice of tests" and pointed out that it was inconsistent "to employ the pitiful invention of tyrants to support the freedom of republics." Viewing nonjurors as "industrious, frugal, [and] temperate" who were "for the most part genuine republicans in dress and manners," Rush argued for repeal. "If they have erred - nay more, if they have sinned during the late war, we shall consult the freedom and prosperity of the state by forgiving them," he wrote, expressing the views of most moderates." 116

The twenty-seven page electoral bill passed only ten days before the Ninth General Assembly adjourned for good. That autumn's elections quickly reestablished a Republican majority and, unbeknownst to Pennsylvanians of all political stripes, conclusively expelled the radicals as an assembly majority when moderate victories persisted into the 1790s. The election law contained thirty-two sections. The bulk dealt with county-by-county voter qualifications and procedures not relevant to this analysis. Four sections, however, discussed the ambiguous status of some nonjurors. The statute acknowledged that "doubts have arisen whether young men of this state, who... were under the age of eighteen years," when the further supplement to the test laws became law in October 1779, "can be admitted to vote at elections." Minors during the revolutionary years had come of age. Many were from patriot families. Lawmakers proposed allowing these nonjurors to vote "upon taking and subscribing the oath or affirmation of allegiance." Simple enough. Yet radicals had no intention of discarding suffrage hurdles erected against the ex-disaffected absorbed into the nonjuror class and

\footnotetext{
${ }^{116}$ Benjamin Rush, Considerations upon the Present Test-Law of Pennsylvania: Addressed to the Legislators and Freemen of the State (Philadelphia: Hall \& Sellers, 1784), 1, 17.
} 
thus reasserted that "it is requisite that the test laws heretofore passed in this state should be carefully regarded in all elections under this act."117

The new legislation reiterated that no white male residents eighteen years of age or older at the time of the test supplement of October 1, 1779 could vote without taking the oath of allegiance. Either the original June 13, 1777 oath or the rewritten December 5, 1778 pledge sufficed to remedy this defect. Moreover, the act settled ambiguities for Pennsylvanians on military assignment who had not been able to take earlier oaths, people who had moved to the province from another state, and citizens affected by the border dispute with Virginia resolved in Pennsylvania's favor in $1780 .{ }^{118}$ The new election law resurrected the debate over tests in the assembly by reasserting the viability of oaths, thrusting the larger reintegration issue into the limelight once again.

The test law dispute forged ahead on a three-step track which ended with full legal reintegration. Six months after the new election law, a restored moderate majority in the assembly returned to the question of loyalty tests. Though the designation insinuated a new slant on the issue, there was really nothing new in "An Act for Securing to This Commonwealth the Fidelity and Allegiance of the Inhabitants Thereof and for Admitting Certain Persons to the Rights of Citizenship" beyond a single key word and yet another

\footnotetext{
${ }^{117}$ Statutes At Large of Pennsylvania, vol. 12, "An Act to Regulate the General Elections of This Commonwealth and to Prevent Frauds Therein," September 13, 1785, Chapter 1175. For the full act, 25-52; test oath sections are in 40-42. For a study on Federalism in the provincial capital, see Richard G. Miller, Philadelphia - The Federalist City (Port Washington, NY: Kennikat Press, 1976). Miller shows that moderates dominated state politics well into the 1790s, although the more radical opposition on occasion won single national or state contests.

${ }^{118}$ Statutes At Large of Pennsylvania, vol. 12, "An Act to Regulate the General Elections of This Commonwealth and to Prevent Frauds Therein," 42. On the state residency issue, the act declared that Fayette, Washington, and Westmoreland county residents "who shall have taken the oath of allegiance and fidelity to the commonwealth of Virginia when such a freeman was under the jurisdiction of the same... shall be admitted to vote as a qualified freeman of this commonwealth."
} 
opportunity to take the oath. Upon taking the new oath, those "omitted or neglected... or debarred of any of the rights citizenship" would "be and hereby [are] declared to be a free citizen of this commonwealth and entitled to all the every rights [sic] and privileges thereof." Staples from prior oath adaptations reappeared: abjuration of George III, promises to "be faithful and bear true allegiance" to Pennsylvania and do nothing "that will be prejudicial or injurious to the freedom and independence thereof," along with an assertion that the oath-taker had never "voluntarily joined, aided, assisted or abetted" the king's forces. The single novelty was the insertion of the word "voluntarily" in the latter claim. The new law thus drew a distinction between those who had helped the British of their own accord and those who argued they had been compelled to do so against their will. Of parallel import, the act did not extend "to any person or persons who have been attainted of high treason." Confirmed traitors remained traitors. The new wording showed a tendency towards greater indulgence in both content and the opportunity afforded. ${ }^{119}$

The 1786 revamped test law was a failure. A year later, the moderate assembly under speaker Thomas Mifflin returned with still another version. This 1787 act reduced the elements of the oath to being faithful and bearing true allegiance to Pennsylvania and doing nothing "willfully and knowingly" prejudicial or injurious to the same. It went to great lengths to explain why the British monarch and "a retrospective clause of uncertain and indefinite meaning" had been eliminated from the fealty equation, a reference to aiding the British during the Revolution, voluntarily or not. The new act admitted that the prior effort had flopped, mentioning complaints of "divers persons coming within the

\footnotetext{
${ }^{119}$ Statutes At Large of Pennsylvania, vol. 12, "An Act for Securing to This Commonwealth the Fidelity and Allegiance of the Inhabitants Thereof and for Admitting Certain Persons to the Rights of Citizenship," March 4, 1786, Chapter 1206, 178-181.
} 
description of persons intended to be relieved by the act [who] have represented to this house their scruples of taking the oath or affirmation, the meaning whereof is not plain and certain upon the face of it." The term "scruples" indicates a renewed attempt to accommodate Quaker nonjurors.

Moderates now astutely couched their reasons in terms of patriot self-interest rather than benefits to nonjurors. Disenfranchisement hurt the state because nonjuror residents did not pull their weight in the republican order. "Whereas many useful citizens are disqualified from service to this commonwealth in several stations by reason of their scruples against taking the oath or affirmation," they argued it was "highly impolitic to deprive the community of their allegiance" and "their assistance in the various offices of burden as well as of trust and profit which are necessary to be executed for the support of government." Besides, times had changed to such a degree "as to render all fears of disaffection thereto groundless," for ex-loyalists and disaffected residents were no longer a threat. Requiring abjuration of the king therefore "is wholly useless as all allegiance from the inhabitants of these United States has been formally and explicitly renounced by the said king and no political connection exists between the said king and the inhabitants of this state." ${ }^{120}$ Even this highly concessionary legislation proved insufficient, however. For many holdouts, conscience reigned supreme. The self-imposed religious prohibition on taking oaths meant just that - no oaths. Few took advantage of the new opportunity.

\footnotetext{
${ }^{120}$ Statutes At Large of Pennsylvania, vol. 12, "An Act to Alter the Test of Allegiance to This Commonwealth Required by an Act Passed the Fourth Day of March One Thousand Seven Hundred and Eighty-Six, Entitled 'An Act for Securing to This Commonwealth the Fidelity and Allegiance of the Inhabitants Thereof and for Admitting Certain Persons to the Rights of Citizenship,"' March 29, 1787, Chapter 1294, 473-475.
} 
Momentum for repeal grew as national issues meshed with the local. Two months after this "act to alter," the Constitutional Convention of 1787 met - in Philadelphia no less - to restructure the frame of confederated government for the thirteen states. Their task concluded in September. Extensive debate followed throughout the young nation. On December 7, Pennsylvania ratified the novel arrangement. Pro-Constitution Federalists defeated the opposition of antifederalists in heated debates across the nation. By mid1788 , enough states had consented to the proposed charter to make it the law of the land. March 4, 1789 was set as the day for the new instrument of government to officially take effect. The Federalist victory boosted moderate interpretations of the Revolution and its consequences in Pennsylvania.

At long last, the door opened for redemption. Nine days after the new federal government took office, moderate legislators rode the momentum and passed "An Act to Repeal All the Laws of This Commonwealth Requiring Any Oath or Affirmation of Allegiance from the Habitants Thereof." This revocation drew a clear distinction between times of war and peace, positing that "however proper and expedient they might be during the late war when it was necessary for individuals to testify their attachment to one or the other of the contending parties," loyalty tests "have become unnecessary... since the restoration of peace and the establishment of government." Hence, all acts which "require any oath or affirmation of allegiance or fidelity to this commonwealth... shall be and they are hereby repealed." As a result, people excluded from the privileges of citizenship earlier for failing to swear allegiance "shall be and they are hereby restored to and placed upon the same footing as to such privileges and burdens and in all other 
respects with the other citizens of this state." The repeal ignored those attainted for treason. For them, existing exclusions endured. ${ }^{121}$

Repeal of the test laws closed the bitter contest over legal reintegration. The intractability of earlier allegiance requirements disappeared. Inclusionary tolerance and compassion had won the day. In the process, Pennsylvania had come full circle. The test act repeal legally rehabilitated those citizens of the commonwealth ostracized when the Tory Act ignited the allegiance controversy in January 1776. The following decades would assimilate their talents and contributions well. Yet for Anti-Constitutionalist Republicans, the test oath repeal reintegrating nonjurors was only a step towards the greater goal of revoking the 1776 state constitution. In the following months, moderates rode the pro-federal wave to victory and realized their long-awaited ambition with passage of the new Pennsylvania Constitution of 1790. But that is another story.

\section{CONCLUSION}

For the disaffected, the repressive package of disarmament, treason laws, test oaths, attainders, confiscations and militia service penalties during the war amounted to a full-scale discriminatory attack on their inherent rights as English colonials. Committed loyalists considered their decision to remain faithful to the king as perfectly natural. As Claude Halstead Van Tyne has noted, "loyalty was the normal condition, the state that had existed, and did exist; and it was the Whigs - the Patriots, as they called themselves,

\footnotetext{
${ }^{121}$ Statutes At Large of Pennsylvania, vol. 13, “An Act to Repeal All the Laws of This Commonwealth Requiring Any Oath or Affirmation of Allegiance from the Habitants Thereof," March 13, 1789, Chapter $1396,222-224$.
} 
- who must do the converting." 122 Other disaffected citizens for whom the monarchy was not necessarily their prime concern based distaste for the incoming regime on perceptions of abusive patriot governance, religious persecution or social disorder. They repudiated rebel conduct as "unconstitutional" because, in practice, it did not protect their rights. Of course, it was the British constitution they had in mind, not the new state charter. Through their non-threatening postwar behavior and acceptance of republican authority, the disaffected-turned-nonjurors helped clear a path to successful reintegration. The coming chapters will explore that path in depth through the lives of the protagonists.

Yet in the final analysis, it was up to the Pennsylvania Revolution's victors to allow or disallow the reintegration of those who had once opposed them. The factional struggle between Anti-Constitutionalist Republican moderates and Constitutionalist Whig radicals ultimately decided that question. Both were revolutionaries. Both were patriots. Yet the two political blocs entertained diametrically opposite views on how to approach the issue of disloyalty to their cause. Moderates favored reattachment and forgiveness. Radicals supported segregation and damnation. The ballot box and the republican legal order provided the terrain for battle. While each faction deployed the law in favor of its proposed objectives, popular sovereignty had the final say. Electoral triumphs in the 1780s awarded moderates the right to resolve the problem according to their vision. Between 1775 and 1794, moderate Republicans refrained from actively sponsoring attainders, slackened the confiscatory regime, abolished capital punishment for treason, and repealed the test oaths permitting the full reintegration of nonjurors. They used the

\footnotetext{
${ }^{122}$ Van Tyne was the first historian to study loyalism as a historical category of its own in the early twentieth century. Claude Halstead Van Tyne, The Loyalists in the American Revolution (Kessinger Legacy Reprint; New York: The Macmillan Company, 1902), 2-3 (emphasis in the original).
} 
law to restore the inherent rights of all Pennsylvanians regardless of revolutionary ideology. As a result, the legal structure which had once chastened and ostracized loyalists and the disaffected became the very tool that facilitated the reassimilation of the once chastened and ostracized to the benefits of a full republican life. 


\section{CHAPTER 2}

\section{REINTEGRATION \& DEPARTURE OF THE ELITE LOYALIST MILITANTS}

Factionalism contributed significantly to the downfall of the Ancien Régime in

Pennsylvania. The asperity between competing colonial blocs first laid the groundwork for revolutionary change and then erupted along a loyalist-patriot axis with fatal effects for proprietary rule. The seeds of disharmony were planted well in advance of rebellion, as contending elites vied for provincial control for almost a century. On one side, the successors of proprietor William Penn and their allies formed a loose coalition. Their authority resided in the original charter of 1681 whereby King Charles II granted Penn and his heirs ownership of all lands in Pennsylvania, to be disposed of as they saw fit, and the power to institute "good Government" in keeping with the founder's vision. ${ }^{1}$ In practice, the Penn family sold substantial tracts to colonizers who settled chiefly in the provincial capital at Philadelphia and the surrounding southeast counties near the Delaware River. William Penn was a pacifist Quaker and accordingly designed his "Holy Experiment" as a haven for persecuted religious minorities, especially members of his own sect who had suffered greatly during the English civil wars of the seventeenth century. Quakers thus comprised a majority of the early colonists. The founder set up a political structure with a governor, a provincial council to advise the governor, and a unicameral representative assembly elected by freeholders, as well as a pledge to deal fairly with the diverse native peoples residing within their royally allotted jurisdiction. The arrangement provided an incentive for settlement, as freemen were to share power with the royal grantees and live in peace with their indigenous neighbors. For most of the

\footnotetext{
${ }^{1}$ Charter for the Province of Pennsylvania-1681, The Avalon Project, Yale Law School, $17^{\text {th }}$ Century Documents: 1600-1699, http://avalon.law.yale.edu/17th century/pa01.asp last accessed December 3, 2017.
} 
next eighty years or so, the Penns ruled from England as absentee proprietors, appointing governors and provincial councilors from afar, and providing their officers with specific instructions on policy. Along the way, the proprietary family drifted from its Quaker roots. Principal proprietor Thomas Penn's 1751 Church of England marriage to the daughter of the first Earl of Pomfret, Lady Juliana Fermor, finalized the conversion to Anglicanism. At the same time, the Quaker-dominated provincial assembly, whose freely elected members all lived in the colony, sought to configure Pennsylvania according to their own image. Not surprisingly, proprietary and Quaker factions in Pennsylvania were at odds with each other for much of the colonial era. ${ }^{2}$

Following the 1763 English victory in the French and Indian War, Thomas Penn decided that the family needed a more hands-on approach in provincial affairs and appointed his nephew, John Penn Sr., governor of Pennsylvania. ${ }^{3}$ From that point until the end of proprietary rule in 1776, a Penn successor served as the colony's chief executive. John held the post through 1771 and again from 1773 to 1776 . His younger brother Richard replaced him for a two-year interval from 1771 to 1773 when their father died and John returned temporarily to England. The Penns used patronage as a formidable political tool and by the mid-1760s had built a strong network of supporters with Chief Justice William Allen Sr. as its informal head. In the parlance of the day,

\footnotetext{
${ }^{2}$ For early colonial politics in Pennsylvania, see Isaac Sharpless, A History of Quaker Government in Pennsylvania, 2 vols. (Philadelphia: T. S. Leach \& Co., 1898-1899); Edwin B. Bronner, William Penn's "Holy Experiment" (New York: Columbia University Press, 1962); Mary Maples Dunn, William Penn, Politics and Conscience (Princeton, N.J.: Princeton University Press, 1967).

${ }^{3}$ Thomas Penn was one of William Penn's three sons. After the death of John Penn "the American" in 1746, Thomas inherited a 3/4 interest in the proprietorship. His surviving brother Richard Penn Sr. held a 1/4 share which was passed down to his sons John Sr. and Richard Jr. at his death in 1771. See Lorett Treese, The Storm Gathering: The Penn Family and the American Revolution (University Park, PA: The Pennsylvania State Press, 1992), Appendix A, "Condensed Penn Family Tree and Interests in the Proprietorship," 205.
} 
Pennsylvanians recognized this network as the "Proprietary party." Meanwhile, a majority in the assembly gathered around the leadership of House speaker Joseph Galloway and his ally Benjamin Franklin. That faction became known as the "Quaker party." ${ }^{\prime 4}$ Two divisive issues framed the contest between these blocs. First, the Proprietary party strongly opposed assembly efforts to tax fallow, unimproved, and unsold Penn lands. Second, because of their pacifist views, the Quaker party generally resisted efforts to organize a militia for armed colonial defense even in the face of Indian and French depredations on the frontier at the height of the war. The factional clash culminated in a Quaker party campaign to have a young King George III replace proprietary rule with direct royal government in the mid-1760s, for which the assembly majority dispatched Franklin as emissary to London. ${ }^{5}$

Over the next decade, a new political faction consisting mainly of Scots-Irish Presbyterian urban artisans, journeymen, laborers and frontier farmers emerged. In time, these lower and middling sorts became the vanguard of provincial rebellion, challenging both dominant parties. As a result, while Joseph Galloway and the Allen clan sat on diametrically opposite poles of colonial contests as the Stamp Act of 1765 launched the revolutionary period, a little more than a decade later they fled Pennsylvania, joining forces with Sir William Howe at New York and assisting British efforts to squelch the insurgency. Given later imperial strategy and the war's results, the portentous decision to

\footnotetext{
${ }^{4}$ The term "party" at this time should be construed as a loose alliance of like-minded interests, not in the modern sense of organized political structures.

${ }^{5}$ For late colonial political divisions, see Hutson, Pennsylvania Politics 1746-1770; Theodore Thayer, Pennsylvania Politics and the Growth of Democracy 1740-1776 (Harrisburg, PA: Pennsylvania Historical and Museum Commission, 1953); William S. Hanna, Benjamin Franklin and Pennsylvania Politics (Stanford University Press, 1964). As the king's refusal to alter the existing colonial structure and shift towards direct royal control of Pennsylvania reveals, the proprietary arrangement and the hands-on approach were well in keeping with overall British colonial policy.
} 
depart appreciably advanced the collapse of colonial Pennsylvania's power structure in two stages. Initially, the 1776 winter flight of elite loyalist militants such as Galloway and the Allen brothers following the introduction of radical constitutional government deprived the Penn proprietors of key allies at a critical moment in their struggle either to preserve the existing regime or to mold the new order in accordance with their interests. ${ }^{6}$ After returning with the imperial conquerors in September 1777, their second departure at the British evacuation of June 1778 definitively decapitated the colonial leadership that had ruled the province from Philadelphia for nearly a century and sealed the Penns' doom once and for all. The exile of loyal Philadelphia elites like the Allens and Galloway constitutes a crucial feature of Pennsylvania reintegration for two reasons. First, their exodus had beneficial effects for disaffected residents who chose to stay in Pennsylvania, laying the groundwork for a lessening of internal political tensions and eventually paving the way for a smoother process of reintegration. On a second and more personal level, the Galloway and Allen sagas show how loyalist militancy during the war obstructed the later path to reintegration. After an extended expatriation, Andrew Allen came back to America and experimented with the possibility of reintegration but ultimately chose to remain a British subject. Joseph Galloway guardedly pursued the same prospect but found former rebel rivals unwilling to grant his wishes. No evidence suggests William Allen Jr. contemplated a return, but there is no doubt that he would have remained in Pennsylvania had events dealt him a more favorable hand. Consequently, these militants are considered examples of failed reintegration.

\footnotetext{
${ }^{6}$ An argument can be made that the 1776 flights occurred because it was already too late to hold back the radical tide. True or not, the larger point is that these departures took opposing elites completely out of the game at a time of acute revolutionary flux, negating all influence they may have been able to later exert.
} 


\section{ELITE ANTECEDENTS \& THE RIGHTS OF ENGLISHMEN (to 1765)}

A devotion to king and empire underscored the fierce battles between the Allen family and Joseph Galloway over the form, control and direction of colonial government. Neither the Proprietary nor the Quaker factions ever questioned the legitimacy of imperial rule, even after the Allens took up arms to defend colonial rights in the early days of the Revolution. As key elements of a provincial elite clustered in and around Philadelphia, each saw themselves as an indispensable vehicle for a properly functioning colony under the British Constitution, the legal instrument that protected their inherent rights as Englishmen. To defend the royal constitutional order was to defend those rights and to accord their homeland its rightful place in the imperial universe. Hence, Pennsylvania's destiny seemed to be inextricably tied to theirs.

By the time the war opened in 1775, John, Andrew and William Allen the younger were in the prime of life or about to enter it - 36, 34, and 24 years of age respectively. ${ }^{7}$ The family had deep roots in Pennsylvania. Their father William was the son of one the earliest Scots-Irish emigrants to the province who at one time had resided at Dunganon, Ireland. ${ }^{8}$ Born August 5, 1704 and baptized twelve days later in the First or Old Side Presbyterian Church, William Allen Sr. spent his youth in Philadelphia. At the

\footnotetext{
${ }^{7}$ Norman S. Cohen, "William Allen: Chief Justice of Pennsylvania, 1704-1780," (Ph.D. Dissertation, University of California, Berkeley, 1966), 24. This chapter is limited to exploring the loyalist trajectories of John Allen, Andrew Allen, and William Allen Jr.; third son James and father William Sr. chose a less loyal path during the Revolution.

${ }^{8}$ Will of William Allen MS probated September 13, 1725, in Ruth Moser Kistler, William Allen: Founder of Allentown, Colonial Jurist, Industrialist, and Loyalist (Allentown, PA: Lehigh County Historical Society, 1962), 7, 54 fn2; "William Allen," Craig W. Horle, Joseph S. Foster and Laurie M. Wolfe, eds., Lawmaking and Legislators in Pennsylvania: A Biographical Dictionary, (Harrisburg: Commonwealth of Pennsylvania, House of Representatives, 2005), vol. 3, 1757-1775: Allen to Kirkbride, 232 (hereafter Legislators in Pennsylvania). William Sr.'s father was also named William. For purposes of this study, the Chief Justice retains the senior designation.
} 
age of sixteen, he crossed the ocean for the first time to study law at London's esteemed Middle Temple. In addition to his maturation in the legal profession from attorney to judge to Pennsylvania Chief Justice from 1751 to 1774 , he succeeded as an affluent merchant, an entrepreneur in the iron industry, an investor in over 75,000 acres of land, and a political leader holding public offices such as councilman, mayor of Philadelphia, assemblyman, and city recorder during a multifaceted career. In the colonial era, he emerged as a vital ally and confidant of the Penn family and the proprietary faction perennially engaged in political tussles with the Quaker-dominant assembly. William Allen Sr. derived much of his power from the ability to dispense patronage under the Penns' authority. Theodore Thayer argues that "after about 1740, almost all appointments made by the Proprietors were at the suggestion of William Allen." Similarly, Stephen Brobeck has called the Proprietary party "a political faction controlled by the non-Quaker gentry... dominated by William Allen from the early 1740s to the early 1770 s and later by his sons." This interpretation is confirmed in a 1764 letter from Governor John Penn to proprietor Thomas Penn, wherein “particular regard was always paid to... Allen's recommendation to every office that fell vacant." Through talent, connections and the trust of the Penn family, William Allen Sr. accrued great wealth and prestige. ${ }^{9}$

The Pennsylvania-born Allen boys followed in their father's elite footsteps, establishing early in life the trans-imperial linkages common to many affluent colonials of the age. John, the eldest, enrolled at the College of Philadelphia in May of 1755 but

\footnotetext{
${ }^{9}$ Cohen, "William Allen: Chief Justice of Pennsylvania," 4-42; "William Allen," Legislators in Pennsylvania, vol. 3, 232-233; Kistler, William Allen, 7-8, 11-33. For William Allen Sr.'s patronage power, see Thayer, Pennsylvania Politics and the Growth of Democracy, 15; John Penn to Thomas Penn, Penn MSS, March 17, 1764 in Stephen Brobeck, "Revolutionary Change in Colonial Philadelphia: The Brief Life of the Proprietary Gentry," William and Mary Quarterly, vol. 33, no. 3 (July, 1976), 419.
} 
did not graduate or attend after $1759 .{ }^{10}$ In 1760 , he accompanied Joseph Shippen III on a visit to England, mixing an exploration of business opportunities with learning. An added excursion to Italy beyond the bounds of empire provoked the mocking curiosity of family friend Colonel John Alford of Massachusetts, who wondered in a letter to Shippen's father why they had "traveled so far just for the honor of kissing the Pope's great toe."11 Having clerked with Tench Francis Sr. in Pennsylvania, John continued his legal studies at the Temple in London like his progenitor but may have veered from this career track and entered commerce instead. ${ }^{12}$ Second son Andrew did graduate in 1759 from the College of Philadelphia, apprenticed locally under then Attorney General Benjamin Chew, and in 1761 similarly crossed the ocean to pursue an English legal education at the Temple. Less is known about fourth son William Jr.'s education and early development. The original attainder law of March 6, 1778, designated him as "Esquire," like his brothers John and Andrew, while the 1774 provincial tax tables describe William Jr. as a

\footnotetext{
${ }^{10}$ Persifor Frazer \& a Committee of the Society of the Alumni, eds., Biographical Catalogue of the Matriculates of the College [of Pennsylvania] Together with Lists of the Members of the College Faculty and the Trustees Officers and Recipients of Honorary Degrees, 1749-1893 (Philadelphia: Society of the Alumni, 1894), 4; “Andrew Allen,” Legislators in Pennsylvania, vol. 3, 199.

${ }^{11}$ John Alford to Edward Shippen III, Charlestown (MA), September 1, 1760, Shippen Papers, vol. 5, 89, Historical Society of Pennsylvania (hereafter HSP), in Klein, Portrait of an Early American Family, 171, 294 fn66; William Allen Letterbook, Burd-Shippen-Hubley Papers in "William Allen," Legislators in Pennsylvania, vol. 3, 241.

${ }^{12}$ Kistler, William Allen, 50. Kistler states that the legal profession was "his life work." Charles Keith maintains that John began his legal studies with Tench Francis but "finished at the Temple." Charles P. Keith, The Provincial Councillors of Pennsylvania Who Held Office Between 1733 and 1776, Who Were Some Time Chief Magistrates of the Province, and their Descendants (Philadelphia, 1883), 145. The University of Pennsylvania's Biographical Catalogue of Matriculates states that John finished his law studies at the Temple. Jonathan Powell lists John Allen's profession as "merchant" in his study of Presbyterian loyalists. His data is taken from the 1774 provincial and city tax tables. Jonathan Powell, "Presbyterian Loyalists: A Chain of Interest in Philadelphia," Journal of Presbyterian History, vol. 57, no. 2 (Summer, 1979), 138. For John's travels, Klein, Portrait of an Early American Family, 102-105, 170.
} 
"gentleman."13 All of the siblings maintained ties with the Presbyterian Old Side congregation. John joined the church's Presbyterian Committee of Correspondence in 1764 to foment unity among the faithful in other counties. Around the same time, Andrew contributed to the building fund for the new Third Presbyterian Church on Pine Street which later rebelled against its First Church donors in a dispute that echoed opposing revolutionary viewpoints. ${ }^{14}$

The third son of William Sr., James, was likewise an integral component of this band of brothers in the early years of the Revolution. He traveled with Andrew in 1761 to study law at the Temple and later fared prominently in colonial affairs, at times leading organized resistance to parliamentary encroachment during the imperial crisis. Like his brethren, James too became disaffected with the Revolution when resistance for a redress of colonial grievances turned into separation from England. But he refused to take up the sword against his fellow Pennsylvanians and disagreed with his brothers' decision to join the British army. ${ }^{15}$ His diary is a critical source for the period. Nonetheless, the analysis here is largely limited to the three militants who enlisted with the British.

\footnotetext{
${ }^{13}$ Frazer/Alumni, eds., Biographical Catalogue of Matriculates, 3; Kistler, William Allen, 50-52. For details on the upbringing of the Allen progeny, Cohen, "William Allen: Chief Justice of Pennsylvania," 2430. Statutes At Large of Pennsylvania, vol. 9, "An Act for the Attainder of Divers Traitors if They Render Not Themselves by a Certain Day, and for Vesting Their Estates in This Commonwealth, and for More Effectually Discovering the Same and for Ascertaining and Satisfying the Lawful Debts and Claims Thereupon," March 6, 1778, Chapter 784, 201; Powell, "Presbyterian Loyalists," JPH, 138.

${ }^{14}$ Patricia Bonomi, Under the Cope of Heaven: Religion, Society, and Politics in Colonial America (New York: Oxford University Press, 2003), 174; Powell, "Presbyterian Loyalists," JPH, 143. A sectarian dispute between the First and Third Churches based on religious lines drawn among ministers and parishioners during the Great Awakening erupted and later contributed to patriot-loyalist divisions among Presbyterians. See Powell, 140-144.

${ }^{15}$ James Allen, "Diary of James Allen, Esq., of Philadelphia, Counsellor-At-Law, 1770-1778," PMHB, vol. 9, no. 2 (July, 1885), 193; Kistler, William Allen, 51-52.
} 
Socially, all four brothers enjoyed the perks available to elite Philadelphians. In the 1770s, John and Andrew were active members of the exclusive Philadelphia Dancing Assembly that arranged galas and balls for those of high public standing. They joined many of the local institutions of prominence such as the St. Regale Fishing Company, the Jockey Club, and the American Philosophical Society. In addition, they were trustees of the College of Philadelphia and common councilors or aldermen of the Philadelphia city corporation. ${ }^{16}$ In his late twenties, Andrew married Sarah "Sally" Coxe, sister of Tench Coxe, during the spring of 1768. Seven years later, John tied the knot in his mid-thirties, wedding Mary Johnston from a prominent New York family in the spring of $1775{ }^{17}$ Unlike his brothers, William Jr. remained a bachelor all his life.

Some of the Chief Justice's early reflections on his sons have survived. He considered the oldest, John, to be "honest and worthy," lacking vice and not extravagant, but with "a taste for English manners and customs" and "more indolent than I could wish" which made him "not as fit... to battle in the world" as he would have liked. As for number two, Andrew, he too was honest, "of rather more vivacity and higher spirits" than John, but with a "temper [which] seems rather too quick, of which I have frequently cautioned him." 18 The elder William's plans in 1762 to build a town from scratch in Northampton County, north of Philadelphia, demonstrates the Allens' high standing in the colonial order. He named the municipality Allentown and dubbed the streets John,

\footnotetext{
16 Table 1: Wealth and Institutional Memberships of Proprietary Gentlemen, in Brobeck, "Revolutionary Change in Colonial Philadelphia," WMQ, vol. 33, no. 3, 416; Konkle, Benjamin Chew 1722-1810, 128; Stern, David Franks, 19.

${ }^{17}$ Edward F. DeLancey, “Chief Justice William Allen,” PMHB, vol. 1, no. 2 (1877), 207, 210.

${ }^{18}$ Penn Official Correspondence, vol. 10, 98 \& Burd Papers, 46, cited in Kistler, William Allen, 50; William Allen Letterbook in "William Allen," Legislators in Pennsylvania, vol. 3, 241.
} 
Andrew, James, William, Anne, and Margaret for his surviving children, while christening the main thoroughfare Allen in remembrance of the full family. Clearly, the Allens laid claim to an exalted social position as the imperial crisis opened. ${ }^{19}$

Joseph Galloway was also a son of privilege. Born in Anne Arundel County, Maryland in 1730 or 1731, Galloway descended from an English great-grandfather who received a land grant from Lord Baltimore in 1662. As a child, his family moved to Kent, Delaware, a province also under the Penn proprietorship. Private tutors provided his early education. After studying law for five years with Quaker attorney John Kinsey in Philadelphia, he set up his own successful practice. Young Joseph rose through the social ranks quickly. At eighteen, he became a member of the prestigious social club, the Schuylkill Fishing Company. Two years later he tutored Benjamin Franklin's son, William, in the law. His friendship with William Franklin proved to be life-long, as both later swore fidelity to their king in the throes of revolution. ${ }^{20}$ In 1749 , the Pennsylvania Supreme Court bar authorized Galloway to practice in that highest of provincial courts. By the mid-1750s, he was "easily leader of that bar." Although raised a Quaker,

\footnotetext{
${ }^{19}$ Kistler, William Allen, 8. The town is still known as Allentown and is now located in Pennsylvania's Lehigh County. As Kistler indicates, by 1962 the streets in question were named Walnut, Linden, Eighth, Sixth, Ninth, Fifth, and Seventh respectively. As settlements expanded in the $18^{\text {th }}$ century, towns were often named for the first white settler in a given area, who was not necessarily of the upper crust. What made William Allen Sr.'s design distinctively elite was the comprehensive character of the town's development plan and the expansive build-out along family lines.

${ }^{20}$ Lawrence Buckley Thomas, The Thomas Book giving the Genealogies of Sir Rhys ap Thomas, K.G., the Thomas Family descended from him, and of some Allied Families (New York: Henry T. Thomas Co., 1896), 317; Ernest H. Baldwin, Joseph Galloway: Loyalist Politician (Philadelphia, 1902), 7. The original grant was for 250 acres, to which he soon added 490 acres more. By 1739, his father Peter Galloway owned at least 5,900 acres in Delaware. See "Joseph Galloway," Legislators in Pennsylvania, vol. 3, 586; John E. Ferling, The Loyalist Mind: Joseph Galloway and the American Revolution (University Park, PA: The Pennsylvania State University Press, 1977), 7; Lorenzo Sabine, Biographical Sketches of Loyalists of the American Revolution, vol. 1, 453; Sheila Skemp, Benjamin and William Franklin: Father and Son, Patriot and Loyalist (Boston: Bedford Books of St. Martin's Press, 1994), 16. The Schuylkill Fishing Company was founded in 1732 for Philadelphia's elites. The New York Times once called it "the oldest dining club in the world." See New York Times, January 15, 1905.
} 
Galloway converted to Anglicanism and married Grace Growden at Philadelphia's Christ Church in 1753. Grace was the daughter of Lawrence Growden, longtime speaker of the colonial assembly and one of the wealthiest men in Pennsylvania. With matrimony came a large house in Philadelphia proper and five country estates. Of these, Trevose in Bucks County became Joseph's refuge during the trials of the early Revolution. The Galloway estate was once valued at $£ 40,000$. After her mother's death, daughter Elizabeth testified to the Royal Claims Commission that her father "was entitled in the right of his wife to an estate worth $£ 20,000 . "$ The up and coming attorney thus tied his family fortune to a larger one and played the gentleman farmer when not engaged in legal affairs. ${ }^{21}$

Galloway entered politics upon his election to the provincial assembly in 1756 for Philadelphia County, following the resignation of six pacifist Quakers in the wake of the colony's war with indigenous nations, a conflict which in turn stemmed from the BritishFrench struggle for imperial control of North America. Over time, Galloway ascended to co-leadership of the Quaker party in the assembly alongside Benjamin Franklin. With the exception of a one-year setback in 1764, he served in the colonial legislature for eighteen years. Although Galloway later testified before the Royal Claims Commission that he had

\footnotetext{
${ }^{21}$ Quote from Konkle, Benjamin Chew, 69-70; Ferling, The Loyalist Mind, 7, 9; “Joseph Galloway,” Peter Wilson Coldham, ed., American Migrations 1765-1799: The lives, times and families of colonial Americans who remained loyal to the British Crown before, during and after the Revolutionary War, as related in their own words and through their correspondence (Baltimore: Genealogical Publishing Co., 2000), 461; "Joseph Galloway," Legislators in Pennsylvania, vol. 3, 586. There has been some historical debate on Galloway's religious affiliation arising from his leadership of the "Quaker party" in the provincial assembly. More a loosely organized and continuously evolving coalition than a party, that grouping included not only Quakers but Germans, middling mechanics, and others at various junctures. Recent scholars include Nathan Kozuskanich, who categorizes Galloway as a Quaker, and Owen Ireland, who classifies him as an Anglican. Kozuskanich, "'Falling Under the Domination Totally of Presbyterians": The Paxton Riots and the Coming of the Revolution in Pennsylvania," in William Pencak, ed., Pennsylvania's Revolution (University Park, PA: The Pennsylvania State University Press, 2010), 14; Ireland, "Bucks County," in John B. Frantz \& William Pencak, eds., Beyond Philadelphia: The American Revolution in the Pennsylvania Hinterland (University Park, PA: The Pennsylvania State University Press, 2010), 34. I consider Galloway an Anglican because of his decision to marry within the Anglican church and lack of formal participation in Quaker Meetings.
} 
been "Speaker of that Assembly for 13 or 14 years," legislative records show the true figure was eight. Notwithstanding this overstatement, he had a gift for public speaking. Admirers touted him as the "Demosthenes of Pennsylvania."22

The Quaker party's bid in the mid-1760s to supplant the Penns' charter with direct royal control of the colony epitomized their adversarial relationship with the proprietorship and typified Galloway's pre-revolutionary political career. While Ben Franklin struggled to shape parliamentary opinion in England, Galloway carried the campaign's standard at home. The battle further alienated Thomas Penn, the absentee proprietor residing in London, and his provincial allies across the sea - most notably Penn's nephews John and Richard, the Allen family, Benjamin Chew, and John Dickinson. Although the royal government effort failed - in large part because of unforeseen entanglements linked to the imperial crisis - the deep personal animosity between opposing factions endured. ${ }^{23}$

During the colonial period, the Galloway star continued to climb. He became a trustee of the Germantown Academy in 1760, trustee of the State House and other public buildings two years later, and received an honorary Doctor of Laws degree from the College of New Jersey - later Princeton University - in 1769. Upon the death of fatherin-law Growden that year, he inherited a sizable interest in the Durham Iron Mines and Iron Works in Bucks County. Galloway also speculated in western lands. With ten others,

\footnotetext{
${ }^{22}$ Charles F. Hoban, ed., Pennsylvania Archives, Eighth Series, vol. 6, October 14, 1756, Votes of the Assembly, 4383; Ferling, The Loyalist Mind, 10-11; Hutson, Pennsylvania Politics, 126; Sabine, Biographical Sketches, vol. 1, 453; "Memorial of Joseph Galloway," Hugh Edward Egerton, ed., The Royal Commission on the Losses and Services of American Loyalists 1783 to 1785, Being the Notes of Mr.

Daniel Parker Coke, M. P., One of the Commissioners of That Period (Oxford: The Rorburght Club, 1915), 82; "Joseph Galloway," Legislators in Pennsylvania, vol. 3, 585, 587.

${ }^{23}$ See especially Hutson, Pennsylvania Politics, Chapter 4, "The Mirage of Royal Government," 178.
} 
he founded the Illinois Company, presided over the Indiana Company for a time, and bought land between the Ohio and Tennessee rivers. Meanwhile, he continued to practice law. Lutheran minister Henry Melchior Muhlenberg noted Galloway's participation in a lawsuit involving church land deeds in March of 1763. Yet interest in his profession waned as politics absorbed more and more of his attention and "he began to decline the practice of the Law in 1769 \& finally quitted it in 1771." Galloway played a key role on behalf of the colonial assembly in land negotiations with the Indians in 1758 and interceded with the tempestuous Paxton Boys when they menaced Philadelphia from the western frontier in 1764. That spring he "harangued a crowd in the State House Yard" and later in the year suffered his only major electoral loss to John Dickinson and the Proprietary party by a mere eight votes out of $3800 .{ }^{24}$ While the Allen brothers and Joseph Galloway chose contrary sides of the colonial political landscape, both came from entitled strands of elite stock centered in the provincial capital. They expected to rule.

COLONIAL RESISTANCE, LOYALIST MILITANCY \& INDEPENDENCE (1765-76)

The Revolution reconfigured the colonial era's loosely organized, tripartite Quaker-Proprietary-Presbyterian competitive political alignments into a much more rigid and demanding loyalist-patriot divide. During the insurgency, loyalist militancy came to mean an unabashed devotion to royal rule. For the Allens early on, royal rule signified government under a proprietorship headed by the Penns and subservient to the king. For

\footnotetext{
${ }^{24}$ Ferling, The Loyalist Mind, 8, 12, 14, 22; Scharf \& Westcott, History of Philadelphia, 242, 254-55, 258; Owen Ireland, "Bucks County," Beyond Philadelphia, 212 fn9; Coldham, American Migrations, 461; Henry Melchior Muhlenberg, The Notebook of a Colonial Clergyman, Theodore G. Tappert \& John W. Doberstein, eds., (Minneapolis: Fortress Press, 1959), 73-74; "Memorial of Joseph Galloway,” Egerton, The Royal Commission, 86; Konkle, Benjamin Chew, 87-89; Benjamin L. Carp, Rebels Rising: Cities and the American Revolution (New York: Oxford University Press, 2009), 186; Nash, The Unknown American Revolution, 31, 58; Hutson, Pennsylvania Politics, 175-77; "Joseph Galloway," Legislators in Pennsylvania, vol. 3, 594-595.
} 
Galloway, the preference was for a more straightforward connection to the monarchy, omitting the proprietors. In either case, there was no need to express one's "loyalism" prior to 1765 . The concept did not exist. In America, colonials everywhere intuitively breathed the air of loyalty to the mother country. It was a given. There was no need to affirm it. The rebellion shattered that common denominator once the crucial issue of allegiance surfaced. Even before formal independence in 1776, those opposed to resistance increasingly defined themselves as "loyal." As imperial bonds dissolved, the more militant among the loyal picked up arms to defend the kingdom or formed an integral part of organized efforts to restore royal authority. Noteworthy among the militarily committed foes of independence were John, Andrew, and William Allen Jr. On the civil side of the conflict, Joseph Galloway arguably became the most conspicuous of all loyalists, not just among Pennsylvanians. The journey into loyalism of these onetime adversaries mapped the rocky political and ideological terrain that all provincials encountered in the early insurrection and illustrates the challenge that independence and later reintegration presented. The Allen brothers' fateful decision to take up arms against the patriot movement and Galloway's concurrence in serving as Sir William Howe's chief civil officer during the British occupation led to their abrupt evacuation from Philadelphia in mid-summer 1778. These departures became symbols of a larger exodus of elite loyalists, resulted in a vacuum the rebels immediately filled, and converted militants like themselves into enemy pariahs, severely circumscribing their options for reintegration later on.

Passage of the Stamp Act in 1765 triggered acute discontent in the colony and inadvertently launched the imperial crisis that led to rebellion. The British Parliament 
approved the stamp legislation in the midst of Benjamin Franklin's mission to London and caught the Quaker party off guard. The push for royal government was the brainchild of Franklin and Joseph Galloway. It failed on two fronts. Not only was Franklin unable to garner sufficient support in England for the proposal, but proprietary interests at home ably conflated prospective royal rule with parliamentary overreach and the demise of the rights and liberties granted under the original Penn charter. ${ }^{25}$ The sons of William Allen Sr. actively defended the proprietary order. Andrew joined 156 chiefly Presbyterian Philadelphians in a petition condemning the royal government campaign. John, Andrew and James helped organize active resistance to the Stamp Act, thus countering Quaker party strategy. The siblings rallied mob sentiment against John Hughes, nominated as royal stamp distributor for Pennsylvania through Franklin's intercession. As Franklin's wife Deborah wrote to her husband, "Jemey Allin was att the Staite house a Sperriting up the mobe and inraigeing of them to porsiste in the affair thay had meet a bought [sic]."26 William Jr. was then only about fourteen-years-old and likely did not participate. The Allen brothers' not-so-veiled activism posed a direct challenge to the Quaker party.

Joseph Galloway's stance on the Stamp Act was a prelude to his position on the later uprising. In fact, unlike some of his contemporaries, Galloway showed a remarkable consistency throughout the entire Revolution. Above all, he wished America to retain its

\footnotetext{
${ }^{25}$ See Hutson, Pennsylvania Politics 1746-1770, especially 168-177, as well as the terms of the remonstrance adopted by the Assembly on September 21, 1765, Scharf \& Westcott, History of Philadelphia, 272.

26 “Andrew Allen," Legislators in Pennsylvania, vol. 3, 200; Deborah Franklin to Benjamin Franklin, October 9, 1765, Leonard W. Labaree, ed., The Papers of Benjamin Franklin (New Haven: Yale University Press, 1968), vol. 12, 301. Jemey is presumably James but it is likely the other brothers were also involved - such is the take in Anne M. Ousterhout, The Most Learned Woman in America: A Life of Elizabeth Graeme Fergusson (University Park, PA: The Pennsylvania State University Press, 2004), 130. See also Cohen, "William Allen: Chief Justice of Pennsylvania," 293-94; Scharf \& Westcott, History of Philadelphia, 271.
} 
ties to the king, the British Constitution, and empire. He conceded "the reasonableness of our being Taxed" by Parliament and accepted the logic of parliamentary supremacy so odious to American patriots. As a pragmatic politician, though, he considered such a course counterproductive and ill-advised. Galloway especially abhorred the mob violence that public passions often generated. Writing as "Americanus," he published a piece in the Pennsylvania Journal recommending that colonial legislatures make voluntary tax donations for defense of the colonies, thereby cutting Parliament out of the equation. Moreover, Galloway advocated the creation of an American legislature to solidify the imperial relationship and resolve matters of mutual interest. He accurately gauged current and later revolutionary ardor, commenting that, insofar as the Stamp Act was concerned, "one Half of the Americans will die rather than submit to it." His attempt to straddle the imperial divide had a price, however. Backlash forced him to print a handbill denying he had intended to embarrass the anti-stamp bloc. ${ }^{27}$ In September, rumors spread that a mob would attack the homes of Franklin and stamp distributor Hughes. On the preset night, Galloway rounded up eight hundred of Franklin's working-class supporters - known as the White Oaks - who patrolled the streets and frustrated the opposition's plans. His decisiveness paid off. Two months later, he regained his seat in the assembly, defeating John Dickinson and overturning the sole electoral defeat of his career. ${ }^{28}$

\footnotetext{
${ }^{27}$ Joseph Galloway to Benjamin Franklin, July 18, 1765, Papers of Benjamin Franklin, vol. 12, 218; "Memorial of Joseph Galloway," Egerton, The Royal Commission, 82; Extract of a Letter from Joseph Galloway, September 20, 1765, in "Intelligence from the Colonies Relating to the Stamp Act," House of Lords Manuscripts, no. 209, Library of Congress cited in Joseph S. Tiedemann, Eugene R. Fingerhut, and Robert W. Venables, eds., The Other Loyalists: Ordinary People, Royalism, and the Revolution in the Middle Colonies, 1763-1787 (Albany: State University of New York Press, 2009), 6-7; Scharf \& Westcott, History of Philadelphia, 279.

${ }^{28}$ Joseph Galloway to Benjamin Franklin, September 20, 1765, Papers of Benjamin Franklin, vol. 12, 269 -
} 
As the imperial crisis played out from 1765 to 1775 , the ascendancy of both the Allen brothers and Joseph Galloway grew. Andrew Allen developed steadily in the legal profession. Like his Quaker party rival, the provincial Supreme Court admitted him to practice in 1765. The Penns named Andrew a Common Councilman of Philadelphia in 1768. Benjamin Chew appointed him Pennsylvania Attorney General the year after. In December 1770, brother-in-law governor John Penn named him to the Provincial Council, where he participated in negotiations in 1774 with Lord Dunmore concerning the jurisdictional dispute between Virginia and Pennsylvania over the Fort Pitt frontier. John Allen, too, gained in prestige. Governor Penn appointed him intermediary to a conference with native nations on the western frontier upset over "the late Murder... on some of their Brethren" by white settlers. Like Andrew, John became a Common Councilman for the city and then a Justice of the Peace. At the 1771 death of Richard Penn Sr., Johnny Allen accompanied his sister Anne and her governor husband to England, returning with them in August of 1773 when the latter came "to assume the Government \& to supersede his Brother [Richard]" who had exercised the governorship in the interim. ${ }^{29}$

270; Skemp, Benjamin and William Franklin, 50; Ferling, The Loyalist Mind, 18-19; "Joseph Galloway," Legislators in Pennsylvania, vol. 3, 597.

${ }^{29}$ For Andrew, see "Memorial of Andrew Allen," PRO AO12-42-223 and AO13-70B(II)-16, DLAR; Colonial Records, vol. 9, 705; Cohen, "William Allen: Chief Justice of Pennsylvania," 304-06; DeLancey, "Chief Justice William Allen," PMHB, vol. 1, no. 2, 208; Konkle, Benjamin Chew, 116; Kistler, William Allen, 50-51. Andrew Allen and James Tilghman's series of reports on the Virginia dispute are in Council Minutes, Colonial Records, vol. 10, 181-191. For John, see detailed instructions for the Indian conference from Gov. Penn, Colonial Records, vol. 9, 493; "Diary of James Allen," PMHB, vol. 9, no. 2 (July, 1885), 179, 181 (last quote is entry of August 23, 1773 page 181); Klein, Portrait of an Early American Family, 171-72. At one point, the Philadelphia Common Council simultaneously included father William and sons John, Andrew, and James. 
The Allens continued as leaders of provincial resistance against parliamentary intrusion throughout the imperial crisis. In September 1770, Andrew joined a committee challenging the breakdown among merchants of yet another nonimportation crusade. After Lexington, the assembly appointed him one of twenty-five members of the Committee of Safety "for providing for the Defence of this Province against insurrection and Invasion." His involvement in provincial security matters from that summer through his last council appearance on June 18, 1776 was substantial. ${ }^{30}$ John participated in virtually every committee tackling a redress of colonial grievances from 1773 to early 1776. In mid-1774, he favored calling a congress to foster resistance and colonial cooperation. Fellow activists assigned him to "take a sense of the people" on a choice of potential delegates to that congress. Now of age, William Jr. participated in the June 1774 debates over the closure of Boston harbor alongside Andrew. As the threat of armed conflict appeared on the horizon, William helped organize the First Troop of City Cavalry that December, assuming the rank of First Lieutenant. The brothers' growth in public stature contrasted with their seventy-year-old patriarch's calculated decline. An aging William Allen Sr. willingly passed the chief justiceship baton to Benjamin Chew on April 29, 1774 at a meeting of the Provincial Council with Andrew present. ${ }^{31}$

\footnotetext{
${ }^{30}$ For Andrew Allen's appointment, see Minutes of the Council of Safety, June 30, 1775, Colonial Records, vol. 10, 280. That body's first meeting was on July 3, 1775, ibid., 282. His 1775-1776 participation is extensively and intermittently documented in Colonial Records, vol. 10, 284-607. For specifics, see Dr. Mary Dunn, ed., Index to Pennsylvania's Colonial Records (Baltimore: Genealogical Publishing Co., 1992), “Allen, Andrew," 2.

${ }^{31}$ Although the Provincial Council named John Allen a justice of the peace in 1772 (Council Minutes, April 27, 1772, Colonial Records, vol. 10, 46), his involvement in the resistance movement was largely in an unofficial capacity. See Ousterhout, A State Divided, 31, 62-63, 158; Scharf \& Westcott, History of Philadelphia, 284; Stern, David Franks, 109; "Diary of James Allen," PMHB, vol. 9, no. 2, 177; Ousterhout, Life of Elizabeth Graeme Fergusson, 191; Henry James Young, "The Treatment of the
} 
In contrast, Galloway's unshakeable insistence that Pennsylvania conserve ties to Great Britain gradually eroded the popular support he had once enjoyed over the course of the decade. His worldview failed to accommodate increasing public dissatisfaction with the direction of imperial relations. For instance, Galloway saw no inherent danger in Parliament's imposition of the Townsend duties in 1767. “I don't well see how the public weal of the Province can be affected by it," he wrote to Franklin in London. ${ }^{32}$ In late 1766 he partnered with Quaker merchant Thomas Wharton Sr. and newspaper editor William Goddard to launch the Pennsylvania Chronicle in hopes that the medium would become the semi-official voice of the Quaker party. When Goddard published an article by rival John Dickinson condemning the Townsend Acts, Galloway withdrew funding and resigned. The polemic further situated him among foes of the resistance. By 1769, he no longer counted on the artisan class that had once formed a core component of his political base. He kept his place in the assembly, however, through a safe and "rotten borough seat" from Bucks County. Even so, he retained the respect of his fellow assemblymen who chose him speaker every year through $1773 .{ }^{33}$

\footnotetext{
Loyalists in Pennsylvania," 39; Council Minutes, April 29, 1774, Colonial Records, vol. 10, 173; Konkle, Benjamin Chew, 133.

${ }^{32}$ Joseph Galloway to Benjamin Franklin, October 9, 1767, Papers of Benjamin Franklin, vol. 14, 277.

${ }^{33}$ The incident is in Sabine, Biographical Sketches, vol. 1, 456-457 \& in "Joseph Galloway," Legislators in Pennsylvania, vol. 3, 601. Galloway published a broadside in defense of his position via Benjamin Towne. See To the Public, and particularly the kind Customers of the Pennsylvania Chronicle, \&c., LCP; for Goddard's version of the newspaper controversy, William Goddard, The Partnership: Or the History of the Rise and Progress of the Pennsylvania Chronicle, \&c.: Wherein the Conduct of Joseph Galloway, Esq: Speaker of the Honourable House of Representatives of the Province of Pennsylvania, Mr. Thomas Wharton, sen. and their Man Benjamin Towne, my late partners, with my own, is properly delineated, and their Calumnies against me fully refuted (Philadelphia: William Goddard,1770). Galloway was still confident of electoral dominance as late as 1767. See Joseph Galloway to Benjamin Franklin, October 9, 1767, Papers of Benjamin Franklin, vol. 14, 276. For the "rotten" seat and speakership, see Ferling, The Loyalist Mind, 21-22.
} 
From 1770 onwards, Galloway spent most of his time at his Trevose estate, traveling to Philadelphia only when the legislature was in session or for essential business. He felt mounting unease with both radical mobs and the "conduct of the assembly." As imperial tensions escalated, he considered permanently retiring from politics. From London, Benjamin Franklin urged him to reconsider: "I must, however, beg you not to retire from public business. You are yet a young man, and may still be greatly serviceable to your country." ${ }^{34}$ Parliament's Intolerable Acts brought the crisis to a head. In the summer of 1774, mass meetings in Philadelphia backed the call for a congress to consolidate a joint colonial response to the closure of Boston harbor and other parliamentary infringements. A battle ensued over the proper mode of electing delegates to the proposed congress. Radicals convened a provincial convention and nominated John Dickinson and his allies to represent Pennsylvania but a revivified Galloway played an instrumental role in assuring that the legally constituted and more conservative assembly had the final say. That body eventually named him to lead the provincial delegation - as he later put it, "at the earnest solicitation of the Assembly of Pennsylvania.",35

\footnotetext{
${ }^{34}$ Benjamin Franklin to Joseph Galloway, January 6, 1773, John Bigelow, ed., The Complete Works of Benjamin Franklin Including his Private as well as his Official and Scientific Correspondence, and Numerous Letters and Documents Now for the First Time Printed, with Many Others Not Included in Any Former Collection (New York: Putnam \& Sons, 1887), vol. 5, 88-89; Ferling, The Loyalist Mind, 22-23; John Walter High, Jr., "The Philadelphia Loyalists, 1763-1783," (Ph.D. Dissertation, Temple University, 1974), 43, 131.

${ }^{35}$ The resolutions and instructions of the provincial congress spawned by the mass meetings are in "Resolutions, \&c.," July 15, 1774, Journals of the House of Representatives of the Commonwealth of Pennsylvania, 4-10; Ferling, The Loyalist Mind, 25; Robert McCluer Calhoon, The Loyalists in Revolutionary America, 1760-1781 (New York: Harcourt Brace Jovanovich), 86-87. The Pennsylvania delegation to the First Congress consisted of Galloway, Edward Biddle, John Dickinson, Charles Humphreys, Thomas Mifflin, John Morton and George Ross. See Journals of the American Congress, October 24, 1774, vol. 1, 26; and Edmund C. Burnett, ed., "List of Members, Pennsylvania," Letters of Members of the Continental Congress (Washington: Carnegie Institution of Washington, 1921), 1viii-lxi; The Examination of Joseph Galloway, Esq; Late Speaker of the House of Assembly of Pennsylvania, Before
} 
The First Continental Congress proved to be Joseph Galloway's sole hurrah as arbiter of colonial destinies. Despite apprehensions over increased radicalization, the Pennsylvania House speaker viewed the September 1774 convocation in Philadelphia with optimism, an opportunity to tackle the imperial rift head-on and re-anchor the overseas dominions to England. Two days before Congress opened, Galloway gathered a sense of those present while awaiting arrival of the delegates in transit. "I think they will behave with Temper and Moderation," he conjectured. ${ }^{36}$ Not unlike the most extreme of provincials at the time, he conceded that the colonies had interests, rights, and safety concerns which "from their local circumstances, cannot be represented in the Parliament of Great Britain." As a remedy for this accident of history, he argued that the colonies "hold in abhorrence the idea of being considered independent communities... and most ardently desire the establishment of a Political Union, not only among themselves, but with the Mother State, upon those principles of safety and freedom which are essential in the constitution of all free governments." His most far-reaching proposal was a "British and American legislature, for regulating the administration of the general affairs of America." This Plan of Union outlined measures for rebuilding fractured imperial relations. A legislative Grand Council would convene annually in America and include "all the said colonies," each to "retain its present constitution, and powers of regulating and governing its own internal police, in all cases whatever.” A President General appointed by the king would administer the government and have veto power over all

the House of Commons, in a Committee on the American Papers, with Explanatory Notes. (London: J. Wilkie, 1779), 44.

\footnotetext{
${ }^{36}$ Joseph Galloway to the Governor of New Jersey (William Franklin), September 3, 1774, Letters of Members of the Continental Congress, 5.
} 
laws passed by the Grand Council whose representatives were to be elected by the provincial assemblies of each colony. A critical clause ensured that all acts approved by the Grand Council and the President General, "shall be valid and passed into a law, without the assent of the British Parliament. ${ }^{37}$

In retrospect, Galloway's plan appears reasonable, visionary and quite possibly capable of resolving contemporary political differences between America and Great Britain. But such a supposition assumes a modicum of political foresight, even tempers and judicious minds willing to compromise, and the corresponding acquiescence not only of the thirteen colonies soon to rebel but also that of King George III, his ministers and Parliament. The Plan of Union is an outstanding illustration of the critical role timing plays in historical processes. It came too late for many colonists who deeply resented Britain's coercive measures against New England and too early for the English who still believed they could bend the unruly provincials to their indomitable will. In fact, given increasing obduracy on the royal side, the success of Galloway's proposal was less probable in Great Britain than among congressional delegates at Philadelphia. Some historians have concluded that the Plan of Union failed in Congress as much from Galloway’s "disabling vanity," self-importance, and personal liabilities in his relations with other delegates as from the timing or contents of the plan itself. Perhaps. The wording of his later Candid Examination surely provides fodder for such a hypothesis.

\footnotetext{
${ }^{37}$ Joseph Galloway, "A Plan of a Proposed Union between Great-Britain and the Colonies," A Candid Examination of the Mutual Claims of Great-Britain, and the Colonies: With a Plan of Accommodation, On Constitutional Principles (New York: James Rivington, 1775), 53-55. This plan is analyzed at length in Julian P. Boyd, Anglo-American Union: Joseph Galloway's Plans to Preserve the British Empire, 17741788 (New York: Octagon Books, 1970; reprint of 1941 edition, University of Pennsylvania Press). See also Moses Coit Tyler, The Literary History of the American Revolution, 1763-1783 (New York: G. P. Putnam's Sons, 1897), vol. 1, 369-378.
} 
His closing remarks grandiloquently announced that "I have... deduced your rights... and explained your duties... [and] pointed out the mode... you ought to pursue." ${ }^{38}$ Little humility informs such a pronouncement and it is not difficult to imagine that freethinking delegates would consider his disposition haughty or condescending.

In the end, it did not matter. Despite a home-court advantage, Galloway's rivals outmaneuvered him politically and procedurally. He did not propose his plan until the First Continental Congress had heard and ratified the Suffolk Resolves' recommendation "to withhold all commercial intercourse with Great-Britain, Ireland, and the West-Indies" - in effect a new round of nonimportation which proved to be more thorough and better organized than earlier attempts. Nevertheless, Galloway's blueprint succumbed only by a narrow vote of six colonies to five - though radicals later rubbed salt in the wound by expunging the Plan of Union debate from the congressional record. At first glance, it seems puzzling that Joseph Galloway's signature adorns the Continental Association which Congress established to enforce the trade restrictions inspired by the Suffolk Resolves. ${ }^{39}$ His later justifications, however, paint a vivid picture of an agitated political climate at this crucial juncture. Although he confessed in private to Samuel Verplanck in New York that "I totally disagree with them [Congress] in all," Galloway signed because "he was told by his friends out of Doors that it would not be safe to refuse to sign it." Similarly, he disagreed with Congress' first petition to the king because it “contain'd many grievances which in his Opinion did not exist," yet added his endorsement

\footnotetext{
${ }^{38}$ William H. Nelson, The American Tory (Boston: Beacon Press, 1964), 54; Robert M. Calhoon, "'I Have Deduced Your Rights': Joseph Galloway's Concept of His Role, 1774-1775," Tory Insurgents: The Loyalist Perception and Other Essays (University of South Carolina Press, 2010), 70-88; Joseph Galloway, A Candid Examination, 61.

${ }^{39}$ Journals of the American Congress, September 17, 1774, vol. 1, 12; ibid., October 24, 1774, vol. 1, 26.
} 
"because it was signed by all the other delegates." Galloway's attitude is indicative of the gulf between patriot and loyalist levels of commitment, not only in Pennsylvania but in most other states. More often than not, revolutionaries dedicated themselves and their resources wholeheartedly to the cause. Conversely, loyalists often declined to stand alone when lacking overt British support. In another contemporary example following the Pennsylvania legislature's approval of Congress' resolves, Galloway noted that assembly consent "has given great uneasiness to many," yet in his estimation the "men of Property [who] begin to think \& speak their Sentiments" would not take the lead in opposition "until the measures of Parliament are known, and they can hope to be protected in their upright conduct." The disparity in commitment and the operational initiative which naturally ensues reveal the importance of political will in deciding the Revolution. ${ }^{40}$ At the close of the First Continental Congress, an anxious Joseph Galloway withdrew briefly from the public arena. In November, he expressed his true feelings to the husband of his wife's sister in London. "Nothing has been wanting on my Part to moderate the Violent Temper of the Warm \& indiscreet People here, and bring about a Reconciliation between the two Countries upon Principles of Liberty and Government," he wrote. "But what can one or a few Men do in so Arduous a Task." ${ }^{41}$ Though "unanimously elected" as Pennsylvania House speaker after Congress adjourned, "he declined it thinking he could be of more use upon the floor." In the meantime, he traveled

\footnotetext{
${ }^{40}$ Joseph Galloway to Samuel Verplanck, January 14, 1775, "Some Letters of Joseph Galloway," PMHB, vol. 21, no. 4 (1897), 477-478. The date for the above $P M H B$ letter when published is given incorrectly as January 1774 since Galloway refers to the Pennsylvania assembly's approbation of Congress' proposals which took place in December 1774. The actual date is more probably the following month; "Memorial of Joseph Galloway," Egerton, The Royal Commission, 83-84.

${ }^{41}$ Joseph Galloway to Thomas Nickleson, November 1, 1774, Paul H. Smith, Ed., Letters of Delegates to Congress 1774-1789 (Washington: Library of Congress, 1976), vol. 1, 255.
} 
to New York City. Violating the delegates' code of secrecy, he reported results of the First Congress to royal Governors Cadwallader Colden of New York and William Franklin of New Jersey. Returning to Trevose on December 6, he did not attend the provincial assembly until the $13^{\text {th }}$, three days after John Dickinson successfully rallied unanimous support for approval of Congress' resolves. ${ }^{42}$ Whether Galloway's presence could have turned the tide or redirected events is open to question, but his absence most assuredly paved the way for pro-congressional unanimity.

For a brief interlude, Galloway appeared optimistic. In February, he confided to his friend Verplanck that "it is with great pleasure I assure you that Moderation is taking place of the violence in this Province, in a more rapid Progress than my most sanguine expectations ever suggested," countering his observation two months earlier that "in these perilous Times... no news perhaps would be most agreeable." Two weeks later, he expressed a similar buoyancy to William Franklin: "I hope, with some Trouble, all Violence will soon cease, \& Peace \& Order take place of Licentiousness \& Sedition."43 But the outbreak of hostilities at Lexington green on April 19, 1775 dramatically raised the stakes and transformed the political panorama. As armed conflict entered the picture, both Galloway and the Allens remained true to the original resistance goal of redressing colonial grievances within existing constitutional bounds. Their approaches to the revolutionary crisis differed, however.

\footnotetext{
${ }^{42}$ Joseph Galloway to Samuel Verplanck, December 7, 1774, "Some Letters of Joseph Galloway," $P M H B$, vol. 21, no. 4 (1897), 478; Ousterhout, A State Divided, 83; "Memorial of Joseph Galloway," Egerton, The Royal Commission, 84; “Joseph Galloway," Palmer, Biographical Sketches of Loyalists of the American Revolution, 305; Hoban, ed., Pennsylvania Archives, Eighth Series, vol. 8, December 10, 1774, Votes of the Assembly, 7162.

${ }^{43}$ Joseph Galloway to Samuel Verplanck, February 14, 1775, "Some Letters of Joseph Galloway," PMHB, vol. 21, no. 4 (1897), 480; Galloway to Verplanck, December 7, 1774, ibid., 479; Joseph Galloway to William Franklin, February 28, 1775, Letters of Delegates to Congress, vol. 1, 319.
} 
Joseph Galloway became more and more disheartened. Still a representative in the Pennsylvania assembly, he proposed motions that the House censure and withdraw from Congress as well as endorse the British House of Commons peace proposals of February 1775. His efforts flopped. Though the assembly no doubt leaned conservative, they did not dare to openly defy the bottom-up fervor which had already erupted prior to the onset of armed conflict. He summarized the reigning legislative climate in March, noting that a procedural measure "was opposed by my Friends but they had not Brass enough to insist upon. ${ }^{, 44}$ Upon publication of his Candid Examination in 1775 charging Congress with intent to secure that "ill-shapen, diminutive brat, INDEPENDENCY," Galloway received "a Box with an halter in it \& persons open'd a Policy of insurance to insure his Life for ten Days." The messengers enclosed a note saying that "they desired him to hang himself or they would do it for him." In April, Galloway joined Thomas Wharton Sr. in funding the Pennsylvania Mercury as a new weekly under the direction of Enoch Story and Daniel Humphreys. Opponents quickly categorized the newspaper as a "Tory" enterprise. That same month, Galloway finally felt "Obliged to quit the Town of Philadelphia \& retire to his Country Seat." ${ }^{\prime 45}$

During his absence, the colonial assembly appointed him a delegate to the Second Continental Congress scheduled to convene in Philadelphia in May but he "absolutely refused to go." Requesting withdrawal of his name, "I very explicitly told them, that I entirely disapproved of them." During his self-confinement at Trevose, Galloway

\footnotetext{
44 “Joseph Galloway," Legislators in Pennsylvania, vol. 3, 610-611.

45 "Memorial of Joseph Galloway," Egerton, The Royal Commission, 84; Joseph Galloway, A Candid Examination, 31; Nash, The Unknown American Revolution, 185. The halter incident came up again during Galloway's testimony before Parliament in 1779. See The Examination of Joseph Galloway, 53-54;

"Joseph Galloway," Legislators in Pennsylvania, vol. 3, 612-613.
} 
received death threats and - as he later testified - local patriots "called on me for my arms." That May he wrote a public letter at the behest of the patriot Committee of Safety in which he denied that he was "inimical" to the cause of America. Benjamin Franklin, who had returned from London thoroughly persuaded of English corruption and malevolent intentions, visited Galloway at Trevose at least three times, trying to secure his friend's support for the rebellion, all to no avail. By summer, Galloway's transient optimism had vanished, conceding instead that "we are on the brink of a Precipice 'big with the fate of America." "He appears to have lost the will to battle, confiding first that "I have I hope retired in Time from the distressing and ungrateful Drudgery of Public Life," and then limiting his efforts to a search for "the place of most Safety for a Family," concluding that "none [was] more safe than the country I live in." In October 1775, the frustrated ex-speaker resigned his post in the assembly and retired from all politics. ${ }^{46}$ Two months later, his investment in the Pennsylvania Mercury came to an abrupt end when unidentified vandals - in all likelihood politically motivated - put the torch to the “obnoxious" weekly's printing press. ${ }^{47}$

Despite their own growing doubts, the Allens tried to stay in the partisan game and lead from within. John Allen played a political and organizational role. In May of

\footnotetext{
${ }^{46}$ Joseph Galloway to Samuel Verplanck, January 14, 1775, PMHB, vol. 21, no. 4, 477; Joseph Galloway to Samuel Verplanck, June 24, 1775, ibid., 483; Joseph Galloway to Samuel Verplanck, August 17, 1775, ibid., 484; The Examination of Joseph Galloway, 62; "Memorial of Joseph Galloway," Egerton, The Royal Commission, 84; Joseph Hewes to Samuel Johnston, May 11, 1775, Letters of Delegates to Congress, vol. 1, 343 fn1; Ferling, The Loyalist Mind, 34; Nelson, The American Tory, 68-69; Skemp, Benjamin \& William Franklin, 128-129; Scharf \& Westcott, History of Philadelphia, 298; Ousterhout, A State Divided, 109. While Galloway claimed he turned down a congressional slot, a Connecticut delegate to Congress wrote that Galloway "was dismissed from being a Member of the Congress by the Assembly of this Province justly despised and Contemned by all." Eliphalet Dyer to Joseph Trumbull, May 18, 1775, Letters of Members of the Continental Congress, 93.

${ }^{47}$ The incident is in John Walter High, "The Philadelphia Loyalists, 1763-1783," 147. The last edition of the Pennsylvania Mercury was Volume 1, Number 38 on Friday, December 22, 1775, available at DLAR.
} 
1775, he became a member of the patriot Committee of Inspection and Observation for Philadelphia and the Northern Liberties and, that summer, joined a committee of six to supervise the production of saltpeter, an essential ingredient in the manufacture of gunpowder. Patriots held John in high esteem at this juncture. From the siege of Boston in the early winter of 1775 , rebel Colonel William Thompson assured him that "I shall think myself happy in having it in my Power, in any part of my Life, to serve either you or your Friends. ${ }^{, 48}$ William Jr. made an even more robust commitment, taking up arms in defense of aggrieved colonial liberty. After the battle of Lexington, he enlisted in the militia as Ensign of the Second Battalion. Congress soon commissioned him as one of the first Pennsylvania officers. In June, the assembly entrusted William Jr. as one of twelve signers for an issue of $£ 35,000$ in bills of credit to bolster the local economy. Captain William Allen Jr. endured the bitterly cold and abortive Quebec campaign of December 1775 under the pooled forces of Benedict Arnold and Richard Montgomery. Serving laudably under Colonel Arthur St. Clair, he rose in rank to Lieutenant Colonel. Of the eight patriots the Committee of Safety recommended to Congress for that distinction, William Jr. tied for the second highest total of votes received. ${ }^{49}$ Meanwhile, Andrew bestrode the political and military spheres. In 1775, he mustered with a troop of horse

\footnotetext{
48 "Diary of James Allen," PMHB, vol. 9, no. 2, 177; Scharf \& Westcott, History of Philadelphia, 292, 301; Kistler, William Allen, 50; "Wm. Thompson to John Allen," Prospect Hill, November 14, 1775, Pennsylvania Archives, First Series, vol. 4, 680. Thompson was a member of the Pennsylvania Assembly who was given command of the companies of riflemen the province sent to support the siege of Boston in June 1775. These troops became known as Thompson's Rifle Battalion. See Robert J. Guy Jr., "William Thompson and the Pennsylvania Riflemen," William Pencak, ed. Pennsylvania's Revolution, (University Park, PA: The Pennsylvania State University Press, 2010), 211-230.

${ }^{49}$ Minutes of the Council of Safety, Colonial Records, vol. 10, June 30, 1775, 281; November 21, 1775, 406; January 3, 1776, 444-445. William's promotion and military activities are mentioned in Richard Smith's diary January 5, January 30 \& March 15, 1776, Letters of Members of the Continental Congress, 297, 335, 393-394 respectively; Scharf \& Westcott, History of Philadelphia, 301; DeLancey, "Chief Justice William Allen," PMHB, 207; Kistler, William Allen, 52; Ousterhout, A State Divided, 132, 158.
} 
assigned in the summer to escort recently appointed Commander-in-Chief George Washington from Philadelphia to Brunswick on the initial leg of his journey to take charge of the patriot army in Boston. The colonial assembly named him to the Committee of Safety in June and in August he helped design new rules for the "association" which later metamorphosed into the state militia. The assembly also appointed him one of nine delegates to the Second Continental Congress for Pennsylvania in November. ${ }^{50}$ Though troubled, the family held steady on resistance.

The extraordinary events of 1776 definitively split Pennsylvania provincials into loyalist and patriot camps and forced Galloway and the Allens to choose their destiny. In January, Thomas Paine set off a firestorm with the publication of Common Sense in which he proposed full-scale independence. Public opinion in the capital city rallied around his radicalized views. As Congress and local popular sentiment edged towards a definitive separation from the mother country, an ever more isolated Joseph Galloway clung to the seclusion of Trevose. The Allen clan continued to engage, although more hesitantly than before. Outwardly, they manifested a pro-patriot posture and fulfilled their political and military duties. As a delegate to Congress, Andrew participated in a secret initiative with Thomas Lundin, Lord Drummond, to develop a plan for peace acceptable to both the revolutionaries and the British. But secrecy brought the opposition of George Washington who reported the business to Congress, while Samuel Adams and John Adams opposed the scheme on political grounds. In March, the plan fizzled away in

\footnotetext{
50 "Memorial of Andrew Allen," AO12-42-226, 237, 240-41, DLAR; Scharf \& Westcott, History of Philadelphia, 298, 300; Kistler, William Allen, 51; DeLancey, "Chief Justice William Allen," PMHB, 208; “Andrew Allen," Legislators in Pennsylvania, vol. 3, 204.
} 
dithering debate. ${ }^{51}$ Meanwhile, New Jersey elected John Allen a delegate to its Provincial Congress. On February 26, the Philadelphia Committee of Inspection recruited John for one of eight district subcommittees to supervise the landing of merchandise by ship or ferry. After the retreat from Canada, the Continental Army assigned Lieutenant Colonel William Allen Jr. to Fort Ticonderoga. Andrew continued in Congress, ran for a seat in the assembly "by-election" of May 1, 1776 on a ticket "favoring reconciliation with Britain" and won, tying for the second highest vote count in a slate of eight candidates. He also continued to serve on the Committee of Safety. Although his attendance there became more sporadic as time passed, minutes show Andrew present as late as June 18, 1776 - two weeks before independence - among a quorum of twelve others. ${ }^{52}$

Inwardly, however, the Allens had grave doubts about the course of the resistance movement. Independence - a step they considered ominous - loomed ever larger. Caught between conflicting impulses, the brothers opted to check the impetus towards a divorce from Great Britain rather than advance the popular cause. As Andrew's by-election to the provincial assembly clearly demonstrated, the Allens were not alone in their sentiments. The conservative ticket had won three of the four seats in question, the more radical Whigs only one. Yet the extremely tight race revealed a bifurcation of popular attitudes along a more or less equal distribution. ${ }^{53}$ Almost everyone agreed on defying

\footnotetext{
51 “Andrew Allen,” Legislators in Pennsylvania, vol. 3, 205-206.

52 John was appointed to the subcommittee for District 4, Philadelphia. Committee of Inspection, 1776. List of the Sub-Committees... February 26, 1776 [Philadelphia, 1776] Broadside, LCP; DeLancey, "Chief Justice William Allen," PMHB, 207-08; Kistler, William Allen, 50-51; Wilbur Siebert, The Loyalists of Pennsylvania, 27. In addition to June 18, Andrew is listed as present at Committee of Safety meetings on May 8 \& 11, 1776, though the committee met almost every day. See Council of Safety Minutes, Colonial Records, vol. 10, 560, 566, 607.
} 
parliamentary interference. But about half of the population wanted to persevere in addressing colonial grievances within the legal bounds prescribed by the British

Constitution, while the other half wanted to sever ties with the monarchy once and for all.

It was at this critical juncture that Congress decisively called for the states to discard all forms of royal authority and forge entirely new governments, opening the door for the July $4^{\text {th }}$ Declaration of Independence. ${ }^{54}$

The turmoil exposed the inadequacy of the idea of resistance upon which the Allens based their antiparliamentary stance. The moment demanded greater zeal. James noted forlornly in his diary that "My Brother John having been elected a member of the Provincial Congress of New Jersey, finding all opposition [to independence] vain, soon left it \& never returned." Upon hearing of the Declaration of Independence, William the younger rode to Philadelphia from Fort Ticonderoga and submitted a letter to the Continental Congress "praying leave to resign his commission," a request duly granted on July 24. As the most visible of the three, Andrew's by-election campaign actively endorsing reconciliation with Great Britain gained particular notoriety. By this point, the Proprietary and Quaker parties had tacitly converged, conscious that political lines had been redrawn and colonial factions no longer mattered. The entire existing order was

\footnotetext{
${ }^{53}$ In the by-election, eight men ran for four available seats, with the four highest individual vote-getters proclaimed as victors. A 4-man radical or "Whig" ticket garnered 3,620 total votes while the 4-man conservative or "Tory" ticket drew a slightly higher 3,696 votes. However, the conservatives took three of the four individual slots. Winners were Samuel Howell (941 votes), Andrew Allen (923), George Clymer (923), and Alexander Wilcocks (921), with Clymer the only radical (he later became a "Republican" moderate). The May 1 election is treated in Ryerson, The Revolution Is Now Begun, 173-174. See also Scharf \& Westcott, History of Philadelphia, 311; “Andrew Allen," Legislators in Pennsylvania, vol. 3, 207; Charles P. Keith, “Andrew Allen,” PMHB, vol. 10, no. 4 (1887), 363.

${ }^{54}$ Journals of the Continental Congress 1774-1789, May 10 \& May 15, 1776, vol. 4, 342, 357-58. Congress' resolution was formulated on May 10,1776 and a committee set up to prepare a preamble. The latter was submitted and approved for publication along with the original resolution on May 15, 1776. The impact of Congress' call for new state governments is discussed in greater detail in Chapter 1.
} 
under siege. Radical Christopher Marshall described the moment thusly: "I think it may be said with propriety that the Quakers, Papists, Church, Allen family, with all the Proprietary party, were never seemingly so happily united as at this election, notwithstanding Friends' former protestation and declaration of never joining with that party since the club or knockdown Election." ${ }^{, 55}$ Erstwhile enemies, Galloway and the Allen brothers now stood arm in arm with the opponents of independence.

Joseph Galloway belonged to a strain of nonconformity with Parliament that wished to remedy violations of colonial rights respectfully and only via proper channels. For Americans like him, retention of the imperial connection reigned supreme. Open defiance - which endangered that crucial linkage - was not an option. Alternatively, the Allen brothers' road from active to reticent resistance was more typical of colonials who resisted parliamentary intrusion but could not cross the Rubicon of independence. While wrestling with the question of allegiance and the prospect of a fall from the provincial summit, it appears they overestimated the degree of influence they still retained. Patriot officer Alexander Graydon noted that William Jr. had "called at our camp on his way to Philadelphia [to resign], where he appeared somewhat surprised and mortified, that his example had no followers." Some saw William's resignation as an act grounded on selfinterest and pride, not principle. A patriot newspaper adduced that "he resigned - not because he was totally unfit for it, but because the Continental Congress presumed to

\footnotetext{
55 "Diary of James Allen," PMHB, vol. 9, no. 2, 191; Journals of the Continental Congress, July 24, 1776, vol. 5, 604; Extracts from the Diary of Christopher Marshall, 68. Marshall's derisive observation on unity referred to the longstanding antagonism between the Quaker and Proprietary parties. The "knockdown election" occurred in 1742 when rowdy sailors allegedly backed by the proprietary faction under the control of William Allen Sr. got into a street brawl with a crowd of pro-Quaker Germans. During the melee, a sea captain punched leading Quaker Israel Pemberton Jr. See Norman S. Cohen, "The Philadelphia Election Riot of 1742," PMHB, vol. 92, no. 3 (July, 1968), 306-319; and Theodore Thayer, Israel Pemberton: King of the Quakers (Philadelphia: The Historical Society of Pennsylvania, 1943), 48-49.
} 
declare the American States Free and Independent, without first asking the consent, and obtaining the approbation of himself and wise family."

Andrew clearly saw himself as a necessary brake on the radicals in the lead-up to independence. His testimony and that of witnesses before the Royal Claims Commission in the 1780 s sought to justify his actions on the patriot front in terms of strict loyalty to the king. Witness Phineas Bond claimed Andrew was "uniformly zealous to maintain the constitutional dependence of North America upon Great Britain," though "constantly adverse to the exercise of unrestrained taxations by this country [England] over the colonies." Bond added that a wish to be "the voice of the Moderate party" and "restrain the measures of violence then in agitation" while opposing "the alarming efforts then making to bring about" independence motivated the colonial assembly's decision to appoint Andrew to Congress as well as his acceptance. ${ }^{57}$

In his own testimony, Andrew Allen noted that radicals nicknamed his Troop of Horse the "Tory Association." He swore he had only joined the patriot Committee of Inspection and Observation which rounded up suspected loyalists "to save these people from the Fury of the Mob, who he feared would proceed to extremities against them." In the same vein, he asserted that "during the time he sat in Congress he did everything in his power to prevent the separation of the two countries - and publicly in the Congress and within closed doors delivered his sentiments against every measure which should bring on a Rupture between the two countries." Andrew took his views beyond Congress,

\footnotetext{
${ }^{56}$ Graydon, Memoirs, 157; Freeman's Journal and New Hampshire Gazette, January 5, 1777 in Frank Moore, ed., Diary of the American Revolution from Newspapers and Original Documents (New York: Charles Scribner, 1860) vol. 1, 369; Cohen, "William Allen: Chief Justice of Pennsylvania," 334-35.

57 Testimony of Phineas Bond, "Memorial of Andrew Allen," AO12-42-236, DLAR. Bond was a Philadelphia attorney who became a loyalist and took refuge in England.
} 
adding that "being appointed a Trustee of the College of Philadelphia, he publicly took the Oaths to the King in the month of April of 1776, for which he was attacked in Congress by one of the Delegates from Virginia" a month later. Historian Henry Young ascribes such importance to this incident that he believed it "probable" that Andrew's public oath to the king "helped precipitate the all-important resolution which Congress passed" in May instigating the colonies to set up new governments. ${ }^{58}$ The episode reveals the Allens' importance as bastions of colonial continuity and as safeguards on separatist impulses barely two months before independence. In order to go forward with their agenda, radicals had to either smash the Allens' opposition or convince them to join the independence movement. Although patriots no doubt preferred the latter option, an outcome like Galloway's self-confinement was also perfectly admissible.

Contemporaries sensed the Allens' allegiance struggles. Looking back from his patriot vantage point, Graydon judged that John "was an acknowledged disapprover of our proceedings" but recalled Andrew as "more ardent, and considered also to be more sincere." He concluded that the family's "early whiggism had perhaps as much disgusted the Tories, as its final defection had exasperated the Whigs," suggesting their loyalism was not a foregone conclusion. On the other hand, exile Daniel Coxe described Andrew to the claims commission as a "steady zealous Loyalist" who "very sincerely repented of the part he had taken." Of Andrew, Sabine said a half century later "he, at first, was found among the leading Whigs." Of William, he said more succinctly "he was a Whig," whereas John, "unlike his brother, was an avowed Loyalist from the first."

\footnotetext{
58 "Memorial of Andrew Allen," AO12-42-226, 227, DLAR; Young, "The Treatment of the Loyalists in Pennsylvania," 40; Cohen, "William Allen: Chief Justice of Pennsylvania," 338-39.
} 
While Joseph Galloway remained out of the public eye, the Allens' tightrope act began to unravel shortly before the Declaration of Independence. Unable to halt the momentum towards a permanent breach, the brothers voluntarily threw in the towel. After John's withdrawal from New Jersey's provincial congress, he moved with his family to an Allen residence at the Union Ironworks in Hunterdon in that state. Andrew resigned from the Troop of Horse in April 1776 and did not venture back to the Council of Safety after June 18 nor to the Continental Congress after June 14, a huge political error since Pennsylvania's delegation to Congress voted in favor of independence by a margin of only one. Benjamin Franklin, James Wilson, and John Morton voted for separation. Thomas Willing and Charles Humphreys voted against independence. Edward Biddle died during the session, while John Dickinson and Robert Morris abstained. There are conflicting accounts regarding the latter's roles - some historians say they were present but did not vote; others claim they purposely did not show up that day at all. Because the final tally was 3-2 out of a potential eight-man delegation minus Biddle, Andrew's anti-independence vote could have brought about a tie and conceivably precipitated a political crisis. ${ }^{60}$

Instead, Andrew Allen purchased a farm at Neshaminy, fifteen miles outside of Philadelphia, and retired like Galloway to wait out events. Said diarist James, "a few weeks before this unhappy declaration my Brother Andrew, with Mr. Willing and Mr.

\footnotetext{
${ }^{59}$ Graydon, Memoirs, 116, 126-27; Daniel Coxe's testimony is in "Memorial of Andrew Allen," AO12-42240, 241, DLAR; Sabine, Biographical Sketches, vol. 1, 157-58. The early loyalist tendencies ascribed to John Allen by Graydon and Sabine contradict Ousterhout's assertion that he participated in most patriot forums from 1773 to 1776.

${ }^{60}$ Burnett, The Continental Congress, 174-177, 182-183; Scharf \& Westcott, History of Philadelphia, $317-$ 18; Ryerson, The Revolution Is Now Begun, 238-239.
} 
Humphries left the Congress." Phineas Bond later elaborated that Andrew "withdrew himself from Congress mainly because he perceived it to be impossible to defeat the schemes of those who were bent on overturning the established Forms of Government." Andrew himself believed delegates to Congress "were plunging America into Ruin." Unlike his brothers, William stayed in Philadelphia that summer. No longer a continental officer, he got into an altercation on September 3. Disowned Quaker and radical Whig Christopher Marshall noted that "yesterday, high words passed at Coffee House, William Allen, Jr., declaring he would shed his blood in opposition to Independency, and Col. John Bayard, in the support of Independency." 61 This was the same John Bayard who became speaker of the radical assembly.

Retirement from the public sphere did not bring tranquility. From July to November 1776, Howe drove Washington and his continentals out of New York. Speculation on his next move ran rampant. James Allen noted in his diary the rumors then circulating that "General Howe was expected in Philadelphia." Patriot fears ignited "a persecution of Tories," a definition applied haphazardly to "every one disinclined to Independance [sic] tho' ever so warm a friend to constitutional liberty and the old cause. ${ }^{, 62}$ Earlier devotion to resistance now provided little protection. Any doubts about stronger measures against Great Britain made one a target. Joseph Galloway considered himself in grave danger during his reclusion, and "to a Degree imprisoned in his own house." Three mobs "excited against him" in the autumn of 1776, some threatening to

\footnotetext{
61 "Diary of James Allen," $P M H B$, vol. 9, no. 2, 191. Allen's information is evidently incorrect, as Willing and Humphries were present to vote against independence. Konkle, Benjamin, Chew, 151; "Memorial of Andrew Allen," AO12-42-227, Bond's statement on 237, DLAR; Diary of Christopher Marshall, 91.

62 "Diary of James Allen," PMHB, vol. 9, no. 2, 193.
} 
tar-and-feather or hang him. The last group consisted of "thirteen intoxicated Dutchmen," allegedly instigated by Massachusetts congressman Samuel Adams. The contradictions wrought by revolution permeate the Galloway saga. Opposed to the country's direction and bullied with violent retaliation, the former House speaker nonetheless managed to present medals to a patriot militia regiment and entertain four hundred troops on his estate. On the eve of Benjamin Franklin's departure for his diplomatic mission to France that October, this onetime political ally - now a consummate revolutionary - stored his personal papers at Trevose and left his last will and testament in Galloway's care. ${ }^{63}$

The threats continued. By late November Galloway had had enough. While his daughter Elizabeth hid at a friend's house, he escaped by night. Wife Grace stayed behind to safeguard the original Growden estate "under an expectation, from some words in the law," said her husband, "that she might retain her own estate even during my life, and at least after my death." Galloway found his way to the British at New Brunswick, New Jersey, and surrendered to General Vaughn. It is possible he responded to the Howe amnesty proclamations for those willing to embrace the royal standard ${ }^{64}$ The patriot Freeman's Journal noted Galloway's exit with poetic sting in early 1777:

\footnotetext{
63 "Memorial of Joseph Galloway," Egerton, The Royal Commission, 84-85: Ferling, The Loyalist Mind, 38; Sabine, Biographical Sketches , vol. 1, 454; Benjamin Franklin to William Franklin, August 16, 1784, in John Eardley-Wilmot, Esq., Historical View of the Commission for Enquiring into the Losses, Services, and Claims, of the American Loyalists, at the Close of the War Between Great Britain and Her Colonies in 1783: With an Account of the Compensation Granted to Them by Parliament in 1785 and 1788. (London: J. Nichols \& Bentley, 1815; War College Series Reprint), Appendix II, 138; “Joseph Galloway," Legislators in Pennsylvania, vol. 3, 613.

64 “Joseph Galloway," Coldham, American Migrations, 461; The Examination of Joseph Galloway, 76. As noted earlier, the Howes issued pardon proclamations from New York on July 14, September 19, and November 30, 1776. See "Proclamation by Lord Howe," American Archives: Documents of the American Revolution Period, 1774-1776, Northern Illinois University Digital Collections and Collaborative Projects, http://amarch.lib.niu.edu/islandora/object/niu-amarch\%3A101937, last accessed on October 19, 2016.
} 
Gall'way has fled, and join'd the venal Howe, To prove his baseness, see him cringe and bow, A traitor to his country, and its laws,

A friend to tyrants, and their cursed cause...

Fit materials for such Tory blood, Who wrong their country, and deny their God... ${ }^{65}$

Meanwhile, the Allens received the chilling news that "a list of 200 disaffected persons [was] made out, who were to be seized, imprisoned \& sent off to North Carolina; in which list, it was said, our whole family was set down." According to Graydon, lawyer Christian Huck "had assured them, that measures were in agitation for their immediate arrest and confinement." William and Andrew fled "under this dreadful apprehension," seeking momentary refuge with brother John at Hunterdon. James met them there soon after. The ensuing exchange among the four brothers resulted in the momentous decision of three to quit Pennsylvania altogether. James' entry of January 25, 1777 about a month later, declared that "against my Judgmt, they all went to Trenton \& claimed protection from General Howe's army. From thence they went to N. York where they now are." The Allens' getaway garnered the attention of Congress. Virginia delegate Thomas Nelson Jr. informed Thomas Jefferson that "your friends John, Andrew and William Allen are now with General Howe," adding that they "have hamm'd themselves finely, for when they went to Howe, there was very little doubt, but he would shortly have been in possession of Philadelphia, as indeed he might, had he play'd his Cards well." ${ }^{\text {} 66}$ The reference is to the British advance southward through New Jersey which Washington repulsed with his

\footnotetext{
${ }^{65}$ Freeman's Journal, February 4 \& March 15, 1777, in Moore, ed., Diary of the American Revolution from Newspapers and Original Documents, vol. 1, 369.

66 “Diary of James Allen,” PMHB, vol. 9, no. 2, 193; Graydon, Memoirs, 296; Siebert, Loyalists of Pennsylvania, 30; Thomas Nelson Jr. to Thomas Jefferson, January 2, 1777, The Papers of Thomas Jefferson, Julian P. Boyd, ed. (Princeton University Press, 1950), vol. 2, 3-4. Nelson's letter was written about a week after Washington's victory at Trenton and one day before the battle of Princeton, also won by the continentals.
} 
victories at Trenton and Princeton. Howe himself later confirmed that Andrew had joined the army at Trenton in 1776. Some historians believe the Allens may have likewise made this decision in response to British pardons. Former patriot partners viewed the move as basely self-interested. Robert Morris wrote of Andrew and John Dickinson that they "have given mortal stabs to their own Characters" and that "the defection of these men was supposed to have originated in a desire to preserve their Estates. ${ }^{, 67}$ The decision split John, Andrew and William Jr. from their father and James who opted to stay behind.

\section{IN THE SERVICE OF THE KING (1776-1783)}

The Galloway and Allen defections left Governor John Penn and the proprietary government on their own at a crucial moment when the fate of the old order still hung in the balance. In the absence of established leadership opposing the revolutionary surge, radical patriots seized the opportunity to shape republican government according to their design. They did so with gusto. ${ }^{68}$ Meanwhile, Galloway and the Allens quickly gained the confidence of the British high command at New York. Andrew Allen took an oath of allegiance to King George III and renounced fidelity to Congress. Joining other highly regarded colonials who had fled, the group coalesced as an unofficial loyalist lobby, peppering Howe with reports of strong pro-British feeling in Philadelphia and pushing for an attack on the capital. Circumstantial evidence suggests an effective lobby, as the commander abruptly modified his plans in the last months of 1776 from an attack on

\footnotetext{
${ }^{67}$ Howe's letter in "Memorial of Andrew Allen," AO13-70B(II)-25, DLAR; "Memorial of William Allen," AO13-96-21, DLAR; Brunhouse, The Counter-Revolution in Pennsylvania, 24; Stern, David Franks, 3; Robert Morris to John Jay, January 12, 1777, Letters of Delegates to Congress, 1774-1789, vol. 6, 87-88. Dickinson did not join the British, but rather temporarily retired from public life.

${ }^{68}$ Many historians will no doubt argue that the proprietary regime's demise was sealed by this time. Although I submit that such was likely the case, I am convinced that it was an unwillingness to stand firm on their own without British cover that undid the Old Guard.
} 
New England via Newport to an assault on Philadelphia. In later preparations for the invasion, Howe appointed Andrew as Lieutenant Governor of Pennsylvania to stand in for then captive Governor John Penn Sr. who remained under rebel arrest in New Jersey through May 1778. ${ }^{69}$ Confidence levels for the Philadelphia offensive were apparently high. Patriot officer Alexander Graydon's mother, in British-occupied New York that June seeking to find her recently captured son, received a visit from fellow Philadelphian John Allen in which "he advised her not to be scrupulous as to the terms of my [Graydon's] release, since the business would soon be over."70

Joseph Galloway felt much the same way. In March 1777, he optimistically hailed British efforts and a weakening rebellion. Expecting a decisive imperial victory, he wrote to Richard Jackson in London that the British were about to undertake the "Reduction of America." In preparation for such an inevitability, Galloway met with fellow Anglicans in New York to discuss the establishment of a bishopric for the Church of England in America. General Howe assigned Galloway to set up an intelligence network of loyalist informants, recruit pilots and guides, secure provisions, and marshal horses for the assault

\footnotetext{
${ }^{69}$ Contrasting the language in Howe's November/December 1776 reports to his superiors in Great Britain reveals how British plans evolved - see Taaffe, The Philadelphia Campaign, 1777-1778, 29. American Loyalists, Commission of Inquiry, III, 400, in Benton, Whig-Loyalism, 201; Jacob E. Cooke, Tench Coxe and the Early Republic (Chapel Hill: University of North Carolina Press, 1978), 32. David Haugaard refutes Benton and Cooke's account, asserting that "members of the Allen family did not serve in an official capacity" during the occupation, although he does grant that Andrew "acted as an advisor to General Howe." "Andrew Allen," Legislators in Pennsylvania, 208. The explanation could be that Howe named Allen in anticipation of establishing civil government but the position did not take effect because the general never relinquished military rule while in Philadelphia. For Penn's arrest, see "Warrant to Arrest Certain Persons, 1777," August 1, 1777 \& "Warrant to Arrest Certain Persons, 1777," August 4, 1777, Pennsylvania Archives, First Series, vol. 5, 478, 484.

${ }^{70}$ Graydon, Memoirs, 245, 275.
} 
on Pennsylvania. ${ }^{71}$ Sir William Howe landed his army at Head of Elk on Chesapeake Bay on August 25, marched towards Philadelphia, and beat back Washington at Brandywine on September 11. On September 26, Robert Morton celebrated in his diary that "about 11 o'clock A.M. Lord Cornwallis with his division of the British and Auxiliary Troops amount'g to about 3000, marched into this city, accompanied by Enoch Story, Jos. Galloway, Andw. Allen, William Allen, and others, inhabitants of this city, to the great relief of the inhabitants who have too long suffered a yoke of arbitrary Power; and who testified their approbation of the arrival of the troops by the loudest acclamations of joy."72 Loyalist fortunes were on the rise. The future was theirs.

The British takeover of Philadelphia finalized the transformation of the AllenGalloway relationship. Once acrimonious enemies along the Proprietary and Quaker party rift, the Revolution purged those distinctions. They now stood shoulder to shoulder on the same team. For most observers, the occupation appeared decisive and permanent, especially after Howe's forces held off the continentals again in a major engagement at Germantown on October 4 and the imperial navy dislodged the patriots' ingenious maritime defenses on the Delaware River to open resupply routes before winter ice froze access to the sea. But on November 4 news arrived that General John Burgoyne had surrendered his entire army to the rebels at Saratoga in mid-October. Some of the earlier buoyancy evaporated. ${ }^{73}$ Still, loyal Pennsylvanians seemed secure in their position.

\footnotetext{
71 "Joseph Galloway," Legislators in Pennsylvania, vol. 3, 614; Chopra, Unnatural Rebellion, 83; James B. Bell, A War of Religion: Dissenters, Anglicans and the American Revolution (Palgrave Macmillan, 2008), 192-193.

72 “The Diary of Robert Morton,” $P M H B$, vol. 1, no. 1, 7-8. Other accounts reveal a more subdued reception for Cornwallis and company. See editor's footnote in Morton's diary for entry of September 26.

73 “Diary of Robert Morton,” PMHB, 26-27. For the river battle, Taaffe, Philadelphia Campaign, 108-144.
} 
Joseph Galloway and the Allen brothers promptly went to work to restore royal rule. General Howe named Galloway Superintendent General of the Police in the City and its Environs \& Superintendent of Imports and Exports to \& from Philadelphia, the highest ranking civil officer of the occupation. Radical Christopher Marshall held a less complementary view, noting that Galloway "was proclaimed in Philada. Governor of this Province, by the knot of Tories there." The designation put him in charge of civil administration and trade, including the night watch, disarmament of suspected rebels, control of access to the city, and regulation of markets, the port, and taverns. He also organized round-ups of suspected Whigs who remained in the city and a campaign to administer the royal oath of allegiance to residents. Elizabeth Drinker noted in late September that "a Number of the [Citysans] taken up, and imprison'd.,"74

The Allens followed a similar path. As the nominal Lieutenant Governor, Andrew Allen first served in a civil capacity. In the fall of 1777, he and Galloway added their signatures to that of more than six hundred Philadelphians who petitioned General Howe to allow the use of colonial currency as legal tender. ${ }^{75}$ Meanwhile, William Jr. "was by Sir William Howe appointed Lieut. Col. Commandant of a Regiment, which he raised at that place called the Pennsylvania Loyalists.” The youngest Allen circulated a broadside addressed to "All Intrepid Able-Bodied Heroes Who are willing to serve His Majesty King George the Third, in Defence of their Country, Laws and Constitution against the arbitrary Usurpations of a tyrannical Congress." His notice offered recruits fifty acres of

\footnotetext{
${ }^{74}$ Diary of Elizabeth Drinker, September 29, 1777, 64; Diary of Christopher Marshall, 149. Siebert argues that many patriots avoided arrest because of Galloway's intercession on their behalf, Siebert, The Loyalists of Pennsylvania, 40. Galloway admitted to his personal involvement in the disarmament of rebels at his testimony before Parliament. See The Examination of Joseph Galloway, 23.

${ }^{75}$ J. W. High, “The Philadelphia Loyalists,”5; Scharf \& Westcott, History of Philadelphia, 360, 365-66.
} 
land at war's end, as well as a five-dollar bounty, arms, clothing and provisions. With authorization to enlist up to 456 men, William Allen Jr.'s regiment numbered 132 soldiers when the unit evacuated Philadelphia in 1778. Among those joining was John Young, nephew of Elizabeth Graeme Ferguson, given the rank of Lieutenant. To opponents, the Allens' resurgence under royal colors appeared ominous. A letter from occupied Philadelphia published in a patriot newspaper beyond the city described the brothers as "insolent and cowardly." That Joseph Galloway and the Allens found themselves on the same side did not necessarily mean that they had become friends. In later testimony before Parliament, Galloway attributed the failure of loyalist enlistments to Howe's selection of "the most unpopular men to recruit," among whom he included William Jr. ${ }^{76}$

Despite the setback at Saratoga, loyalist fortunes still appeared robust as late as January 1778. Galloway faithfully tended to his duties, assembling a series of detailed reports on colonial conditions for royal authorities, such as "An Account of the General Property of the Thirteen United States of America" calculating "the whole value of the real and personal property \& taxables in the thirteen United Colonies." In a demographic analysis entitled "The Present State of America," he surmised that 450,000 out of $1,800,000$ whites and 200,000 of 800,000 blacks were capable of bearing arms on either side of the conflict. Galloway favored arming the enslaved to fight for the royal cause, arguing that "the Negroes may be all seemed so many Intestine Enemies [of the patriots],

\footnotetext{
76 "Memorial of William Allen Jr.," AO13-96-21, DLAR; Teucro Duce Nil Desperandum [Sire, do not despair], Recruitment Broadside for the First Battalion of the Pennsylvania Loyalists, Evans 15351, LCP; Jackson, With the British Army in Philadelphia, 100; Ousterhout, The Most Learned Woman in America, 198; Paul H. Smith, Loyalists and Redcoats: A Study in British Revolutionary Policy (New York: W. W. Norton \& Company, 1964), 49; Scharf \& Westcott, History of Philadelphia, 360.
} 
being all Slaves and desirous of Freedom, and wou'd, was an opportunity offer'd them, take up Arms against their Masters." He also completed a study on comparative prices for essential goods, contrasting the colonial era with the current situation. In February, British troops escorted wife Grace and daughter Elizabeth to a family reunification in the capital. Then in March, his intelligence network supplied data on Washington's nearby encampment and confidently reported that 1134 soldiers and 354 sailors had deserted the rebels, seeking refuge in occupied Philadelphia and taking an oath to the king. ${ }^{77}$

Meanwhile, the Allens were guests at the January 14 wedding of Tench Coxe and Catherine McCall, a high point of occupied Philadelphia's social season. That same month, the three siblings reunited with absentee brother James when the latter finagled a pass from General Washington permitting a reunion dinner on the perimeter of the city. Describing his "inexpressible" joy at seeing them for the first time in over a year, the state of their affairs impressed James: "the accounts my brothers gave of the military events that had happened \& the situation of things in Philadelphia gave me a new set of Ideas; \& made me ardently wish to be there. ${ }^{, 78}$ But his optimism was short-lived. Worst

\footnotetext{
${ }^{77}$ Joseph Galloway to the Earl of Dartmouth, "Account of the General Property of the Thirteen United States of America, with the Continental Congress," January 23, 1778, B. F. Stevens, Facsimiles of Manuscripts in European Archives Relating to America 1773-1783 With Descriptions, Editorial Notes, Collations, References and Translations, (Wilmington, DE: Mellifont Press, 1970), vol. 24, 2080; Joseph Galloway to the Earl of Dartmouth, "Present State of America," January 23, 1778, ibid., vol. 24, 2079; Joseph Galloway to the Earl of Dartmouth, "An Estimate of the difference in Price of the Necessaries of Life before the commencement of the Rebellion and [at] the present time," January 23, 1778, ibid., vol. 24, 2082; Joseph Galloway to the Earl of Dartmouth, "Sketch of the Position of Washington's Camp on the Schuylkill," March 24, 1778, ibid., vol. 24, 2093; Joseph Galloway to the Earl of Dartmouth, "An Account of the Number of Deserted Soldiers, Galleymen \&c. from the Rebel Army and fleet, who have come into Philadelphia and taken the Oath of Allegiance, with a particular account of the Places in which they were Born,” March 25, 1778, ibid., vol. 24, 2094, DLAR. “Joseph Galloway," Legislators in Pennsylvania, vol. 3, 617. For more on Galloway \& arming slaves, see Alan Gilbert, Black Patriots and Loyalists: Fighting for Emancipation in the War for Independence (Chicago: University of Chicago Press, 2012), 29-30.

${ }^{78}$ Stern, David Franks, 136; Cooke, Tench Coxe, 34; “Diary of James Allen,” January 18, 1778, PMHB, vol. 9 , no. 4 (January, 1886), 431.
} 
of all, John Allen succumbed to "a putrid fever, insensible during an illness of 16 days," and died in the provincial capital on February 2. Diarist James recalled him as "the most affectionate of brothers \& best of men." From his confinement in New Jersey with Governor Penn, Benjamin Chew described the family's grief to James Hamilton three days later, observing that "the tender feelings of nature in hopes of this kind are for some time deaf to the calls of reason and religion." British officer John Peebles' verses on John's demise reveal admiration for him in imperial circles:

Let death attack us in the bed or field

All Ranks \& ages to his force must yield

Happy the Man Who meets the foe unafraid

For death or his Enemy never unprepar' ${ }^{79}$

The winter optimism did not last and the loyalist cosmos soon entered a tailspin.

On March 6, the Pennsylvania Assembly at Lancaster passed the first attainder law. The text accused Joseph Galloway and Andrew Allen, "late members of the Congress of the thirteen United Colonies," John Allen, "late member of the committee of inspection and observation for the city and liberties of Philadelphia," and William Allen, the younger, "some time a captain and afterwards a lieutenant-colonel of a regiment or battalion of foot in the service of the said United Colonies, now states of America" of high treason. Not coincidentally, Galloway and Andrew Allen headed the list of the thirteen most notorious loyalists in the province. The act gave the attainted until April 20 to report for

\footnotetext{
79 "Diary of James Allen," February 27, 1778, PMHB, vol. 9, no. 4, 433; Dreer Collection, American Lawyers, 2, HSP in Konkle, Benjamin Chew, 152; John Peebles, John Peebles' American War: The Diary of a Scottish Grenadier, 1776-1782, Ira D. Gruber, ed., (Mechanicsburg, PA: Stackpole Books, 1998), entry of April 27, 1778 cited in Jackson, With the British Army in Philadelphia, 215.
} 
trial in order to avoid an automatic verdict of guilt. Only the timing of John's earlier death preserved him from prosecution, an event which later benefited his heirs. ${ }^{80}$

In the late spring of 1778 , loyalist fortunes plummeted further. Rumors swirled of Howe's resignation, a Franco-American treaty, a peace commission soon to arrive from London, and a new British strategy that mandated the evacuation of Philadelphia. Morale sank. Andrew Allen pushed hard against any withdrawal. Ambrose Serle, secretary to William Howe, penned this entry in his journal as the evacuation neared: "Had some Conversation with Mr. Andw Allen. His most material Remark was, that from the Persuasion, that five Sixths of the Province were against the Rebels, our Army had only to drive off Washington \& to put arms into the Hands of the well-affected, and the Chain of Rebellion would be broken." ${ }^{81}$ Official news of the French alliance signed in February arrived on May 2. Six days later Sir Henry Clinton disembarked to replace Howe. Sir William sailed away on May 24 after a lavish tribute organized by his officers and elite loyalists known as the Meschianza. Joseph Galloway received verification of the coming evacuation on May 21. Serle noted the next day that "It filled my poor Friend, as might be expected with Horror \& melancholy on the View of his deplorable Situation; exposed to the Rage of his bitter Enemies, deprived of a fortune of about $£ 70,000$, and now left to wander like Cain upon the Earth without Home, \& without property." 82

\footnotetext{
80 Statutes At Large of Pennsylvania, vol. 9, "An Act for the Attainder of Divers Traitors if They Render Not Themselves by a Certain Day, and for Vesting Their Estates in This Commonwealth, and for More Effectually Discovering the Same and for Ascertaining and Satisfying the Lawful Debts and Claims Thereupon," March 6, 1778, Chapter 784, 201.

${ }^{81}$ Ambrose Serle, Thursday, May 14, 1778, Edward H. Tatum, Jr., ed., The American Journal of Ambrose Serle (San Marino, CA: The Huntington Library, 1940), 293.

${ }^{82}$ Ambrose Serle, Thursday \& Friday, May 22-23, 1778, American Journal, 295-296. For the Meschianza, Scharf \& Westcott, History of Philadelphia, 377-83.
} 
Galloway refused to serenely accept the inevitable. Aboard his evacuation vessel, he penned reports to the Earl of Dartmouth arguing against the withdrawal and proposing new strategies for the British army to regain control of colonial territory. He argued that Washington's army was ineffective, “composed of many Boys old and Infirm Men... without Discipline," and in echoes of later accusations against the ineptitude of the Howe command, that "10,000 Men would have been raised... had the British Army operated in this Quarter." He held Philadelphia as "the most important place to either contending Party who shall possess it, of all in America," enumerating benefits such as the city's ability to supply the British army with provisions, its central location as a nexus between the other colonial capitals, support from Indians and loyalists on the frontier, and the strength of the present British army which "is at least of four times the Force of the rebel Army." Most importantly, he noted "the evident good effects wich [sic] followed the taking of this city" and the subsequent "extraordinary Revolution [that] has taken place in the minds of the People in the middle colonies" against the rebellion, all of which would be pointlessly reversed, as "by a Repossession of the city the Rebels will be restored to their former Resources of Men and Provisions." Instead of retreat, Galloway claimed that he was in contact with "Men of the first Weight and Influence," disposed "to raise the well-affected and Loyal in their several Districts and form them into a Militia." These "Three Hundred Gentlemen of Weight and Influence are now ready to engage and will immediately do so." They only needed to be supplied with weapons and authority "to disarm and secure those few Men who now oppress them" and to follow the lead of "some Person, whose Attachment to Government is indisputable" who could "be appointed as Brigadier or General Commander of the Provincial Troops.” With his lack 
of military experience, it is doubtful Galloway foresaw himself as that leader - but then again, given his personality, it is not beyond the realm of possibility. ${ }^{83}$ This last-ditch effort on the Delaware came to naught. On June 18, the final British army contingents abandoned Philadelphia. William Allen Jr. went with them. Galloway and Andrew Allen sailed with the loyalist evacuees for New York. By the time the Earl of Dartmouth received Galloway's desperate pleas from "your Lordships most obliged \& obedient servant," the withdrawal was a long-gone fait accompli. ${ }^{84}$

Along with reinstatement of the radical constitution that had wrested political power from the proprietors, the departure of Joseph Galloway and the Allens effectively put an end to historic elite leadership and certified the demise of the colonial regime. In retrospect, their decision is perfectly understandable given the collective weight of the patriot radicals" program: the "suffer death" clause in the February 1777 treason law, the June 1777 Test Act and multiple militia service requirements entailing a betrayal of their declared allegiance to the king, the March 1778 attainder act specifically targeting them by name, and the property confiscation measures projected in that statute which were in fact later carried out. The decision of the pre-war Quaker and Proprietary leadership to remain loyal to the Crown merged the interests and destiny of these Philadelphia elites with the fate of Great Britain and, given the war's trajectory, sealed their downfall.

\footnotetext{
${ }^{83}$ Letter of Joseph Galloway to the Earl of Dartmouth, June 17, 1778, B. F. Stevens, Facsimiles of Manuscripts in European Archives Relating to America, vol. 24, 2095; Joseph Galloway to the Earl of Dartmouth, "Reasons against abandoning the City of Philadelphia and the Province of Pennsylvania," June 17, 1778, , ibid., vol. 24, 2096; Joseph Galloway to the Earl of Dartmouth, "Proposal for covering and reducing the Country as the British Army shall pass through it,” June 17, 1778, ibid., vol. 24, 2097.

${ }^{84}$ J. W. High, "Philadelphia Loyalists," 185-86; Middlekauff, Glorious Revolution, 411; Jackson, With the British Army in Philadelphia, 222, 230-34; Taaffe, Philadelphia Campaign, 186-92; "Diary of James Allen," PMHB, vol. 9, no. 4, 440; Letter of Joseph Galloway to the Earl of Dartmouth, June 21, 1778, B. F. Stevens, Facsimiles of Manuscripts in European Archives Relating to America, vol. 24, 2100.
} 
Eventual patriot victory proved to be not only the triumph of revolution over monarchy but also of a new provincial faction over the two parties that had governed Pennsylvania for nearly a century. For the disaffected who stayed, however, the exodus of militant loyalists like Galloway and the Allens lessened internal loyalist-patriot frictions through the postwar era, opening the door for a smoother process of reintegration by helping to divert political animosity toward the radical-moderate dynamic of Constitutionalists vs. Anti-Constitutionalists/Republicans.

Anticipating the upcoming withdrawal before his return to England, General William Howe advised Pennsylvania loyalists "to make... Peace with the States, who, he supposed, would not treat them harshly." Some among the less compromised took his advice. But committed militants who had stuck their necks out for the king distrusted the radicals who then led the Revolution. Neither Joseph Galloway nor Andrew and William Allen Jr. considered reporting for trial by April 20, as per their attainder instructions. In Galloway's later testimony before Parliament, he underscored that "I came away from Philadelphia, knowing that my life would be taken if I stayed." Given the subsequent executions of Abraham Carlisle and John Roberts, they judged wisely. ${ }^{85}$ It was therefore fear of rebel retribution that drove loyalist militants to reject their first opportunity to reintegrate into provincial society in the summer of 1778 . From that moment forward, reintegration for committed militants meant nothing short of British military victory and wholesale subjugation of the rebellion. Galloway and the Allens responded accordingly.

The Allens revitalized their militancy. While William Allen Jr. continued as Lieutenant Colonel of the Pennsylvania Loyalists, Andrew received a commission as

\footnotetext{
${ }^{85}$ Serle, May 21, 1778, American Journal, 295; The Examination of Joseph Galloway, 76; Carlisle and Roberts are covered in depth in Chapter 5.
} 
Ensign in the Queen's Rangers on August 24 and a subsequent promotion to Lieutenant. ${ }^{86}$ During the retreat from Philadelphia, General Clinton assigned William's Pennsylvania Loyalists to cover the right flank of the army's lengthy baggage train as it crossed New Jersey during the tedious march to New York. On June 28, the rebel army attacked at the battle of Monmouth but the unit managed to satisfactorily defend its stores. A muster roll of two companies on July 11 had William Jr. commanding his loyalist troops at Camp Yellow Hook. ${ }^{87}$ In the early autumn, the expatriate siblings received the regrettable news that James had died in the capital on September 19 at the age of thirty-seven from a selfdescribed "disorder [that] appears to be a collection of wind in the upper part of the Chest, - accompanyed [sic] with a shortness of breath, \& a weariness \& relaxation." 88 Two of the four brothers were now deceased.

In November 1778, the royal army reassigned the youngest Allen brother and his loyalist corps to garrison Pensacola in West Florida, "where they remained until it was taken by the Spaniards" in May 1781. The regiment endured not only Spanish onslaughts but the ravages of smallpox. In late 1779, their depleted corps temporarily merged with the Maryland Loyalists, also stationed there, despite opposition from Clinton back at headquarters, who did not wish William Jr. to be placed above James Chalmers, the Maryland unit's commanding officer, because of seniority concerns. Both regiments returned to an autonomous status in December 1780. Meanwhile, William's forfeited

\footnotetext{
86 “Andrew Allen,” Coldham, ed., American Migrations, 448.

87 “Muster Roll of Captain Kearney's Company1st Battalion Pennsylvania Loyalists Commanded by Lt. Col. Allen" and "Muster Roll of Captain Stephens Company 1st Battalion Pennsylvania Loyalists Commanded by Lt. Col. Allen," July 11, 1778, National Archives of Canada, RG 8, "C" Series, Vol. 1907, 9,12 , DLAR.

88 "Diary of James Allen," Introduction, PMHB, vol. 9, no. 2, 176; ibid., July 15, 1778, PMHB, vol. 9, no. 4,440 . This was the last entry in James' diary and the only one after the British evacuation.
} 
estate in Pennsylvania was "to be speedily sold by Public Auction or Vendue, to the best and highest bidders." Sabine says of William at this time, "he was noted for wit, for good-humor, and for affable and gentlemanly manners" but Sabine also recounts the severe whipping of a deserter during the Spanish siege. Since William had been on extended leave at one point, it is unclear whether he was the officer then in charge. The British disbanded the Pennsylvania Loyalists at New Brunswick on the St. John River on October 10, 1783. William Allen Jr. received a grant of Canadian land from a grateful Crown. Thus closed the military adventures of the onetime Lieutenant Colonel of the Second Pennsylvania Battalion who began the conflict on the rebel side with an invasion of Canada, a province of the monarchy, and ended it accepting a donation of the same territory he had invaded from the very king he had attacked. ${ }^{89}$

Andrew Allen's war tour turned out to be less risky. At the June evacuation, he sailed for Manhattan, leaving wife Sarah and his younger children behind. Rebels began selling his seized assets only three months later. ${ }^{90}$ After his military promotions, he sailed from New York for England in November, arriving on January 1, 1779 in the company of the Carlisle Commissioners. ${ }^{91}$ An ocean now separated him from his family. Back in

\footnotetext{
89 "Memorial of William Allen Jr.," AO13-96-21, DLAR; "Estate Sales on April 12, 1779," Colonial Records, vol. 11, 745; Sabine, Biographical Sketches, vol. 1, 157-58; "History of the Provincial Corps of Pennsylvania Loyalists, Part 3, Philadelphia to Pensacola, Part 4, War with Spain and the United Corps \& Part 6, The Siege of Pensacola," The On-Line Institute for Advanced Loyalist Studies http://www.royalprovincial.com/military/rhist/paloyal/pal3hist.htm last accessed on February 4, 2017.

${ }^{90}$ Agents appraised these goods - mostly a chariot and furniture - for $£ 377$. See Estate of Andrew Allen, August 23, 1778, Pennsylvania Archives, Sixth Series, vol. 12, 68. The merchandise sold at public auction for over $£ 700$ a month later. “Andrew Allen,” Legislators in Pennsylvania, vol. 3, 209.

${ }^{91}$ These were king's peace commissioners - the Earl of Carlisle, William Eden and George Johnstone sent to negotiate with the rebels in the summer of 1778. See O'Shaughnessy, The Men Who Lost America, 63; Taaffe, The Philadelphia Campaign, 184-85, 192-94, 208, 228, 230, 239-40. The October 3, 1778, "Manifesto and Proclamation" of the Carlisle Peace Commission is available online at
} 
Philadelphia, his wife suffered a severe long-term disorder "connected with a variety of nervous Symptoms." These health problems had an upside, however, permitting her to remain in the city even after the radical Supreme Executive Council under President Joseph Reed issued a decree forcing the wives of loyalist exiles to leave within ten days for security reasons. ${ }^{92}$ As a newly arrived American in Britain, Andrew Allen found the going a bit tough. The rebellion had severed his sources of income. By the summer of 1779 , he realized the need for official support. William Jr. noted in a letter on behalf of his brother that " this Gentleman has hitherto declined applying to Government for any sort of assistance, which has been dispensed with equal Justice \& Wisdom to many of His Majesty's Subjects who are under a temporary distress on account of their Loyalty." $\mathrm{He}$ added: "I now hope that Mr. Allen will overcome a Reluctance which under such circumstances is certainly ill founded." Apparently the reluctance had already been overcome because Andrew sent a letter to Lord Germain on the same day asserting that because of his loyalty he had been "deprived of every Resource of Subsistence" and was therefore "constrained to look to Government for some Provision... making the present application and requesting your Lordship's Assistance.” The petition was successful and Andrew received an annual pension of $£ 400$ sterling. In 1783, the British government undertook an investigation headed by John Eardley-Wilmot which modified some of the 315 Treasury pensions then in effect. Andrew was among the ninety recipients judged to

https://www.scribd.com/document/316810991/Manifesto-and-Proclamation-of-the-Carlisle-PeaceCommission.

92 “Andrew Allen," Legislators in Pennsylvania, vol. 3, 209. The quote is from patriot Dr. William McIlvaine's certification of Sarah's health to the Supreme Executive Council. Her primary physician was Dr. Adam Kuhn, but he was under suspicion for disaffection. For the order that loyalist wives leave the city, see Council Minutes, June 6, 1780, Colonial Records, vol. 12, 377. 
be receiving "more than their relative situation and circumstances required." Officials reduced his per annum to $£ 300$ sterling. This decision naturally provoked displeasure, leading the victim to censure "the Insinimuation [sic]... of some Demerit in point of Pretensions or Conduct, which I am by no means conscious of."${ }^{93}$

Andrew Allen correctly understood his economic circumstances. The choice of fidelity, subsequent exile, and the expropriation proviso of the March 1778 attainder devastated his earnings and holdings. Patriot authorities confiscated and sold vast extensions of his property in Bucks, Berks, Northampton, and Philadelphia counties valued between $£ 16,000$ and $£ 18,000$, mostly between 1779 and 1781 . The inheritance of his father's substantial assets, income derived from colonial duties such as provincial Attorney General and Recorder of the City of Philadelphia, and the earnings from his private practice as legal counsel also ceased.${ }^{94}$ His choice to remain loyal had ruined him.

Joseph Galloway's New York sojourn was also brief. While there, he learned that stockholders of the still active Indiana Company, speculators in western lands, had named David Franks to replace him as president. Exile spurred Galloway's resentment towards his fellow Americans. While making arrangements to travel to England with daughter Elizabeth who had evacuated Philadelphia with him, he wrote a revelatory note to his sister. "I call this country ungrateful," he confessed, "because I have attempted to save it

\footnotetext{
${ }^{93}$ Letter of William Allen Jr., "Memorial of Andrew Allen," AO13-70B(II)-19/20; Andrew Allen to Lord Germain, "Memorial of Andrew Allen," AO13-70B(II)-21\&22; Evidence on the foregoing Memorial of Andw Allen, Esq. "Memorial of Andrew Allen," AO12-42-228, all in DLAR; "Andrew Allen," Palmer, Biographical Sketches of Loyalists, 13, derived from AO12-42-223 and AO12-109-72; John EardleyWilmot, Historical View of the Commission, 20; Andrew Allen to Lord Shelburne, February 16, 1783, Shelburne MSS, LXXXVII, 278-79, in Mary Beth Norton, The British-Americans: The Loyalist Exiles in England 1774-1789 (Boston: Little, Brown \& Company, 1972), 120.

94 "Memorial of Andrew Allen," AO13-70B(II)-17\&18, DLAR; Allen's confiscations are in Pennsylvania Archives, Sixth Series, vol. 12, 20-29, 68-71, 149, 152, 310-340, 404, 406-425, 555-559, 562.
} 
from the distress it at present feels, and because it has not only rejected my endeavors, but returned me evil for good." 95 In October, the Galloways left New York, arriving in London in December. Wife Grace stayed behind in Pennsylvania. Adding insult to injury, the radical assembly passed an act designating his confiscated property on the corner of Sixth and Market streets in Philadelphia as the official residence of none other than the President of the Supreme Executive Council. Auction of his other seized properties began in earnest in the spring of 1779 and continued into the next decade. According to radical Charles Willson Peale, patriots made a conscious decision to begin sales of forfeited estates with loyalists "who were of most consideration among those named in the Proclamation," inaugurating the process with Galloway and Samuel Shoemaker. ${ }^{96}$

The British received Galloway favorably. Officials granted him an annual pension of $£ 500$, one of the highest sums the Treasury awarded during the war. In the spring of 1779, he became a member of the Loyalist Association, a non-governmental organization composed of prominent expatriates from all thirteen colonies. ${ }^{97}$ That year, the House of Commons opened its inquiry into the failed conduct of the war at the behest of the Howe brothers who felt their reputation had been sullied. Frustrated exiles readily joined in condemnation. Lord Germain's ministry recruited Galloway as a star witness to lead the anti-Howe charge. Benjamin Thompson, an assistant to Germain, bluntly acknowledged that "we should scarcely know what to do without you."98 British officials also asked

\footnotetext{
${ }^{95}$ Stern, David Franks, 140, 151; Sabine, Biographical Sketches, vol. 1, 454.

${ }^{96}$ Diary of Elizabeth Drinker, $80 \mathrm{fn} 10$.

${ }^{97}$ Norton, The British-Americans, 162-166; “Joseph Galloway,” Palmer, Biographical Sketches, 306.

${ }^{98}$ Benjamin Thompson to Joseph Galloway, March 1, 1779, Balch Papers, cited in Norton, The BritishAmericans, 161.
} 
Andrew Allen to prepare testimony. Back in Philadelphia, Galloway's wife Grace heard from visitors that Andrew "Made a Most Eloquent speech \& was greatly applauded" and "had done himself Great credit," though she herself had an unfavorable opinion of him. ${ }^{99}$

The Howes argued before British legislators that the American Revolution had widespread support, loyalists were a minority, and as commanders they had operated to the best of their ability under the circumstances. Galloway and the ministry's acolytes rebutted their contentions, blaming the Howes for feeble prosecution of the war and failure to mobilize loyal followers. Galloway even went so far as to assert that four out of five Americans were faithful to Britain. In hindsight, the pro-Howe position resembled facts on the ground more closely than Galloway's. While true that the Howes had often been lax in engaging the enemy and could have done more to integrate provincials into British forces, their assessment of rebel sentiment was accurate, while Galloway's inflated appraisals of loyalist support were nowhere within the realm of reality. The probe resolved nothing, neither proving nor disproving negligence on the part of the general and the admiral. But a series of pamphlet exchanges with the Howes thrust Galloway into the spotlight as unofficial spokesperson for the loyalist cause. ${ }^{100}$

\footnotetext{
${ }^{99}$ Grace Growden Galloway, "Diary of Grace Growden Galloway, Kept at Philadelphia, July 1 to September 30, 1779," PMHB, vol. 58, no. 2 (1934), August 12 \& 13, 1779, 167-168. Sabine contradicts the diary account, stating Andrew was asked to prepare testimony "but was not examined." Sabine, Biographical Sketches, vol. 1, 158.

${ }^{100}$ Galloway's estimate of loyalist strength is in The Examination of Joseph Galloway, 11. In addition to The Examination, pamphlets specifically engaging the Howes included: A Letter to the Right Honourable Lord Viscount Howe, on His Naval Conduct in the American War (London: J. Wilkie, 1779); Letters to a Nobleman, on the Conduct of the War in the Middle Colonies (London: J. Wilkie, 1779); A Reply to the Observations of Lieut. Gen. Sir William Howe, on a Pamphlet Entitled Letters to a Nobleman : In Which His Misrepresentations are detected, and those Letters are supported, by a Variety of New Matter and Argument (London: G. Wilkie, 1780); The Detail and Conduct of the American War, under Generals Gage, Howe, Burgoyne, and Vice Admiral Lord Howe: With a Very Full and Correct State of the Whole of the Evidence, as Given Before a Committee of the House of Commons: And the Celebrated Fugitive Pieces, Which are said to have given rise to that Important Enquiry. The Whole Exhibiting a Circumstantial,
} 
Joseph Galloway’s most prolific labors followed that inquest. From 1779 to 1783, he authored twelve essays on the war, America, and colonial relations with England before turning his attention to the plight of the loyalist exiles once it became obvious that the rebels had achieved independence. Since the goal of these wartime tracts was to influence imperial policy, Galloway directed the gist of his message at British public opinion, not Americans back home. In essence, he argued that the loss of the thirteen colonies was detrimental to Britain; the poor conduct of the war was disastrous if not treasonous; the British should resort to sterner measures to subdue the rebellion; and the monarchy should institute major reforms in its relations with the colonies. ${ }^{101}$ Several core assumptions succinctly captured in a letter to Lord North's Secretary of War, Charles Jenkinson, nurtured Galloway's views on the war and its conduct. First, he blamed "the Prevalence of the Aristocratical as well as Democratical Principles of the Proprietary and Charter Governments in America" as "the great source from whence the present Rebellion has sprung," seeds planted in the original formation of the colonies. Second, he

Connected and Complete History of the Real Causes, Rise, Progress and Present State of the American Rebellion. (London: Richardson \& Urquhart, 1780); Plain Truth: Or a Letter to the Author of Dispassionate Thoughts on the American War. In Which the Principles and Arguments of that Author are refuted, and the Necessity of carrying on that War are clearly demonstrated (G. Wilkie, 1780); A Letter from Cicero to the Right Hon. Lord Viscount H--e: Occasioned by his late Speech in the H---e of C-----ns (London: J. Bew, 1781); Letters from Cicero to Catiline the Second. With Corrections and Explanatory Notes. (London: J. Bew, 1781).

${ }^{101}$ Other pamphlets dealing with the Revolution included: Cool Thoughts on the Consequences to Great Britain of American Independence, on the Expence of Great Britain in the Settlement and Defence of the American Colonies, on the Value and Importance of the American Colonies and the West Indies to the British Empire. (London: J. Wilkie, 1780); Historical and Political Reflections on the Rise and Progress of the American Rebellion. In Which The Causes of that Rebellion are pointed out, and the Policy and Necessity of offering to the Americans a System of Government founded in the Principles of the British Constitution, are clearly demonstrated. (London: G. Wilkie, 1780); Fabricius: Or, Letters to the People of Great Britain; On the Absurdity and Mischiefs of Defensive Operations only in the American War; And on the Causes of the Failure in the Southern Operations. (London: G. Wilkie, 1782); Political Reflections on the Late Colonial Governments: In Which Their original Constitutional Defects are pointed out, and shown to have naturally produced the Rebellion, which has unfortunately terminated in the Dismemberment of the British Empire. (London: G. Wilkie, 1783). 
believed the Crown had "illegally, inadvertently and improperly, granted away" to the colonies power "necessary to its authority" and which "it ought to possess." Third, it was foolish to equate the rebels with the sentiment of most colonials. "We must not take the wishes of the people of America from the Congress," he argued. "They are not the Representatives of America, but Usurpers" who generate "Tyranny and Licentiousness." Lastly, he was absolutely certain "the great bulk of the People of America... dread a separation in polity from this Country [England], and are distressed at the prospect of independence." In fact, he held that Britain's misappropriated powers could be "regained without murmur and with the assent of nine tenths of the people to whom they have been granted." Although he may have been correct regarding the Revolution's root causes, Galloway erred consistently when gauging levels of popular support for either side. ${ }^{102}$ Galloway's writings circulated in tandem with the rise and fall of British fortunes as the ministry played out its southern military campaign in America. His Majesty's forces took Savannah in late December 1778 but abandoned occupied Newport, Rhode Island, in October of the following year. Charleston fell to the British in May 1780. Wilmington, North Carolina followed suit in January 1781. Cornwallis pursued his Carolina victories with a march into the southern backcountry. Some loyalists in that region did in fact come out in support of the king. There was a ferocious patriot-loyalist engagement at King's Mountain and loyalists accompanied British regulars at the battles of Cowpens and Guilford Courthouse. But their numbers did not meet expectations or needs, nor ensure success. Cornwallis eventually staggered north until his trapped army

\footnotetext{
102 Joseph Galloway and Julian Boyd, "Notes and Documents: Joseph Galloway to Charles Jenkinson on the British Constitution," PMHB, vol. 64, no. 4 (October, 1940), 517, 519, 521, 533, 538. Boyd estimates that Galloway penned these views in late 1780 or early $1781(516$, fn. 1$)$.
} 
succumbed at Yorktown in October 1781. The collapse of Lord North's ministry in March 1782 signaled that British will for continued prosecution of the war had expired. Evacuations of occupied southern cities followed. Later that year peace negotiations began with the Continental Congress. ${ }^{103}$

In the later stages of the war, William Temple Franklin wrote to loyalist Galloway in London from Passy near Paris on behalf of his patriot grandfather, Benjamin, as to the whereabouts of Franklin's last will and testament left at Trevose in October of 1776. The epistle divulged that, not only had Franklin entrusted Galloway with his will, but he had named him as "one of the Executiors [sic]." Daughter Elizabeth responded for Galloway, informing the Franklins that "your Grandfathers will committed to his care when in America, remains in the Cover with the seal unbroken, in a trunk with his own private papers, at N. York.” About two-and-half years later, Galloway himself sent the will to William Temple after "having lately received from New York a few Papers saved when my House and property was destroyed." His letter also refers to a missing note from Elizabeth notifying the Franklins that the will had been "destroyed among other papers of his and mine at my Country Seat by a Mob." ${ }^{104}$ Presumably this clarification was sent sometime during the interlude. The episode shows that, even in revolution, personal relations could surmount political differences. William Temple dispatched his opening

\footnotetext{
${ }^{103}$ See O'Shaughnessy, The Men Who Lost America, 247-288; Thomas B. Allen, Tories: Fighting for the King in America's First Civil War (New York: Harper, 2010), 288-290.

${ }^{104}$ William Temple Franklin to Joseph Galloway, May 13, 1781; Eliza Galloway to William Temple Franklin, May 28, 1781; Joseph Galloway to William Temple Franklin, October 28, 1783. All three letters are unpublished but available online at Papers of Benjamin Franklin, http://franklinpapers.org/franklin/framedVolumes.jsp last accessed January 3, 2018. The two 1781 exchanges are in vol. 35 of the online edition. Galloway's own letter is in the second unpublished series for 1783 alone. Grandson William Temple Franklin should not be confused with Franklin's loyalist son William who was governor of New Jersey and a close friend of Galloway.
} 
note after Galloway had publicly condemned the Howe brothers before the House of Commons but five months before the patriot victory at Yorktown, while Galloway sent his concluding missive a month after the formal signing of the Definitive Treaty of Peace had finalized his fate. Judging from Franklin's voluminous collected papers, the October 1783 letter was the last communication between these former allies. Sadly for Galloway, personal tragedy further magnified British defeat. His spouse Grace died in Philadelphia in February 1782. She willed the Growden inheritance to absentee daughter Elizabeth. When the heralds of independence arrived the following year, all hope for a favorable resolution to perpetual exile dissipated.

\section{THE CHALLENGE OF POSTWAR REINTEGRATION (1783-1838)}

Like the decisive 1778 evacuation, the war's termination granted the likes of Joseph Galloway and the Allen brothers another opportunity to reintegrate. Yet once again, the vast majority of exiles declined the chance to return to their former homeland and seek reconciliation. Galloway and the Allens were no exception. Although moderate Anti-Constitutionalist Republicans were gradually gaining control of state government by 1783 and the Continental Congress had an avowed interest in compliance with the peace treaty's recommended leniency towards loyalists, Pennsylvania still based its disaffection policy on radical Constitutionalist treason, test, attainder, confiscation, and militia laws. And there was also the extralegal issue of popular anger. The prospects were not good. For the disaffected who remained, however, the prolonged departure of the Philadelphia elites was a blessing, as the stain of overt loyalism could only exacerbate tensions in the wake of the treaty's articles suggesting a restoration of "tory" property. Andrew Allen wrote to James Hamilton in Pennsylvania for the first time in half-a-dozen years in 
February 1783, acknowledging that the end of "the unhappy Contest... gives me little Prospect of ever returning." He realized that his part in the conflict "must render me too obnoxious to those whom I have opposed" but defended his stance. "What I have done has flowed from Principles which what I have suffered has neither changed nor shaken," he avowed. ${ }^{105}$

Instead of reintegration, Andrew and brother William chose a diametrically opposite approach. In May, Sarah Coxe Allen overcame an earlier hesitancy and set off for England with daughter Margaret and son Andrew Jr. to reunite with her husband, leaving daughters Anne and Elizabeth in the temporary care of Sarah's parents and Andrew's sister Anne Penn and her ex-governor husband John. ${ }^{106}$ Brother Tench Coxe took on the role of agent in defense of the economic and property interests Andrew and John Allen's families still retained as a result of William Allen Sr.'s astute inheritance transfer to his grandchildren, bypassing his attainted sons and avoiding confiscation of some assets in the succession following his death. ${ }^{107}$ Coxe handled taxes and rents on Allen properties, as well as disbursing funds for Sarah, Andrew's children, and John's wife Mary residing in New York. Matters did not always flow smoothly. For nearly a year beginning in the autumn of 1785, contact between Coxe in Philadelphia and the Allens in London ceased because of a mix-up in the mail with an English merchant firm.

\footnotetext{
105 Andrew Allen to James Hamilton, Gratz Collection, Old Congress, 1:3 cited in "Andrew Allen," Legislators in Pennsylvania, 209.

106 Tench Coxe to Andrew Allen, February 20, 1783, Coxe Family Papers, Collection 2049, Tench Coxe Letterbook, Series 1a, vol. 2, HSP. As Coxe explained to Andrew, Sarah's concerns had to do with both her delicate health and the uncertainty of her living conditions in England.

${ }^{107}$ The codicil altering William Allen Sr.'s will was dated December 1, 1779. The will itself was probated on September 16, 1780. See "William Allen," Legislators in Pennsylvania, vol. 3, 268. Although patriot laws prohibited transferring property rights to family relations to avoid seizure, this rule did not apply to William Allen Sr. because he was never attainted.
} 
The mishap led to recriminations until batches of misplaced letters finally found their destination, leading Sarah to "most sincerely ask your pardon for any thing we have said." Then again, prior to ratification of the new federal constitution, Coxe confessed that legal matters involving the Allen children could be "affairs of difficult nature, in a country whose business is much deranged."108 Property issues frequently surfaced. In 1785 Andrew's children brought suit in Pennsylvania to eject occupants from a plot of land in Reading known as the Big Spring Tract as a prelude to its recovery. In 1786, issues arose over the "Ralston and Wolfs Deeds" for a Northampton County tract these individuals purchased from William Sr. "in his lifetime," while in 1789 Andrew's former one-quarter share of a strip of 36,000 acres on the northeast branch of the Susquehanna came under legal scrutiny. Like his older brother, William Jr. also set his sights eastward. Despite the compensatory land grant in Canada for his military service, he too crossed the Atlantic. ${ }^{109}$ The family had decided to embrace Great Britain in full.

Realizing the futility of their situation at the peace, loyalists in England turned their attention to the British government in search of reparations for losses incurred as a result of their fidelity. Working alongside exiled colleagues, Joseph Galloway contributed

\footnotetext{
${ }^{108}$ Sarah Allen to Tench Coxe, August 10, 1786, Coxe Family Papers, Series 2a, Box 25, Correspondence to Tench Coxe, April-December 1786; Tench Coxe to Andrew Allen, October 10, 1787, Coxe Family Papers, Tench Coxe Letterbook, Series 1a, vol. 4, all in HSP. These Coxe Family Papers contain detailed ledgers for the Allen accounts in America. For wife Sarah, son Andrew Jr. \& daughter Margaret, see Allen accounts 1780-1783, vol. 231; Allen accounts 1780-1785, vol. 232; and Allen accounts 1780-1787, vol. 233, HSP. For letters on financial matters from Tench Coxe to John Allen's wife Mary, see examples in Tench Coxe Letterbook, Series 1a, vol. 4, dated February 9, 1786; September 28, 1787; October 29, 1787; December 7, 1787; December 20, 1787; March 15, 1788; July 27, 1788; July 4, 1789; May 21, 1796, HSP. For an example of requests to Coxe, see Mary Allen to Tench Coxe, October 27, 1786, Coxe Family Papers, Series 2a, Box 25, Folder 12, HSP in which Mary requests “ $£ 50$ more" after spending a prior allotment in the same amount.

${ }^{109}$ Tench Coxe to Andrew Allen, June 27, 1786, Coxe Family Papers, Tench Coxe Letterbook, Series 1a, vol. 4, HSP; Cooke, Tench Coxe, 60-61; DeLancey, "Chief Justice William Allen," PMHB, 209; "Wm. Bradford, Jr. to Pres. Dickinson," April 25, 1785, Pennsylvania Archives, First Series, vol. 10, 712; Council Minutes, September 1, 1789, Colonial Records, vol. 16, 146.
} 
to two essays arguing that the British government had surrendered loyalist property in America as part of the price of peace. By doing so, loyalists had given more than their fair share to the common good. Those both affected by the capitulation and faithful to the monarchy were thus entitled to recompense. Fortunately, sympathy for the loyalists ran deep in Britain. Parliament lost no time in setting up a commission to bestow equity and restitution. ${ }^{110}$ Later in the year, Galloway added to the conversation with publication of his views on how the terms of the Treaty of Peace impacted loyalists. ${ }^{111}$ His published works fell off sharply thereafter, although he wrote a comprehensive and lucidly reasoned justification for the compensation of loyal Americans as the Royal Claims Commission finalized its investigation in 1788. He based arguments on historical precedents, the right of loyalists to indemnification under the British Constitution, their contributions to the suppression of rebellion, and benefits the British nation derived from their sacrifice. ${ }^{112}$ Galloway's personal postwar travails overlapped with his public persona. As early as 1784 , Rebecca Shoemaker noted from Philadelphia that the ex-assembly speaker tried to hire Owen Jones and Dr. De Normandie "to make a formal application to Government here for the restoration of his estate." Although this was the inaugural period of moderate

\footnotetext{
${ }^{110}$ The Case and Claim of the American Loyalists Impartially Stated and Considered (Printed by Order of their Agents, London, 1783); Collections with Regard to the Case of the American Loyalists (London, 1783); Norton, The British-Americans, 188. In addition to the Royal Claims Commission's loyalist manuscripts in the British Public Record Office (PRO), Hugh Edward Egerton's condensed account is taken directly from the notes of Daniel Parker Coke, one of the commissioners. Another direct account is John Eardley-Wilmot's Historical View of the Commission. Also Peter Wilson Coldham, American Loyalist Claims (National Genealogical Society, No. 45). A concise account of the history of the Loyalist Claims Commission can be found in the introduction to Palmer, Biographical Sketches of Loyalists, $\mathrm{x}$-xxiv, xxxiv-xxxvi.

${ }^{111}$ Joseph Galloway, Observations on the Fifth Article of the Treaty with America: And on the Necessity of appointing a Judicial Enquiry into the Merits and Losses of the American Loyalists. (1783).

${ }^{112}$ Joseph Galloway, The Claim of the American Loyalists Reviewed and Maintained upon Incontrovertible Principles of Law and Justice (London: G. \& T. Wilkie, 1788).
} 
rule in Pennsylvania, Galloway's über-loyalist stance remained noxious. Jones rejected the offer outright. The doctor asked attorney William Rawle and "B.S." to join him on the pro-Galloway team but both refused and the effort evaporated. ${ }^{113}$ Royal government then became the focus of the ex-champion of royal government. In 1785, perhaps as a way to gain proximity to his homeland, Galloway pursued an imperial appointment as chief justice of Nova Scotia. Andrew Allen also threw his hat into that ring but the nomination went elsewhere. Yet even before his effort to secure a royal sinecure, Galloway's primary focus turned to the recently constituted Royal Claims Commission.

In early February 1784, Joseph Galloway submitted an extensively documented request for $£ 42,657$ in compensation to Parliament’s commissioners. Describing himself as "always a friend to Monarchy," a who's who of supporters backed his application. General Vaughn "found him a sensible zealous \& steady man" who had been "very useful in Philadelphia." General Gage believed that Galloway, while colonial assembly speaker, had done all he could to organize the possible quartering of British troops in Philadelphia just before the war. Lord Cornwallis considered him "well affected" and "a very zealous Loyalist" who "took the side of the British Gov't from Principle." Colonel Montresor, on whose ship the loyalist had sailed from New York at the invasion of Pennsylvania, declared that Galloway had procured "very material" intelligence and "always endeavor'd to promote the Success of the British arms \& Meant to render Service to Gov't." New Jersey Governor William Franklin argued that Galloway was "uniformly loyal" and "has given the most unequivocal proofs of it," having "join'd the King's Troops from Principle only" - a point of added merit because "Mr. Galloway

${ }^{113}$ Rebecca Shoemaker to Samuel Shoemaker, August 8, 1784, Shoemaker Papers, vol. 2, 147, in J. W. High, "Philadelphia Loyalists," 272. 
could have made his peace at any time with the Rebels." Franklin's testimony also provides insight into his friend's political evolution, conceding that "Dr. [Benjamin] Franklyn accused his Son of having poison'd Mr. Galloway's sentiments." 114

Two witnesses stand out in Galloway's claims. Although radical patriot Daniel Roberdeau did not venture to pass judgment on Galloway's choice of allegiance, he did present a declaration certifying the value of the latter's Sepicken estate upon which his own adjoined. Roberdeau's testimony once again shows how personal relations often superseded revolutionary ideology and allegiance. The most remarkable of Galloway's witnesses, however, was former rival and ministerial scapegoat Sir William Howe. The general affirmed Galloway had been "zealous in the Cause of Gov't" and "discharged very well" his duties as civil administrator during the occupation. Moreover, from his subordinate's actions he had "no Doubt about his Loyalty or his wishes to promote the King's service." But Howe apparently still harbored some bitterness for his onetime foe's testimony before Parliament because he downplayed the value of Galloway's intelligence operations, judged that the cavalry regiment this right-hand man had raised "was found to consist chiefly of Deserters," and cast doubt on the Pennsylvanian's loyalty by concluding that, although an effective activist, he “does not believe his [Galloway's] Heart was materially concern'd in it." Galloway minimized the less complimentary parts of this statement by furnishing a letter from Howe dated one month before the British evacuation of Philadelphia "speaking of him in the highest possible terms" and probably

114 “Memorial of Joseph Galloway," Egerton, The Royal Commission, 88. 
netted a positive score from the general's intercession. The claims commissioners ultimately awarded Galloway $£ 19,242$ plus a pension of $£ 40 .{ }^{115}$

The Allens' attention likewise switched from events in America to the postwar realities of life in England. Daughter Anne made the transatlantic journey to rejoin her parents in 1784. Elizabeth would follow in 1788. Three more children were born to Andrew and Sarah while in Britain: John Penn, Thomas Dawson and Maria. From their residence in Southampton, Hampshire, the Allens moved to London by March 1785 so that Andrew could lobby on behalf of his request before the Royal Claims Commission for $£ 14,335$ in reparations. From Philadelphia, Tench Coxe provided documentation to substantiate Andrew's claim, while empathizing that "your Situation has been a very hard one" and hoping that "it will be justly and liberally considered in your Compensation." Andrew eventually received $£ 9,986$ sterling, a high percentage in comparison to most claimants. William too presented a claim but its adjudication is not clear. On one hand, "his Estate has been confiscated... in Consequence of his Loyalty to his Majesty and Attachment to the British Government." But as of March 15, 1783, he had "not been able to obtain an account of the Losses that he has sustained" from America. William also used his influence as an ex-loyalist officer to back the claims of comrades in arms such as Colonel John Hamilton and Nathaniel Wilson who had fought in the Georgia and South Carolina expeditions. ${ }^{116}$

\footnotetext{
115 "Memorial of Joseph Galloway," Egerton, The Royal Commission, 87, 89; "Joseph Galloway," Palmer, Biographical Sketches of Loyalists, 305-306.

116 "Andrew Allen," Legislators in Pennsylvania, 199, 210, 216 fn86 \& fn89; Tench Coxe to Andrew Allen, January 5, 1787, Coxe Family Papers, Tench Coxe Letterbook, Series 1a, vol. 4, 67, HSP; "Andrew Allen," Palmer, Biographical Sketches of Loyalists, 13; "Memorial of William Allen Jr.," AO13/96/21-23, DLAR; "Memorial of Col. John Hamilton," Egerton, The Royal Commission, 185; "Memorial of Nathaniel Wilson," ibid., 365.
} 
In the end, the surviving brothers tackled the question of reintegration differently, albeit with analogous results. The little evidence available for the latter part of his life shows William Jr. adapting to life in England for the long haul and never seriously considering a pardon or a homecoming, though he charged his brother with the task of interceding on his behalf regarding inheritance property issues back in Pennsylvania upon the latter's return. William Allen Jr. died in London on July 2, 1838, at the ripe old age of eighty-seven, unmarried and without descendants. ${ }^{117}$ As for Andrew, his views fluctuated over time. Ongoing correspondence with brother-in-law Tench Coxe during the 1780s reveals both an underlying resentment and a distancing from his former homeland. As late as 1785 , the Revolution still represented "all the Injustice I have met with," while America was "a country which I once sincerely loved but now thoroughly detest \& despise." 118 On American commerce, he opined that it did "not to me wear that bright aspect as to hold certainly flattering encouragement" and "must decline from their having lost the only market for their Ships by declaring Themselves Aliens to the British Empire," which in turn had determined "to exclude Aliens of all denominations from a participation of the commercial Advantages reserved to British Subjects." It was his estimation that "for many years to come the trade of the American states must be more and more contracted." Andrew would not concede that independence could eventually bring prosperity but rather regarded the new nation as irretrievably laden with "mischiefs and Distresses," especially because the confederated government then in existence presented "Obstacles to a Commercial Treaty... arising... from the want of proper

${ }^{117}$ Charles Keith, Provincial Councillors, 14; DeLancey, "Chief Justice William Allen,” PMHB, 209.

\footnotetext{
${ }^{118}$ Andrew Allen to Tench Coxe, July 14, 1785, Tench Coxe Papers, Incoming Correspondence, cited in
} “Andrew Allen," Legislators in Pennsylvania, vol. 3, 210. 
Authority being invested in the Congress." In sum, independence had generated a debilitating internal fragmentation which imperial rule had earlier solved. Even more illuminating was the language he used to describe his ex-compatriots. Beyond seeing himself as a British subject, Andrew's remarks referred to "their character," "they," and "themselves" as if Americans were a foreign people to whom he had never belonged. Despite the subliminal repudiation, the Allens became core affiliates of a social cluster of conspicuously American exiles in England which included Anglican clergymen Jacob Duché, Samuel Seabury, and Charles Inglis, as well as Philadelphians like ex-governor John Penn Sr., Samuel Shoemaker and Joseph Swift Jr. ${ }^{119}$

In the face of revolutionary turmoil and loss, Andrew Allen adapted well to his resurrected condition in England. Reunited with his family, amply compensated for his loyalty, and managing the clan's assets in Pennsylvania from afar through his agent, he let go of worldly pretensions and accepted domestic contentment as his lot. Letters from Sarah Coxe Allen to her brother Tench reveal genuine happiness. In 1788, she professed "to be thankful for my situation here, for though Mr Allen has lost an Affluent fortune, things have turned out so much better than we expected, that we cannot be too grateful for it." In early 1790, Andrew told her that "he had just been settling his affairs and he found himself now freed from every anxious thought about his circumstances." For Sarah, "this best of Men" had dedicated himself "to promote the happiness of his Family"

${ }^{119}$ Andrew Allen to Tench Coxe, August 11, 1786, Coxe Family Papers, Collection 2049, Series 2a: Tench Coxe Correspondence \& General Papers, April-December 1786, Box 25, Folder 8, HSP. Sarah Allen to Molly Coxe, January 30, 1789 \& Andrew Allen to Tench Coxe, November 13, 1787, Coxe Papers, cited in Cooke, Tench Coxe, 85, 101; Norton, The British-Americans, 238; Kevin J. Dellape, America's First Chaplain: The Life and Times of the Reverent Jacob Duché (Bethlehem, PA: Lehigh University Press, 2013), 163. Exiles tended to associate by region. The cluster noted above was a Mid-Atlantic grouping: Seabury and Inglis were from New York and the others from Pennsylvania. Intra-exile relations in England are discussed at length in Norton, The British-Americans, especially Chapter 3, "America Transplanted to London," 62-95. 
and achieved "a comfortable and Independant [sic] situation... without anxiety" in the midst of "kind and affectionate Friends." 120 England had been good to them.

Concerning America, ratification of the federal constitution in 1788 mellowed Andrew Allen's animosity somewhat. He liked that the new governmental structure provided "Unity to the different \& otherwise discordant Interests of the States" from which might flow "Law \& Justice" and "a greater Respect \& Veneration for Authority" to offset "the narrow \& partial Schemes of factious Demagogues." ${ }^{121}$ In the early 1790s, he contemplated a return visit. By then, Pennsylvania's political climate had changed considerably. Moderates had ascended to power, repealed the test acts in 1789, and for the most part dispelled lingering anti-loyalist sentiment. Yet the test act repeal did not contemplate forgiveness for the attainted. Officially designated a traitor under the first attainder act of 1778, Andrew sought to recover his good standing and requested a formal pardon from the state government in 1792. Authorities granted his appeal that year, opening the door for a homecoming. Loyalist militancy had been forgiven.

Crossing the ocean again with his full entourage of seven children, sister Anne, and her husband John Penn Sr., Andrew Allen disembarked at Philadelphia on September 15. Missing was wife Sarah, who had either died or endured deteriorating health since her upbeat missives to her brother two years before. Andrew rented a house in the city but also purchased a 155-acre homestead in Bucks County as lodgings for his large family. He dedicated himself to "secure his children's interests" in Pennsylvania, to try to recover

\footnotetext{
${ }^{120}$ Sarah Allen to Tench Coxe, circa July 1, 1788, and Sarah Allen to Tench Coxe, February 1, 1790, both in Tench Coxe Papers, Incoming Correspondence, cited in "Andrew Allen," Legislators in Pennsylvania, 210, 217 fn94.

${ }^{121}$ Andrew Allen to Tench Coxe, September 8, 1788, Tench Coxe Papers, Incoming Correspondence, cited in "Andrew Allen," Legislators in Pennsylvania, vol. 3, 211.
} 
some of his own forfeited losses from the Revolution, and to act on behalf of his brother William Jr. on inheritance property issues. Not all of his efforts succeeded. For example, Governor Mifflin refused to suspend the sale of one of Andrew Allen's seized properties, despite his entreaties to the contrary. Nevertheless, he speculated profitably in real estate while in Pennsylvania. Most significantly, daughter Margaret wed George Hammond, the king's first minister to the United States, at Philadelphia’s Anglican Christ Church in 1793. Although he "remained a few years" and was still in Philadelphia in March 1796, he did not stay. The America he encountered was not the America he had known. ${ }^{122}$

Joseph Galloway also sought a pardon. Unlike Andrew Allen and other exiles, however, his notoriety as Pennsylvania's tory par excellence significantly complicated the appeal despite a moderate majority in state government. In May 1790, the Supreme Executive Council read his plea for absolution a second time but council members only resolved that Galloway's attorney Thomas Clifford "have leave to withdraw the said petition," presumably an elegant way to avoid an outright rejection. ${ }^{123}$ Indignation for his role during the war persisted even at this late date. When Alexander Hamilton appointed ex-loyalist Tench Coxe to the federal Treasury Department that year, a Philadelphia newspaper satirically predicted the beginnings of a future American monarchy with Joseph Galloway as secretary of state and Benedict Arnold as secretary of war. Later that year, the moderate council presided by Thomas Mifflin entertained the possibility of "a

\footnotetext{
122 “Andrew Allen," Legislators in Pennsylvania, vol. 3, 211, 217 fn100; Clemency and Conviction Papers, Division of Public Records, Pennsylvania Historical Association and Museum Commission cited in Henry Young, "Treatment of Loyalists in Pennsylvania," Appendix XI, 400; Charles Keith, "Andrew Allen," $P M H B$, vol. 10, no. 4, 364; Charles Keith, Provincial Councillors, quote on 149; DeLancey, "Chief Justice William Allen," $P M H B, 209$; Kistler, William Allen, 51.

${ }^{123}$ Colonial Records, May 18, 1790, vol. 16, 363.
} 
general pardon of persons who have been attainted of high treason" but postponed the discussion. Historian Wilbur Siebert argues that Galloway was still so significant that his inclusion probably prevented approval of the general amnesty. ${ }^{124}$ Back in England, Galloway later heard about the pardon debate and objections raised against him. In response, he penned a letter to Chief Justice Thomas McKean explaining that mob attacks had driven him into the arms of the British. Although there is little doubt that Galloway's actions prove he was indeed a true loyalist, he sometimes circumscribed the language of allegiance to the audience and the occasion. For Parliament's commissioners, he was "always a friend to Monarchy." But when soliciting forgiveness from revolutionary authorities, he blamed patriot mobs for plunging him into disaffection. Expediently, it was not really his decision. ${ }^{125}$ This ideological elasticity - fairly common among postwar loyalists - once again suggests meaningful distinctions between patriot and loyalist commitment during the Revolution. If we accept agency as a historical determinant or at least as a critical factor in historical outcomes, it is not hard to see why patriots won.

Pardon or no pardon, it is possible that Joseph Galloway never intended to return to Pennsylvania. What is certain is that his efforts for a reversal of his attainder for high treason had much to do with daughter Elizabeth's inheritance via the Growden lineage. In 1791, Galloway wrote to a colleague that he hoped to have the attainder erased in order to collect as "Surviving Executor... Monies due to L. Growden's Estate." Notwithstanding the intent, his legal exertions failed. In a judgment reminiscent of Sir William Blackstone,

\footnotetext{
${ }^{124}$ The Independent Gazetteer, “The Vision,” June 12, 1790; Colonial Records, December 3, 1790, vol. 16, 528; Siebert, Loyalists of Pennsylvania, 86.

${ }^{125}$ Ousterhout, A State Divided, 221; Ferling, The Loyalist Mind, 63-64; Young, "The Treatment of the Loyalists in Pennsylvania," 316; "Memorial of Joseph Galloway," Egerton, The Royal Commission, 83; "Joseph Galloway," Legislators in Pennsylvania, vol. 3, 620.
} 
the Pennsylvania courts ruled that his attainder made him "civilites mortuus, and as dead in consideration of Law." Galloway persisted, however, and in 1795 he finally realized his ambition, receiving an official pardon from Governor Thomas Mifflin. Litigation over the Growden estate continued. Sabine states that "a considerable portion of it was restored finally to his daughter."126

Although officially forgiven for his betrayal, Galloway never ventured back to Pennsylvania. In England, he arranged for Elizabeth to marry William Roberts, a London aristocrat. The union produced daughter Grace but the couple's relationship deteriorated, obliging Galloway to make inheritance arrangements alienating the husband in his will. ${ }^{127}$ The aging loyalist turned from the temporal to the spiritual in his twilight years. In 1802, over 950 subscribers from New Jersey and Pennsylvania sponsored publication of his last major work. Last names such as Carlisle, Roberts, Tomlinson and Doan dot the list of 350 Pennsylvania subscribers, quite possibly extended family relations of loyalists covered in this study. Most prominent is Samuel Shoemaker, whom Galloway named as police magistrate during the Philadelphia occupation. Interestingly, no British subscribers were listed as donating to the two-volume work, despite Galloway’s residency there. ${ }^{128}$

\footnotetext{
${ }^{126}$ Joseph Galloway to In. Jeffrey, Twickenham, December 10,1791, Thompson Collection; Pennsylvania State Archives, RG 26, Pardon Books 1791-1795, no. 1, 189 \& Executive Minute Book 1794-1796, vol. 3 , 216, all cited in J. W. High, "The Philadelphia Loyalists," 273-274. High mentions that Mifflin inserted Galloway's pardon into a February 28, 1795 governor's proclamation on state election results for the federal Congress. That election proclamation is also in Reed, ed., Pennsylvania Archives, $4^{\text {th }}$ Series, Papers of the Governors, vol. 4, 330-334, but Galloway's pardon there has been excised. "Joseph Galloway," Legislators in Pennsylvania, vol. 3, 620; Sabine, Biographical Sketches, vol. 1, 455.

127 “Joseph Galloway,” Legislators in Pennsylvania, vol. 3, 620.

${ }^{128}$ Joseph Galloway, Esq., formerly of Philadelphia in America, Brief Commentaries Upon Such Parts of the Revelation and Other Prophecies as Immediately Refer to the Present Times: In Which the Several Allegorical Types and Expressions of Those Prophesies Are Translated into Their Literal Meanings, and Applied to Their Appropriate Events: Containing a Summary of the Revelation, the Prophetic Histories of the Beast of the Bottomless Pit, the Beast of the Earth, the Grand Confederacy, or Babylon the Great, the
} 
The Brief Commentaries examined Christian revelation through the lens of "The Seven Vials of the Wrath of God." The contents of each vial reveal a worldview steeped in Protestant eschatology. The targets reserved for divine fury included Rome and the Pope, the King of France, papal Germany, the Turkish and Mohamedan apostasy, "atheistical" France and the "atheistical and revolutionary republic" - the latter allusions to the French Revolution and Napoleonic France. Galloway limited his views on the American Revolution to a brief appendix. "Defended by one of the greatest nations in Europe, and enjoying every blessing that reason could hope for, or heart ought to desire," the colonies had "ungratefully and wantonly" revolted. For this rebellion, he blamed "a great, powerful, and traitorous faction rising up in the supreme councils of a great nation" that had incited and supported the rebels and, in 1781, compelled "the parent state to grant them independence, at the moment they were at her feet." Colonial self-government had come about "through the treason of that faction... from motives of ambition, and a thirst for riches and power." Judging from the text's almost exclusive focus on Europe, the treasonous faction consisted of those in Parliament opposed to king and war, not America's homegrown rebels. His insistence that the Revolution was at England's "feet" at that date - presumably after Cornwallis' defeat at Yorktown - shows a monumental misreading of military realities akin to his earlier misreading of loyalist support. ${ }^{129}$

\footnotetext{
Man of Sin, the Little Horn, and Antichrist (London, 1802), vol. 2, "Subscribers Names to Galloway's Commentaries," 401-416; Ferling, The Loyalist Mind, 64. The Dean of Canterbury took issue with the Brief Commentaries, prompting Galloway to reply with his final publication entitled The Prophetic Anticipated History of the Church of Rome just before his death. Posthumous editions of these works combine the two into a single text. See for example the 1809 Trenton edition reprinted for Daniel Fenton.

${ }^{129}$ Joseph Galloway, Brief Commentaries, vol. 1, Appendix, 471 (emphasis in original).
} 
Joseph Galloway died the next year at Watford, Herts, England "in obscurity" but he had no way of knowing that when the Brief Commentaries went to print. Hence, the omission of America from the list of those awaiting God's vengeance suggests he did not wish to rile Pennsylvania officials or American public opinion. Elizabeth's property proceedings may have played a role in that decision. Or perhaps Galloway actually harbored hopes to someday visit or return to his former home. The fact is he did neither. In the end, his loyalism yielded permanent exile. A codicil to his will instructed executors to bury the ex-chief civil administrator of the British occupation "without any pomp or ceremony... in an oaken Coffin... to be carried to the place of Internment in watford church yard by four poor men having families," each paid $£ 5$ for their service. Only his name and age were to be etched on "a Stone at the head" of the grave. ${ }^{130}$

By 1798, Andrew Allen had returned to England from his transatlantic sojourn but he could not get America out of his system either. The next year he filed suit with the Mixed Commission set up by Great Britain and the United States under the Sixth Article of the 1795 Jay Treaty. The treaty tasked the commission with arbitrating the claims of “divers British Merchants and others His Majesty's Subjects" seeking to collect debts "contracted before the Peace" due them from "Citizens or Inhabitants of the United States." ${ }^{131}$ The mixed commissioners found their task daunting and could not agree on many complicated legal issues. Andrew's initial effort thus failed. But in 1802 the

\footnotetext{
130 "Joseph Galloway," Legislators in Pennsylvania, vol. 3, 620-621; Ferling, The Loyalist Mind, 64; Siebert, Loyalists of Pennsylvania, 98; Sabine, Biographical Sketches, 456.

${ }^{131}$ Treaty of Amity Commerce and Navigation, between His Britannick Majesty; and The United States of America, by Their President, with the advice and consent of Their Senate, Article Six, signed November 19, 1794, Avalon Project, Yale Law School at http://avalon.law.yale.edu/18th century/jay.asp\#art6 last accessed February 8, 2017.
} 
Jefferson administration reached a settlement with the United Kingdom whereby the United States would pay Great Britain $£ 600,000$ sterling to be used by the British government to conclusively resolve all claims under this rubric. Andrew's persistence netted him a payment of $£ 6,977.15 .9 .{ }^{132}$ Allen lived out his remaining years in England, residing initially in London and later in Middlesex County. In November 1815, Andrew Jr. wrote confidently that "my father at 74 enjoys a vigour of mind \& body equal to what I can remember in his best days... He has not a complaint in the world." In 1816, the family embarked on a European tour and spent that winter in Paris. ${ }^{133}$

From the perspective of reintegration, what stands out is Andrew Allen's legal rationale several years after his return to Pennsylvania that he was a natural-born British subject who had never relinquished allegiance to the king despite early support for the rebellion and an attainder naming him a "late member of the Congress" and a "subject and inhabitant of the state of Pennsylvania." ${ }^{, 134}$ In less than fifteen years, Andrew had overcome the stigma of loyalist militancy, received a pardon, and opened the door to the possibility of a successful reincorporation into republican society. There is no evidence to suggest that reintegration was ever the goal of his trip to Pennsylvania, however. Beyond financial concerns, he probably pursued the voyage as a nostalgic visit to his old haunting grounds and a reconnection with the extended family that had stayed behind. Perhaps on

\footnotetext{
${ }^{132}$ Andrew Allen's original case is discussed at length in John Bassett Moore, ed., International Adjudications Ancient and Modern, History and Documents Together with Mediatorial Reports, Advisory Opinions, and the Decisions of Domestic Commissions, on International Claims, Modern Series, vol. 3 (New York: Oxford University Press, 1931), 238-256. The later settlement is referenced in Young, "Treatment of Loyalists in Pennsylvania," 333-34.

133 “Andrew Allen,” Legislators in Pennsylvania, vol. 3, 212.

${ }^{134}$ Statutes At Large of Pennsylvania, vol. 9, “An Act for the Attainder of Divers Traitors...," March 6, $1778,201$.
} 
some unexpressed level he hoped to be pleasantly surprised and reassimilated on a more enduring basis. But Andrew Allen encountered a dramatically altered Pennsylvania in which the Allens no longer played a leading role. Rejecting the reintegrative option if it ever existed - he removed once and for all to England, affirming all the while that he had always been a faithful Briton. Andrew died in England in March of 1825 in his mideighties. He consciously defined himself through the lens of loyalism, spurning America according to the terms of his 1799 memorial to the Mixed Commission: "of London, in the Kingdom of Great Britain... from his birth and ever... a British subject."135

The final episode in the reintegration chronicle of the three loyal Allen brothers involves John, the eldest, who died one month before he was charged with high treason in the original attainder act of March 1778. His wife Mary Johnston Allen bore him two sons on January 14, 1776, as the Revolution kicked into high gear. By a quirk of fate, his "timely" death two years later allowed the surviving family to fully reintegrate. Though attainted, radicals never confiscated John's assets, corroborating that the intent of patriot legal measures against loyalists was to contain the spread of disaffection, not to procure vengeance or the spoils of war. In testimony supporting Andrew's claim to the royal commission, Daniel Coxe stated that "the children of Mr. Allens two Brothers who died in America are in possession of their Parents prop[ert]y." John, son of John, assimilated well into post-revolutionary society - in 1802, he married Christina Livingston Jones, granddaughter of manorial scion, prosperous merchant, and signer of the Declaration of

\footnotetext{
${ }^{135}$ DeLancey, "Chief Justice William Allen," PMHB, 209; Kistler, William Allen, 51; J. B. Moore, ed., International Adjudications Ancient and Modern, vol. 3, 238. Permanent relocation had permanent consequences. His children too became faithful subjects of the Crown. Andrew Jr. joined the His Majesty's diplomatic service and was named British Consul for New England in 1805. Son Thomas Dawson became an Anglican minister and rector of the parish of North Cerney in Gloucestershire. See "Andrew Allen," Legislators in Pennsylvania, vol. 3, 212; Sabine, Biographical Sketches, vol. 1, 158.
} 
Independence for New York, Philip Livingston. They lived comfortably in Dutchess County in that state. Son William married Maria Cornelia Verplanck, another New York notable, lived for a time in Hyde Park, also in Dutchess County, and eventually moved to Ulster County. The original John Allen's demise therefore saved his family from a probable English exile like that of his siblings. ${ }^{136}$

\section{CONCLUSION}

The militant loyalism of Quaker and Proprietary party elites like Joseph Galloway and John, Andrew and William Allen Jr. played an instrumental role in both the rebellion and reintegration. Collapse of the Philadelphia-centered colonial leadership in the face of insurgency occurred in large measure because of their overt commitment to loyalism. Like many other provincial elites, their failed pro-British militancy and fear of radical retribution engendered initial isolation and subsequent exile, disqualifying these once dominant figures from steering the course of the Revolution or the formation of a postwar republic. Loyalism thus unwittingly helped destroy the old colonial order and opened the path to power for a third faction composed of revolutionary radicals and moderates.

After the British evacuation, the disappearance of elite militants led to a major reduction of internal political tensions between patriots and the disaffected who stayed, especially in the provincial capital, a factor which eased the process of reintegration over time. That militancy, however, hindered the militant's own reintegrative possibilities. Andrew Allen's case is exemplary. His active support for the king barred him from remaining or returning to Pennsylvania at the critical junctures of evacuation in 1778 and peace in 1783. Rightfully fearful for his life, Allen chose to not hazard the turbulent

${ }^{136}$ Daniel Coxe's testimony is in "Memorial of Andrew Allen," AO12/42/241, DLAR; Charles Keith, Provincial Councillors of Pennsylvania, 146. 
winds of reintegration in the land of his birth. Only after an extensive political and legal transformation had taken place did he seek a pardon and tentatively test those waters. That journey ultimately persuaded him to return to England, however. Rather than bringing about a resumption of royal rule as intended, elite loyalist militancy in Pennsylvania paradoxically enabled a more comprehensive and successful revolution and facilitated a smoother reintegration process for the less disaffected whose commitment did not match that of the militants. 


\section{CHAPTER 3 \\ REINTEGRATION \& DEPARTURE OF THE ORDINARY LOYALIST MILITANTS}

Commitment to an active military defense of royal authority was the clearest marker of loyalist militancy. Many of the militarily loyal were not just dissatisfied with patriot rule but manifestly pro-British. The Revolution encountered their opposition throughout the province. The overwhelming majority of Pennsylvanians who brandished arms in defense of the Crown did not belong to the elite class, however. For the most part, they were "ordinary" loyalists from the middling and "inferior" sorts, sometimes illiterate, consisting of farmers, artisans, mechanics, journeymen, and laborers. Lowerorder militants came from diverse religious, ethnic, and geographic backgrounds. They were non-pacifist Quakers, Roman Catholics, Anglicans, German immigrants, British subjects born outside of North America, frontiersmen, and city dwellers. These class, regional, and in some cases ethnic and religious distinctions separated the great body of Pennsylvania loyalists from the Philadelphia-centered elite militants like Galloway and the Allens who evacuated with the British in 1778 , even as their ideology, circumstances and choices remained somewhat similar. Three populations based on geographic dispersal emerge from the sources when exploring these largely non-elite militants. A first set consisted mostly of artisans, laborers, and agrarians from the well populated southeastern core of the colony encompassing the city of Philadelphia and the contiguous rural corridor of Chester, Philadelphia and Bucks counties. Settled farmers and husbandmen along the intermediate agricultural belt of York, Lancaster, Berks and Northampton counties between the provincial center and the periphery comprised the bulk of a second group. Families trying to eke out a living on the "unimproved" and largely uninhabited 
frontier counties of Northumberland in the northeast and Cumberland, Bedford and Westmoreland in the west represented a third contingent. While technically also farmers, their hazardous existence involved much more than that term implies. ${ }^{1}$

In all three regions, pro-British militancy produced results akin to those of their elite city counterparts. Whether casualties of failed conspiracies, martial defeat or deliberate withdrawal, overt loyalism usually ended in departure and permanent exile. Frontier militants picked up weapons, fought their battles for the monarch on the colony's outer fringes, lost, and generally fled, died, or were captured. Those in the inner counties collaborated with Howe's army as it passed on the road to Philadelphia, aided the escape of British prisoners throughout the war, organized for a post-evacuation uprising directed from Clinton's headquarters at New York, and ran when thwarted or discovered. The largest group - the mass of loyal militants in or near occupied Philadelphia who joined Howe's provincial regiments - departed for good at the evacuation under the orders of their officers. These setbacks all but depleted loyalist strength in a province once considered an obstacle to revolutionary progress. ${ }^{2}$

Despite analogous endings, however, the circumstances and events in each area differed. On the frontier, pre-war territorial disputes with nearby colonies framed patriot-

\footnotetext{
${ }^{1}$ Even the population of indigenous peoples in these areas was not very extensive. Considered alien nations and not citizens, Pennsylvania's natives were not part of census efforts and numbers are scarce. A 1708 count gave 6,000 Indians in the colony alongside 35,000 whites or about one-seventh of the population. See Evarts B. Greene \& Virginia D. Harrington, eds., American Population Before the Federal Census of 1790 (Baltimore: Genealogical Publishing Co., 2006; reprint of 1932 Columbia University Press edition), 114. Since white settlement and immigration continued at a brisk pace throughout the $18^{\text {th }}$ century and drove natives westward, while imported European diseases probably had an additional impact, it is likely the native population did not grow substantially. Bedford County was created from a chunk of Cumberland in 1771. Then in 1773, Westmoreland County was cut from Bedford. See "Pennsylvania County Formation" online, Pennsylvania Gene http://www.pagenweb.org/formation.html accessed January 8, 2018.

${ }^{2}$ For example, Pennsylvania was a prime target of Congress' May 1776 resolution encouraging the states to form new governments, leading to the Declaration of Independence only two months later.
} 
loyalist divisions and impacted outcomes. The middle ring of counties witnessed many of the same tensions and conflicts that shaped the resistance-to-independence process for elites in the provincial capital. In Philadelphia and its environs, lesser loyalists cast as appendages of the British army responded to royal strategic priorities. The stories of John Connolly in Cumberland County, the Pennamites of Northumberland County, the Rankin brothers of York County, the middle-tier officers and the common soldiery of the provincial corps recruited during the Philadelphia occupation who gathered around the king's cause reveal that military commitment was the most likely forecaster of departure, exile, and the future failure to reintegrate. Moreover, the parting, capture, defeat or death of ordinary loyalist militants contributed to the resolution of intracolonial clashes over boundaries, shattered pro-British fervor among loyal sectors of the populace, and reduced serious military threats to the rebellion in the state. Hence, the breakdown of loyalist militancy among the common folk diminished internal tensions and strife, eased the eventual reacceptance of the disaffected who stayed in Pennsylvania, but led to their own failure to reintegrate as in the case of elite Philadelphia counterparts. ${ }^{3}$

\section{JOHN CONNOLLY \& MILITANCY ON PENNSYLVANIA’S WESTERN FRONTIER}

In both the western and northeastern frontiers of the state, the Revolution injected new fissures into standing colonial antagonisms. During the early 1770s, Pennsylvania quarreled with Virginia for jurisdiction over the Fort Pitt region, leading to frequent altercations between both officials and partisans from each band. An equally pugnacious

\footnotetext{
${ }^{3}$ It is my judgment that the loyalists who departed Pennsylvania because of possible rebel retribution and never opted to return must be counted as a subcategory of those who failed to reintegrate. In such cases, the absence of an attempt to reintegrate reflected more a fear of returning than a desire to stay away. It is highly unlikely anyone would have voluntarily left who did not think they had to leave. The default position was the wish to remain integrated as a member of Pennsylvania society, not a longing to leave. The inability to return was therefore a reintegrative failure.
} 
conflict developed between Pennsylvania and Connecticut during the late colonial era along the northern Susquehanna River, each provincial government citing their respective royal charters as the basis for sovereignty over the area. The rebellion introduced the dynamic of competing allegiances between America and Great Britain into an already fluid and volatile environment, transforming intercolonial discord into loyalist-patriot confrontation. As instigator of pre-war discord in the west on the side of royal Virginia, the Pennsylvania-born John Connolly became a principal standard-bearer of the king on the frontier in the early years of revolution. His arrest and imprisonment threw local supporters of the Crown into disarray, appreciably weakened the king's influence in the region, and placed imperial fortunes largely in the hands of British-allied Indian nations trying to defend their own civilization and territory. Thus, Connolly's militancy inadvertently helped rally white settlers in the west to the patriot banner as a means of defending their lives and interests against indigenous threats. His steadfast loyalism accordingly quashed any later chance of return or personal reintegration.

Born near Wright's Ferry in Lancaster County between 1742 and 1744 as the only child of an English surgeon, John Connolly was orphaned in 1753 with the passing of his mother. His father had died six years earlier. The child was put under the care of James Wright who apprenticed him in the medical field. ${ }^{4}$ Connolly's own ambition, however, was to become a military man. By 1762 , he had fused the two tracks, becoming a surgeon's mate and serving in the Martinique expedition during the latter stages of the French and Indian War. Two years later he joined the British army in two campaigns

\footnotetext{
${ }^{4}$ James Wright was likely the son of John Wright, Quaker founder of Wright's Ferry in 1726, later located in Lancaster County. See Franklin Ellis and Samuel Evans, History of Lancaster County, Pennsylvania, with Biographical Sketches of Many of its Pioneers and Prominent Men (Philadelphia: Everts \& Peck, 1883), 585. Lancaster County was considered on the outer fringes of the colony at that time.
} 
against indigenous nations on the western Pennsylvania frontier. "Animated by a strong desire to make myself worthy to serve my King and country on future occasions, after peace was established with the Indians," Connolly dedicated the postwar period to an extensive exploration of the western frontier, visiting with natives, traversing the wilds in their company, and familiarizing himself with "their different manners and customs."5 Sometime before 1767, he married Susannah Sample, daughter of a Pittsburgh tavern keeper. Rather than fulfilling his desire for worthiness, Connolly got himself into debt at Pittsburgh. In 1769, he plunged farther west into the Illinois country then under British dominion, expanding his regional expertise while engaging in the Indian trade. Regional expertise did not necessarily translate into business acumen, however, and he returned to Pittsburgh in 1770 deeper in debt than before. In the process, he sold his patrimonial estates to buy lands on territory claimed simultaneously by Virginia and Pennsylvania. Thus was born the driving force of John Connolly's royalist fidelity. ${ }^{6}$

As a wannabee landed magnate, John Connolly spent the five years leading up to the outbreak of open revolution building the tight-knit relationships and personal interests that bound him to the king's cause while attempting to secure, preserve and defend title to his property or sell it at a profit. Much of this contested "Virginia" terrain was located in

\footnotetext{
${ }^{5}$ John Connolly, "A Narrative of the Transactions, Imprisonment, and Sufferings of John Connolly, an American Loyalist and Lieut. Col. in His Majesty's Service," The Pennsylvania Magazine of History and Biography, vol. 12, no. 3 (October, 1888), 310-11 (hereafter "Narrative").

${ }^{6}$ Doug MacGregor, “The Ordeal of John Connolly: The Pursuit of Wealth through Loyalism,” Joseph S. Tiedemann, Eugene R. Fingerhut, and Robert W. Venables, eds., The Other Loyalists: Ordinary People, Royalism, and the Revolution in the Middle Colonies, 1763-1787 (Albany: State University of New York Press, 2009), 162-63; Palmer, Biographical Sketches, 170; "Memorial of Lt. Col. Connolly," Egerton, ed., The Royal Commission, 67, 78.
} 
present-day Pittsburgh. ${ }^{7}$ Along the way, he befriended or came in contact with some of the main players on both sides of the future Revolution. In 1770, Connolly dined with George Washington and other Virginia gentlemen exploring land investments in the area. Impressed with the Pennsylvanian's vast knowledge of the west, Washington called him a "very sensible intelligent man." Connolly's most important contact came in the summer of 1773 in the person of John Murray, Fourth Earl of Dunmore and royal governor of Virginia, also on tour through the Ohio valley in search of investment acreage. Dunmore was sufficiently impressed to make the Pennsylvanian-turned-Virginian his agent. That December, John Connolly traveled to Williamsburg to attend a meeting with the royal governor and Patrick Henry, among others, in which they devised a strategy to drive out the Shawnee from the west, seize their land, and sell it. The campaign became known as Dunmore's War. The governor assured Connolly's collaboration by granting him 4,000 acres at the Falls of Ohio, ignoring instructions from the British ministry not to issue new land grants to avoid conflict with the Indians. A 1772 order from General Thomas Gage, commander of British forces in North America, withdrawing the imperial army from Fort Pitt opened the door for Dunmore's ploy. The pullout created a local power vacuum which triggered a three-sided tug of war among the original native residents, Virginia, and Pennsylvania. While Penn's colony filled the void by selling land to settlers under the Fort Stanwix Treaty of 1768 and in the process created the counties of Bedford in 1771 and Westmoreland in 1773 from swaths of the original Cumberland County, Lord Dunmore claimed the territory as part of Virginia. In addition, the Mingo, Shawnee and

\footnotetext{
${ }^{7}$ For an account of the colonial land dispute on the western frontier, see John E. Potter, "The Pennsylvania and Virginia Boundary Controversy," PMHB, vol. 38, no. 4 (1914), 407-426.
} 
Delaware nations disputed the Fort Stanwix agreement itself - an accord that had received Iroquois assent but never theirs. ${ }^{8}$

Into this quagmire of power politics and shady legalities stepped John Connolly on the side of Virginia. By this time, he had sold four hundred half-acre town lots in Fincastle County, Virginia, for four Spanish dollars at a dollar a year quitrent. Buyers under contract pledged to clear another seven acres each, slated to revert to Connolly in seven years. Between four and five hundred families settled in the area under these terms. William Preston, royal surveyor of Fincastle County, thought Dunmore had exceeded his authority. Confiding to George Washington that he had signed the certificates granting these lands to Connolly "with some Reluctance," the surveyor noted the transaction had "made a great deal of noise" publicly and "many good Judges" believed "the Patents are altogether illegal." Connolly returned to Fort Pitt to assert Virginia's jurisdiction over the contested territory. The entire viability of his speculative land project - his future prosperity - rested on two factors: the successful claims of the royal colony of Virginia over the disputed territory and confirmation of the grants Lord Dunmore had awarded him. Pennsylvania and the native inhabitants stood in his way. ${ }^{9}$

\footnotetext{
${ }^{8}$ Connolly, "Narrative," PMHB, vol. 12, no. 3, 311-12; Sabine, Biographical Sketches, vol. 1, 331; MacGregor, "Ordeal of John Connolly," The Other Loyalists, 163; Ousterhout, A State Divided, 250; "Memorial of John Connolly," Egerton, ed., The Royal Commission, 68. The Delaware, Shawnee and Mingo nations had been relegated to a subservient status under the Iroquois as a result of defeats in earlier tribal wars. Hence, the Iroquois did not include them in their treaty negotiations. For Dunmore's War, see Daniel K. Richter, Facing East from Indian Country: A Native History of Early America (Cambridge: Harvard University Press, 2001), 213-216, 221; Woody Holton, Forced Founders: Indians, Debtors, Slaves, \& the Making of the American Revolution in Virginia (Chapel Hill: University of North Carolina Press, 1999), 33-34, 144, 176; Nash, The Unknown American Revolution, 167-171.

${ }^{9}$ Palmer, Biographical Sketches, 170; “From Colonel William Preston, March 7, 1774," Stanislaus Murray Hamilton, ed., Letters to Washington and accompanying papers (Boston: Houghton, Mifflin \& Co., 1898) vol. 4, 345-347; MacGregor, "Ordeal of John Connolly," The Other Loyalists, 161, 164; Sabine, Biographical Sketches, vol. 1, 331.
} 
On January 6, 1774, Connolly proclaimed himself Captain Commandant of the Militia of Pittsburgh and its Dependencies and on the $25^{\text {th }}$ ordered the Virginia militia to muster. Filling the militia rolls with ease, he took control of Fort Pitt by month's end. Pennsylvania responded through Westmoreland County magistrate Arthur St. Clair, who detained Connolly on orders from an indignant Governor John Penn. The controversy resulted in his release on February $2 .{ }^{10}$ Chaos ensued as contrarian colonial governments each arrested supporters from the opposing band. Meanwhile, Virginia settlers used the turmoil as an excuse to attack the Shawnee and Mingo peoples in the area, predictably producing retaliation. Virginians exploited a circular letter from Connolly that April as justification for hostilities, leading to the brutal massacre of the family of Mingo chief Logan. Lord Dunmore subsequently used Logan's reprisals as a pretext for Virginia counterattacks. While fighting the governor's war, John Connolly and his business partner John Campbell continued to advertise lots for sale, asserting that their area "will, in short time, be equalled [sic] by few inland places on the American continent." ${ }^{11}$ In September of 1774, the same month the First Continental Congress met in Philadelphia, Lord Dunmore visited Fort Pitt and mounted a successful military operation that forced the Shawnee to seek peace. Virginia officials claimed Pennsylvania land grants were invalid and harassed Pennsylvania settlers. St. Clair thought Virginia’s attacks were all part of a well-designed "Connolly plan" to subdue the region, an indication of his

\footnotetext{
${ }^{10}$ This was the same Colonel Arthur St. Clair under whom then-patriot William Allen Jr. served as a continental officer during the failed invasion of Quebec.

${ }^{11}$ Connolly, "Narrative," PMHB, vol. 12, no. 3, 313; Arthur St. Clair to Gov. Penn, February 2, 1774, Pennsylvania Archives, First Series, vol. 4, 476-77; MacGregor, "Ordeal of John Connolly," The Other Loyalists, 164-65; Sabine, Biographical Sketches, vol. 1, 331. Governor Penn's letters to Lord Dunmore are in George Edward Reed, ed., Pennsylvania Archives, $4^{\text {th }}$ Series (1900), vol. 3, 478-81.
} 
growing influence. Into this cauldron of discord and distrust, the news arrived in Pittsburgh on May 1, 1775 that the British army had engaged the Massachusetts militia on the fields of Lexington two weeks earlier. ${ }^{12}$

Events quickly escalated. Virginia and Pennsylvania settlers unexpectedly set aside their differences, established a patriot Committee of Correspondence, mobilized militia, and declared their intent to seek peace with local natives. Westmoreland County residents nominally under the jurisdiction of Pennsylvania met at Hannastown and declared their support for the patriot cause. Although John Connolly was still technically militia commander of Augusta County, Virginia, these actions put him in a precarious position, for events had made his patron Lord Dunmore persona non grata. Passing through the frontier in July 1775, British traveler Nicholas Cresswell noted the political climate: "the people here are Liberty mad nothing but War is thought of." Throughout the turmoil, Connolly confidentially retained his fidelity to kingly authority, adducing later that "my loyalty to my Prince, and respect for the established form of government, were too confirmed to admit of the least doubt which party I should espouse; I decided instantly, and resolved to exert every faculty in the defence [sic] of the royal cause."13

\footnotetext{
${ }^{12}$ Connolly, "Narrative," PMHB, vol. 12, no. 3, 313; MacGregor, "Ordeal of John Connolly," The Other Loyalists, 165. Connolly's role is also in Douglas MacGregor, "Double Dishonor: Loyalists on the Middle Frontier," William Pencak, ed., Pennsylvania's Revolution (University Park, PA: The Pennsylvania State University, 2010), 144-49; and in Richard White, The Middle Ground: Indians, Empires, and Republics in the Great Lakes Region, 1650-1815 (Cambridge, UK: Cambridge University Press, 2011), 356, 359-363. Connolly's personal participation in the pre-war border dispute comes up repeatedly during 1774 and early 1775 in Pennsylvania's Colonial Records, vol. 10, 140-42, 145, 149, 157, 161, 165-171, 176, 193, 197, 227-228, 234.

13 "Memorial of John Connolly," Egerton, ed., The Royal Commission, 68; MacGregor, "Ordeal of John Connolly," The Other Loyalists, 165-66; MacGregor, "Double Dishonor," Pennsylvania's Revolution, 146147; Nicholas Cresswell, A Man Apart: The Journal of Nicholas Cresswell (Lanham, MD: Lexington Books, 2009), 69; Connolly, "Narrative," $P M H B$, vol. 12, no. 3, 315.
} 
Whether his defense of "the royal cause" was attributable to an ideologically principled commitment or simply a vehicle for private aggrandizement is open for debate. His later testimonies seeking parliamentary compensation naturally affirmed the former. He was "conscious of having acted with good intentions, and from principles which he believed were descriptive of a loyal subject, an honest man, and a man of honour." $\mathrm{He}$ was "taught from my earliest infancy to serve my King and my country." He had been "the first person of influence, who had attempted to support the Royal cause, by raising troops in America." He "still had the consolation to reflect, I had done every thing possible in the discharge of my duty." His "greatest faults" were "my sufferings, my zeal, and loyalty... taken in the execution of my duty as a faithful servant of the Crown." And he thought himself exceptional, even among the loyal, for "Congress... resolved to detain me... in an extraordinary manner, and quite distinct from any other Loyalist, during the whole contest." ${ }^{14}$ Yet despite such avowals of fealty, his actions before, during, and after the Revolution almost invariably responded to projects defending his own interests. That he sided with Dunmore and Virginia though raised a Pennsylvanian is especially telling. ${ }^{15}$

Covertly committed to the king, John Connolly conspired with Lord Dunmore through 1775 while publicly trying to wear a patriot face. He played his dual role well. From a refuge aboard an English warship on Virginia's York River, Dunmore authorized the converted Virginian to raise a loyalist regiment and secure an alliance with the Ohio

\footnotetext{
${ }^{14}$ Connolly, "Narrative," $P M H B$, vol. 12 , no. 3 , 310, 311; vol. 12, no. 4, 418; vol. 13, no. 1, 61; vol. 13, no. 3, 290; vol. 13 , no. 2,158 .

${ }^{15}$ I have found no evidence that Connolly ever thought of himself as connected to Virginia until he sold his Pennsylvania patrimony circa 1770 in his late twenties. Furthermore, his links to Pennsylvania were not simply geographic but also involved kinship. For example, famed Pennsylvania Indian trader George Croghan was his uncle - see MacGregor, "Ordeal of John Connolly," The Other Loyalists, 163.
} 
Indians in support of Britain. Western patriots also sought an Indian alliance or at the very least their neutrality, so Connolly convened a June conference with natives in the region while feigning allegiance to the rebel movement. As the convocation approached, Pennsylvania officials arrested Connolly as a suspected tory. Virginians saw this as no more than a ruse in the continuing border dispute and countered with the arrest of three Pennsylvania magistrates. The maneuver worked: Arthur St. Clair ordered the release of Connolly, whereupon the latter dutifully joined the conference in progress and performed his tightrope act ably enough to receive the compliments of Virginia's patriot delegation. Connolly later claimed he had stealthily achieved his goal of bringing local Indians into the British fold while there. After the gathering, Connolly used three Shawnee chiefs as cover and headed eastward towards Williamsburg with associate Alan Cameron to meet Lord Dunmore face-to-face at his offshore sanctuary and plan strategy for a loyalist uprising on the frontier. The Earl sent him to Boston to discuss operations with General Thomas Gage, British commander for North America, who gave Connolly his blessing and instructed him to coordinate with Sir Guy Carleton in Canada and Guy Johnson in New York's Mohawk Valley. On November 5, 1775, Connolly received a commission as Lieutenant Colonel Commandant in anticipation of the upcoming expedition, with Dunmore "reposing especial trust in your loyalty, courage, and good conduct." At a time when Britain's Privy Council canceled the western land grants of patriots like George Washington, Patrick Henry, and Thomas Jefferson, it is noteworthy that the same officials left Connolly's royal claims unscathed. ${ }^{16}$

\footnotetext{
${ }^{16}$ Sabine, Biographical Sketches, vol. 1, 331; Coldham, ed., American Migrations, 544; MacGregor, "Ordeal of John Connolly," The Other Loyalists, 167-69; Siebert, The Loyalists of Pennsylvania, 10; MacGregor, "Double Dishonor," Pennsylvania's Revolution, 148-49; "Memorial of John Connolly,"
} 
Lord Dunmore's instructions to Connolly proved fateful. Writing on August 9 from Portsmouth, Virginia, to former friend John Gibson in the Fort Pitt area, Connolly referred to "the infatuated people" and "their folly" while asking for his cooperation. "Be prevailed upon to shun the popular error," he advised, "act as a good subject, and expect the rewards due to your services. ${ }^{, 17}$ Unbeknownst to the loyalist conspirator, Gibson turned the letter over to the patriot county committee. Connolly set out from eastern Virginia on November 13 in the company of Alan Cameron and Dr. John Smyth, bound for Detroit to execute the opening round of Dunmore's stratagem. ${ }^{18}$ On the $19^{\text {th }}$, he unexpectedly ran into a private once under his command, who disclosed Connolly's militant past to locals at Hagerstown, Maryland. That night patriots arrested the travelers and uncovered Dunmore's instructions. Upon receiving the news, Congress ordered the group to Philadelphia. En route through York in Pennsylvania on January 1, 1776, escorts paraded the trio before the populace to the tune of the infamous Rogue's March. Among the witnesses to the spectacle was his saddened half-brother and radical patriot, James Ewing. Two days later the party arrived in the capital. Congress turned the cohort over to the Pennsylvania Committee of Safety. Andrew Allen was present when the sixteenmember committee followed Congress' recommendations and cast the group in jail,

Egerton, ed., The Royal Commission, 67; Robert M. Calhoon, "Civil, Revolutionary, or Partisan: The Loyalists and the Nature of the War for Independence," Tory Insurgents, 206; John, Earl of Dunmore... to John Connolly, Esq., November 5, 1775, Peter Force, ed., American Archives, $4^{\text {th }}$ Series (Washington, DC: 1840), vol. 4, 617.

${ }^{17}$ John Connolly to John Gibson, August 9, 1775, Force, ed., American Archives, $4^{\text {th }}$ Series, vol. 3, 72; Connolly, "Narrative," PMHB, vol. 12, no. 4 (January 1889), 408-09.

${ }^{18}$ Detroit was then under British control, not a part of the United States. 
inaugurating Connolly's half-decade incarceration, among the lengthiest of any loyalist during the Revolution. ${ }^{19}$

John Connolly's detention and captivity left the few adherents to the Crown in the west leaderless and temporarily disbanded loyalist efforts there. Although admonitions the next year from William Lyon - radical member of the Supreme Executive Council for Cumberland County - on "the growing party of disaffected persons, which unhappily exist at this time" called for recruitment of five hundred men from the county for new militia battalions and frontier battles against Indians aligned with the British, loyalist militants in the vicinity conducted few armed enterprises on their own beyond Connolly's efforts. In one such case, Henry Magee helped recruit 431 men for an uprising around Chamberstown in 1777 . The movement disintegrated when one of the conspirators betrayed the group to patriots. ${ }^{20}$ In the spring of 1778 , seven men under the direction of Captain Alexander McKee, the king's deputy agent for Indian affairs in the area for over a dozen years, then under house arrest for suspected communications with the enemy, broke from confinement at Fort Pitt and made a successful dash for the British garrison at Detroit. The fugitives left behind a clandestine "band of tories" among the Virginia patriots stationed at Fort Pitt who plotted to blow up the installation and flee by watercraft in the dark. The scheme failed and some of the plotters fell prisoner. Patriot officials

\footnotetext{
${ }^{19}$ A summary of Connolly's instructions \& letters from confinement in Fredericktown, Maryland, are in Force, ed., American Archives, $4^{\text {th }}$ Series, vol. 4, 598, 616-18; Connolly, "Narrative," PMHB, vol. 12, no. 4, 413-14, 418; "Examination of A. Cameron, Dr. Smith and Jno. Connolly," November 23, 1775, and "Copy of John Connelly's Letter to John Gibson," Pennsylvania Archives, First Series, vol. 4, 682-84; MacGregor, "Ordeal of John Connolly," The Other Loyalists, 169-70; "Memorial of John Connolly," Egerton, ed., The Royal Commission, 67, 78; MacGregor, "Double Dishonor,” Pennsylvania's Revolution, 149; Colonial Records, vol. 10, 444, 472.

${ }^{20}$ Council Minutes, October 16, 1776, Colonial Records, vol. 10, 757; Joan Magee, Loyalist Mosaic: A Multi-Ethnic Heritage (Toronto: Dundurn Press, 1984), 158, DLAR.
} 
shot two of the leaders, hanged one, and publicly whipped another pair with one hundred lashes. McKee later received a commission in the His Majesty's armed forces and played an instrumental role in securing the collaboration of the region's natives on the side of the British in the continuing conflicts which plagued the frontier for the remainder of the war and into the postwar era. ${ }^{21}$

That April, patriots frustrated another loyalist conspiracy of about thirty men in the upper Juniata valley under the leadership of John Weston. Known as the tories of Sinking Valley, they intended to join indigenous allies in an attack on patriot positions. The venture failed when the conspirators who had taken an oath of allegiance to King George III accidentally clashed with a large band of Iroquois not part of the intrigue. The Iroquois killed Weston and forced the loyalist frontiersmen to disperse into the wilderness. In an initiative more typical of the imperial approach to the frontier war, British Captain Henry Bird and Simon Girty - who fled to Detroit with McKee the previous year - led two hundred Miami and Mingo natives on an assault on Fort Laurens in February 1779. The besieged patriot garrison withstood near starvation and bitter weather until a relief force saved the day on March $23 .{ }^{22}$ As these incidents illustrate, regional loyalism did not die altogether with John Connolly's departure. From the original Attainder Act of March 1778 onward, twenty-eight individuals from Cumberland

\footnotetext{
${ }^{21}$ Edward W. Hassler, Old Westmoreland: A History of Western Pennsylvania during the Revolution (Cleveland: The Arthur H. Clark Company, 1900), 44-48. Two of the seven "dashers" were slaves. The leaders of the Fort Pitt plot were Sergeant Alexander Ballantine, William Bentley and Eliezer Davis. McKee's exploits are especially prominent throughout Richard White, The Middle Ground and in Alan Taylor, The Divided Ground: Indians, Settlers, and the Northern Borderland of the American Revolution (New York: Vintage Books, 2006).

${ }^{22}$ Hassler, Old Westmoreland, 49-53, 80-87.
} 
County were attainted for high treason, out of a state total of $488 .{ }^{23}$ Of these, at least eight can be considered as militants who bore arms against the Revolution, including Simon Girty, his brother James, and Matthew Elliott, all of whom took flight with Alexander McKee to Detroit. Yet loyalist militancy in the west as a contribution to the British war effort on its own without Indian cooperation never regained the vigor Dunmore's agent initially instilled in the cause.

John Connolly's protracted imprisonment is a tale of unremitting petitions and laments over his treatment and corresponding denials of improper handling by patriot officials. ${ }^{24}$ On January 26,1776 , he was only one of six loyalists housed in a facility with over a hundred prisoners jailed for a variety of crimes. Because he was an alleged traitor, officials restricted his freedom of movement until his health began to suffer. Patriot doctors confirmed his physical deterioration, at which point he was allowed to walk the prison yard. In March, he planned an escape after the visit of his father-in-law Samuel Sample. Authorities uncovered the plot, preventing its execution. ${ }^{25}$ In May, his wife

\footnotetext{
${ }^{23}$ The Cumberland portion of attainted loyalists was about one-third of the county's comparative percentage of the state population. According to tax lists for 1779, the counties of Cumberland, Bedford and Westmoreland (the extent of the original Cumberland County) had 8,404 taxables out of a statewide total of 54,683 or $15.4 \%$ of all taxables. See Greene \& Harrington, eds., American Population Before the Federal Census of 1790, 113. A count of 28 attainted out of 488 represents only $5.7 \%$ of all attainted. This data suggests much stronger support for the Revolution in the west than in the state's southeast core, which fits regional demographic patterns in the west such as the large numbers of Scots-Irish Presbyterians, a group more prone to support the rebellion.

${ }^{24}$ Some examples of Connolly's laments: "Immured as I am within the cold dark walls of an inhospitable jail, secluded from all Society, and almost suffocated with smoke from a lower apartment," John Connolly to Committee of Safety, January 26, 1776, Pennsylvania Archives, First Series, vol. 4, 703-04. "It has been my misfortune to have experienced a very long and rigorous confinement, highly aggravated by a constant sickness, the effects of this complicated distress, has reduced me to the lowest condition" John Connolly to Council of Safety, December 11, 1776, Pennsylvania Archives, First Series, vol. 5, 101. "Immured within a solitary room, \& cutt [sic] off from every social intercourse with mankind, it must be acknowledged is a punishment, highly afflicting and scarcely tolerable to the most vigorous constitutions" John Connolly to Council, December 23, 1776, Pennsylvania Archives, First Series, vol. 5, 130.

25 “Intelligence Received by Congress,” April 2, 1776, Pennsylvania Archives, First Series, vol. 4, 728-29.
} 
Susannah visited him over five days, leading to a denial of her request to depart for fear she would carry intelligence to the enemy. She continued there into the summer, despite several petitions to Congress. In July, Pennsylvania's Council of Safety decided to grant her a retroactive weekly allowance of thirty shillings, followed by twenty-five shillings thereafter. Growing desperate, she told Congress that her husband was planning an escape, whereupon he began to "mistreat her" after learning of the accusation. Eventually concluding that Susannah Connolly posed no threat, Congress resolved that she "may be enlarged with Safety to these States, and suffered to go to her family in Cumberland County. ${ }^{26}$ When General Howe's army made incursions into New Jersey in December 1776 after capturing Manhattan, Congress fled momentarily to Baltimore. John Connolly remained in Philadelphia, where half-brother James Ewing took command of revolutionary forces. A month later, Ewing arranged to swap jail for house arrest on a farm near Wrightsville but shortly thereafter patriots ordered Connolly back to prison. Detention kept the prisoner from meeting his financial obligations at this time and creditors appropriated much of his lands. In April 1777, Ewing posted a $£ 4,000$ bond for Connolly's good behavior and obtained the latter's transfer to one of his farms. Howe's August invasion of Pennsylvania upset the arrangement. Radicals moved Connolly to jail at York under the watchful of a relocated Congress. He remained there until two months after Clinton's evacuation when, in early August 1778, he returned to confinement at

\footnotetext{
${ }^{26}$ Council of Safety Minutes, July 16, 1776 \& August 22, 1776, Colonial Records, vol. 10, 648, 696; Monday, September 9, 1776, Journals of the Continental Congress, vol. 5, $748 \mathrm{fn} 1$. For an example of Susannah Connolly's intervention, Mrs. Connolly to Committee, June 25, 1776, Pennsylvania Archives, First Series, vol. 4, 778-79. Susanna Connolly is discussed in Elisabeth O'Kane-Lipartito, "Civilians and Society in the American Revolution and After, 1775-1830," (PhD Dissertation, University of Houston, 1993), 127.
} 
Philadelphia. The vicissitudes of captivity thus kept Connolly from ever consciously choosing or rejecting the option to reintegrate at the first fault line of evacuation. ${ }^{27}$

Although the radical Pennsylvania government had decreed five sweeping attainders by the end of 1778, revolutionaries never attainted John Connolly for high treason. Already jailed, he had no need to surrender for trial. During his incarceration, he dedicated himself to two tasks: seeking an upgrade in prison conditions and petitioning for exchange as an officer of His Majesty's service. Congress tasked a team with investigating Connolly's mistreatment. This committee not only concluded that his allegations were "scandalous and groundless" but upped the ante, accusing him of being a spy rather than a commissioned royal officer. The charge posed a grave peril: spies were subject to a different set of wartime rules, including execution. A surprised Connolly fought the novel imputation, triggering yet another congressional probe that decided on July 14, 1779 that he was indeed an officer, not a spy. Finally, in July 1780 patriot authorities granted Connolly a parole and exchanged him three months later at New York for Lieutenant Colonel Nathaniel Ramsey, a hero of the battle of Monmouth. As part of the deal, Connolly promised to do nothing in the future that would harm the United States - terms he instantly violated. ${ }^{28}$

Promptly rejoining the British army, John Connolly drew up plans for a new attack on the west that would restore British hegemony on the frontier - and title to his

\footnotetext{
${ }^{27}$ Dr. John Connolly to Pres't Wharton, April 7, 1777, \& James Ewing to Dr. John Connolly, April 4, 1777, Pennsylvania Archives, First Series, vol. 5, 297-98; Council Minutes, April 2, 1777, Colonial Records, vol. 11, 196, 200; MacGregor, "Ordeal of John Connolly," The Other Loyalists, 170-72; Scharf \& Westcott, History of Philadelphia, 305, 339.

28 “THURSDAY, November 12, 1778," Journals of the American Congress: From 1774 to 1788 (Washington, DC: Way and Gideon, 1823), vol. 3, 121-22; Connolly, "Narrative," PMHB, vol. 13, no. 2, 161-64, 166.
} 
lands. Although Sir Henry Clinton approved the plan, Washington received news of the affair in March 1781. Patriots punctually fortified Fort Pitt and the expedition never took place. Instead, Clinton dispatched Connolly south as Lieutenant Colonel Commandant of the Queen's Loyal Foresters to assist Cornwallis in his push through Virginia. Connolly soon fell ill and received permission to leave British lines to recuperate, leading to his recapture in the countryside on September 21 while en route to his refuge. Had he remained with Cornwallis, he would likely have fallen prisoner at Yorktown on October 19 anyway. Patriot officials shipped Connolly back to Philadelphia in December, where he was brought before the Supreme Executive Council and jailed again. The following March Washington ordered his release on condition that he go to British-occupied New York and proceed onward to England. With the post-Yorktown royal cause in tatters, he complied. Officials in London kept Connolly on the military payroll. ${ }^{29}$

Connolly did not consider postwar reintegration in Pennsylvania or Virginia a viable option while adrift in exile, especially after sweeping changes on the frontier. The competing states had settled their longstanding boundary clash on September 23, 1780, agreeing to locate Fort Pitt and the surrounding area within Pennsylvania's jurisdiction as long as settlers could retain title to lands acquired under Virginia's earlier authority. ${ }^{30}$ The Definitive Treaty of Peace in 1783 dashed Connolly's last hopes. The area he had claimed as the source of prospective riches no longer fell under the dominion of either

\footnotetext{
${ }^{29}$ John Connolly to Sir Henry Clinton, November 22, 1780, in Calhoon, "Civil, Revolutionary, or Partisan," Tory Insurgents, 215; Gen. Washington to Pres. Reed, April 25, 1781, Pennsylvania Archives, First Series, vol. 9, 102-03. Connolly, "Narrative," PMHB, vol. 13, no. 3, 281-86; MacGregor, "Ordeal of John Connolly," The Other Loyalists, 173; Palmer, Biographical Sketches, 171; Allen \& Braisted, "Loyal Foresters," The Loyalist Corps, 59-60; Coldham, ed., American Migrations, 544; "Memorial of John Connolly," Egerton, ed., The Royal Commission, 67; Colonial Records, vol. 13, 161. The best treatment of American loyalist exiles in Great Britain remains Mary Beth Norton's The British-Americans.

${ }^{30}$ Potter, "The Pennsylvania and Virginia Boundary Controversy," PMHB, vol. 38, no. 4 (1914), 417.
} 
Virginia or Great Britain. Lord Dunmore's word - the cornerstone of Connolly's claims was worthless. After breaking faith with his Pennsylvania origins in the colonial border dispute with Virginia and the struggle for independence, Connolly's dreams of landed wealth lay in ruins.

Like many loyalist militants, Connolly turned his postwar attention to reparations for his fidelity. In 1783, he published his narrative to bolster a claim to Parliament for $£ 6,849$, a solicitation grounded in large measure on the 4,000 acres Lord Dunmore had assigned him prior to the war. Joseph Galloway was among those who backed Connolly's land claim, declaring that it was "better than the title of those persons employed by him," while Dunmore himself affirmed that his former officer "would certainly have received it [the land] if it had not been for the rebellion." ${ }^{, 31}$ Unfortunately, the parliamentary commissioners had removed uncultivated lands from the ledger of viable claims. As a result, Connolly only received $£ 793$ in compensation.

John Connolly's land dreams did not die with exile, however. In the winter of 1787, he moved to Quebec. The next year the British dispatched him to Detroit as Lieutenant Governor. From there, he again tried to recover his Ohio properties, a maneuver quashed by the Virginia Assembly in response to petitions from local settlers. In September 1788, the ever-enterprising Connolly set out for Kentucky to reunite with his onetime partner John Campbell, to whom he proposed an expedition to seize New Orleans from Spain. He promised locals royal arms, ammunition, and men to secure the Mississippi River for Great Britain all the way down to the Gulf of Mexico. Campbell found Connolly “obnubilated" by alcohol and dismissed him as any sort of threat to

\footnotetext{
31 “Memorial of John Connolly," Egerton, ed., The Royal Commission, 67-69; Palmer, Biographical Sketches, 171.
} 
Spanish sovereignty over the region. Kentuckians for their part rejected his offer, forcing him to flee once again. ${ }^{32}$ By 1798 , he was in Montreal, warning his patriot half-brother James Ewing by letter that Europe's conflicts would inevitably cross the Atlantic and involve the United States in war with Spain. His earlier ardor against "the tyranny and insolence of republican faction" and the "madness" of those who "overlook his duty to the present [British] constitution" had evidently dissipated, for he offered his assistance to the United States should such an event occur. ${ }^{33}$ Connolly suffered one final setback as the eighteenth century drew to a close. Appointed royal Superintendent of Indian Affairs at Detroit in December 1799 on the Duke of Kent's recommendation, he discovered that the long arm of imperial patronage had already offered the post to someone else. The British ministry canceled the assignment by July 1800. Connolly died in Montreal on January 30, 1813. According to his last wife, Margaret, he spent the later part of his life lamenting his multiple failures. ${ }^{34}$

Of modest borderland origins, John Connolly was the most militant of western Pennsylvania's loyalists. Like Galloway and the Allens in southeastern Pennsylvania, his departure from Cumberland County left loyalists without direction, mitigated local revolutionary tensions, and paved the way there for a more harmonious reintegration process. His efforts to resurrect the land issue in Kentucky in the late 1780s provide ample proof that his presence, if allowed, would have substantially muddied the republic-

\footnotetext{
${ }^{32}$ MacGregor, "Ordeal of John Connolly," The Other Loyalists, 174; Sabine, Biographical Sketches, vol. 1, 332. Virginia still held jurisdiction at this late date over the territory that would soon become the state of Kentucky. The Pennsylvania-Virginia border resolution did not apply there.

${ }^{33}$ Connolly, "Narrative," PMHB, vol. 13, no. 1, 61; Connolly, "Narrative," PMHB, vol. 12, no. 4, 408.

${ }^{34}$ MacGregor, “Ordeal of John Connolly,” The Other Loyalists, 174.
} 
building process on the western frontier. Connolly rode pre-war colonial factionalism into the rebellion. His failed militancy had two significant consequences: it drew the issue of allegiance to the king out of the Pennsylvania-Virginia boundary dispute, leaving rebels to resolve the matter in 1780, and unintentionally placed the brunt of England's fortunes in the region on the shoulders of allied Indian nations, thereby pushing the white settlers who bore their attacks away from the royal cause.

On a personal level, Connolly's belligerence generated prison and exile, while crippling any chance at reintegration. From the perspective of Pennsylvania patriots, he had the dubious distinction of betraying his birthplace not once but twice: initially on the side of the royal colony of Virginia over the proprietary colony of Pennsylvania and later as a devotee of monarchy against revolution. Though he consistently ascribed his actions to selfless aims, the historical Connolly seems less a loyalist militant than a militant Connollyist, inspired and driven by what he perceived would bring the greatest personal advancement. While steady in his fidelity, his personal stake in western land speculation - in all endeavors at all junctures - strongly suggests that self-interest was the sine qua non of his allegiance.

PENNAMITES \& LOYALIST MILITANCY ON THE NORTHEASTERN FRONTIER

The infusion of colonial factionalism played an even more significant role in the revolutionary struggle on Pennsylvania's northeast frontier in Northumberland County and upper Northampton County. As in the dispute with Virginia westward, competing pre-war settlers from Connecticut and Pennsylvania coveted the largely unpopulated lands along the northern Susquehanna River, in what was known as the Wyoming country near present-day Wilkes-Barre. Both colonies claimed their respective royal 
charters granted them legal title over the area. The New Englanders argued that, since their 1662 charter gave Connecticut the right of sea-to-sea colonization "from the said Narraganset-Bay on the East, to the South Sea on the West Part" two decades before William Penn's grant, their jurisdiction skipped over the existing province of New York and extended to the west. ${ }^{35}$ Yankee settlement began in earnest in 1753 with formation of the Susquehannah Company of Connecticut. As Pennsylvanian "Pennamites" also put down roots in the region, the conflict escalated, especially after the Fort Stanwix Treaty with the Six Nations of the Iroquois in 1768. Pennsylvania governors John and Richard Penn fervently disputed the outsiders' claims. Yet by the early 1770 s, it was clear that the colony of Connecticut was doing a better job backing its settlers than Pennsylvania's "weak and disorganized" efforts. ${ }^{36}$

When the Revolution entered the picture, colonial factions divided along a much more precise and evenly split loyalist-patriot axis than in the west. Connecticut frontier farmers quickly placed themselves under the radical patriot standard, impugning their Pennsylvania adversaries with the taint of loyalism and treason. Although divergences centered around the geographic locus of governmental authority, an ethno-cultural element also exacerbated tensions. For example, almost forty percent of the loyalist militants in the Susquehanna valley documented for this study were either German

\footnotetext{
${ }^{35}$ Charter of Connecticut, April 23, 1662, The Avalon Project, Yale Law School, $17^{\text {th }}$ Century Documents: 1600-1699, available at http://avalon.law.yale.edu/17th century/ct03.asp last accessed January 11, 2018.

${ }^{36}$ Anne M. Ousterhout, "Frontier Vengeance: Connecticut Yankees vs. Pennamites in the Wyoming Valley," Pennsylvania History, vol. 62, no. 3 (July, 1995), 338. The Fort Stanwix Treaty of 1768 (there was another by the same name in 1784) is online at the University of Nebraska-Lincoln's "American Indian Treaties Portal” http://treatiesportal.unl.edu/earlytreaties/treaty.00007.html last accessed January 11, 2018.
} 
immigrants or of Germanic ancestry. ${ }^{37}$ The violent struggle which ensued along the Susquehanna River proved to be far more rancorous, chaotic and definitive than its western counterpart. Outmaneuvered, the Pennamites turned to the British for validation of their land claims. Actively embracing loyalist militancy, they were routed by local proConnecticut revolutionaries who forced them to abandon their homesteads and flee in the dead of winter. With the exception of a number of particularly brutal return raids bent on vengeance, the departure of these Pennsylvania militants not only reduced but virtually eliminated loyalist support in the region and essentially canceled the need for a postwar process of reintegration altogether. Moreover, their flight furthered resolution of the intracolonial clash over boundaries by taking the imperial question out of the equation, allowing Congress and patriots in each state to decide the matter. In terms of the destiny of the exiles, the ferocity of the internecine conflict combined with British defeat and the coming of independence to keep Susquehanna loyalist militants from ever returning to Pennsylvania.

The Connecticut-Pennsylvania disagreement became untenable when both colonies created competing governments in the region. Connecticut set up a town named Westmoreland in 1774 as part of the existing Connecticut county of Litchfield and about two-and-a-half years later, with the Revolution in full swing, restructured Westmoreland into its own county. But two years before this event, Pennsylvania had established the county of Northumberland covering more or less the same geographic expanse. In each

\footnotetext{
${ }^{37}$ Of the 63 documented loyalist armed militants here from the Susquehanna area, 24 were German (38.1\%). Given limited data, the possibility of anglicized names, and a procedural tendency to overlook Germanic origins when uncertain, the percentage is probably higher.
} 
case, local officials behaved like extensions of their respective provincial governments. ${ }^{38}$ Yankees thus vied with Pennamites to reclaim what was viewed as an unpopulated wilderness. As can be expected whenever governmental authority is ambiguous, the struggle turned violent. When the Revolution came to the frontier, the Yankees moved swiftly to side with the rebels while Pennsylvanians hesitated to declare allegiance either way. Focused more on the intercolonial dispute rather than the spreading rebellion against the empire, Governor John Penn Sr. asked justice of the peace William Plunkett to reassert Pennsylvania's authority on the northeastern frontier in November 1775, declaring "I do most chearfully [sic] order you to use your utmost Diligence and Activity, in putting the Laws of this Province in Execution throughout the County of Northumberland., ${ }^{, 39}$ Plunkett's military expedition ended in defeat and permitted the clearly pro-patriot Yankees to position the Susquehanna Pennsylvanians as "tories" in the eyes of outsiders. Thereafter, Connecticut authorities accused even avowed patriots on the Pennsylvania side - like Adonijah Stanburrough - of tory tendencies and compelled them to appear before their accusers. After his audience with the local patriot committee, mill owner Stanburrough promptly disposed of his property and left the area. ${ }^{40}$

\footnotetext{
${ }^{38}$ The essence of this account is taken from Ousterhout, "Frontier Vengeance," Pennsylvania History, 33063; and Frederick J. Stefon, "The Wyoming Valley," Beyond Philadelphia, 133-152. In 1773, Pennsylvania created its own Westmoreland County out of Cumberland County lands farther west near Pittsburgh. Connecticut's Westmoreland jurisdiction was in the Pennsylvania northeast. The two were separate entities and should not be confused. For practical purposes, Connecticut's Westmoreland was largely Pennsylvania's Northumberland County.

${ }^{39}$ John Penn to William Plunket, November 25, 1775, Colonial Records, vol. 10, 275.

${ }^{40}$ For the Plunkett expedition to Wyoming, see Robert J. Taylor, ed., The Susquehanna Company Papers, vol. 6 (Ithaca: Cornell University Press), 410-411, cited in Ousterhout, "Frontier Vengeance," Pennsylvania History, 346. For Stanburrough, Ousterhout, "Frontier Vengeance," Pennsylvania History, 348.
} 
By early 1777, the Yankee-Pennamite schism had reached a crescendo. In the midst of winter, harassment against Pennsylvanians forced many to forsake their farms and undertake the arduous journey to Niagara, where Lieutenant Colonel John Butler - in charge of local Indian affairs for the British - welcomed the refugees. The Revolution had transformed the colonial land conflict: Connecticut's Yankees were now patriots and Northumberland's Pennamites loyalists. ${ }^{41}$ In December 1777, the British authorized Butler to organize the newly arrived émigrés into companies which became known as Butler's Rangers. While the Niagara-based rangers were not technically a Pennsylvania loyalist unit like the others analyzed here, Pennamite frontier farmers heavily manned these units. Whole families' worth of able-bodied males joined en masse - people like Thomas Millard, son Thomas, and his two brothers; Daniel, George, and Gilbert Field; Casper, Henry, and Jacob Hover; James, John, and Peter Secord; and Frederick and William Vanderlip, father and son, all farmers. ${ }^{42}$ Strategically, the rangers usually operated in conjunction with the allied Indian nations Butler had helped to salvage for the imperial cause. Militarily, the blend proved highly effective. Most of these Pennamites believed they were regrouping at Niagara to take back their lands but events would prove that they had embarked on the first leg of a long exile.

\footnotetext{
${ }^{41}$ It is not correct to assume that the Pennamites were patriots forced into the arms of the British. Their interests and views were mainly focused on local affairs. They saw loyalism as a way to advance those local interests, as evidenced in the Pennsylvanians' hesitancy to declare allegiance early on. Like Detroit, Niagara was a British dominion at the time.

${ }^{42}$ For Millard - Coldham, American Migrations, 474; Palmer, Biographical Sketches, 604; Field Coldham, American Migrations, 460; Palmer, Biographical Sketches, 271; Sabine, Biographical Sketches, vol. 2, 514; Hover - Coldham, American Migrations, 466; Palmer, Biographical Sketches, 404; Secord Coldham, American Migrations, 484; Palmer, Biographical Sketches, 771;Sabine, Biographical Sketches, vol. 2, 273, Stefon, "The Wyoming Valley," Beyond Philadelphia, 144; Vanderlip - Coldham, American Migrations, 492; Palmer, Biographical Sketches, 885, Stefon, "The Wyoming Valley," Beyond Philadelphia, 144.
} 
Pennamite-Indian vengeance culminated in a fabled raid known as the Wyoming Massacre on July 3, 1778, a little over two weeks after the British had withdrawn from Philadelphia. Colonel Butler reported the taking of 227 scalps from about 400 Yankee militia defenders. Furthermore, over 1,000 farms were plundered and torched, crops destroyed, and more than a thousand head of cattle butchered. ${ }^{43}$ The violence devastated the region. The Pennamites did not resettle, however, retreating once again to Niagara. In response to the loyalist militants' scorched earth policy, patriot retribution raids began in September and extended well into the war. The lack of security nearly depopulated the northeast frontier of white settlement. The clash had an ironic ending. Congress resolved the Pennsylvania-Connecticut territorial dispute in Pennsylvania's favor in 1782, even though the Yankees were the ones who had originally supported the patriot cause. ${ }^{44}$ By June 1784, Pennsylvania had reestablished jurisdiction over the area by using two militia companies to clear out the Connecticut settlers for their own newcomers, which of course did not include the Pennamites who had gone over to the British. Resurgent hostility, though, netted the opprobrium of the Pennsylvania state government under moderate council president John Dickinson. Yankees were subsequently permitted to return. The quarrel over competing title claims persisted for more than two decades, obligating the

\footnotetext{
${ }^{43}$ Ousterhout, "Frontier Vengeance," Pennsylvania History, 336-37; Stefon, "The Wyoming Valley," Beyond Philadelphia, 147-48. Early analyses of four American historians including David Ramsay and George Bancroft are summarized in Egerton Ryerson, The Loyalists of America and Their Times: From 1620 to 1816 (New York: Haskell House Publishers, 1970; reprint of original 1880 edition), vol. 2, 85-98.

${ }^{44}$ Congressional records include the lengthy debate held at Trenton between the two states. However, after laying out arguments, documentation for the decision is limited. On December 30, 1782, the five judges appointed by Congress simply declared: "We are unanimously of opinion, that the State of Connecticut has no right to the lands in controversy. We are also unanimously of opinion, that the jurisdiction and preemption of all the territory lying within the charter boundary of Pensylvania [sic], and now claimed by the State of Connecticut, do of right belong to the State of Pensylvania." Journals of the Continental Congress, vol. 24. Full record is on pages 6-32. Quote from December $30^{\text {th }}$ is on 31-32. A more detailed set of documents is provided in Pennsylvania Archives, $1^{\text {st }}$ Series, vol. 9, 679-724, especially 700-708 \& 711715 where each state presented their case. Justifications for the court's decision are also missing here.
} 
legislature to pass acts in 1787, 1799 and 1808 that tried to placate litigants. Generally speaking, Pennsylvania under moderate rule honored the land rights of Yankee farmers while granting fellow Pennsylvanians compensation with lands elsewhere in the state. ${ }^{45}$

For the Pennamites of the northern Susquehanna who joined Butler, departure begot perpetuity. Their experiences are best summarized in three prototypical cases. Philip Buck lived in Northumberland County "at the beginning of the late unhappy disturbances in America, in possession of a good Farm with Building erected thereon, Live Stock, Household Furniture, Farming Utensils, etc. valued at the time at $£ 275$ in New York currency." Buck was a native of Germany who had arrived in America as an infant. "He made his escape to the British Army in the year 1777 - from which period to the close of the War he served the King in Col. Butler's Rangers." He ascribed the loss of grain and twenty hogs to "the rebels when he went away in 1777" and "to the Indians" the loss of his cattle a year later, in addition to the property and goods he left behind. Buck was captured and sent to New York in a 1778 prisoner exchange, rejoining Butler for the war's duration. In 1786, he was at Niagara, then a part of the British province of Quebec. Like many of his Northumberland compatriots, Buck was illiterate, signing his claim for compensation with an "X." Apparently the commissioners converted the $£ 275$

\footnotetext{
${ }^{45}$ Stefon, "The Wyoming Valley," Beyond Philadelphia, 151-52; Statutes At Large of Pennsylvania, vol. 12, "An Act for Ascertaining and Confirming to Certain Persons Called Connecticut Claimants the Lands By Them Claimed within the County of Luzerne and for Other Purposes Therein Mentioned," March 28, 1787, Chapter 785, 436-440; ibid., vol. 16, "An Act for Offering Compensation to the Pennsylvania Claimants of Certain Lands Within the Seventeen Townships, in the County of Luzerne, and for Other Purposes Therein Mentioned," April 4, 1799, Chapter 2053, 245-251; Acts of the General Assembly of Pennsylvania, Passed at a Session, Which Was Begun and Held at the Borough of Lancaster, on Tuesday, the First Day of December, in the Year of Our Lord, One Thousand Eight Hundred and Seven (Philadelphia: John Bioren, 1808), "An Act making appropriations to defray certain expenses of Government,” Section III, March 28, 1808, Chapter 123, 176-177.
} 
in New York currency into a British equivalent of $£ 154.13 .9$, for that amount turned out to be his official claim. Of this sum, he was awarded $£ 62 .{ }^{46}$

Philip Bender told a similar tale. Also a native of Germany and residing in Northumberland, he "left his home in the Spring 1777" because he "could not stay without taking part with the Rebels.” Bender was clearly part of a Pennamite mass migration, stating that he "came with the Loyalists off his settlement... to join Butler." He served with the Rangers as a private until his discharge in 1782 as the war neared its conclusion. For compensation, Bender claimed a 320-acre farm and specified that "the Rebels got some" of his stock of 200 bushels of corn and wheat, while a cow was "killed by Indians" and five sheep "by Indians and Rangers." Before leaving the area, he had taken the precaution of moving his furniture to a fort for safekeeping but this transfer "was found out by the Rebels" and the fixtures "taken by them." By 1783, Bender was residing at Niagara. He made his formal compensation claim in April 1786 to Colonel Thomas Dundas and Jeremy Pemberton, members of the Royal Claims Commission sent to Canada to substantiate and clarify loyalist petitions. ${ }^{47}$ Like Buck, Bender signed his affidavit with an "X," as did his witnesses John Depue and Charles Depue. The lower sorts predominated in the Susquehanna settlements. Bender’s original claim for $£ 246.10$ in New York funds was acknowledged as £130.13.1 British currency, of which the modest sum of $£ 53$ was granted. ${ }^{48}$

\footnotetext{
46 "Memorial of Philip Buck," AO12/40/349-352 and AO13/57/84-85, DLAR. The commissioners' decision is rendered in AO12/66/57.

${ }^{47}$ Eardley-Wilmot, Historical View of the Commission, 55.

48 "Memorial of Philip Bender," AO12/40/370-37and AO13/57/77-78, DLAR. The commissioners' decision is rendered in AO12/66/62, DLAR.
} 
The most telling of these Susquehanna cases was that of Frederick Anger, whose account contained many similarities to Buck, Bender, and other Northumberland settlers. $\mathrm{He}$, too, was a native of Germany, arriving in America at the relatively advanced age of thirty. He, too, owned a farm, furniture, farming utensils, cattle, horses, hogs, sheep, grain, and the like seized or plundered by rebels or Indians. He, too, "made his escape to the British army" in 1778 and then "served the King in Colonel Butler's Rangers" - in his case for seven years as a private. He, too, signed his claim with an " $\mathrm{X}$ " and wound up at Niagara in the 1780s. And like other refugees from the region, he also had two sons who served with him in the same regiment. But in seeking reparations for his loyalty, Anger was one of the few who openly discussed the land dispute between Pennsylvania and Connecticut in his claim and thus provides a unique gaze into the conflict's evolution. ${ }^{49}$

Anger filed documents with the claims commissioners on at least three occasions. On April 13, 1786, and August 27, 1787, he judged himself a Susquehanna River settler of Pennsylvania's Northumberland County. But his claim of November 14, 1783 - eleven days before the British evacuated New York City - referred to himself as "late of Susquehanna in the province of Conecticut [sic]" and "late of Waomen [Wyoming] in Westmoreland County in the Province of Conettucut [sic]. ${ }^{, 50}$ This initial testimony came less than two years after Congress granted the area to Pennsylvania. His willingness to identify himself as a Yankee even after Congress' adjudication shows that those who

\footnotetext{
${ }^{49}$ Anger summaries are in Palmer, Biographical Sketches, 21; Coldham, American Migrations, 449.

${ }^{50}$ The Connecticut preference is in "Memorial of Frederick Anger," AO13/96/62. The later Pennsylvania reorientations are in "Memorial of Frederick Anger," AO12/40/335 and AO13/57/1, all in DLAR. Anger may have been a latecomer to the Pennamite camp or a traitor to Connecticut. Unlike Buck and Bender, he is on the "List of Taxable Inhabitants in the Town and County of Westmoreland, State of Connecticut, 1776-1780," Proceedings and Collections, Wyoming Historical and Geological Society, vol. 5 (1900), 205241, cited in Ousterhout, A State Divided, 272 fn.10. Regardless of his earlier provincial status, he clearly considered himself a Pennamite in his final claims.
} 
lived there earlier recognized that Connecticut had the upper hand in the territorial clash throughout the war, regardless of partisanship. His stance was not contradictory, for he was among those Pennamites who had originally recognized the claims of Connecticut but later wound up fighting for Pennsylvania and the king. ${ }^{51}$

The New Englanders' victory all but obliterated loyalist support in the northeast, leaving control in the hands of radical revolutionaries who fought off joint British-Indianloyalist incursions through the war. ${ }^{52}$ Their dominance added a pre-war colonial twist to the prospect of Pennamite reintegration, for the perception that Yankee rage still reigned supreme in the northern river country eliminated this option after the British withdrew from the state in 1778. Besides, had Frederick Anger believed reintegration viable at the war's closure, he would by his own admission have returned to Connecticut rather than Pennsylvania, as his first compensation petition makes clear. The evidence thus suggests that militarily active Pennamites like Anger had far greater reason to reject reintegration than Pennsylvanians elsewhere. In fact, the Northumberland Pennamites were the least likely to return among all exiles. Of sixty-three loyalists from the region known to be militarily active, none came back. Only Henry Windecker even so much as visited a part of newly independent America in the aftermath of war. Colonial antecedents elevated local antagonisms beyond a straightforward patriot-loyalist enmity. Not surprisingly,

\footnotetext{
${ }^{51}$ Oscar J. Harvey, A History of Wilkes-Barre (Wilkes-Barre, PA: Raeder Press, 1902), vol. 2, 658-659 \& 682, as cited in Ousterhout, "Frontier Vengeance," Pennsylvania History, vol. 62, no. 3, 342. Although other Pennsylvanians like Partial Terry and Jacob Anguish did fight at one time for the Yankees and then went over to the opposing side, there is no direct evidence to suggest that Frederick Anger had earlier fought for either the cause of independence or Connecticut, only that he accepted Yankee jurisdiction.

${ }^{52}$ The composition of pro-British Indians fluctuated during the war according to alliance structures along the revolutionary divide at any given moment. The western nations of the Iroquois confederacy like the Onondaga, Cayuga and Seneca joined Butler when he took command of Niagara in the fall of 1775 and were especially prominent. See Taylor, The Divided Ground, 85.
} 
Pennamites who bore arms for the king stayed away. No need for a process of loyalist reintegration developed in the Susquehanna valley. ${ }^{53}$ The "reintegration" that did occur concerned the removal, restoration, relocation or compensation of Connecticut and Pennsylvania patriots once Congress granted Pennsylvania control of the area.

\section{MILITANT LOYALIST LEADERSHIP IN THE COUNTRYSIDE: THE RANKINS}

Loyalist militancy in the band of agricultural counties between the southeastern core around Philadelphia and the frontier bore a greater resemblance to the center than the periphery. The territory comprising York, Lancaster and Berks counties, as well as the more settled southern part of Northampton County, was a land of established and productive farms, with the towns of York, Lancaster, Reading and Easton acting as hubs of each jurisdiction. This middle sector witnessed many of the same revolutionary strains that shaped the resistance-to-independence process for elites in the provincial capital, with a rural variant. The Rankin brothers of York County - James, William and John illustrate this pattern. In local terms, the Rankins could plausibly be classified as elites, for they were among the more prosperous citizens in their district by the Revolution. But contrasted with Philadelphia's gentlemanly elites, these sons of an early frontier pioneer were quite "ordinary." ${ }^{54}$ Despite regional and class differences, the Rankins' commitment to the royal cause exhibited characteristics much like Joseph Galloway and the Allens. Their militancy developed gradually in conjunction with the increasing radicalism of events. They too tied success to a dependence on direct British support, hesitated to

\footnotetext{
${ }^{53}$ After settling with his wife Dorothy at British Fort Erie, Windecker was on a visit to relatives in New York's Mohawk Valley in 1787 when Dorothy filed the couple's compensation claim. For Windecker, see Coldham, American Migrations, 495-96; Palmer, Biographical Sketches, 940.

${ }^{54}$ Fraternal relations and family background are in "James Rankin," Horle, Foster \& Wolfe, eds., Lawmaking and Legislators in Pennsylvania, vol. 3, 1757-1775: Knight to Yardley, 11-49-1150, 1152.
} 
operate autonomously, and had to flee when failure became manifest. Their departure likewise attenuated internal political tensions and smoothed passage towards successful reintegration locally, including the reassimilation of some of their own descendants who elected to remain in Pennsylvania.

James and William Rankin entered the revolutionary conflict as key movers and shakers of York County. James settled in Newberry Township sometime after 1754. He married Quaker Rebecca Bennett in 1756 but it appears he was not active in the faith. His contrite wife told the Warrington Monthly Meeting that year that "for want of keeping to the principles of truth in my own heart," she "gave way so far as to get married by a Licence [sic] and to a man not Joined to our Society.” The Quakers would launch strict reforms that decade which stipulated disownment of those who married outside the discipline, but they allowed Rebecca to remain within the congregation until her death in in 1773, when the York County leadership authorized her internment in the Quaker burial ground. The couple had at least two sons and two daughters over seventeen years. James wed second wife Ann a year after Rebecca's death. That union engendered two more Rankins. Which of the wives gave birth to another pair of offspring is unclear, but James had a total of eight children with his two spouses. Although engaged in agriculture, James Rankin had entrepreneurial ambitions, preferring to run business operations and speculate in land rather than rely exclusively on farming, as did most of his neighbors. Early on, he added a tavern and store to a residence on his original 222-acre property and set up an orchard harvesting apples for cider. For a decade from 1767 onward, he procured more than 3600 acres, two islands on the Susquehanna River, a ferry operation, a shelling mill, a grist mill, and a merchant mill that ground wheat for export instead of local use. To set 
up the neglected mills, he invested over $£ 3000$ and hired more than 150 workers. James was not particularly interested in public affairs before the Revolution, limiting his involvement to serving on local juries. ${ }^{55}$

Like his brother, William Rankin also became a large landholder. In his claim to Parliament, he asked to be compensated for sixteen confiscated properties totaling 2,426 acres. William was not averse to public service, however, and in 1771 he began a six-year stretch as a York County justice of the peace in the Court of Common Pleas and Quarter Sessions. ${ }^{56}$ John was a man of more modest means and lived on one of James' plantations. He owned 190 acres in York, as well as a lot adjoining James' Newbury property. Of the three brothers, he is the only one identified clearly as a Quaker, which suggests that all three had antecedents in that sect but only John was religiously active. ${ }^{57}$

Like the Allens, the Rankins voluntarily signed on to the resistance against Parliament's onerous infringements. But unlike their Philadelphia counterparts, they did not participate during the decade of the imperial crisis and came to the fray after the shots at Lexington. William joined York's patriot Committee of Observation and Inspection and became "a Colonel of a regiment of Militia" in the county in 1775. As noted in his later testimony, "when the Declaration of Parliament to Tax and in all cases to bind the

\footnotetext{
55 “James Rankin," Legislators in Pennsylvania, vol. 3, 1148-1150. The eight children were: James, Mary, Abraham \& Ann from the marriage to Rebecca; William \& Richard from the marriage to Ann. John \& Rebecca were the offspring whose mother is unknown.

${ }^{56}$ Council Minutes, March 11, 1771, Colonial Records, vol. 9, 730-731; Council Minutes, April 9, 1774, ibid., vol. 10, 162-163; Officers of the State of Pennsylvania, York, Pennsylvania Archives, Second Series, vol. 3, 656; "Memorial of William Rankin," AO12/42/210-217, DLAR; "James Rankin," Legislators in Pennsylvania, vol. 3, 1150.

${ }^{57}$ Palmer, ed., Biographical Sketches, 715; Coldham, ed., American Migrations, 481; Arthur J. Mekeel, The Relation of the Quakers to the American Revolution (Washington, DC: University Press of America, 1979), 319; Siebert, Loyalists of Pennsylvania, 102.
} 
people in America was made known," William Rankin was "free to own, that conceiving the Exercise of such Power oppressive he was opposed to that Measure.” James Rankin, too, was an early member of the county's conservative antiparliamentary faction. Six months after hostilities broke out, Governor John Penn Sr. professed to be "pleased to Commissionate" James as a Sheriff and Coroner for York County. In the crucial Pennsylvania colonial assembly by-election of May 1, 1776, he was overwhelmingly elected for York when "the Majority of that Assembly were friends to this country [England]." He did not play a significant role as a member of that body, receiving only two minor committee assignments during the early summer as the established colonial assembly faded into oblivion. ${ }^{58}$

As with many other conservatives, the road to independence set the bounds of proper allegiance for the Rankins. James' path to open disaffection against the rebellion was the most rapid of the three. At a meeting of Whigs to discuss the local response to Congress' appeal for a new state government less than a month after his election, radicals accused James of violating "the trust reposed in him by the good people of this county." In propagating an anti-independence stance, he opposed the call for a provincial conference to summon a constitutional convention and circulated "seven letters and a bundle of remonstrances" for no other alleged purpose than "to draw this Province off from the present union with the other Colonies, or to divide the people so as to fall an

${ }^{58}$ MEMORANDUM, $10^{\text {th }}$ October, 1775. Council Minutes, Colonial Records, vol. 10, 271; "Memorial of William Rankin," AO12/42/205, DLAR; Minute of a Committee of Officers of Militia of York County, July 28-29, 1775, Pennsylvania Archives, First Series, vol. 4, 639; Associators and Militia, County of York, October 1, 1777 \& April 5, 1778, Pennsylvania Archives, Sixth Series, vol. 2, 457, 460; "James Rankin," Legislators in Pennsylvania, vol. 3, 1150; Egerton, ed., Royal Claims Commission, 302. 
easy prey to our inveterate enemies.. ${ }^{59}$ A publicity battle ensued after radical Whig investigators published their findings in a June edition of the Pennsylvania Gazette. James defended himself publicly, asserting that he had only circulated the papers in question to inform his constituents because the resolution of Congress left it to each province to decide whether to establish a new government or not. In short, he was doing his duty as an assemblyman.

His efforts proved to be in vain. When the day arrived for York citizens to select delegates to the state constitutional convention, James led supporters to the polls in a failed effort to scatter voters in defense of the existing assembly, even as the electorate chose brother William as a representative. Perhaps swayed by his sibling's participation, James caved with a recantation in the Gazette in which he admitted to injuring the county's patriot committee via “sundry public misrepresentations, as well as by personal insults." Upon reflection, he was now "convinced of the bad tendency of my past conduct." "I do thus publicly ask forgiveness," he added, "and do promise... that I will in future pay due regard to the rules and regulations of the Honourable Continental Congress, and behave, in all respects, as becomes a good citizen of the United States of America." The radical patriot committee accredited his penance, resolving he should be "restored to his liberty, and the confidence of his countrymen."

William Rankin also had doubts about the political path on which radicals had embarked. As events evolved towards an imperial divorce and "the liberal offers of Great

\footnotetext{
59 “In Committee for York County,” May 30, 1776, Pennsylvania Archives, $2^{\text {nd }}$ Series, vol. 14, 545; “James Rankin," Legislators in Pennsylvania, vol. 3, 1150.

${ }^{60}$ Pennsylvania Gazette, June 12, 1776 \& July 31, 1776; “James Rankin,” Legislators in Pennsylvania, vol. 3, 1150-1151; Sabine, Biographical Sketches, vol. 2, 210; Ousterhout, A State Divided, 136-37.
} 
Britain were rejected," William "determined at every risque [sic] to prevent a Separation between the two Countries... from a sense of Duty to his Sovereign and love to his Country." In pursuit of this objective, he decided to retain his spot within revolutionary circles. York voters had elected him as one of nine county delegates to the Provincial Conference which met at Carpenter's Hall in Philadelphia from June 18 to June 25, 1776. Conference minutes did not take attendance nor single him out for any specific reason, but the fact that voters elected him again as part of the nine-man delegation to the state constitutional convention at Philadelphia beginning July 15 suggests he fulfilled his duty at the provincial conference. ${ }^{61}$ William also complied with responsibilities as a patriot militia officer. In June, the Committee of Safety reimbursed him for $£ 200$ "towards the payment of Firelocks purchasing by him in York County on account of Congress" and a month later the Council of Safety ordered delivery to "Col. Rankin, of York County, 8 Muskets, for the use of his Battalion" and "30 stand of Arms." William led his troops through the capital three weeks after independence. Radical Christopher Marshall duly noted on July 26 that "this afternoon, came to town and passed by our door to the barracks, two companies of clever fellows, one from [the] back parts of Lancaster, the other from York County, [under] Col. William Rankin." ${ }^{62}$

On September 3, the convention appointed him one of seventeen state justices of the peace for York County, the only direct mention of his activities while there. When

\footnotetext{
61 "For the Committee of York County," Proceedings of the Provincial Conference of Committees, of the Province of Pennsylvania, Held at the Carpenter's Hall, at Philadelphia, Journals of the House of Representatives of the Commonwealth of Pennsylvania, 35; "For the County of York," Minutes of the Proceedings of the Convention of the State of Pennsylvania, Held at Philadelphia, the Fifteenth Day of July, 1776, ibid., 49.

${ }^{62}$ Council Minutes, June 25, 1776, Colonial Records, vol. 10, 615 \& July 29, 1776, ibid., vol. 10, 659; Diary of Christopher Marshall, July 26, 1776, 87.
} 
time came to officially indorse the final rendering of the new constitution on September 28, however, William was missing in action. He was not alone. Only two of York's nine delegates signed, by far the lowest count of the twelve county delegations. Whether that denoted more discontent in York than elsewhere in the state or simply reflected the delegates' other obligations is uncertain. Around this time, York County's committee ordered the militia colonel to lead his men and "lay waste the Estates and seize the Persons of a Number of Loyalists.” But William's doubts on allegiance had gelled as loyalist conviction by then. As a result, he "obeyed the orders in appearance, but in the Execution of them pursued such Measures as to prevent the intended effect," in essence becoming a double agent for the British. ${ }^{63}$

Sir William Howe's landing at Head of Elk, Maryland, in August of 1777 recast the political panorama in York County as elsewhere in the province. As the invasion advanced, informants William Beckworth and Adam Laughlin gave patriot officials a sworn deposition on September 6, 1777 that, while lodging at the tavern of John Rankin, they had learned that bands of loyalists were organizing to join the British. Heavily pledged in this venture was James Rankin who "had one or two thousand bushels of Wheat and Rye laid in his mill for Hows [sic] Army, could raise 500 men and he belived [sic] he would be one of the Chief Commanders." On the $15^{\text {th }}$, the Supreme Executive Council learned "of divers treasonable \& dangerous intentions and designs of levying men \& destroying the Public Stores at York, Lancaster \& Carlisle \& elsewhere" likewise implicating James. Apparently his public retraction a year earlier was not heartfelt. Key arrests dismembered the plot. Marshall recorded on September 17 that James Rankin

${ }^{63}$ The Proceedings Relative to Calling the Conventions of 1776 and 1790 (Harrisburg: John S. Winstling, 1825), 65-66; "Memorial of William Rankin," AO12/42/206, DLAR. 
stood "accused of forming a scheme to destroy all our magazines, arms, tents, baggage, provisions, \&c... was taken about sixteen miles from our enemies' camp, and secured, but where I could not learn.” The reason he did not learn was that the revitalized loyalist had scampered. "Obliged to flee for his Life," James found his way to the British fleet on the Chesapeake and joined the army after the capture of Philadelphia. From the occupied city, James often rode out to gather intelligence from as far away as York to aid British war efforts. On one occasion, he led five accomplices on a visit to George Washington's camp at Valley Forge to gauge the ragged state of continental troops. That his was a high profile case is evident in the Attainder Act of March 1778, when "yeoman" James Rankin earned notoriety as one of the original thirteen attainted under the new law.

John was less precipitous but, by helping British prisoners of war to escape, he was later "obliged to flee to Philadelphia" where he joined the British army in March 1778. Two months later, he too was attainted in the first of the Supreme Executive Council's eight proclamations. The brothers left for Manhattan with Clinton in June 1778. Like other loyalist militants, James and John rejected the first opportunity to reintegrate by exiting at the evacuation. ${ }^{64}$ The exiled duo settled in royally controlled Long Island for the war's duration. Lorenzo Sabine has James involved in loyalist politics at New York as chairman of the loyalist Board of refugees in 1781. Three months after

\footnotetext{
${ }^{64}$ Coldham, ed., American Migrations, 481; Palmer, ed., Biographical Sketches, 715; "Deposition of Wm. Beckworth and Adam Laughlin, 1777," Pennsylvania Archives, ${ }^{\text {st }}$ Series, vol. 5, 624-25; Council Minutes, Monday, September 15, 1777, Colonial Records, vol. 11, 307-08; Diary of Christopher Marshall, 128; "James Rankin," Legislators in Pennsylvania, vol. 3, 1152; Statutes At Large of Pennsylvania, "An Act for the Attainder of Divers Traitors...," March 6, 1778, vol. 9, 201; "A Proclamation: By the Supreme Executive Council of the Commonwealth of Pennsylvania," May 8, 1778, Colonial Records, vol. 11, 48185. The sequence of James' flight is not entirely clear. Coldham, who derived his account exclusively from claims testimony, has James finding his way to the Chesapeake, then joining the British army at Philadelphia. Joseph S. Foster, who wrote Rankin's bio in Legislators in Pennsylvania, has him seeking British shelter directly at Philadelphia.
} 
James' departure, the Supreme Executive Council granted his wife Ann a pass to join him at New York. John's wife Abigail also reunited with her husband in late $1780 .{ }^{65}$ Between the journeys of the two wives, the radical council under President Joseph Reed gave notice that the seized estates of James and John Rankin, along with a host of other departed loyalists, were to be sold at public auction. The notification set in motion a decade of property transactions and issues that dot council records primarily because James had left behind substantial debts and creditors made claims on his seized estates. ${ }^{66}$ William Rankin's life took a different twist. He may have been involved in the Carlisle plot also but, if so, he did not take credit for this episode in his later claim. That he was not attainted at this point, yet continued to reside in York County, demonstrates that the militia colonel was not under the same suspicion as his brothers. Nonetheless, according to his own testimony, in 1778 he began to form "Associations among the Loyalists and engaged some thousands of them to take up Arms in His Majesty's favor whenever the opportunity should offer." Most recruits were "reputable farmers." The mobilization included an oath "abjuring the Congress and the Rebel States, of Secrecy in regard to the Association of Fidelity and Allegiance to His Majesty, and of Enlistment under their respective Officers," in effect enforcement of the patriot test act in reverse. His links to the clandestine association lasted about three years beyond the imperial retreat from Philadelphia. At least two major operations were contemplated during this

\footnotetext{
${ }^{65}$ Sabine, Biographical Sketches, vol. 2, 210; Council Minutes, September 19, 1778, Colonial Records, vol. 11, 562; Council Minutes, October 2, 1780, ibid., vol. 12, 494; Council Minutes, April 12, 1779, ibid., vol. 11, 745; "James Rankin," Legislators in Pennsylvania, vol. 3, 1152 \& 1155 fn15.

${ }^{66}$ Council Minutes, April 12, 1779, Colonial Records, vol. 11, 745. For property issues, see Council Minutes, Colonial Records, vol. 12, 174, 218-219, 560, 577, 680; ibid., vol. 13, 98, 273, 385; and ibid., vol. 15, 468. For John and William's properties, see Colonial Records, vol. 13, 384 \& vol. 15, 425.
} 
time. In the first half of 1778 , Rankin was in veiled communication with General Howe in occupied Philadelphia through chief civil administrator Joseph Galloway, to whom he proposed seizing the delegates of the lightly defended Continental Congress assembled at York in a nighttime raid of six hundred loyalists then purportedly under his command. But in a typical demonstration of Howe's restraint, William received no answer. The evacuation and Congress' return to the capital ended the scheme. Rankin persisted in his organizational efforts and established contact in New York with Howe's replacement, Sir Henry Clinton, offering the new commander the services of his loyal adherents. Clinton accepted the proposition in principle and Rankin resurrected a reworked version of the plot to attack the Carlisle arsenal. But once again, the order never came. William's continued militancy reveals that he held fast to the hope of reintegration after 1778 - but his version of reintegration was built entirely on a British victory over rebels. ${ }^{67}$

In the meantime, William Rankin operated - at least nominally - as head of a loosely knit and unofficially sanctioned guerrilla corps in southeastern Pennsylvania that probably included the Doan brothers, and the Schockey-Nugent gangs. These rural bands wreaked havoc on patriots in the area, committing robberies and conducting counterfeit schemes to devalue continental and state currency. ${ }^{68}$ Four conspirators were captured and hanged in 1779 . While operating surreptitiously as a loyalist militant, William engaged

\footnotetext{
67 "Memorial of William Rankin," AO12/42/206, DLAR; Coldham, ed., American Migrations, 481; Palmer, ed., Biographical Sketches, 715; “Memorial of Joseph Galloway,” Egerton, ed., Royal Claims Commission, 85. As late as April 5, 1778 - only ten weeks before the British evacuation - William was still listed as a colonel in the muster roll of the Second Battalion of the Pennsylvania Militia. See "Muster Rolls and Papers relating to Associators and Militia of the County of York," Egle, ed., Pennsylvania Archives, $2^{\text {nd }}$ Series, vol. 14, 488 .

${ }^{68}$ Counterfeiting became such a problem in Pennsylvania during the war that it was legislated as a capital crime. See for example Section VI of the Assembly's act emitting bills of credit, March 20, 1777, Statutes At Large of Pennsylvania, vol. 9, Chapter 752, 100, where counterfeiters of these bills "shall suffer death."
} 
the patriot legal system as an ordinary patriot citizen, obtaining a ruling in his favor from the state on lands once owned by exiled brother James. In November 1779, the Supreme Executive Council paid James Smith £74.9.6, "the amount of the claim of William Rankin on the Estate of James Rankin, decreed him by the Supreme Court. ${ }^{, 69}$ His loyalist cover did not withstand the war. In March of 1781, informants apprised General George Washington of Rankin's subversion, whereupon the veiled loyalist "was immediately seized on and committed to the Gaol of York Town, from whence he found means to Escape and with great Risque [sic] and Difficulty got safe to New York.” The British Army engaged his services there with a $£ 200$ per annum salary. Duties included renewed efforts to "encourage the Associators to continue firm in their Allegiance and to be ready to render those services" as needed. In the midst of the British military campaign in the southern states, Rankin submitted a plan to Sir Henry Clinton to attack portions of Maryland, southeastern Pennsylvania, and Delaware, areas still thought to contain strong loyalist contingents. Clinton and Lord Cornwallis, who would have had to implement such a strategy in the field and were by then fed up with overpromises of loyalist support, had other ideas. The project came to naught. ${ }^{70}$

\footnotetext{
${ }^{69}$ For the rural guerrillas, Colonial Records, vol. 12, 179, 375, 386; Robert McCluer Calhoon, The Loyalists in Revolutionary America 1760-1781, 401. For William's claim on James' estate, Council Minutes, November 18, 1779, Colonial Records, vol. 12, 174. On the same date as William, a much higher disbursement for $£ 3,015$ to James Smith on a claim by John Rankin was honored. Since our John was in New York in 1779 and the large sum seems to indicate a possible inheritance, it is probable that this John was the son of James by the same name.

70 "Memorial of William Rankin," AO12/42/207, DLAR; Coldham, ed., American Migrations, 481-82; Palmer, ed., Biographical Sketches, 715-16; George W. Kyte, "A Projected British Attack upon Philadelphia in 1781," PMHB, vol. 76, no. 4 (October, 1952), 385-86; "A Plan proposed by W[illiam] R[ankin] for subduing the Rebellion in the Provinces of Pennsylvania, Maryland, and the three Lower Countys on the Delaware," April 27, 1781, Clinton Papers, cited in Smith, Loyalists and Redcoats, 158.
} 
William Rankin's hurried flight from York brought the wrath of patriot legal justice upon him. On April 27, 1781, the Supreme Executive Council rewarded William with an attainder all his own, one of only three such single-person attainders during the entire conflict in Pennsylvania. Acknowledging that William "did lately break the said prison and make his escape from justice," the loyalist militant was ordered to "render himself" for trial by June 14 or "suffer such pains and penalties and undergo all such forfeitures" customary for those charged with high treason. In a corollary, the state offered an incentive of fifty pounds in Pennsylvania currency to anyone who could "apprehend" and "deliver" the fugitive to state officials. ${ }^{71}$ After Rankin failed to report for prosecution by the prescribed date, state agents seized his property. ${ }^{72}$

The peace of 1783 presented the three brothers a second chance to reconcile with Pennsylvania and seek reintegration. But once again they would have none of it. At the evacuation of New York, William crossed the Atlantic for English shores. There the British Treasury awarded him a living pension of $£ 120$ per annum. John and James headed northwards instead. Still in British-occupied New York in the summer of 1783, John was appointed, along with fellow Quakers Joshua Knight and Samuel Fairlamb, as agent for a mission to Canada to inspect locations for a future settlement of Friends. His

\footnotetext{
71 "By his Excellency Joseph Reed, Esquire, President, and the Supreme Executive Council of the Commonwealth. A Proclamation," Council Minutes, April 27, 1781, Colonial Records, vol. 12, 710-11; Sabine, Biographical Sketches, vol. 2, 569. The other single person attainders were an SEC proclamation for Frederick Kesselman on May 5, 1779, and an act of the state assembly for Harry Gordon on January 31, 1783. With the patriot victory at Yorktown only six months away and the moderate Anti-Constitutionalist faction gaining strength, Rankin's turned out to be the Supreme Executive Council's last proclamation.

${ }^{72}$ For confiscations against all three Rankins, see Estate of James Rankin, Inventories and Sales, Forfeited Estates, May 28, 1779, Pennsylvania Archives, Sixth Series, vol. 12, 265; Estate of James Rankin, Pennsylvania Archives, Sixth Series, vol. 13, 38-77; Estate of James and John Rankin, ibid., vol. 13, 77-84; Estate of John Rankin, ibid., vol. 13, 84-95; Estate of William Rankin, ibid., vol. 13, 95-108; Estate of William, James \& John Rankin, ibid., vol. 13, 109-122.
} 
appointment to such a delicate assignment shows the trust of his coreligionists. Their inquiry gave birth to the colony of Pennfield at Beaver Harbor in New Brunswick, where John received a grant of land after a stay in Annapolis Royal, Nova Scotia. In 1784, he filed his compensation claim to Parliament from Nova Scotia through a London proxy. ${ }^{73}$ Exile for James at the peace likewise took him from the New York evacuation to Nova Scotia. In August of 1784, however, he concluded that his presence in England was "absolutely necessary" to the successful execution of his quite substantial claim. Leaving his wife and three children behind in Canada, he joined William in England. Like his brother, he applied for and received a pension from the Treasury - in his case $£ 140$ per annum, $£ 20$ more than William. As part of a growing community of loyalist exiles in the mother country, James provided testimony to Parliament on the fidelity of his American compatriots. In a typical example beyond support for his siblings, James spoke highly of Abel Evans, confiding that "he has no Doubt of his being a very good Loyalist \& speaks very strongly of his Attachment to the Cause of Great Britain.” The two Rankin brothers in Britain eventually received ample compensation for their losses from the Royal Claims Commission. William applied for $£ 8,209$ in recompense, based on the loss of 2,426 acres from his sixteen seized properties. The claim was backed by Joseph Galloway and former commander-in-chief Sir Henry Clinton, among others. The commissioners awarded him $£ 3,806$. James pressed for the huge sum of $£ 44,387$ sterling for his vast land holdings. He

\footnotetext{
${ }^{73}$ Palmer, Biographical Sketches, 715; Arthur J. Mekeel, The Relation of the Quakers to the American Revolution, 319-20; Sabine, Biographical Sketches, vol. 1, 569; Coldham, ed., American Migrations, 481.
} 
received $£ 10,801$ sterling. The less affluent John sought only $£ 915$ sterling in his claim, for which he was granted $£ 327$ sterling. $^{74}$

Unlike most other petitions, the Rankin claims faced several challenges, which suggests they exaggerated their losses. Witness Daniel Batwell, a diehard loyalist and Anglican minister who collaborated with James Rankin in planning the aborted Carlisle munitions expedition, refused to pinpoint a value on James' alleged $£ 44,387$ in holdings, feigning ignorance of such matters. When commissioners told witness Andrew Allen that James estimated a yearly income of $£ 3000$ from his confiscated properties, Allen wryly countered that "there was no body in the province who possessed so large a property." Then in 1789, the claims commission received a letter from Pennsylvania signed by "A Loyalist" with "a heart that's pure" who had not filed his own claim but had "suffered considerable loss of property." The writer explained that rumors then circulated in the province that James and William were asking for $£ 40,000$ in compensation, which was true. The self-described loyalist cast doubt on the Rankins' wealth, stressing that if the rumor was correct "they are the basest men who have made their appearance before you" because "they were never worth fifteen thousand pounds Pennsylvania Currency."75 The

\footnotetext{
74 "Memorial of William Rankin,” AO12/42/205, 209, DLAR; Egerton, ed., Royal Claims Commission, 302; Palmer, ed., Biographical Sketches, 715; Coldham, ed., American Migrations, 481; Siebert, Loyalists of Pennsylvania, 102. Coldham states that the land portion of John's claim was for 93 acres. Palmer puts the acreage at 190 with 40 cleared. Palmer and Coldham are also at odds on the William Rankin claim. Palmer depicts two separate loyalists by the name of William Rankin, one from Pennsylvania and another from Portsmouth, Virginia. Coldham seems to combine the two William Rankins into a single claim from Pennsylvania. My interpretation conforms to Palmer for two reasons: 1) the William Rankin property claims I have seen from the Public Records office (PRO) make no mention of any property in Virginia; 2) military events applicable to the Virginia William contradict the timeline for the Pennsylvania William. I have therefore ignored all the Virginia evidence presented by Coldham for William Rankin.

75 “James Rankin,” Legislators in Pennsylvania, vol. 3, 1153; Coldham, ed., American Migrations, 481-82; Palmer, Biographical Sketches, 715; "Memorial of William Rankin,” AO12/42/220, DLAR; Egerton, ed., Royal Claims Commission, "Memorial of Abel Evans," 302; William Pencak, "Out of Many, One:
} 
observations had no impact on William's application but may have hurt James who received only $24.3 \%$ of his claim when the average award was for $39.9 \%$ after the typical adjustments made by commissioners. ${ }^{76}$

Despite exile, the Rankins did not forget Pennsylvania. While William disappears from loyalist accounts in England, John and James reengaged the reintegration route. In late 1785, as moderate Republicans took definitive control of state government, John returned to his York home, ostensibly to trade but one cannot rule out that his real intent may have been to explore relocation. He did not remain long, however, hurrying back to Canada to give first-hand testimony to the claims commission representatives assigned to interview loyalists in the royal provinces there. ${ }^{77}$ John's Pennfield community went through some tough times in the late 1780s. As the following decade dawned, he decided to seek redemption in Pennsylvania. With Thomas Mifflin presiding, fifteen members of the moderate Supreme Executive Council heard a petition from John Rankin on March 9, 1790, "stating that he is desirous of returning to this State, and praying that Council would be pleased to grant him a pardon that he may restored to the rights of a citizen of this State." The conclave "Resolved, that the said John Rankin be pardoned." As for

Pennsylvania's Anglican Loyalist Clergy in the American Revolution," Pennsylvania's Revolution, 111117.

76 According to Parliament's Royal Claims Commission, loyalists presented a total of 5,072 claims as of May 1790. Of these, 954 were withdrawn or not prosecuted. The remaining 4,118 cases claimed a total of $£ 8,026,045$ in compensation. From this amount, Parliament paid $£ 3,292,455$ or an average of $41.0 \%$ per claim. These final figures include substantial payments to chartered proprietors and royal grantees like the Penn family in Pennsylvania, Virginia, Maryland, and North Carolina. But even when these special cases are subtracted from the compensation totals, the commission's average allocation per loyalist was $39.9 \%$. See Appendix IX in John Eardley-Wilmot, Historical View of the Commission for Enquiring into the Losses, Services, and Claims, of the American Loyalists, 199.

${ }^{77}$ Palmer, Biographical Sketches, 715. In September 1785, Parliament sent newly appointed commissioners Jeremy Pemberton and Colonel Thomas Dundas to Nova Scotia to gather information on loyalist claims. John Anstey was likewise sent to the United States at around this time with a similar investigative task. See Eardley-Wilmot, Historical View of the Commission, 55-59. 
James, he first took tentative steps. In 1793, the moderate assembly restored a small portion of his unsold estate to son Abraham and daughter Ann who had never left their homes in Pennsylvania. Three years later James followed his brother's example, receiving an official pardon on February $2,1796 .^{78}$

James Rankin never returned to Pennsylvania. After receiving his compensation, he settled in England at Mill Hill, Hendon Parish, Middlesex until his demise. He drafted a will on January 11,1803 in which he set aside an annual income of $£ 150$ for the rest of wife Ann's life, apportioned double shares of his remaining estate to his five sons and single shares to his three daughters, and appointed Ann, son William then a resident of Grenada, and local friend Sir John William Anderson as executors. In addition, he made provision for possible recuperation of additional portions of his Pennsylvania holdings, naming offspring Abraham and Ann executors of any such windfall. Nine months after the January version, James supplemented his will with a codicil placing his son Richard's share in trust for "not having conducted himself with that prudence and discretion which I could wish.” James Rankin's will was executed in London on January 29, 1804 with wife Ann and associate Anderson awarded administration of finances. Ann lived at Mill Hill another twenty-six years. ${ }^{79}$

\footnotetext{
${ }^{78}$ The details of John's pardon are in Council Minutes, March 9, 1790, Colonial Records, vol. 16, 297. The pardon ascribes John's treason to the original March 6,1778 attainder act when in fact he was attainted two months later on May 8. It was James who was attainted in the first round. On Pennfield, see Wilbur Siebert, Loyalists of Pennsylvania, 85. For the restoration of property to James' children, Statutes At Large of Pennsylvania, vol. 14, "An Act to Vest in Abraham Rankin and Ann Nebinger, the Wife of George Nebinger, Two of the Children of James Rankin, Such Parts of his Forfeited Estates as Have Not Been Sold for the Benefit of the Commonwealth," April 11, 1793, Chapter 1688, 428-429; and Sabine, Biographical Sketches, vol. 2, 210. Both James and John's pardons are also listed in the Pardon Appendix in Henry Young, "The Treatment of the Loyalists in Pennsylvania," 401.

79 “James Rankin,” Legislators in Pennsylvania, vol. 3, 1153-1154.
} 
Analysis of the brothers' revolutionary account requires acknowledgement that a number of Rankins from York County and the surrounding area supported the patriot cause during the war. Council records disclose several instances of reimbursement from patriot officials for services in the years after the conflict. David Rankin, Robert Rankin, Thomas Rankin, a second William Rankin and Elizabeth Rankin furnished provisions to the state militia, with Elizabeth's supplies dating from 1776 and also including the Continental Army. It is not likely this William was James' son of the same name alluded to in the prior paragraph because that William had clearly decided to reside within British dominions. Robert was a militia lieutenant and Thomas a militia captain of Washington County who served on the frontier in $1781{ }^{80}$ The radical Supreme Executive Council commissioned another John Rankin - in all probability James' son - as justice of the peace for Newberry Township in York County in 1780. The previous year he had petitioned the Supreme Executive Council for assistance in resolving a claim on "a part of the confiscated Estate of James Rankin... under certain articles and covenants" which was "of such a nature as cannot be settled in the usual mode before the Justices of the Supreme Court." In 1789, this same John Rankin requested that fines imposed by the Court of Oyer and Terminer on himself and eleven others for instigating a riot in Washington County be remitted. Officials granted the rioters' wishes. ${ }^{81}$

The Rankin clan carried forward the banner of reintegration further than anyone in the history of Pennsylvania. In 1846-1847, heirs claimed restitution of all funds

\footnotetext{
${ }^{80}$ Most of these matters date from 1784 \& 1785. For David Rankin, Council Minutes, Colonial Records, vol. 14, 365. For Robert, ibid., vol. 14, 81, 94, 433. For Thomas, ibid., vol. 14, 214, 365 \& vol. 16, 174. For the second William, ibid., vol. 14, 214. For Elizabeth Rankin, ibid., vol. 14, 15.

${ }^{81}$ For the patriot John Rankin, Council Minutes, May 9, 1780, Colonial Records, vol. 12, 342; Council Minutes, August 24, 1779, ibid., vol. 12, 82; Council Minutes, March 12, 1789, ibid., vol. 16, 24.
} 
collected by the state during the Revolution from the forfeiture sales of family property.

Attorney Charles Penrose argued in representation that, since James Rankin had always been a British subject and not a citizen of the United States, he could not have committed treason as per his attainder and all of his property should have been restored according to the 1783 Treaty of Peace. ${ }^{82}$ The senate postponed the decision at the time but the case resurfaced in 1879 when James' descendants managed to have the lower house of the state legislature adopt a bill declaring that their ancestor had been attainted illegally. Not privy to their ancestor's testimony in England before the Royal Claims Commission, they refuted any notion that he had been a loyalist. The senate had other ideas, however. There the "Act for the Relief of the Heirs of James Rankin, Deceased," was first turned over to the senate finance committee on April 15, officially read for the first time on May 19, a second time on May 26, and "determined in the negative" by a vote of 31-12 on June 5 . With that verdict, the legal legacy of James Rankin was finally laid to rest. As subsequent historical scholarship would show, the senate was correct. James had in fact been a loyalist - and quite the militant one at that. ${ }^{83}$

The Rankin saga reaffirms several key points about loyalist militancy in Pennsylvania. Like other regional kingpins beyond Philadelphia engaged in activities

\footnotetext{
${ }^{82}$ Journal of the Senate of the Commonwealth of Pennsylvania: Commenced at Harrisburg, On Tuesday, the seventh Day of January, in the Year of Our Lord One Thousand Eight Hundred and Forty-Six. And of the Commonwealth the Seventieth. (Harrisburg: J. M. G. Lescure, 1846), vol. 1, January 30, 1846, 120; Argument of Charles B. Penrose, Esq., Before the Judicial Committee of the Senate, Relative to the Restitution of Confiscated Property of James Rankin (Philadelphia: William Y. Owen, 1851); "James Rankin,” Legislators in Pennsylvania, vol. 3, 1154; Sabine, Biographical Sketches, vol. 2, 210. Sabine gives the year as 1852 .

${ }^{83}$ For the case in the lower house, see Pennsylvania Legislative Record, 1879 footnotes in Young, "The Treatment of the Loyalists in Pennsylvania," 318. For the senate decision, Journal of the Senate of the Commonwealth of Pennsylvania for the Session Begun at Harrisburg, on the $7^{\text {th }}$ Day of January, 1879 (Harrisburg: Lane S. Hart, 1879), 627, 933, 1154, 1180-81.
} 
such as farming, milling and land development, they were more ordinary than elite. The brothers' repudiation of parliamentary interference initially tempered their view of royal aims and led instead to resistance. As William's militia service reveals, that resistance could even involve armed opposition. Their attitude changed slowly as the Revolution radicalized. When forced to choose allegiance to king and empire or self-rule, the threesome tied their fortunes to the mother country. The way the brothers interpreted the imperial linkage inextricably tied their success to a dependence on British support, ratified by the fact that James took no action until Howe's army had disembarked on the Chesapeake Bay. William was similarly unwilling to follow through on his military intrigues without British collaboration and reinforcements. That self-imposed reliance inhibited their ability to operate effectually in a fluid environment. When failure became manifest, they fled.

The departure of militant loyalists like the Rankins in the middle corridor reduced the numbers of those willing to fight for the colonial order during the war, but paved the way for a smoother reintegration process. The absence of these former leading lights of York County and their like-minded compatriots during the critical postwar years allowed for development in the region of a more tolerant view of former "tories" that contributed to the repeal of the test acts, precisely because their militancy no longer posed a threat. By the 1790s, loyalism and disaffection had become an after-thought under the stability conferred by the moderate-led state and national institutions that arose from the federal constitution of 1787 and the Pennsylvania Constitution of 1790 rescinding the radical Constitution of 1776. Despite a transformation of the political climate, the Rankin brothers did not return or personally reintegrate, although John may have reconnoitered 
that possibility during his visit in the mid-eighties. Yet their descendants reassimilated to such a degree that they erased the specter of loyalism from family lore a century later and solicited damages from the state legislature for Pennsylvania's alleged mistreatment of their forefathers. Ironically, then, Rankin reintegration succeeded without the presence of the protagonists who originated the need for reintegration in the first place.

\section{LOYALIST MILITANCY IN AND AROUND PHILADELPHIA}

Any variation of Great Britain's strategy for putting down the colonial rebellion recognized the need to defeat or disarticulate the Continental Army under the leadership of General George Washington and his subordinates. The insurrection would continue as long as Americans demonstrated the capability to organize militarily and put armed men in the field. ${ }^{84}$ After 1778, the army and navy of Catholic France joined the Americans in the battle, as did Spain the next year in a less straightforward manner. The intervention of France in particular proved pivotal. ${ }^{85}$ Still, the Continental Army, funded via Congress, was the key. The prime counter to Washington's forces was the British army. In addition to the fabled redcoats, Hessian conscripts formed an integral part of the imperial war effort. Indigenous allies likewise made important contributions on behalf of the king, especially along the frontier. America's loyalists comprised the final link in the British chain of suppressive deterrents. Of all the departures in different regions and at varying

\footnotetext{
${ }^{84}$ For British strategy, Piers Mackesy, The War for America: 1775-1783 (Cambridge: Harvard University Press, 1964). For the American military, John Shy, A People Numerous and Armed: Reflections on the Military Struggle for American Independence (New York: Oxford University Press, 1976).

${ }^{85}$ It was the French maritime component which ultimately proved decisive at Yorktown, a capability the continentals did not have nor could have acquired in the foreseeable future without the assistance of a European power. Bourbon king Charles III officially allied Spain with France and declared war on Great Britain in 1779, but refused to seek a formal alliance with the United States. Spanish attacks on British West Florida drew away British units from other battle fronts, such as William Allen Jr.'s Pennsylvania Loyalists who were assigned to defend Pensacola after the Philadelphia evacuation. Holland also entered the war on the side of the Americans in 1780, providing financial rather than military support.
} 
junctures during the war in Pennsylvania, the June 1778 exodus of the ordinary loyalist militants who filled the ranks of the provincial regiments recruited at Philadelphia during the British occupation was without doubt the most devastating to Great Britain's chances for victory. Their definitive retreat removed from the Pennsylvania theater of war the overwhelming majority of those colonials willing to bear arms for the king in actual practice as opposed to the hypothetical or botched intrigues of William Rankin and John Connolly. Though its impact was not entirely clear at the moment, their withdrawal doomed loyalism in the state as English commanders dispatched recruits to fight elsewhere. Then again, the departure of these armed loyalist militants greatly lessened any possibility of an uprising on behalf of the monarchy afterwards, by definition opening the door for a smoother passage towards reintegration in Pennsylvania. The fact that few of these militants later returned or visited also contributed to the less threatening political environment which ultimately resulted in the full legal reintegration of the disaffected.

Loyalist militants joined provincial regiments in almost all the colonies, fighting in over 150 units raised by the British over eight-plus years of war. ${ }^{86}$ In Pennsylvania, the main military engagements of the Revolution occurred in September 1777 at Brandywine and in October at Germantown, where redcoats and Hessians faced off against the Continental army. Loyalists formed only a minor contingent of British forces in these engagements, just as state militias comprised marginal slices of Washington's assets on the opposing side. Most notable were the Queen's American Rangers, the most adept partisan regiment accompanying the royal army during the campaign for Philadelphia

\footnotetext{
${ }^{86}$ Allen \& Braisted, The Loyalist Corps, 9.
} 
that autumn which included some Pennsylvanians. ${ }^{87}$ Once Howe occupied the provincial capital, however, the British launched an energetic appeal to enroll locals to the king's cause. Recruitment led to the formation of William Allen Jr.'s Pennsylvania Loyalists and Alfred Clifton's Roman Catholic Volunteers in October of 1777, the Philadelphia Light Dragoons commissioned in November, and the Bucks County Volunteers and Bucks County Light Dragoons authorized in the spring of $1778 .^{88}$

Pennsylvania's collective impact on loyalist strength was greater than that, however. While occupying Philadelphia, the British raised regiments bearing the names of other colonies which incorporated many Pennsylvanians. Most prominent among these were the Maryland Loyalists in November 1777 and the West Jersey Volunteers recruited in January 1778. The New Hampshire Volunteers drew from recruitment pools from both Philadelphia and New York in 1777, and the Caledonian Volunteers also pulled from those two sources in 1778. Pennsylvanians likewise fed the ranks of regiments such as the Guides and Pioneers, the Maryland Royal Retaliators, and the First and Second Battalions of the Royal Highland Emigrants. In addition, prominent loyalists with ties to Pennsylvania played roles of varying significance with other regiments. Captain James Forrest formed the Loyal Irish Volunteers in Boston in December of 1775 when the city was still under the control of General Thomas Gage. He was captured at sea in 1776, after the British evacuation there, and underwent protracted incarceration at Philadelphia. ${ }^{89}$ On

\footnotetext{
${ }^{87}$ For the Queen's Rangers in Pennsylvania, see Jackson, With the British Army in Philadelphia, 180-183, 224, 226-227; Allen \& Braisted, The Loyalist Corps, 88-89. Andrew Allen joined the Queen's Rangers with the rank of Ensign in August, 1778, following the Philadelphia evacuation.

${ }^{88}$ Allen \& Braisted, The Loyalist Corps, 29, 84-85, 91.

${ }^{89}$ Allen \& Braisted, The Loyalist Corps, 31, 44-45, 60, 62-63, 65, 70, 93-94.
} 
the frontier, we have seen how John Connolly recruited the royally faithful in both Cumberland County in 1775 and Virginia in 1781 and how Northumberland County loyalist refugees filled the ranks of Butler's Rangers at Niagara. ${ }^{90}$

Despite Joseph Galloway's later protestations before Parliament that the British bungled loyalist enlistments at Philadelphia by assigning the task to "the most unpopular men to recruit" like William Allen Jr., Sir William Howe made loyalist deployment a priority during the occupation. Between November 1777 and January 1778, Richard Hovenden of Bucks County and Jacob James of Chester County marshaled militants under Howe's direction for the Philadelphia Light Dragoons. ${ }^{91}$ Each was captain of his own independent troop of cavalry, conducting repeated incursions into patriot territory beyond Philadelphia to secure supplies and open roads for local farmers who wished to bring their products to market in the city. That substantial numbers of agrarians preferred to sell to British occupiers in specie rather than to Americans for continental or provincial paper reveals not only self-interest, but the depth of indifference or antirevolutionary sentiment in southeastern Pennsylvania at the time. ${ }^{92}$ Hovenden was especially renowned for collecting large quantities of clothing for the army, while James garnered a reputation for "kidnapping Whigs of note in the Philadelphia vicinity" and stealing horses for

\footnotetext{
${ }^{90}$ For the Loyal Foresters, Allen \& Braisted, Loyalist Corps, 59-60, 90. For Butler's Rangers, ibid., 29-30.

91 "Memorial of Jacob James," AO12/38/356, DLAR; Carlos E. Godfrey, "Muster Rolls of Three Troops of Loyalist Light Dragoons Raised in Pennsylvania1777-1778," PMHB, vol. 34, no. 1 (1910), 1-8; Allen \& Braisted, The Loyalist Corps, 85-86; Siebert, Loyalists of Pennsylvania, 41, 49. On February 8, 1778, Jacob James' unit became the Chester County Light Dragoons - see Jacob James entry in "British Legion Biographical Sketches, Cavalry Officers," The On-Line Institute for Advanced Loyalist Studies at http://www.royalprovincial.com/military/rhist/britlegn/blcav1.htm, last accessed May 1, 2017.
}

${ }^{92}$ Many local farmers from Bucks, Chester, and Philadelphia counties preferred to sell their produce to the British not as a matter of allegiance but because His Majesty's officials paid in hard specie, whereas the American army paid in much less valuable continental paper. 
Howe's army. George Washington wrote to Pennsylvania President Thomas Wharton Jr. from Valley Forge in the winter of 1778, stressing that "the insolence of the disaffected in Philadelphia and Bucks Counties had arisen to a very alarming Height. They have seized and carried off a number of respectable inhabitants of those Counties, and such officers of the Army as fell in their way." Days before the British evacuation, General John Lacey - charged with defending the patriot perimeter around the occupied city and preventing supplies from reaching the capital - wrote from Bucks County to state vice-president George Bryan, informing him that "this Country is left intirely [sic] open to the insults and ravages of the Tories and Vagabonds from the Enemy... Parties of these Malignant Villains Comes into Makefield, Newtown \& Northampton Townships, and Steals [sic] all the good Horses they Can find and takes them to Philadelphia..93

Like many other loyalists, Jacob James at least tacitly aided the patriot cause early on. As an innkeeper in 1776, the Pennsylvania Council of Safety ordered repayment to “Jacob James [of] $£ 29$ 6, for dieting Capt. Allbright’s Company of Col. Miles’ Batt'n.” But James later turned his back on the revolutionaries and "Tho Oath was twice tendered to him but he refused to take it." ${ }^{, 94} \mathrm{He}$ joined General Howe the day after the battle of Brandywine and served as a guide and recruiter of guides for the British army. The Light Dragoons participated in the notorious battle of Crooked Billet on May 4, 1778 earning the wrath of contemporaries and historians alike as "refugee scoundrels" for bayoneting

\footnotetext{
${ }^{93}$ Sabine, Biographical Sketches, vol. 1, 546, 569; Scharf \& Westcott, History of Philadelphia, 373, 375; General Washington to President Wharton, 1778, February 23, 1778, Pennsylvania Archives, First Series, vol. 6, 291; Brig. Gen. Lacey to V. P. Bryan, June 11, 1778, ibid., First Series, vol. 6, 595.

${ }^{94}$ Palmer, Biographical Sketches, 430; "In Council of Safety," October 23, 1776, Colonial Records, vol. 10, 762; "Memorial of Jacob James," AO12/38/357-358, DLAR. Since the Pennsylvania test oath was passed on June 13, 1777, these incidents likely occurred afterwards. See Statutes At Large of Pennsylvania, vol. 9, "An Act Obliging All White Male Inhabitants of This State to Give Assurances of Allegiance to the Same and for Other Purposes Therein Mentioned," June 13, 1777, Chapter 756, 110-111.
} 
patriot prisoners. Both Hovenden and James were attainted four days later in the first Supreme Executive Council attainder proclamation after the initial March $6^{\text {th }}$ act of the General Assembly. ${ }^{95}$

The pair evacuated to New York with Clinton's army in June of 1778 and two months later their units were integrated into the British Legion. The British command reassigned Jacob James with his unit to the southern campaign, where North Carolina patriots took him prisoner in April, 1780. Upon receiving word of James' capture, Joseph Reed, radical president of the Supreme Executive Council, asked the North Carolina governor that the "distinguished Partizan" not be exchanged as a prisoner but rather held until he could be extradited back to Pennsylvania to stand trial and "suffer the Punishment his many Villainies \& offences so justly deserve.” Apparently the request was not fulfilled, for James was eventually released on parole. Then in January of 1781, a patriot privateer captured James, eleven of his men, and their horses on a sea voyage from New York to Savannah. The rebels slit the horses' throats, paroled his men, kept James as prisoner, and let the sloop transporting them continue the journey. Presumably James was exchanged, for he later surrendered at Yorktown with Cornwallis on October 19, 1781. After the war, he went to Canada. James makes no mention of the above incidents in his 1783 claim for compensation, declaring instead that he "continued to serve until $24^{\text {th }}$ Oct. 1783 when he with his Corps disbanded." The exiled ex-innkeeper left a wife and five children behind in Pennsylvania and his property was seized. By 1785, his wife was dead and the children were "living among his Enemies without care or education, or taught only to execrate their Father's name as a Traytor [sic] to his Country

95 "A Proclamation: By the Supreme Executive Council of the Commonwealth of Pennsylvania," May 8, 1778, Colonial Records, vol. 11, 485. 
and a deserter of his kindred." His military commitment earned him a higher percentage of compensation than most loyalists, receiving $£ 300$ sterling out of the $£ 471$ claimed. For his part, Richard Hovenden accompanied the infamous British Lieutenant Colonel Banastre Tarleton in the cruel Carolina countryside civil war during the southern campaign which followed the Philadelphia evacuation. He was "laid up with fever and ague" on December 4, 1780, was at the battle of Cowpens on January 17, 1781, and surrendered at Yorktown in October of 1781. By December of that year, he had relocated to Ireland. Curiously, despite his exile in the United Kingdom where word of the Royal Claims Commission was commonplace, there is no record that he filed a claim for compensation. ${ }^{96}$

In addition to William Allen Jr.'s Pennsylvania Loyalists and the Philadelphia Light Dragoons, other notable loyalist regiments included the Bucks County Volunteers, the Bucks County Light Dragoons, and the Roman Catholic Volunteers, led respectively by Captain William Thomas, Captain Thomas Sandford, and Lieutenant Colonel Alfred Clifton. A farmer from Northampton County, rebels arrested William Thomas and six others "suspected of being Tories," confining them at the Reading jail months before the British invasion. Thomas must have escaped or obtained his release because he fled to the British lines at Philadelphia and assembled a true volunteer company without pay or official uniforms in the spring of 1778. By the June evacuation, his unit consisted of

\footnotetext{
${ }^{96}$ Council Minutes, April 12, 1780, Colonial Records, vol. 12, 314; Pres. Reed to Gov. Caswell, 1780, Pennsylvania Archives, First Series, vol. 8, 191; Sabine, Biographical Sketches, vol. 1, 546; "Memorial of Jacob James," AO12/38/356, DLAR; Coldham, American Migrations, 468; Palmer, Biographical Sketches, 430. Parliament considered the militarily committed the most loyal of subjects. Military activities of Hovenden and James after the evacuation in "British Legion Biographical Sketches, Cavalry Officers," OnLine Institute for Advanced Loyalist Studies www.royalprovincial.com/military/rhist/britlegn/blcav1.htm, last accessed May 1, 2017. The 63.7\% Jacob James received was a much higher percentage of his claim than the average allocation per loyalist of $39.9 \%$.
} 
eighty men. Thomas was attainted on May 8, 1778 and his personal and real property later confiscated and sold. At the peace, he settled in Digby, Nova Scotia. One of his claim witnesses believed Thomas was illiterate, even though he had achieved the rank of captain. In Arthur Mekeel's study on the Quakers, there is a William Thomas that was disowned by the Philadelphia Monthly Meeting, quite possibly the Bucks County Volunteer captain. ${ }^{97}$

Thomas Sandford recruited his dragoons in the fall of 1777 but fell captive afterwards. Scharf and Westcott place his capture in a mid-June 1778 action as the patriots retook Philadelphia, but a muster of his loyalist unit covering December 1777 to April 1778 already listed him as "Prisoner with the Rebbels [sic]," his troops under the command of Lieutenant Colonel Watson. Given no overlap in dates, it is possible both incidents occurred. From mid-June 1778 until his parole in November, Sandford remained a prisoner in the patriot jail at Easton, Pennsylvania. After his release, he was paroled to patriot-reoccupied Philadelphia where, on November 10, he visited Grace Growden Galloway in the company of the latter's friends, Mrs. Craig and Pegg Johns, after her husband and daughter had evacuated with the British army that June. Of Captain "Sansford," she found that "the rebels Used him very cruelly" and that he was "a clever young Man." Sandford returned six days later to "Tea in ye evening," this time in the company of Benjamin, Sally and Peggy Chew. A Bucks County Light Dragoons muster roll still listed him as a prisoner on parole as of June 25,1779 . He must have been

\footnotetext{
${ }^{97}$ Council of Safety Minutes, Colonial Records, vol. 11, 89, 109; Allen \& Braisted, Loyalist Corps, 29; “A Proclamation: By the Supreme Executive Council of the Commonwealth of Pennsylvania," May 8, 1778, Colonial Records, vol. 11, 485; Palmer, Biographical Sketches, 856; Coldham, American Migrations, 491; Philadelphia Monthly Meeting Minutes 1771-1777 in Mekeel, Relation of the Quakers to the American Revolution, $291 \mathrm{fn} 15$. Quakers were disowned by their congregation for violating pacifist principles. Some of Thomas' seized property sales are in Colonial Records, vol. 12, 481, 734; ibid., vol. 14, 56, 642.
} 
exchanged shortly thereafter because in January of 1780 Sandford was captured at sea while en route to Savannah from New York, like Jacob James a year earlier. Transferred to a prison in Massachusetts, he escaped from Concord jail on September 3 with two companions. Finding his way back into service, Sandford was ordered to take charge of the rank and file remnants of the British Legion at Charleston from June 25, 1781 to February 23, 1782. Despite his military track record and imprisonment, Thomas Sandford was never attainted. Like Richard Hovenden, he did not make a compensation claim. ${ }^{98}$

The British Empire discriminated against Roman Catholics for historical and religious reasons dating back to Henry VIII, the Spanish Armada of 1588, the Glorious Revolution in the seventeenth century, and the longstanding religious conflict over Ireland. As Reverend Thomas Phelan has noted about pre-revolutionary conditions in North America, "Catholics were deprived of civil and religious rights in all the colonies except Pennsylvania." ${ }^{99}$ Contemporary English law prohibited Catholics from holding a military commission. Hence, Protestant officers normally led imperial units containing large contingents of Catholics. In America, however, this restriction was not always

\footnotetext{
${ }^{98}$ Siebert, Loyalists of Pennsylvania, 41; Sabine, Biographical Sketches, vol. 2, 574; Scharf \& Westcott, History of Philadelphia, 385; Allen \& Braisted, Loyalist Corps, 29; Godfrey, "Muster Rolls of Three Troops of Loyalist Light Dragoons Raised in Pennsylvania1777-1778," PMHB, vol. 34, no. 1, 2; "Diary of Grace Growden Galloway," PMHB, vol. 55, no. 1 (1931), 57-58; "British Legion Biographical Sketches, Cavalry Officers," The On-Line Institute for Advanced Loyalist Studies at http://www.royalprovincial.com/military/rhist/britlegn/blcav1.htm, last accessed May 1, 2017.

${ }^{99}$ Thomas P. Phelan, "Catholic Patriotism in Revolutionary Days," The Catholic Historical Review, New Series (April 1921 to January 1922), vol. 1, 434. Phelan may have overstated his argument in the cases of Maryland and Rhode Island. Maryland was originally founded in 1632 as a haven for Roman Catholics but that status changed substantially by the end of the seventeenth century. Roger Williams founded Rhode Island in 1636 as a bastion of religious liberty, but Catholics there were never numerous in the colonial era.
} 
applied. ${ }^{100}$ Alfred Clifton's Roman Catholic Volunteers therefore offer a glimpse not only into loyalist militancy but also social conditions in colonial Pennsylvania.

Clifton was a leading member of Philadelphia's two Catholic parishes, St.

Joseph's and St. Mary's. His name appeared on the St. Joseph registry in 1773 and he was a frequent witness at marriages and baptisms prior to the war. Father Ferdinand Farmer described Clifton as an "English gentleman of an Irish mother." His prestige among his religious peers exceeded his wealth. As one historian has noted, "he does not appear to be a man of property as no evidence thereof has been found in the Recorder's Office." Nonetheless, when Howe decided to expand his provincial forces during the occupation, he turned to this "chief" among those of "Roman Catholic persuasion of whom there were said to be many in Philadelphia, as well as in the Rebel army serving against their inclinations." Given the rank of Lieutenant Colonel, Clifton was authorized to "receive and form for service all the well affected that could be obtained." Catholic otherness is evident in that the unit was to "consist of Roman Catholicks only [,] on a presumption that they will prefer serving under an officer to whom they are naturally attached."101

Alfred Clifton's recruitment effort was highly successful, managing to raise about three hundred officers and men. Militarily, however, they were a bust. Unlike other loyal

\footnotetext{
${ }^{100}$ During the Revolution, Catholic officers led at least two Roman Catholic units - Clifton's Roman Catholic Volunteers and the Royal Scotch Catholics in New York's Mohawk Valley. See "Catholic Loyalists of the American Revolution," The American Catholic Historical Researches, New Series, vol. 4, no. 4 (October, 1908), 301.

101 "Catholic Loyalists of the American Revolution," The American Catholic Historical Researches, New Series, vol. 4, no. 4, 300-301; Robert Mackenzie to Alfred Clifton, October 7, 1777, "Roman Catholic Volunteers Approval for Corps," PRO 30/55/698, The On-Line Institute for Advanced Loyalist Studies, http://www.royalprovincial.com/military/rhist/rcvol/rcvlet1.htm, last accessed March 16, 2017 (emphasis in the original); Allen \& Braisted, Loyalist Corps, 91.
} 
regiments, the unit never participated in a major engagement during the occupation and was continually plagued by disciplinary problems, including a notable clash between officers on parade. Clifton led his troops out of Philadelphia at the June 1778 evacuation and they did fight at the battle of Monmouth under General Knyphausen. More typically, however, Captain Martin McEvoy of the Roman Catholic Volunteers was court martialed in September of 1778 for "behaving indecently on the Parade" and "plundering the Jerseys in taking a Horse, and Cow." In the former instance, two officers witnessed McEvoy kick a fellow officer, a charge the accused not only acknowledged but justified as "being provoked by some abusive language of Captain McKinnon." The Roman Catholic Volunteers did not last much beyond this incident. Clifton himself retired from military service in British-occupied New York on October 25, 1778, and his unit was amalgamated into the Volunteers of Ireland. Alfred Clifton never returned to Philadelphia, expiring in Manhattan on June 16, 1780, at "age 75 years, a Stranger, buried in Trinity Church yard, died of decay."

Richard Hovenden, Jacob James, William Thomas, Thomas Sandford, and Alfred Clifton personify the middle echelons of loyalist armed militancy. They came from the southeast core of Bucks, Chester, Northampton and Philadelphia counties, exercised commonplace occupations such as farmer and innkeeper, and belonged to faiths as dissimilar as Quakerism and Catholicism. At least one was probably illiterate. Though commissioned as officers, they were quite ordinary in the social sense of the term. Even

\footnotetext{
102 “General Court Martial of Martin McEvoy,” Public Records Office, War Office, Class 71, Volume 87, 176-178, The On-Line Institute for Advanced Loyalist Studies, http://www.royalprovincial.com/military /rhist/rcvol/rcvlet1.htm, last accessed March 16, 2017; obituary in New York Gazette and Weekly Mercury, June 19, 1780 cited in "The Roman Catholic Regiment of the American Revolution," The American Catholic Historical Researches, New Series, vol. 8, no. 1 (January, 1912), 83-84.
} 
Clifton, reputed to be a "gentleman," lacked the financial wherewithal to fulfill that lifestyle. Two factors indelibly bound these men together. They all fought proactively for the king and they all abandoned their homes in Pennsylvania, never to return. As integral components of British arms in America, reintegration did not prove to be a viable option for any of them either at the evacuation or the peace.

Leaders need followers. The mass of militants who joined loyal provincial regiments to engage the rebels were unexceptional everyday men from the middling and lower sorts with no claim to superior status, connections or landed wealth. A glance at muster rolls of some of these units gives an indication of their hierarchical composition. The muster roll of William Allen Jr.'s Pennsylvania Loyalists on July 11, 1778, shows that Captain Kearney's company had nine officers, including the surgeon and chaplain, six non-commissioned officers with the grade of sergeant or corporal, and 36 men among the rank and file. On the same day and place, Captain Stephens' company - also under Allen - had three officers of rank, five non-commissioned officers, and 31 soldiers. The muster of Richard Hovenden's dragoons in the occupied capital on January 10, 1778 counted four officers, five non-commissioned and 35 soldiers from the lower orders. In February 1778, Jacob James' unit mustered at Philadelphia three full officers and a like number of three non-commissioned officers, along with 41 privates. ${ }^{103}$ A composite of the four units shows that conventional soldiers comprised about four-fifths of their

\footnotetext{
103 “Muster Roll of Captain Kearney's Company $1^{\text {st }}$ Battalion Pennsylvania Loyalists Commanded by Lt. Col. Allen" and "Muster Roll of Captain Stephens Company $1{ }^{\text {st }}$ Battalion Pennsylvania Loyalists Commanded by Lieutenant Colonel William Allen," both at Camp Yellow Hook, $11^{\text {th }}$ July 1778, National Archives of Canada, RG 8, "C" Series, vol. 1907, pages 9 \& 12, DLAR; Godfrey, "Muster Rolls of Three Troops of Loyalist Light Dragoons Raised in Philadelphia 1777-1778," PMHB, vol. 34, no. 1, 3-5.
} 
overall strength. Though plentiful, militantly loyal commoners populate the sources almost as fleeting postscripts when contrasted with provincial notables.

For example, John Howell of Solsbury in Bucks County acted as a guide for both the British army and loyalist regiments. The Supreme Executive Council attainted him on June 15,1778 , classifying him as a common laborer, though he later described himself as a farmer. Howell left with the British army for New York three days after his attainder. In 1783, he repeated the exodus, conveying his wife and children from New York City to England. His travels were not over, however. His compensation claim to Parliament's commission requested funds to travel and start anew in Nova Scotia. Reintegration in Pennsylvania was never on his itinerary, although no legal prohibition prevented him from using royal compensation to return to his former home. ${ }^{104}$

Laborer Jacob Holder of Linton in Northampton County was attainted on May 8, 1778. The twenty-year-old had sought British protection in Philadelphia during the occupation and enlisted in the Bucks County Volunteers despite being raised by pacifist Moravian parents of German descent. After Holder's evacuation to New York, the British high command assimilated his unit into the Queen's Rangers. Franco-American forces later captured Jacob Holder at the battle of Yorktown in 1781. At the peace, he settled in Canada. The royal compensation commissioners rejected his claim, but Canadian officials granted him land lot number 566 at Parrtown, now St. John, to provide him with a new beginning. Holder eventually moved to Kingston, New Brunswick. In 1789, he married Mary Sharp, daughter of a New Jersey loyalist farmer. They had nine children,

\footnotetext{
104 "A Proclamation: By the Supreme Executive Council of the Common Wealth of Pennsylvania," June 15, 1778, Colonial Records, vol. 11, 514; Coldham, American Migrations, 466; Palmer, Biographical Sketches, 406; Sabine, Biographical Sketches, vol. 2, 533.
} 
all of whom lived into adulthood. Holder prospered and adapted well to life in New Brunswick, in the process joining the Anglican faith. He purchased an additional lot of land in 1795 and during his life "he was able to develop the lot into a productive farm" which remained in possession of future generations of the family. He died on June 29, 1828, two months before his seventy-first birthday. His success shows how a new life in exile was often a better option for departed militants of the lower sort than the unknown challenge of reintegration. ${ }^{105}$

Artisans and especially farmers made up the lion's share of the soldiery. Joseph Paxton was a carpenter from Middletown in Bucks County. Though a minor, he joined the British when Howe took Philadelphia and served for six years in the army, first in wagon transport and then in the engineering department. He presumably withdrew with the army to New York, for he evacuated from there again in 1783. Paxton was attainted in the last Supreme Executive Council group proclamation of March 20, 1781 and patriots seized his inherited estate. In the spring of 1782, patriots decided to allocate his property to the University of Pennsylvania and sent appraisers to value the land. By the mid-1780s, he was exiled at Halifax, Nova Scotia. ${ }^{106}$ Similarly, Christopher Curtis was a Philadelphia cooper who served as a guide for Colonel Robert Rogers and recruited

\footnotetext{
105 "A Proclamation: By the Supreme Executive Council of the Commonwealth of Pennsylvania," May 8, 1778, Colonial Records, vol. 11, 483-84; Cleadie B. Barnett and Elizabeth S. Sewell, Loyalist Families: A Loyalist Bi-Centennial Project (1783-1983) for the Fredericton Branch of the United Empire Loyalists' Association of Canada, "Jacob Holder," 24; Coldham, American Migrations, 465; Palmer, Biographical Sketches, 392; Sabine, Biographical Sketches, 531. Holder's claim testimony says he sought protection in Philadelphia in March of 1777 but the British did not take the capital until September of that year, so the reference is probably to March of 1778 . His life in New Brunswick is summarized in his entry and the links in the Loyalist Directory of the United Empire Loyalists' of Canada at http://www.uelac.org/LoyalistInfo/extras/Holder-Jacob/Holder-Jacob-biography.pdf last accessed May 2, 2017.

${ }^{106}$ Palmer, Biographical Sketches, 676; Coldham, American Migrations, 479. Sometimes Paxton was referred to officially as Joseph Paxson. Paxton's confiscation is in Pennsylvania Archives, Sixth Series, vol. 12, 170. The patriot appraisers are in Colonial Records, vol. 13, 257, 280.
} 
soldiers, first for the Queen's Rangers and then the Bucks County Light Dragoons. He abandoned his native city for exile in Sorel, Quebec, from where he filed his compensation claim in $1786 .^{107}$

Tallow chandler Thomas Badge of Philadelphia used his trade as an excuse to gather intelligence for the British. Because he offered needed supplies for sale to the rebel army, he was able to penetrate their encampment and conduct in situ surveillance for Howe. ${ }^{108}$ Badge was born in England and raised in Ireland, emigrating to America in 1767. Initially, his allegiance was ambivalent, as evidenced in his three-month service with the rebels. He bluntly declared in his later compensation claim that he sided with the royalists because "he thought the British Army would conquer." Badge served as a guide for the British invaders on their march from Head of Elk to Philadelphia in the fall of 1777 and was severely wounded by a musket ball in the right arm, rendering further military service ineffective. He was attainted on May 21, 1778. While seeking exile in England, his ship was apprehended by a privateer and taken to the French port of Brest where all his personal property was seized. He eventually found his way to London, where he filed his loyalty claims. Badge is typical of those born outside of the thirteen colonies who emigrated to Pennsylvania before the war and never renounced their allegiance to king and empire. ${ }^{109}$

${ }^{107}$ Coldham, American Migrations, 456; Palmer, Biographical Sketches, 198.

${ }^{108}$ For example, a patriot official noted on January 17, 1777, that he had "Receiv'd a Box of Candles, $54 \mathrm{lb}$, of Mr. Badge." Memorandum, as Found in Council Book, No. 3, from Dec. 31, 1776, to March 17, 1777. Minutes of the Council of Safety, Colonial Records, vol. 11, 155.

109 "Memorial of Thomas Badge," Egerton, ed., The Royal Commission, 172; Coldham, American Migrations, 449-450; Palmer, Biographical Sketches, 34; Sabine, Biographical Sketches, vol. 2, 474; "Ordered, That a Proclamation be now issued..." Supreme Executive Council, May 21, 1778, Colonial Records, vol. 11, 493. 
Although militant mechanics were numerous, farmers proliferated far more than most among militarily committed loyalists. They were often smalltime cultivators like Samuel Custard Jr., Hugh Pugh and Henry Steininger who owned family-sized farms. These three were all residents of Northampton County and combatants with William Thomas’ Bucks County Volunteers. Custard was a typical yeoman with a 200 acre farmstead, a horse and a cow. Son of a loyal Quaker, patriot intimidation forced him to abandon his farm and flee early in the Revolution, relegating his impoverished wife and large family to the care of friends. After his stint with the Volunteers, Custard joined the Queen's Rangers and eventually wound up exiled in Sunbury County, New Brunswick. Parliament's commissioners rejected his claim. ${ }^{110}$ Hugh Pugh likewise sought refuge with the British army in occupied Philadelphia and joined the Bucks County Volunteers for two years without pay, as customary for that unit. He was classified as a husbandman in his attainder of May 8, 1778. His 1786 claim stressed the loss of cattle. Like many men of modest means who served in royal regiments, Pugh sought a mere $£ 88$ in compensation from the claims commissioners. He settled after the war at Digby, Nova Scotia, in close proximity to his wartime commander, Captain William Thomas. ${ }^{111}$ The tale repeats itself

\footnotetext{
${ }^{110}$ Coldham, American Migrations, 456; Palmer, Biographical Sketches, 199-200. Custard's confiscations are in Montgomery, ed., Pennsylvania Archives, Sixth Series, vol. 12, 342-47, 458. Rejection of claims was usually based on the ground rules set by the commissioners for compensation, not as a result of fraud. For example, the Commission did not provide compensation for uncultivated lands; claimants had to prove that they held title; and all property claimed had to have been both confiscated and sold. There were numerous other requirements. The low number of reputedly fraudulent claims is striking. In the Commission's report to Parliament of June 10,1789, only ten of 3,157 cases examined by then were considered outright frauds. For a summary of the Commission's investigative framework, see Gregory Palmer's "Introduction" in his Biographical Sketches of Loyalists of the American Revolution, especially xiv-xv. The June 10, 1789 report is in Eardley-Wilmot, Historical View of the Commission, Appendix VIII, 196.

${ }^{111}$ Coldham, American Migrations, 480; Palmer, Biographical Sketches, 707; Sabine, Biographical Sketches, vol. 2, 568; "A Proclamation: By the Supreme Executive Council of the Commonwealth of Pennsylvania," May 8, 1778, Colonial Records, vol. 11, 483. Pugh's confiscated property is in Montgomery, ed., Pennsylvania Archives, Sixth Series, vol. 12, 370-72, 462-63, 465-67.
} 
in the case of farmer Henry Steininger, likely of German origin or ancestry, who bolted to the British at Philadelphia in early 1778 and joined the Bucks County Volunteers, serving three years. Steininger had the dubious distinction of being attainted twice, one of only six such individuals in Pennsylvania. His two attainders came in 1779 and 1780, quite late after the evacuation for a militant. Although the patriot government did not explain why Steininger was twice attainted, duplication and delay suggest legal uncertainties in the confiscation of his property. Radical patriots seized his lands and sold them in 1782 and 1784 as per attainder penalties. Steininger too eventually put down postwar roots in Digby, Nova Scotia. ${ }^{112}$

Enlistment in the king's provincial regiments was surely a promising prospect when Howe's call for “All Intrepid Able-Bodied Heroes Who are willing to serve His Majesty King George the Third" first went out in the early winter of 1777 from occupied Philadelphia. Despite a recent setback at Saratoga, the likelihood of British victory seemed irrefutable. For many of the lower sorts who had little or nothing, then, the enticement of a five-dollar bounty, arms, clothing, provisions and fifty acres of land at war's end made perfect sense. John Howell and Joseph Paxton came in from Bucks County. Jacob Holder made the trek from Northampton County. Local Philadelphian Christopher Curtis followed suit. ${ }^{113}$ Other factors prompted the likes of Thomas Badge,

\footnotetext{
${ }^{112}$ Coldham, American Migrations, 488; Palmer, Biographical Sketches, 823; Sabine, Biographical Sketches, vol. 2, 581; "A Proclamation. By His Excellency, JOSEPH REED, Esquire, President; and the Supreme Executive Council of the Commonwealth of Pennsylvania," June 22, 1779, Colonial Records, vol. 12, 27-29; "BY HIS EXCELLENCY, JOSEPH REED, ESQUIRE, PRESIDENT and the Supreme Executive Council of the Commonwealth of Pennsylvania, A Proclamation - No. 7," July 27, 1780, Pennsylvania Archives, $3^{\text {rd }}$ Series, vol. 10, 537-39. Seizures of Steininger's lands are in Montgomery, ed., Pennsylvania Archives, Sixth Series, vol. 12, 376-77, 459. Orders for conveyances of some of his property are in Colonial Records, vol. 13, 273 \& vol. 14, 34.
} 
Samuel Custard Jr. and Hugh Pugh who owned some assets. For Badge the Briton, it seems to have been national origin and opportunism. Custard and Pugh responded to rebel persecution, suggesting political provocation. Nevertheless, the trajectories of the lesser loyalists depicted here demonstrate that official enrollment in the king's army initially led to a post-evacuation military deployment away from home, followed by permanent exile. Most ordinary loyalists who took up arms against the Revolution never saw their native soil again after the fighting stopped. Their dispersion removed from the Pennsylvania scene the overwhelming majority of those colonials actually willing to bear arms for the king, as opposed to the illusory schemes of the likes of William Rankin or John Connolly. Although not entirely clear at the time, their withdrawal doomed loyalism in the state. Militant departures greatly reduced the possibility of armed uprisings on behalf of monarchy and opened the door for a smoother passage towards reintegration in Pennsylvania. The fact that few of them later returned or visited also contributed to the less threatening political climate which ultimately resulted in the full legal reintegration of the disaffected who stayed.

\section{CONCLUSION}

Revolutionary conflict offered many gradations for expressing a commitment to Great Britain. One was clear-cut and unambiguous. From the standpoint of the victors, bearing arms against those aligned with the cause of independence carried a stigma far greater than any other anti-patriot activity. Most who bore arms for the king came from the lower sorts. On the province's outer fringes, pre-war territorial conflicts among lesser agrarians fused into an especially vicious patriot-loyalist divide. Given the trajectory of

${ }^{113}$ Teucro Duce Nil Desperandum [Sire, do not despair], Recruitment Broadside for the First Battalion of the Pennsylvania Loyalists, Evans 15351, LCP. 
the war, it is no surprise that many - if not most - of those ordinary folks who took to the field under the loyalist banner on the frontier, in the countryside, and at Philadelphia and its environs decided to abandon their homes and depart for the insecurity of exile. Few of these ever returned. Yet active loyalism in Pennsylvania conceivably could have survived the departure of both the royal army and Philadelphia's elite colonial leadership, at least provisionally, if the British high command had formulated plans to open a new battlefront for those willing to stay and continue to bear arms beyond the reach of revolutionary forces or if these combatants had organized on their own. But loyalist operational independence never formed part of the strategic paradigm for either the British or the great body of Pennsylvania loyalists themselves. As Joseph Galloway's ongoing analyses exposed, explicit British support was deemed a precondition for military or political action, inadvertently ceding the initiative to the rebels. ${ }^{114}$

In practical terms, King George III's renunciation of any and all claims to the rebellious colonies in the Definitive Treaty of Peace left his surviving supporters in America with two options: adapt to the new republican order or go elsewhere. In Pennsylvania, His Majesty's advocates had already faced this grueling choice at the British evacuation of Philadelphia in 1778. Loyalist militants in particular did not weigh their choices in a vacuum at either juncture. Wartime behavior was especially critical in making the determination for or against reintegration. Militants juxtaposed their actions

\footnotetext{
${ }^{114}$ Loyalist frustration with British inaction in the mid-Atlantic colonies reached a crescendo in occupied New York in 1780 when William Franklin and nine other prominent loyalists formed the Board of Associated Loyalists with Lord Germain's formal approval from London. The British ministry hoped this organization could operate autonomously within overall imperial objectives. Opposed to such a measure but required to comply with the ministry's orders, Commander-in-chief Henry Clinton placed them directly under military command and made sure nothing was done without his permission, thereby frustrating the operational independence the group sought. For the Board of Associated Loyalists, see Ruma Chopra, Unnatural Rebellion, 170-174, 194-197.
} 
to the prospects for redemption that triumphant rebels offered. Legal status played a critical role, for patriots made a point of targeting those who bore arms against the rebellion in the treason, attainder, and confiscation statutes. Loyalist militants also paid a great deal of attention to the revolutionary faction exercising power. Fear of radical retribution under the leadership of council vice-president George Bryan and assembly speaker John Bayard at the 1778 evacuation motivated from three to five thousand loyalists to flee with General Clinton's forces. ${ }^{115}$

While no numbers are available for 1783 during the transition to moderate political ascendancy under council president John Dickinson, the contemporary debate in the newspapers - though vigorous - suggests no mass exodus and only isolated incidents of rebel reprisal. The evidence analyzed in this and the preceding chapter thus reveals that the evacuation of 1778 was the single most significant factor in nullifying loyalist commitment in Pennsylvania. The sizeable number of militant departures put control of the state in the hands of radical revolutionaries, leaving only a few willing to stick their necks out to fight for the imperial order. The colossal decline in pro-imperial militancy for the most part removed armed conflict as a menace from daily life in the settled areas of the province. After the close of the revolutionary struggle in 1783, nowhere in the state did threats from large numbers of "tories" brandishing weapons against republican rule persist. This departure of the ordinary militants who formed the core of the king's support

\footnotetext{
${ }^{115}$ Bryan replaced radical president Thomas Wharton Jr. at the head of the Supreme Executive Council a month before the evacuation because of the latter's death. As noted in Chapter 1, estimates for loyalist evacuees in 1778 are in Johann Heinrichs, "Extracts from the Letter-Book of Captain Johann Heinrichs of the Hessian Jäger Corps, 1778-1780," PMHB, vol. 22, no. 2, (1898), 145; the Earl of Carlisle is cited in Wilbur H. Siebert, The Loyalists of Pennsylvania (Columbus: Ohio State University, 1920), 52; William Eden to Alexander Wedderburn in Jackson, With the British Army in Philadelphia, 260.
} 
reduced tensions and established a more tolerant political climate, permitting successful reintegration of the ex-disaffected who did stay and try to adapt. To them we now turn. 


\section{CHAPTER 4 \\ REFUSING THE OATH: REINTEGRATION \& THE QUAKER PACIFISTS}

While most loyalist militants chose to depart and face the prospect of a new life elsewhere, a substantial number of those who did not bear arms against the movement for independence but were nonetheless dissatisfied with patriot rule opted to remain through the trials and tribulations of the early rebellion, the British occupation and evacuation, the later war years, and the aftermath of the peace. These Pennsylvanians are best understood as disaffected rather than loyalist. They included religious pacifists, neutralists, selfinterested opportunists, pragmatists convinced that England would emerge victorious, doubters of the direction, righteousness or legality of independence, apolitical provincials immersed in their own daily affairs, and people fearful of social disorder or terrified by the savagery of war who wanted nothing else than to be left alone. Despite a diversity of motives, revolutionaries viewed them all with suspicion, frequently with disdain, and sometimes as outright traitors. In the radical Constitutionalist view that dominated the patriot movement into the late 1770s, there was no room for the hesitant or the unsure. Everyone not unambiguously for the insurgency was judged to be against it. Radicals accordingly configured the law under the auspices of the state Constitution of 1776 to reflect that interpretation. ${ }^{1}$

Many disaffected-only Pennsylvanians no doubt preferred an orderly colonial government under the king to a more chaotic republican regime subject to popular rule. The depth of their commitment to that preference, however, was at best subdued. Unlike

\footnotetext{
${ }^{1}$ The Constitution of 1776 was the culminating expression of the radical ideological program, especially the Preamble and Declaration of the Rights of the Inhabitants. See Constitution of Pennsylvania, September 28, 1776, The Avalon Project, Yale Law School, http://avalon.law.yale.edu/18th_century/pa08.asp last accessed on October 20,2016. Radical attitudes and activity after passage of the constitution are covered at length in Brunhouse, The Counter-Revolution in Pennsylvania, Chapters 2 \& 3, 18-87.
} 
the militantly loyal, the merely disaffected were tentative - often silent - in articulating their position publicly in the face of radical opposition. Their disaffection was more about reacting to the political, economic and social transformation taking place around them than any proactive defense of monarchy - more against change than for preservation of the old order. ${ }^{2}$ Although motives varied, a series of core issues can be identified that summarize the disaffection of most of the less militant. In general, they were against popular sovereignty, warily considered the reign of "the rabble." They opposed loyalty tests, restrictions on freedom of expression and assembly, compulsory militia service, war-related taxation and fines, appropriation of foodstuffs, animals or goods for military defense, property confiscations, constraints on commerce, and the mandatory use of continental currency as legal tender, all the while holding a profound distrust for the revolutionary authorities who repeatedly fashioned, ordered and enforced these nefarious measures. Significantly, most espoused a common sentiment that Pennsylvania was their legitimate home - in many cases the only home they had ever known. Some also believed in the inevitability of British victory. Since royal arms would one day win the war and restore the prior regime, these disaffected residents only had to wait out events, thus engendering a mentalité of patience and forbearance rather than activism in the face of real or latent radical antagonism. And so they stayed.

The marginalized residents who chose to withstand rebel intransigence rather than abandon their native soil constitute the heart and soul of the Pennsylvania reintegration saga. Patriot anti-disaffection legal measures, especially the Test Act, played a central

\footnotetext{
${ }^{2}$ Henry James Young refers to this dichotomy as "static" and "dynamic" loyalists. I prefer to distinguish between loyalist militants and the disaffected-only because it is often difficult to find loyalist conviction in the attitudes or actions of the disaffected "static" residents who were mainly dissatisfied with the rebels.
} 
role in their experience. In the dozen or so years following the loyalist exodus of 1778 , the disaffected who stayed legally evolved into disenfranchised nonjurors - that is, people denied their rights as citizens for refusing to swear allegiance to the revolutionary state. Treatment of the disaffected/nonjurors drew deep political cleavages among patriot factions, with radical Constitutionalists opposing and moderate Anti-Constitutionalists or Republicans favoring their reincorporation into society. We have seen how these blocs configured and applied the law to further their respective exclusionary or inclusionary goals. Beyond patriot actions, however, the disaffected themselves furnished critical pieces of the reintegration puzzle.

Among the disaffected non-militants who stayed in Pennsylvania, reform-minded pacifist Quakers afford us the most comprehensive picture of the intricacies of reintegration because of their principled dogmatism in the face of radical hostility. This antipathy developed well before the colonial insurrection. Much like the Virginia and Connecticut controversies on Pennsylvania's frontier, the rivalries and societal visions of pre-war Quaker and Presbyterian "parties" mutated into disaffected vs. radical discord during the Revolution. The root of this revolutionary strife lay in the absolute refusal of pacifist Quakers to aid the rebel war effort or submit to the test oath mandated by patriot law. The need to support the war ended with the peace of 1783 but the requisite oath endured. By spurning every opportunity to conform to the state's demands on allegiance, Quaker nonjurors played a decisive role in fostering the conditions that allowed republican legislators to repeal the Test Act. Through their commitment to pacifism, reformist Friends clearly established that they posed no threat to revolutionary rule, unlike militant loyalists. After independence, Quakers signaled further that they were 
perfectly willing to embrace the nascent republican order. This non-threatening posture and the readiness to accept republican sovereignty converged with moderate AntiConstitutionalist electoral triumphs, culminating in the Test Act repeal of 1789 and the full legal reintegration of the formerly disaffected.

\section{QUAKER PACIFISM, RELIGIOUS REFORM \& THE PEMBERTON BROTHERS}

The Quaker admixture of pacifism plus the determination to stay in Pennsylvania was diametrically juxtaposed to loyalist militancy, with its predisposition to bear arms and abandon the province when martial endeavors did not accomplish their ends. Since most pacifist Friends chose to remain and face an uncertain future, they provide an ideal model for an in-depth analysis of non-militant disaffection and reintegration. ${ }^{3}$ Pacifists censured the struggle for independence not necessarily because they disagreed with the goals of the Revolution - though most likely did - but because they believed violence and war were inherently evil and contrary to the principles espoused in their particular interpretations of Christianity. ${ }^{4}$ Beyond this passivity, however, three other issues

\footnotetext{
${ }^{3}$ Of the 146 disaffected men identified as Quakers in the research thus far for this study, 98 stayed in Pennsylvania after the evacuation (67.1\%), 10 returned later (6.9\%), and 38 remained in exile (26.0\%).

${ }^{4}$ The Quaker pacifist view was first advocated in England on March 5, 1654 by founder George Fox in response to a request by Oliver Cromwell: "I [who am of the world called George ffox] doe [sic] deny the carrying or drawing of any carnall [sic] sword against any, or against thee Oliver Cromwell or any man in the presence of the lord god I declare it." See Norman Penney, ed., The Journal of George Fox Edited from the MSS (New York: Octagon Books, 1973), 161-162. For background on the Fox-Cromwell encounter, see H. Larry Ingle, First Among Friends: George Fox and the Creation of Quakerism (New York: Oxford University Press, 1994), 118-125. This statement became the basis for the Quaker Peace testimony which Fox and 11 other Friends published on November 21, 1660 in A Declaration from the Harmless \& Innocent People of God, called, Quakers Against All Sedition Plotters \& Fighters In the World. For the removing of the Ground of Jealousie and Suspicion from both Magistrates and People in the Kingdome concerning Wars and Fighting (London: Reprinted by John Bringhurst, 1684). In addition to the biblical references cited in the above declaration, select verses of Christian scripture instruct disciples to love their enemies or refrain from employing force, as in the Gospels of Matthew and Luke. Matthew 5:39 states: "But I say to you, offer no resistance to one who is evil. When someone strikes you on [your] right cheek, turn the other one to him as well." Matthew 5:44 declares: "But I say to you, love your enemies, and pray for those who persecute you." Luke 6:27-29 says: "But to you who hear I say, love your enemies, do good to those who hate you, bless those who curse you, pray for those who mistreat you. To the person who strikes you on one
} 
nurtured a seemingly unavoidable clash between pacifism and revolution. The first concerned willful rejection of the payment of taxes and fines levied for direct or indirect promotion of the war. This conviction brought pacifists into conflict with the patriot authorities responsible for collecting fines for refusal of militia service. A second scriptural imperative prohibited the taking of oaths of any sort. Such a stance violated the patriot Test Act obligating citizens to take an oath of allegiance to the state of Pennsylvania. ${ }^{5}$ Finally, Quakers believed government was the work of divine revelation: the jurisdiction of God, not humankind. In their view, established government had the blessing of the Creator. Mere human beings had no right to meddle with what Providence had designed, which naturally forbade partaking in any enterprise calculated to dissolve existing authority. ${ }^{6}$ Together, these four tenets rendered adherents to pacifism antithetical to the broader republican crusade, relegating them in patriot eyes to the ranks of the tories, the inimical, and the obnoxious - all contemporary terms for disaffection.

Reformist Quakers were the most conspicuous of Pennsylvania's pacifists. As the revolutionary crisis opened in the mid-1760s, Quakers comprised about one-third of the

cheek, offer the other one as well.” All quoted verses are from The New American Bible (World Bible Publishers, 1987).

${ }^{5}$ The scriptural basis for the refusal to take an oath was based on Matthew 5:34, which states "But I say to you, do not swear at all; not by heaven, for it is God's throne; nor by the earth, for it is his footstool." And again in James 5:12, which states "But above all, my brothers, do not swear, either by heaven or by earth or with any other oath."

${ }^{6}$ There are multiple references in both the Old and New Testament which substantiate this position. The most poignant may be Paul's Letter to the Romans 13:1-3 which specifically addresses the point: "Let every person be subordinate to the higher authorities, for there is no authority except from God, and those that exist have been established by God. Therefore; whoever resists authority opposes what God has appointed, and those who oppose it will bring judgment upon themselves. For rulers are not a cause of fear to good conduct, but to evil." 
colony. ${ }^{7}$ Members of the Society of Friends resided mainly in the city of Philadelphia proper and the rural counties in the southeast which formed the backbone of European settlement. The structure of colonial government responded to this demographic and historical reality. William Penn and his Quaker followers had founded the colony under a 1681 charter from King Charles II, initially controlled all branches of government into the early 1700 s, and continuously dominated the provincial assembly for decades. ${ }^{8}$ By any measure, they were a major political force with which to be reckoned. During the Revolution, an unyielding commitment to pacifism forced reformist Quakers to wrestle with a distinctive set of disaffection issues that greatly contributed to shaping the overall process of reintegration.

Key figures among Pennsylvania’s Quaker leadership provide a template for a comprehensive analysis of the disaffected who stayed. The sect's internal dynamic played an instrumental role in determining the composition of that leadership. Quakers in the revolutionary era can be divided into at least four groups. First and foremost were those who led and obeyed the precepts of the spiritual renewal that began in Pennsylvania prior to the outbreak of the French and Indian War. These reformers claimed divine inspiration and urged followers to return to the more steadfast and pious discipline of their English

\footnotetext{
${ }^{7}$ This oft-cited estimate comes from "The Examination of Doctor Benjamin Franklin \&c., in the British House of Commons, Relative to the Repeal of the American Stamp Act, in 1766," Albert Henry Smyth, ed., The Writings of Benjamin Franklin (New York: The Macmillan Company, 1907), vol. 4, 415-416. It is also the only reference to Quakers in pre-revolutionary Pennsylvania given in the widely used Greene \& Harrington, eds., American Population Before the Federal Census of 1790, 116.

${ }^{8}$ Charter for the Province of Pennsylvania - 1681, The Avalon Project, Yale Law School, http://avalon.law.yale.edu/17th century/pa01.asp last accessed May 12, 2017. For Quakers in $17^{\text {th }} \& 18^{\text {th }}$ century Pennsylvania, see Rufus M. Jones, The Quakers in the American Colonies (New York: Russell \& Russell, 1962), especially 417-580.
} 
forefathers. Central to reform was an unconditional commitment to pacifism. ${ }^{9}$ More worldly Quakers prone to material affluence and the continuation of Quaker political dominance in the colony's affairs, who otherwise tried to respect reform-sanctioned religious and disciplinary ways, comprised a second group. The third cohort consisted of disowned Quakers who maintained a cultural affiliation with the sect but did not abide by the stricter religious and behavioral requirements of reformers. A fourth set considered themselves patriots, rejected pacifism altogether, and actively supported the colonial rebellion. They evolved into the Free Quakers.

In terms of religious and cultural identity, reformers stood at the center of the faith as adjudicators of Quaker orthodoxy. In Pennsylvania, they controlled the Monthly, Quarterly, and Yearly Meetings in the principal Quaker jurisdictions, the Meeting for Sufferings which decided how to approach the persecution emanating from revolutionary conflict, the Women's Meetings, and the Yearly Meeting for Elders and Ministers of the Yearly Meeting. Crucially, reformers had the final word on who was to be allowed to remain within the congregation and who was to be disowned. ${ }^{10}$ Control of religious institutions like the Society's seasonal Meetings greatly elevated the standing of reformers. Significantly, the overwhelming majority of those who identified as Friends acknowledged the reformers as final arbiters of all things Quaker.

\footnotetext{
${ }^{9}$ Jack D. Marietta, The Reformation of American Quakerism, 1748-1783 (Philadelphia: University of Pennsylvania Press, 1984), 136-141, 169-170, 178-182, 192, 236-237.

${ }^{10}$ Disownment was not as severe as excommunication in other Christian faiths. The main penalty was a prohibition to attend the Society's business meetings, separating the culprit from the inner workings of the sect. Disowned Quakers were not shunned by the Society's members. In fact, those disowned could still attend worship services and were often encouraged to do so in the hope that they would recognize their errors and reform. Moreover, as per Marietta, "disownment was never final. There was no kind of behavior or belief which Friends in Pennsylvania never forgave" - Reformation of American Quakerism, 10.
} 
The lines separating the other three groups blurred and sometimes overlapped. For example, the critical disownment penalty could be equally applied to the materially and politically prominent, as well as those culturally Quaker or the combative Free Quakers. Distinctions lay in the reasons for disownment. Over the years, reformers gave Friends who pursued political and economic power a great deal of leeway to allow them to arrive at their own realization that their priorities were askew and needed rectification. In many cases, this approach succeeded, integrating those worldly astray back into the fold although disownment could eventually apply in cases of continued noncompliance. Those whose prime affiliation to the sect was cultural rather than religious often fell victim to disownment for behavioral breaches such as marrying outside the faith, inattendance at Meeting and breaking the Sabbath, or moral problems such as profanity, rowdiness, inebriation, gambling, sexual misconduct or loose business ethics. Free Quakers came into direct conflict with the denomination's increased pacifism by contravening the core call to nonviolence and reformers unabashedly disowned them for partaking in the war. Individual Quakers' positions were not stagnant: as followers of the Society evolved in their devotions, their personal lives, or their response to the Revolution, they could move from one group to another. Jack Marietta's comprehensive study of the eighteenth-century Quaker reform movement tabulated disownment cases in four major delinquency categories: marriage, sectarian (which included violations of pacifist conduct), sexual, and delinquency with victims. ${ }^{11}$ The overwhelming majority of infractions had to do with behavioral norms. Only 539 of about 13,000 disownments

\footnotetext{
${ }^{11}$ Marietta divides delinquency into personal faults such as drunkenness, profanity, lying, Sabbath breaking, taking oaths, or military activity and those that affect others which he labels as "delinquency with victims." The latter include debt, assault, slaveholding, fraud, theft, destroying property, counterfeiting, and smuggling, among others.
} 
during the age of reform concerned military activity or subscribing to the patriot oath of allegiance, a rate of 4.1\%. In another detailed study, Arthur Mekeel unearthed 906 warrelated disownments in Pennsylvania for military activism, assisting the war effort, paying fines and taxes, taking the test oath, and holding public office. ${ }^{12}$ Whether warrelated or not, it was reformers who set the bar for Quaker propriety, decided disownments, and controlled the faith's pivotal institutions in Pennsylvania. For all intents and purposes, the religion was theirs, a fact Quaker leadership in England fully recognized. ${ }^{13}$

These internal nuances were not always evident to outsiders. Given the Society's insularity, patriots often conflated disowned Quakers or those in the public eye with the reformers who emphasized withdrawal from all involvement in government and a strict adherence to pacifism, leading to charges of hypocrisy. Typical examples are in Lutheran minister Henry Melchior Muhlenberg's journal, peppered with derisive anti-Quaker remarks. In 1764, he criticized "these pious sheep, who had had such a tender conscience during the long Spanish, French, and Indian War, and would have rather died than lift a hand for defense against the most dangerous enemies." As the patriot militia mobilized a dozen years later, he scoffed at "the inhabitants who make a matter of conscience... and

\footnotetext{
${ }^{12}$ Marietta, Reformation of American Quakerism, Table 1, "Varieties of Quaker Delinquency," 6-7. There were 504 offenses for military activity and 35 for taking oaths; Mekeel, The Relation of the Quakers to the American Revolution, "Disownments by Cause," Appendix IV, 336.

${ }^{13}$ There were 19 Monthly Meetings in the three key Quaker counties of Pennsylvania at the time of the Revolution. In Chester County: Uwchlan, Sadsbury, Bradford, Newgarden, Concord, Goshen, Warrington \& Chester. In Bucks County: Buckingham, Falls, Middletown \& Wrightstown. In Philadelphia County: Philadelphia, Abington, Exeter, Darby, Gwynedd, Radnor \& Richland. See Marietta, Reformation of American Quakerism, Table 2, "Severity of Discipline in Monthly Meeting," 27. As for the relative import of Meetings, Mekeel emphasizes "especially those of Philadelphia and London, whose leadership in the Society was well recognized," The Relation of the Quakers, 3. In America, there were also Quaker Meetings in New England, New York, New Jersey, Delaware, Maryland, Virginia, North Carolina, South Carolina \& Georgia. Mekeel, "Disownment by Years," Appendix III, 335.
} 
meanwhile raised the price of all necessities and amassed money for their tender consciences." ${ }^{14}$ The misconstruction of reformist ends came to a head as General Howe and his invading redcoats marched towards Philadelphia in 1777. Radical revolutionaries reacted to this existential threat with a series of arrests and banishment, targeting those perceived as potential enemy collaborators. Renowned Philadelphia Friends headed the list. These deportees became known as the Virginia exiles. Rebels allowed their return about seven weeks before the British evacuated, whereupon most of the banished chose to remain in Philadelphia rather than depart. Their ensuing decade-plus journey through the political landscape presents a guide to the Quakers who stayed and successfully reintegrated on the basis of non-threatening behavior and acceptance of the postwar republican order.

Most conspicuous among the original reformers and later Virginia exiles were Israel, James, and John Pemberton. By the time of the Revolution, Israel had earned the nickname "King of the Quakers" because of "his extensive undertakings and influence, and his vigorous, assertive manner." 15 As torchbearers of the Quaker community, the brothers played a major role in the deportation drama that unfolded from the late summer of 1777 through the spring of the following year. Their stature, commitment to pacifism and reform, return from forced exile, and decision to stay in Philadelphia thrust them into the unwelcome turmoil of revolutionary and postwar politics. Unlike the militant loyalists who fled at the British evacuation of June 1778, all three Pembertons deliberately chose

\footnotetext{
${ }^{14}$ Henry Melchior Muhlenberg, Notebook of a Colonial Clergyman, Tappert \& Doberstein, eds., February 6, 1764, 99 \& October 29, 1776, 166. Quakers used the expression "tender consciences" as a positive affirmation justifying their pacifism but opponents often flipped the term in derision or irony.

${ }^{15}$ Richard Bauman, For the Reputation of Truth: Politics, Religion, and Conflict among the Pennsylvania Quakers 1750-1800 (Baltimore: Johns Hopkins Press, 1971), 241.
} 
reintegration over departure. Philadelphia was their home, and their home it would remain. Although the brothers' reintegrative paths diverged over time - the design of both choice and fate - their long-term commitment to pacifist principles and reform contributed notably to alleviating political tensions in the postwar era and creating a climate conducive to the legal reassimilation of nonjurors.

The siblings had deep roots in Pennsylvania. They were grandsons of Phineas Pemberton, one of the original Quaker pioneers who embarked on William Penn's Holy Experiment. Their father, Israel Pemberton Sr., was among the first colonial offspring of English Quaker stock, born in Bucks County on the outskirts of Philadelphia in 1684, only two years after the settlement's founding. Israel Sr. went on to a prosperous life as a merchant, accruing land and wealth, serving in the colonial assembly, and exercising the faith until his death in 1754. Along the way, he married Rachel Read, who gave birth to ten children. Not all survived into adulthood like the three brothers. Israel Jr. arrived in 1715, James in 1723, and John in 1727. Mother Rachel died in February 1765, a month before passage of the Stamp Act inaugurated the imperial crisis. ${ }^{16}$ By the time hostilities broke out at Lexington and Concord in April 1775, the Pemberton brothers were at the apex of their influence: Israel was 59, James 51, and John 47.

Raised in strict adherence to Quaker doctrines, the Pembertons received "a careful, guarded education while young," including instruction at the Friends' school. ${ }^{17}$

\footnotetext{
${ }^{16}$ Thayer, King of the Quakers, 3-5; "Brief Memoirs of the Life of John Pemberton, intended as an Introduction to a Journal of some parts of his Life and Travels," Friends Miscellany, vol. 8, no. 2 (First Month, 1836), 49 (hereafter John Pemberton Journal); "Memoirs of James Pemberton," Friends Miscellany, vol. 7, no. 2 (First Month, 1835), 52 (hereafter Memoirs of James Pemberton).

${ }^{17}$ John Pemberton Journal, 49; John F. Watson, Annals of Philadelphia and Pennsylvania, in the Olden Time; Being a collection of Memoirs, Anecdote, and Incidents of the City and Inhabitants and of the
} 
Israel was more aggressive than his even-tempered father but "kind and generous" nonetheless. In 1737, he married Sarah Kirkbride. The union produced eight children. Sarah died around the year 1747, at which point Israel married twice-widowed 43-yearold Mary Stanbury Hill Jordan, with whom he had one more child. Of the nine total offspring, six lived to maturity. ${ }^{18}$ James was studious and "distinguished for diligence, integrity, and benevolence" from his youth. His mother noted in him a "mildness of temper and steadiness of conduct." The editor of his memoirs considered him "humble." Because of the uncertain health conditions of the day, the second brother went through three marriages, engendering seven offspring. In 1751, he married Hannah Lloyd. They had four daughters and two sons. Hannah died in 1764 before the age of thirty. Four years later, James married Sarah Smith, who died of childbirth complications in 1770. A half decade later, he remarried, this time to the widow Phoebe Lewis Morton, who bore no children. ${ }^{19}$ John too was noted for his compassion and generosity. Not overly concerned with worldly matters, he did not marry until the age of thirty-nine. At his wedding to Hannah Zane in 1766 at the Meeting House on High Street, he ordered provisions sent to all prisoners then confined in the Philadelphia jail. Unlike his brothers, John never had occasion to remarry and had no children with Hannah. ${ }^{20}$ Of this matrimonial collage,

earliest settlements of the Inland part of Pennsylvania, from the Days of the Founders (Washington DC: Ross \& Perry, 2003; reprint of the 1856 edition), vol. 1, 595; Thayer, King of the Quakers, 5.

18 "Israel Pemberton," Legislators in Pennsylvania, vol. 3, 1000; Thayer, King of the Quakers, 5, 7-8, 26; Crane, ed., The Diary of Elizabeth Drinker, Biographical Directory, 329.

19 "James Pemberton," Legislators in Pennsylvania, vol. 3, 1020; Memoirs of James Pemberton, 50, 52, 57, 60; Diary of Elizabeth Drinker, Biographical Directory, 329; Sabine, Biographical Sketches, vol. 2, 158-59.

${ }^{20}$ John Pemberton Journal, 51-52; Diary of Elizabeth Drinker, Biographical Directory, 329; The Life and Travels of John Pemberton, A Minister of the Gospel of Christ (London: Charles Gilpin, 1844), 49. 
Mary (with Israel), Phoebe (with James), and Hannah (with John) survived to confront the revolutionary challenge alongside their respective husbands.

As sons of a prosperous merchant, the brothers received training in commerce from early on. Since London Quakers dominated North American markets during the colonial period, it is not surprising that much of the Pemberton trade was tied to England, where these Philadelphians likewise had deep religious roots. Correspondingly, all three crossed the ocean to fortify their business connections and religious commitment. Israel first did so in 1735, James followed in 1748, and John in 1750. These trips reinforced bonds with the mother country. By the end of the 1740s, Israel Pemberton had made a fortune as a merchant and transitioned much of his wealth into land, mortgages, notes, and bonds. In addition, he and his brothers came into "one of the largest fortunes in Pennsylvania" at their father's death. Investments and inherited wealth produced a financial stability that allowed Israel more time for civic affairs and philanthropy. He toyed with politics briefly - voters elected him to succeed his father in the colonial assembly in 1750 after the latter's retirement. But he was surprisingly defeated the following year and lost the taste for public office. ${ }^{21}$

Israel's return to civic activity included membership in the Library Company, the American Philosophical Society, the Union Fire Company, the establishment of Quaker and private schools for children, charitable aid to the poor and needy, and coordination of relief efforts for displaced French Acadian refugees shipped to Philadelphia in 1760. As founder and manager of the Pennsylvania Hospital, he personally donated $£ 100$ for its

\footnotetext{
${ }^{21}$ John Pemberton Journal, 49; Mekeel, Relation of the Quakers, 15; Memoirs of James Pemberton, 51; "James Pemberton," Legislators in Pennsylvania, vol. 3, 1022; "Israel Pemberton," Legislators in Pennsylvania, vol. 3, 1003-1005.
} 
construction. Israel is probably best known today as an early antislavery activist, playing a leading role as clerk of the 1754 Quaker Yearly Meeting which first took up the issue of coerced bondage and decreed internal reforms prohibiting Quaker ownership of slaves. In 1775, he helped found the Society for Relief of Free Negroes Unlawfully Held in Bondage which later evolved into the Pennsylvania Abolition Society, the first organization of its kind in America. ${ }^{22}$

James Pemberton was also successful in commerce, continuing steadily in the merchant trade well into the revolutionary and postwar era. Like Israel, he too engaged in religious and civic affairs, dedicating much of his life to the "distribution of religious and instructive books among that class of the community who did not possess the advantages of a liberal education." Above all, he committed to service among his fellow Quakers. He was clerk of the Philadelphia Monthly Meeting from 1756 to 1777, overseer from 1757 to 1760, and an elder from 1759 onward. James also received appointments to the Quarterly Meeting eleven times between 1760 and 1795. Most importantly, he played a leading role in the Philadelphia Yearly Meeting and the Yearly Meeting for Sufferings that confronted revolutionary ire. Other activities included his election as manager of the Pennsylvania Hospital in 1758, for which he remained a lifelong contributor. Later, he joined his older brother as a founder of the abolition society. Well into the nineteenth century, James maintained a reputation for being "devoted to deeds of charity and love.",23

\footnotetext{
22 "Israel Pemberton," Legislators in Pennsylvania, vol. 3, 1009-1010; Thayer, King of the Quakers, 28, 3639, 195-200; Theodore Thayer, "The Pemberton Papers," PMHB, vol. 67, no. 3 (July, 1943), 284. John \& Isaac Comly, eds., "Annals of the Pemberton family, with notes respecting some of their contemporaries," vol. 7, no. 1, Fourth Month, 1835, Friends Miscellany (Philadelphia: J. Richards, 1835), 48.

${ }^{23}$ Memoirs of James Pemberton, 59; “James Pemberton," Legislators in Pennsylvania, vol. 3, 1022-1024; Sabine, Biographical Sketches, vol. 2, 159.
} 
John Pemberton was smitten by a deep religious fervor during his voyage to England in the company of Quaker minister John Churchman. On landing at Dover on May 6, 1750, the "sober, well inclined young man" - as per Churchman - continued with the preacher on his mission into the English countryside and all but disregarded the economic aspect of his trip. In a letter to Israel two months later, John noted "how much longer I shall stay with our said friend, I do not at present know; but have no satisfaction when I think of leaving him, though I cannot account for the reason." Not until September 1753 did the two part ways. By then, John had decided to dedicate his life to the propagation and consolidation of his deepening faith. This sacred vow never allowed him to achieve the wealth of his brothers, although his share of the family inheritance provided relative affluence. John expressed his religious sentiment through personal contributions to the indigent, spiritual consolation, and application of Quaker disciplinary norms. The youngest Pemberton often would "go to the shambles" on the spur of the moment and disburse money to the poor. He also spent a great deal of time visiting the aged, the afflicted, orphans and widows. John too was present at the 1754 Quaker Yearly Meeting which first tackled the question of slavery among the faithful. Visibly devout, he led efforts to uphold Quaker morality. In 1765, Friends charged him with delivering a remonstrance to Governor John Penn opposing "vain amusements." As clerk of the Yearly Meeting three years later, he signed a letter to Quaker youth against "the ensnaring diversions of the horse-races and stage-plays." The brothers' responses to the Stamp Act in 1765 reflect the value each placed on the material and the spiritual. Israel and James signed the antiparliamentary nonimportation agreement. John did not. ${ }^{24}$ 
Beyond civic assistance, philanthropy, commerce and other secular activities, the siblings increasingly devoted their efforts to the purification of Quakerism through the reform movement. That commitment remained unshakable throughout their lives but each stressed different aspects of devotion. John dedicated himself entirely to the divine realm, becoming a renowned preacher and advocate of the Quaker testimony. James became embroiled in provincial affairs of state during peacetime, responding to a belief that politics held the key to the preservation of Quaker religious liberties. As the eldest and wealthiest, Israel continued in the dual role of humanitarian and social activist. The application of religious principles to local matters, however, often projected the King of the Quaker's activism into provincial politics, conflating the spiritual and temporal.

\section{COLONIAL POLITICS, THE IMPERIAL CRISIS \& THE EARLY REVOLUTION}

The two decades preceding the opening hostilities at Lexington set the conditions, context and tone for the subsequent Virginia exile, the persecution of pacifists during the war, and the Quaker reintegration drama in the revolutionary aftermath. Central to this dynamic was the complex interplay between Quaker religious reform, the Quaker party in the assembly, the proprietor in England and his provincial supporters, and the arriviste faction of Philadelphia mechanics and frontier farmers known initially as the Presbyterian party. During this period, the Pembertons tried to bridge their denomination's spiritual reform/temporal politics divide, not always successfully. Given the brothers' prominence among Friends, outsiders came to regard them as the quintessential expression of official Quaker positions and values. It is not possible to understand radicals' bitter resentment against Quakers at the dawn of the Revolution, their decision to arrest, banish and

${ }^{24}$ John Pemberton to Israel Pemberton, July 30, 1750, The Life and Travels of John Pemberton, 4; ibid., 51; John Pemberton Journal, 51-52; Scharf \& Westcott, History of Philadelphia, 272-273. 
marginalize pacifists during the war, and the later movement to permanently exclude nonjuror Friends from participation in republican life without an appreciation of prerevolutionary politics in Pennsylvania. Quaker wartime mistreatment and postwar reintegration was an extension of pre-war disputes with radicals.

The French and Indian War and the expansion of white settlement on the colony's western frontier destroyed the political paradigms which ruled Pennsylvania for about eighty years, compelling Quakers to examine their pacifist doctrine. The alliance of France and Indians in the west sought to turn back British-American incursions into indigenous territory. Pennsylvania's frontier settlements soon came under attack. ${ }^{25}$ With the borderlands aflame, frontier calls for creation of a provincial militia followed. The crisis created rifts between reform purists and key Quaker delegates in the assembly. Confronted with the breakdown of colonial peace and a bottom-up clamor for martial remedies throughout the province, reformers called for a Quaker withdrawal from public life as the only viable alternative for preserving a true adherence to pacifist principles. Yet prominent Quakers in the assembly shrank from voluntarily relinquishing power.

The contrasting views of House speaker Isaac Norris and James Pemberton help explain the divisions within the reform-driven Society of Friends, the Quaker party in the assembly, and the relationship between the two. Norris chose to adjust his faith to the government's need to provide for military defense. James did not. ${ }^{26}$ Richard Bauman has

\footnotetext{
${ }^{25}$ The Anglo-French clash for dominance in North America is treated at length in Richard White, The Middle Ground, especially chapters one to six, 1-268.

${ }^{26}$ Isaac Norris was elected to the assembly in all but two years between 1735 and 1765. As House speaker from 1749 to 1764, he led the Quaker party in the assembly through the entirety of the French and Indian War. Norris rose to the level of a political legend in Pennsylvania politics and became the personification of those affluent politically inclined Quakers who tolerated religious reforms but prioritized the temporal. See "Isaac Norris," Legislators in Pennsylvania, vol. 3, 944-974.
} 
divided Quakers in this era into three categories: reformers, politicians, and politiques. Reformers stressed obedience to the sect's peace testimony and discipline. Politicians were the worldly and often prosperous Quakers who refused to renounce political power. Politiques tried to function in both worlds simultaneously. According to Bauman, John Pemberton belonged to the first group, Isaac Norris the second, and both Israel and James Pemberton the third. In addition, eminent political figures like Joseph Galloway and Benjamin Franklin led the Quaker party in the assembly against the proprietary bloc but were not religiously affiliated with the Society. Before the Revolution, these divisions produced some curious situations among imagined allies. For example, James led a minority faction within the Quaker party in the assembly against Franklin's majority that voted against any legislation violating "traditional Quaker pacifism." Later in the mid1760s, Israel would publicly defend the proprietors, his historical enemies, in favor of maintaining Penn's original charter and opposing the royal government plan, while James would side with Galloway and Franklin against his brother. ${ }^{27}$

These positions played out during the opening round of the war against France. In November 1755, representative James Pemberton voted with six other Quakers against a $£ 60,000$ military appropriation which passed despite their opposition. In March 1756, he voted to defund the troops raised the year before. For James, the clash between religious honesty and temporal accommodation revealed that many Friends had capitulated to temptation. "[T]here is indeed a majority amongst us who show little regard to the Principles of their Profession," he wrote to a fellow Quaker in England. His desire to promote pacifism as an assemblyman proved untenable. In June 1756, James resigned

${ }^{27}$ Bauman, For the Reputation of Truth, Appendix II, Capsule Biographies, 235-245; Thayer, King of the Quakers, 83-84, 202; Marietta, Reformation of American Quakerism, 153-155. 
from the colonial assembly alongside five other conflicted Quaker representatives. ${ }^{28}$ Their resignation initiated what became a voluntary abdication of Quaker power in succeeding years that, on the other hand, strengthened the reform movement among the faithful with the inauguration of a parallel crusade for stricter enforcement of the discipline's behavioral norms. Like the mandate to retire from wartime politics, these reforms met with internal resistance. When members chose not to conform, reformers granted the disobedient a chance to reconsider their transgressions and make amends. But failure to comply ultimately resulted in disownment.

The roots of revolutionary discontent with the Quakers can be traced directly to the reformist rigor of the colonial period. Two interrelated issues drove the developing antagonism: Quaker policy towards indigenous peoples and the longstanding historical acrimony between Presbyterians and Friends. William Penn's peaceful settlement of Pennsylvania with the cooperation of resident natives was a core component of Quaker identity. True to their appellation, the Society of Friends regarded Indians as friends. As an exemplary colonial address signed by Israel Pemberton explained, "they received our Ancestors with Gladness, relieved their Wants with open Hearts ... and for a long Course of Time gave constant and frequent Proofs of a cordial Friendship." In contrast to North American colonies like Massachusetts and Virginia, no major conflicts with indigenous peoples erupted into war under Pennsylvania Quaker governance. Harmony with natives was a point of pride among Friends who regarded its preservation as the fulfillment of the sect's “testimony" and the founder's original vision. In a word, peace was sacred. ${ }^{29}$

\footnotetext{
28 “James Pemberton,” Legislators in Pennsylvania, vol. 3, 1025-1026.
} 
Intersecting this view was a profound Quaker fear of the Calvinists who had persecuted the Society as far back as the English civil wars of the seventeenth century. On the American side of the Atlantic, Calvinist Congregationalists in New England had inflicted similar sufferings on local Quakers there, also in the seventeenth century. Over time, Presbyterians became the dominant Calvinist sect in Pennsylvania. Although this factor did not weigh much in the colony's early history, Presbyterians made up the bulk of a large Scots-Irish migration during the middle part of the eighteenth century and changed conditions. Quakers viewed this influx with trepidation as the advent of intolerance. Since sizeable portions of the newcomers chose to settle on the frontier, indigenous and sectarian issues soon merged.

The Pembertons' own observations leading up to the Revolution confirm Quaker qualms over Presbyterian intentions. As the most politically immersed of the siblings, James left an abundant trail of evidence. He first became aware of the divide between the faiths in 1740, at the age of seventeen, when he noticed a mob of "fanatical Presbyterians, with axes in their hands, going to destroy a Catholic chapel.” A dozen or so Quakers "exhorted them" to stop and, in this instance, "they dispersed without effecting their design." ${ }^{30}$ In the aftermath of the French war, James drew upon historical antecedents in communications with fellow Quakers in Britain, referring to "the old envious persecuting spirit" of the seventeenth century and "the Insolence of Presbyterian Cabals." By 1768,

\footnotetext{
29 "The Humble Address of the People called Quakers, residing in the city of Philadelphia, on behalf of themselves and many others," April 12, 1756, Colonial Records, vol. 7, 85-86. Israel Pemberton was one of six signatories. Jake Marietta calls the relationship between Pennsylvania's Quakers and the Delaware Indians of "mythic importance." Reformation of American Quakerism, 156-157.

${ }^{30}$ Jean Pierre Brissot de Warville, "Letter XXXIV - The Refusal of Quakers to Take Any Part in War," New Travels in the United States of America (Bowling Green, OH: Historical Publications Company, 1919), 249.
} 
he was censuring "ye rashness of their conduct." Israel held similar views. When some colonial legislators asked the Pennsylvania governor to declare war on the Delaware people in 1756 and approve a bounty for the taking of native scalps, a horrified Israel blamed "blood-thirsty Presbyterians." ${ }^{, 1}$ This Pembertonian imagery speaks volumes. Fanatical, envious, rash, insolent, bloodthirsty, and cabals are not the stuff of a dispassionate lexicon. Since Presbyterians came to dominate radical elements among rebels in Pennsylvania much like Congregationalists in New England, the terms radical and Presbyterian conflated idiomatically among Quakers during the revolutionary era.

As frontier and sectarian concerns converged in colonial Pennsylvania, QuakerPresbyterian rancor played out in the domain of Indian relations. Conforming to the sanctity of their founding commitment, Quakers tried to preserve peace with native peoples despite the disruptive challenges of imperial war with France. They viewed Presbyterians as a major obstacle in this endeavor. Quite simply, Friends did not believe Indians were the problem - Presbyterian frontier settlers were. All the natives needed for a return to peace was better treatment from frontiersmen. Correspondingly, the three brothers participated in numerous bids to restore colonial concord with local Indians. Israel and James led the 1756 effort to create The Friendly Association for Regaining and Preserving Peace with the Indians by Pacific Measures - a designation which in itself encapsulates Quaker views succinctly. ${ }^{32}$

\footnotetext{
${ }^{31}$ Marietta, Reformation of American Quakerism, 156-157, 193; Hutson, Pennsylvania Politics, 155; Mekeel, The Relation of the Quakers, 39. Some of the legislators proposing the scalp measure were unreliable Quakers. They were disowned within the month.

${ }^{32}$ Marietta, Reformation of American Quakerism, 188-89; Thayer, King of the Quakers, 105, 125-29; Memoirs of James Pemberton, 59; Watson, Annals of Philadelphia and Pennsylvania, in the Olden Time, vol. 1, 595.
} 
The period was rife with peace talks between Indian nations and the Pennsylvania government. Official colonial delegations sometimes included Quakers, other times not. In latter instances, unwanted Friends often inserted themselves into the negotiations as independent advisors anyway, creating further friction with other provincials. The Easton Treaty peace conference the next year was perhaps the most instructive of Quaker labors in this regard. Israel, James and John led a delegation of twenty-four Quakers whose intercession with the chief of the Delawares created the impression among non-Quakers that the pacifists were acting against the colony's best interests. Indian trader George Croghan noted months later that "the Quakers Still Continue to Sett up Teadyuscung [sic] Against ye Governor." ${ }^{, 3}$ Quaker repute for deceitful engagement persisted through the French and Indian War, so much so that, when the Paxton rioters amassed in 1764 on the outskirts of Philadelphia in the wake of Pontiac's War and penned their "Declaration of the injured Frontier Inhabitants," they explicitly condemned "Israel Pemberton (an ancient leader of that Faction, which for so long a time have found means to enslave the Province to Indians), together with others of the Friends" for giving the natives "a Rod to scourge the White People that were settled on the purchased Lands." 34 Thus, frontier conflict with the Indians exacerbated an already historically deep distrust between Quakers and Presbyterians.

This mutual suspicion, later aggravated by class tensions and dubious imperial policies, continued in the lead-up to revolutionary hostility, during the war, and in the

${ }^{33}$ A List of Quakers at Easton Treaty, August, 1757, Pennsylvania Archives, $1^{\text {st }}$ Series, vol. 3, 262; George Croghan to anonymous recipient in New York, December 18, 1757, Pennsylvania Archives, ${ }^{\text {st }}$ Series, vol. 3, 319. Teedyuscung was a Delaware chief.

34 "The Declaration of the injured Frontier Inhabitants, together with a brief sketch of Grievances the good Inhabitants of the Province labour under," February 17, 1764, Colonial Records, vol. 9, 142-145 (quote is on 145). 
reintegrative aftermath of the peace. Prior to the rebellion, control of the assembly had guaranteed Quaker security. But by 1775, the provincial balance of power had shifted. The Society of Friends' reformist retreat from public life facilitated a Presbyterian-led radical surge in local politics. When armed revolt against Great Britain finally arrived, the perception that the Quaker faction had betrayed the interests of the state loomed large. For their opponents, Friends had demonstrated beyond the shadow of a doubt that they could not be trusted. After the sect's pronouncements in the early years of revolution, it was but a short skip and a jump to presume that Quaker allegiance lay with the British.

The voluntary Quaker descent from power came in spasmodic contractions over the peaks and valleys of the imperial crisis. The Pembertons led the way. As noted earlier, Israel and James joined four hundred other merchants - many of whom were Quakers - in signing the nonimportation agreement against the Stamp Act in October of 1765. From the British perspective, that association was an extralegal and, in effect, illegal body. The brothers and their coreligionists thus began the crisis on the side of an unlawful resistance. ${ }^{35}$ Their worries over imperial overreach were genuine, as Israel's later comments revealed. "How unreasonable it is to attempt to govern a people with severity when gentle methods and constitutional laws would secure their affection \& allegiance in ye most effectual manner," he wrote in the midst of the tea controversy. ${ }^{36}$ But disapproval of British colonial policy clashed with a greater fear of lawlessness, anarchy, and radical supremacy. Crowd actions against the appointed Stamp distributor,

\footnotetext{
${ }^{35}$ Thayer, King of the Quakers, 204; Scharf \& Westcott, History of Philadelphia, 272-273; Marietta, Reformation of American Quakerism, 207.

${ }^{36}$ Israel Pemberton to Mildred, January 3, 1774, Cox/Parrish/Wharton Collection, XI in Thayer, King of the Quakers, 207.
} 
John Hughes, turned violent. As Hughes wrote to his associate Benjamin Franklin in England, "it seems to me that a sort of Frenzy or Madness has got such hold of the People of all Ranks." Recognizing danger, he added that "perhaps when a Mob is on foot, my Life and Interest may fall a Sacrifice to an infatuated Multitude." James blamed radical Presbyterians for the riots and threats against Hughes. In letters to Quaker colleagues in London, he argued that the Calvinists feigned to be "actuated by a spirit of Liberty \& Patriotism" while in reality working towards the "very oppressive \& dangerous" day when they could take over the government. The agitations of the Allen brothers, affiliated with the proprietor and the Old Light Presbyterians, buttressed his view. ${ }^{37}$

The ongoing tension between a redress of grievances through legal means and the bottom-up pressures of illicit crowds and associations led by radicals continued through the next decade. Along the way, Pennsylvanians witnessed Parliament's passage and repeal of the Townsend Acts, a Tea Act, and the Coercive Acts which closed Boston harbor, united the colonies, and led to the First Continental Congress in 1774. Quaker marginalization from the resistance, even on occasions when they agreed with the movement's goals, increased as dissent radicalized. After a ten-year hiatus from the assembly on account of the conflicts posed by French and Indian War, James ran for a seat in the House in 1765, targeting the incumbent, future radical vice-president George Bryan, whom he considered "an Envious Pres[byteria]n." The contest initially ended in a tie. A special election followed in which Pemberton won handily when the Presbyterians

\footnotetext{
${ }^{37}$ James Pemberton to Fothergill, December 17, 1765 in Mekeel, The Relation of the Quakers, $29 \mathrm{fn} 31$ \& 27fn10; John Hughes to Benjamin Franklin, Treasury Papers, Class I, Bundle 442 in Morgan \& Morgan, The Stamp Act Crisis, 247-248; Marietta, Reformation of American Quakerism, 206. For the Allen brothers stirring up the mob during the Stamp Act, see Chapter 2 of this study. For the Allens' religious affiliation, Jonathan Powell, "Presbyterian Loyalists: A Chain of Interest in Philadelphia," Journal of Presbyterian History, Table One, "Loyalists in the First Presbyterian Church,"138.
} 
failed to get out the German vote. ${ }^{38}$ After repeal of the Stamp Act, Pemberton reported to John Fothergill in England that no Quakers had illuminated their windows in the celebrations which followed, unlike other sectors of the population. The attempts of political Quakers like James to partake in legal resistance activity while opposing illegal means proved unsustainable. It was a stance tested not only by external pressures, but also by the hardcore reformers who had recaptured the faith.

For a while, James Pemberton kept a foot in both camps. As an elected official, he was a key cog in the assembly's fourteen-man Quaker committee of June 1766 that drafted an address of thanks to the king for the Stamp Act's repeal while stressing the colony's continuing loyalty to the Crown. In 1768 , he again helped draft an assembly petition, this time for repeal of the Townsend Acts. In October that year, he was reelected to the assembly on a platform opposing nonimportation and elected again on the same issue in 1769. Even so, the nonimportation association resumed its activities. ${ }^{39}$ The downward political spiral progressed as Quakers tried to stem the popular tide. When a consignment of malt arrived from England on the Philadelphia docks in July 1769 and challenged the merchants' new nonimportation accord, Israel led opposition to the mass meetings organized to impede unloading the cargo. The Quaker Meeting for Sufferings drafted an epistle with the collaboration of Israel and James condemning "the dangerous tendency of contributing to the support of such Associations" which they believed incited upheaval. The vessel returned to England with its freight on board anyway, and radicals

\footnotetext{
38 "James Pemberton," Legislators in Pennsylvania, vol. 3, 1028; Joseph S. Foster, In Pursuit of Equal Liberty: George Bryan and the Revolution in Pennsylvania (University Park, PA: The Pennsylvania State University Press, 1994), 55.

${ }^{39}$ Marietta, Reformation of American Quakerism, 208, 210; Mekeel, The Relation of the Quakers, 24, 38; Ousterhout, A State Divided, 28.
} 
continued to meet. Fearful that events were drawing him to a "conduct inconsistent" with "religious principles," James decided to forego another run for the assembly in 1770 after five consecutive years of service. ${ }^{40}$

The oscillations in imperial policy from colonial taxation to repeal and back again continued to upset the political panorama. In response to the Tea Act, Philadelphians forced the Polly, laden with tea, to return to England in 1773, an action that Quakers generally opposed and James dubbed an arbitrary breach of law and justice. He noted further that no Friend "of any Account" was seen among the seven hundred people who met at the State House to organize that crowd action. A year later, James justified the presence of Quakers at a public meeting against the Coercive Acts only on grounds of preventing "the ill-timed and rash proceedings" of the citizenry. All the while, he warned of "the most tyrannical disposition" of Presbyterians and radicals. The Quaker Meeting for Sufferings concurred, admonishing extralegal committees for promoting "anarchy" and above all threatening Quaker "Civil, \& religious Liberties.” Philadelphia Quakers made a financial donation for the relief of the citizens of Boston in January of 1774 , while simultaneously denouncing the dumping of tea into the city's harbor. It was too delicate a balancing act to sustain. ${ }^{41}$

The futility of the Quaker position came to a head that year. In June, the Society of Friends decided to "keep from mixing with the people in their Public Consultations" in effect a directive to retreat from political life once and for all. At a public convocation

\footnotetext{
40 "James Pemberton," Legislators in Pennsylvania, vol. 3, 1032; ; Thayer, King of the Quakers, 205-206; Mekeel, The Relation of the Quakers, 45.

${ }^{41}$ Marietta, Reformation of American Quakerism, 213, 217-218; Mekeel, The Relation of the Quakers, 61, 72; Thayer, King of the Quakers, 207.
} 
only days later, citizens appointed James Pemberton one of twelve Quakers to a larger Committee of Correspondence without his approbation. While other Quakers opted to join, James refused to serve. The episode reveals that, despite reformist retreat, Quaker influence was still considerable even at that late date. Their conformity with proceedings was judged vital. The collision between Quaker reformist instructions to withdraw from public life and the patriot committee's growing militancy proved to be a turning point. This was the last extralegal body in which Quaker moderates participated. ${ }^{42}$

The First Continental Congress which adjourned at Philadelphia in October of 1774 planted the seeds for full radical control of the resistance movement nationally and locally. Congress rejected Joseph Galloway's proposal for an American Parliament and preservation of the imperial union, organizing instead a Continental Association to curtail trade with Great Britain. Later rumors had James calling those who supported the congressional measures "rebels," at the time an incendiary and pejorative term. James' language affords us an opportunity to trace evolving Quaker perceptions of colonial antagonisms over the pre-war decade - the expanding opposition had gone from Presbyterians to radicals to rebels. For Quakers, though, Presbyterians formed its core. ${ }^{43}$ Coinciding with the first congress, the Philadelphia Yearly Meeting issued an epistle of advice to Friends emphasizing that Quakers were beholden to the king for their liberties in America, obligated to express their allegiance to him, and opposed to all efforts "to excite disaffection or disrespect to him." Alarmed by the course of events,

\footnotetext{
${ }^{42}$ Mekeel, The Relation of the Quakers, 73; Marietta, Reformation of American Quakerism, 219. The Committee of Correspondence was replaced in November 1774 by a new Committee of 66 which included five Quakers, all later disowned.

${ }^{43}$ Diary of Christopher Marshall, May 7, 1775, 23; Mekeel, The Relation of the Quakers, 95; Thayer, King of the Quakers, 210; Marietta, Reformation of American Quakerism, 223.
} 
Friends published two key clarifications of their position in early 1775 - one for in-house instruction and the other as a public pronouncement. As clerk of the Meeting for Sufferings, John Pemberton signed a new epistle to believers on January 5 condensing Quaker views. The Meeting declaimed against "the present distracted proceedings of the Colonies" which had approved "publick Resolves... evidently contrary to our religious principles," a stance they understood would produce "the most fatal consequences both to themselves and the parent country." As a remedy, reformers urged steadfast pacifism: Friends were to "to act agreeable to the peaceable principles and testimony we profess." The missive targeted those Quakers who had participated in recent political proceedings, urging them not to "deviate" from "the peaceable spirit and temper of the Gospel.",44

Later that same month, reformers issued a public address which James signed on behalf of the congregation as "Clerk at this time." Three thousand copies of a Testimony of the people called Quakers were printed and distributed. The document became the basis for Quaker pacifist orthodoxy during the Revolution. True to reformist precepts, the piece argued in no uncertain terms that the established political regime was legitimate. Thus, "peaceable subjects" should "discountenance and avoid every measure tending to excite disaffection to the king, as supreme magistrate, or to the legal authority of his government." It went on to condemn the direction of colonial resistance. Referring to the "late political writings," these were deemed "contrary to the nature and precepts of the gospel" and "destructive of the peace and harmony of civil society." As such, Quakers were "led by a sense of duty to declare our entire disapprobation of them." The Meeting

\footnotetext{
${ }^{44}$ Philadelphia Yearly Meeting Minutes, vol. 3, 366 in Mekeel, The Relation of the Quakers, 88; An Epistle from the Meeting for Sufferings, held in Philadelphia, for Pennsylvania and New-Jersey, fifth day of the first Month, 1775, Force, ed., American Archives, $4^{\text {th }}$ Series, vol. 1, 1093-1094.
} 
admitted that deep differences existed between the mother country and her colonies but trusted that "decent and respectful addresses from those who are vested with legal authority" - that is, the colonial assembly, governor or council - "would avail towards obtaining relief" of grievances. The path Congress and its supporters had chosen was likely to "produce violence and bloodshed, and threaten the subversion of constitutional government, and of that liberty of conscience" which had induced their ancestors to seek refuge in Pennsylvania in the first place. The Testimony ended by declaring "against every usurpation of power and authority... and against all Combinations, Insurrections, Conspiracies, and Illegal Assemblies... inconsistent with our religious principles" which violated "the fidelity we owe to the king and his government, as by law established." 45

The address captured all of the key elements of Quaker doctrine. Established authority must not be disturbed. Grievances existed but redress should be undertaken only via legal means within the British Constitution. Order, stability, and imperial union must be maintained. Congress, spontaneous assemblies, and crowd actions were illicit and would generate violence, disarray, and an unwelcome change in regime. Pacifism was morally righteous and pragmatically indispensable. The testimony is notable for its foresight. Unauthorized assemblies and radical multitudes did generate violence, chaos, and ultimately overthrew the existing government. An unspoken fear in the declaration also proved accurate. Because of historical acrimony and their opposition to change, Quakers would bear much of the brunt of that disorder.

\footnotetext{
${ }^{45}$ The Testimony of the People called Quakers, given forth by a Meeting of the Representatives of said People, in Pennsylvania and New-Jersey, held at Philadelphia the twenty-fourth Day of the first Month, 1775, (Philadelphia, 1775), Broadside, Evans 14052; Force, ed., American Archives, $4^{\text {th }}$ Series, vol. 1, 1176-1177.
} 
The hostility between radicals and Quaker pacifists escalated from 1775 to 1777 as open warfare with England erupted, the colonies declared independence, and rebels deposed proprietary rule in Pennsylvania by enacting a new constitution and government. Multiple Quaker efforts to stem the tide proved ineffectual. They petitioned the assembly for immunity in military matters on the basis of Penn's original charter. They opposed Congress' proclamations for national days of fasting. They insisted Quakers resign from public office and not elect Friends to positions of power. They disowned those who participated in the war. They refused test oaths and militia service, substitutions, and the payment of fines. As independence approached, they issued an emphatic restatement of their position in the Ancient Testimony. ${ }^{46}$ Although reformers left the acceptance of continental bills of credit to individual conscience, many Quakers additionally refused to receive the new paper currency because it was seen as a funding mechanism for the war. In sum, pacifist reform-minded Quakers like the Pembertons who set appropriate conduct for the sect opposed virtually every novelty the revolutionaries sought to put into effect. ${ }^{47}$

\footnotetext{
${ }^{46}$ Ancient Testimony and Principles of the People called Quakers, renewed, with respect to the King and Government; and touching the Commotions now prevailing in these and other parts of AMERICA, addressed to the People in general, January 20, 1776, Force, ed., American Archives, $4^{\text {th }}$ Series, vol. 4, 785787. Discussions of the Ancient Testimony also in Robert F. Oaks, "Philadelphians in Exile: The Problem of Loyalty during the American Revolution," PMHB, vol. 96, no. 3 (July, 1972), 299-300; Thayer, King of the Quakers, 212; Scharf \& Westcott, History of Philadelphia, 305; Marietta, Reformation of American Quakerism, 228, Mekeel, The Relation of the Quakers, 137-38. Some historians place greater significance on the Ancient Testimony of 1776, rather than the Testimony emitted almost a year earlier to the day. An argument can certainly be made that the timing of the later declaration made it more significant since it was emitted as the path to independence intensified rather than before the outbreak of hostilities. But in terms of content, core principles were actually stronger in the 1775 testimony regarding the king's authority, legal approaches to redress grievances, and a commitment to pacifism, order and tranquility. The later testimony placed greater emphasis on the spiritual - "conformity to the precepts and doctrine of our Lord Jesus Christ" - and added a class dimension, admonishing "those of inferior stations" to strive for peace while warning "those in superior stations" to reject all measures leading to discord. In my view, it is much more significant that the Quakers staked out their definitive position on the Revolution early in January 1775.

${ }^{47}$ Stephen L. Longenecker, The Christopher Sauers: Courageous Printers Who Defended Religious Freedom in Early America (Elgin, IL: The Brethren Press, 1981), 133; Diary of Christopher Marshall, June
} 
Unsurprisingly, radicals viewed the antiwar stance of pacifist Quakers as duplicitous. Moreover, patriot leadership often placed blame for Quaker disaffection on the Pembertons. John Adams saw Israel Pemberton as "an artful Jesuit" and noted his negative influence over patriot John Dickinson and other moderates in the Continental Congress on the question of independence. Thomas Paine was more blunt - condemning Quakers wholesale: "O! ye fallen, cringing, priest and Pemberton-ridden people!" Reprisals followed. A committee report for the Monthly Meeting of the Northern District in Philadelphia a month before Howe's invasion gives an excellent summary of conditions. Quaker houses had been "stripped of the leaden weights used for the hanging of windows." Blankets had been "forcibly taken" for use of the army. The homes of Friends had been "wantonly abused, and their windows broke and destroyed by a rude rabble." Quaker shops had suffered similar property damage. In an ironic reminder of the earlier British quartering policies in Boston which incited revolution, Quaker families "had soldiers forced into their houses and kept there for some time." Rebels carrying weapons had seized some Quakers on the street. Others were "taken from their dwellings by an armed company of men, and with drum and music paraded through the streets for a considerable time." Still others were fined and their personal goods "distrained" for declining to serve in the civil government. When this committee report was presented, Quaker William Compton had been in prison for six weeks, though "nothing criminal in the view of those who now exercise authority in this place, had upon examination been

30, 1775, 30; Thayer, King of the Quakers, 211; Marietta, Reformation of American Quakerism, 226, 231232; Mekeel, The Relation of the Quakers, 133-134, 162.

${ }^{48}$ Charles Francis Adams, ed., The Works of John Adams, Second President of the United States: With a Life of the Author, Notes and Illustrations (Boston: Little \& Brown, 1850), vol. 2, 398-399; Thomas Paine, The Crisis (New York: Peter Eckler Publishing Co., 1918), April 19, 1777, no. 3, 111. 
found against him." 49 The parading of victims, smashing of windows, and forced detentions demonstrate the patriot government's lack of control over bottom-up effervescence and the resulting arbitrary and tumultuous nature of radical rule. Presbyterian/Quaker hostility had found renewed vigor in the rebellion.

\section{VIRGINIA EXILE \& THE RETURN TO PHILADELPHIA}

That antagonism detonated when word arrived in Philadelphia that Sir William Howe had landed his army at Head of Elk on the Chesapeake Bay in August of 1777. Events soon came to a climax. With Philadelphia targeted, the various manifestations of patriot government scampered. Before leaving for York, Congress recommended that the Pennsylvania Supreme Executive Council "apprehend and secure" key disaffected figures deemed likely to collaborate with the advancing British. This congressional resolution honed in on eleven individuals, all Quakers, including Israel, James, and John. By the time the council gave the arrest order three days later, the list had ballooned to forty-two people from multiple faiths. ${ }^{50}$

The Quakers and the Pembertons fought back. Israel and two others prepared a written objection on September 4, telling the council that "your issuing that order is arbitrary" and stressing the arrestees were "peaceable men \& have never borne arms," as well as "good Citizens sollicitous [sic] to promote the real interest and welfare of our Country." The protest claimed "our undoubted rights as Freemen" and emphasized that patriot authorities were violating their own recent constitution as "no opportunity is given

\footnotetext{
${ }^{49}$ Committee Report to Monthly Meeting of Friends of the Northern of Philadelphia, July 29, 1777 in Thomas Gilpin, ed., Exiles in Virginia, 295-298.

${ }^{50}$ Journals of the Continental Congress, August 28, 1777, vol. 8, 694; Colonial Records, August 31, 1777 , vol. 11, 283.
} 
them to be heard." That same day another protest with twenty signatures, including the three Pembertons, showed how Quakers perceived their homeland, "claiming to ourselves the liberties and privileges to which we are entitled... by our birthright and inheritance." The later choice to stay and reintegrate was a natural derivative of this core attitude that they were sons of a Pennsylvania that was theirs by right. ${ }^{51}$ The prisoners issued a similar complaint to the Continental Congress the next day, once again underscoring their right to a hearing, followed by publication of an "Address to the Inhabitants of Pennsylvania" explaining the injustice of their situation. ${ }^{52}$ The Supreme Executive Council countered that the matter could be laid to rest if the prisoners would "take and subscribe the oath or affirmation required by law" or accept a modified, more generic version assuring fidelity and "true allegiance" to the state. The imprisoned Quakers refused. The council reacted by declaring that the captives had chosen to "consider themselves subjects of the King of Great Britain" and "do hereby renounce all the privileges of citizenship.",53 The test oath thus became the justification for permanent Quaker separation from the body politic.

The controversy mushroomed. One hundred and two petitioners appealed to the President and Supreme Executive Council to grant a hearing to the prisoners. Their petition went unheeded. Congress had likewise denied a hearing days earlier. On the $9^{\text {th }}$, twenty-two captives signed a more extensive "Remonstrance and Protest of the Prisoners

\footnotetext{
51 "Remonstrance of Israel Pemberton, \&c.," September 4, 1777, Pennsylvania Archives, First Series, vol. 10, 158-159; "To the President and Council of Pennsylvania," September 4, 1777, Gilpin, Exiles in Virginia, 77-78.

52 "To the Congress," September 5, 1777, Gilpin, The Virginia Exiles, 82-84; "An Address to the Inhabitants of Pennsylvania," September, 1777, Gilpin, The Virginia Exiles, 86-88.

53 "In Council, Philadelphia, September 5, 1777," Gilpin, The Virginia Exiles, 106; “In Council, Philadelphia, September 5, 1777," Gilpin, ibid., 124. For passage of the Test Act, Statutes At Large of Pennsylvania, vol. 9, "An Act Obliging All White Male Inhabitants of This State to Give Assurances of Allegiance to the Same and for Other Purposes Therein Mentioned," June 13, 1777, Chapter 756, 111-114.
} 
in Mason's Lodge." The detainees reiterated that they had not been heard, a violation of due process rights; that "we utterly \& solemnly deny" maintaining correspondence with the enemy; that they had "steadily maintained our Religious Principles"; and in a defiant reference to the test act approved the prior summer, that "the Tests you proposed we were by no Law bound to subscribe." The appeal concluded with echoes of earlier sectarian enmities and fears: "that the Evil \& destructive Spirit of Pride, Ambition \& arbitrary Power with which you have been actuated may cease \& be no more. ${ }^{, 54}$ For the victims, a noxious Presbyterian presence lurked behind the entire affair.

Additional measures proved futile. The prisoners requested a writ of habeas corpus to delay and possibly overturn the departure order. Revolutionary judge Thomas McKean granted the request but patriot officers ignored it. Nameless intimidators forced printers to cancel publication of a second public address, even though the type for that text was cast. In the end, all efforts failed. The council assigned a troop of City Guards to escort the captives on their way, pursuant to prior instructions that they be "treated in such manner as shall be consistant [sic] with their respective Characters." Adherence to protocols of class and station persisted even under the duress of insurgency and invasion. On September 11, the prisoners departed the city in wagons, "a spectacle to the people." Crowds of men, women, and children lined the streets, "their countenances sufficiently though silently expressed the grief they felt on the occasion." John Pemberton took special solace in the sympathy of "many poor blacks" who came to say good-bye and

\footnotetext{
54 "To the President and Council of Pennsylvania," September 5, 1777, Gilpin, The Virginia Exiles, 115117; "Remonstrance and Protest of the Prisoners in Mason's Lodge," September 9, 1777, Pennsylvania Archives, First Series, vol. 6, 509-510.
} 
"shook me by the hand, being affected with our hard treatment," an acknowledgement of the brothers' earlier reform efforts across racial lines. ${ }^{55}$

Their journey first took them northwards to Pottsgrove, away from Howe's invading hordes, then on to a more menacing Reading, where "there appeared to be much enmity among the people, and some stones were thrown at us." From there it was on to Lancaster, then across the Susquehanna to Carlisle. Turning south, they crossed the Potomac on September 28, reaching Winchester, Virginia, two days later. The reception there was chilly. About thirty armed men appeared at noon demanding their "immediate removal." Virginia officials convinced the protestors to disband, promising the prisoners would remain in their lodgings until Congress could clarify their situation. ${ }^{56}$

It soon became clear that the pacifists posed no real threat as they adapted to life in Virginia. Gradually, rebel jailors extended privileges. From house arrest, the prisoners were first allowed to walk the garden, then to separate and arrange for more commodious lodgings. On October 11, their common journal reported "our old guards went away, and took leave of us in a very kind feeling and disposition." Four days later, they petitioned and received permission to ride anywhere within six miles of Winchester. Local Friends soon received permission to join the religious services of the captives. Sometimes other Virginians participated in silence, including officials and landlords. More often than not, John Pemberton and fellow exile John Hunt preached before these gatherings, providing spiritual instruction on their banishment. Turnout grew. On November 2, nearly seventy people attended the meeting. In the interim, some prominent Virginians called to pay

\footnotetext{
${ }^{55}$ Gilpin, The Virginia Exiles, 127, 130, 133-134; Council Minutes, August 31, 1777, Colonial Records, vol. 11, 283; The Life and Travels of John Pemberton, 76.

${ }^{56}$ Gilpin, The Virginia Exiles, 136, 160.
} 
their respects. Most conspicuously, Colonel John Augustine Washington, brother of army Commander-in-chief George, stopped in on October 19 for "some friendly conversation," taking the opportunity to relay the stunning news of Burgoyne's surrender at Saratoga. In the meantime, news from Philadelphia was slow to arrive. James noted in his memoirs as late as November 9 that the exiles had received no word from family since departure. ${ }^{57}$

Several noteworthy incidents marked the exiles' stay in Winchester. In early October, the local militia forced a pacifist Quaker to stand guard over the prisoners, though he refused to touch his assigned musket. The spectacle lasted two days. On the $24^{\text {th }}$ of the month, Virginians paraded with drum and fife in celebration of the Saratoga victory, then lit bonfires and illuminated their houses at night. "By way of insult," rebels smashed the windows of a Quaker neighbor who refused to participate. On December 8, fellow prisoner Dr. William Drewitt Smith - granted special permission to roam freely and treat local patients - escaped. As a result, officials again placed sentries at the exiles' residences. Four days later, the Board of War accused captive Quaker Owen Jones Jr. of conspiring to depreciate continental currency in faraway Lancaster while "exchanging gold at a most extravagant premium for paper money." Patriots ordered Jones removed to a jail at Staunton, Virginia. In mid-February 1778, prisoner Thomas Pike absconded. Notably, neither Smith nor Pike appear to have been Quakers. How exiled Friends reacted to these getaways says much about their code of ethics. In the former case, Quakers themselves informed Major Joseph Holmes that evening at dinner of "our apprehensions that he [Smith] had gone to Philadelphia." In the latter, a journal entry of

\footnotetext{
${ }^{57}$ Gilpin, The Virginia Exiles, 172, 174-176, 181; Memoirs of James Pemberton, 68. Gilpin incorrectly calls Washington's brother John Augustus. See “George Washington's Family Chart," Mount Vernon Ladies' Association, available online and last accessed on June 8, 2017, at https://web.archive.org/web/20110717064248/http://www.mountvernon.org/visit/plan/index.cfm/pid/348/
} 
February 16 remarked that "our company considered that Thomas Pike had acted dishonourably [sic]. ${ }^{.58}$

Yet all of these incidents paled in comparison to the deaths of fellow exiles Thomas Gilpin and John Hunt, both of whom fell seriously ill in the late winter and never recovered. ${ }^{59}$ Gilpin died at Winchester on March 1 after about a month with a violent cold. Israel Pemberton recorded in his journal that "one of us is happily released from the power of our oppressors," along with the landlady's observation that Gilpin had "died like a Christian," to which he added "which I believe may be truly said of him." As for Hunt, eleven days later the exiles received word that "a mortification had begun in his leg." Doctors recommended severing the limb as the only way to spare his life. The operation took place on March 22. At first Hunt appeared to recover but he soon faded, dying nine days after the amputation. ${ }^{60}$ As a result of these events, only sixteen of the twenty original prisoners remained in custody by the spring of 1778 .

During the entire experience, the exiles continued to lobby the Continental Congress in York and the Supreme Executive Council in Lancaster for release. Frequent visitors from Philadelphia and elsewhere aided these efforts, with Quakers conveying information and petitions back and forth. The captives likewise appealed to the Virginia governor and council. Virginians saw themselves solely as custodians of congressional

\footnotetext{
${ }^{58}$ Gilpin, The Virginia Exiles, 172, 180, 185-186, 208. Joseph Holmes, Esq., was Deputy Commissary General of Prisoners in the Western District of Virginia.

${ }^{59}$ Hunt and Gilpin were not the only ones plagued by infirmities. Several other exiles became severely ill but survived. In January, Thomas Wharton Sr. was "quite unwell" (Gilpin, 200). Henry Drinker and Samuel Pleasants were depicted as "recovering" on March 2 (Gilpin, 212). On March 16, Edward Pennington "continued very poorly" and Miers Fisher too was "unwell" (Gilpin, 214).

${ }^{60}$ Gilpin, The Virginia Exiles, 212-213. Thomas Gilpin's brother, George, was a patriot colonel of the Fairfax militia, which was then stationed near Philadelphia (Gilpin, 171).
} 
resolves, however, so the problematic issue festered mainly as a dispute among the two political entities located in Pennsylvania, neither of which wanted to accept responsibility for the detainees. Direct appeals to patriot authorities from Quaker Meetings and the exiles' wives brought their plight into public scrutiny in the hope of ending the wrangling over jurisdiction and the unwillingness to rule in the case. Finally, the Supreme Executive Council responded on April 8 to a March 16 resolve of Congress, ordering that the prisoners "be brought to Shippensburg, and there enlarged." In the following days, officials made the necessary logistical arrangements for the return home. On April 19 the exiles left Virginia after "taking affectionate leave" of Friends at morning Meeting. ${ }^{61}$

The homeward journey went as planned. On April 26 they reached Lancaster, where the sixteen banished Quakers presented Pennsylvania's Supreme Executive Council - still on their own exile from British-occupied Philadelphia - with a petition "to be reinstated to the full Enjoyment of that Liberty, of which we have been so long deprived." The next day the council ordered the exiles sent to Pottsgrove and "there discharged from confinement." To facilitate passage through Continental Army lines, they received copies of the discharge and certificates allowing them to travel "unmolested" into Howe's Philadelphia. ${ }^{62}$ Israel and James heeded the immediacy of the directive, proceeding onwards. John tarried a bit because he "was not satisfied with the

\footnotetext{
${ }^{61}$ Gilpin, The Virginia Exiles, 218-219, 226. This council order of April 8 included Owen Jones Jr., who returned alongside his exiled brethren. It included Gilpin and Hunt as well. Presumably patriot officials were not yet aware of their recent deaths. It also named William Drewitt Smith who had escaped way back in December but not Thomas Pike who had fled less than two months earlier.

62 "Petition of Prisoners from Virginia, 1778," Pennsylvania Archives, First Series, vol. 6, 510-511; Council Minutes, April 27, 1778, Colonial Records, vol. 11, 473. In addition to the three Pembertons, the thirteen other petitioners were Miers Fisher, Charles Eddy, Edward Pennington, Thomas Wharton Sr., Henry Drinker, Samuel Pleasants, Charles Jervis, Thomas Fisher, Thomas Affleck, Elijah Brown, William Smith (broker), Owen Jones Jr., and Samuel Rowland Fisher.
} 
order of discharge," claiming instead that "this was far short of what we demanded; which was to be reinstated in our families in the manner in which we had been wrested from them." Responding for the patriot government, Timothy Matlack curtly informed him that "the council would do no more." Council minutes derisively note "Mr. John Pemberton's tender conscience being hurt by the words, 'agreeable to the said order"' in authorizing the journey through Philadelphia County, inserting instead the phrase "and he is there to be considered as discharged" to his certificate of release. Heading home, James noted the "devastation committed by parties of the English army in their excursions" and duly recorded upon arrival that he had been absent for thirty-two weeks and six days. The exile experience seemed to have the greatest effect on Israel. Upon his return, he found his wife ill, his fortune in ruins, rampant inflation, and his various estates in the no-man's land around the city in dire straits after expropriation for the quartering of His Majesty's troops. John's exile ended on April 30, concluding the final leg "without molestation or difficulty" after an early breakfast on the city's outskirts with the family of Quaker John Roberts where he lodged. In a gesture indicative of his priorities, the next day he visited the widows of Thomas Gilpin and John Hunt who had succumbed to illness in exile. ${ }^{63}$

It is noteworthy that, after months of separation from their homes and family for alleged political perfidy, patriot authorities never brought charges of treason, misprision of treason or otherwise against the captives they had once feared as British collaborators. For the Quaker faithful, the conditions under which the state government restored the prisoners vindicated their pacifist position. The first post-return Monthly Meeting of the

\footnotetext{
${ }^{63}$ Council Minutes, April 27, 1778, Colonial Records, vol. 11, 473; The Life and Travels of John Pemberton, 91; John Pemberton Journal, 82, 86; Memoirs of James Pemberton, 77; Diary of Elizabeth Drinker, 76; Thayer, King of the Quakers, 231. This was the same John Roberts who the patriots executed in November later that year.
} 
Middle District in Philadelphia, to which the brothers belonged, recorded in the official minutes that those sent to Virginia had "been permitted by their Persecutors to Return to their Habitations without any Charge exhibited against them, or any Concessions or Obligations on their Parts," a fact "which sufficiently demonstrates their Innocency." This was a common sentiment among the exiles themselves, best expressed in Thomas Wharton Sr.'s statement to his wife Rachel during the early stages of confinement: "I have done No Wrong, \& therefore My Conscience is Easy." ${ }^{64}$

In the next six weeks of whirlwind activity and rumors, the Pemberton brothers resumed their lives. General Howe was returning to England. Israel met with the imperial commander and claimed compensation of several thousand pounds for British devastation of his property. Howe rejected the claim. John attended a Meeting for Sufferings on May 14 which discussed the "dissipation" of the forthcoming Meschianza organized for the outgoing general. The Meeting urged Quakers to refrain from attending the celebration. Nine days later John noted that preparations for a purported evacuation had "put many into great hurry and fears" but that he himself was calm and "preserved in much quiet." James faced an especially difficult season with the May $20^{\text {th }}$ death of his grown son, Phineas, best known as an accomplished amateur meteorologist, much respected for his documentation of Pennsylvania's weather patterns. As the month closed, the Philadelphia Monthly Meeting officially noted the return of the Virginia exiles and reassigned John to his ministerial duties by a way of a formal committee appointment. ${ }^{65}$

\footnotetext{
${ }^{64}$ Minutes, Philadelphia Monthly Meeting, Middle District, May 29, 1778, vol. 2, 46, Haverford College (hereafter HAV); Thomas Wharton Sr. to Rachel Wharton, Carlisle, September 24, 1777, Wharton \& Willing Families Papers, Collection 2014, Box 3, HSP.

${ }^{65}$ Jackson, With the British Army in Philadelphia, 270; John Pemberton Journal, 83; Memoirs of James Pemberton, 77; Eli K. Price, Diary of John Pemberton, for the Years 1777 and 1778 (Philadelphia: Henry
} 
Meanwhile, Israel Pemberton had a long conversation in early June with Ambrose Serle, Secretary to Lord Howe, on the causes and nature of the American rebellion. The talk provides an insightful look into Quaker views on the Revolution at the crossroads of their homecoming. The eldest Pemberton argued that Parliament "had no constitutional Right to tax America, but that he was equally averse to the violent Proceedings of the People here and particularly to the atrocious Act of Independency." Here again was the locus of pacifist orthodoxy wedged between imperial and radical overreach. On June 6, John recorded that the king's Carlisle Commission had arrived from London to negotiate peace with the Continental Congress but two days later noted that "the city continues in commotion," as the British army was "moving their baggage, cannon, etc." and the evacuation seemed to be proceeding without interruption. When that momentous event finally arrived in mid-month, John expressed no emotion either way. He simply stated that "early in the morning of the $18^{\text {th }}$, they [the British] marched to Gloucester Point, and went over to New Jersey. Some of the American light-horse then entered the city, and large numbers of soldiery and of the former inhabitants, came in by the $20^{\text {th }} ., 66$

Unlike many of those displeased with patriot supremacy, Israel, James and John Pemberton never considered abandoning Philadelphia at this first critical juncture of reintegration. Their recent return from banishment and a matching desire to stabilize life no doubt influenced that view. But the lack of any sort of introspection or discussion on this issue in any of the Pembertons' firsthand accounts is itself revealing and suggests

B. Ashmead, 1867), 5; Minutes, Philadelphia Monthly Meeting, Middle District, May 29, 1778, vol. 2, 45 46, HAV.

${ }^{66}$ Serle, The American Journal of Ambrose Serle, 303-304; Diary of John Pemberton, 5; John Pemberton Journal, 84; The Life and Travels of John Pemberton, 92. 
that, as direct descendants of the colony's founders, they understood Philadelphia to be their one and only home and never contemplated any other option. Their attitude reflected that of other disaffected Quakers for whom the choice of reintegration over departure was not a choice at all. It was a given.

\section{PACIFIST CONVICTION \& REINTEGRATION DURING THE WAR}

The non-threatening nature of the reformist Quaker presence in Pennsylvania which the Pemberton brothers epitomized is abundantly clear in the period that followed the British evacuation in the summer of 1778 . True to their nonviolent worldview, the Pembertons and their reform-minded coreligionists focused on peaceful activities within the civic, social and religious spheres during the rest of the war and its aftermath. This was a conscious decision, consonant with the reforms demanding withdrawal from political life and their interpretation of Christianity. Quakers made sure to avoid patriot factional squabbles while restricting their public encounters to deeply felt social causes or situations directly affecting the Society or fellow Friends.

Following their return from Virginia in April 1778, the Pemberton brothers renewed efforts to aid persecuted Quakers. After the evacuation, the Monthly Meeting appointed Israel and James as representatives to the broader Meeting for Sufferings responsible for monitoring and assisting mistreated Quakers. They quickly organized a campaign for the release of Friends imprisoned for pacifism. In August, the brothers contributed to the text of the Society's representation to the General Assembly publicly restating their position for the first time since the British evacuation. Because of "a steady adherence to our peaceable principles, and testimony against wars and fightings," they called for a repeal of "those laws, which have a tendency to oppress tender consciences," 
meaning those mandating the test oath and militia service. The duo then played a key role in the Yearly Meeting of September 1778 which set official Quaker policy on the Test Act question, reinforcing the sect's refusal to take oaths as manifested at the beginning of the exile controversy. A month later, Israel's wife Mary died, never recovering from the illness which preceded her husband's exile. The eldest Pemberton was devastated. ${ }^{67}$

John Pemberton was especially active after the British withdrawal. In July, he visited German Pietist Christopher Sower II, whom local radicals had "stripped naked, and painted in different colours" for his pacifism and pro-British sympathies. ${ }^{68}$ In August, he attended a series of Friends Meetings in Bucks County, extending his spiritual support to fellow Quakers "who had been much stripped by foraging parties, and for fines, etc." Most he found in good spirits. In September, he joined Israel at the Philadelphia Yearly Meeting. In October, he received a letter from Moses Brown, a leading Rhode Island Quaker, who advised Pennsylvania Quakers to pay taxes to patriot authorities in order to remain “quiet \& peaceable Subjects under Every Government.” Brown's interpretation of proper Quaker conduct shows a lack of unanimity among Friends across colonies on the payment of war fines and taxes. In fact, Pennsylvania Quakers proved to be the most intractable among the sect in their rejection of all things construed as contributing to the

\footnotetext{
${ }^{67}$ Pennsylvania Evening Post, August 13, 1778; Minutes, Philadelphia Monthly Meeting, Middle District, June 26, 1778, vol. 2, 56, HAV; Diary of John Pemberton, 11-12; John Pemberton Journal, 86; Thayer, King of the Quakers, 232.

${ }^{68}$ The Life and Travels of John Pemberton, July 18, 1778, 92; Donald F. Durnbaugh, ed., The Brethren in Colonial America: A Source Book on the Transplantation and Development of the Church of the Brethren in the Eighteenth Century (Elgin, IL: The Brethren Press, 1967), 401-402. Sower's written account of his treatment was given on May 30, 1778.
} 
war effort, a posture which generated controversy not only among colonial Friends but with leading Quakers in Great Britain too. ${ }^{69}$

In November, John comforted condemned Quakers Abraham Carlisle and John Roberts just two days before their execution, sadly noting afterwards they did not deserve such treatment. Later that month, he responded to the inquiries of Maryland Quakers, refuting rumors that Philadelphia's faithful had taken the test oath. In December, he set out on a religious tour of Delaware but a severe illness sidelined him for three months at Wilmington. On his return to Philadelphia in March, he lamented a tragic shipwreck off the coast of New Jersey in which an armed American privateer impeded rescue efforts of an English transport, resulting in the death of over one hundred passengers, even as defiant locals managed to save forty-two of them. For John, the incident exemplified the cruelty and futility of war, which thwarted the exercise of basic Christian compassion. ${ }^{70}$

The trio of brothers came together for a final time in the spring of 1779 . Israel was gravely ill, never fully recovering from his wife's death and the emotional and physical distress of prolonged exile. On April 23, Grace Growden Galloway noted forlornly in her diary that "poor Israel Pemberton died yesterday Morning." The King of the Quakers had tried to advise her on property seizures after husband Joseph's departure. A public funeral attended by "a great concourse" of all denominations followed three days later. In a replay of the banishment drama of 1777 , John made special mention that "many coloured people" had come to say goodbye to the abolitionist they considered

\footnotetext{
${ }^{69}$ John Pemberton Journal, 84; Mekeel, Relation of the Quakers, 232. For tensions between Pennsylvania reformist Friends and London Quakers, see Marietta, Reformation of American Quakerism, 162-163.

${ }^{70}$ Diary of John Pemberton, 5-6; Life and Travels of John Pemberton, November 4, 1778, 92; ibid., March 22, 1779, 93; Mekeel, Relation of the Quakers, 260; John Pemberton Journal, December 8, 1778, 85.
} 
their friend and patron. ${ }^{71}$ Despite philanthropic inclinations, Israel left his entire fortune of about $£ 60,000-70,000$ to his children. Nothing to charity. He was probably concerned about son Joseph who had gone bankrupt in the West Indies trade before the Revolution and exhibited a disturbing predilection for gambling. On one occasion, the father paid the “worldly and spoiled” son’s massive debt of $£ 10,000$. Israel’s passing strengthened the sincere bond among the brothers. "I have myself particular cause to mourn his absence," wrote John, "he having been to me a steady, sympathizing friend.",72 Despite tragedy, it was the rapid return to the routine of daily life which characterized the critical year from repatriation through Israel's death. In the face of external political hurdles, an effortless recovery took place inside the Quaker realm as the Pembertons quietly resumed their earlier standing. Within the discipline's insular horizons, nothing had changed.

The exterior universe was another matter. For Quakers, turbulence plagued this first phase of reintegration under radical rule. At the height of Constitutionalist power in 1779, Mrs. Galloway confided to her diary that "a Mob is raised in ye Town \& they are taking Up Tories... we were much alarm'd.” While visiting her neighbor Smith that day, she noted "he is very reserved but I find is Much frigthen'd... we are quite alone." In the summer a crowd attacked the home of Quaker merchant John Drinker for allegedly violating radicals' price-fixing imperatives. With Philadelphia in the midst of a cycle of spiraling inflation, severe shortages of flour and other key staples, and a heated political debate over the continuing presence of loyalist wives accused of conveying intelligence

\footnotetext{
71 "Diary of Grace Growden Galloway," April 23, 1779, PMHB, vol. 55, no. 1 (1931), 77; Marietta, Reformation of American Quakerism, 242; Thayer, King of the Quakers, 232; "Journal of Samuel Rowland Fisher," PMHB, vol. 41, no. 2 (1917), 159; John Pemberton Journal, 87.

${ }^{72}$ Marietta, Reformation of American Quakerism, 103; John Pemberton Journal, 85-87; The Life and Travels of John Pemberton, April 22, 1779, 94-95; Thayer, King of the Quakers, 195-96, 214.
} 
to their émigré husbands in New York, radical militiamen seized Drinker and three other Quakers coming out of the Yearly Meeting in October. Patriot officials intervened and put the captives in prison for their protection. The confrontation escalated into the armed clash between patriot factions at Fort Wilson. Rebel officials released John Drinker and his associates once the government regained control. ${ }^{73}$

In June of the following year, the Supreme Executive Council declared martial law, called out the state militia, and targeted for seizure the horses of disaffected citizens. James Pemberton lost two mounts, John one. In August, patriot newspapers republished earlier Quaker antiwar epistles in a renewed campaign to stir up the populace, what John called "fresh enmity against Friends." Then on September 29, 1780 radicals carted Benedict Arnold's effigy through Philadelphia's streets "with a great rabble following" about a week after his treachery. When John Pemberton and Henry Drinker went out for a walk later that evening, the mob cursed them. ${ }^{74}$ Radical antipathy prevented Quakers from recovering any sense of normalcy as members of the larger community while the war remained undecided. Friends lived in perpetual uncertainty, never knowing when external forces might disrupt their insular world. The most Friends could hope for was that rebels would allow them to go about their daily lives unmolested. Under radical ascendancy, legal reintegration or a broader social reassimilation was unimaginable.

\footnotetext{
73 "Diary of Grace Growden Galloway," May 24, 1779, PMHB, vol. 55, no. 1, 82. The Fort Wilson confrontation is in Nash, The Unknown American Revolution, 318-319; Rosswurm, Arms, Country and Class, 205-227; Brunhouse, The Counter-Revolution in Pennsylvania, 75-76; Ousterhout, A State Divided, 205-206.

${ }^{74}$ Rosswurm, Arms, Country and Class, 212; Diary of Christopher Marshall, June 10, 1780, 245; Scharf \& Westcott, History of Philadelphia, 411; The Life and Travels of John Pemberton, August 12, 1780, 99-100; Marietta, Reformation of American Quakerism, 244.
} 
Amid this climate of insecurity after their brother's death, the surviving siblings continued to champion reforms. John Pemberton placed special emphasis on matters of the spirit, missions, and compliance with the Quaker peace testimony. Only two weeks after Israel's funeral, John made the rounds of Quaker Meetings in southern New Jersey. Returning to Philadelphia, he witnessed the devastation of war in the countryside and decried both this "disposition opposite to the spirit of Christ" and "the spirit in man which delights in another's overthrow." ${ }^{, 75}$ Over the next few years, the youngest brother joined a variety of missions in support of fellow Quakers. In late 1779, he visited the Quaker master of a vessel who had been jailed for three weeks. In 1780 and 1781, he and James traveled to Lancaster three times to encourage Moses Roberts and Job Hughes, Quakers imprisoned for refusing militia service. Local officials released the pair after an eleven month incarceration. In the summer of 1780 , John participated in a failed effort to convince radical authorities to allow Quakers to send a delegation to Canada to seek the release of Benjamin Gilbert and his family, taken captive by Indians in alliance with the British. John Pemberton found these obligations fulfilling. Discouragement surfaced only when encountering laxness among Friends. In February 1780, he accompanied Isaac Zane Sr. on a mission through Bucks County to admonish "such as had deviated from our religious principles and testimonies in relation to war." Making religious rounds a year later, he wrote of "an exercising time" and "a season of much depression and suffering to me" because Quakers at Deer Creek ignored pacifist principles, what he termed "a wrong spirit prevalent in some." John's ubiquitous scruples carried into temporal matters. In 1780 , he rented a tavern property inherited from his father and structured the agreement

\footnotetext{
${ }^{75}$ John Pemberton Journal, May 31, 1779, 88; The Life and Travels of John Pemberton, May 31, 1779, 96.
} 
to counter the possibility that the facility might succumb to Quaker interpretations of immorality. Pemberton's contract stated that the lessee would "exert his endeavors as a Christian to preserve decency and order in said house... that the house on the first day of the week shall always be kept closed from public use... and that he will not allow or suffer any person to use, play at, or divert themselves with cards, dice, back-gammon, or any other unlawful game."76

John and James Pemberton belonged to Quaker committees assigned to mediate between the radical government and Samuel Rowland Fisher, imprisoned anew for purportedly providing intelligence to the enemy in a letter to his exiled brother Jabez Maud Fisher in New York. The formal charge was misprision of treason. Fisher was a fellow Virginia exile well known to the Pembertons. His most recent arrest had put Friends in a precarious political position, for the prisoner refused to acknowledge patriot governmental authority in any way. Quaker officialdom coincided with Fisher on virtually everything. They opposed military service, test oaths, war taxation, militia fines, and what they perceived as the arbitrary laws of the revolutionary regime. But by this time the Quaker hierarchy did not publicly question the legitimacy of the rebel state. Fisher did. As part of five committee visits to the inmate from January to October of 1780, John Pemberton offered spiritual guidance while advising Fisher to present the injustice of his case to the President and Supreme Executive Council of Pennsylvania, an implicit recognition of patriot governance. The prisoner had other ideas. He was only

\footnotetext{
${ }^{76}$ The Life and Travels of John Pemberton, July 20, 1780, 98-99; Mekeel, The Relation of the Quakers, 198; John Pemberton Journal, February 16, 1780 to March 15, 1781, 89-90, 92-93; Watson, Annals of Philadelphia and Pennsylvania, in the Olden Time, vol. 1, 394. The "first day" was Sunday. For tavern disorderliness in Philadelphia/Pennsylvania and Quaker attitudes, see Peter Thompson, Rum Punch \& Revolution: Taverngoing \& Public Life in Eighteenth-Century Philadelphia (Philadelphia: University of Pennsylvania Press, 1999), 1-2, 44, 92, 98, 102-105, 112-113, 122-125; Sharon V. Salinger, Taverns and Drinking in Early America (Baltimore: Johns Hopkins University Press, 2002), 89, 115-118, 144-148.
} 
willing to address authorities "by their names as Men \& the Instruments of our suffering only, \& not as Body."77 These visits produced no results. Fisher stoically lingered in jail.

Between April and June of the next year, three new Quaker committees called on the detainee. James Pemberton replaced his younger brother. During the last visit on behalf of the Meeting for Sufferings, Fisher noted that James "gave me to understand that they expected me to make some concessions." He did not budge, responding it was "out of the Question," suggesting instead that the Pine Street Meeting disown him if Quaker leaders felt a need to ease their concerns. The brothers' intercession in the Fisher case reveals the willingness of reformist Friends to engage the Revolution when the Society was at risk. Samuel Rowland Fisher's denial of revolutionary authority jeopardized the unofficial truce with radicals that permitted Quakers to live out their pacifist faith. ${ }^{78}$

Difficulties continued. In the summer of 1781, Philadelphia received shiploads of patriot ex-prisoners from South Carolina, exchanged under a flag of truce. Many of their families had arrived in the city the previous summer after the surrender of Charleston to the British. Patriot moderate Robert Morris appealed to James and John Pemberton and other prominent Quakers to raise a loan to the United States among their brethren to alleviate the suffering of the exiles. The Society of Friends, however, turned down the request, pleading poverty and an inability to raise funds because of measures imposed by

\footnotetext{
${ }^{77}$ Diary of Elizabeth Drinker, July 23, 1779, 85; “Journal of Samuel Rowland Fisher," PMHB, vol. 41, no. 2, 150; ibid., January 27, 1780, 187.

78 “Journal of Samuel Rowland Fisher," PMHB, vol. 41, no. 4 (1917), April 20, 1781, 424-425; ibid., May 17, 1781, 427; ibid., June 22, 1781, 430-431. After two years of controversy, the frustrated Supreme Executive Council in the last year of radical Joseph Reed's presidency ordered the release of Fisher, alleging that he had been "represented to us in a bad state of health, and that his life may be endangered by his continuance in prison during the summer months." See Council Minutes, July 23, 1781, Colonial Records, vol. 13, 13.
} 
the rebel government. ${ }^{79}$ Three months later, when "intelligence as surprizing [sic] as vexatious" arrived of Cornwallis' surrender at Yorktown, the displaced southerners took their revenge, joining Philadelphia revolutionaries in castigating those like the Quakers who did not illuminate their homes in celebration. Mobs roamed the streets freely on the night of October 25, looting Quaker shops. The throng beat Friends John Drinker and the wife of Benjamin Gibbs. Quaker diarist Anna Rawle wrote that "for two hours we had the disagreeable noise of stones banging about, glass crashing, and the tumultuous voices of a large body of men, as they were a long time at the different houses in the neighborhood." Alert and sympathetic acquaintances concocted a stratagem of lighting candles in Friends' windows ahead of the rowdy crowd, "which pacified the mob, and after three huzzas they moved off." For Anna, "it was the most alarming scene I ever remember." She noted the Walns and the Drinkers, Quaker families of note, "make heavy complaints of the Carolinians in their neighborhood." While conversing with frightened neighbors the next day, Anna lamented the passing of an age: "it seems universally agreed that Philadelphia will no longer be that happy asylum for the Quakers that it once was. ${ }^{\Perp 80}$ Her reflection seemed prophetic.

As the war dragged on, John Pemberton began to feel the pull of a religious mission to the mother country. For pacifists like himself, Great Britain was not the enemy, but a spiritual field in need of cultivation. On January 26, 1781, the Quaker Meeting formally authorized his trip, but it was not until the first half of 1782 that John

\footnotetext{
${ }^{79}$ Scharf \& Westcott, History of Philadelphia, 418. Morris proposed a loan at $6 \%$ interest.

80 “A Loyalist's Account of Certain Occurrences in Philadelphia after Cornwallis's Surrender at Yorktown, Extracted from the Diary of Miss Anna Rawle," October 22 to October 26, 1781, PMHB, vol. 16, no. 1 (April, 1892), 103-107.
} 
decided to move forward ${ }^{81}$ Pemberton put his affairs in order and assigned power of attorney to his wife, Hannah, and Quakers John Field and John Wilson. For Field, he prepared additional documentation delineating the state of his accounts and detailing the penalties and articles patriots had seized for his adherence to pacifist principles. ${ }^{82}$

Anxious that his travels might be misinterpreted as loyalist defection to England, John Pemberton paid a visit in May to boyhood companion William Moore, then the first moderate president of Pennsylvania's Supreme Executive Council. Friend William Matthews and brother James accompanied him. President Moore encouraged John to write to the full council because state law forbade passage through British lines without a passport on penalty of death and forfeiture. John's letter eloquently discloses Quaker attitudes towards politics. Adducing that his trip had "no sinister View or Worldly concern to promote," the missionary declared he did not need human consent to depart but wanted to make his plans known to patriot authorities nonetheless. Some radicals on the council pressed for application of the treason and confiscation penalties but the council's moderate majority made sure that effort came to naught. Patriot power alignments once again determined treatment of the disaffected. On June 10, John finally bid good-bye to his wife and set out for New Jersey. As a prelude to his European ministry, he visited Quaker Meetings in the northern states over the next six months, zig-

\footnotetext{
${ }^{81}$ John Pemberton Journal, January 26, 1781, 90; “Journal of Samuel Rowland Fisher,” PMHB, vol. 41, no. 4, February 6, 1781, 412.

82 John Pemberton, Power of Attorney to Hannah Pemberton, John Field and John Wilson, May 15, 1782, Pemberton Papers, Box 36, 13; John Pemberton, Account of sums demanded and seizures made on John Pemberton, Covering note to John Field, June 6, 1782, ibid., Box 36, 143; Theobald Shibbell, Sales of articles taken in seizure made upon John Pemberton for taxes, May 17, 1782, ibid., Box 36, 115; John Pemberton, Sales at City Auction, April 19, 1782, ibid., Box 36, 114, HSP.
} 
zagging his way to New York City in due course. From there, he embarked for England on December $21 .^{83}$ The youngest brother would be gone for seven years.

While John planned his trip, a heated political battle with the disowned Free Quakers developed, further exposing the interplay between patriot factional disputes and the handling of the disaffected. James Pemberton led the charge to vindicate Friends' conduct. In December 1781, the Free Quakers - which included notable patriots like Timothy Matlack, Samuel Wetherill, Christopher Marshall, Clement Biddle, and Betsy Ross - petitioned the state assembly to assert their right over the Quaker property that remained in the hands of the sect's governing body. While demanding the use of meeting houses, schools, burial grounds and the like, Free Quakers emphasized the disaffection of reformist Quaker leaders and their own not insignificant contributions to the rebel cause which had provoked their disownment. The distribution of radical-moderate power in Pennsylvania was then beginning to tilt toward the Anti-Constitutionalists. Moderate William Moore presided over the Supreme Executive Council and John Dickinson would follow later that year. Constitutionalist radical influence was still sufficient to preserve a political equilibrium, however. Unwilling to address the issue, the legislature tabled the Free Quaker petition. Opponents hardened their positions. The spinoff group insisted on drawing an ideological division, arguing that, as patriots and former members of the faith in good standing, they had contributed to the acquisition and upkeep of Quaker property and continued to have a vested right in its use. Reformers replied that church discipline was an internal matter, not a state prerogative. Their constitution set the rules for

\footnotetext{
${ }^{83}$ Pennsylvania Archives, First Series, May 30, 1782, vol. 9, 551; The Life and Travels of John Pemberton, May 4, 1782 to December 21, 1782, 103-106, 113; John Pemberton Journal, 55-56.
} 
membership. Since the Free Quakers had violated those rules, they no longer belonged. Government had no business regulating the church's conduct. ${ }^{84}$

James Pemberton believed the Free Quaker attack even graver than the Virginia banishment because it "exceeds any we have before experienced, it being upon the whole body." He understood the move as an assault "directed in the same line as former persecutions to misrepresent our conduct and bring in the laws of the land to their assistance amusing the people that we are legally disenfranchised of our liberties and the protection of government and have forfeited our inheritance." James emphatically denied that Quakers were traitors or aliens or that they had lost their birthright as citizens of Pennsylvania. A dithering legislature played ping pong with the dispute, eventually assigning it to a study committee in the fall of 1782 . Two events saved the established order. First, seventy-five disowned Friends with revolutionary credentials wrote an address to the assembly stressing that, despite their disownment, they respected the current denominational leadership and endorsed its right to enforce Quaker discipline as they saw fit. Then in the October elections, moderate Republicans supplemented their majority in the Supreme Executive Council with increased numbers in the assembly. The House committee took no further action and faded into obscurity. "Blessed be the Lord who hath not given us a prey to their teeth," concluded James thankfully. ${ }^{85}$ The Free Quaker affair offers another example of the decisive impact of Pennsylvania's factions on the fate of the disaffected. The moderate electoral surge had checked the radical assault.

\footnotetext{
${ }^{84}$ Mekeel, Relation of the Quakers, 283-293; Marietta, Reformation of American Quakerism, 246-247.

${ }^{85}$ James Pemberton to John Pemberton, September 20, 1782 \& November 10, 1782, Pemberton Papers, Box 37, 36-37 \& 93 cited in Marietta, Reformation of American Quakerism, 247-248.
} 
The inward-looking temper of spiritual reform held fast through the external complications arising from cases like Samuel Rowland Fisher and the Free Quakers. Quaker interpretations of the nature of suffering enhanced this inner strength, for pacifist Friends saw the travails of war not only as hardships but also as a blessing and a vehicle for saintly purification. For pacifists, the sacrifice of political hegemony, material wealth, and greater security enjoyed during the colonial era only strengthened their resolve. The Meeting for Sufferings articulated this view at war's end, commending Friends who had borne rebel fury and "measurably seen and felt the sufficiency of his protecting power, and in the day of their humiliation have been permitted to sit under the cover of his paternal care. ${ }^{\prime 86}$ The view that devout suffering was a beneficial rather than detrimental experience invigorated Quaker conviction, contributed to the postwar perception that they posed no threat to the standing order, and became a pillar of successful reintegration.

Notwithstanding radical ire and reaction, Quaker pacifists never threatened republican government in the post-evacuation era. Yes, foes often accused them of manipulating prices, refusing continental paper currency, or harboring displeasure with the course of events - and there was some truth to these allegations. But such "threats" paled in comparison to William Allen Jr.'s regiment of Pennsylvania Loyalists, William Rankin's loyal cohorts in the southeastern counties, John Connolly's frontier escapades, or the Doan guerrillas beyond Philadelphia's perimeter. That the British never tried to make use of this untapped resource as part of a grand strategy, even as cogs within their civil administration, speaks to the view that the king's generals did not consider pacifists a trustworthy or adequately loyal asset. Rebel rancor against Quakers thus seems wholly

${ }^{86}$ Philadelphia Meeting for Sufferings, November 20, 1783 cited in Marietta, Reformation of American Quakerism, 259. 
misplaced within the narrow context of the independence struggle. It is only when we add pre-war Presbyterian and Quaker tensions to the equation that radical actions make sense as a "rightful" correction of perceived political wrongs.

POSTWAR REINTEGRATION, NONJURORS \& THE TEST ACT REPEAL

Non-threatening behavior did not necessarily spawn acceptance of the new order. While restraint was a quality intrinsically consistent with pacifist doctrine, embracing republicanism required no less than divine intervention. Since Friends believed God ordained state authority, they could not consent to republican government unless King George III renounced his rule over Pennsylvania. Recognition of the new order was therefore circumscribed to the outcome of the war. The divine verdict arrived in 1783 with the Definitive Treaty of Peace, when the monarch relinquished "all claims to the government, propriety, and territorial rights" of the rebellious colonies, Pennsylvania included. ${ }^{87}$ While the severing of ties with England produced anxiety among many Quakers, their consternation did not preclude acknowledgement that God had indeed spoken. As Quaker banker David Barclay surmised from London, "the pleasing prospect of peace affords ground for expectation that an intercourse may be established to the comfort of many on both sides the Water." ${ }^{88}$

For Friends, Barclay's optimism was well founded, for independence resolved or softened three of the sect's four principal objections to the Revolution. The war's end eliminated demands for participation in military aggression against the British. The need for active militia service on the frontier continued but declined considerably, reducing

\footnotetext{
${ }^{87}$ The Definitive Treaty of Peace, September 3, 1783, Article 1, The Avalon Project, Yale Law School, available at http://avalon.law.yale.edu/18th_century/paris.asp last accessed 05/18/2017.

${ }^{88}$ David Barclay to James Pemberton, June 21, 1782, Pemberton Papers, Box 36, 155, HSP.
} 
pressures to pay war taxes, fines or find a substitute. And God had resolved the dilemma of established authority by divinely sanctioning patriot victory. Only resistance to the taking of oaths endured. For the disaffected, however, the peace did not at first bring peace. As details of the treaty recommending restitution of loyalist property swept through public venues, the challenge of reintegration rose to the forefront as the single most important issue facing the new republic. Contemporary press accounts reveal deep apprehensions over loyalism, disaffection, and citizenship, with vociferous radicals pushing for exclusion of those who had not contributed to the revolutionary cause in Pennsylvania. A similar dynamic played out in the other twelve rebel states. Quakers who opposed the war on pacifist principles found themselves woven into the drama.

In May 1783, Berks County residents formed a Whig association "calling to remembrance the cowardly desertion and undermining arts of a set of men, unworthy of the name Americans, who now come out of their hiding places." The Berks associators were willing to allow these turncoats to reside among them and "in silence peaceably enjoy the common benefits flowing from a glorious revolution," their tolerated presence lauded as "monuments of the clemency of government." But local Whigs were likewise prepared to do everything in their power to "discountenance in this county, the voting at elections for any man, whose principles in politicks [sic] have been inimical to the independency of this country." Freemen of the city of Philadelphia and the Liberties met at the State House the following month and approved popular resolves for transmission to the state assembly. In essence, these citizens argued that it was inconsistent with the people's dignity and interest that those who had "deserted their country in the hour of danger and sacrifice" and had "voluntarily withdrawn" from the state or any other state in 
rebellion, or who had joined the enemy, been attainted or banished "should be suffered to return to, or reside within the state of Pennsylvania." They saw it as their duty to not only prevent but "to expel, with infamy," all such individuals. Naturally, they opposed "the restoration of the estates forfeited by law," a reference to treaty proposals. Their instructions to the assembly forbade "the return of those degenerate and apostate sons of America, who hold principles incompatible with a republican government." Attitudes in the city - where greater numbers of radicals had endured the British occupation - were clearly more uncompromising than in Berks County, though both saw full citizenship as an earned privilege of revolution, not a right of residency. ${ }^{89}$

In August, "independent electors" of Bucks County published and submitted to their representatives in the state legislature a set of "instructions for the government of your conduct" as the war drew to a close. They asked for a new law prohibiting the return of loyalist exiles and targeted the disaffected who remained through "your strongest efforts... to oppose repeal of the test laws," insisting that "we will use every effort in our power to exclude all descriptions of men, who have deserted their country and joined the enemy of these United States... from residing among us." Like Whigs in Berks and Philadelphia, the Bucks County language supported an exclusionary citizenship based on revolutionary credentials. A comparable sentiment prevailed in a letter published on December 27 from a gentleman in Scotland whose son in Philadelphia had served as an American officer. The writer blamed the war on "your American delinquents and apostates, [who] by their nefarious misrepresentations, did inflame and abet our rulers here," a not-so-veiled reference to loyalist exiles in Great Britain like Joseph Galloway

${ }^{89}$ Pennsylvania Packet, May 24, 1783; Pennsylvania Evening Post, June 17, 1783. 
and Andrew Allen. On the issue of returnees, the gentleman questioned "with what grace, in the name of wonder, can these miscreants and malevolent wretches supplicate to return and live amongst a people they have so much prejudiced and injured?" He then called upon "the friends of liberty" to "spurn at the idea of receiving again into their bosoms those vipers who have sucked their blood already." ${ }^{90}$ The battle over nonjurors thus evolved into a battle over who was worthy to stay and to be allowed to hold republican citizenship. To reintegrate was to become a fully enfranchised citizen.

In the short run, the peace treaty's recommendations did more to resurrect the antipathies of eight years of war than to restore local harmony. Fortunately for the disaffected-turned-nonjurors, however, the outburst of anti-loyalist fervor proved fleeting. Various factors contributed to the reinstatement of tranquility over the next few years. On the one hand, radical patriots beyond official control on occasion achieved their exclusionary ends, compelling the hurried flight of some suspected of royalist complicity. Capt. Thomas Rawlings, Capt. Joseph Crathorne and Thomas Plunket "received peremptory notice to depart in a specified time" from a citizens committee and five others were "denounced to the committee and warned off." $"$ "The intermittent success of these scare tactics and threats seems to have acted as a mollifier of radical anger at the local and neighborhood level, satiating specific enmities or personal grudges. Once repelled, the immediate adversary disappeared for good. The Pennsylvania government - like their counterparts throughout America - lent a deaf ear to the Definitive Treaty of Peace's prompting that "Congress shall earnestly recommend" a restoration of loyalist property in

\footnotetext{
${ }^{90}$ Pennsylvania Packet, August 7, 1783; Independent Gazetteer, December 27, 1783.

${ }^{91}$ Scharf \& Westcott, History of Philadelphia, 428.
} 
the independent states. When it became clear that the treaty articles that had triggered the commotion were not to be enforced, public passions subsided. But the remaining issue of allegiance to the state did not. While postwar refusal to take the test no longer conveyed the blot of treason, only men who swore allegiance to Pennsylvania were entitled to full citizenship. For reformist Friends, God had sanctioned patriot government but oaths were still forbidden. Thus, the test oath became the single most significant barrier to enfranchisement for male Quaker nonjurors, drawing an ideological divide between reintegration and legal citizenship..$^{92}$

During the rest of the decade, patriot factions dueled over the status of nonjurors, but the ultimate Test Act repeal of 1789 had little directly to do with the reform-minded Quakers, who persisted in their pacifist withdrawal from the political arena. John Pemberton encapsulated the need to assume a non-threatening public position while remaining true to the sect's beliefs in a wartime letter still valid after the peace. Asking Henry Drinker to intercede with Abel Evans against a "menacing entanglement" that could be misconstrued as a breach of Quaker neutrality, John cautioned that "we need to be Wise as Serpents \& Harmless as Doves." $" 93$ At the height of the Test Act debates in the mid-eighties, James Pemberton remarked that "there are great Contests among our Politicians about Repeal of the Test Law." He observed that some state representatives "are very solicitous that friends should write in an application to the Assembly for removal of the grievance \& the restoration of our Just rights.” Yet James opposed Quaker

\footnotetext{
${ }^{92}$ Women were not required to swear allegiance under the Test Act. See Statutes At Large of Pennsylvania, vol. 9, "An Act Obliging All White Male Inhabitants of This State to Give Assurances of Allegiance to the Same and for Other Purposes Therein Mentioned," June 13, 1777, Chapter 756.

93 John Pemberton to Henry Drinker, September 1, 1779, Pemberton Family Papers, Box 3, HSP. The "menacing entanglement" had to do with the timber on Grace Growden Galloway's confiscated lands. See "Diary of Grace Growden Galloway," August 21, 1779, PMHB, vol. 58, no. 2 (1934), 173.
} 
involvement, reflecting that "hitherto we have been quiet, and I hope shall so Continue, from a persuasion that our safety \& union consist in avoiding to join in the Councils of such unstable men." James expressed similar sentiments amid a later climate of national insecurity, writing to John in Europe that "a general discontent prevails among the people in the Massachusetts and Rhode Island governments, which keeps up a great ferment \& agitation." To this disorder he added a resurgence of war with the natives in the west placing the blame once again on the "avarice \& imprudence of the Frontier Inhabitants," code for the Scots-Irish Presbyterians - and renewed troubles with the northeast's Connecticut settlers. His formula for handling the widespread chaos remained secession from public life. After proudly declaring that "there is not in our Assembly any acknowledged member of our Religious Society," he extolled the benefits of strategic isolation, advising that "our safety consists much in keeping free from having any connection in their Councils or disputes.” The Philadelphia Yearly Meeting of 1786 validated James' sentiments, exhorting Friends to "beware of taking an active part in government, either to elect or be elected" - in other words, refrain even from voting. ${ }^{94}$

This conscious self-reliant insularity among committed Friends made followers almost impervious to outside influences and, in the long run, earned patriot respect and acquiescence. Final Quaker reintegration correspondingly took place on the same two fronts that had followed the British evacuation: the legal external sphere and the internal self-structured domain. The first required patriot consent. Quaker readiness to embrace republicanism after God's ringing verdict on state authority greatly facilitated that path.

\footnotetext{
${ }^{94}$ James Pemberton to John Pemberton, January 16, 1785, Pemberton Papers, Box 42, 165; James Pemberton to John Pemberton, November 25, 1786, ibid., Box 47, folder 40, HSP; Mekeel, Relation of the Quakers, 318. The "ferment and agitation" was Shay's Rebellion then in full swing.
} 
On the other hand, reformists built the interior world on an amalgam of family, faith, community, business, and social concerns, none of which posed a threat to the nascent republican regime. Illness and death shaped much of daily life. A typical missive had James Pemberton remarking to John that their sickly sister was now "well and in good spirits" but his own wife Phoebe "has met with a fresh affliction by the death of her mother." Three years later, James described his spouse's "weak state of mind" and reclusion in her bed chamber over a period of weeks after the death of a close friend, a condition resolved by the timely intercession of Quakers Sarah Harrison and Elizabeth Drinker who insisted Phoebe accompany them to a religious rendezvous in Shrewsbury which spurred her recovery. ${ }^{95}$ John Pemberton kept an ongoing tally of acquaintances who had died since his departure from Philadelphia in 1782, a list enumerating thirtythree such deaths, including merchant Joshua Fisher, physician Thomas Bond, noted Quaker abolitionist and "my worthy Friend" Anthony Benezet, and extended family such as cousin Elizabeth Pleasants and nephew Joseph Pemberton, Israel's son. ${ }^{96}$

Traveler Jean Pierre Brissot de Warville, a future French revolutionary, witnessed the candor of a Quaker funeral firsthand. Escorted by James Pemberton, the unidentified Quaker preacher who delivered the eulogy made a vivid impression on the visitor. The minister had "trembled in all his body, and his eyes were staring and wild," and then "a woman [who] threw herself on her knees, made a very short prayer." Quaker sincerity of

\footnotetext{
${ }^{95}$ James Pemberton to John Pemberton, June 29, 1782, Pemberton Papers, Box 36, 164; James Pemberton to John Pemberton, October 29, 1785, ibid., Box 44, 117, HSP.

${ }^{96}$ John Pemberton, Death of Friends \& Acquaintances since I left my Habitation. $6^{\text {th }}$ mo; 11. 1782, Pemberton Papers, Box 36, 148, HSP. Given John began his journey on June 11, 1782, and various deaths listed here are known to have occurred after that date, the stand-alone document must represent a tally from that date forward. For example, James informed John of Anthony Benezet's death in a letter from Philadelphia dated September 20, 1784. James Pemberton to John Pemberton, Box 42, Folder 15, HSP.
} 
emotion made a deep impression on the foreigner. Later that year, Brissot conversed at length with James a day after his daughter Hannah's death. As the teary but serene father reflected on his offspring's demise, the guest concluded that Quakers “consider Heaven as their country; and they cannot conceive why death, which conducts to it, should be a misfortune. ${ }^{, 97}$ Friends held the view that, after living in union with Christ, death led to greener pastures, invigorating their capacity to endure mortifications such as persecution and banishment.

The Quaker outlook on earthly suffering likewise subsumed personal needs to the imperatives of heaven. The letters of John Pemberton's wife, Hannah, to her husband abroad exude this sentiment and provide a portrait of the postwar attitudes of the Quaker faithful. "I wish my dear to be encouraged to fulfill every duty that thou art Called to perform," she wrote from Philadelphia three years after his departure. Although she missed him dearly - "I Salute thee in the tenderest Love \& Sympathy even more than I can express for thou art often in my remembrance by day and by night" - Hannah expressed solidarity with John's mission, news of which had "awakened... every tender feeling on thy account my Beloved Spouse, with whom all that is liveing [sic] within me is made at times partaker with thee in thy deep Baptisms and unusual path, in which thou has been led." Emblematic of the Quaker devout, Hannah Pemberton did not believe John had made a personal decision to cross the ocean. Instead, he was an instrument of divine

\footnotetext{
${ }^{97}$ Jean Pierre Brissot de Warville, "Letter X - The Funeral of A Quaker," New Travels in the United States of America, 118-120 (quote on 119). The funeral was for Thomas Holwell, a Quaker elder. Brissot de Warville, "Letter XXXI - The Quakers, Their Private Morals, Their Manners, Etc.," New Travels in the United States of America, 230. Brissot does not identify Hannah by name, only referring to James' daughter. That it was Hannah can be deduced from other sources: the Biographical Directory in Elaine Forman Crane's edition of The Diary of Elizabeth Drinker has daughter Hannah dying in 1788, the year of Brissot's comments, while biographical notes from "The Diary of Robert Morton" in the PMHB, vol. 1, no. 1 (1877), 1 state Hannah died on September 4, 1788.
} 
guidance. A year later, she reaffirmed that "I often very often think of thee \& feel myself thy Companion Closely united in \& through thy many trials \& exercises which I believe Infinite Wisdom has Allotted thee for the Promotion of his truth \& Righteousness among many that have been much of Strangers to the precious life \& his Holy leadings. ${ }^{" 98}$ In short, their shared sacred duty was far more important than personal need or suffering. Sacrifices had to be made for the Lord. It was the same blueprint that steered Quaker pacifist conduct during the war.

The religious comings and goings of Friends offer further indication of the stature of faith in the Quaker community during postwar reintegration. A typical trio of letters from James to John Pemberton in 1784 mention the return from England of American Friends Robert Valentine and Samuel Rowland Fisher after preaching there; the arrival of Thomas Irwin with news of Quakers in Ireland; "the business transacted with such harmony" by "the considerable number of friends now collected from various parts" such as North Carolina and Virginia for the Yearly Meeting in Philadelphia; and the arrival in town of Quaker preacher William Kersey. John received encouragement while in Great Britain not only from wife Hannah, brother James, and other relations but also from the extended Quaker community. A particularly eloquent letter at mid-decade from Ann Emlen Jr. heartened the missionary to continue his efforts "to gather in the shieves [sic] which shall be reaped, \& which thou art now as foreman, made to help bind up in the harvest field of the divine." ${ }^{99}$ Ann's poetic images show the depth of conviction pacifist

\footnotetext{
${ }^{98}$ Hannah Pemberton to John Pemberton, January 30, 1785, Pemberton Papers, Box 42, 184; Hannah Pemberton to John Pemberton, December 20, 1785, ibid., Box 44, 169; Hannah Pemberton to John Pemberton, November 28, 1786, ibid., Box 47, 44, HSP.

99 James Pemberton to John Pemberton, September 20, September 27 \& October 3, 1784, Pemberton Papers, Box 42, 15, 23 \& 29; Ann Emlen, Jr. to John Pemberton, January 15, 1785, Box 42, 162, HSP.
} 
Quakers felt in the quest to bring the world into rightful alignment with their view of the Gospel. That view posed no threat to patriot authorities of either faction.

Quaker peaceful behavior and acceptance of republican rule is implicit in the mundane personal, social and business interactions of both the post-evacuation and postwar eras. The accounts of Thomas Wharton Sr. expose how believers' focus on the personal all but erased external politics from daily life in the midst of revolution. Bills from his carpenter show work recommencing on a remodeling of his estate the summer after his return from Virginia. In the fall he leased out a lot in the Southwark ward. The next year he discharged a bond from the colonial era, then borrowed money in gold and silver, and later rented out his property on the Delaware wharfs as a storefront. In one instance, patriot moderate Benjamin Rush canceled a lease agreement with Wharton, blaming "the unjust tender laws" in existence. Rush's interaction shows that moderates were willing to do business with those officially tainted with disaffection, while his condemnation of monetary policy reveals yet another division between patriot radicals and moderates. ${ }^{100}$ Life's routines expunged politics from Wharton's post-evacuation communications. Although he had admitted that "great is my uneasiness" and received assurances from his brother Isaac for "the severe pressure of unmerited captivity" during "this Deeply afflicting Period" of exile in Virginia, Thomas' decision afterwards to

\footnotetext{
${ }^{100}$ John King Account Book with Thomas Wharton Sr., August 25, 1778; Memorandum of an Agreement, Felix Fenner \& Thomas Wharton Sr., November 13, 1778; John Baynton, Samuel Wharton \& Thomas Wharton's Bond, dated $27^{\text {th }}$ February 1767, discharged \& delivered April 21, 1779; Borrowed an [sic] Received of William Fisher Sr. £100 in Gold, February 21, 1780; Borrowed \& Recd from Brother William Wharton $£ 100$ in Silver, April 26, 1782; Agreement between Daniel Wier Commissary General \& Co. and Thomas Wharton Sr., August 4, 1782; Benjamin Rush to Madam, March 21, 1781, Wharton \& Willing Families Papers, Collection 2014, Box 3, HSP. It appears "Madam" was handling the rental for Wharton, who Rush mentions directly in the letter.
} 
jettison the revolutionary conflict from his daily record epitomized the Quaker tendency towards insularity in the midst of rebellion. ${ }^{101}$

James Pemberton's correspondence yields a similar air of the commonplace.

While conveying reports of itinerant Quaker preachers in his vicinity, friend Thomas

Colley took the opportunity to request that James send him a batch of good boots.

William Rodman wanted to know if James had received interest payments on a probate matter implicating the forfeited properties of loyalists Gilbert Hicks and Thomas Smith.

If not, Rodman wanted to apply to the assembly for restitution of his share. ${ }^{102}$ A year

later, James mediated a debt between the estate of Benjamin Taylor, a deceased

American, and Thomas Wagstaffe, a Quaker merchant in London. The following year he interceded with Friends in Rhode Island who had questions on an inheritance due to Pennsylvania Quaker Susannah Fisher. These requests for James' arbitration reveal his prestige and standing in the Society of Friends. Social and family interactions dotted the details of the daily, as if no war or banishment had ever taken place. James notified Dr. Parke that "thy Company will be acceptable" to dine with Dr. Thornton and himself one fine afternoon between one and two o'clock. Cousin Jacob Read felt the pinch of war scarcities in New Jersey and asked for funds to purchase clothing. ${ }^{103}$ James and John

\footnotetext{
${ }^{101}$ Thomas Wharton Sr. to Rachel Wharton, October 12, 1777; Isaac Wharton to Thomas Wharton Sr., October 31, 1777; Isaac Wharton to Thomas Wharton Sr., September 11, 1777, Wharton \& Willing Families Papers, Collection 2014, Box3, HSP.

102 Thomas Colley to James Pemberton, January 4, 1787, Pemberton Papers, Box 47, 91; William Rodman to James Pemberton, January 2, 1782, ibid., Box 36, 53, HSP. The assembly named Gilbert Hicks as one of the thirteen loyalists attainted in the original law of March 6, 1778. Rodman refers to the seizure of Thomas Smith's property. That Smith was never attainted did not exonerate his property from confiscation.

${ }^{103}$ James Pemberton to Isaac Taylor, January 14, 1783, Pemberton Papers, Box 38, 19; Susannah Fisher to James Pemberton, September 9, 1784, ibid., Box 42, 3; James Pemberton to Dr. Parke, October 26, 1786, ibid., Box 47, 13, HSP. Quaker accounts of the era are replete with references to daytime and evening
} 
arbitrated payment of long overdue debts that Israel's son Joseph had inherited as part of his father's estate. Testy exchanges with their "Loving nephew" had the uncles insisting Joseph “comply with his [claimant's] equitable demands" as nephew alluded to a supposed alacrity hampered by "great interruptions to trade." ${ }^{104}$ Even brotherly connections sometimes required Quaker intercession. John appealed to Henry Drinker to plead on his behalf about an upcoming religious journey in the company of Thomas Lightfoot. "If thou would join in giving my Bro[the]r a Hint of the necessity of his helping me at this time, it would have much effect," he proposed. ${ }^{105}$ It appears colleague Henry had more influence with James than brother John himself did.

The resumption of ordinary life beyond the political is also evident in James Pemberton's continuing involvement in the merchant trade, an activity which afforded him economic viability and more options in worldly affairs than his younger brother. In a typical business note, London-based Quakers John and Robert Barclay informed James of financial adjustments involving clients in Rotterdam and the British capital. St. Thomas merchant Daniel Tyson blamed a missing shipment of silks on a probable capture at sea because "B." - his friend and intermediary - "is incapable of neglect." communications sometimes disclosed the larger economic tenor of the times. Referring to visitations to the homes of neighbors. Such activity served as the backbone of community life. Jacob Read to James Pemberton, September 21, 1781, ibid., Box 36, 9, HSP.

\footnotetext{
${ }^{104}$ James \& John Pemberton to Joseph Pemberton, May 13, 1782, Pemberton Papers, Box 36, 100; Joseph Pemberton to James \& John Pemberton, May 21, 1782, ibid., Box 36, 120, HSP. The claimant was London merchant Thomas Powell who wrote detailed letters with attachments to James and John explaining the debt's complicated history and then enlisted the aid of prominent London Quaker David Barclay in resolving the transatlantic issue. See for example, Thomas Powell to James \& John Pemberton, February 28, 1782 and David Barclay to James \& John Pemberton, February 28, 1782, ibid., Box 36, 77 \& 79, HSP.

${ }^{105}$ John Pemberton to Henry Drinker, January 30, 1781, Pemberton Family Papers, HSP.

${ }^{106}$ John and Robert Barclay to James Pemberton, June 15, 1785, Pemberton Papers, Box 44, 2; Daniel Tyson to James Pemberton, November 10, 1781, ibid., Box 36, 18b, HSP.
} 
an influx of Quakers "whose motives being of a temporal nature" had relocated from the countryside to Philadelphia in the mid-eighties, James confided that "they will I expect find their mistake" soon enough because of "the very great change of mercantile affairs, which are almost daily growing worse, by frequent bankruptcies among the Traders." Two years later he again lamented that "our traders \& mercantile people complain much of the dullness of the times." The economic stagnation reflected in James' letters contributed to the changes that spurred the triumph of moderates and resulted in the test act repeal and state constitution of $1790 .{ }^{107}$

James and John Pemberton dedicated much of their postwar efforts to fortifying Quaker institutions and reforms at home - in effect reintegrating the Society of Friends back into the fabric of Pennsylvania society. The education of Quaker youth, the spiritual purity of the discipline, and an ambitious project to write a history of Quakerism incorporating the denomination's expansion to America headed their agenda. In the first case, James was named to a committee of Overseers to investigate the "State of our schools," specifically the number and quality of "Tutors" and "Schollars [sic]." John zealously committed to reinforcing the Society's disciplinary conventions before his European trip. Though later published during his absence, the 1788 "Epistle of tender Caution and Counsel Affectionately Addressed to the Members of our Religious Society in Philadelphia" summarizes John's earlier objectives and reformists' anxiety that

\footnotetext{
${ }^{107}$ James Pemberton to John Pemberton, January 16, 1785, Pemberton Papers, Box 42, 165; James Pemberton to John Pemberton, January 4, 1787, ibid., Box 47, 92, HSP. That economic considerations played a leading role in bringing about structural change in the new republic is seen in the convocation of the Annapolis Convention of 1786 which acted as a prelude to the Constitutional Convention of 1787. The largely unsuccessful Annapolis gathering was convened expressly for the purpose of reconsidering commercial relations between the states. Its failure led to a motion to convene what became the federal Constitutional Convention the following year. See Edmund Cody Burnett, The Continental Congress, especially Chapter XXXIII, 654-668.
} 
worldly success among the faithful had rendered a parallel loss of religious purity.

Embedded within the epistle's language was the implicit success of the broader Quaker reintegration a year before the repeal of the test laws. ${ }^{108}$ James in particular devoted his time to gathering firsthand evidence from Meetings throughout the former colonies for the edition which eventually became John Gough's four-volume A History of the People Called Quakers from their First Rise to the Present Time. ${ }^{109}$ Visitations, ministrations, mediations, commerce, discipline and service went on as usual as the inner track of Quaker reintegration bred a semblance of normalcy. Daily life in the postwar era gradually came to resemble peacetime before the Revolution.

Although focused for the most part inwardly, reformists ventured into the public arena on behalf of select social causes important for their heavenly aims. Antislavery and the suppression of vice and immorality headed the list of Quaker advocacy in the 1780s. While the Society braved some backlash from these external commitments, negative tremors were subsidiary to recognition from the patriot moderates in power who reacted to Quaker proposals as if petitioners were fully vested citizens rather than disenfranchised nonjurors. By acting as "normal" citizens, Friends quietly advanced the notion that they should be restored as citizens.

The Quaker push against slavery which predated the Revolution typified this approach. Israel Pemberton and his brothers worked to prohibit slave ownership among

\footnotetext{
${ }^{108}$ James Pemberton to Henry Drinker, December 1, 1783, Pemberton Family Papers, HSP; Minutes, Philadelphia Monthly Meeting, Middle District, August 29, 1788, "Epistle of tender Caution and Counsel Affectionately Addressed to the Members of our Religious Society in Philadelphia," vol. 3, 392-401, HAV.

${ }^{109}$ John Gough, A History of the People Called Quakers from their First Rise to the Present Time; Compiled from Authentic Records, and from the Writings of That People (Dublin: Robert Jackson, 1790). For a typical example of James' efforts, see James Pemberton to John Pemberton, January 30, 1785, Pemberton Papers, Box 42, 183, HSP in which he describes how "an united concern \& desire prevailed [in the meeting] to furnish our fr'd J. G. with all the materials we can, to promote the work he is engaged in."
} 
Friends from mid-century forward, disowning those who refused to comply. Sanctions continued against fellow Quakers who failed to abide by the sect's manumission dictates into the postwar period. ${ }^{110}$ Over time, reformers' efforts expanded into relief assistance and the establishment of schools for people of African descent. ${ }^{111}$ The logic of applying antislavery tenets to one's own members led reformist leaders to combat the immorality beyond the bounds of the faith, lobbying government and the general population for an end to the slave trade and the abolition of slavery itself. In their view, what was evil for Quakers was naturally evil for the greater society. In 1780, the state assembly's passage of "An Act for the Gradual Abolition of Slavery" crowned Friends' antislavery efforts. ${ }^{12}$ Quaker opposition to slavery afterwards extended beyond the provincial borders of Pennsylvania to the southern states, the Continental Congress headquartered in New

\footnotetext{
${ }^{110}$ Quaker Meeting Minutes contain frequent cases of less committed Friends who continued to hold slaves despite instructions from the reformist leadership to manumit them. Failure to comply usually led to disownment. Israel Pemberton's mediation with Jacob Russell and John Jervis in November 1778 was a typical instance, as was the case of Thomas Mayberry a month later. See Minutes, Philadelphia Monthly Meeting, Middle District, November 27, 1778 \& December 28, 1778, vol. 2, 89 \& 96, HAV. The policy had become Quaker "law" in 1776 when the Philadelphia Yearly Meeting opted to disown Quakers who did not free their slaves. See Marietta, Reformation of American Quakerism, 120. For the evolution of prerevolutionary Quaker views on slavery, see Brycchan Carey, From Peace to Freedom: Quaker Rhetoric and the Birth of American Antislavery, 1657-1761 (New Haven: Yale University Press, 2012).

${ }^{111}$ Reformer Anthony Benezet was a prime promoter of education and established a Quaker school for free blacks in Philadelphia before the Revolution. See Marietta, Reformation of American Quakerism, 31, 36. For Benezet, see Maurice Jackson, Let This Voice Be Heard: Anthony Benezet, Father of Atlantic Abolitionism (Philadelphia: University of Pennsylvania Press, 2009); Marie-Jeanne Rossignol \& Bertrand Van Ruymbeke, eds., The Atlantic World of Anthony Benezet (1713-1784): From French Reformation to North American Quaker Antislavery Activism (Leiden: Brill, 2016); Wilson Armistead, Anthony Benezet. From the Original Memoir (London: A. W. Bennett, 1859).

${ }^{112}$ Statutes At Large of Pennsylvania, vol. 10, "An Act for the Gradual Abolition of Slavery," March 1, 1780, Chapter 881, vol. 10, 67-73. The Quaker crusade against slavery is well documented. See Julie L. Holcomb, Moral Commerce: Quakers and the Transatlantic Boycott of the Slave Labor Economy (Ithaca: Cornell University Press, 2016); Brycchan Carey \& Geoffrey Plank, eds., Quakers and Abolition (Urbana, IL: University of Illinois Press, 2014); the revolutionary era essays in Richard Newman \& James Mueller, eds., Antislavery and Abolition in Philadelphia: Emancipation and the Long Struggle for Racial Justice in the City of Brotherly Love (Baton Rouge: Louisiana State University Press, 2011); Jean Soderlund, Quakers \& Slavery: A Divided Spirit (Princeton: Princeton University Press, 1985); and Thomas E. Drake, Quakers and Slavery in America (Gloucester, MA: Yale University Press, 1950).
} 
York, and across the ocean to Parliament and the English public. Devoted reformer Warner Mifflin asked John Pemberton to provide him with materials "particularly respecting the Negroes" to take to Virginia and later again for an address to Parliament while he was in England. Patriot printer Francis Bailey, who published the Freeman's Journal or the North American Intelligencer in Philadelphia from 1781 to 1792, informed James Pemberton that he hoped to send to Charleston one hundred copies of "Mr. Day's letter" opposing the slave trade. He enclosed another two hundred copies for circulation in Pennsylvania and offered a like number "if you have connections in the southern states... for the purpose of circulating among them." ${ }^{113}$ Like Benjamin Rush's lease with Thomas Wharton Sr., antislavery cooperation between Bailey and Pemberton less than a year after the war's termination suggests collaboration between nonjurors and patriots was perfectly acceptable despite the former's continued disenfranchisement.

In the mid-1780s, James Pemberton and fellow reformist leaders revved up their campaign against the slave trade by taking the debate to the Continental Congress seated at New York. In a letter to John, James referred to "an application... lately made to the President of Congress" on the subject and distribution of a pamphlet on "the Case of the Oppressed Africans, sufficient to deliver one to each member." The drive continued over the next few years. In 1786, key Philadelphia Quakers including James teamed with coreligionists in New York and sent a delegation to Congress to advance the antislavery

\footnotetext{
${ }^{113}$ Warner Mifflin to John Pemberton, December 5, 1781, Pemberton Papers, Box 36, 32; Warner Mifflin to James Pemberton, January 16, 1785, ibid., Box 42, 166; Francis Bailey to James Pemberton, September 10, 1784, ibid., Box 42, 4, HSP. Francis Bailey was a printer who published the Freeman's Journal or the North American Intelligencer in Philadelphia from 1781 to 1792 . "Mr. Day" is in all probability Thomas Day and the work in question A LETTER from ********, in London, to his friend in America, on the subject of the slave trade; together with some extracts from approved authors of matters of fact, confirming the principles contained in said letter (New York: Samuel Loudon, 1784). See Peter C. Hogg, The African Slave Trade and its Suppression: A Classified and Annotated Bibliography of Books, Pamphlets and Periodical Articles (London: Routledge, 2013), 149.
} 
message. The delegation met with Foreign Minister John Jay, late President of Congress Nathaniel Gorham, New York radical Melancthon Smith, and a bevy of congressional delegates from South Carolina, North Carolina, Georgia, Maryland, and Massachusetts. Significantly, radical Philadelphian Charles Thomson "gave us a list of divers of the Members of the Southern Governments with his apprehensions of their Views in Relation to the Matter under Care." ${ }^{114}$ As long-time secretary to Congress, Presbyterian Thomson had been an active proponent of the 1777 Quaker deportation to Virginia and opposed pacifist rigidity throughout the revolutionary conflict. Still congressional secretary when the delegation visited New York, Thomson's willingness to lend a hand demonstrates an increasing acceptance of ex-disaffected pacifists as legitimate constituents of the nation, despite their legal marginalization at home. ${ }^{115}$

Reformists likewise viewed with alarm the population's mounting postwar preoccupation with earthly cares. In response, they mounted campaigns to suppress vice and depravity. The Quaker hierarchy was especially wary of institutions that fostered moral decay. In their view, the two most notorious were taverns, considered "ensnaring Nurseries of Idleness, Drunkenness and Debauchery," and "the Amusements of the Stage" which promoted "the most pernicious Evils" contrary to the teachings of

\footnotetext{
114 James Pemberton to John Pemberton, January 30, 1785, Pemberton Papers, Box 42, 183; Report of Isaac Zane on behalf and desire of the Committee to the Meeting for Sufferings in Philadelphia, November 11, 1786, ibid., Box 47, 40, HSP.

${ }^{115}$ Quaker delegations to the Continental Congress under the Articles of the Confederation continued, but their efforts had less effect because Congress itself became more and more irrelevant as political power and interest turned to the new federal government created by the Constitutional Convention of 1787. The last day in which the Continental Congress conducted business was October 10, 1788. For that institution's waning days, see Burnett, The Continental Congress, Chapter XXXV, "Passing the Torch," 703-726. For an example of the impact of Congress' demise on Quaker antislavery labors, see Edmund Prior to James Pemberton, January 7, 1787, Pemberton Papers, Box 47, Folder 96, HSP where the author comments that, although hopeful for their common cause, recent efforts were at a standstill because "Congress have not yet been able to make a House \& of course no President is yet Chosen."
} 
Christianity. While countering this declension in virtue, Quakers addressed the state assembly as concerned inhabitants on multiple occasions. ${ }^{116}$ In 1786, Friends succeeded in strengthening an anti-vice bill that had served as the revolutionary state's morality compass since 1779. Extended provisions targeted iniquities such as godless "worldly business" and diversions on Sundays, profanity, intoxication, cockfighting, bulletplaying, billiards, gaming for money, betting, duels, theatrical productions, and the number of taverns. Three years later, opposing petitioners succeeded in repealing the sections applying to "dramatic entertainments," the assembly declaring itself "desirous of promoting the interests of genius and literature by permitting such theatrical exhibitions as are capable of advancing morality and virtue and polishing the manners and habits of society." 117

The postwar national battle over the inhumanity of slavery and the slave trade and the local campaign over the impropriety of theatrical entertainments and distribution of spirited liquors both failed. The Quaker push to have the first federal Congress end the slave trade in 1789 rather than delaying its prohibition for twenty years as negotiated into the federal Constitution did not succeed. Congress did pass a Slave Trade Act the next decade barring U. S. ships from participation in that inhumane commerce under a penalty

\footnotetext{
${ }^{116}$ For example, The Address and Memorial of the People called Quakers in Philadelphia, To the General Assembly of Pennsylvania, November 28, 1785 in Interesting Minutes, Philadelphia Monthly Meeting, Middle District, December 30, 1785, vol. 3, 233-236, HAV. James Pemberton was one of twelve signers. In addition to the above address, see for example To the General Assembly of Pennsylvania, The Memorial and Petition of the People called Quakers in the City of Philadelphia, November 6, 1788 in Interesting Minutes, Philadelphia Monthly Meeting, Middle District, November 28, 1788, vol. 3, 414-417, HAV which James Pemberton signed as one of twenty-two Quaker leaders.

${ }^{117}$ Statutes At Large of Pennsylvania, vol. 9, “An Act for the Suppression of Vice and Immorality,” March 30, 1779, Chapter 833, 333-338; ibid., vol. 12, "An Act for the Prevention of Vice and Immorality and Unlawful Gaming and to Restrain Disorderly Sports and Dissipation," September 25, 1786, Chapter 1248, 313-322; ibid., vol. 13, "An Act to Repeal So Much of an Act of General Assembly of this Commonwealth as Prohibits Dramatic Entertainments within the City of Philadelphia and the Neighborhood Thereof," March 2, 1789, Chapter 1391, 184-186.
} 
of forfeiture for vessels that violated federal law. And in 1808 Congress outlawed the slave trade as per the earlier constitutional covenant, one year after passage of the Act Prohibiting the Importation of Slaves. ${ }^{118}$ Quakers indisputably contributed to the public sentiment encouraging these measures but the broader goal of national abolition proved elusive. Similar results occurred on the local vice and virtue front. Taverns and theaters not only survived but thrived in Pennsylvania in the ensuing years. The secular current was simply too strong.

Nevertheless, efficacious public advocacy in the case of gradual abolition at the state level suggests that Quaker reintegration began well before the war ended. It is striking that pacifist reformers achieved passage of an abolition act through a historically hostile radical-dominant assembly at the height of its power less than two years after the public execution of two Quakers. Contemporary radical ideology is ascertainable in the Pennsylvania Constitution of 1776, that faction's most distinctive pronouncement during the Revolution. The issue of slavery appears only once in the document, an allusion in the preamble to England's use of "foreign mercenaries, savages and slaves, for the avowed purpose of reducing them [Pennsylvanians] to a total and abject submission to the despotic domination of the British parliament." The topic does not appear in any of the sixteen articles in the key section entitled "A Declaration of the Rights of the Inhabitants

\footnotetext{
${ }^{118}$ An Act to prohibit the carrying on the Slave Trade from the United States to any foreign place or country, March 22, 1794, http://avalon.law.yale.edu/18th_century/s1001.asp; 2 Statutes 426, An Act to Prohibit the Importation of Slaves into any Port or Place Within the Jurisdiction of the United States, From and After the First Day of January, in the Year of our Lord One Thousand Eight Hundred and Eight, March 2, 1807. http://avalon.law.yale.edu/19th_century/s1004.asp, both at Avalon Project, Yale Law School, last accessed February 15, 2018.
} 
of the Commonwealth or State of Pennsylvania." ${ }^{119}$ In other words, slavery was not a crucial concern for radicals in 1776. Yet they joined forces with Quaker rivals in 1780.

This achievement could not have occurred without the coalescence of various factors. First, radicals had come to recognize a notable difference between armed loyalist militants and the relatively innocuous character of religious pacifists like those banished to Virginia. Second, the unfortunate executions of Quakers Abraham Carlisle and John Roberts in 1778 satisfied the clamor for revenge against the sect among rebel officials. Third, revolutionaries turned their wrath against the overt loyalists who departed rather than the merely disaffected who stayed through the confiscation and sale of exiles' assets. These attitudinal changes allowed radical patriots to honor the entreaties of pacifist Quakers at permissible junctures with the same attention and dignity given to full citizens of the commonwealth, in a sense obscuring the legal status of the disaffected. The pattern continued into the postwar era. Quaker reformers accordingly engaged authorities as if they had an inherent right to participate in government. James Pemberton and eleven other Quaker leaders said as much in their 1785 anti-vice address to the state assembly. "Incited by an Apprehension of religious duty and a real concern for the prosperity of our Country," Friends implied they were already citizens of Pennsylvania despite their nonjuror status. ${ }^{120}$

\footnotetext{
${ }^{119}$ Preamble \& A Declaration of the Rights of the Inhabitants of the Commonwealth or State of Pennsylvania, Constitution of Pennsylvania, September 28, 1776, The Avalon Project, Yale Law School, http://avalon.law.yale.edu/18th_century/pa08.asp last accessed on October 20, 2016. Radicals did have their own antislavery crusader in council vice-president George Bryan. His biographer credits Bryan's "untiring efforts," not the Quakers, for passage of the gradual abolition act. See Foster, In Pursuit of Equal Liberty: George Bryan and the Revolution in Pennsylvania, 109.

${ }^{120}$ The Address and Memorial of the People called Quakers in Philadelphia, To the General Assembly of Pennsylvania, November 28, 1785 in Interesting Minutes, Philadelphia Monthly Meeting, Middle District, December 30, 1785, vol. 3, 233, HAV (emphasis mine).
} 
Official postwar reactions to Quaker efforts at both the local and national levels presupposed that Friends did not object to republican rule. Many members of Congress received their antislavery delegations to New York with open arms - even southern delegates met with them and listened. Meanwhile, Pennsylvania authorities did not deny access to Quakers because of their legal condition. On the morality question, religious leaders from other denominations joined in the campaign to ban stage plays and limit the effects of taverns, further validating Quaker legitimacy. When the national government moved from New York to Philadelphia, reformers widened their anti-vice campaign to include federal authorities. President Washington's response to a 1789 address of the Philadelphia Yearly Meeting illustrates the sentiment of many patriots. "Your principles and conduct are well known to me," said the president, "and it is doing the People called Quakers no more than Justice to say that (excepting their declining to share with others the burthen of the common defense) there is no Denomination among us who are more exemplary and useful Citizens."121 Although this exchange took place several months after the test act repeal had reestablished nonjurors as fully enfranchised Pennsylvania citizens, the underlying tone of the president's words suggests a long-standing attitude. In the end, Quaker reengagement on social issues strengthened the view that they were valuable citizens who posed no threat and willingly accepted a republican government born of revolution.

\footnotetext{
${ }^{121}$ George Washington, "To the Religious Society Called Quakers, at their Yearly Meeting for Pennsylvania, New Jersey, Delaware, and the Western Part of Maryland and Virginia," October, 1789 in Jared Sparks, ed., The Life of George Washington, Commander-in-Chief of the American Armies, and First President of the United States, to which are added his Diaries and Speeches; and Various Miscellaneous Papers Relating to his Habits \& Opinions, vol. 2 (London: Henry Colburn, 1839), 310-311.
} 


\section{REINTEGRATION AFTER THE TEST ACT REPEAL}

Legal reintegration for members in good standing of the Society of Friends came full circle with the test act repeal. James Pemberton and a minority of his brethren who still believed in the positive effects of political participation during peacetime reentered public life immediately after reacquisition of their "just rights." Two days before the repeal, the Pennsylvania assembly passed an act incorporating the City of Philadelphia and restructuring the government to include the election of fifteen aldermen and thirty common councilmen. Polls opened about three weeks after the incorporation and repeal. James Pemberton won a seat as a common councilman. With him, Quakers Miers Fisher, Henry Drinker, and Edward Pennington also emerged victorious. ${ }^{122}$ Their election speaks volumes on changing conditions and reintegrative success. The four had been banished to Virginia in 1777. A dozen years after that tragedy, the freemen of the city had elected those they once repudiated to rule over them. The election suggests Quaker reintegration exceeded legal constructs to include a much fuller social reacceptance.

At the close of the eighties, a new era dawned in Pennsylvania. The local and the national merged to make the state - and especially the capital city - the center of life in the early republic. The confluence of the test act repeal and the new state constitution of 1790 , on the one hand, and the federal constitution and the relocation of the seat of national government to Philadelphia, on the other, exemplified the decisive victory of patriot moderates. That triumph brought Quakers closer to a resumption of pre-war

\footnotetext{
${ }^{122}$ Statutes At Large of Pennsylvania, vol. 13, "An Act to Incorporate the City of Philadelphia," March 11, 1789, Chapter 1394, 1193-214. The city government had been run as a corporation during the proprietary era but the Pennsylvania Constitution of 1776 eliminated this framework. The 1789 act authorized the election of aldermen for seven-year terms and councilmen for three years. Aldermen were also to annually elect from their number someone to serve as mayor; Scharf \& Westcott, History of Philadelphia, 455-456.
} 
normalcy. John Pemberton finally returned from Europe in the fall of 1789. Arriving after the repeal battle, John's acceptance of the new order was barely an afterthought. His reintegration was seamless. Disembarking at Wilmington, Delaware, on September 26, John was pleased to find that former council president and patriot moderate "John Dickinson sent his carriage with us to Chester." Dickinson's civility was yet another manifestation that Quakers merited respect. Hannah was delighted to see her husband. The youngest Pemberton brother resumed his duties at home with the same characteristic fervor as earlier. He rejoined the Philadelphia Meeting. He again distributed personal funds to the poor. He accompanied other ministers on religious outings to fellow Friends in the surrounding countryside, like the three weeks he spent calling on Quaker families in Bucks County with James Thornton in 1792. In community circles, John and Hannah revived their close contacts with Philadelphia Quakers. Elizabeth Drinker noted that the couple were often guests at her home in the early 1790 s. $^{123}$

Yet even seamless reintegration proved unsatisfactory for a John Pemberton burdened by weightier concerns. His "return to his relatives and friends after a long absence on his former European visit, was very gratifying," James observed. But it soon became apparent that "he came to us under an apprehension that his duty was not fully performed; which occasioned so great distress and conflict, as sometimes to affect his bodily health." After nearly a half-decade at home, John reapplied to the Monthly and Quarterly Meetings for a new certificate which would allow him to return to Europe as a missionary. Prolonged introspection and debate followed. Eventually he received the blessing "of the full unity of his brethren." On May 27, 1794, he boarded the Adrian at

${ }^{123}$ The Life and Travels of John Pemberton, September 26, 1789, 286; John Pemberton Journal, 56-57; Diary of Elizabeth Drinker, October 30, 1793 \& February 25, 1794, 118 \& 125. 
Newcastle, Delaware, and set off for Amsterdam, the first leg of a voyage to the faithful in Germany. ${ }^{124}$ John Pemberton would never see America again. During his first winter abroad, he became ill and "reduced to a very weak state." In the final entry of his diary, the dedicated disciple counseled two errant congregants "not willing to be subject to the discipline and good order, in wisdom established among Friends" and then recorded that mail delivery had been interrupted because the armies of the French Revolution had crossed into Holland. John died among his beloved people at Pyrmont, Germany, on January 31, 1795 and was interred days later at the Friends burial ground there. Hannah lived on till the age of seventy-seven, finally passing away in 1811. Her death signaled the end of that branch of the family. The pair had no children. ${ }^{125}$

Israel Pemberton's legacy after his 1779 death carried further. As the last male heir of the King of the Quakers, worldly son Joseph lasted only a few more years, dying in 1782 at the age of thirty-five soon after the terse exchanges with his uncles on the payment of inherited debts. Joseph's marriage to Ann Galloway of Maryland in 1767, however, produced eight children - four boys and four girls - all of whom survived the war. Four of the eight lived into the nineteenth century. Youngest son, John, born after Joseph's death, endured longest among those of his generation, breathing his last in 1847 - a year after Lorenzo Sabine resurrected loyalists in the first edition of his Biographical Sketches of Loyalists of the American Revolution. Like Joseph, two of Israel's daughters - Mary and Sarah - also survived the revolutionary era. In 1762, Mary married future

\footnotetext{
${ }^{124}$ The Life and Travels of John Pemberton, 288-290.

${ }^{125}$ The Life and Travels of John Pemberton, 332-336. John's final diary entry was on January 18, 1795; John Pemberton Journal, 57-58. The year of Hannah's death is in Diary of Elizabeth Drinker, Biographical Directory, 329.
} 
Virginia exile Samuel Pleasants. Their union produced ten children. Mary Pemberton Pleasants died in 1821. Sarah married Samuel Rhoads in 1765, had three children, and died in 1810. Despite the fact that these descendants did not carry forward the Pemberton surname, Israel's lineage nonetheless reaped the long-term benefits of reintegration, leading productive lives into the antebellum period. ${ }^{126}$

Whereas fate had willed the death of his older brother and religious fervor had taken away his younger sibling, it was James Pemberton who was left to fulfill the promise of reintegration in Pennsylvania as the Age of Federalism dawned. James and wife Phoebe continued in their roles as leaders of a community that still looked mainly inward. In 1794 the couple were overseers at the wedding of Elizabeth and Henry Drinker's son. Two years later they consoled the Drinkers after daughter Molly chose to marry outside the faith. During this time, James' reputation grew within Quaker Meeting circles. Brissot de Warville's description shortly before the test act repeal extended into the future. Referring to James' station among his coreligionists, the Frenchman held that he was "one of the most wealthy, and one whose virtues have placed him among the most respectable of their chiefs." ${ }^{127}$ Although postwar troubles affected Quaker legal rights, citizenship, and social standing in the broader society, Brissot de Warville's comment

\footnotetext{
${ }^{126}$ Joseph Pemberton (1747-1782), Ancestry.com, https://www.ancestry.com/genealogy/records/josephpemberton_1553882, last accessed July 29, 2017; Diary of Elizabeth Drinker, Biographical Directory, 329330.

${ }^{127}$ Diary of Elizabeth Drinker, December 11, 1794, 141; ibid., August 10, 1796, 167; Brissot de Warville, "Letter XXXI - The Quakers, Their Private Morals, Their Manners, Etc.," New Travels in the United States of America, 225.
} 
reveals that these effects did not extend into the economic arena. Quaker merchants continued to prosper in the immediate postwar period. ${ }^{128}$

In the newly reopened public sphere, James refreshed his commitment to dearly held social causes. He signed petitions to Pennsylvania's Supreme Executive Council on behalf of the Society for the Abolition of Slavery in 1789. Six months later he was elected President of the organization, replacing the revered and recently deceased Benjamin Franklin. That a formerly banished pacifist Quaker replaced the most renowned Pennsylvania patriot of the American Revolution at the head of an institution on the cutting edge of social change ratifies the view that reformist Friends had regained the broader society's respect by 1790 and reintegrated well beyond the legal realm. Under James' tutelage, the Abolition Society's hopes for abolishing the slave trade expanded into the global arena through partnership with the Société des Amis des Noirs in France, founded in 1788 with the collaboration of Brissot de Warville. ${ }^{129}$ James was reelected annually as the society's president until his advanced age in 1802 prompted a resignation. During the Federalist era, Quakers also turned their attention again to Indian affairs but

\footnotetext{
${ }^{128}$ In his study of Philadelphia elites, Stephen Brobeck notes the disintegration of an earlier cohesion among Philadelphia's Quaker upper class in the new republic. He attributes this to demographic and social forces, such as the death of many prominent Quakers, their sons' unwillingness to band together in a unified Quaker grouping like earlier generations, and increased secularization. The surviving descendants of the pacifist Quakers of the Revolution prospered like non-Quakers but they did not see themselves as distinctive. See Stephen James Brobeck, "Changes in the Composition and Structure of Philadelphia Elite Groups, 1756-1790," (Ph.D. Dissertation, University of Pennsylvania, 1972), especially the subsection entitled "The Disintegration of the Quaker Elite" in Chapter 6, 184-194.

${ }^{129}$ See Council Minutes, November 19, 1789, Colonial Records, vol. 16, 210; “James Pemberton,” Legislators in Pennsylvania, vol. 3, 1035; Thayer, King of the Quakers, 200. James had been elected one of two vice-presidents of the organization in 1787 while Franklin was president. Scharf \& Westcott, History of Philadelphia, 445. For the French abolitionists, Gilbert, Black Patriots and Loyalists, 244-246, 251-252.
} 
the Pembertons played a diminished role. ${ }^{130}$ A renewed Quaker call for pacifism went out during the Quasi-War storm when an address to the federal Congress urging the United States to refrain from war with France set off a public firestorm that caused James and others to withdraw their names from the petition. The conflagration was the product of the newly emergent Democratic-Republican/Federalist factionalism of the 1790s. In this instance, William Cobbett's notorious Porcupine's Gazette led a pro-Federalist attack on the pacifist petitioners, charging that James and his Quaker colleagues had aligned themselves "with Democrats, with disorganizers and atheists" - meaning French revolutionaries. The accusation implied that James supported war on the side of France, a misunderstanding he resolutely wished to rectify. ${ }^{131}$

As the revolutionary century closed, James Pemberton entered life's final stages. In his last decade, the indefatigable reformer maintained an armchair devotion for his favored causes, for example corresponding with President Thomas Jefferson on the antislavery question. James passed away in Philadelphia on February 9, 1809 and was buried in the city's Quaker cemetery in the presence of "a very large concourse of his fellow citizens." He was eighty-five. His will divided substantial wealth in real estate holdings and personal property not only among his wife, children and grandchildren but also six friends and three domestic servants. Phoebe Lewis Morton Pemberton survived her husband for another three years, dying in 1812 at the age of seventy-four. Two

\footnotetext{
${ }^{130}$ For the Quaker role with the native nations in the Federalist era, see Bauman, For the Reputation of Truth, 201-216. Bauman argues these renewed efforts led to the establishment of an Indian Committee within the corporate structure of the Society of Friends that went beyond social concerns, institutionalizing Quaker political activism. Such an outcome strengthens the view that legal reintegration for pacifist Quakers opened the door to all arenas.

${ }^{131}$ Porcupine's Gazette, March 26, 27, 28, 1798; Petition from the Quakers of Philadelphia to Congress, March 23, 1798, cited in Miller, Philadelphia - The Federalist City, 104, $172 \mathrm{fn} 31$.
} 
decades later Philadelphia historian John Watson painted a vivid sketch of the final Pemberton of the revolutionary generation, describing James as "almost the last of the race of the 'cocked hats' and certainly one of the very best pictorial illustrations of bygone times and primitive men." In a later assessment, loyalist historian Lorenzo Sabine remarked that James had died "universally respected." Judging from the admiration and esteem bestowed upon this Quaker icon in his waning days, there can be no doubt that long-term reintegration was a success for pacifist Friends like him. Patriot Pennsylvania had forgiven - or perhaps chosen to forget - the sins of suspected British collaborators who had once spurned the noble ideal of self-government. ${ }^{132}$

\section{CONCLUSION}

Despite a preference for monarchy and the old order over republican rule, pacifist and reform-driven Quakers like the Pemberton brothers were never pro-British militants. They are better understood as disaffected Pennsylvanians rather than loyalists. Their main objective was to preserve Pennsylvania as a sanctuary of peace, tolerance and prosperity according to the vision of founder William Penn. Two wars challenged that promise. During the French and Indian War, Quakers who dominated the provincial assembly blamed Presbyterian settlers rather than natives for the savagery of frontier conflict, in the process alienating many non-Quaker whites. That struggle accelerated an internal move to purify Quakerism as reformers pressed for a wholesale retreat from public life in order to preserve pacifist ethics. By the time the American Revolution reared its head, reformist Friends were well on their way to dismantling the Quaker party in the assembly and voluntarily abdicating power. Presbyterian-led radicals with anti-Quaker antecedents

\footnotetext{
132 “James Pemberton," Legislators in Pennsylvania, vol. 3, 1035-1036; Watson, Annals of Philadelphia and Pennsylvania, in the Olden Time, vol. 1, 595-596; Sabine, Biographical Sketches, vol. 2, 159.
} 
exacerbated by colonial tensions repudiated pacifist passivity in the wake of imperial tyranny and filled the power vacuum. After Lexington, the rebel call to arms collided head-on with Quaker pacifism and, in the eyes of radical insurgents, developed into a loyalist vs. revolutionary divide. Friends' belief that violence and war were inherently evil and contrary to Christ's teachings bound them to reject militia service and the payment of taxes and fines linked to prosecution of the war. A scripturally inspired Quaker prohibition against the taking of oaths further distanced Friends from rebels, as did Quaker faith in the inviolability of established government.

The resentment and distrust between Quakers and radicals culminated in the arrest of key Quaker leaders such as Israel, James, and John Pemberton suspected as British collaborators when General William Howe invaded Pennsylvania in the fall of 1777. The detainees refused to take the oath of allegiance to the state or sign paroles, resulting in their banishment to Virginia without a hearing. Refusal of the test oath thus became the engine for Quaker disenfranchisement. After much controversy, patriot authorities permitted the return of the exiles to Philadelphia in late April 1778. The group was never formally charged with a crime. When Clinton's imperial army evacuated the city and the revolutionary government returned in June, the Pembertons and their fellow Virginia exiles chose to remain in Pennsylvania rather than depart with the British, launching their reintegration journey.

The Pembertons and like-minded pacifists responded to the restoration of patriot rule by assuming a non-threatening posture that avoided politics and focused on their daily lives and businesses. Initially, their only public concern was a campaign to help jailed antiwar Friends and their families affected by patriot retribution. Uplifted by the 
convictions that saintly duty superseded personal desire and suffering was an instrument of God's grace, disenfranchised Quakers channeled their energies into inward-looking family, religious, community, business, and social activities beyond the scope of politics. Friends only reentered the public arena to defend their faith, uphold divine virtue and right social wrongs, mainly in campaigns against moral decay and the institution of slavery. The antislavery effort led to the passage of the Gradual Abolition Act of 1780.

The patriot victory that ended the war allowed Quakers to accept republican rule since Providence had ordained a new source of governmental authority. Ignoring their protracted nonjuror status, postwar Quakers repeatedly assumed the role of enfranchised citizens who had a right to petition government. In general, these efforts were received agreeably in key patriot circles such as the Pennsylvania General Assembly and the Continental Congress. Friends' non-threatening pacifist posture and their readiness to accept republican rule established favorable conditions for the legal reincorporation of nonjurors. These factors coincided with the political triumph of patriot moderates at the state level, leading to the 1789 repeal of the test acts - with little Quaker input. By reinstating citizenship rights, the repeal closed the book on the legal reintegration process for nonjurors.

That James Pemberton and other reformist Quakers ran for office immediately following the test act revocation ratifies that Friends valued legal enfranchisement. Yet citizenship played second fiddle to the precepts of their religious faith, especially the call to pacifism. The electoral triumphs of James and three other pacifist candidates banished in 1777 illustrates that Quakers had successfully reintegrated by 1790, a point further evidenced in James' election as president of the Abolition Society following the death of 
celebrated patriot Benjamin Franklin that year. Over the long haul, the inoffensive nature and consistency of Quaker pacifist behavior - inspired and guided by reformers like the Pembertons for nearly half a century - generated trust among former revolutionaries.

This trust aligned with the inclusionary views of patriot moderates and paved the way for the legal reintegration of those once thought to be obnoxious and inimical. 


\section{CHAPTER 5 \\ LOYALIST DEFIANCE, THE RULE OF LAW \& REINTEGRATION}

In addition to the attitudes, behaviors and actions of the disaffected, the root

causes of reintegrative success must also take patriot contributions into account. For only

the victors could confer a full-scale reassimilation of onetime enemies. Taking over a

decade to crystallize, patriot consent for reintegration was the outgrowth of two

underlying premises. The first was ideological. Revolutionary theory touted the inherent

rights of English subjects - reborn as republican citizens - as moral justification for

rebellion. During the imperial crisis, violations of these rights emphasized issues like

taxation without representation in Parliament, local jury trials in cases with political

overtones rather than adjudicatory venues in England, colonists' forcible quartering of a

British standing army in peacetime, and the ongoing authority of provincial assemblies to

pay the salaries of royal governors. The later push towards popular sovereignty added a

philosophical orientation to these rights that was more inclusionary, building on concepts

such as greater equality, extension of citizenship and the franchise to those willing to

swear allegiance, and expanded representation in democratically elected bodies. ${ }^{1}$ The

enforcement of these natural rights required an impartial system of justice based on the

rule of law equally applicable to all citizens, a universal ideal regulated by contemporary

views of citizenship among patriot radicals and moderates.

The second premise was pragmatic. For hard-fought revolutionary aspirations to endure, Pennsylvania society had to achieve a degree of stability that would foster long-

\footnotetext{
${ }^{1}$ For example, greater representation in the state legislature from the outer and frontier counties beyond the original Quaker settlements in and around Philadelphia was a key element of the Pennsylvania patriot movement. See Charles Henry Lincoln, The Revolutionary Movement in Pennsylvania 1760-1776 (Philadelphia: University of Pennsylvania, 1901), especially 45-50.
} 
term political, economic and social development. As a class of residents legally removed from public participation, nonjurors were an impediment to the postwar vision and reality of a successful revolution with the potential to extend well into the protracted lifetimes of the disaffected generation. Because radical Constitutionalists favored permanent exclusion of nonjurors who had not taken the test oath, their political dominance meant that the state would require two sets of rights and laws well into the future, one for fullfledged citizens and another for proscribed nonjurors, contradicting the inclusionary tendency of inherent rights philosophy, and in practice prolonging the political insecurity that defined much of the 1780s. On the other hand, a sectarian win for moderate AntiConstitutionalists heralded one set of rights and laws for all citizens and growing societal stability, as per their more inclusive outlook. As the popular will increasingly backed moderates in local elections after 1781, their triumphs laid the groundwork for a reinstatement of the rights of large segments of the disenfranchised and the elaboration of a single system of laws for all qualifying citizens, providing ideological consistency and political stabilization.

While application of the law to defend the rights of citizens who pledged allegiance was a foundational principle of the Revolution, defiance often generated a hostile reaction. Quaker pacifists challenged the new order by publicly protesting military violence and refusing to take the test oath. Despite a profound disdain for their antiwar stance and an initial policy of banishment, revolutionaries concluded over time that reformist Friends did not present a genuine danger to the budding republic. But there were others, much more palpably loyalist, who engendered fiercer reactions from rebel officials. Two examples stand out. Quakers Abraham Carlisle and John Roberts, who 
collaborated with General William Howe's administration during the British occupation, tried to resume life as usual after the evacuation only to find themselves the foils of official and popular rage. After their conviction for high treason, the radical government executed the pair in a very public display in November 1778. Meanwhile, the Doan guerrillas personified the remnants of the loyalist militants who continued to fight for the king in Pennsylvania after the British evacuation. Their actions jeopardized the security and stability of the revolutionary government into the postwar period. Both radical Constitutionalists and moderate Republicans interpreted the Doan gang's activities as an existential threat and successfully joined forces to eradicate the danger.

When juxtaposed with the treatment of Quaker pacifists, the Carlisle/Roberts and Doan cases reveal the bounds of dissent that Pennsylvania's revolutionary factions chose to allow. As ongoing radical vs. moderate patriot factionalism disclosed, one could dispute the nature of republicanism and popular sovereignty from within. Allegiance permitted internal divisions. The nascent state was also willing to tolerate the continuing presence of recalcitrant nonjurors such as the Quakers as long as they posed no threat. Moreover, contrition was not only feasible but encouraged. Many attainted during the war willingly surrendered, banking on the clemency of rebel authorities. Most judged correctly. Patriot officials discharged the cases of prominent citizens like Provost William Smith of the College of Philadelphia and merchant Tench Coxe, as well as those of lesser sorts like artisans Ludwig Kercher and John Palmer, farmers Peter Robeson and Uriah Hughes Jr., and laborers John Burnett and Henry Effinger. Artisan Joseph Bolton, pilot John Poor, farmer James Hartnett, and merchant Samuel Garrigues Sr. surrendered and 
went to trial, only to be acquitted. ${ }^{2}$ Discharge or acquittal led to a restoration of citizenship after the requisite oath of allegiance. Those attainted could also solicit official forgiveness. The state exonerated a number of attainted Pennsylvanians between 1779 and 1802, with most pardons granted in the postwar era of moderate ascendancy. ${ }^{3}$ In these ways, the revolutionary legal order bolstered republican rights and reintegration, while legitimizing patriot authority and control. Yet the Carlisle/Roberts and Doan affairs depict the reverse side of the coin, demonstrating that patriots denied consent for reintegration when it was perceived that the disaffected did pose a threat to republican rule. The nature of that threat was in the eye of the beholder, however. Whereas radicals and moderates came together to exterminate the Doans' armed insubordination, radicals went at it alone in the case of Carlisle and Roberts, who by any measure no longer posed a danger to the Revolution at the time of their arrest in late 1778. This punitive disparity between revolutionary factions reaffirms that successful legal reintegration could only have taken place under moderate rule.

\section{THE EXECUTION OF QUAKERS ABRAHAM CARLISLE \& JOHN ROBERTS}

On November 4, 1778, revolutionaries executed Quakers Abraham Carlisle and

John Roberts in Philadelphia for high treason. The news pervaded local accounts. Noting

\footnotetext{
2 "List of Persons Against Whom Proclamations Were Issued by the Supreme Executive Council \& Who Surrendered Themselves to be Tried for High Treason," June 28, 1779, from the Records of the Courts of Oyer \& Terminer \& for the Several Counties of Philadelphia, Chester, Bucks, Lancaster \& Northampton, Pennsylvania Archives, Sixth Series, vol. 13, 475-477; Scharf \& Westcott, History of Philadelphia, 395.

${ }^{3}$ The difference between discharge/acquittal and forgiveness/pardon was mainly procedural. Most of those found guilty through attainders did not voluntarily surrender for trial as required by law. Most who did surrender were discharged or acquitted. See my footnote on Anne Ousterhout's study of rebel prosecutions for infidelity in the section entitled "Quelling Disaffection" in Chapter 1. Henry James Young's list of 42 pardons shows that radical-dominant government granted six between April 1779 and 1781, three were the product of the transitional stage of mixed radical-moderate rule between November 1781 and September 1783, while moderate-led governments granted 33 thereafter. Young, "The Treatment of the Loyalists in Pennsylvania,” Appendix XI, “A List of Proclaimed Traitors Who Were Pardoned," 400-401.
} 
the calamity, Grace Growden Galloway recorded in her dairy "all things are gloomy." Elizabeth Drinker also confided to her journal, "An awful Solemn day it has been.” That evening she and husband Henry went to pay their respects at "Neigr. Carliles [sic]" where "the Body is brought home, and laid out - looks placid \& Serene.” Quaker preacher John Pemberton, who had visited the prisoners in jail two days before the execution and "found them in a thoughtful disposition, and tender," noted that "they appeared resigned, and died without a struggle," their faces as if "in an easy deep sleep." ${ }^{4}$ Moravian minister John Ettwein was present at the morbid spectacle, "meditating with unusual fervor upon our doctrinal text: 'For none of us liveth to himself."' Ettwein considered the death of these "old and otherwise highly respected and beloved men" an injustice engineered by the radical Presbyterian faction who "had contrived to prevent the House from assembling before they had been hanged." Given the city's inflamed political tensions in the wake of the British evacuation, he believed the execution was inevitable, for "Quakers were to be and had to be hung."

Ettwein's analysis accurately reflects the contemporary partisan dynamic between patriot radicals and moderates. After Sir Henry Clinton's army abandoned the provincial

\footnotetext{
4 "Diary of Grace Growden Galloway," November 4, 1778, PMHB, vol. 55, no. 1, 56; Diary of Elizabeth Drinker, November 4, 1778, 82; John Pemberton, Eleventh Month $2^{\text {nd }}$ (November 2, 1778) \& Fourth day (November 4, 1778), The Life and Travels of John Pemberton, 92-93. Although he does not say so explicitly, Pemberton's language strongly suggests he was present at the execution.

${ }^{5}$ John Ettwein, Short Account of the Disturbances in America and of the Brethren's Conduct and Suffering in This Connection in Kenneth Gardiner Hamilton, John Ettwein and the Moravian Church during the Revolutionary Period (Bethlehem, PA: Times Publishing Co., 1940), 222 (emphasis mine). The biblical meditation is from St. Paul's Letter to the Romans 13:7. Ettwein's suspicions were well founded. The radical-dominated assembly convened as scheduled on Monday, October 26, but could not put together a quorum. Some elected officials continued to meet without a quorum every weekday through Wednesday, November 4 inclusive (the day of the execution). Then miraculously on Thursday, November 5, enough members finally attended to constitute a quorum. See Journals of the House of Representatives of the Commonwealth of Pennsylvania, 231.
} 
capital in mid-June, returning revolutionaries found Philadelphia devastated. ${ }^{6}$ A popular clamor for revenge arose. Historical antagonisms between Presbyterians from the lower and artisan classes and the once dominant Quakers led to bottom-up pressures targeting Friends, among others, who could be identified as loyal to King George III - a perilous state of affairs with the potential to metastasize. Unfortunately for the vengeful, most diehard followers of the king like Joseph Galloway and the loyalist Allens had departed with the British. Aware that backlash could lead to anarchy, patriot moderates counseled prudence. The resulting tug of war between rebel factions culminated in the arrest and execution of Carlisle and Roberts as a means to satiate popular rancor while restraining further bloodletting. Measured in those terms, it worked. Whether it was justified or not is another matter. ${ }^{7}$ The episode was irrefutably the pinnacle of revolutionary events in Pennsylvania in late 1778. Sundry aspects of the affair have been covered in the historical scholarship over the years. David Maxey's outstanding treatment of the John Roberts trial is of particular note. ${ }^{8}$ Given the present study's reintegrative focus, however, the concern here is as much about the aftermath as the trial and execution itself. The hanging of Abraham Carlisle and John Roberts shows that patriots were bent on eradicating what they perceived as direct threats to their authority, although in this case only the radicals in power envisaged the peril. The execution further reveals that reintegration could only

\footnotetext{
${ }^{6}$ Jackson, With the British Army in Philadelphia, especially Chapter XVI, “A Devastated City,” 265-273.

${ }^{7}$ This statement reflects the way events actually played out in the long run. When authorities executed the two Quakers, however, it was not at all clear how many more executions would be forthcoming.

${ }^{8}$ David W. Maxey, Treason on Trial: The Case of John Roberts, Miller (Philadelphia: American Philosophical Society, 2011). Also significant are Carlton F. W. Larson, "The Revolutionary American Jury: A Case Study of the 1778-1779 Philadelphia Treason Trials," Southern Methodist University Law Review, vol. 61, no. 4 (2008); and Peter C. Messer, "'A Species of Treason \& Not the Least Dangerous Kind': The Treason Trials of Abraham Carlisle and John Roberts," PMHB, vol. 123, no. 4 (October, 1999).
} 
occur on terms that legitimized and institutionalized republican rule and stability. Lastly, it exposes that the law, when wielded under radical authority, could be a double-edged sword for the disaffected and not necessarily a vehicle assuring successful reintegration, as in later periods of moderate hegemony.

As rumors swirled that the British were going to voluntarily relinquish occupied Philadelphia, Pennsylvania's Supreme Executive Council attainted Abraham Carlisle, "House Carpenter" of the City of Philadelphia, and John Roberts, "late of the Township of Lower Merion, Miller,” on May 8, 1778. This council attainder proclamation issued from Lancaster following the original assembly attainder act of March 6 targeted fiftyseven presumed loyalists, placing the pair among the first seventy attainted provincials. ${ }^{9}$ Disregarding contrary cautions, the carpenter and the miller decided to stay and adapt to the revolutionary regime rather than depart. Regarding Carlisle, Joseph Galloway said that "I positively advised him to leave the city, because I knew he would not be safe." Similarly, Roberts' cousin and future U. S. Senator Jonathan Roberts later wrote "my father thought that his return within the power of the Whigs, was unwise, and advis'd accordingly."10 The Quakers' confidence in revolutionary moderation was not wholly unfounded. In April, the Continental Congress sitting at York had recommended "to the legislatures of the several states to pass laws, or... issue proclamations, offering pardon,"

\footnotetext{
9 “A Proclamation,” May 8, 1778, Colonial Records, vol. 11, 481-485. The earlier assembly attainder act named thirteen individuals. See Statutes At Large of Pennsylvania, vol. 9, "An Act for the Attainder of Divers Traitors if They Render Not Themselves by a Certain Day, and for Vesting Their Estates in This Commonwealth, and for More Effectually Discovering the Same and for Ascertaining and Satisfying the Lawful Debts and Claims Thereupon," March 6, 1778, Chapter 784, 201-202.

${ }^{10}$ The Examination of Joseph Galloway, Esq; Late Speaker of the House of Assembly of Pennsylvania, Before the House of Commons, In a Committee of the American Papers, With Explanatory Notes (London: J. Wilkie, 1779), 76-77; Jonathan Roberts and Philip Shriver Klein, "Notes and Documents: Memoirs of a Senator from Pennsylvania: Jonathan Roberts, 1771-1854,” PMHB, vol. 61, no. 4 (October, 1937), 455.
} 
to those who surrendered while asking "good and faithful citizens... to receive such returning penitents with compassion and mercy, and to forgive and bury in oblivion their past failings and transgressions." Even radical judge Thomas McKean expressed optimism two weeks before the British evacuation for "a general Pardon" to exclude only those who had earlier committed "an Overt-Act, such as bearing arms, or annexing his person to the troops of the Enemy... or furnishing them with provisions or intelligence." At the very least, he believed those who willingly surrendered "ought to be bailed." 11 John Roberts took immediate action to remedy his situation. The day after the British army left the city, he made a good faith visit to a patriot justice of the peace to affirm his allegiance to Pennsylvania, thereby complying with the June $25^{\text {th }}$ surrender deadline of his attainder. In a written declaration, Justice Zebulon Potts confirmed that Roberts had taken the test oath and commanded "all Sheriffs, Constables, \&c., not to detain nor keep in Custody the said John Roberts, on any Account, Cause, Action or thing." All seemed in good order. Besides, Roberts possessed favorable pre-war resistance credentials, nominated as one of forty-three representatives for Philadelphia city and county to "a large and respectable Committee... to correspond with the Sister colonies" for the purpose of setting up a colonial Congress at the mass citizens' meeting that protested Parliament's closure of the port of Boston on June $18,1774 .{ }^{12}$

\footnotetext{
${ }^{11}$ Journals of the American Congress, vol. 2, April 23, 1778, 525; Thomas McKean to William Atlee, June 5, 1778, Letters of Delegates to Congress, vol. 10, 31-33 (quotes on 32).

${ }^{12}$ Zebulon Potts, Esq., June 19, 1778, Pennsylvania Archives, First Series, vol. 7, 42; The Pennsylvania Gazette, June 22, 1774. The citizens' meeting provides a fascinating glimpse of revolutionary development. Co-chaired by Thomas Willing and John Dickinson, other committee members later accused of disaffection included Virginia exiles Edward Pennington and Thomas Wharton Sr., as well as John Allen, Jeremiah Warder, and Rev. William Smith. Attending patriots who surface in this study on occasion include radicals Thomas Wharton Jr., John Bayard, and Charles Thomson, along with moderates George Clymer, Thomas Mifflin, George Gray and Robert Morris. Notably absent are radicals Joseph Reed, George Bryan and
} 
But the popular outcry swelled. Indicative of growing resentment against the "notoriously disaffected, and others of suspicious characters, [who] presuming upon the indulgence and lenity of their virtuous and forbearing countrymen, have lately manifested an unbecoming and insolent spirit," nearly two hundred patriots signed a public pledge to root out those guilty of "misdoings before and during the enemy's possession of this city" and "bring such offenders to proper trial." A round-up of many of the attainted - and unattainted - soon followed. Officials issued a warrant for Roberts' arrest on July 27 and he was taken into custody on August 10. Ten days later he faced a hearing with the recently sanguine Judge McKean who now denied him bail. ${ }^{13}$ Abraham Carlisle was arrested on August 1. After a grand jury recommended indictment, his jury trial began on September 25. Patriots officially charged him with "1. Taking a commission, 2. Levying war, and 3. Aiding \& assisting the Enemies of this State" - legalese for having supervised the administration of passes in and out of the city under Howe during the occupation, in effect the British gatekeeper. The grand jury likewise indicted Roberts and his jury trial followed on September 30. The state charged him on five counts: "In endeavoring to procure a party of Light horse to rescue those banished to Virginia; Acting as a Guide; Being at Offices under the King \& causing People to be imprisoned as Rebels; That he endeavored to persuade people to inlist [sic] under Captn James; That he lived in the Country and joined the enemy in the city." Of these, the most serious was the second: his

Thomas McKean, as well as future assembly speaker from October 1780 to September 1783 Frederick Augustus Muhlenberg.

${ }^{13}$ The Pennsylvania Packet, July 25, 1778, DLAR. The first signature on the published list was that of Joseph Reed, who was to prosecute John Roberts and Abraham Carlisle for the state. "Diary of Grace Growden Galloway,” August 10, 1778, PMHB, vol. 55, no. 1, 48; Maxey, Treason on Trial, 28. 
role as a guide during a particularly destructive British army foraging expedition in December $1777 .^{14}$

During the period between arrest and trial, Philadelphia's Quakers published a reaffirmation of their pacifist principles and protested what they considered unwarranted revolutionary persecution. Recognizing that "a number of our friends have been and are imprisoned, some for refusing to pay the fines imputed in lieu of personal services in the present war, and others for refusing to take the test prescribed by some laws lately made," Friends reiterated their "steady adherence to our peaceable principles, and testimony against wars and fighting," and appealed to the religious protections of the original Penn charter, circuitously ignoring the rebel government's legitimacy. In addition, they asked for a repeal of those laws "which have a tendency to oppress tender consciences." For Friends Roberts and Carlisle, the timing could not have been worse. Radicals blamed Quaker acquiescence under the British occupation for much of the city's devastation. As "Belisarius" noted in a typical reaction, the address "has excited the most general resentment among all other orders of people that I have ever yet observed to follow any publication.",15

\footnotetext{
${ }^{14}$ Diary of Elizabeth Drinker, August 1, 1778, 79; "Respublica v. Abraham Carlisle, Indictment for Treason," A. J. Dallas, Reports of Cases Ruled and Adjudged in the Courts of Pennsylvania Before and Since the Revolution (New York: Banks \& Brothers, 1882), vol. 1, 35-38; "Notes of C. J. McKean in Case of Ab'm Carlisle," September 25, 1778, Pennsylvania Archives, First Series, vol. 7, 44; "Respublica v. John Roberts," Dallas, Reports of Cases Ruled and Adjudged in the Courts of Pennsylvania Before and Since the Revolution, vol. 1, 39-40; "Respublica Pennsylvania v. John Roberts," Appendix A, Maxey, Treason on Trial, 137-138. It was rumored that Roberts had attempted to organize a military rescue of the Virginia exiles as they made their way through Pennsylvania. The Captain James in the fourth charge was probably Jacob James who led the loyalist Philadelphia Light Dragoons. See Chapter 3. The general grand jury and trial jury processes are covered in Larson, "Revolutionary American Jury," SMU Law Review. For the grand jury, 1455-1457; for the trial jury, 1463-1467.

15 "To the assembly of Pennsylvania, the MEETING for SUFFERINGS for Pennsylvania and New Jersey, on behalf of the Society called Quakers, August 5, 1778," Pennsylvania Evening Post, August 13, 1778, DLAR. Nicholas Waln signed as the Society's clerk. The memorial was read and "ordered to lie on the
} 
With tensions thus magnified, radical Joseph Reed prosecuted both treason cases in the state Courts of Oyer \& Terminer \& General Gaol Delivery. Eleven witnesses stepped forth to condemn Carlisle for his arbitrariness and malice as administrator of passes, while seven censured Roberts, principally for his role as a guide in Howe's foraging excursion. The Roberts defense countered with twenty-nine witnesses, the Carlisle defense with at least twelve. For the most part, both defenses did not contest the facts but rather argued that the accused had acted in fear under British duress and compulsion. ${ }^{16}$ Trial testimony exposed the irony that John Roberts had at times aided the revolutionaries, cooperating with a neighbor to safely secure the papers of the Continental Congress during the British invasion and informing General Washington so that the documents could be successfully recovered. Later forfeiture evidence also shows that he provided the patriot army with two horses "for the use of the quarterMasters [sic] General Departmt" less than a month after the British captured Philadelphia. When all was said and done, however, the trial juries found both prisoners guilty. In accordance with due process, the court sentenced them to death as per the reigning treason statute. ${ }^{17}$

table."; "To the Printer of the PENNSYLVANIA PACKET," The Pennsylvania Packet, August 15, 1778. David Maxey notes that the records of the Radnor and Merion Quaker Meetings show that Roberts was "a member in good standing." See Treason on Trial, 13.

\footnotetext{
${ }^{16}$ The Carlisle witnesses - for and against - and the trial are in McKean's notes, Pennsylvania Archives, First Series vol. 7, 44-51. The Roberts witness count is in Larson, "Revolutionary American Jury," SMU Law Review, 1487. These witnesses are covered extensively in the prosecution and defense chapters of Maxey, Treason on Trial, 41-49 \& 51-69.

${ }^{17}$ James Lovell to George Washington, December 31, 1777, and George Washington to James Lovell, January 9, 1778, Edward G. Lengel, ed., The Papers of George Washington: Revolutionary War Series (Charlottesville: University of Virginia Press, 2003), vol. 13, 87-88, 192. Mention of the incident is in the Trial Notes, Appendix A, Maxey, Treason on Trial, 148; details are provided in 54-55. For the horses, see Chester County - Miscellaneous. The U. States to Penna. Dr., Pennsylvania Archives, Sixth Series, vol. 12, 215-216. Based on Roberts' attainder, "the debt was forfeited to the state." See Judge Thomas McKean's sentencing statement for John Roberts in Appendix B, Maxey, Treason on Trial, 159-162.
} 
While the verdicts did not surprise many, the severity of the sentence set off a firestorm of protest. Moderate patriot judge Jasper Yeates wrote that "the city is in the greatest ferment." ${ }^{\prime 18}$ A petition drive requesting clemency in favor of the condemned followed. Official records show that, beginning on October 18, forty-seven people signed four different memorials on behalf of both prisoners, 329 signed five memorials seeking moderation for Abraham Carlisle, and 1,006 signed twenty memorials for John Roberts. The signees comprised a cross section of the community, including at least thirty-seven officers in the revolutionary armed forces, fifteen from the uneducated lower sorts who signed with "X," and eleven patriots imprisoned by the British during the foraging expedition who Roberts attended with compassion. All twelve of the Carlisle jurors and ten of the twelve Roberts jurors who had convicted the duo asked for mercy, as well as judges Thomas McKean and John Evans who presided over the trials and sentenced the traitors. ${ }^{19}$ Anti-Constitutionalist moderates like Benjamin Rush, Thomas Fitzsimmons and Benjamin Wynkoop signed, as did some Constitutionalist militia on the radical Committee of Privates. Conspicuously, neither the radical leadership nor the principal Quaker reformers, foes on opposite ends of the local political spectrum, joined in the plea for commiseration. The radical leaders favored execution; the Society of Friends wanted to establish distance between their professed pacifist neutrality and the active pro-British

\footnotetext{
18 "Judge Yeates to Col. Burd," October 10, 1778, Thomas Balch, ed., Letters and Papers Relating Chiefly to the Provincial History of Pennsylvania with Some Notices of the Writers (Philadelphia: Crissy \& Markley, 1855), 267.

${ }^{19}$ Memorials for both prisoners are in Pennsylvania Archives, First Series vol. 7, 21-24; pro-Carlisle memorials are in $i b i d ., 52-58$; pro-Roberts memorials $i b i d ., 24-43$. There are nine published pro-Roberts memorials but the "Memorial of Phil. \& Chester Co's in Behalf of Jno. Roberts," which includes 768 signatures, is a compilation of twelve separate petitions - see footnote on page 36. I have accounted for these petitions individually. Many of the officers and illiterates are in the 768-signature compilation, while the prisoners sent their own petition revealingly entitled "Memorial of the Beneficiaries of John Roberts" (36-37). The juror/judge memorials were among the first in both cases (Roberts 24-25; Carlisle 52-53).
} 
stance Carlisle and Roberts had assumed. ${ }^{20}$ Imposition of the death penalty - or not rested with the Supreme Executive Council. Petitioners were hopeful. In spite of discernible preparations for the fateful event, Elizabeth Drinker noted the day before the execution that "I am still of the mind, that they will not be permitted, to carry this matter to the last extremity." 21 The recalcitrant radical council thought otherwise. As Reverend Ettwein had perceived, Quakers "had to be hung" to satiate popular pressures.

Word of the hangings spread quickly. Quaker pacifist Hannah Griffitts penned a tribute to the victims the same day of the execution, blaming radical patriots "whose mad ambition, Lawless grasp Of Proud Dominion, and oppressive power Have spread the flames of war around the shores Where Peace once smiled \& social union dwelt." ${ }^{22}$ New Jersey lawyer Isaac Ogden wrote to Joseph Galloway, exiled in England, that "Roberts's Wife with ten children went to Congress, threw themselves on their knees \& supplicated Mercy." Although it is doubtful Roberts ever uttered the following words, Ogden stressed Roberts' commitment as a diehard loyalist who spoke courageously before the gallows "for doing his Duty to his Sovereign" while reprimanding the patriots "That his Blood would one day be demanded at their hands." From his New York exile, printer James Humphreys Jr. - who had published the loyalist Pennsylvania Ledger in Philadelphia during Howe's occupation - lamented to Galloway that the Quakers had been "cruelly

\footnotetext{
${ }^{20}$ Quakers explained their 1778 position seven years later when the Society reviewed the Carlisle-Roberts controversy as an internal matter. That Meeting's analysis is discussed later in this chapter. See "To the Meeting for Sufferings in Philadelphia, December 15, 1785," reproduced in full in Maxey, Treason on Trial, Appendix C, 163-167.

${ }^{21}$ Maxey, Treason on Trial, 80; Messer, “A Species of Treason,” PMHB, 305; Diary of Elizabeth Drinker, November $3,1778,82$.

${ }^{22}$ Hannah Griffitts, "On the Death of John Roberts and Abraham Carlisle," November 4, 1778 in Ruma Chopra, ed., Choosing Sides: Loyalists in Revolutionary America (Lanham, MD: Rowan \& Littlefield, 2013), 157-159.
} 
and wantonly sacrificed" in a scene "with hardly any spectators." Behaving "with the utmost fortitude and composure," the sickly Carlisle had said nothing but Roberts "spoke for some time" from the gallows. Enormous crowds turned up for the funerals. John Pemberton wrote that "the burials were very large." Humphreys estimated that Carlisle's corpse was "attended by above four thousand people in procession.",23

Despite the horror, analysis of the trial leads to the undeniable conclusion that the radical patriot government honored the rule of law and respected the procedural rights of the prisoners throughout the entire judicial process. The accused chose their own counsel, selecting attorneys with revolutionary credentials. James Wilson, George Ross and William Lewis represented both prisoners. Procedurally, first a grand jury composed of citizens of the Commonwealth had to indict. It did. The defendants then requested and received a trial by a jury of peers, not a politically motivated judge who could guarantee a specific outcome. The court provided a large pool of potential jurors and the defense had ample opportunity to reject those they did not like. ${ }^{24}$ The indicted summoned their own witnesses to counter the claims of the prosecution. Everyone was satisfactorily heard. The judges' sentence followed the letter of the law: "every person so offending and being legally convicted by the evidence of two sufficient witnesses in any court of Oyer and

\footnotetext{
23 "Isaac Ogden to Joseph Galloway," November 22, 1778; “James Humphreys Jr. to Joseph Galloway," November 23, 1778, both in Catherine S. Crary, ed., The Price of Loyalty: Tory Writings from the Revolutionary Era (New York: McGraw Hill, 1973), 237; Life of John Pemberton, 93. Ogden's facts do not add up. At least three of Roberts' twelve children had died by 1778; he also likely conflated Congress with the Pennsylvania Supreme Executive Council, as I have found no record of the family seeking the former's intercession. Given these inconsistencies, it is also probable that Ogden's account of Roberts' pro-loyalist diatribe is apocryphal, as it contradicts John Pemberton's grim firsthand view of the victims' resignation and the evidence put forth in Maxey's detailed trial account of a vacillating John Roberts.

${ }^{24}$ Larson, "Revolutionary American Jury," SMU Law Review 1485; Maxey, Treason on Trial, 33. The defense could reject up to 35 jurors from the pool. In Roberts' case, they did not reach 35 challenges, which later worked against him. Regarding the Carlisle and Roberts defense teams, Larson says "these lawyers were among the best attorneys in America" (1485).
} 
Terminer shall be adjudged [guilty] of high treason and shall suffer death, and his or her estate shall be and is hereby declared to be forfeited to the commonwealth." As Carlton Larson has observed, "these trials were conducted according to customary rules of procedure even in the middle of a divisive civil war." ${ }^{25}$ The post-trial/pre-execution process was also fair. Official minutes disclose that the Supreme Executive Council received, considered and duly noted all citizen memorials and petitions in the trial's aftermath. If there was an injustice in any of this, it lay in the implacability of the law and the parameters for its enforcement, a responsibility of the radical legislature which had earlier passed the treason statute and decreed proper punishment.

And yet the Carlisle and Roberts execution is striking for its near singularity. ${ }^{26} \mathrm{In}$ order to understand why, context is crucial. Between September 1778 and April 1779, the state grand jury looked into thirty-nine possible cases of treason and issued twenty-three indictments prosecuted as such. Of the twenty-three, jurors convicted only four men. In one conviction, authorities reprieved George Harding "after being forty minutes under the gallows." In another, Abijah Wright had charges changed from treason to burglary when it was discovered he had tried to kidnap or murder Andrew Knox, Esq., for the British. Wright was hanged but not under the treason statute. ${ }^{27}$ That leaves Carlisle and Roberts as the only two individuals executed for treason in this volatile period.

\footnotetext{
${ }^{25}$ Statutes At Large of Pennsylvania, vol. 9, "An Act Declaring What Shall Be Treason and What Other Crimes and Practices against the State Shall Be Misprision of Treason," Chapter 740, February 11, 1777, Section II (Section III, P.L.), 46; Larson, "Revolutionary American Jury," SMU Law Review, 1445.

${ }^{26}$ The state executed only one other person for treason - Ralph Morden in 1780. In addition to Carlisle and Roberts, I have found another 28 Pennsylvania executions thus far but none except Morden were explicitly for treason. Charges against the others included outlawry, spying, desertion, counterfeiting, and militaryrelated activities such as stealing horses for Howe's army or guiding loyalist recruits to the British lines.
} 
The explanation resides in the timing and evolution of the trials. Chronologically, Abraham Carlisle was the first person tried and John Roberts the third of the twenty-three purported traitors. As the petition campaign and later trials confirm, jurors were never comfortable with the "suffer death" sanction in the treason statute, believing that to be too severe a sentence. Over time, jury panel members opted to impose stark financial burdens in lieu of a death sentence. ${ }^{28}$ But the Carlisle and Roberts verdicts came before juries had witnessed the dramatic real-life consequences of their decisions. In addition, the only surviving account of the jury deliberations suggests that two of the twelve Roberts jurors who insisted he was guilty of treason convinced the other ten who leaned towards acquittal to change their votes "by promising that a pardon would be granted and by persuading the others of the necessity of a conspicuous example. ${ }^{29}$ The prospect of leniency allowed them to go forward with a guilty verdict. When the state-approved killings proved otherwise, patriot citizens selected for subsequent juries transformed what

${ }^{27}$ Wright's sentence and his wife's petition pleading clemency are in Council Minutes, November 30 \& December 4, 1778, Colonial Records, vol. 11, 631, 635; Larson, "Revolutionary American Jury," SMU Law Review, 1456. The grand jury actually issued 25 indictments but Larson notes discrepancies in the Docket Book data. Only 23 came to trial. For George Harding, see Larson, 1496-1497. For Wright's change of charge, Henry J. Young, "Treason and Its Punishment in Revolutionary Pennsylvania," PMHB, vol. 90, no. 3 (July, 1966), 298.

${ }^{28}$ Larson, "Revolutionary American Jury," SMU Law Review, 1498. This included the payment of bonds ranging from $£ 500$ to $£ 2000$ and two additional sureties collectively providing an equal amount. Eleven of the 23 treason defendants incurred this penalty.

${ }^{29}$ Larson, "Revolutionary American Jury," SMU Law Review, 1492; "Memorial of Judges and Jurors in favor of Ara'm Carlisle," Pennsylvania Archives, First Series vol. 7, 52-53; "Petition of the Jury in the Case of John Roberts," ibid., 24-25; "Respublica Pennsylvania v. John Roberts Trial Notes," Appendix A, Maxey, Treason on Trial, 137. James Hood and James Barnes were the two jurors who did not sign the Roberts clemency petition. The information on the Roberts jury deliberation is from French traveler J. P. Brissot de Warville who heard it from Quakers during his time in Philadelphia in 1788. Larson does not give Brissot much overall credibility but admits there could be some truth to the story because "it would explain why the jury in these cases both convicted and petitioned the Council for clemency" and especially "why two jurors in Roberts' case did not sign the clemency petition" (1493). In my view, the account is entirely credible, given Quakers' tendency to refrain from hearsay and deal factually with issues regardless of consequences. Moreover, insular Quakers would not have made this knowledge public at a time when they were still viewed as nonjuror outsiders but nonetheless would likely have confided in someone like Brissot who admired them. 
radical officials likely intended as the beginning of a pruning process into a unique event. Popular sovereignty, in effect, halted a political purge - a result only possible when application of the law is subject to the direct input of a more indulgent citizenry. ${ }^{30}$

The Carlisle-Roberts execution provides a window into the attitudes of both patriots and the disaffected. On the revolutionary front, it ratifies that patriots refused to tolerate direct challenges to republican authority. Beyond the wishes of radical prosecutors like Joseph Reed, common citizens sitting on the jury likewise agreed that the Carlisle-Roberts collaboration with the king was treason. And treason was quite simply unacceptable. Second, the rule of law was supreme. Even presumed traitors deserved due process. Third, the relative strength of patriot factions ultimately decided the fate of the disaffected. Most exclusionary radicals championed the executions and most inclusionary moderates opposed them. But in the immediacy of the British withdrawal, radicals were ascendant and the executions went forward. Fourth, radicals pushed the law to its logical conclusions. For them, "suffer death" meant "suffer death.” Radical justice afforded no middle ground. Fifth, radical officials acquiesced to bottom-up pressures. Although prosecutor Joseph Reed was then a firebrand exhorting execution over mercy, judge Thomas McKean wavered, only to succumb to the popular clamor within his own faction

\footnotetext{
${ }^{30}$ Maxey stresses that the radical council was "especially attentive to their political base that demanded retaliatory justice," while prosecutor Joseph Reed feared that "the whole attainder apparatus [would] collapse" if suspected tories went free, making Carlisle and Roberts "the prime targets for hanging" at that critical juncture. See Maxey, Treason on Trial, 109-110. Larson takes an in-depth look at the composition of both types of juries in later trials. He concludes that "defense counsel was able to shape the jury in ways favorable to the defense" and that jurors as a whole were less radical and more lenient than the state's Constitutionalist leadership at the time. Thus, actual jurors - and not the radical political base or leadership - were the "more indulgent." For demographics on the grand jury, Larson, " Revolutionary American Jury," SMU Law Review, 1457-1462; for trial jury demographics, 1467-1478. Above quote is on 1478.
} 
when it finally came time to sentence. ${ }^{31}$ Sixth, reintegration of the disaffected could only take place under republican terms which legitimized and invigorated republican authority. The executions left no doubt that patriots were in charge and, at least initially, served notice as to what was and was not acceptable behavior towards the Revolution. Lastly, the Carlisle-Roberts episode once again echoed the historical bitterness between Presbyterians and Quakers. As Reverend Ettwein noted, Quakers "had to be hung." The lawful killing shows that radicals valued practical politics over technical legalities. Both Quaker prisoners followed the dictates of the attainder law and voluntarily surrendered on time. Roberts affirmed allegiance to the republic the day after the British evacuated. ${ }^{32}$ But his declaration of fidelity did not supersede the charge of treason or the popular demand for loyalist atonement and the prosecution pressed onward.

From the loyalist perspective, the Carlisle-Roberts affair reveals that at least a portion of the disaffected was predisposed to trust patriot goodwill. Obviously Abraham Carlisle and John Roberts believed they could navigate the revolutionary tide or they would have left with Galloway, the Allen brothers and the British. The decision to stay also demonstrates a very strong preference for their Pennsylvania homeland over exile

\footnotetext{
${ }^{31}$ For Reed and McKean's respective attitudes and actions during the trial and execution process, see Maxey, Treason on Trial, especially 88-89. McKean's harsh sentencing is in Appendix B, 159-162.

${ }^{32}$ In addition to Justice of the Peace Zebulon Potts' testimony on June 19, 1778 that Roberts "hath taken \& subscribed the Affirmation of Allegiance," two John Roberts are listed in another source among postevacuation oathtakers as "Affirmed," one on August 22, 1778 and the other on May 5, 1779. All three instances indicate that the individuals were practicing Quakers, as Friends could "affirm" but not take an oath under their religious strictures. The August 22, 1778 affirmation could be an official reiteration of our John Roberts' earlier affirmation. But it could also refer to another John Roberts, "Blacksmith" from "upper Dublin Township" in Philadelphia County attainted in the council proclamation of May 21, 1778. Although both attainted John Roberts are from Philadelphia County, ours was a miller from Lower Merion Township. However, the John Roberts of the 1779 affirmation was also a farmer of Lower Merion, though obviously it was someone else because our protagonist was dead by then. See Thompson Westcott, Names of Persons Who Took the Oath of Allegiance to the State of Pennsylvania Between the Years 1777 and 1789, with a History of the 'Test Laws' of Pennsylvania, 9, 42.
} 
elsewhere within Britain's presumably friendlier and more accommodating dominions. As we saw with the Pembertons, such a predisposition was quite common among Quaker descendants of the colony's founders. The executions likewise lay bare the unremitting dedication of reform-minded Friends to the sect's peace testimony. Because Abraham Carlisle and John Roberts had violated pacifist principles by aiding the British, Quaker leaders were unwilling to actively intercede on their behalf. Instead, they let events take their course and limited official Quaker involvement to comforting the condemned in their final hours. Most significantly, their case shows the difference between moderate and radical uses of the law to foster or deter successful reintegration when in control of government. Moderates repealed the test acts and reestablished nonjuror rights in 1789. But radicals dictated provincial politics in 1778. Rather than retract the sword of Damocles, they made certain it fell.

\section{THE DOAN GUERRILLA GANG}

Whether openly loyal to the British or more dissatisfied with patriot ways, the disaffected took various approaches to the prospect of reintegration. Some like John Connolly, Joseph Galloway, or the Allens and Rankins spurned reintegration altogether, choosing instead to depart a clearly hostile revolutionary Pennsylvania. Others such as the Pembertons and like-minded Quaker pacifists stayed on as second-class nonjurors or took the oath a la John Roberts and tried to remain under the radar. A small cadre of loyalists and disaffected colonials in Pennsylvania, however, repudiated the notion of reintegration while choosing to stay and carry on the war. These bands did not concede republican rule, never gave a thought to swearing allegiance, and tested the security of the new state. 
The Doan guerrillas are a prime illustration of this blueprint. Patriots were well aware that armed defiance from sectors that did not subscribe to republican authority imperiled the entire foundation of government by popular consent, much like opposition from the king and his armies. Locally spawned subversive elements continued to plague Pennsylvania after the British evacuation, despite a dramatic reduction in royal support. The extermination of this threat became a matter of the highest priority. The Doan gang was the most enduring, menacing and notorious of these scattered troupes, contesting patriot legitimacy throughout the war and its aftermath. Revolutionaries declared its members outlaws and offered rewards for their apprehension or death with growing urgency. Consolidation of the Revolution in the state increasingly isolated the band, spelling their inevitable doom. The Doan guerrilla challenge shows that continuing to bear arms against the new republic served as a litmus test barring all possibility of reintegration. Patriots passed legislation allowing greater flexibility in the capture and prosecution of the "banditti," while simultaneously fortifying republican government. These methods succeeded in extinguishing the peril during the 1780s. While there is no doubt that the Doans degenerated into mere outlaws by war's end, it is also clear that their support for royal aims well after the evacuation of Philadelphia was heartfelt, valued by the British high command, and highly effective in actions such as procuring intelligence and requisitioning horses from patriots for the imperial army.

The Doans had a long contrarian history. As a religious dissenter in England, the original Americanized Doan, John, landed in Plymouth, Massachusetts, as a worthy Puritan in 1629. His grandson Daniel Doan Jr., however, dissented from the dissenters, abandoning his father's faith to join the Quakers of Cape Cod. Consequently, Daniel Sr. 
severed his wayward son's access to the family inheritance. Eventually Daniel Jr. and wife Mehetabel moved to Bucks County, Pennsylvania to begin anew, setting down the family's roots in the province. Initially welcomed as a capable teacher of the Quaker discipline, Daniel Jr. dabbled a bit too much in astrology. The sect disowned him in 1711. Quakers also disowned his son Israel in 1725 for not following the discipline's rules on marriage. By the onset of the Revolution, the Doans had proliferated in rural Bucks, north of the provincial capital at Philadelphia. Two of Israel's progeny fathered the core of the future guerrillas. Joseph Sr. and wife Hester Vickers begot Moses, Levi, Aaron, Mahlon, Joseph Jr. and sole daughter Mary, while Israel II and Rachel Vickers - possibly Hester's sister - engendered Abraham, reputedly one of the most spiteful of the gang. Locally, the boys were renowned for their athletic prowess, especially as outdoorsmen and hunters. ${ }^{33}$ The younger Doans, smitten like many contemporaries with the winds of rebellion raging through the province, initially contemplated fighting against British tyranny. But their Quaker elders, farmers Joseph Sr. and Israel II, refused to pay war taxes as a result of their pacifist beliefs. When rebel authorities threatened to declare the family outlaws and seize their farms, the sons joined the tory opposition. ${ }^{34}$

\footnotetext{
${ }^{33}$ Arthur Edwin Bye \& George MacReynolds, eds., The New Doane Book: Bucks County's Bandittories of the Revolution (Doylestown, PA: Bucks County Historical Society, 1952), 3-7. No author or editor is listed on the title page but Arthur Edwin Bye, Bucks County Historical Society president at the time, provides a post-mortem in an "Editor's Preface" that "the manuscript of this volume was completed by our beloved and distinguished librarian George MacReynolds." It therefore appears that Bye edited the manuscript which MacReynolds put together. Accordingly, I am crediting them both.

${ }^{34}$ John Pugh Rogers, The Doan Outlaws or Bucks County's Cowboys in the Revolution (Doylestown, PA: Doylestown Publishing Co., 1897), reproduced in its entirety in The New Doane Book, 155, 163, 167; H. K. Brooke, Annals of the Revolution: Or, A History of the Doans (Philadelphia: John B. Perry, 1843), 12; Sabine, Biographical Sketches, vol. 1, 381-382. The Rogers account initially appeared as an eleven-part newspaper series in the Doylestown Democrat and Bucks County Republican from January 11 to March 22, 1853. It was first published in book form in the 1897 version cited here. Although Rogers wrote the original articles, Albert S. Paxson did most of the research for the project, personally interviewing Bucks County residents who had been alive during the Revolution. The primary sources, then, are mostly local
} 
At least forty-four additional people belonged to or collaborated with the original six Doan guerrillas and their two fathers during the gang's existence. ${ }^{35}$ Moses Doan was the inspiration behind the gang's organization and its recognized leader until his death in 1783. If oral accounts are to be taken at face value, ${ }^{36}$ the Doans played an important role as loyalist allies of the British army during the war, serving mainly as scouts and spies. The brothers - and especially Moses - interfaced directly with Major John Andre who ran General Howe's loyalist spy network and Lieutenant Colonel John Graves Simcoe, commander of the Queen's Rangers, an active and effective loyalist regiment. ${ }^{37}$ Moses became a favorite of General William Howe, reconnoitered Continental Army positions during the battle of Long Island, and is credited for guiding the British through "an unguarded pass to the heights" in August of 1776 which enabled imperial forces to

individuals who, as children or young adults, had witnessed events or heard stories of the Doans from their parents and relations. As the editors of The New Doane Book note, Rogers' writing style "was florid and alliterative to a fault" (107), embellishing incidents with novelistic on-site dialogue and descriptions. While the specific details of his account must therefore be taken with a grain of salt, it is likely that the essence of the story "is in the main authentic," as the editor of the 1897 volume declared in the Publisher's Note (113).

${ }^{35}$ The band was in constant flux and their numbers varied depending on time and region. This cumulative figure is taken from a variety of official and biographical sources and represents actual gang members, as well as accomplices like those who hid or harbored the guerrillas or who provided information enabling their robberies. Many collaborators received a cut of the action. While operating in Lancaster County in the summer of 1778, the gang consisted of 18 members (The New Doane Book, 373). The Pennsylvania Assembly's act in 1783 named 13 outlaws and 5 collaborators, again for a total of 18 (Statutes At Large of Pennsylvania, Chapter 1028, September 8, 1783). Reports from a Washington County prison breakout in 1784 had the number at 28 (Pennsylvania Archives, First Series, vol. 10, 581-583; The New Doane Book, 379-380). Brooke counts 18 members in Bucks County before the British invasion. See Brooke, Annals of the Revolution, 25.

${ }^{36}$ There are few official sources on the Doans before the 1780s. Biographers accumulated most of their material from the Bucks County locals mentioned in footnote 34, an oral tradition much like the WPA narratives in the 1930s based on the personal memories of African Americans who had been slaves as children or young adults during the Civil War.

${ }^{37}$ Bye \& MacReynolds, eds., The New Doane Book, 54; Sabine, Biographical Sketches, vol. 1, 382; Brooke, Annals of the Revolution, 13; Allen \& Braisted, The Loyalist Corps, 88-89; René Chartrand, American Loyalist Troops 1775-1784 (Oxford, UK: Osprey Publishing, 2008), 15. 
surprise and defeat Washington on the drive towards New York City. ${ }^{38}$ The Doans surfaced again at the key battle of Trenton that December as the royal messengers who delivered a warning on a wintry night to the Hessian commander regarding Washington's approach. Annoyed with interruption of his festive card game, Colonel Johann Gottlieb Rahl refused to receive the emissary and put the latter's handwritten note in his pocket unread. It was found on his dead body the following morning after the Continentals' surprise attack. $^{39}$

As Abraham Doan's robbery of farmer Gilbert Nugent around this time illustrates, patriots recognized all too well the Doans' predatory activities and alliance with the British early in the revolutionary contest. Nugent encountered Doan at a tavern on the road between Philadelphia and Bristol. Abraham expressed support for the rebel cause, received Nugent's approbation, and discovered the farmer was returning from market after selling eggs and butter for a tidy profit. After a hearty round of drinks, Nugent invited Doan to hitch his horse to his wagon and ride with him. "Made merry by the liquor he had imbibed," Nugent "became quite loquacious." Asked if he had ever heard of the Doans, the farmer affirmed "yes, $\mathrm{d}-\mathrm{n}$ them, we seldom hear of anything else. The villains keep the whole country in a state of alarm." He then erupted into song recounting the feats of Moses Doan, ending with a verse concerning the latter's loyalty.

\footnotetext{
${ }^{38}$ Bye \& MacReynolds, eds., The New Doane Book, 55; Rogers, The Doan Outlaws in The New Doane Book, 208-209; Brooke, Annals of the Revolution, 16-17. Bye \& MacReynolds pinpoint Moses Doan's first meeting with Howe to August 27, 1776. As Howe's secretary during the period, Ambrose Serle's journal entry for that date does not mention Doan by name, although he could possibly have been the "Aid de Camps [who] waited upon the Admiral with this Intelligence.” Serle, Journal, August 27, 1776, 79.

${ }^{39}$ The note is said to have read: "Washington is coming on you down the river, he will be here afore long. Doan.” Bye \& MacReynolds, eds., The New Doane Book, 59, 227. For the battle of Trenton within the larger war, see Robert Middlekauff, The Glorious Cause, 364-366.
} 
"He is the Briton's friend, He is the freeman's foe; And may we pray God send To him a quick death-blow."

The long wagon ride eventually put the inebriated Gilbert Nugent to sleep, at which point Abraham Doan stole his watch and money and rode off into the night without a struggle. ${ }^{40}$ Thus, the Doans had already achieved a notorious reputation among the general populace by late 1776 .

Once the British occupied Philadelphia in September 1777, the Doans provided intelligence to Howe on Washington's vulnerable position at Whitemarsh and guided the imperial army to that spot on December 4 only to find the Americans prepared for their strike because an opposing spy had signaled the British advance. From the captured city, the guerrillas roamed the adjacent counties of southeastern Pennsylvania, robbing horses for Howe's army and a tidy profit. ${ }^{41}$ There is even empirical evidence suggesting possible Doan involvement in the Benedict Arnold treason conspiracy of August, 1780. A map dated August $10^{\text {th }}$ found at the cabin of John Tomlinson - a gang collaborator who used the site as a Doan hideout and headquarters for tory and British spies in the area - shows the "Line of Encampment and order of Battle" of Washington's army in Bergen County, New Jersey six weeks before Arnold's treachery. ${ }^{42}$ As these incidents denote, the Doans were a valuable asset for the king's cause. After Sir Henry Clinton abandoned the

\footnotetext{
${ }^{40}$ Rogers, The Doan Outlaws in The New Doane Book, 234-237.

${ }^{41}$ Bye \& MacReynolds, eds., The New Doane Book, 70, 211; Brooke, Annals of the Revolution, 47-49.

${ }^{42}$ Bye \& MacReynolds, eds., The New Doane Book, 72-78, speculates that the Doans may have participated as scouts and spies because they were assisting Hessian General Knyphausen in New Jersey at the time. These 1780 Jersey military escapades ratify their value to the British as loyalist militants at that late date in the war and shows that the Doans cannot be dismissed as mere bandits despite patriot inclinations to do so.
} 
provincial capital in June 1778, local cooperation with the imperial high command diminished. It is likely that Colonel William Rankin considered the Doan guerrillas a part of his loyalist force of "thousands" awaiting instructions that never came for a postevacuation royal insurrection in southeastern Pennsylvania. In the interim, the Doans gradually evolved from imperial military scouts and spies into semi-independent guerrillas and later outlaws and banditti. Rogers ascribes the gangs' original plans in early 1776 as seeking British protection for the primary purpose of plundering their Whig neighbors. Initial raids in this vein occurred before their formal attachment to Howe's forces. ${ }^{43}$ Even while embedded in royal army activities, the band exhibited a penchant for pillage. For years, they raided Whigs seemingly at will, sending Bucks and Chester County patriots into a panic. Long-held grudges against neighbors of yesteryear sometimes inspired these mostly nighttime robberies that often led to cruelty. But revolutionaries were not always the victims. On one occasion they robbed Quaker loyalist Isaiah Hallowell for his money. On another occasion, a chivalrous Moses Doan was said to have slain a British officer in defense of an ill-treated patriot damsel. ${ }^{44}$ The band became exceptionally obnoxious to patriot authorities when they targeted Whig tax collectors. The October 1781 robbery of Bucks County Treasurer John Hart at Newtown was especially egregious because of the temerity exhibited and the considerable bounty extracted. As the war drew to a close, patriot pursuit intensified, forcing the Doans to flee to Pennsylvania's outer counties where they invariably renewed their depredations. ${ }^{45}$

\footnotetext{
${ }^{43}$ For Rankin's loyalists, see Chapter 3. Rogers, The Doan Outlaws in The New Doane Book, 163.

${ }^{44}$ For vengeance on neighbors, Rogers, The Doan Outlaws in The New Doane Book, 314-321. For loyalist Hallowell, ibid. 254-263 \& Brooke, Annals of the Revolution, 34-43. For the killing of the British officer, Rogers, The Doan Outlaws, 245 \& Brooke, Annals of the Revolution, 22-23.
} 
All did not end well for the loyalists-turned-guerillas-turned-outlaws. Of the eight surnamed Doans implicated in the gang's activities, four perished as a result of their actions. For starters, the war "unpacified" the formerly pacifist stance of Israel II and Joseph Sr. whose religious refusal to pay war taxes had initially triggered Whig antagonism. Israel II, Abraham's father, died in prison after his arrest for harboring the gang at the time of the Newtown robbery. A patriot posse shot and killed leader Moses while attempting to arrest him. Officials publicly executed Moses' brother Levi and cousin Abraham. Four other Doans became exiles. The council proclamation of June 15, 1778 attainted Joseph Sr. - Israel II's brother and father of five Doans. Officials seized and sold his property. ${ }^{46}$ Apprehended later in Bedford County, the elder Joseph eventually found his way to Canada. Two captured sons, Joseph Jr. and Aaron, also eventually sought refuge northwards. Although patriots seized their brother Mahlon, he

\footnotetext{
${ }^{45}$ For Newtown robbery details, see the "Confessions of Jesse and Solomon Vickers," August 7-9, 1782, Pennsylvania Archives, First Series, vol. 9, 608-617 and "Robbery of the County Treasury at Newtown," The New Doane Book, 386-411. According to Jesse Vickers, "there was Sixteen or Seventeen full shares, which was near 140 Dollars hard, and about as much State money a Share \& several other shares from 20 to 40 Dollars" given to three other collaborators," ibid., 391. For activities in the outer counties, see for example Pennsylvania Archives, First Series, vol. 10, 114, 581-583, 594 covering between September 29, 1783 \& June 5, 1784; and The New Doane Book, 370-385.

${ }^{46}$ For the fate of Israel II, The New Doane Book, 19-20. His petition from jail on February 26, 1783 to the Supreme Executive Council is in Pennsylvania Archives, First Series, vol. 9, 759. The letter of Samuel Hart to John McAllister Jr., November 11, 1846, reproduced in The New Doane Book, Note No. 5, 461 A, relates Moses' death on September 1, 1783. Hart had heard the story years earlier from one of the participants in the struggle with Moses. Rogers also provides his customary dramatization in The Doan Outlaws in The New Doane Book, 325-328. Joseph Sr.'s attainder is in Supreme Executive Council Proclamation, June 15, 1778, Colonial Records, vol. 11, 512-518, issued three days prior to the British evacuation and well before the Doans had made the transition from loyalists to banditry. Since attainders were used primarily as a confiscatory weapon and Joseph Sr. owned the Doan property, the attainder omitted his five sons - though Moses forfeited "A Bay Mare" with saddle and bridle worth $£ 45$ on August 18, 1778. The seized Doan estate is described in "Inventories and Sales," Pennsylvania Archives, Sixth Series, vol. 12, 87-95. Moses' mare is on 96. On January 1, 1783, state agents held a public auction at the Newtown courthouse. A plot of 42 acres with a dwelling in Plumstead Township sold for $£ 858.14$ and another plot for 108 acres sold for $£ 448.12$, both in Soldier’s Certificates. See agents' note to President John Dickinson on 94.
} 
escaped and made his way to New York and then England. ${ }^{47}$ Also of note, sister Mary Doan married gang member Isaac Vickers and moved to Canada. Despite the clan's tory/criminal proclivities, patriot authorities nonetheless allowed family members not tied to gang activities to stay in Pennsylvania. ${ }^{48}$

\section{ARMED HOSTILITY \& THE LONG ARM OF REVOLUTIONARY LAW}

By definition, republican government cannot function without the consent of the governed. An indispensable ingredient of that consent under the aegis of republican ideology is preservation of the public peace. The Doans directly threatened this paradigm. As such, they provide a laboratory in which to dissect how revolutionary interpretations of citizens' rights and the rule of law intersected with reintegration. Specifically, the pardon of Aaron Doan and the later execution of cousins Abraham and Levi Doan reveal that, even in cases of armed defiance after the British withdrawal, republican authorities granted rights of due process to disaffected transgressors and meticulously followed the procedural demands of rebel law. In addition, the late-life return to Pennsylvania of Joseph Jr. from Canadian exile and the claim put forth by similarly exiled Mary Doan Vickers show that Pennsylvanians adhered to the dictates of the law irrespective of one's stance during the Revolution. Most importantly, the Doans' disaffection compelled the

${ }^{47}$ Patriot Joseph Wilson delivered Joseph Sr. to the Bedford County jail on September 25, 1783, and Mahlon Doan suffered a similar fate days later. "Depositions Respecting Arrest of Joseph Doan (Sr.)," September 25, 1783, Pennsylvania Archives, First Series, vol. 10, 110-111; "Depositions Respecting Arrest of Mahlon Doan," September 27, 1783, 111-112; "Mess. Dougherty and Espy to Pres. Dickinson - The Doans," September 29, 1783, 114. Reward payments for their capture are discussed in 110-112 and in Colonial Records vol. 13, 770 \& vol. 14, 4. Patriots John Greer, Josiah Ferguson and others captured Joseph Jr. in Bucks County sometime between June 30, 1783 and April 20, 1784. "Petition of Captors of Joseph Doane (Jr.)," April 20, 1784, Pennsylvania Archives, First Series vol. 10, 565-566. Reward payment for Joseph Jr. on January 8, 1784 and again September 28, Colonial Records, vol. 14, 4, 214. Both Joseph Jr. and Mahlon escaped from jail. For Mahlon's flight and exile, see The New Doane Book, 25, 337.

${ }^{48}$ A Grand Jury indicted Eleazar Doan I, uncle of the outlaws, for aiding the gang but he was acquitted, The New Doane Book, 338. Eleazar Doan II owned a tavern in Plumstead, Bucks County, until his death in 1811, ibid., 7. Thomas Doan, youngest son of Joseph Sr. \& Hester, never joined the gang, ibid., 166. 
patriot government to configure and enforce the law in a way that ensured the total destruction of armed threats and the stabilization of revolutionary rule.

The Doans' despoliations continued unabated well into the latter part of the war. By 1782, the Supreme Executive Council was finally focusing on the banditti menace with some success. Captured gang members Jesse and Solomon Vickers provided detailed confessions implicating their fellow outlaws. Patriots then arrested John Tomlinson, a key cog in the band's network. Supreme Court Justices Thomas McKean and George Bryan convicted and sentenced Tomlinson to death for felony on September 30,1782 . He was executed on October 17. In early 1783, officials jailed the elder Israel Doan II for aiding his son and nephews, and then dismissed a petition for release from the "languishing prisoner." The "unwell' Israel died in prison. ${ }^{49}$ Rather than stifling the gang's efforts, however, setbacks only seemed to redouble their determination. Operating from secreted caves, old deserted houses and the dwellings of local collaborators, the Doans stepped up their robberies of tax collectors and Whig locals, culminating on July 21,1783 in a series of six attacks on a single night. Five days later the Supreme Executive Council issued a proclamation offering a reward of $£ 100$ in specie for the capture of Moses, Abraham, Levi or Malin Doan “and other persons unknown," along with a "free and full pardon to any one of the said robbers, their aiders, abettors, or comforters, who shall discover, apprehend, and secure" them. This and similar proclamations that summer constituted a watershed moment. Officials had previously refrained from identifying the Doans by name, generically referring to "armed men"

\footnotetext{
49 "Confessions of Jesse and Solomon Vickers," August 7-9, 1782, Pennsylvania Archives, First Series vol. 9, 608-617; Council Minutes, October 14, 1782, Colonial Records, vol. 11, 394; The New Doane Book, 422; "Petition of Israel Doan," February 26, 1783, Pennsylvania Archives, First Series, vol. 9, 759. The New Doane Book provides contradictory accounts of Israel II's fate but death in jail seems most likely.
} 
because of reservations that the gang targeted those who denounced them. ${ }^{50}$ Necessity now transcended fear.

Galvanizing popular support proved successful. In late summer 1783, a posse in pursuit of three of the band killed leader Moses Doan. Abraham and Levi escaped, while one of their patriot pursuers, Major William Kennedy, also perished in the clash. Reward payments followed. ${ }^{51}$ Learning from the incident, the Pennsylvania assembly appointed a committee on August 27 to draft a bill for the quick capture of outlaws. In a testament to both the urgency of the situation and patriot respect for legal procedure, the proposed statute was read for the first time on August 30, a second time on September 1, debated on the $4^{\text {th }}$ and read for a third and final time on September $6 .{ }^{52}$ Two days later the legislature passed a comprehensive law specifically targeting eighteen gang members, including the five remaining younger Doans. The measure increased rewards for the capture of each robber to $£ 300$, gave immunity plus the $£ 300$ prize to anyone who killed a gang member while trying to apprehend him, and compensated law-abiding citizens for damages earned in the endeavor - if wounded, $£ 150$; if killed, $£ 300$ to the victim’s executors. In addition, legislators inserted a category of "discoverers" slated to receive a payment of $£ 50$ for relaying information on offenders or stolen goods and offered gang defectors a full pardon and their own $£ 100$ reward for turning in their comrades. The law

\footnotetext{
50 “A Proclamation," July 26, 1783, Colonial Records, vol. 13, 630; The New Doane Book, 402, 432-433. Moses and Abraham Doan had been specified by name in a proclamation weeks earlier in one of the first such references. See “A Proclamation," June 30, 1783, Colonial Records, vol. 13, 616. An example of the anonymous reference to "a number of armed men" is President William Moore's proclamation of July 29, 1782, Colonial Records, vol. 13, 338-339.

${ }^{51}$ The New Doane Book, 325-329; Brooke, Annals of the Revolution, 75-77. Rewards for Moses' death in Council Minutes, March 3, 1784, Colonial Records, vol. 14, 47.

${ }^{52}$ Minutes of the Seventh General Assembly of the Commonwealth of Pennsylvania, Which commenced at Philadelphia, on Monday the twenty-eighth Day of October, in the Year of our Lord One thousand seven hundred and eighty-two (Philadelphia: John Dunlap), 904-905, 912-93, 928, 931, Evans 17663, LCP.
} 
was to remain in effect until January 1, 1785, giving officials over a year to fulfill their mission. $^{53}$

Conveniently considering the guerrillas a law enforcement rather than the longstanding military problem they had been, the state consciously decided to treat the Doans as outlaws rather than militant loyalists in a systematic effort to crush the gang. Attainder for outlawry rather than attainder for treason allowed authorities to target a much broader range of offenses and expedite the persecution and prosecution of perpetrators, even as existing law provided for forfeiture of property and penalties as severe as death in either category. ${ }^{54}$ Timing was another reason for this legal predilection: the war's conclusion held the potential to complicate the prosecution of wartime sins in a new era of peace. Uncertainty reigned, above all with the Peace Treaty's proposals on loyalist property restitution. ${ }^{55}$ Since the Doan threat could extend into a more problematical future, its resolution required immediate attention.

From the passage of the September $8^{\text {th }}$ act forward, patriot authorities waged a vigorous campaign to bring the outlawed Doans and their cohorts to justice. Five days later, the Supreme Executive Council issued a proclamation putting the state's assets

\footnotetext{
${ }^{53}$ Statutes At Large of Pennsylvania, vol. 11, "An Act to Encourage the Speedy Apprehending and Bringing to Justice Divers, Robbers, Burglars and Felons," September 8, 1783, Chapter 1028, 109-114. It appears Levi Doan was captured earlier in the year but somehow escaped. On March 26, 1783, the council authorized payment of a $£ 50$ reward for his apprehension. See Colonial Records, vol. 13, 542.

${ }^{54}$ Radical judge George Bryan expressed this sentiment explicitly when writing that "Doane's [case] is at Common Law, the mode of demanding being only under an old Act of Assembly." See "Hon. George Bryan to Hon. James Irwin," October 20, 1784, Pennsylvania Archives, First Series vol. 10, 609. The relevant statutes were the 1718 colonial law on capital crimes and the newer 1777 treason law. Statutes At Large of Pennsylvania, vol. 3, "An Act for the Advancement of Justice, and More Certain Administration Thereof," May 31, 1718, Chapter 236, especially Section II and Section XII, 200 \& 205-206; and Statutes At Large of Pennsylvania, vol. 9, "An Act Declaring What Shall Be Treason and What Other Crimes and Practices against the State Shall Be Misprision of Treason," February 11, 1777, Chapter 740.

${ }^{55}$ Particularly relevant were Congress' recommendations to the states in Article $5^{\text {th }}$ and Article $6^{\text {th }}$ of "The Definitive Treaty of Peace." See Richard B. Morris, The Peace-Makers, 463-464.
} 
fully behind the new law, requiring "all Judges, Justices, Sheriffs, and Constables... and all other persons, when called upon... to give their assistance for apprehending and securing the aforesaid felons or offenders, their aiders, abettors, and comforters, and every one of them." They succeeded. Officials captured Mahlon and Joseph Doan Sr. in Bedford County in September 1783 and Joseph Jr. in Bucks County around the same time. Aaron faced a similar fate in August $1784 .{ }^{56}$ Moreover, state officials hanged gang members Peter Brown, James Burke, George Crowder and Richard Williams at the Philadelphia gallows on October $16,1784 .{ }^{57}$ Although the Doan law expired and sporadic banditry continued into the latter half of the postwar decade, energized revolutionaries gradually accomplished their objectives, eradicating the band and all armed resistance, containing outlawry, buttressing the rule of law, and ensuring republican stability. ${ }^{58}$ Paradoxically, the armed guerrilla threat reinforced rather than weakened the Revolution's commitment to the core principles of inherent rights and the rule of law. As the cases of Aaron Doan and Levi/Abraham Doan reveal, patriots abided by the constraints of due process even against their most implacable enemies. Hunted for participation in the Newtown robbery three years earlier, Aaron Doan fell victim to patriot pursuit in Baltimore on August 14, 1784. Conducted to Philadelphia by his captors, he remained in prison for several years under a sentence of death as his case

\footnotetext{
56 “A Proclamation," September 13, 1783, Colonial Records, vol. 13, 687-690; "Deposition Respecting Aaron Doane," August 14, 1784, Pennsylvania Archives, First Series, vol. 10, 597-598. The council drew an order on the state treasury to reward Aaron's captors on August 16, Council Minutes, Colonial Records, vol. $14,179$.

57 The New Doane Book, 376; Brooke, Annals of the Revolution, 79. Brooke includes "the younger Joseph Doan" among gang members executed on this date but, given later developments, this assertion is incorrect.

${ }^{58}$ For example, as late as March 1788 the assembly passed a new law to reward the captor of gang member George Sinclair apprehended in Lancaster. See Statutes At Large of Pennsylvania, vol. 13, "An Act for Rewarding the Person or Persons Concerned in Apprehending George Sinclaire Attainted by Outlawry," October 4, 1788, Chapter 1379, 163-164.
} 
wound its way through Pennsylvania's judicial and political system. During the process, this Doan petitioned the Supreme Executive Council for mercy on at least two occasions and even managed to generate support from loyalist exiles in Halifax, Nova Scotia. ${ }^{59}$

Patriot factions split over Aaron Doan's destiny. No one questioned that he was an outlaw but doubts arose as to his guilt on the specified charges. Frightened by too arbitrary an application of the death penalty, moderate president John Dickinson and his Supreme Executive Council majority, charged with executing the execution, threw their support behind a pardon based on a series of seven legal "defects in the proceedings." They argued that "where life depends on proclamations, it seems scarcely possible to adhere with too scrupulous an exactness to injunctions positively directed by law, for giving them their destructive efficacy," and counselled caution lest officials set a perilous precedent in cases of capital punishment. ${ }^{60}$ Meanwhile, radical Supreme Court judges George Bryan and Thomas McKean, upon reviewing the case at Dickinson's request, concluded that "we... have no doubt, that Aaron Doan, besides the forfeiture of his estate, has forfeited his life." They urged execution as just retribution for Doan's crimes and observed that "it is as much a breach of duty, to reverse a good, as it would be to

\footnotetext{
59 "Petition of Aaron Doane," October 17, 1784, Pennsylvania Archives, First Series, vol. 10, 348; "Petition of Aaron Doane," November 8, 1785, ibid., 716-717; "Petition in Favor of Aaron Doane, Halifax," December 30, 1785, ibid., 717-718. The illiterate "X" of William Thomas is among the seven Nova Scotia signatures, in all likelihood that of the former commander of the Bucks County Volunteers discussed in Chapter 3, which presumes another formal Doan guerrilla link to loyalist arms. There is no indication in the evidence whether the Halifax petition helped or hurt Aaron Doan.

60 "Respublica vs. Doan," September, 1784, A. J. Dallas, ed., Reports of Cases Ruled and Adjudged in the Courts of Pennsylvania Before and Since the Revolution, vol. 1, 86. The seven disputed legal points included language, timing and procedural issues related to the warrant. See Council Minutes, March 29, 1785, Colonial Records, vol. 14, 388-393. Dickinson and company also accepted Aaron Doan's claim that he had been in New Jersey during the Newtown robbery, although Jesse Vickers' confession placed him at Newtown. But it was the death penalty precedent that worried patriot moderates the most. For the Vickers testimony on Aaron Doan, Pennsylvania Archives, First Series, vol. 9, 612.
} 
affirm a bad outlawry."61 The Supreme Executive Council voted on the issue in the spring of 1785. By similar tallies of 7-3, Dickinson's moderates first resolved to pardon the prisoner and then declared that the council could not legally issue a warrant to put Doan to death. The Pennsylvania General Assembly - fleetingly under a resurgent radical majority - weighed in afterwards. A committee convened to assess the matter maintained that the Supreme Executive Council had overstepped its mandate and "are not instructed by the Constitution nor laws, to declare what the law is" or "whether this out-lawry [sic] is legal or not." The council only had power to "reprieve or pardon, or to issue a warrant for the execution." The legislature thus agreed with the court that "the laws in being should have their course." 62 All three branches of government had spoken.

The Supreme Executive Council stalled for over two years. At last, a moderatemajority council revisited the case in 1787 . Overlooking the Supreme Court judgment and General Assembly findings, the council used its recognized powers to produce their preferred result anyway. They decreed that convicted felon Aaron Doan "be pardoned, on condition that he transport himself beyond the seas, not to return to the United States." The freed prisoner only partially complied with these conditions on his liberty. On July 29, 1788, New Jersey authorities reprieved Aaron Doan at the gallows in Newark after a conviction for breaking into the house of Hassel Patterson at Acquackanonk. He had left Pennsylvania and not returned, but he was still in the United States. This Doan brother eventually reached exile in Canada and later fought against the Americans in the War of

61 "Respublica vs. Doan, Answers to the Questions," January 15, 1785, Dallas, Reports of Cases Ruled and Adjudged in the Courts of Pennsylvania Before and Since the Revolution, vol. 1, 89-90.

${ }^{62}$ Council Minutes, March 28, 1785, Colonial Records, vol. 14, 387; Minutes of the Second Session of the Ninth General Assembly of the Commonwealth of Pennsylvania, April 7, 1785, 296-297, Evans 19162. The assembly speaker during this brief radical resurgence was John Bayard, who had also been speaker from February 1778 to September 1780 at the height of radical power. 
1812. ${ }^{63}$ The process leading to his pardon and the pardon itself support the view that officials on both sides of the factional divide in Pennsylvania placed enormous value on the rights of individuals and the rule of law, especially since Aaron Doan the outlaw technically had no rights - that is, he was living outside the law. Nonetheless, honoring rights and the law did not necessarily translate into successful reintegration. Postwar belligerent behavior against the republic meant banishment at best and execution at worst. State officials afforded Aaron the first option. A cousin and one of his brothers would face the second.

Authorities captured Abraham and Levi Doan in Chester County on May 15, 1787, only two days before Aaron's pardon. "Broken in spirit and worn down by continued anxiety," the pair did not resist their captors. After a judicial process that lasted sixteen months, they were convicted of outlawry and sentenced to death. As in the case of Aaron, the duo petitioned for clemency and the Supreme Executive Council sent the matter to the Supreme Court for review. Again, judges Bryan and McKean heard the arguments and found "nothing favorable concerning them or either of them" meriting a change of verdict. ${ }^{64}$ The council ordered the execution to go forward in early August but two weeks later declared a four-week "respite.” In the interim, “free negro" Benjamin Hall, a cellmate of the outlaws, "undertook to execute the Doans" on his own. The failed attempt made him a target of Doan vengeance and placed his life in danger. As a result,

\footnotetext{
${ }^{63}$ Council Minutes, May 17, 1787, Colonial Records, vol. 15, 214; Bye \& MacReynolds, eds., The New Doane Book, 25; Rogers, The Doan Outlaws in The New Doane Book, 337; Henry Mercer, "The Doans and Their Times," The New Doane Book, 347.

${ }^{64}$ The capture and quote are in Rogers, The Doan Outlaws in The New Doane Book, 332. Council Minutes, July 23, 1788, Colonial Records, vol. 15, 497; "Opinion of Judges of the Supreme Court, in answer to the act of Council of the twenty-third instant," July 29, 1788, ibid., July 29, 1788, 500-501; "V.P. Muhlenberg to C.J. McKean,” July 24, 1788, Pennsylvania Archives, First Series, vol. 11, 351.
} 
the council decided that Hall's fine and prison punishment of hard labor "be remitted." On September 16, the council finally decided to issue a warrant "for executing the sentence of the Court upon them" on September 24. The moderate General Assembly then interceded the day before the fateful event, this time on the side of the prisoners, and appointed a committee to request a six-day stay of execution. The legislature's three-man committee attended the Supreme Executive Council meeting of the $24^{\text {th }}$, expressed their concerns and then withdrew, leaving the twelve council members in attendance to conclude the affair. A motion "to respite... until Tuesday next... was negatived," as was another motion "to reconsider the vote respecting Abraham Doan and Levi Doan.",65

Patriot law had the final say. Sheriff Joseph Copperthwait executed the outlaws as scheduled at Smith's Island "in the presence of an immense concourse of spectators." Years later, John Pugh Rogers interviewed an unnamed Philadelphia gentleman who visited the condemned prisoners two days before the end. According to the eyewitness, Abraham spoke openly and admitted that their conviction was just but a "moody and sullen" Levi only expressed a desire for revenge against those who had testified against him. Not unexpectedly, the local Quaker Meeting decided to deny the Doan family permission to bury the outlaws in their graveyard. ${ }^{66}$

Official sources do not explain why Aaron Doan received a pardon while Levi and Abraham did not. The courts ruled for execution in both instances but the Supreme Executive Council and the General Assembly saw their roles reversed. In Aaron's case,

\footnotetext{
${ }^{65}$ Council Minutes, August 6 \& August 20, 1788, Colonial Records, vol. 15, 505, 515. Report of the Hall incident on August 22, 1788, ibid., 516. Execution order is on September 16, 1788, ibid., 535. "Resolution of General Assembly - Doane," September 23, 1788, Pennsylvania Archives, First Series vol. 11, 398. The council's decision on the assembly's intercession is on September 24, 1788, Colonial Records, vol. 15, 544.

${ }^{66}$ Rogers, The Doan Outlaws in The New Doane Book, 332-333.
} 
the assembly took the side of execution while the council elected to pardon. With Levi and Abraham, the opposite held true - the assembly pushed for a stay and the council ordered the execution. The court judges were Constitutionalist radicals, which explains their consistency. Radicals also promulgated the first assembly recommendation in 1785 upholding Aaron's execution, while Anti-Constitutionalist moderates held a majority in the 1788 debate - which explains that body's inconsistency. Moderates dominated the council at both junctures, however, which does not explain their inconsistency. Perhaps personal leadership influenced the decision. John Dickinson presided over the council in 1785 and Thomas Mifflin headed that body in 1788 . While Dickinson personally led the charge for a stay of Aaron's execution during his tenure, Mifflin was absent the day of the final vote on Abraham and Levi. ${ }^{67}$ Or maybe news had recently arrived of Aaron Doan's noncompliance with the mandate to leave the United States, persuading the council to choose a less lenient course. But it is more likely that past crimes had a major stake in the council's final resolve. Abraham and Levi were reputedly the cruelest of the guerrillas. A drunken Abraham had killed Mrs. Caldwell, the wife of a pastor, in New Jersey during the war. Levi shot and killed Major William Kennedy during the raid which resulted in the death of guerrilla leader Moses Doan. ${ }^{68}$ Those incidents likely affected the vote. Regardless, patriots respected due process for Levi and Abraham Doan, while making a conscious and thorough effort to obey the dictates of contemporary justice.

\footnotetext{
${ }^{67}$ Compare the Council Minutes of March 28, 1785 with those of September 24, 1788, Colonial Records, vol. 14, 387 \& vol. 15, 544 respectively. Membership in the Supreme Executive Council changed 100\% during these three years. No council member who voted in 1785 was present on the council in 1788.

${ }^{68}$ Abraham Doan's murder of Mrs. Caldwell occurred on September 7, 1780. Levi Doan killed Major Kennedy on September 1, 1783. Both incidents are in Rogers, The Doan Outlaws in The New Doane Book, 293-294 \& 329-332 respectively; and also in Brooke, Annals of the Revolution, 58-59 \& 75-77.
} 
In retrospect, it is difficult to explain why Abraham and Levi still resided in Pennsylvania in 1787 . They were legally outlaws with a price on their heads, devoid of rights. Most of their relations were either dead or exiled. They must have known that no possibility for accommodation existed and yet they did not leave, choosing instead to "reintegrate" in their own way as outlaws under a perennial cloak of concealment. Maybe as descendants of Quakers with historic roots in the province, on some level they too preserved a deep sense of belonging to the Pennsylvania homeland - like the Pembertons - and could not fathom life elsewhere. And yet they continued to openly defy the new order. In the final analysis, the ostracism and failure of Abraham and Levi Doan shows that loyalists could not prescribe the terms of reintegration. That prospect could only occur with republican consent - and consent would never be tendered in cases of sustained armed aggression.

A parting Doan incident suggests that over time, not only patriot government but broader republican society in general, came to accept as definitive the inclusionary model of moderates in relation to the onetime disaffected. An aging Joseph Doan Jr. visited Bucks County from his Canadian exile sometime in 1820. There he sought the legal services of Josiah Shaw in hopes of recovering a legacy of $£ 40$. Shaw had received a flogging or two from Joseph Jr. in colonial days when the latter had been a strict schoolteacher in Plumstead and the former his pupil. The attorney was also the son of patriot John Shaw, whose farm Joseph and his brothers raided during the war. In fact, the boy Josiah had been dispatched on a dark midnight to warn neighbors of the Doans' attack in the area. After a cold reception, Shaw accepted the visitor's commission, arranged a meeting of the parties in question, and succeeded in recuperating the legacy for Joseph Jr. 
Equally exiled sister Mary Doan Vickers and her gang member husband, Isaac, later enlisted Shaw's assistance in a similar instance. ${ }^{69}$ The episodes again demonstrate that Pennsylvania patriots willingly recognized the claims of onetime adversaries, when just, within a republican construct of the rule of law.

\section{POSTWAR REINTEGRATION \& THE CARLISLE/ROBERTS LEGACY}

Despite the blot of treason and execution, the families of Abraham Carlisle and John Roberts declined to leave Pennsylvania. Their persistence presupposes a hope, if not a belief, that the treacherous behavior attributed to the patriarchs was not transmittable and they would be able to lead tolerable lives thereafter. The hope was not misplaced, for Pennsylvania had inherited the British legal tradition which prohibited "corruption of blood" - the transmission of a crime to heirs or familial relations. Sir William Blackstone observed in his study of Britannic law that "after the decease of the late pretender, no attainder for treason should extend to the disinheriting of any heir, nor to the prejudice of any person, other than the traitor himself., ${ }^{, 70}$ Pennsylvania law reflected this view. For example, a 1770 anti-crime statute "Provided, that no attainder for any of the offenses made felony by virtue of this act shall make or work any corruption of blood, loss of dower, or forfeiture of lands or tenements, goods or chattels." Similar clauses reappeared in postwar penal legislation. ${ }^{71}$ In addition, the state's 1777 treason law allowed judges to

\footnotetext{
${ }^{69}$ The New Doane Book, 25, 337, 314-317, 342. Sabine, Biographical Sketches, vol. 1, 382.

${ }^{70}$ Blackstone, Commentaries on the Laws of England, Book the Fourth, Chapter 29, 384. The "late pretender" was James Francis Edward Stuart, Prince of Wales, son of the Catholic King James II who abdicated in the Glorious Revolution of 1688. He led the failed Jacobite uprising of 1715 in Great Britain and died in 1766. Charles Edward Stuart, a.k.a. "Bonnie Prince Charlie," also led a Jacobite uprising in 1745 a generation later but he was still alive when Blackstone wrote his Commentaries in the late 1760s, so he could not have been the "late" pretender. The Bonnie Prince died in 1788.
} 
"order and appropriate" portions of a convicted traitor's forfeited property "to the support of such traitor's children or wife and children (if any) as to them may appear sufficient." The original 1778 attainder statute contained a similar clause. ${ }^{72}$

From the onset, both families proceeded on the assumption that they had an inherent right to stay but approached that prospect differently. The Roberts clan pursued a proactive path to reintegration that harnessed the state's legal edifice and the law itself in their favor, engaging the General Assembly, the Supreme Executive Council, and the Supreme Court as necessary. The Carlisles opted for a more reactive approach. For both, however, reintegration came in two phases. Survival and adaptation characterized the initial phase from the executions until the war's end. Reestablishing the family's social and financial position then shaped the early republic stage which followed. Since seizure of real and personal property accompanied imposition of the death penalty for treason, primary reintegration concerns often revolved around property and goods. For almost two decades, the heirs engaged state authorities. Their struggle assumes faith in the republican legal system for family members and corroborates a patriot adherence to the rule of law,

\footnotetext{
${ }^{71}$ Statutes At Large of Pennsylvania, vol. 7, "An Act for Punishing Wicked and Evil-Disposed Persons from Going Armed in Disguise and Doing Injuries and Violences to the Persons and Properties of His Majesty's Subjects within this Province, and for the More Speedy Bringing the Offenders to Justice," February 24, 1770, Chapter 712, [Section IV], 353. See also Statutes At Large of Pennsylvania, vol. 12, "An Act Amending the Penal Laws of this State," September 15, 1786, Chapter 1241, [Section II] (Section III P. L.), 281; and ibid., vol. 13, "An Act to Reform the Penal Laws of the State," April 5, 1790, Chapter 1516, [Section II], 512.

${ }^{72}$ Statutes At Large of Pennsylvania, vol. 9, "An Act Declaring What Shall Be Treason and What Other Crimes and Practices against the State Shall Be Misprision of Treason," February 11, 1777, Chapter 740, [Section II] (Section III, P. L.), 46; Statutes At Large of Pennsylvania, vol. 9, "An Act for the Attainder of Divers Traitors if They Render Not Themselves by a Certain Day, and for Vesting Their Estates in This Commonwealth, and for More Effectually Discovering the Same and for Ascertaining and Satisfying the Lawful Debts and Claims Thereupon," March 6, 1778, Chapter 784, [Section XIX.] (Section XX, P.L.), 215.
} 
this time increasingly coupled with a sentiment of remorse among authorities that over time helped to ameliorate the sufferings inflicted by the executions.

The state confiscated John Roberts' assets on October 3, two weeks before actual sentencing. ${ }^{73}$ Given the pain and pace of events, it is remarkable how quickly his family responded to the crisis. Less than three weeks after the execution, the General Assembly received two petitions, the first "to restore to our afflicted Mother the Dower she was by law entitled to, and to grant to us her Children the Inheritance we had a Right to expect, and which no act of ours has contributed to forfeit." When the legislature took no action, Jane Roberts and her children asked for a temporary stoppage of all forfeited property sales until the assembly could decide on their petition, as auctions were scheduled to take place before that entity reconvened. Consciously or not, the Roberts family initially avoided contact with the Supreme Executive Council and the courts, the institutions responsible for the execution. Instead, they appealed to the assembly, "fully persuaded that the House as Guardians of the Rights of every Individual, will not reject the second Reading of a Petition which asks for an act of Clemency towards Persons against whom no Crime is alledged [sic]. ${ }^{, 74}$ The radical guardians of their rights took no action.

The Roberts family then turned to the Supreme Court and found in the judges unexpected - and perhaps contrite - allies. Four days after the petition to the assembly, the court ordered officials in charge of the forfeited assets to "stay their proceedings...

\footnotetext{
${ }^{73}$ See "Inventory of the Movable Effects Belonging to John Roberts - Lower Merion Township Philada. County Seized in Behalf of the State of Pennsylvania October 3d 1778," Pennsylvania Archives, Sixth Series, vol. 12, 710-715.

${ }^{74}$ Reference to a November $23^{\text {rd }}$ petition is in "Memorial of Widow, \&c, of John Roberts," Pennsylvania Archives, First Series, vol. 7, 122-123. Most of the "children" were adults at this point. The two oldest were the only sons, Thomas and Jehu, 35 and 27 respectively. All told, seven were twenty years of age or older. Only fifteen-year-old Elizabeth and ten-year-old Ann were clearly minors.
} 
untill [sic] the decision of the said Court upon the said Claims" and assigned to widow Jane the "Plantation with the Edifices Mills and Appurtenances... and the Goods and Chattles [sic] in the foregoing Inventory" until April 1 of the next year for support of her underage children. Either the court transmitted the November $27^{\text {th }}$ stay order to the agents too late or their decision did not include all of John Roberts' property, for second son Jehu successfully bid on and repurchased a portion of his father's personal assets on December 1. Of the 158 items sold at auction that day, Jehu bought 87 of them. Others with the last name of Roberts bought additional items. Five months later, Justices Thomas McKean and William Atlee formally ruled in favor of the claimants, granting the children the seized goods and Jane Roberts "the several Articles \& Things mentioned in the above Inventory \& Interlocutory Decree... for her Support and Maintenance and that of her three youngest Children." ${ }^{, 75}$ Remorse is especially evident in the court's decision of May 1779 granting widow Jane Roberts a compensatory annuity of $£ 75$ per year, the disbursement of which fell upon the radical-controlled Supreme Executive Council headed by President Joseph Reed - he of prosecutorial fame propelled to the summit of provincial politics thereafter, in no small measure for his inflexibility during the trials and executions. It comes as no surprise, then, that Jane Roberts did not receive her annuity anytime during Reed's presidential tenure through 1781. New president John Dickinson and the executive council eventually authorized three initial annuity payments in August

\footnotetext{
${ }^{75}$ Stay order on November 27, 1778 \& court decision on April 23, 1779, both in Pennsylvania Archives, Sixth Series, vol. 13, 281. The full inventory claimed is in "Estate of John Roberts. Inventory of Sundry Goods Necessary for the Support of Jane Roberts, Relict of John Roberts (Deceas'd) and Family," ibid., 278-281. For Jehu Roberts' December 1, 1778 repurchase effort, see "List of the Goods \& Chattels Late the Property of John Roberts Sold This First Day of December 1778," Pennsylvania Archives, Sixth Series, vol. 12, 716-719. Jehu's purchases represented $55.1 \%$ of all goods sold that day. For the state revenue grossed on the December 1 Roberts sale, see ibid., vol. 12, 794, 796.
} 
of 1783 after moderates took political control. ${ }^{76}$ There is no record that Ann Carlisle sought a similar state pension.

Strategically, it appears that the family decided to proceed on two tracks in their efforts to retain the John Roberts legacy. Widow Jane Downing Roberts, second son Jehu and the married and unmarried daughters formed a single collective front, while eldest son Thomas proceeded along a parallel but separate path. Sometime after the execution, Thomas Roberts convinced the Supreme Court that his father had transferred to him a sizeable portion of a seized three-hundred acre tract on the Schuylkill River before the crucial cut-off date of July 4, 1776. That legal acknowledgement kept the property beyond the purview of the forfeiture statute. In the interim, Jane Roberts and her minor children continued to live on the principal family estate while the issue of her husband's holdings remained in flux. State agents sold one hundred acres of the Roberts estate to Daniel Clymer in August 1779. Clymer had tepidly supported John Roberts as a defense witness during the trial. ${ }^{77}$ In November, Jehu Roberts petitioned the assembly to suspend further land sales. As of December 16 that year, state agent Thomas Hale noted that three seized Roberts properties consisting of 678 acres in toto were still unsold. When the legislature failed to respond to the November request, Jehu redirected his attention to

\footnotetext{
${ }^{76}$ Maxey, Treason on Trial, 122; Council Minutes, August 23, 1783, Colonial Records, vol. 13, 671. On that date the council drew an order from the state treasury on behalf of Jane Roberts for £228.10.3, representing "the annual allowance for herself and her two children... with costs of suit for its recovery for three years, at seventy-five pounds per annum." In other words, she had to sue to get the money legally authorized for her.

${ }^{77}$ Maxey, Treason on Trial, 118. The strategic bifurcation is confirmed in Jehu Roberts' 1780 petition to President Reed where it is established that Thomas "having received part of the said Estate... does not propose to make application for a Share of the Residue" - "Jehu Roberts to Pres. Reed," June 3, 1780, Pennsylvania Archives, First Series, vol. 8, 296. Thomas also made a separate claim on his father's personal goods in the 'stay order' process: "Sundries claimed by Thomas Roberts," Pennsylvania Archives, Sixth Series, vol. 13, 280-281. Reference to Clymer's purchase is in Council Minutes, April 19, 1780, Colonial Records, vol. 12, 324.
} 
Reed's Supreme Executive Council the following summer. Needless to say, that body rejected the appeal. ${ }^{78}$

Failure to defer or reverse the process resulted in the sale of the two largest Roberts tracts less than three weeks later. For the sum of $£ 271,600$, Bucks County miller Edward Milner purchased the tract of three-hundred acres which harbored the main Roberts residence and the site's mills in Bucks County, along with an adjoining plot of seventy-eight acres. President Reed signed the deed in December. Despite the sale, Jane Roberts and her children did not leave, for Thomas Roberts managed to lease back the property from the buyer, including the mills. Subsequent mill production generated an income flow which allowed his mother to close out the war on the property. ${ }^{79}$

Less evidence is available for Abraham Carlisle's widow and only son but what exists suggests that they were less fortunate, at least initially. Like Jane Roberts, Ann Brooks Carlisle continued to reside at the family home on Front Street in Philadelphia after her husband's execution. And like the Roberts family, she lived in uncertainty while the state decided how to dispose of the property. For example, the "Secretary \& keeper of the Register for forfeited Estates" published notices in April of 1779 that her residence "will be speedily sold by Public Auction or Vendue, to the best \& highest bidders." That July the state also settled accounts with Philadelphia Sheriff James Claypoole, disbursing

\footnotetext{
78 "A Return of sundry forfeited Estates in the County of Philadelphia which are clear of Incumbrances [sic] and not yet Sold," December 16, 1779, Pennsylvania Archives, Sixth Series, vol. 12, 793; "Jehu Roberts to Pres. Reed," June 3, 1780, Pennsylvania Archives, First Series, vol. 8, 296; Council Minutes, June 3, 1780, Colonial Records, vol. 12, 374.

${ }^{79}$ Council Minutes, December 16, 1780, Colonial Records, vol. 12, 571; Maxey, Treason on Trial, 120. The sale took place on June 21, 1780. These were a portion of the same tracts the state agent described as "unsold" on December 16, 1779. The currency paid is not specified but the large sum implies inflated Continental or Pennsylvania pounds rather than specie. The lease arrangement is described in AO12/42/82 and AO13/71pt.2/267-268, cited in Maxey, Treason on Trial, 120-121 \& 200fn25.
} 
a payment of $£ 79.3 .11$ for "the amount of his Bill of Costs in the case of Abraham Carlisle." ${ }^{" 80}$ The widow's wait ended the next summer. In June 1780, forfeiture agents sold the Carlisle property to Captain Robert Bethel for the sum of $£ 20,000$ in continental funds. President Reed reviewed and signed a deed dated September 20, 1780 in April of the following year. George A. Baker acquired rights to the property from Bethel sometime in the next three months and soon encountered an intractable Ann Carlisle. Baker turned to Reed's Supreme Executive Council in mid-July because "the widow of the said Abraham Carlisle is in possession of the premises, and refuses to deliver them up." The council accordingly applied the law and ordered the sheriff to "give possession of the said premises to him [Baker]. ${ }^{\Perp 81}$ Despite the directive, Ann remained in Philadelphia through the war's conclusion.

When independence finally arrived in 1783 , the two widows and their offspring stayed in Pennsylvania - a final de facto acceptance of republican rule. Two years later, the Philadelphia Meeting for Sufferings revived the Carlisle-Roberts controversy while compiling documents for English Quaker John Gough's forthcoming history of the sect. The 1785 official Quaker version of events reiterated most of what Friends affirmed in a 1779 report signed by James Pemberton in the immediate aftermath of the executions. The Society held that Carlisle and Roberts were among those "divers making profession

${ }^{80}$ Council Minutes, April 12, 1779, Colonial Records, vol. 11, 745-747. The notice included Roberts and Carlisle properties, among others. It does not appear that the announced sale took place. The "Secretary \& keeper" was radical Timothy Matlack who later joined the Free Quaker movement against the Quaker reformers. Council Minutes, July 3, 1779, Colonial Records, vol. 12, 38. Claypoole also received £99.9.8 for his work in the John Roberts trial.

${ }^{81}$ Confirmation of the sale to Bethel is in Ann Carlisle's testimony to the Royal Claims Commission on June 30, 1787, AO12/95/4 and in "Estate of Abraham Carlisle," Pennsylvania Archives, Sixth Series, vol. 12, 503. Quakers Abel James, Robert Waln and Henry Drinker appraised the property’s value at £1,000 PA currency on September 9, 1783: see AO12/95/13, DLAR. Approval of the deed is in Council Minutes, April 9, 1781, Colonial Records, vol. 12, 687-688. Eviction order is in Council Minutes, July 17, 1781, Colonial Records, vol. 13, 5-6. 
of the Truth with us [who] have been misled $\&$ become entangled in the confusions prevailing." They had been "inattentive to the Divine principle" and "manifested open \& active deviations from our antient peaceable testimony." "Overtaken \& ensnared," the duo had disobeyed and "involved themselves in difficulties, and distress, [and] become obnoxious to party resentment... which is lamentably the case of the members now under our consideration." Official Quakerdom had not intervened at the time because of "their [the prisoners] inadvertence to the principle of Divine Grace, and overlooking repeated advice... they were suffered to fall into such error, \& deviation [which]... affected the reputation of Truth." Consequently, "this meeting or any other was restrained from interposing in their favour or vindication." The report alluded to visits with the prisoners prior to the executions and the latter's admission of religious impropriety. Roberts acknowledged that "he had gone beyond the line, \& seen his deviation" from Quaker orthodoxy. Carlisle "saw the Station he had filled, \& acted in, in a different light, and that he had been under a cloud when he thought he was doing right." Although the report often reads like a justification of Quaker inaction while the fate of the captives hung in the balance, there is no reason to doubt the veracity or sincerity of the testimonies as the detainees approached their final hours. For the widows, the Quaker account officially appended religious error to their husbands' costly political error, but did not affect their membership in good standing within the faith in the postwar era. ${ }^{82}$

As the decade of the eighties worn on, the Carlisle and Roberts survivors turned their attention to Parliament's Royal Claims Commission across the sea as a source of

\footnotetext{
82 "To the Meeting for Sufferings in Philadelphia, December 15, 1785," reproduced in full in Maxey, Treason on Trial, Appendix C, 163-167. The continuing Quaker membership of both families is evidenced in their testimonies before the Royal Claims Commission. Summaries are in Coldham, American Migrations, 453 for Carlisle \& 482-483 for Roberts.
} 
possible compensation. In 1784, exile Samuel Shoemaker filed a memorial in London on behalf of Ann Carlisle. Abraham Carlisle Jr.'s deposition from Philadelphia also found its way to the commissioners. The twenty-four-year-old silversmith and only son verified that his father had a house and lot in the provincial capital and had "served in the police during the British administration." References to "police" and "administration" spoke a modified language that accommodated royal rule. During Abraham Sr.'s trial, the prisoner had only granted passes, not joined the police, while Philadelphia had suffered an occupation, not an administration. Parliament took the Carlisles' plight to heart, awarding the family their entire $£ 600$ claim, one of the few to receive one-hundred percent compensation. ${ }^{83}$

The Roberts family followed a similar track. In 1783, Jane Roberts petitioned Parliament for compensation as a result of her husband's death, submitting an appraisal of forfeiture losses. Another report followed in February 1786 from Cape Breton, Canada, where parliamentary appointees Colonel Thomas Dundas and Jeremy Pemberton had traveled from London to gather first hand evidence from loyalist exiles. That same year eldest son Thomas decided to venture to England to plead the family's claim for $£ 5,780$ sterling in person. Among the exiles who bore witness to the family's torments was Colonel William Rankin. In their assessment of the case, the British commissioners explained that John Roberts had been "condemned, \& executed, and his Property was confiscated... on account of his active Exertions on behalf of the British Government."

\footnotetext{
${ }^{83}$ Coldham, American Migrations, 453; Palmer, Biographical Sketches, 139-140. As noted earlier, the average award was $39.9 \%$ of each loyalist claim. See Eardley-Wilmot, Historical View of the Commission for Enquiring into the Losses, Services, and Claims, of the American Loyalists, Appendix IX, 199.
} 
They also recognized "the Widow \& Children" as "having taken no Part whatever in the Dispute." ${ }^{84}$ Parliament awarded the widow $£ 3,931$ sterling or $68 \%$ of her claim.

Jane Roberts' saga reveals how the changing political climate in Pennsylvania affected application of the rule of law while popular support for moderates intensified. As Thomas Roberts prepared for his transoceanic trip in 1786, he solicited the aid of wellknown Quaker merchant Abel James. James in turn directed attention to the Supreme Executive Council, requesting that the patriot government certify the events leading to the Roberts execution and the consequences thereof in order to facilitate the family's claim before the British Parliament. With Thomas Mifflin as assembly speaker and Benjamin Franklin as council president, moderates at the time controlled both the executive and legislative branches of government. In addition, James had established a personal relationship with Franklin after encouraging the latter to complete his autobiography in $1782 .^{85}$

For patriots, however, there was a potentially ominous side to this sketch. Abel James had been on the August 1777 council list of those "who have in their General conduct \& conversation evidenced a disposition inimical to the Cause of America." In fact, he was one of eleven Quakers that radicals "particularly" sought to apprehend as Howe's army approached Philadelphia. James was initially slated for banishment to Virginia, but revolutionaries allowed him to remain under virtual house arrest on his

\footnotetext{
${ }^{84}$ Coldham, American Migrations, 482-483; Eardley-Wilmot, Historical View of the Commission, 55, 127; Palmer, Biographical Sketches, 731-732; Maxey, Treason on Trial, 124-128. Case of Jane Roberts Widow of John Roberts, AO13/70B/250, DLAR.

${ }^{85}$ Franklin was one of the few Pennsylvania political figures of the day who could easily bridge both the radical and moderate patriot camps. In terms of state politics (as opposed to his critical role in Congress or as a national diplomat), his hometown factional allegiance was more radical in the early Revolution than later. In my view, by the mid-1780s when he returned from Europe and became council president he was a moderate - albeit very much acceptable to radicals.
} 
Frankford plantation after receiving his promise to avoid cooperation with the oncoming British invaders. Once Philadelphia fell, James joined the British in the greater safety of the capital, for his country estate outside the city was located in no-man's land. The radical Supreme Executive Council attainted “Abel James, Merchant," on May 21, 1778, a month before the British evacuation. His name headed the seventy-five suspected loyalists appearing on that third attainder. James surrendered according to attainder guidelines and authorities discharged his case. Resuming his pursuits in the merchant trade, council secretary Timothy Matlack wrote to James the following year about the delivery of a seized shipment of salt as if nothing had ever happened. In addition to James' track record of suspected disaffection, Jane Roberts' memorial to the Royal Claims Commission in 1786 explicitly condemned "the inflamed temper of Persons active in the Execution of those [revolutionary] Laws" who had killed her spouse simply for "continuing to manifest a respectful Attention to the British Government." 86 These factors did not upend Abel James' request for a certification of events under the more tolerant moderates. The Supreme Executive Council complied, outfitting Thomas Roberts for his mission.

This sequence is truly extraordinary. It exposes that, by 1786, an inimical Quaker once targeted for banishment, placed on house arrest, and attainted could intercede with the approbation of the revolutionary regime on behalf of the family of another obnoxious Quaker who had actually been executed, for the purpose of facilitating financial redress

${ }^{86}$ Council Minutes, August 31, 777, Colonial Records, vol. 11, 283; Attainder Proclamation, Council Minutes, May 21, 1778, ibid., vol. 11, 493-495; “Abel James," Lawmaking and Legislators in Pennsylvania: A Biographical Dictionary, 766-770; “Sec'y Matlack to Abel James," October 20, 1779, Pennsylvania Archives, First Series, vol. 7, 758-759; Jane Roberts Memorial, AO12/42/73-75 and Abel James account in Maxey, Treason on Trial, 124-126. Abel James is among those on the "List of Persons Against Whom Proclamations Were Issued by the Supreme Executive Council \& Who Surrendered Themselves to be Tried for High Treason," Pennsylvania Archives, Sixth Series, vol. 13, 476. 
from none other than the tyrannical institution most patriots of all stripes considered the chief culprit for the abrogation of colonial rights which had led to armed insurrection in the first place: the British Parliament. Clearly, a dramatic change had taken place. The elimination of internal armed opposition and external military peril, the non-threatening behavior of nonjurors and their willingness to accept republican government teamed with the rise of the moderate faction, allowing patriot government institutions and the new legal order to side with the ex-disaffected.

The two widows spent their last days in republican Pennsylvania in comparative peace. On September 15, 1788, Quaker Hannah Callender Sansom chronicled in her diary "Ann Carlisle is dead, thus has she finished a course of affliction, heavy both before and after the decease of her husband, Abram Carlisle, he being one of the unhappy sufferers in the late commotion." Ann was in her mid-sixties and never really derived satisfaction from the compensatory valuation the Crown had placed on her husband's loyalty. Jane Roberts continued to faithfully submit her yearly requests to the Supreme Executive Council for the $£ 75$ annuity a remorseful court awarded her in 1779 . Although payment may not have been forthcoming without her solicitations, she encountered no further obstacles in its collection under continued moderate government. Added to the sizable compensation award from the Royal Claims Commission, she and her numerous family could lead a comfortable existence. In 1791, the Roberts clan - including Jane, daughters, and Jehu - abandoned the memories of Lower Merion Township in Bucks County for 
West Whiteland Township in Chester County where Jane was born. The Merion Meeting provided the family with a certificate authorizing a move to the Uwchlan Meeting. ${ }^{87}$

The following year the Carlisles and Roberts joined forces in a final gesture of solidarity. Matriarch Jane Roberts and sole survivor Abraham Carlisle Jr. successfully lobbied the Pennsylvania legislature for a return of properties still in state hands "as hath not heretofore been seized, sold, aliened or otherwise disposed of." Moderate lawmakers passed a special bill for the express purpose of effectuating this reacquisition. ${ }^{88}$ That same year Thomas Roberts sold the property procured from his father and moved to Philadelphia. He spent much of his time there with a Quaker drinking companion and coffin maker named Joseph Price whose diary provides insight into the minutiae of daily life in the early republic and further confirms the family's return to normalcy. In 1796, Thomas abruptly wed Polly Cochran. The Radnor Meeting subsequently disowned him "for his irregular marriage." The eldest Roberts male only lived a few more years, aptly saying good-bye to God's green earth in 1799 in a coffin his drinking buddy fabricated for the occasion. In the intervening time, Jane Roberts had succumbed in 1795 at the age of seventy-three and second son Jehu had married Elizabeth Jones in 1792. Remaining active in the Quaker faith, Jehu became an overseer of the Uwchlan Meeting soon after and lived until 1818. He and Elizabeth had two children, one a male. Despite the tragedy

\footnotetext{
${ }^{87}$ Susan E. Klepp and Karin Wulf, eds., The Diary of Hannah Callender Sansom: Sense and Sensibility in the Age of the American Revolution (Ithaca: Cornell University Press, 2010), 340; Diary of Elizabeth Drinker, Biographical Directory, 311. Examples of requests for payment are in Council Minutes, August 6, 1784, Colonial Records, vol. 14, 174; September 15, 1785, ibid., vol. 14, 538; May 6, 1786, ibid., vol. 15, 17; June 13, 1787, ibid., vol. 15, 225; June 4, 1788, ibid., vol. 15, 467; April 27, 1789, ibid., vol. 16, 65; April 30, 1790, ibid., vol. 16, 350. The Roberts family move is in Maxey, Treason on Trial, 129.

${ }^{88}$ Statutes At Large of Pennsylvania, vol. 14, “An Act to Vest in the Widow of John Roberts, Deceased, and in Abraham Carlile, the Only Son of Abraham Carlile, Deceased, Respectively, Such Parts of Their Forfeited Estates as Have Not Been Sold for the Benefit of the Commonwealth," March 8, 1792, Chapter 1608, 204-205; Sabine, Biographical Sketches, vol. 1, 296 \& vol. 2, 219.
} 
of the Revolution, it appears that the couple was proud of their family history. They named their son John Roberts. This sentiment appears to have endured. "I remember to have seen, $\&$ had been taught, to revere, this respectable kinsman," declared cousin and U.S. Senator Jonathan Roberts years later. As if pronouncing final judgment on his extended relations' reintegration experience, he added that "his fate had no effect, on lowering the standing of his numerous family., 89

The post-execution and early republic experience of the Carlisle and Roberts families confirms that reintegrative success or failure was intimately linked to the struggle between patriot factions. The law was the law, but radical and moderate revolutionary "parties" often configured or applied that law according to their respective aims. After the Carlisle-Roberts executions, radicals speedily pressed for seizure of the victims' estates in 1778 . Fourteen years later, moderates passed a statute giving back the unsold portions of those same estates. When radical judges approved an annual pension for an executed traitor's wife in 1779 , the radical executive branch did not disburse the funds. It took a surge in moderate political fortunes to endow a grieving widow with what was legally due her. The moderate council furnished Thomas Roberts with an official certification of the circumstances leading to his father's death sentence for presentation to an enemy inquiry despite testimony that put the Revolution in a bad light. It is doubtful radical cooperation would have been forthcoming if the tables had been turned.

In retrospect, much of this radical relentlessness seems overly rigid and unnecessary. While scrutiny of the Doan despoliations often leads the investigator to root

\footnotetext{
${ }^{89}$ Maxey, Treason on Trial, 128-129, 202 footnotes 45-47; Joseph Price Diary online at Lower Merion Historical Society, http://www.lowermerionhistory.org/texts/price/ last accessed November 2, 2017; Jonathan Roberts and Philip Shriver Klein, "Notes and Documents: Memoirs of a Senator from Pennsylvania: Jonathan Roberts, 1771-1854," PMHB, vol. 61, no. 4 (October, 1937), 455.
} 
for their victimized patriot rivals, the opposite holds true for Abraham Carlisle and John Roberts. For unlike the Doans, these elderly Quakers and their heirs were never really much of a threat to the revolutionary cause. Perhaps justification for the executions can be made in lieu of rebel fear and rage following the British evacuation. Granted. But it is much more difficult to defend carrying that attitude forward to the guilty parties' wives and children who committed no offense against the Revolution. The Carlisle-Roberts affair paints an added dimension onto the exclusionary/inclusionary divide between patriot radicals and moderates during the war. Simply put: moderates were willing to forgive, radicals were not. How each gauged absolution determined what was or was not perceived as a threat. Corresponding applications of the law obeyed these contending visions.

\section{CONCLUSION}

The cornerstone of Pennsylvania republicanism, as elsewhere in the rebellious colonies, was a belief in the inherent rights of citizens and the rule of law. The new political and legal order applied the law principally to defend the rights of those who demonstrated their fidelity. How to apply that law to the disaffected who failed to prove their allegiance presented patriot authorities with a dilemma. In cases like the Quaker pacifists who posed no real threat, revolutionaries developed a reticent tolerance that led to creation of the exclusionary legal category of nonjurors in the postwar era. Nonjurors were tolerated as residents but not enfranchised as citizens. Direct threats to revolutionary authority, however, struck a different chord. For example, British military aggression had to be repulsed by force. There was no middle ground. The same held true for threats to republican rule from within. Patriot radicals and moderates often diverged, however, on 
how to interpret what constituted a true threat. While both factions considered armed opposition like the Doan guerrillas an inexcusable affront requiring extermination, officials in each coalition differed on how to treat lesser loyalist transgressions like collaboration with British occupiers. This divergence collided in the treason cases of Quakers Abraham Carlisle and John Roberts. Two factors drove competing factional responses: historical animosity between pacifist Quakers and radical Presbyterians, and the contrasting views of patriot radicals and moderates on forgiveness. Constitutionalist radicals preferred fire and brimstone justice as per the movement's underlying Calvinist worldview, while Anti-Constitutionalist Republican moderates took a more lenient stand. Since radicals held the reins of power in November 1778, their vision prevailed and the prisoners were executed. Once again, "party" decided the fate of the disaffected.

On a broader scale, the law served to legitimize patriot authority and control in both the Doan and Carlisle-Roberts cases, while helping to pave the way for a smoother reintegration process. The unified factional response to Doan guerrilla depredations eliminated the last armed threat to the Revolution on Pennsylvania soil and steadied the public's faith in republican authority. In turn, the Carlisle-Roberts executions satiated the desire for anti-Quaker retribution among radical leaders, most of whom ceased to insist on application of the "suffer death" sentence in cases of high treason and looked instead to forfeiture penalties thereafter. The executions thus contributed to reducing internal tensions. Authorities even permitted the families of the deceased or banished who had not contravened revolutionary law to remain in Pennsylvania, so that Doan, Carlisle and Roberts survivors retained their rights as citizens and assimilated. For a society no longer faced with real or perceived threats from within, the resultant increase in political and 
social stability fostered a climate of forbearance that consolidated moderate power in the 1780s, contributing to the repeal of the Test Act that restored nonjurors to the rights of citizenship and reintegrated them into the republican fold. 


\section{CHAPTER 6}

\section{THE PENNS, REVOLUTIONARY TRANSFORMATION \& REINTEGRATION}

We have traced how revolutionary factions used the rule of law to promote and consolidate their visions of the brave new republican world. Patriot radicals demanded an untainted republic that limited citizenship, even residency, to those who had earned their stripes through selfless devotion to the Revolution. Less strident but no less devoted patriot moderates exhibited a willingness to accommodate a diversity of viewpoints as long as skeptics or the inimical posed no threat to the new order. We have likewise considered the impact competing patriot ambitions had on disaffected Pennsylvanians who refused to accept or endorse the innovations wrought by rebellion. A majority of the loyally militant willing to bear arms and fight the king's fight departed or were defeated. Most never saw Pennsylvania again. Quaker pacifists stayed but declined to swear allegiance, serve in the militia, or contribute in any way to the war effort. They were ostracized as nonjurors well into the postwar period but eventually reintegrated. Others who supported the British also stayed after the evacuation of 1778. Guerrilla bands remained defiant and carried on the military struggle. They were crushed. Radicals made a devastating example of two Quakers who violated the pacifist tenets of their faith, found them guilty of high treason, and executed them as enemy collaborators. We turn now to the descendants of William Penn, the most prominent provincials of the era who witnessed, participated, and bore the brunt of much revolutionary turmoil. In transformative phases defined by reverence for monarchy, political resistance, armed rebellion, and legal reintegration, their singular experience wove a common thread through the last third of the eighteenth century in Pennsylvania. 
Under the hands-on leadership of John Penn Sr., the proprietorship tried to walk a fine line between republican and royal governance during the war. Placed in an almost impossible predicament, the family approached the unwelcome conflict on two fronts: their personal status as citizens of Pennsylvania and their privileged status as proprietors under William Penn's founding charter. The Penns successfully navigated the first set of obstacles, adapting to long-term republican rule after a series of unsettling misfortunes. But their efforts failed entirely in the second case, resulting initially in a loss of political power and later in the expropriation of most of their vast land holdings. The fate of the Penn family proprietorship unearths three important aspects of the American Revolution and its aftermath in Pennsylvania. First, the colonial order as structured locally was inherently incompatible with the new republican configuration based on popular sovereignty and egalitarianism. This irreconcilability led to both its inevitable overthrow and an expansion of the rights of those citizens committed to revolt. Second, absent the encumbrance of earlier colonial antagonisms such as Presbyterian-Quaker distrust or Yankee-Pennamite hostility, revolutionary justice was relatively benign, even at the height of radical supremacy. A core respect for the rights of citizens and the rule of law grounded and constrained rebel power. Third, in most instances, subscribing to the patriot oath of allegiance and voluntarily acquiescing to republican authority greatly facilitated reintegration.

WILLIAM PENN'S HEIRS \& THE PROPRIETARY REGIME Proprietary rule officially ended with passage of the new Constitution of Pennsylvania on September 28, 1776 promulgated by radicals. Political realignment reduced the Penns to the category of common citizens and terminated the privileges they 
had long enjoyed as endowed seigniors of the province. The revolutionaries of 1776 did not conceal their intent. After noting that the purpose of government was to provide security and enable citizens to enjoy their natural rights, the constitutional preamble condemned the English monarch for withdrawing protection from the commonwealth and waging a tyrannical war against its citizenry. As a result, radical delegates at the state constitutional convention expressly declared that "all allegiance and fealty to the said king and his successors, are dissolved and at an end, and all power and authority derived from him ceased in these colonies." Article V of the new charter underscored that government was for the "common benefit... and not for the particular emolument or advantage of any single man, family, or sett [sic] of men who are only a part of that community," specifying that the community had a "right to reform, alter or abolish government in such manner as shall be... most conducive to the public weal."1 It was the heirs of Quaker founder William Penn that convention representatives had in mind when alluding to emoluments and the king's derivative power and authority in the province. As per the Charter of Libertie enacted under the auspices of King Charles II, the Penns had reigned as lords of Pennsylvania since 1682. The original arrangement made William Penn and his "heirs and assigns forever" owners of all land in the territory and free to set up any system of government they saw fit. ${ }^{2}$ Over time the Penns sold substantial portions of their land to settlers and established an administration headed by an appointed governor and council on the executive side and a Quaker-dominated elected assembly on

\footnotetext{
${ }^{1}$ Preamble \& Article V of the Constitution of Pennsylvania, September 28, 1776, available online at the Yale Law School: http://avalon.law.yale.edu/18th_century/pa08.asp - last accessed August 15, 2017 (emphasis mine).

${ }^{2}$ Penn's Charter of Libertie, April 25, 1682, available online at the Yale Law School: http://avalon.law.yale.edu/17th_century/pa03.asp - last accessed August 15, 2017.
} 
the legislative flank. ${ }^{3}$ Battles between the proprietary and Quaker "parties" defined Pennsylvania's colonial era. The main clashes revolved around the Penn heirs' refusal to allow the assembly to tax their extensive unsold and undeveloped lands and Quaker unwillingness, based on pacifist scruples, to raise an armed force to defend the colony during repeated military crises. ${ }^{4}$

For most of the eighteenth century, appointed governors ruled Pennsylvania on behalf of the absentee Penn family in England. But in 1763, Thomas Penn - son of founder William who in 1746 acquired a controlling 3/4 interest in the proprietorship named his nephew John Penn Sr. as governor. From that date through 1776, Penn family members directly governed the province. Younger brother Richard replaced John for a short stint in 1771 while the elder sibling returned to England after father Richard Penn Sr.'s death. Then in 1773, Uncle Thomas reappointed John, who obligingly returned to Philadelphia from the mother country. ${ }^{5}$ John Penn Sr. would continue as governor in the lead-up and through the outbreak of hostilities with Great Britain. Much like pacifist Quakers, Governor Penn strove to toe a middle line between parliamentary overextension and colonial self-determination. Again, it was a precarious stance. If the Penns openly

\footnotetext{
${ }^{3}$ The enduring governmental framework was set up in the Charter of Privileges Granted by William Penn, Esq. to the Inhabitants of Pennsylvania and Territories, October 28, 1701, available online at the Yale Law School: http://avalon.law.yale.edu/18th_century/pa07.asp - last accessed August 15, 2017.

${ }^{4}$ For colonial politics, see Huston, Pennsylvania Politics 1746-1770; Thayer, Pennsylvania Politics and the Growth of Democracy 1740-1776; and Rufus M. Jones, The Quakers in the American Colonies (New York: Russell \& Russell, 1962), especially Book V, "The Quakers in Pennsylvania."

${ }^{5}$ John Penn Sr. was also referred to as John Penn, Esq. to distinguish him from John Penn Jr.; Richard Penn Sr.'s death gave older brother John Penn Sr. the father's $1 / 4$ minority interest in the proprietorship. For a chronology of the Penn proprietorship in the $18^{\text {th }}$ century, see Lorett Treese, The Storm Gathering: The Penn Family and the American Revolution (University Park, PA: The Penn State University Press, 1992), Appendix B: Chronology, 207-212. A historical summary of the evolving holdings of individual Penn family members is also provided in Appendix A: Condensed Penn Family Tree and Interests in the Proprietorship, 205.
} 
refuted monarchical authority, they could lose the royal charter which granted them the right to rule as proprietors in the first place. On the other hand, if they opposed colonial resistance to imperial measures such as the Stamp, Townsend, Tea or Coercive acts, they faced the wrath of a broad swath of the disgruntled local population. As crisis devolved into crisis, the middle ground gradually buckled.

Three important family events preceded the dynasty's decline. After nine years of marriage, Thomas Penn's wife Lady Juliana Fermor Penn gave birth to a new John in 1760, the same year George III acceded to the English throne. The boy was the couple's second child but the principal proprietor's first male successor. To avoid confusion with his governor cousin, contemporaries referred to the youngster either as John Jr. or John of Stoke - an allusion to the English manor near London that Thomas purchased in 1760. Then four weeks before the insurgent eruption at Lexington in 1775, Thomas died. As the lone male heir, John Jr. inherited his father's $3 / 4$ proprietary interest. ${ }^{6}$ Lastly, Richard Penn Jr. - John Sr.'s brother who had remained in Pennsylvania after replacement as provincial governor in 1773 - re-crossed the Atlantic to England once war broke out in the colonies. Richard bore with him the Continental Congress" "Olive Branch Petition," the doomed brainchild of John Dickinson and other patriot conservatives who insisted on one final attempt at reconciliation with the motherland before independence. ${ }^{7}$ Months after the battle of Bunker Hill had consolidated revolutionary fervor throughout the colonies, Pennsylvania's proprietary regime was in a state of disarray. Chief proprietor John Jr.

\footnotetext{
${ }^{6}$ Daughter Juliana Penn was born in 1753, two years after Thomas Penn married Lady Juliana. For Thomas' death, Treese, The Storm Gathering, 144.

7 “To the King's Most Excellent Majesty," Saturday, July 8, 1775, Journals of the American Congress, 104-106.
} 
was an absentee fifteen-year-old minor. Richard had said good-bye to the growing crisis for good, joining his younger cousin in Britain. The family's overseas destiny rested exclusively on the shoulders of John Penn Sr.

Events quickly moved beyond the scope of his political capabilities. In response to bottom-up revolutionary pressures, Governor Penn chose a path of cautious indecision and delay rather than vigorous enforcement of established royal authority. John Allen's revealing letter to Lady Juliana Penn in England describes the proprietorship's precarious position. Writing from his recent New York exile on behalf of John Penn because of "the danger there would be in his venturing to write himself," the eldest Allen brother stressed that the governor had "supported the authority of the Crown, in most points, long after it had been lost in every other part of the Continent." While doing so, Penn had acted with such prudence that he had "baffled" the rebels who awaited any mistake to pounce upon proprietary interests. Unable to hold out against the "frenzy of the people," however, John Penn had "thought it proper to retire to his house on the Schuylkill, where he has lived in a most private manner." ${ }^{\prime 8}$ Colonial institutions replicated his retreat. The governor's provincial council did not convene at all in 1776, while the legally constituted colonial assembly voluntarily disbanded that fall after months of inaction. For all intents and purposes, the proprietorship had ceased to function as a ruling body by mid-1776. After Congress formally declared independence in July, homegrown revolutionaries organized a constitutional convention which temporarily supplanted the legislature and then closed the proprietary death spiral with passage of the new state constitution in

\footnotetext{
${ }^{8}$ John Allen to Lady Juliana Penn, April 3, 1777, Dreer Collection, Autographs: A, Box 1, Folder 16, HSP. Lady Juliana was the widow of Thomas Penn, John Penn Sr.'s uncle.
} 
September. In little more than a year, radical republicans had ended a royally sanctioned proprietary reign of nearly a century.

The proprietorship's tenuous position between radical revolution and kingly fidelity is apparent in a January 1777 proposal that came to nothing. As Penn resided in seclusion on his Schuylkill estate nine months before Howe's attack on Pennsylvania, the British contemplated the isolated ex-governor's prospects from recently captured New York. General Howe's personal secretary, Ambrose Serle, foreseeing that "the Rebels wd. Certainly sacrifice all Proprietorship \& Charter-authority," proposed to Andrew Allen that John Penn should issue a royalist proclamation from his refuge. Serle suggested a proprietary decree "for convening or electing an Assembly" that would "firmly \& expressly renounce all the Determinations of the Congress as a factious \& illegal Body," as well as "warmly exhort all men... to profess with him [Penn] a dutiful allegiance to His Majesty, and an Hatred of all Rebellions \& treasonable Conspiracies; and command them to give no aid or Succor to the Rebels." In Serle's judgment, this proclamation would "give a Convincing Proof of Loyalty \& attachment to the King \& Constitution," which he observed "was now rather doubted at Home." Allen left the meeting "with the apparent Conviction of the Rectitude \& Prudence of the measure, and with the Resolution of communicating it, as an Idea of his own, to some leading people in Pennsylvania." That Andrew Allen ever discussed the notion with anyone else or that it reached John Penn is not clear. Regardless, the idea had no chance of ever coming to fruition. If undertaken, it would likely have found little resonance among Pennsylvanians. Patriots would have repudiated it, while loyalists, conservatives or middle-of-the-roaders had already shown themselves incapable of action, allowing the dissolution of the elected 
colonial assembly only months before. More importantly, Serle's idea assumed a type of royalist commitment which did not exist. The Penns held an undeniable attachment for the Crown. They no doubt preferred the old order to the new. But their interests came first. Amid uncertainty, the proprietors awaited events. They did not wish to antagonize either side. ${ }^{9}$

\section{THE ARREST \& EXILE OF JOHN PENN SR.}

John Penn Sr.'s retirement “in a most private manner” was short-lived. Following the capture of New York City in the fall of 1776, Sir William Howe set his sights on Philadelphia as the next target for the military campaign scheduled to open the following spring. Unwilling to begin operations until he had received new equipment and supplies, the British general leisurely organized his plans and forces. The drive did not start until well into the summer, to the consternation of impatient loyalist exiles. ${ }^{10}$ Anticipating the coming events, the Continental Congress passed a resolution in July recommending that Pennsylvania's Supreme Executive Council "make prisoners, such of the late crown and proprietary officers" and others "as are disaffected, or may be dangerous to the public liberty." Delegates suggested that those arrested be either confined in the backcountry or "enlarged upon parole, as their characters and behavior may require." The next day the council issued a warrant for the detainment of thirty-six colonial officials or persons suspected of hostility to the patriot cause. The Honorable John Penn, late Governor of the province of Pennsylvania, headed the list. ${ }^{11}$

\footnotetext{
${ }^{9}$ Serle, Saturday, January 4, 1777, American Journal, 169.

${ }^{10}$ Taaffe, The Philadelphia Campaign, 36. As Joseph Galloway testified before Parliament, Howe was seen by many on his own side as exceedingly slow and overly cautious in his pursuit of continental forces after his 1776 capture of New York.
} 
A tug of war between revolutionary authorities and the deposed embodiment of colonial authority ensued. Patriot light horsemen assigned to implement the council's warrant arrived at John Penn's home in the countryside after 9:00 p.m. on Monday, August 4, with instructions to either imprison the governor or oblige him to sign a parole confining him to an area within six miles of his home. As Penn later noted, "the unexpected \& abrupt manner of their coming at Such an unseasonable time of night threw the family into great confusion." The proprietor refused to sign and demanded more time. He wrote a one-sentence note to the council indicating that he was "desirous of considering the propriety of signing" the parole and would provide a final answer on Friday. With that, the arresting committee left. On the appointed day, however, no one called upon the fallen governor. It was not until the following Monday that the light horsemen returned with a new parole expanding Penn's confinement "to the whole Province." When Penn refused the new offer, warrant officers declared they had orders to conduct him to President Thomas Wharton Jr. and the Supreme Executive Council. "Denying their authority to summon me before them," the proprietor asserted that he "never could submit to... the indignity," leaving the envoys with the sole option of “carrying me away by force.” Unwilling to take such a provocative step, the messengers negotiated a compromise whereby Penn agreed to go to the Philadelphia home of exChief Justice, proprietary confidant and father-in-law William Allen Sr. the next day by noon "to receive any message the President and Council had to send." John Penn Sr.

\footnotetext{
${ }^{11}$ Journals of the American Congress, July 31, 1777, vol. 2, 210; "Warrant to Arrest Certain Persons, 1777," August 1, 1777, Pennsylvania Archives, First Series, vol. 5, 478. Six future Virginia exiles formed part of this 36-person arrest list: Henry Drinker, Elijah Brown, Charles Eddy, Charles Jervis, William Drewett Smith and William Smith (broker).
} 
arrived at William Allen's home by the appointed time but again refused to sign a parole.

He was then arrested. ${ }^{12}$

The council first considered sending the ex-governor to Hartford, Connecticut, then pondered Fredericksburg, Virginia. In the meantime, responsibility for the prisoner passed to Congress' Board of War. The changing circumstances compelled Penn to reassess his options. Acknowledging the fierce pro-patriot "temper" of Virginians and the resolve of his wife Anne "who was determined to share my fate," John Penn Sr. decided to sign the parole "as the least evil of the two." Congress then reciprocated, ordering that “removal to Virginia, be superseded." The situation temporarily stabilized. But on August 26, Congress received news of the British army's landing at Head of Elk on Chesapeake Bay and ordered the Board of War to remove Penn - along with colonial Chief Justice Benjamin Chew - "under guard, to a place of security out of the state of Pennsylvania." Once "safely secured," they were to be "entertained agreeable to their rank and station in life." ${ }^{13}$ Penn received this news the next day.

In keeping with the spirit of the order, the Board of War's letter asked him to select a suitable place of residence for his proposed banishment. He chose the Union Iron Works in Hunterdon County, New Jersey, an extensive property with an accommodating

\footnotetext{
12 "Warrant to Arrest Certain Persons, 1777," August 4, 1777, Pennsylvania Archives, First Series, vol. 5, 484; John Penn, “After 1778," Dreer Collection, Box 21, Folder 24, HSP; Colonial Records, August 12, 1777, vol. 11, 264; Journals of the American Congress, August 12, 1777, vol. 2, 224. I have not found an explicit motive for John Penn Sr.'s initial refusal to sign a parole, but the tone of his writings implies that the refusal was based on the dignity and status of the proprietorship and his belief that the patriots were acting illegally. Biographer Lorett Treese attributes the issue to "pride." See Treese, The Storm Gathering, 176. John Penn married Anne Allen, daughter of Pennsylvania Chief Justice William Allen Sr., in 1766.

${ }^{13}$ John Penn, "After 1778," Dreer Collection, Box 21, Folder 24, HSP; "Board of War to President Wharton, 1777," August 12, 1777, Pennsylvania Archives, First Series, vol. 5, 512; Colonial Records, August 13, 1777, vol. 11, 265-266; Journals of the American Congress, August 14, 1777, vol. 2, 226. Journals of the American Congress, August 26, 1777, vol. 2, 240 \& August 28, 1777, vol. 2, 246. While Fredericksburg is mentioned in official and personal documents, the Hartford connection appears only in Penn's notes.
} 
home owned by his in-laws, the Allens - the same locale where the three Allen brothers had decided to join the British against the advice of sibling James. The Board of War initially objected because of the large numbers "disaffected to the cause of America" in that vicinity but after "some delay \& a great deal of trouble," they relented and Penn made the transition. A few weeks into exile, patriot Governor William Livingston of New Jersey unexpectedly dispatched the state militia with orders to escort Penn to Worcester, Massachusetts. The ex-governor of Pennsylvania adamantly refused removal, prompting another stalemate. After weeks of wrangling, Livingston finally rescinded the expulsion order. According to Penn, “it seems his [Livingston's] dignity was not a little hurt that the Congress should send me into Jersey without his permission.” Penn overcame this adversity when "some of the warm friends to America who lived near me" informed the New Jersey governor that he "had behaved exceedingly well" during his time at Union. ${ }^{14}$ Beyond temperamental personalities, the incidents leading to arrest and exile show, first, that Pennsylvania's revolutionary government was not yet entirely confident of its authority and, second, no one - not even the proprietor himself - was above their interpretation of the law.

From New Jersey, John Penn maintained a low profile in the following months. Official records reflect that obscurity. He wrote innocuously to radical Timothy Matlack at the Pennsylvania government's Lancaster refuge in November, asking the Secretary of the Supreme Executive Council how to go about procuring three hundred pounds of clover seed for a friend who had requested his intervention in the matter. In December, council president Thomas Wharton Jr. confided to a patriot general that "respecting Mr.

\footnotetext{
${ }^{14}$ John Penn, “After 1778," Dreer Collection, Box 21, Folder 24, HSP.
} 
Penn and Mr. Chew, Council has not lately heard anything about them." In February, the council drew an order on the state treasury for the reimbursement of expenses the light horsemen had incurred while carrying out the parole mission the previous year. ${ }^{15}$ With General Howe occupying Philadelphia and Continental Army provisions in short supply at Valley Forge, the fate of John Penn was not high on the rebel agenda.

Debate on the proprietor's destiny began in earnest in early March, an issue patriot officials often linked to the controversy over the Quaker exiles still in Virginia. In keeping with the continuing dispute over jurisdiction, Pennsylvania's Supreme Executive Council asked Congress if they objected to a return of Penn and Chew "under the authority of the state." That body referred the matter to an investigative committee of three. ${ }^{16}$ After some reflection, the group acknowledged that Penn and Chew had been Crown officers prior to independence, "\& yet taking no active part (that we know of against us)... [this] renders their situation very peculiar." In the event the prisoners were liberated, the congressional committee foresaw three scenarios. If allowed to join the British in Philadelphia, the Revolution's enemies might use the proprietor's authority to create "mischief," even without Penn's consent. "Mischievous consequences" could also arise if Penn was freed in those parts of Pennsylvania still controlled by Whigs because "they are so intermixed with Tories." And a transfer to Pennsylvania while still a prisoner

\footnotetext{
15 “John Penn to Timothy Matlack, 1777," November 16, 1777, Pennsylvania Archives, First Series, vol. 6, 10; "President Wharton to Maj. Gen. Armstrong, 1777," Pennsylvania Archives, First Series, vol. 6, 85; Colonial Records, February 24, 1778, vol. 11, 426. The light horsemen were James Hunter, William Hall, John Dunlap, and Thomas Lieper. Penn mentions the first three in his recollections of exile - see page one in John Penn, "After 1778," Dreer Collection, Box 21, Folder 24, HSP.

${ }^{16}$ Journals of the American Congress, March 10, 1778, vol. 2, 472 \& March 16, 1778, vol. 2, 479; "Resolutions of Congress, 1778," March 16, 1778, Pennsylvania Archives, First Series, vol. 6, 364 \& "Pres. of Congress to Pres. Wharton, 1778," March 21, 1778, vol. 6, 378. In all of the above sources, Congress and the Pennsylvania Supreme Executive Council treated the cases of the Virginia exiles and John Penn at the same time but as separate issues.
} 
who refused to take the requisite oath of allegiance would likely produce "discontent \& caballing." Despite these legitimate concerns, the committee concluded that Congress had no objection to their return to local authority "provided it can be done without danger to the state of Pennsylvania in particular, or the United States in general." ${ }^{, 17}$

The Pennsylvania government took about a week to reply to Congress' analysis. Their lengthy communiqué examined the contradictions of Penn's initial arrest and, again like the Quakers in Virginia, raised questions of jurisdiction between state and national authorities. The council made sure to justify its earlier actions, concluding that those who had not renounced commissions under the king "are friends to the enemies of that [America] country" and "the arrest of those Gentlemen was unquestionably proper." They contemplated not only the effects of releasing the prisoners, but also considered their continued retention. Although the council did not perceive any "injury to the general cause of America, or to this state" that John Penn could exercise "under the pretence of being Governor of Pennsylvania" even with Howe in Philadelphia, they could see no benefit to Penn's release. Should America win the war, Penn and other colonial officials could act as a rallying point for "their dependants and connexions, and the dissatisfied of all parties" leading to an effort "to re-establish them in government." If Britain emerged victorious, patriots would then "have done every thing in the power of men to do to reestablish them in their former power." Moreover, it was "impossible" to think that Penn and company could be "enlarged" in Pennsylvania without taking the oath of allegiance.

\footnotetext{
17 “Abm. Clark \&c., Committee of Congress to President Wharton, 1778," March 18, 1778, Pennsylvania Archives, First Series, vol. 6, 367.
} 
Such a refusal would render them "enemies of the state." 18 The subject was momentarily laid to rest.

The issue resurfaced two months later after the Virginia exiles had returned to Philadelphia at the end of April and news had leaked that the British were to evacuate the capital. Aware of the Quaker restoration, John Penn Sr. "was fearful of being detained for some particular purpose," a thought that left him "very uneasy" and in a "disagreeable state of uncertainty." On May 10, he and Benjamin Chew petitioned Congress once more for release. Five days later, Congress finally agreed, resolving that the pair "be conveyed, without delay, into the state of Pennsylvania, and there discharged from their parole." Providing no further explanation, they immediately transmitted their decision to the Pennsylvania and New Jersey governments. ${ }^{19}$ The sudden ruling perplexed the Supreme Executive Council at Lancaster, which replied that "we are wholly at a loss to know why they have been discharged in this manner." Nevertheless, the council played along, explaining that "the respect we have for the determinations of Congress, induces us to suppose that there may be good and sufficient reasons for it." Governor Livingston of New Jersey promptly arranged for a military escort to take Penn and Chew back to Pennsylvania. ${ }^{20}$ While the Penn family's earlier encounter with the constitutionally

\footnotetext{
18 "Council to Abraham Clarke, \&c., 1778," March 27, 1778, Pennsylvania Archives, First Series, vol. 6, 389. See also "Council to Delegates in Congress, 1778," March 21, 1778, Pennsylvania Archives, First Series, vol. 6, 380, which alludes to a delay in considering the matter until "the business is matured... probably in a day or two."

${ }^{19}$ John Penn, "After 1778," Dreer Collection, Box 21, Folder 24, HSP; Journals of the American Congress, May 15, 1778, vol. 2, 555. Congressional records refer here to a letter from Penn and Chew dated May 10. John Penn's own recollection gave the letter's date as May 15 but Congress is probably correct because the discharge order is also on the fifteenth.

20 "President of Congress to President Wharton, 1778," May 15, 1778, Pennsylvania Archives, First Series, vol. 6, 507 \& "Council to President of Congress, 1778," May 18, 1778, vol. 6, 523; John Penn, "After 1778," Dreer Collection, Box 21, Folder 24, HSP.
} 
reconfigured patriot government had destroyed their political authority, pushed John Sr. into involuntary seclusion and Richard into permanent retirement across the Atlantic, the suspicions of disaffection underpinning this second major engagement with the Revolution - even after a seemingly successful outcome allowing John Sr.'s return exposed the potential for a continuing degeneration of the Penns' already humbled status, from that of common citizens to permanent enemies of the new order. Danger lurked on both the personal and proprietary fronts.

Pursuant to Congress' recommendation, John Penn returned to his country estate at Lansdown in the summer of 1778. From the family's perspective, conditions soon worsened: the British evacuation of Philadelphia in mid-June eliminated any prospect of restoring the powers of the proprietorship once the rebels reoccupied the provincial capital. Facing increased uncertainty, John Penn Sr. made the dramatic decision to take the Pennsylvania oath of allegiance, complying on July 8. According to James Allen, Penn had found himself "under the cruel necessity of abjuring the King \& swearing allegiance to the mob-government of Pensylvania [sic] \& the united states to prevent confiscation of his whole property." In the end, he succumbed "by the advice of his friends \& in consequence of a letter from Mr. Baker in England, advising him to become an American. ${ }^{21}$ Almost two weeks after swearing allegiance to the revolutionary government, John Penn Sr. sat down to write his first post-banishment communication to

\footnotetext{
21 "Oaths of Allegiance to Pennsylvania, July 8, 1778," Pennsylvania Archives, Second Series, vol. 3, 23; Diary of James Allen, July 15, 1778, $P M H B$, vol. 9, no. 4, 440. The Penn's seemingly conditional loyalty to England based on property ownership did not affect the family's later compensation from Parliament. As we shall see, they received the largest compensation award of all claims in all colonies. James Allen was one of Anne Allen Penn's four brothers. William Baker became a key cog in the proprietorship after his marriage to Thomas Penn's eldest child Juliana in 1771. Following Thomas' death in 1775, Lady Juliana took over management of proprietary affairs because her son and prime inheritor John Penn Jr. was only fifteen-years-old at his father's death. Son-in-law Baker became Lady Juliana Penn's foremost advisor and administrator until John Jr. came of age.
} 
Lady Juliana in England. The brief three-paragraph missive carried by exiled Anglican minister Thomas Coombe makes clear the duress under which the released ex-governor then lived. "As I am obliged to send my letter open, I do not think it prudent to say anything respecting the publick [sic] or our own private affairs," he asserted. Reflecting on his captivity and the changed circumstances, Penn expounded that "my time has been spent in a very disagreeable manner for a long while past, \& I still ardently wish an end to our present troubles, when I may have an opportunity again of writing to you without restraint. ${ }^{, 22}$ It seems Penn still distrusted the rebel authorities despite his recent oath. His instincts proved correct. For revolutionaries, deposing the Penns from the provincial seat of power was not enough. The proprietorship retained control over vast expanses of Pennsylvania land. Seeking a definitive break with the royalist past, radicals launched a full-scale legal assault on proprietary holdings in 1779 .

\section{PROPRIETARY DIVESTMENT: DEFINITIVE END OF AN ERA}

Inherent rights and the rule of law lay at the heart of Pennsylvania's seizure of proprietary lands. Proprietary ownership of unsold private lands, as granted in the royal charter, was intrinsically at odds with the nature of republicanism. In a republic, the government was recognized as the organized political expression of the citizenry. It was proper that the people, not vested interests, should rule. The Pennsylvania Constitution of 1776 unseated King George III and the Penn family from power, resolving the political aspect of this equation. Power and property, though, were not necessarily one and the same. The uniqueness of the proprietary formula of government placed Pennsylvania authorities in a quandary, especially after John Penn Sr. swore allegiance to the new state.

${ }^{22}$ John Penn Sr. to Lady Juliana Penn, July 20, 1778, Simon Gratz Autograph Collection, Governors of Pennsylvania/The Penns: Penn Family, Case 2, Box33a, Folder 8, HSP. 
As a citizen of the republic, Penn had a right to his property. The new constitution said so: "But no part of a man's property can be justly taken from him, or applied to public uses, without his own consent." 23 At the same time, the Penn's holdings were ostensibly larger than the combined properties of all other citizens of the state. Such proportions were clearly incompatible with a government based on an egalitarian distribution of both rights and property. Constitutional articles $\mathrm{V}$ on government for the benefit of the people and VIII on the protection of private property were therefore at odds with each other. That citizen John Penn Sr. held a one-quarter share in the proprietorship while his nineteen-year-old cousin and British subject John Jr., who had never set foot in America, possessed a three-quarter interest further complicated the issue. In sum, the rights of Pennsylvania's republican citizens locked horns with the Penns' chartered rights.

In examining Pennsylvania patriot reactions to the proprietary legacy, it is important to understand that stability, order, and continuity - whenever feasible under a republican framework - were core aspirations of revolutionary rule for both the radical and moderate factions, although each often interpreted the meaning of those elements differently. The tendency for continuity was best expressed in the post-constitution legislature's decision to grandfather in "each and every one of the laws or acts of general assembly that were in force and binding on the inhabitants on the fourteenth day of May last [1776]" with the exception of those measures which were "repugnant to, against or inconsistent with the constitution of this commonwealth." This seminal statute approved in a radical-controlled assembly no less - in effect transferred the body of English common law, as well as the bulk of colonial law, into the new legal system.

${ }^{23}$ Article VIII, Constitution of Pennsylvania, September 28, 1776, available online at the Yale Law School: http://avalon.law.yale.edu/18th_century/pa08.asp - accessed August 15, 2017. 
Unfavorably for the proprietors, the transfer omitted any law or act which "acknowledges any authority in the heirs or devisees of William Penn, Esquire, deceased, the former governor of the said province, or any other person whomsoever as governor." ${ }^{24}$ Legally speaking, the Penns in their multiple roles as proprietors and colonial governors including specifically John Penn Sr. - were among the "repugnant," despite his earlier incorporation as a sworn citizen.

Patriot discussion and activity concerning proprietary land holdings began even before passage of the Constitution of 1776. Early into his exile, John Allen relayed to Lady Juliana Penn that "a motion was indeed made in their convention, to seize upon the Quitrents and vacant lands, and to apply them to the support of their new government." The proposal was defeated, however, as "the Injustice was too glaring to pass even then. ${ }^{, 25}$ In the winter of 1776-77, the patriot army violated proprietary land rights when they cut down and distributed firewood to soldiers from the ungranted common areas in the capital city, a previously recognized Penn possession, without proprietary approval. Attorney James Tilghman protested to the revolutionary Council of Safety on behalf of John Penn. The debate intensified in the aftermath of the British withdrawal. In early 1779, Supreme Executive Council president Joseph Reed officially opened the legislative

\footnotetext{
${ }^{24}$ Statutes At Large of Pennsylvania, vol. 9, "An Act to Revive and Put in Force Such and So Much of the Late Laws of the Province of Pennsylvania As Is Judged Necessary To be in Force in This Commonwealth and [To] Revive and Establish the Courts of Justice and for Other Purposes Mentioned Therein," January 28, 1777, Chapter 737, 30-33. The acceptance of English common law in many colonies explains why celebrated British jurists like Sir William Blackstone retained such a high level of respect among Americans during and after the Revolution.

${ }^{25}$ John Allen to Lady Juliana Penn, April 2, 1777, Dreer Collection, Autographs: A, Box 1, Folder 16, HSP. We must take Allen at his word because official minutes do not mention the proprietorship or any other debate specifics, limiting references for September 5 to 28 when the measure was discussed to a generic "the house resumed the consideration of the frame of government." See "Minutes of the Proceedings of the Convention of the State of Pennsylvania," Journals of the House of Representatives of the Commonwealth of Pennsylvania, 75-96.
} 
debate on the future of proprietary holdings in a message to the Pennsylvania Assembly, urging that body to tackle the "nature and extent of the claims or estates of the late proprietaries, and their consistency with the interests and happiness of the people under the late revolution." ${ }^{26}$ John Penn hurriedly emerged from his seclusion, requesting time to appoint counsel to consider the matter in-depth. Through the assembly adjournment two months later, the issue of the proprietary estates came up nine times. After reading an opinion from the Chief Justice on March 30, the legislature decided to postpone discussion until the next session "in order that the members of the assembly may have an opportunity of consulting their constituents on so important a question.” Even radical representatives hesitated to embark on such a sweeping measure without popular sanction. In the interim, the assembly resolved that the proprietors "forbear to exercise any of those powers, which they have heretofore used" over proprietary lands and related finances. The Penns were put on hold. ${ }^{27}$

When the assembly reconvened in the late summer, President Reed again urged the people's delegates "to proceed in the great business of the Proprietary estates, at least so far as to give the next Assembly an opportunity to put the finishing hand to this important and necessary work." The House appointed a committee the following day to study the proprietary question in earnest. Less than two weeks later, legislators read the draft of a bill for the first time and proposed amendments. ${ }^{28}$ Debate was reaching a

\footnotetext{
${ }^{26}$ James Tilghman to Council of Safety, January 3, 1777, Society Miscellaneous Collection, HSP, cited in Treese, The Storm Gathering, 186; Journals of the House of Representatives of Pennsylvania, February 5, $1779,307$.

${ }^{27}$ Journals of the House of Representatives of PA, March 30, 1779, 350. Most of these interventions were procedural, although extensive hearings were held on March 22 and 23. See additional entries for February 26, March 9, March 11, March 18, March 24, March 25 and March 30, pages 323, 334-35, 339-342, 344.
} 
crescendo. Radicals then won a majority once again in the annual October elections and led the charge in the new assembly. ${ }^{29}$ Barely a month after convening on October 25 , Pennsylvania lawmakers reassigned the bulk of the Penns' lands to the state by a 40-7 vote in a sweeping divestiture ordinance entitled "An Act for Vesting the Estates of the

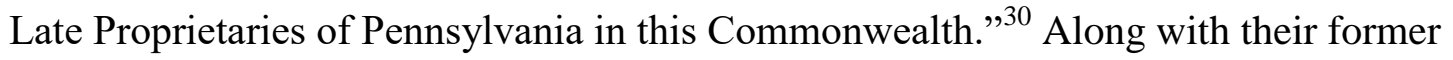
royal mandate to govern, Penn family control of the province's extensive land holdings had constituted the backbone of proprietary authority. The patriot radical faction then at the summit of its influence thus made sure new regulations put an end once and for all to whatever vestiges remained of that authority. There was no longer any doubt - the Penns were out for good.

The Divestment Act is an outstanding example of patriot reliance on rights and the rule of law as fundamental principles of the Revolution. In essence, the measure contained three central elements. It conveyed all unsold proprietary or "public" lands to the Commonwealth of Pennsylvania, as of the Declaration of Independence; allowed the Penn family to retain ownership of their private estates, as well as holdings known as the Proprietary Tenths or Manors which were surveyed as Penn property before July 4, 1776; and provided compensation to William Penn's heirs in the amount of $£ 130,000$ for the

\footnotetext{
${ }^{28}$ Joseph Reed, "To the Assembly concerning various matters of State policy and internal improvement," September 9, 1779, Pennsylvania Archives, $4^{\text {th }}$ Series, vol. 3, 734 ; Journals of the House of Representatives of Pennsylvania, September 10, 22 \& 23, 1779, 366, 372-373.

${ }^{29}$ The 5-man committee formed "for bringing in a bill for vesting the estate of the late proprietaries" on November 3, 1779 included leading radicals George Bryan and Charles Willson Peale. See Journals of the House of Representatives of Pennsylvania, November 3, 1779, 392.

${ }^{30}$ Statutes at Large of Pennsylvania, vol. 10, "An Act for Vesting the Estates of the Late Proprietaries of Pennsylvania in this Commonwealth," November 27, 1779, Chapter 874, 33-39. The vote count is in Journals of the House of Representatives of Pennsylvania, November 27, 1779, 403.
} 
forfeiture. ${ }^{31}$ Not surprisingly, the Penns believed the act to be patently unfair. Yet the comparative hindsight of both eighteenth-century conflagrations such as the French Revolution and nearly two hundred and fifty years of subsequent revolutionary turmoil around the world lends credence to the view that the terms of the seizure were rather benevolent. Given power dynamics and the political climate after the British evacuation, radical authorities could simply have declared the Penns to be the king's minions, impounded all their proprietary and private lands, and abandoned the Penns altogether. As the underlying notions in the Divestment Act reveal, however, revolutionaries consciously chose not to do so because of a desire to legally justify a righteous process of continuity - not unlike the justifications provided for the Protestant Reformation more than two centuries before.

Five critical assumptions inspired the resolutions and procedures enacted in the Divestment Act. The core idea of inherent rights suffused three of them. First and foremost, the citizenry's rights were supreme. The act's preamble left no doubt that "the safety and happiness of the people is the fundamental law of society." By republican extension, then, it was also "the right and duty of the representatives of the people to assume the direction and management of such interest and property as belongs to the community." A second postulate asserted that proprietary claims to the soil and its pecuniary derivatives such as quitrents were incompatible with popular sovereignty and "cannot longer consist with the safety, liberty and happiness of the good people of this commonwealth." A single individual or family had no right to such entitlements in a

\footnotetext{
${ }^{31}$ Statutes at Large of Pennsylvania, vol. 10, "An Act for Vesting the Estates of the Late Proprietaries of Pennsylvania in this Commonwealth," Section I (Section V, P.L.), 34-35; Section IV (Section VIII, P.L.), 36; Section VIII (Section XIII, P.L.), 37.
} 
republic. The state legislature therefore settled the issue of conflicting rights in favor of the citizenry. Nonetheless, a third implicit premise argued that citizens' rights must also apply to the Penns. Radical patriots thus validated the proprietors' personal estates, the Proprietary Tenths or Manors, and all financial benefits stemming from these. And since John Penn Sr. was a citizen in good standing, the family had a right to financial compensation for its losses. These were defined in the amount of $£ 130,000$ paid in installments to begin one year after the conclusion of the war with Great Britain. ${ }^{32}$

Concepts of continuity and the rule of law grounded the other two key assumptions for both ideological and pragmatic reasons. As a matter of principle, the act extolled the historical connection with the colony's founder and accepted his successors as appropriate bearers of that legacy. Legislators understood that "the rights of property and powers of government thereby vested in the said William Penn and his heirs were stipulated to be used and enjoyed as well for the benefit of the settlers as for his own particular emolument." They approved compensation not only in "remembrance of the enterprising spirit which distinguished the founder of Pennsylvania" but also because the freemen of the commonwealth were "mindful of the expectations and dependence of his descendants on the propriety thereof... which will be wholly defeated and the parties exposed to great disappointment and loss if no provision is made therein." Unlike the Quaker-Presbyterian friction of the colonial era, radicals allowed that historical bonds with Quakers now went hand in hand with republican principles. Yet legal continuity had practical ramifications that had to be weighed in light of republican theory. Uncontested legal title to land was critical for revolutionaries in an agricultural society with an

${ }^{32}$ Statutes at Large of Pennsylvania, vol. 10, Preamble (Section II, P.L.), 34; Section IV (Section VIII, P.L.), 36; Section VIII (Section XIV, P.L.), 38. 
expanding frontier. The act thus ratified the legitimacy of all prior transactions between proprietors and settlers: "all and every the rights, titles, estates, claims and demands which were granted by or derived from the said proprietaries... shall be and they are hereby confirmed, ratified and established forever." Pennsylvanians could rest assured that revolutionary law secured their property rights and the opportunity to prosper. ${ }^{33}$

For the Penns, the conclusion of the opening phase of reintegration stripped them of all political power and most property. As the only family member who could claim uncontestable citizenship, divestment permanently fixed John Penn Sr.'s status as a republican commoner, albeit a potentially affluent one if authorities fulfilled the postwar terms of the confiscatory act. Despite ousting the former regime, patriots as a collective body did not display any sense of vindictiveness in their anti-proprietary posture, only an ambition to establish egalitarian conditions for a functional republican order. The family's subsequent reintegrative ride substantiates this view.

\section{THE PENNS’ QUEST FOR COMPENSATION}

Radicals justified the anti-proprietary coup as a defense of citizen rights. By carving into law compensation and retention of a portion of the Penns' vast assets, revolutionaries believed they had also honored and consolidated that family's legitimate rights. The Penns had other ideas. From divestiture forward, they avoided politics and the public sphere except when proprietary affairs came to the forefront. Two of the family tackled reintegration, approaching that prospect as both uniquely favored ex-proprietors and private individuals. During this time, John Penn Jr. came of age in England. Holding a majority three-quarter share, he assumed an increasingly prominent role and eventually

${ }^{33}$ Statutes at Large of Pennsylvania, vol. 10, Section VII (Section XII, P.L.), 37; Section III (Section VII, P.L.), 35-36. 
supplanted his mother Lady Juliana Penn in that branch's proprietary pursuits. As the war wound down, John Jr. traveled for the first time to the faraway province his ancestors had acquired from the king. The rise to power of a more moderate political faction in Pennsylvania animated the journey. According to Lady Juliana's son-in-law and proprietary partner William Baker, the Penns in London held "the most sanguine Expectations" that the end of the war and a more friendly state government provided an exceptional opportunity to reopen "the Proceedings by which the Property of the Family has been so deeply affected. ${ }^{34}$ John Jr. arrived in America in the autumn of 1783 for what would turn out to be a five-year sojourn.

Meanwhile, from his retreat at Lansdown citizen John Penn Sr. resumed his post as the family point person. The once banished governor led a secluded life while keeping an eye on entreaties from state authorities which could impact an eventual financial settlement. Of particular note were the whereabouts of missing Land Office records from the colonial era. Various exchanges between the Pennsylvania government and John Sr. or his representatives began in 1780 , the requisite documents finding their way to officials in due time. ${ }^{35}$ Since John Penn Sr. maintained a low profile, it comes as no surprise that mundane incidents dominate the sources for the duration of the war. For example, in the late summer of 1780 wife Anne Allen Penn inquired of Dr. Parke if her ill-disposed husband should "continue taking the Bark... [and] whether he may eat grapes, without the skins, or watermelon." Later, John Sr. reciprocated with an invitation:

\footnotetext{
${ }^{34}$ William Baker to James Hamilton, January 13, 1783, in Treese, The Storm Gathering, 195.

${ }^{35}$ See Pennsylvania Archives, First Series, vol. 8, "Pres. Reed to Edmund Physic," February 19, 1780, 113; “Joseph Shippen, Jr. to Pres. Reed,” April 20, 1780, 200. Pennsylvania Archives, First Series, vol. 9, "Order on Secretary Matlack for Books and Papers," May 7, 1781, 202. Supreme Executive Council Minutes in Colonial Records, vol.12, April 21, 1780, 326. Colonial Records, vol.13, November 8, 1782, 418; November 11, 1782, 420; November 25, 1782, 437; and January 3, 1783, 462-471.
} 
"the company of Doctor Parke is requested at dinner at Lansdown on Sunday next." In 1783, the Supreme Executive Council granted "John Penn, Mrs. Penn, and their attendants" passports for a visit to British-occupied New York, possibly in anticipation of John Penn Jr.'s arrival. ${ }^{36}$ Tracking down papers, illness, Sunday dinners, travel - these were the stuff of a five-year lull.

Richard Penn - governor from 1771 to 1773 and erstwhile bearer of the Olive Branch Petition to George III in 1775 - never returned to Pennsylvania. As a non-resident and younger brother of John Sr., Richard collaborated with his relations but took a back seat from afar in efforts to protect proprietary interests. The proprietary question surfaced not only in America but also in England. In the spring of 1776, Richard dined with an American visitor in London, expressing a hope that Hessian recruits in the British army "might all be persuaded to join the Germans already in Pensylvania [sic], and so the back parts of that Province be filled \& settled with People.” Many later did, but as escaped war prisoners of the patriots, not as royal settlers. ${ }^{37}$ After Yorktown but before the definitive peace, Lady Juliana received an inquiry asking if "the two Beaver Skins would be wanted as heretofore to present at Windsor on New Years Day" as part of the Penns' traditional quitrent to the king. ${ }^{38}$ It was a reasonable query - the family still retained the

\footnotetext{
${ }^{36}$ Anne Penn to Dr. Parke, August 27, 1780, Etting Collection, Early Quakers, Box 54 (Old 37), Folder 18, HSP; John Penn Sr. to Dr. Parke, Friday Evening, no specific date, 1781, Etting, Folder 19, HSP; Colonial Records, vol. 13, April 17, 1783, 561.

${ }^{37}$ Serle, Tuesday, December 17, 1776, American Journal, 160. For German prisoner escapees during the war in the German-speaking regions of Pennsylvania, see Ken Miller, Dangerous Guests: Enemy Captives and Revolutionary Communities during the War for Independence (Ithaca: Cornell University Press, 2014), 164, 171-72, 179-180.

${ }^{38}$ Samuel West to Lady Juliana Penn, December 26, 1782, in Treese, The Storm Gathering, 195. The 1681 charter established as compensation for the king's territorial grant the following conditions: "Yielding and paying therefore to Ifs, Our heires and Successors, Two Beaver Skins, to bee delivered at Our said Castle of Windsor on the First Day of January in every Year; and also the Fifth Part of all Gold and Silver Oare,
} 
Proprietary Manors or Tenths. Peace finally arrived in 1783. Renewed Penn incursions into the public sphere ensued as the family dedicated the decade of the 1780s to seeking financial redress for their losses. They pressed their cause along three paths. First, collect the $£ 130,000$ due them from the commonwealth as per the Divestment Act. Second, reopen discussion of the compensation issue among Pennsylvania legislators with an eye towards increased reparations. And third, seek additional restitution from the British Parliament. It appears they also initially considered but discarded a fourth route requesting repeal of the Divestment Act itself. The Penns would encounter success in two of the three endeavors they pursued.

As an unpublished internal draft of John Penn Sr.'s thoughts on the proprietary issue exposes, the Penns contemplated an option to seek repeal of the Divestment Act after the general public learned of the signing of the Preliminary Treaty of Peace but before ratification of the Definitive Treaty ending the war. ${ }^{39}$ The fifteen-page handwritten manuscript provides extraordinary insight into the family's state of mind at this critical juncture. It began with a summary of the Penns' established rights under the royal charter: the right to appoint governors, name a provincial council, veto or approve assembly laws, appoint provincial officers, remedy debts, and the right of "Pre-emption from the Natives in all Lands," all of which were "entirely taken away by the late Revolution." It went on to delineate the family's property grants: all "Vacant Lands

which shall from Time to Time happen to bee found within the Limitts aforesaid, cleare of all Charges." Charter for the Province of Pennsylvania - 1681 in The Avalon Project, Yale Law School, available at http://avalon.law.yale.edu/17th_century/pa01.asp, accessed September 23, 2017.

\footnotetext{
${ }^{39}$ American and British negotiators agreed to the Preliminary Articles of Peace on November 30, 1782. The Definitive Treaty of Peace, also known as the second Treaty of Paris, was signed on September 3, 1783. Congress ratified the treaty on January 14, 1784, and the British Parliament followed on April 9, 1784. See The Avalon Project, Yale Law School - http://avalon.law.yale.edu/subject_menus/18th.asp
} 
throughout the Province," the Manors or Tenths which reserved 10,000 of every 100,000 acres to the proprietorship, purchase moneys mortgaged for surveying and patenting settler lands, quitrents for both vacant and manor lands, manor tenths on city or town lots, and private lots or tracts the Penns' purchased over the years. The memo then listed the Penns' losses as a result of the assembly's divestment: all vacant lands, all Manor or Tenths lands not surveyed before July 4, 1776, quitrents and arrears on both of these, and purchase monies and arrears not within the retained Manors or Tenths. The draft included a summary of the properties the family retained - the Manors or Tenths surveyed before July 4, 1776, purchase monies due for Manor lands sold to settlers, quitrents from Manor lands, and "private Estates, Lands \& Hereditaments" - and cited the $£ 130,000$ in legislated compensation. ${ }^{40}$

In a lengthy closing analysis, Penn refuted patriot motives as elucidated in the Divestment Act preamble, admonishing that the assembly's "conclusion does not follow very Logically from the Premises," for legislators had failed to show that the proprietaries "had either abetted Great Britain in this War" or that "they had not borne their Proportion of the Burthens... in the Prosecution of the War." Moreover, justifications for patriot measures "cannot be ascribed to their [the Penns'] misconduct" because the state had proceeded "without any crime alledged [sic]." He therefore deduced that "State Necessity is then the only Plea for these Proceedings.” The former governor ended by placing his revived hopes on the peace treaty's recommendations to Congress asking the individual states to revisit property confiscations during the war, which led him to optimistically

\footnotetext{
${ }^{40}$ John Penn Sr., "Rights and Property of Penn Family," Penn Family Papers, Series II, Box NB-041, Folder 18, 1-4, HSP.
} 
avow that "this business will be reviewed and the Act repealed." 41 This optimism did not last. The Penns tossed out the repeal option when it became clear that Pennsylvania and the other states had no intention of embracing Congress' recommendations on forfeited properties. $^{42}$ Instead, the arguments elaborated in John Penn's draft would later be applied in the family's appeals for a more adequate compensation settlement.

Even minus repeal, the provisions in the Divestment Act seemed to comprise the low-hanging fruit on the Penn restitution agenda. Yet gathering that bounty did not prove to be a simple task. According to the original statute's postwar clause, already authorized compensation installments could have begun after September 1784, one year after the signing of the Treaty of Peace. A temporarily reconstituted radical majority in the General Assembly, however, delayed payment until the legislature could pass a new ordinance approving the initial disbursement of $£ 15,000 .{ }^{43}$ Judging from subsequent lawmaking activity, the problem may have been budgetary as well as political. A month later the assembly approved a lengthy ordinance targeting funds for the yearly interest

\footnotetext{
${ }^{41}$ John Penn Sr., "Rights and Property of Penn Family," Penn Family Papers, Series II, Box NB-041, Folder 18, 5-15, HSP.

${ }^{42}$ British negotiators pushed hard for a full restoration of loyalist property in the 1783 peace treaty. American diplomats argued that Congress had no authority to obligate individual states to restore property and that such a stipulation was therefore unenforceable. With neither side budging and the real possibility that peace negotiations could collapse, the face-saving "recommendation" allowed the British to declare they had not abandoned their loyal followers, while simultaneously permitting the Americans to make the final decision on the loyalist property question. None of the thirteen states obeyed the recommendation. The loyalist factor in the negotiations is explained in detail in Richard B. Morris, The Peace-Makers, especially Chapter 15 entitled "Setting Metes and Bounds," 341-385.

${ }^{43}$ Patriot radicals made a fleeting comeback in the 1784 elections after several years of defeats against patriot moderates. See Brunhouse, The Counter-Revolution in Pennsylvania, 156-184. For the legislation, see Statutes at Large of Pennsylvania, vol. 11, "An Act to Authorize and Direct the Immediate Payment of the Sum of Fifteen Thousand Pounds Sterling to the Devisees and Legatees of Thomas Penn and Richard Penn and to the Widow and Relict of the Said Thomas Penn, Being the First Yearly Payment Directed to be Paid to Them by an Act of Assembly of this Commonwealth, Entitled 'An Act for Vesting the Estate of the Late Proprietaries of Pennsylvania in the Commonwealth," February 10, 1785, Chapter 1130, 42-426.
} 
due to the national confederation government as well as the $£ 130,000$ proprietary debt. ${ }^{44}$ The Supreme Executive Council, charged with implementing divestment, called on the Penns to appear before them and formally submit their claims, while launching an inquiry into the legitimacy of the proprietors' rights. Following a detailed review of the Penn documentation by the Pennsylvania Supreme Court, radical judges Thomas McKean and George Bryan reported "that the vouchers support the said Claims as stated." 45 While soliciting their first installment in January of 1786, questions arose regarding retroactive interest payments due to the proprietors, one of many tangential issues to follow. In 1787 , a moderate-dominant legislature settled the matter, passing a new law authorizing interest outlays and setting more viable procedures for disbursement of future installments. ${ }^{46}$

The collection ordeal continued through 1794. By 1790, the state government under the soon-to-be-repealed Constitution of 1776 had completed five of the six major installments and authorized a sixth disbursement of $£ 25,812.10 .^{47}$ The revamped

\footnotetext{
${ }^{44}$ Statutes at Large of Pennsylvania, vol. 11, "An Act for Furnishing the Quota of this State Towards Paying the Annual Interest of the Debts of the United States and for Finding and Paying the Interest of the Public Debts of this State," March 16, 1785, Chapter 1137, 454-486.

${ }^{45}$ Colonial Records, vol. 14, April 2, 1785, 396-398; Colonial Records, vol. 14, July 18, 1785, 502; "Claims of Messrs. Penn, and Opinion of the Judges," August 3, 1785, Pennsylvania Archives, First Series, vol. 10, 485-488. The formal investigation that followed was part of the process delineated in the original Divestment Act - see Section VIII (Section XIII P.L.) which stipulated that compensation was to "be paid out of the treasury of this state... in such proportions as shall hereafter by the legislature be deemed equitable and just upon a full investigation," 37-38.

${ }^{46}$ For the initial requests of the Penns' representatives, see Colonial Records, vol. 14, January 12, 1786, 622 \& January 16, 1786, 623; and “C. J. McKean to Pres. Franklin," January 24, 1786, Pennsylvania Archives, First Series, Vol. 10, 79. For the new legislation, Statutes at Large of Pennsylvania, vol. 12, "An Act to Make Effectual Provision for the Payment of One Hundred and Thirty Thousand Pounds Sterling Granted to the Late Proprietaries of Pennsylvania by an Act, Entitled 'An Act for Vesting the Estates of the Late Proprietaries of Pennsylvania in this Commonwealth,' and for Allowing Interest on the Several Installments Thereof from the Times They Have Fallen and Shall Fall until Actual Payment Thereof," March 28, 1787, Chapter 1284, 431-435.
} 
government under the new Constitution of 1790 may have felt the need to introduce its own procedures, for the assembly approved legislation in 1791 reauthorizing interest payments and setting the date of September $3^{\text {rd }}$ for both 1791 and 1792 to settle "the two last installments" with accrued interest. ${ }^{48}$ A final sticking point concerned back taxes on proprietary quitrents, for which the state comptroller-general had deducted $£ 7,249.2 .10$ from the final installment until the government could rule on the issue. The legislature under moderate control resolved the dispute in favor of the proprietaries. ${ }^{49}$

Along with inaugural overtures to collect their lawful recompense from the Divestment Act, the Penns simultaneously pursued a reopening and renegotiation of the entire compensation issue in the immediate aftermath of the war. Cousins John Sr. and John Jr. joined hands in America with an absentee Richard Penn to present a memorial in early 1784 to the state assembly arguing three fundamental points. They were patriotic and "willing to make any necessary Sacrifice of their own private Rights to the Happiness of the whole People." Moreover, they "would have been contented to wave [sic] their hereditary Rights of Government for the peoples good" much earlier if an arrangement could have been "secured by the same charter, under which the Soil is held and the Country had flourished for near an hundred years." The language set pliable distinctions between lost political power and property.

\footnotetext{
${ }^{47}$ See Colonial Records, vol. 15, May, 8, 1787, 211; ibid., June 25, 1787, 233; ibid., December 28, 1789, 634; ibid., January 26, 1789, 651; ibid., January 30, 1789, 653. Colonial Records, vol. 16, February 13, 1789, 5; ibid., March 20, 1789, 33; ibid., March 11, 1790, 300; ibid., March 20, 1790, 306.

${ }^{48}$ Statutes at Large of Pennsylvania, vol. 14, "An Act Making Provision for the Discharge of the Legislative Grants to the Late Proprietaries of Pennsylvania," April 9, 1791, Chapter 1562, 81-85. The reference to "the last two installments" when the fifth of six had supposedly been paid suggests that, in order to meet the full amount, the state allotted the Penns more than the six installments initially targeted.

49 Statutes at Large of Pennsylvania, vol. 15, “An Act to Exonerate the Late Proprietaries from the Payment of Certain Taxes, and to Authorize the State Treasurer to Pay Them Such Moneys as Have Been Retained by Him on Account Thereof," April 3, 1794, Chapter 1727, 26-28.
} 
Yet despite proprietary goodwill, the state's actions had ruined them. They had "born [sic] the Overthrow of their Government, the Sequestration of their Estates, and almost total Wreck of their better Fortunes." While others benefitted from the Revolution, their family had been "left in a State of unparalleled Distress and Uncertainty respecting every Thing on which they and their Posterity are to depend." Consequently, they now sought "a Compromise and final Settlement upon the prior Principles of Justice and Equity." If it was therefore "judged necessary and reconciliable [sic] to Justice" that a historic right to their chartered property "should stand dissolved," they now questioned "whether the Compensation proposed bears any adequate Proportion to the Value of the Property taken for the Use of the State. ${ }^{, 50}$ In short, the Penns were willing to concede the irreversible loss of power and real property but the state needed to make amends for their sacrifice with a more satisfactory compensation package.

Despite the optimism generated by the advent of moderate government, the crusade for more revenue stalled. The petition never garnered the support of either patriot faction. As early as 1784, John Penn Jr. noted "the treatment of our memorial; from the abuse of one party, by which, tho robb'd, we were almost branded as thieves, $\&$ the others' apparent desertion, in their answer." A year later he added that "we did not petition the assembly, for which there were many arguments. ${ }^{.51}$ The delay continued until the ex-proprietors finally submitted another request three years later, hoping that the "weighty matters" presented in the earlier memorial "may now be taken up for a final

\footnotetext{
${ }^{50}$ John Penn Jr., John Penn Sr. and Richard Penn, "To the Honorable the Representatives of the Freemen of the Commonwealth of Pennsylvania in General Assembly met," March 17, 1784, Wilson Manuscripts, Collection 721, Vol. 10, Box 7, Folder 6, HSP.

${ }^{51}$ John Penn Jr. Commonplace Book, Penn Family Papers, Collection 485A, III. Penn Family Members, vol. NV-129, 35-36. The party of abuse was likely the radicals and the deserters probably the moderates.
} 
consideration and discussion" towards "an amicable and final settlement" so that the family "may not remain longer in that state of uncertainty and distress." The House heard a reading of both the new letter and the earlier memorial but the matter was "ordered to lie on the table." ${ }^{, 52}$ And there it would remain. Handling of the divestment issue shows that, once the patriot government resolved the conflict between the rights of the citizenry and the proprietorship, the Commonwealth of Pennsylvania applied a principled concern for the rights of founder William Penn's heirs etched into the law from beginning to end. But this principled concern had limits which obeyed republican priorities driven by political and economic realities. Although the Penns never received what they interpreted as their just due, they were heard and granted due process at every step of the way. Given the tone of the written exchanges, relations between authorities and former proprietors were always publicly respectful and perhaps even cordial. The relatively amicable climate contributed to the personal reintegration decisions of both John Sr. and Jr.

The Penns followed the money. When it became clear that $£ 130,000$ was all the compensation to be had in America, the onetime proprietors decided to solicit damages from Parliament's Royal Claims Commission. Cousins John Sr. and John Jr. embarked for England with that purpose in mind in the spring of 1788. By then, royal officials investigating loyalist losses had been on the job for nearly a half decade, well on the way to concluding their task. It is likely that the Penns postponed submitting a British claim as long as possible because they sustained hopes that Pennsylvania would respond favorably to the request for further restitution. This explains the underlying tone of urgency in their 1787 appeal to the Pennsylvania legislature: "it becomes everyday more necessary that

\footnotetext{
52 “A letter from the Honorable John Penn, junior, John Penn and Richard Penn," March 16, 1787, Etting Collection, Early Quakers, Box 54 (Old 37), Folder 20, HSP.
} 
there should be an arrangement and settlement of affairs..." ${ }^{53}$ Aware of the royal commission's approaching expiration, the Penns made a strategic decision to abandon the Pennsylvania effort and concentrate on England. In strict financial terms, they judged properly. The English received them with open arms. Whereas a dubious indifference to the patriot cause had served as an obstacle in America, royalists viewed such behavior in a much more favorable light.

This study is not the place to develop the details of the extensive case the Penns put before Parliament, as these specifics have little bearing on citizen rights or the rule of law in Pennsylvania or on the reintegration experiences of the protagonists other than to furnish the family with substantial wealth. Suffice it to say that John Penn Sr. claimed a loss of income as governor, Richard Penn a loss of income as an appointed naval officer for the Port of Philadelphia and the destruction of his wife's property by British troops during the city's occupation, and that the two brothers joined widow Lady Juliana Penn and her son John Jr. in a massive $£ 944,000$ claim for the forfeiture of $21,592,127$ acres of land. Sympathetic commissioners granted the ex-proprietors an annuity of $£ 4,000$ per annum, three-quarters of which went to the John Penn Jr. lineage and one-quarter to the John Penn Sr. branch, and a massive payout of $£ 500,000$ for their expropriated properties. The latter was by far the largest settlement the commissioners authorized, representing by itself almost one-sixth of the $£ 3,292,455$ of total loyalist compensation cited in the commission's report. ${ }^{54}$ Yet it appears the amount did not entirely satisfy the Penns. "I

\footnotetext{
53 "A letter from the Honorable John Penn, junior, John Penn and Richard Penn," March 16, 1787, Etting Collection, Early Quakers, Box 54 (Old 37), Folder 20, HSP (emphasis mine).

${ }^{54}$ The loss of income and the extent of the Penns' claimed acreage are in Coldham, American Migrations, 479-480. The RCC's annuity and payout is in Eardley-Wilmot, Historical View of the Commission, 87, 92,
} 
understand the family have fallen short of their expectations from Parliament," observed James Tilghman. As a former attorney for John Penn Sr., he was privy to comments circulating in elite social circles in America. ${ }^{55}$ Notwithstanding inflated expectations or personal sentiment, the Penns' English excursion had proven quite rewarding.

\section{REINTEGRATIVE TRAJECTORIES}

By swearing allegiance and securing his rights as a Pennsylvania citizen, John Penn Sr. provided the Pennsylvania government a justification for codifying into law the preservation of a portion of the family's property holdings. The rights of citizens and the rule of law thus set the stage for the personal reintegration experiences of the three Penns with an enduring interest in the proprietorship. Each chose a distinct path. John Penn Sr. decided he was a Pennsylvanian. John Penn Jr. toyed with the novelty of republican America but ultimately elected to remain a British subject. And to judge from later activities and his decision to not ever alight again on the former colony's shores, Richard Penn took note of Pennsylvania solely when his personal interests were at stake.

Of the three, Richard Penn's reintegration path was the most consistent. Periodic manifestations of resentment against his older brother, John Sr., certainly influenced his behavior and decisions. They had a history. Following his father's death in 1771, Richard staked a personal legal claim to the reserved lots and manors of the proprietary legacy during his stint as governor on the shaky advice of interested counsel. This maneuver infuriated principal proprietor Thomas Penn and upset his older brother John Sr., who

\footnotetext{
188, 192, 196. The last compensation report is in Appendix IX, 199. The next largest award was for $£ 210,000$ to the trustees of the proprietors in Maryland.

55 “James Tilghman to Col. Shippen, at Plumley, Chester County," September 2, 1790, Balch, ed., Letters and Papers Relating Chiefly to the Provincial History of Pennsylvania, 293-294.
} 
pressed Richard to reverse his conduct. Uncle Thomas demanded withdrawal of the legal claim, which proved unfounded, and then in 1773 replaced Richard as governor with his brother ${ }^{56}$ Richard took umbrage and did not speak to John for some time. James Allen observed in his contemporary diary that John had arrived from England "to supersede his Brother," a move "it is thought, will lay the foundation of a lasting animosity between the brothers." Two weeks later Allen noted that the two "at Club" had "met for the first time since his [John's] arrival, but they took no notice of each other." Lorenzo Sabine recounts a similar incident: "Mr. Bob Morris, the head man at the merchant's feast, placed Governor [John] Penn on his right hand, and his brother, the late Governor, on his left hand, but not a word passed." Though the two momentarily patched up differences when Governor John offered his slighted sibling the profitable sinecure of port naval officer at Philadelphia and their respective wives interceded, tensions between them invariably simmered beneath the surface. ${ }^{57}$ Being forced to play second fiddle to John in the proprietary inheritance no doubt played a significant role in nourishing this friction.

Richard, however, had been a popular governor and patriots considered him an ally of the early revolutionary cause. Caesar Rodney wrote to Thomas Rodney on September 24, 1774 from Philadelphia that "Mr. R. Penn is a great friend to liberty, and has treated the gentlemen Delegates with the greatest respect. More or less of them dine with him every day." He was also a guest of George Washington. It is no surprise, then, that these same delegates placed their trust in Richard Penn to deliver the sensitive Olive

\footnotetext{
${ }^{56}$ Richard Penn's impulsive land grab is covered in Treese, The Storm Gathering, 116-121.

57 “James Allen Diary," August 23 \& September 8, 1773, PMHB, vol. 9, no. 2 (July 1885), 181; Chief Justice Shippen to Colonel Burd in Sabine, Biographical Sketches, vol. 2, 164. The brotherly spat is detailed in Treese, The Storm Gathering, 142-143.
} 
Branch Petition to King George III on his 1775 voyage to England. Nevertheless, Richard evidently came to the conclusion that there was little for him in Pennsylvania. By his marriage to Philadelphian Mary Masters in 1772 he had accrued portable assets. Before embarking with his wife, sister-in-law, and mother-in-law, he confessed to Lady Juliana that "the Happy and advantageous Marriage I have contracted in this country enables me to live like a gentleman in England.. 58

The parting proved permanent. Thus, reintegration as a transatlantic homecoming did not seriously factor into Richard Penn's later calculations. Instead, over the years he limited his involvement to proprietary issues which could benefit him directly. He visited Paris in 1782 as American independence loomed on the horizon and reestablished contact with Congress' envoy to France, old family nemesis Benjamin Franklin. Through his agent Tench Francis Jr., he co-signed the Penns' memorial to the Pennsylvania assembly requesting renegotiation of divestment compensation. Later in the decade, he became embroiled in a dispute with land speculator Samuel Wallis over ownership of tracts in the Susquehanna region and also lent his cooperation from afar to his brother and cousin who led the charge when questions arose on title to commonly held Pennsylvania properties. After his brother died in 1795, Richard sued John's wife Anne over proprietary funds John had agreed to pay him from compensation sources. He lost that lawsuit in $1800 .{ }^{59}$

\footnotetext{
${ }^{58}$ Sabine, Biographical Sketches, vol. 2, 164; Richard Penn to Lady Juliana Penn, May 10, 1775, Penn Papers, Personal Correspondence V, cited in Treese, The Storm Gathering, 145.

${ }^{59}$ Treese, The Storm Gathering, 194, 199-200; Treese argues that a failing financial situation motivated Richard's lawsuit against Anne. John Penn Jr., John Penn Sr. and Richard Penn, "To the Honorable the Representatives of the Freemen of the Commonwealth of Pennsylvania in General Assembly met," March 17, 1784, Wilson Manuscripts, Collection 721, Vol. 10, Box 7, Folder 6, HSP. "Notes on Arbitration, 1787: Richard Penn vs. Samuel Wallis," Dreer Collection, Box 21, Folder 31, HSP. As examples of title issues concerning Penn city lots in Philadelphia from 1786 to 1788, see Colonial Records, vol. 15, 63, 68, 430-
} 
Despite ancestral ties to the colony he had governed, Richard Penn chose British subjecthood over allegiance to Pennsylvania. He died in England in 1811 at the age of seventy-six, having twice resided in the colony his grandfather founded for a combined total of ten years. ${ }^{60}$ Given his brother's and cousin's experiences, Pennsylvania would most likely have welcomed back Richard Penn but he never pursued the citizenship the state could have conferred, opting instead for the life of the English gentry. Moreover, the benefits he derived from patriot adherence to the supremacy of the law as aired in the divestment settlement were mostly the product of his brother's accomplishments rather than his own. In the end, he turned down the potential rights of citizenship which revolutionary law had set for him in America.

Initially, John Penn Jr. took a diametrically opposite route. At twenty-three-yearsold, he arrived in Pennsylvania for the first time in 1783 open to the opportunities that his coming of age, a new land, a concluding war, and the expectations of the peace treaty on the issue of confiscated property offered. The main Penn heir found Pennsylvania to his liking. While his primary mission was to procure added compensation from divestiture, he explored the prospect of permanent residence. At first, John Jr. missed the motherland. "I felt indeed, the accustomed 'amor patriae,' \& admiration of England," he confessed. But "sometimes a republican enthusiasm, which attached me to America, \& almost tempted me to stay" surfaced. This burst of egalitarian zeal was short-lived, however, as he did not receive criticism of the family's memorial to the Pennsylvania legislature well.

431,439-440, 477-478 \& 554; issues regarding the Manor of Springetsbury during 1787-1788 can be found in the same volume, $153 \& 541-542$.

${ }^{60}$ Richard Penn first arrived in Pennsylvania in 1763 at the age of twenty-eight. He remained there until 1769, went back to England for two years, and then returned as newly appointed governor in 1771. Though he was replaced as governor in 1773, he stayed in Pennsylvania until his final "Olive Branch" return to England in 1775. See family chronology in Appendix B, Treese, The Storm Gathering, 207-212. 
"I may date my becoming wholly an Englishman from the breaking [up of the] assembly, $\&$ publication of its minutes" in 1784 , whereby the proprietors bore the wrath of historic enemies and the abandonment of purported allies. ${ }^{61}$ Explicably, he never took the patriot oath of allegiance.

The youngest Penn's stay in Pennsylvania lasted five years. He built himself a stylish home on the banks of the Schuylkill which he christened "Solitude,"62 traveled extensively throughout the province, reconnoitered the proprietary Manors and inherited holdings, and developed favorable relations with revolutionaries and republicans. On a protracted journey through Pennsylvania in 1788, prominent patriots received him with pleasure. In the countryside outside Philadelphia, John Jr. called on Frederick Augustus Muhlenberg, Pennsylvania house speaker from 1780 to 1783 and subsequently first speaker of the U.S. House of Representatives. Daniel Clymer and "Mr. Biddle" escorted him on a tour of surrounding farms and later dined with him. Near Reading, General Mifflin "with agreeable frankness \& affability... received us in a neat farm-house.” On the Susquehanna, he met Mr. Harris - "owner and founder of this town" which later became Harrisburg, the state capital. Near Carlisle, he met revolutionary officers General Armstrong and Colonel Magaw. Although entertained cordially, John Jr.'s trips also increasingly highlighted aspects of American life that he did not like. On a manor plot near Reading, he encountered "fertile vallies [sic] \& low places which were all settled by encroachers." In a conversation with a tavern-keeper, he lamented "how qualified respect is in this democratical country." On an excursion through Delaware, he witnessed a

\footnotetext{
${ }^{61}$ John Penn Jr. Commonplace Book, Penn Family Papers, Collection 485A, III. Penn Family Members, vol. NV-129, 35.

${ }^{62}$ Today the "Solitude" mansion is within the confines of the Philadelphia Zoo.
} 
squabble between "two rustics completely drunk." These were not the proper English ways in which he had been raised among those of his class. ${ }^{63}$

Proprietary business before the Royal Claims Commission served as the pretext for John Penn Jr.'s departure for England in 1788. As the male heir with a controlling proprietary interest, the parliamentary commission granted him the lion's share of the family's successful claim, consolidating his financial position. John decided to settle permanently at Stoke and resumed gentry life. It does not appear he ever returned to Pennsylvania. Over the years, he held several government positions - High Sheriff of Buckinghamshire in 1798, member of Parliament for Helston in 1802-1803, Governor of Portland Castle in the county of Dorset for 1805, and Captain of the Portland Island Legion from 1804-1807 at the height of the Napoleonic Wars. In homage to his ancestral grounds, he built Pennsylvania Castle on Portland Island. Although he founded the Outinian Society in 1818 as a "matrimonial society intended to improve the domestic life of married persons," John Jr. never married. ${ }^{64}$ He participated actively in contemporary

\footnotetext{
${ }^{63}$ John Penn Jr. Commonplace Book, Penn Family Papers, Collection 485A, III. Penn Family Members, vol. NV-129, 40-42, 44. Daniel Clymer was the purchaser of the John Roberts property, a Lieutenant Colonel in the Pennsylvania militia, Deputy Commissary-General of Prisoners, and a state representative. Mr. Biddle could have been any of a number of relations of Edward Biddle who served in the Pennsylvania Assembly and on various patriot committees in the early years of the Revolution; he was later a delegate to the Congress and died in 1799. Thomas Mifflin was Quartermaster General in the Continental Army, state representative, delegate to Congress, President of the Supreme Executive Council from 1788 to 1790, and Governor of Pennsylvania for much of the 1790s. John Armstrong served on the colonial assembly, was Brigadier General in the Continental Army, a general in the Pennsylvania militia, a delegate to Congress, and a state justice of the peace. Robert Magaw was colonel of Pennsylvania regiments in the Continental Army, most noted for his participation in the battle for New York in 1776. The data on Biddle and Armstrong is from Horle, Foster, and Wolfe, eds., Lawmaking and Legislators in Pennsylvania, vol. 3, Allen-Kirkbride (Harrisburg, 2005), 281-297, 337-351. The information on Mifflin and Magaw is from L. Edward Purcell, ed., Who Was Who in the American Revolution (New York: Facts on File, 1993), 312-313, 327-328. The Clymer biography is taken from The Reading Times, June 13, 1884, as transcribed at https://www.findagrave.com/cgi-bin/fg.cgi?page=gr\&GRid=47242557 accessed September 29, 2017.

64 “John Penn (PN776J)," A Cambridge Alumni Database, University of Cambridge, available online at http://venn.lib.cam.ac.uk last accessed September 29, 2017. The society was founded "in the hundredth
} 
political debate, publishing his views on sundry issues in 1800 . He also fancied himself a man of letters. In 1796 John Penn Jr. composed a series of essays entitled Letters on the Drama discussing drama in Athens, England, and France, along with refined subjects such as "poetical Probability," "the Unities," differences between "minute and delicate Taste," and "the Material of Imitation." That same year he dedicated to William Pitt an original play touting the origins of English freedom in the era of Alfred the Great. ${ }^{65} \mathrm{He}$ died at Stoke Park in 1834.

Unlike his cousin Richard, John Penn Jr. experimented with the real possibility of a permanent home in Pennsylvania. Since he had been raised in Great Britain and did not visit America until 1783, his was more a case of post-revolutionary integration than reintegration. Upon his return to England, however, that distinction became a moot point. Of the three Penn males of the revolutionary period, he was the one most visibly faithful to his English roots, the product of an eyewitness empirical comparison between the relative advantages of the two nations. Perhaps it could not have been any other way, given his upbringing. In any case, his was a conscious choice, with links to England ultimately outweighing whatever gains the rights of citizenship in Pennsylvania could confer. Despite a continued fondness for America evident in the evocation of Pennsylvania Castle on English soil, John Penn Jr. at heart was a loyal British subject.

year after the death of the benevolent William Penn," deceased in 1718. See Records of the Origin and Proceedings of the Outinian Society, vol. 1, part 1 (London: Nicol, late Bulmer \& Co., 1822).

${ }^{65}$ John Penn, Esq., Letters on the Drama (London: printed for Elmily, Faulder, Sewell, Owen and White, 1796); J. Penn, Esq., Further Thoughts on the Present State of Public Opinion; Being a Continuation of a Timely Appeal to the Common Sense of the People of Great Britain in General, and of the Inhabitants of Buckinghamshire in Particular, on the Present Situation of Affairs (London: printed for Hatchard, 1800); John Penn, Esq., The Battle of Eddington; or British Liberty: A Tragedy (London: printed for Elmily, Faulder, Sewell, Owen and White, 1796), all in LCP. 
It was left to John Penn Sr. to carry on the Penn presence in Pennsylvania. We have seen how the senior John patiently lived out the war in seclusion. After the peace, he not only swung into action when necessary in defense of the proprietary legacy but deliberately abandoned his isolation to make visibly public appearances in an effort to gain acceptance from the victors. As Rebecca Shoemaker explained to her loyalist husband then exiled in New York, "that set have prudently determined, as they cannot exist in retirement either at Landowne or any where else out of public places, to join the others, and Gov. Penn and lady, Mrs. Allen and mother... and all their former intimates, are now as happy at Mrs. Stewart's, formerly M'Clanachan, at the French Minister's, or in any other Whig society, as ever they were in the select circle they were once the principals of., ${ }^{, 66}$ Daily life appears to have slowed down after the immediate postwar flurry, however. A 1786 letter to Joseph Shippen Jr. is especially instructive, exuding an air of routine and an undertone of loneliness. He was sorry his acquaintance was ill at Lancaster, where Penn could not "suppose that you can spend your time very agreeably." Life there was surely dull and "your company must be very confined \& not always of the sort you would chuse [sic]." Perhaps Shippen should consider coming to Philadelphia where "a change of air, \& company might be of service to you... and raise your spirits." Besides, in the city there was better medical care and "you would even have inducements for using exercise, which you cannot have where you are. ${ }^{, 67}$ The missive reads more like

\footnotetext{
${ }^{66}$ Rebecca Shoemaker to Samuel Shoemaker, December 13, 1783, in Howard M. Jenkins, "The Family of William Penn," PMHB, vol. 22, no. 1 (1898), 85.

${ }^{67}$ John Penn Sr. to Joseph Shippen Jr., January 7, 1786, Dreer Collection, Box 21, Folder 24, HSP. John Penn Sr.'s isolation appears to be at least partially self-induced and continued during his time in Great Britain. James Tilghman wrote to Colonel Shippen in 1790 that he had only received one letter from John Penn while abroad and added: "You know his aversion to letter-writing, even where he had subjects of business, and was urged by considerations of interest." See "James Tilghman to Col. Shippen, at Plumley,
} 
a plea for company than the extension of a helping hand to a sickly friend it purports to be.

In 1788, John Penn Sr. traveled to England as part of the family's successful appeal to the Royal Claims Commission. That the former governor may have envisioned an extended or even permanent separation from America is insinuated in the auction of his furniture and goods prior to his departure. The advertisement offered to the general public seventy-seven types of items from nine large rooms at "his House on Chestnut Street," including carpets, bedsteads, mattresses, dining tables, "elegant China," chimney piece ornaments, calico curtains, and even "a case of excellent Sherry Wine." The inventory’s completeness implies a close-out sale for his city home. ${ }^{68}$

There is further circumstantial evidence to suggest that John Penn Sr. had doubts about a return to America. For one, he and wife Anne extended their English visit well beyond the timeline of their application to the Royal Claims Commission. In August of 1789, he informed Dr. Thomas Parke in Philadelphia that "our affairs will not be wound up till after Christmas," inferring that claim matters would be resolved in the late winter or early spring of 1790. In fact, Prime Minister William Pitt brought the proprietorship's case before Parliament on May 14, 1790. Yet the Penns did not go back to Pennsylvania until September, 1792. The language in the Parke letter reveals psychological distance. "I hope your New Government may succeed," he said referring to America's recently reworked constitutional framework. The "your" implies it was not his. Furthermore, John

Chester County," September 2, 1790, Balch, ed., Letters and Papers Relating Chiefly to the Provincial History of Pennsylvania, 294.

68 "Inventory of the Furniture and Goods of ... John Penn," May 15, 1788, Broadside (Philadelphia: Claypoole, 1788), Evans 21362. John Sr. and wife Anne kept the Lansdown estate, leasing it to wealthy patriot merchant William Bingham. The city sale may have also served to finance the trip to England. 
Sr. was clearly displeased with republicanism. "Honor \& Honesty seemed to be very thinly sown among the worthy patriots of America... when I left you," he chided sardonically. The recent flow of exiles to England escaping "the miserable situation in France" especially disturbed him. He placed ample blame for that revolution's excesses on republican America, alleging that French subjects "have drank so deep of the cup of liberty in America \& Holland, that they have become intoxicated with it." In contrast, he lauded British monarch George III. "You must long before this have been apprized of the King's recovery \& the joy it has incited in the Nation," declared Penn. "I have heard nothing of him that was not praiseworthy, except from the opposition" whom he disparaged as "gamblers without honor or money."

John and Anne Penn's views continued to evolve over the next few years. While residing at the family estate near London in late 1791, John Sr. received a letter from Lady Juliana who confirmed that "you are making Stoke delightful” while expressing optimism about life in his former home. "I hope your accts. from America are favorable for the News Papers tell us much of their prosperity \& I wish you to benefit by it," she reflected. ${ }^{70}$ In the end, the call of Pennsylvania proved too strong. Along with prospects of good fortune, reduced status may have had something to do with the couple's decision. The ever observant James Tilghman "had heard in a roundabout, uncertain way, that Mrs. Penn is not so fond of England as she expected to be. She left her consequence in America, as most people do, who go to England. It is not always a portable commodity."

\footnotetext{
${ }^{69}$ John Penn Sr. to Dr. Thomas Parke, August 2, 1789, Simon Gratz Autograph Collection, Governors of Pennsylvania/The Penns, Case 2, Box 33a, Folder 5, HSP; Eardley-Wilmot, Historical View of the Commission, 92; Treese, The Storm Gathering, 199.

${ }^{70}$ Lady Juliana Penn to John Penn Sr., October 24, 1791, Penn Family Papers, Collection 485A, I. Correspondence, Private Correspondence V, vol. NV-023, HSP.
} 
John and Anne returned to Pennsylvania in 1792. The oldest Penn heir lived out his remaining days in the quietude of his estate. Expiring in 1795, he was buried near the altar in Anglican - now Episcopal - Christ Church in Philadelphia. ${ }^{71}$

Despite divestment and doubts, John Penn Sr. succeeded in reintegrating back into Pennsylvania life in all three stages he faced: during the uncertainty of his post-exile seclusion during the war, in the half-decade following the peace, and upon his return from England in 1792. He was never attainted or legally charged for infidelity to the American cause. On the contrary, his avowal of allegiance in 1778 set in stone his rights as a republican citizen while Pennsylvania's adherence to the rule of law guaranteed not only those rights of citizenship, but the redefined rights of the proprietorship. Although only he of the Penn heirs chose to reintegrate, his linkages to Pennsylvania ultimately proved brittle. Wife Anne chose to leave Bucks County for England six years after John's death. Her close ties to her brother, loyalist exile Andrew Allen, probably played a leading role in her determination, overcoming earlier status concerns about reduced “consequence.” Judging from a statement of accounts for her deceased husband's estate at the time, it appears she lived comfortably. ${ }^{72}$

\footnotetext{
71 "James Tilghman to Col. Shippen, at Plumley, Chester County," September 2, 1790, Balch, ed., Letters and Papers Relating Chiefly to the Provincial History of Pennsylvania, 293-294. Some historical accounts speculate that John Penn Sr.'s body was later disinterred and taken to England but I have not seen any concrete evidence substantiating that claim. The Anglican/Church of England underwent a transformation during the American Revolution which resulted in its reconfiguration as the American Episcopal Church. Although the theology, liturgy and rituals remained essentially the same, American clerics eliminated linkages to the British monarchy and set up a wholly independent ecclesiastical institution. See for example James B. Bell, A War of Religion: Dissenters, Anglican, and the American Revolution (New York: Palgrave Macmillan, 2008).

72 Treese, The Storm Gathering, 200. "The Estate of John Penn deceased in account with John F. Mifflin, Executor," Dreer Collection, Box 21, Folder 29, HSP. Mifflin's accounting reveals that wife Anne Allen Penn received five living expense payments between July 13, 1809 and July 12, 1810 ranging from $\$ 700$ to $\$ 900$ each. The balance on the account as of July 2,1809 , was $\$ 153,654.33$ - quite the tidy sum for the era.
} 


\section{CONCLUSION}

The Penn proprietorship lay at the heart of revolutionary transformation in Pennsylvania. The proprietary order of the colonial era proved irreconcilable with an egalitarian republicanism built on the will and consent of the people. The two were intrinsically at odds. Faced with an irresolvable contradiction, radicals overthrew the long-established royally chartered regime. The collapse of proprietary hegemony signaled not only the beginning of a new era but an expansion of rights and a reconfiguration of the legal order and the law under the novel republican parameters established in the Constitution of 1776 which stressed a more equal distribution of divested land.

Revolutionary commitment to the rights of citizens and the rule of law in Pennsylvania was not an empty slogan. Since John Penn Sr. had sworn allegiance to the state and both patriot factions held the colony's founding in high esteem, revolutionaries sought accommodation with the proprietary family's unique historical circumstances. Besides, unlike pacifist Quakers, the Penns never publicly condemned the advent of republican rule. The terms of the 1779 Divestment Act passed by a radical legislature then at the zenith of its power are especially enlightening. By respecting legal due process, allowing the Penns to retain a generous share of their landed inheritance, establishing conditions for postwar financial compensation, and welcoming a continued proprietary presence in the state, radicals ensured fairness within the limits imposed by a destructive war, economic realities, and the social and political expectations of their rebel constituents. Given these problematic challenges, it is my judgment that radicals were not only evenhanded but quite magnanimous - despite the Penn family's protestations to the contrary regarding compensation. That later moderate-dominant governments did not 
augment Penn reparations or grant any other substantial concessions shows that a sense of just restitution pervaded all revolutionary factions.

From the perspective of the proprietorship, the Revolution was a disaster. The Penn family first lost all political power and then the greater part of their royally granted lands - the foundation for their wealth and status. In sum, the proprietorship ceased to exist. From the narrower viewpoint of the Penns as individuals, however, the picture is not as somber. Richard Penn never ventured back to Pennsylvania, preferring instead the perks of gentry life in a hierarchical kingdom. After a brief jaunt through republican fancies, John Penn Jr. decided he was an Englishman after all and definitively returned to the mother country. These cousins consciously chose to reject reintegration. There was no revolutionary coercion. Hence, Penn reintegration - if there was to be any at all - rested ultimately on John Penn Sr.'s choices. Of the three relations, he no doubt professed the greatest affinity for the family's ancestral homeland in America. His decisions reflect that. Although forcibly banished in 1777 , John Penn Sr. cast his lot with revolutionary Pennsylvania at four critical junctures. He opted to stay following the British evacuation in June 1778, despite a combustible climate laden with rebel suspicion. He voluntarily took the patriot oath of allegiance shortly thereafter. He remained in Pennsylvania at the peace of 1783 and tried to regain status and prestige by entering republican social circles. After several years in Britain prompted by an appeal for compensation from Parliament, he returned to Pennsylvania in 1792 to live out his remaining days. Although no longer the privileged proprietor of a royalist yesteryear, the reintegration of citizen John Penn Sr. was nonetheless largely successful. He enjoyed the privileges of a fully enfranchised citizen. He retained sufficient wealth to live comfortably according to his "rank and 
station in life," as his radical adversaries had counseled in his banishment order. Higherorder patriots accepted him in elite social circles. He reconnected with surviving pre-war friends and acquaintances. In the end, John Penn Sr. willingly embraced the republic. And the republic reciprocated. 


\section{CLOSING SCENES AND CONCLUSIONS}

A curious visitor to Philadelphia circa 1791 drawn to the novelty of popular sovereignty through republican government would have recorded the preeminence of William Penn's "City of Brotherly Love" on the Delaware River in the affairs of both the century-old state and the emerging nation. Philadelphia then served as both the provincial and federal capitals and would continue as such for most of the decade. ${ }^{1}$ Making the rounds of formal introductions to noteworthy figures in the republican landscape at the local and national levels, the inquisitive guest would likely have had occasion to greet Pennsylvania Supreme Court Justice Edward Shippen and Benjamin Chew, President of Pennsylvania's High Court of Errors and Appeals. ${ }^{2}$ A few blocks away, United States Secretary of the Treasury Alexander Hamilton would have cordially received the attentive traveler and perhaps asked Assistant Treasury Secretary Tench Coxe to escort the caller on his way to the offices of the United States Attorney for the District of Pennsylvania, William Rawle. ${ }^{3}$ The interested voyager would no doubt have been impressed with the character and quality of these enterprising republicans who had embarked on a political experiment laden with risk. Skeptics in both Europe and America were convinced this "democratical" audition could not work and would end in disaster. After all, who in their right mind could ever countenance a government under the

\footnotetext{
${ }^{1}$ In 1799, the Pennsylvania State Assembly moved west to Lancaster. The following year, the federal government transitioned to its permanent home at Washington, D.C.

${ }^{2}$ For background on Shippen and Chew, see Klein, Portrait of an Early American Family: The Shippens of Pennsylvania Across Five Generations; Konkle, Benjamin Chew 1722-1810.

${ }^{3}$ For background on Coxe and Rawle, see Cooke, Tench Coxe and the Early Republic; T. I. Wharton, Esq., A Memoir of William Rawle, LL.D., Read at a meeting of the Council, held on the $22^{\text {nd }}$ day of February, 1837.
} 
direction of "the people"? Yet the caliber of these revolutionaries clearly contravened the conventional wisdom spewed forth by the cynics. Our visitor would have felt reassured.

But buried beneath these heartening reflections was a hidden layer of ambiguity. Unfamiliar with the intricacies of the revolutionary struggle in Pennsylvania, our impressionable political examiner would have had no way of knowing that Mr. Coxe had been attainted for high treason on May 21, 1778. Or that Judge Chew had been banished to New Jersey with colonial Governor John Penn Sr. on the eve of the British occupation of Philadelphia because real revolutionaries feared he would collaborate with the king's forces. Or that Mr. Rawle had accompanied his loyalist stepfather Samuel Shoemaker to New York City at Sir Henry Clinton's evacuation of the city in the summer of $1778 .{ }^{4}$ Or that at the height of the war in the state, Judge Shippen had lived in daily fear of arrest by radicals and signed a parole under duress ensuring his good behavior. Or that his son Edward had joined the British army and fallen prisoner to the continentals at the decisive battle of Trenton. Or that his daughter Peggy had married notorious traitor Benedict Arnold and followed him into exile. ${ }^{5}$ Only someone with a detailed knowledge of the rebellion in the province could possibly have detected all of these inconsistencies. And yet it is precisely contradictions like these that validate the unequivocal success of the process of reintegration in Pennsylvania.

Although evocations of tory duplicity surfaced now and then, especially in the heat of political campaigns, reintegration as a core issue of the new republic essentially

\footnotetext{
${ }^{4}$ Coxe's attainder is in Council Minutes, Colonial Records, vol. 11, May 21, 1778, 493-495; Chew's banishment order is in Council Minutes, Colonial Records, August 13, 1777, vol. 11, 265-266; for Rawle to New York in the company of Shoemaker, see Van Buskirk, Generous Enemies, 26-27.

${ }^{5}$ For these specific Shippen family incidents, see Klein, Portrait of an Early American Family, 184-191.
} 
ceased to exist by the early 1790s. The transfer of political power from the proprietor to the people's representatives; the departure of elite and ordinary loyalist militants; the non-threatening attitudes and behavior of the disaffected who stayed; the seizure of the bulk of the Penn family's land holdings for the benefit of patriot soldiers and settlers; the eradication of genuine armed threats; the readiness of those opposed to revolution to accept republican rule with the divine verdict of peace; the continued presence of upright citizens of the new republic descended from ex-loyalists and disaffected denizens; the triumph of Anti-Constitutionalist moderate leadership in the state; and the repeal of all discriminatory legislation constructed on the basis of allegiance coalesced to render the problem of reintegration extraneous to Pennsylvania society. In only a decade or so, revolutionaries and the ex-disaffected united to solve the grave predicament of what to do with actual or suspected enemies who had remained in Pennsylvania at the conclusion of a terrible war or returned afterwards, arguably the most pressing challenge facing the embryonic republic. Confronted earlier with the options of expulsion, ostracism, accommodation or reassimilation, by 1789 patriots had joined hands with onetime opponents and welcomed them to the republican fold - the equivalent of a mass pardon for the unattainted. The conduct and consent of former foes of the Revolution played an instrumental role in this success.

The Pennsylvania reintegration experience reveals key characteristics of the early republic's concern over the interplay between rights, citizenship, institutions, and the law. Revolutionaries of all stripes championed a robust commitment to the inherent rights of citizens and a legal and political system designed to defend those rights. Although discrepancies over the nature of allegiance meant that each faction defined republican 
citizenship differently, the linkage between rights and the rule of law was indivisible for both radicals and moderates. The diagnosis of Henry Steele Commager and Richard Morris that "these leaders insisted that the Revolution be managed in an orderly and lawful fashion" was manifest in Pennsylvania. ${ }^{6}$ Witness radical council president Joseph Reed's cavalry charge against his own radical partisans to restore order at Fort Wilson and the strict adherence to legal due process at the trials of John Roberts and Abraham Carlisle under radical ascendancy. ${ }^{7}$ Moreover, each party used the law to advance its vision of what republican citizenship should look like and who should possess those rights. For both, the debate centered exclusively on males of European ancestry. This criterion placed ex-loyalists, the onetime disaffected, and nonjuror men at the heart of the factional dispute. ${ }^{8}$ Clearly, citizenship was highly valued. Even Quaker nonjurors who refused to budge on their core beliefs regarding pacifism and oath-taking recognized that value. Observe James Pemberton's allusion to "our just rights" in the midst of the Test Act repeal debates and his decision to run for office with fellow Friends Miers Fisher, Henry Drinker, and Edward Pennington only weeks after the repeal. ${ }^{9}$ The reincorporation of the formerly disaffected steadied institutions in the early republic and aligned with a wider move towards institutional stabilization in more centralized governments under the

\footnotetext{
${ }^{6}$ Henry Steele Commager and Richard B. Morris, eds., The Spirit of Seventy Six: The Story of the American Revolution as Told by Participants (Edison, NJ: Castle Books, 1967), xliv.

${ }^{7}$ For Reed's charge at Ft. Wilson, Rosswurm, Arms, Country, and Class, 216-217. For due process at the Roberts and Carlisle treason trials, Larson, "Revolutionary American Jury," SMU Law Review, 1441-1524.

${ }^{8}$ By definition, all nonjurors were white men since the test act legislation specifically ordered only white males to take the oath of allegiance. See Statutes At Large of Pennsylvania, vol. 9, "An Act Obliging All White Male Inhabitants of This State to Give Assurances of Allegiance to the Same and for Other Purposes Therein Mentioned," June 13, 1777, Chapter 756, 110.

${ }^{9}$ James Pemberton to John Pemberton, January 16, 1785, Pemberton Papers, Box 42, 165; Scharf \& Westcott, History of Philadelphia, 455-456.
} 
federal Constitution of 1787 and the new Pennsylvania Constitution of 1790 endorsed by moderates.

The reintegration process in Pennsylvania also parallels the inclusionary political trends of the 1780s identified in the earlier studies of Coleman, Palfreyman, Brannon and Maas. With two broadly national inquiries and now three detailed analyses of specific states, a historical pattern emerges which signals, first, that substantial numbers of the formerly disaffected - perhaps most - favored life under republican rule to displacement elsewhere within the British Empire, despite their earlier hostility. They were Americans first, not Britons. Second, resolution of the loyalist reintegration challenge opened the way for the success of the new republic. ${ }^{10}$ The nation could now look forward and build its future, rather than backward and worry about its past. Finally, pragmatic republicans preferred the consequences of a reassimilation of the disaffected to the consequences of their rejection, a choice inadvertently facilitated by the effects of loyalist militancy that separated acceptable republican wheat from unacceptable monarchist chaff. Loyalist militants who had either actively fought for the king or collaborated extensively with the British feared radical reprisals and more often than not chose to depart. Rebels were more than happy to have them quit the scene and confiscate their property. Conversely, the disaffected who did not bear arms or whose collaboration with the British was less conspicuous commonly sifted back into Pennsylvania society. Patriots chose to tolerate their presence as long as they posed no threat. The passage of time and the mounting success of the republican experiment gradually alleviated these earlier distinctions

\footnotetext{
${ }^{10}$ This is also one of Palfreyman's key conclusions. See Brett Palfreyman, "Peace Process: The Reintegration of the Loyalists in Post-Revolutionary America," (Ph.D. Dissertation, Binghamton University, 2014), v.
} 
grounded on militancy and allowed the return or visit of even the most committed armed opponents of revolution like Joseph Doan Jr. or the most ardently pro-British ideologues like Andrew Allen. ${ }^{11}$ In Pennsylvania, the attitudes, behavior, and actions of the disaffected created conditions conducive to a peaceful and successful resolution of the challenge of reintegration by fostering the reciprocal cooperation of revolutionaries.

Like Rebecca Brannon for South Carolina and David Maas for Massachusetts, my study inserts Pennsylvania's distinctive revolutionary history into the national story of reintegration. Not surprisingly, loyalism in Penn's colony featured ingredients common to other states such as militancy, guerrillas, executions, exile, evacuations, and all too human characters guided by a plethora of motives ranging from selfless sacrifice to baseless opportunism. Loyalism in Pennsylvania, however, also had attributes either unique to the state or not commonly found elsewhere. For instance, Pennsylvania faced more boundary disputes with neighbors than any other state. Although the drawing of the Mason-Dixon line had quieted a quarrel with Maryland by the time of the Revolution, conflicts with Connecticut and Virginia strongly impacted patriot-loyalist partisanship. Colonial antagonism between Quakers and Presbyterians also played a critical role, in tandem with the idiosyncratic response of pacifist Friends to military conflict. Nowhere else was pacifism as noteworthy. Pennsylvania was also among the few colonies under proprietary government and, of those, it was the one in which the proprietors played the most visible role. Furthermore, intra-patriot factional contentiousness between radicals and moderates in Pennsylvania was arguably the most pronounced of all the colonies. In authoring the first study of reintegration in Pennsylvania, I have tried to underscore this

\footnotetext{
${ }^{11}$ For Joseph Doan Jr.'s visit to Bucks County, see The New Doane Book, 25, 314-317, 337, 342; for Andrew Allen's return, see “Andrew Allen," Legislators in Pennsylvania, vol. 3, 211.
} 
historical singularity, as well as give the loyalists an active voice and stress the joint contributions of both revolutionaries and antirevolutionaries in achieving reintegrative redemption. In the final analysis, the representative cases of the most militant, most pacifist and most obdurate among the disaffected merged with the most vengeful, most accommodating and most consequential from the viewpoint of the revolutionaries to establish the uniqueness of Pennsylvania's process of reintegration.

Though the present study strives for thoroughness, the prospect a preliminary database of 1,858 disaffected individuals unfurls admittedly leaves the reintegrative drama as told here incomplete, for each and every loyalist or disaffected Pennsylvanian has his or her own personal chronicle to relate. I have tried to select for these pages the historical actors who most appropriately explain the key ingredients that contributed to successful reintegration in Pennsylvania. Yet the most explicatory characters are not necessarily the most intriguing. Among the noteworthy for future scrutiny - in addition to Tench Coxe, Benjamin Chew, Edward Shippen IV and William Rawle - are the wives of loyalist exiles who purposely stayed behind in an attempt to preserve family property. Their struggles with patriot authorities are especially poignant. Prominent among these women were Grace Growden Galloway, wife of loyalist militant Joseph, and Rebecca Shoemaker, wife of Samuel, General Howe's Magistrate of Police during the British occupation. The successful reintegration of the wives of the Quakers banished to Virginia is likewise significant. Elizabeth Drinker, Mary Pleasants, Susanna Jones and Phoebe Pemberton who actively petitioned for release of the Virginia exiles merit special attention. Particularly intriguing are women like Jane Bartram and Elizabeth Graeme Fergusson who publicly rebuffed the loyalism of their exiled husbands, remained in 
Pennsylvania while claiming an affinity for the patriot cause, then wrangled with the revolutionary legal system to avoid eviction and retain possession of the property they inhabited. Their appeal as republicans to a republic that did not recognize their legal status as full citizens on the basis of gender exposed the contradictions of an ideology not yet willing to accept its professedly self-evident notion of equality under the law for all. The case of Susannah Adams, the only attainted woman out of nearly five hundred loyalists decreed as such in Pennsylvania, also deserves consideration.

The singular circumstances of Pennsylvania's black loyalists warrant attention. Research for this study has identified at least 79 individuals of African heritage in the state whom patriots considered disaffected. Of these, 27 were women. Of the 74 whose legal status is known, nine were born free, sixty-two escaped their masters and joined the British at varying times, and three went into exile as slaves of loyalists after the 1778 evacuation of Philadelphia. Thus, British authorities emancipated 62 of the 65 known to be enslaved, raising the incongruity of a purportedly oppressive monarchy and not republican revolution acting as guarantor of the freedom of Americans of African ancestry. That no evidence has yet materialized that any black loyalists who sided with the British stayed behind after the evacuation or later returned adds to the need for investigation, as do their scattered exile experiences in the royal Canadian provinces, England, and in isolated cases, the formation of Britain's Sierra Leone colony for former slaves on the west coast of Africa. Questions likewise surface on the other side of the coin in the few Pennsylvania instances where the British allowed loyalists with slaves to retain them as property after departing for exile elsewhere in the empire. 
Generational conflicts across the loyalist/patriot axis command attention. The split between renowned patriot Benjamin Franklin and his diehard loyalist son William who became royal governor of New Jersey with the aid of his father's intercession needs to be examined with an eye turned towards reintegration. Similarly, revolutionary James Young, brother-in-law of Elizabeth Graeme Fergusson, had a permanent falling-out with his loyalist son, John, who joined the British and was attainted in May 1778. Also worth exploring are loyalist father Jared Ingersoll Sr., the king's vice-admiralty court judge at Philadelphia, and his patriot son Jared Ingersoll Jr., an attorney friend of radical council president Joseph Reed who convinced him to settle at Philadelphia. Jared Jr. became one of the most important legal figures in the state in the early republic. ${ }^{12}$ The contrasting trajectories of Charles Humphreys and Thomas Willing, the two men who voted against independence as Pennsylvania delegates to the Continental Congress in July 1776, are worth exploring at length. Humphreys later got into trouble with radical authorities for disaffection while Willing integrated harmoniously and became the first president of the Bank of North America in 1782. Why the difference?

Those who expediently switched sides back and forth defy sectarian logic, not only for their ideological mutation but for their ability to pull off the alterations. Printer and newspaper editor Benjamin Towne was the most artful of these chameleons. He deftly navigated his Pennsylvania Evening Post from a pro-patriot tri-weekly to a vocal loyalist mouthpiece during the nine month British occupation of Philadelphia and reversed course again after the evacuation as a pro-rebel publication. Merchant Joseph Stansbury - best known for his loyalist verses and association with Benedict Arnold,

${ }^{12}$ Jared Ingersoll Jr.'s return to Philadelphia is in Lawrence Henry Gipson, American Loyalist: Jared Ingersoll (New Haven: Yale University Press, 1971), 363. 
military commandant of Philadelphia appointed by General Washington when revolutionaries retook the city in 1778 - dithered into the postwar period between residence in Philadelphia and forced exile and eventually earned the dubious distinction of having his claim before Parliament rejected outright because the royal commissioners deemed him twice a traitor.

Attainted returnees who received pardons present glimpses into the evolution of patriot clemency as well as the competing calls of England and America for loyalist exile fidelity. Delegates to the First Continental Congress designated Anglican minister Jacob Duché to inaugurate the sacred work of that body in 1774 and he was named chaplain to Congress after the Declaration of Independence. But Duché faltered when the British captured Philadelphia and wrote George Washington an ill-timed letter describing the futility of further resistance and asking the patriot commander-in-chief to use his personal influence to reconcile the country with Great Britain. Rebuffed by both Washington and Congress, and jailed briefly by Sir William Howe who shipped him off to his Church of England superiors in Britain, Duché lived to return and die in Philadelphia. Attorney Phineas Bond was among the suspected tories targeted in the radical round-up preceding the invasion of 1777 but avoided deportation. He evacuated with the British army the next year. From his London exile, Bond found his way back to Philadelphia through a controversial royal appointment as British Consul for the Middle States. Those who tried to toe a middle line between revolution and disaffection, failed, and then succeeded in returning merit analysis. Among these, Jewish merchant David Franks and Anglican minister Provost William Smith stand out. The trials and tribulations of pacifist German Pietists such as Moravian John Ettwein, Schwenkfelder George Kriebel, and Dunkard 
Christopher Sower - similar to their pacifist Quaker brethren in some ways and yet distinct in others - also deserve special scrutiny. Lastly, a comprehensive study of the 488 citizens who were officially attainted during the course of the war can likewise add depth to the reintegration saga in Pennsylvania.

The cases outlined above further elaborate the findings in this study. Disaffected residents such as Coxe, Chew, Shippen, Rawle and others who chose to take the oath of allegiance found the path to republican acceptance much more expeditious and less hazardous than those like the Quaker pacifists who refused the oath. Yet oath-takers had to reassure patriots of their commitment by avoiding the suspicion of antirevolutionary activity. The likes of Stansbury or Franks who failed to do so suffered patriot reprisals in due course. While German pacifists resisted the taking of oaths and the payment of fines for failure to serve militarily, they were not as unyielding as reformist Friends. Their struggle to find a middle ground between patriot requirements and the tenets of their faith resulted, for the most part, in greater acquiescence and less retribution from rebels. These instances reaffirm that the attitude, behavior and actions of the disaffected proved decisive in shaping patriot treatment of the disaffected. At the same time, the experiences of loyalist women and pro-British blacks ratify that revolutionary radicals and moderates both circumscribed the lines of republican citizenship to males of European descent, thereby limiting a more comprehensive application of the Revolution's achievements.

I will end on a personal note. When I began exploring graduate study in history in 2009, I was drawn to the underlying reasons for the strength of America's governmental institutions which had maintained democratic stability for two-and-a-half centuries while enduring a vicious civil war, grave armed threats from abroad, and contentious social 
unrest from within. As a onetime refugee from the ravages of an armed revolution that witnessed the total collapse of a nation's institutions and the establishment of totalitarian dictatorship, I decided to focus on American history at the founding as my specialty to attempt to address this larger issue in contemporary terms. Specifically, I wanted to examine the intrinsic qualities of America's political institutions that had endowed them with a lasting solidity.

The study of loyalism and disaffection in Pennsylvania during the American Revolution has reaffirmed my original view of the strength of the American republic's institutions. But I have discovered to my surprise that this strength is not intrinsic to the institutions themselves. Instead, I have come to realize that two critical substrata underlie America's governmental structure and sustain its institutions. The first is the rule of law. The present-day American system is designed to be fair and evenhanded, equally applicable to all across the board, allowing the nation's institutions to operate under a known set of guidelines which everyone accepts. It doesn't always meet this lofty ideal but that is its designed intent nonetheless. Yet the rule of law by itself is woefully insufficient, for totalitarian dictatorships also create coherent legal structures while using the law to destroy or limit liberty rather than reinforce it. The difference is the foundation on which the rule of law rests.

At the core of the current American political structure lies an almost universal belief in inherent rights among the country's citizens. This underlying premise more often than not is taken for granted - a trait that verifies its foundational essence. Citizens' rights are so ingrained among Americans that they merit almost no discussion or are relegated to the realm of "civics." They are accepted as a given, like the air we breathe. 
This seminal conviction commands an equal application of the rule of law for all citizens. In practice, the issue of rights only seems to surface when they are violated or when the law is unequally applied. This blend of faith in inherent rights and the equal application of the law in turn sustain the American republic's institutions. The institutions function because people believe in them and in their core components underneath. Democracy is ultimately the product of the citizenry's faith in their rights. The lesson I have drawn from the study of loyalism, disaffection, and revolution in Pennsylvania is that only when a country's citizens believe they have a right to rights, can they hope to secure and preserve them. 


\section{BIBLIOGRAPHY}

\section{UNPUBLISHED PRIMARY SOURCES}

\section{Historical Society of Pennsylvania (HSP) / Library Company of Philadelphia (LCP)}

Boudinot Papers, Collection 68

Chew Papers, Collection 2050

Coxe Family Papers, Collection 2049

Dreer Collection, Autographs, Collection 175

Etting Collection, Early Quakers, Collection 0193

Simon Gratz Autograph Collection, Collection 0250A

Pemberton Papers, Collection 484A

Penn Family Papers, Collection 485A

Shippen Family Papers, Collection 0595B

Society Historical Collection

Wharton Family Papers, Collection 2047A

Wharton \& Willing Families Papers, Collection 2014

Wilson Manuscripts, Collection 721

\section{David Library of the American Revolution (DLAR)}

British Public Records Office (PRO), Audit Office (AO), Bundles 12 \& 13, Memorials. Allen, Andrew, Allen, William, Jr. Anger, Frederick Bender, Philip

Buck, Philip

Carlisle, Ann

Galloway, Joseph

James, Jacob

Rankin, William

Roberts, Jane 


\section{Haverford College, Quaker and Special Collections (HAV)}

Society of Friends, Minutes, Philadelphia Monthly Meeting, Middle District, vols. 2, 3

\section{NEWSPAPERS}

The Independent Gazetteer

The New York Times

Pennsylvania Evening Post

Pennsylvania Packet

The Pennsylvania Gazette

Porcupine's Gazette

\section{PUBLISHED PRIMARY SOURCES}

Acts of the General Assembly of Pennsylvania, Passed at a Session, Which Was Begun and Held at the Borough of Lancaster, on Tuesday, the First Day of December, in the Year of Our Lord, One Thousand Eight Hundred and Seven. Philadelphia: John Bioren, 1808.

Adams, John. The Works of John Adams, Second President of the United States: With a Life of the Author, Notes and Illustrations. Charles Francis Adams, ed. Boston: Little \& Brown, 1850. vol. 2.

Allen, James. "Diary of James Allen, Esq., of Philadelphia, Counsellor-At-Law, 17701778." Pennsylvania Magazine of History and Biography vol. 9, no. 2 (July, 1885).

. "Diary of James Allen, Esq., of Philadelphia, Counsellor-At-Law, 1770-

1778," Pennsylvania Magazine of History and Biography vol. 9, no. 3 (October, 1885).

. "Diary of James Allen," January 18, 1778, Pennsylvania Magazine of

History and Biography vol. 9, no. 4 (January, 1886).

A Proposed Ordinance for the State of Pennsylvania, Declaring What Shall Be Treason, and for Punishing the Same, and other Crimes and Practices against the State.

Broadside, Philadelphia: Styner \& Cist, 1776. Evans 14992, LCP.

Balch, Thomas, ed. Letters and Papers Relating Chiefly to the Provincial History of Pennsylvania with Some Notices of the Writers. Philadelphia: Crissy \& Markley, 1855. 
Blackstone, Sir William, Knight. Commentaries on the Laws of England, Twelfth Edition. Edward Christian, Esq., ed. London: A. Strahan \& W. Woodfall, Law-Printers to the King's Most Excellent Majesty, for T. Cadell in the Strand, 1795.

Brissot de Warville, Jean Pierre. New Travels in the United States of America. Bowling Green, OH: Historical Publications Company, 1919.

Burnett, Edmund C., ed. Letters of Members of the Continental Congress. Washington: Carnegie Institution of Washington, 1921.

Case and Claim of the American Loyalists Impartially Stated and Considered, The. Printed by Order of their Agents, London, 1783.

Chopra, Ruma, ed. Choosing Sides: Loyalists in Revolutionary America. Lanham, MD: Rowan \& Littlefield, 2013.

Coldham, Peter Wilson ed. American Migrations 1765-1799: The lives, times and families of colonial Americans who remained loyal to the British Crown before, during and after the Revolutionary War, as related in their own words and through their correspondence. Baltimore: Genealogical Publishing Co., 2000.

Collections with Regard to the Case of the American Loyalists. London, 1783.

Colonial Records. Minutes of the Provincial Council of Pennsylvania, from the Organization to the Termination of the Proprietary Government. Harrisburg: Theo. Fenn \& Co., 1852. vols. 9, 10, 11, 12, 13, 14, 15, 16.

Commager, Henry Steele and Richard B. Morris, eds. The Spirit of Seventy Six: The Story of the American Revolution as Told by Participants. Edison, NJ: Castle Books, 1967.

Connolly, John. "A Narrative of the Transactions, Imprisonment, and Sufferings of John Connolly, an American Loyalist and Lieut. Col. in His Majesty's Service." The Pennsylvania Magazine of History and Biography vol. 12, no. 3 (October, 1888).

. "A Narrative of the Transactions, Imprisonment, and Sufferings of John Connolly, an American Loyalist and Lieut. Col. in His Majesty's Service." The Pennsylvania Magazine of History and Biography vol. 12, no. 4 (January, 1889).

. "A Narrative of the Transactions, Imprisonment, and Sufferings of John Connolly, an American Loyalist and Lieut. Col. in His Majesty's Service.” The Pennsylvania Magazine of History and Biography vol. 13, no. 1 (April, 1889).

" A N Narrative of the Transactions, Imprisonment, and Sufferings of John Connolly, an American Loyalist and Lieut. Col. in His Majesty's Service." The Pennsylvania Magazine of History and Biography vol. 13, no. 2 (July, 1889). 
Connolly, John. "A Narrative of the Transactions, Imprisonment, and Sufferings of John Connolly, an American Loyalist and Lieut. Col. in His Majesty's Service.” The

Pennsylvania Magazine of History and Biography vol. 13, no. 3 (October, 1889).

Constitution of the United States and The Declaration of Independence, The.

Washington, DC: Superintendent of Documents, U.S. Government Printing Office.

Crary, Catherine S., ed. The Price of Loyalty: Tory Writings from the Revolutionary Era. New York: McGraw Hill, 1973.

Cresswell, Nicholas. A Man Apart: The Journal of Nicholas Cresswell. Lanham, MD:

Lexington Books, 2009.

Dallas, Alexander James, ed. Reports of Cases Ruled and Adjudged in the Courts of Pennsylvania Before and Since the Revolution. New York: Banks \& Bros., 1882. vol. 1.

Day, Thomas. A LETTER from ********, in London, to his friend in America, on the subject of the slave trade; together with some extracts from approved authors of matters of fact, confirming the principles contained in said letter. New York: Samuel Loudon, 1784.

Declaration from the Harmless \& Innocent People of God, called, Quakers Against All Sedition Plotters \& Fighters In the World. For the removing of the Ground of Jealousie and Suspicion from both Magistrates and People in the Kingdome concerning Wars and Fighting, A. London: Reprinted by John Bringhurst, 1684.

Drinker, Elizabeth Sandwith. The Diary of Elizabeth Drinker: The Life Cycle of an Eighteenth-Century Woman. Elaine Forman Crane, ed. Philadelphia: University of Pennsylvania Press, 2010.

Eardley-Wilmot, John, Esq. Historical View of the Commission for Enquiring into the Losses, Services, and Claims, of the American Loyalists, at the Close of the War Between Great Britain and Her Colonies in 1783: With an Account of the Compensation Granted to Them by Parliament in 1785 and 1788. London: J. Nichols \& Bentley, 1815; War College Series Reprint.

Egerton, Hugh Edward, ed. The Royal Commission on the Losses and Services of American Loyalists 1783 to 1785, Being the Notes of Mr. Daniel Parker Coke, M. P., One of the Commissioners of That Period. Oxford: The Rorburght Club, 1915.

Ettwein, John. Short Account of the Disturbances in America and of the Brethren's Conduct and Suffering in This Connection. Bethlehem, PA: Times Publishing Co., 1940.

Fisher, Sarah Logan. "'A Diary of Trifling Occurrences': Philadelphia 1776-1778." Pennsylvania Magazine of History and Biography, vol. 82, no. 4 (October, 1958). 
Fisher, Samuel Rowland. "Journal of Samuel Rowland Fisher, of Philadelphia, 17791781." Pennsylvania Magazine of History and Biography, vol. 41, no. 2 (1917).

. "Journal of Samuel Rowland Fisher, of Philadelphia, 1779-1781."

Pennsylvania Magazine of History and Biography, vol. 41, no. 3 (1917).

. "Journal of Samuel Rowland Fisher, of Philadelphia, 1779-1781."

Pennsylvania Magazine of History and Biography, vol. 41, no. 4 (1917).

Force, Peter, ed. American Archives, $4^{\text {th }}$ Series. Washington, DC: 1840 . vols. $1,3,4$.

Ford, Worthington Chauncey ed. Journals of the Continental Congress 1774-1789.

Washington: Government Printing Office, 1906. vols. 4, 5, 8, 24.

Franklin, Benjamin. The Complete Works of Benjamin Franklin Including his Private as well as his Official and Scientific Correspondence, and Numerous Letters and Documents Now for the First Time Printed, with Many Others Not Included in Any Former Collection. John Bigelow, ed. New York: Putnam \& Sons, 1887. vol. 5.

. The Papers of Benjamin Franklin. Leonard W. Labaree, ed. New Haven: Yale University Press, 1968. vols. 12, 14.

. The Writings of Benjamin Franklin. Albert Henry Smyth, ed. New York: The Macmillan Company, 1907. vol. 4.

Galloway, Grace Growden. "Diary of Grace Growden Galloway, Kept at Philadelphia, July 1 to September 30, 1779." Pennsylvania Magazine of History and Biography vol. 55, no. 1 (1931).

. "Diary of Grace Growden Galloway, Kept at Philadelphia, July 1 to September 30, 1779." Pennsylvania Magazine of History and Biography vol. 58, no. 2 (1934).

Galloway, Joseph \& Julian Boyd. "Notes and Documents: Joseph Galloway to Charles Jenkinson on the British Constitution." Pennsylvania Magazine of History and Biography vol. 64, no. 4 (October, 1940).

Galloway, Joseph. A Candid Examination of the Mutual Claims of Great-Britain, and the Colonies: With a Plan of Accommodation, On Constitutional Principles. New York: James Rivington, 1775.

. A Letter to the Right Honourable Lord Viscount Howe, on His Naval Conduct in the American War. London: J. Wilkie, 1779. 
Galloway, Joseph. A Letter from Cicero to the Right Hon. Lord Viscount H--e: Occasioned by his late Speech in the H---e of C-----ns. London: J. Bew, 1781.

. A Reply to the Observations of Lieut. Gen. Sir William Howe, on a Pamphlet Entitled Letters to a Nobleman: In Which His Misrepresentations are detected, and those Letters are supported, by a Variety of New Matter and Argument. London: G. Wilkie, 1780.

. Brief Commentaries Upon Such Parts of the Revelation and Other

Prophecies as Immediately Refer to the Present Times: In Which the Several Allegorical Types and Expressions of Those Prophesies Are Translated into Their Literal Meanings, and Applied to Their Appropriate Events: Containing a Summary of the Revelation, the Prophetic Histories of the Beast of the Bottomless Pit, the Beast of the Earth, the Grand Confederacy, or Babylon the Great, the Man of Sin, the Little Horn, and Antichrist. London, 1802.

. The Claim of the American Loyalists Reviewed and Maintained upon Incontrovertible Principles of Law and Justice. London: G. \& T. Wilkie, 1788.

. Cool Thoughts on the Consequences to Great Britain of American Independence, on the Expence of Great Britain in the Settlement and Defence of the American Colonies, on the Value and Importance of the American Colonies and the West Indies to the British Empire. London: J. Wilkie, 1780.

. The Detail and Conduct of the American War, under Generals Gage, Howe, Burgoyne, and Vice Admiral Lord Howe: With a Very Full and Correct State of the Whole of the Evidence, as Given Before a Committee of the House of Commons: And the Celebrated Fugitive Pieces, Which are said to have given rise to that Important Enquiry. The Whole Exhibiting a Circumstantial, Connected and Complete History of the Real Causes, Rise, Progress and Present State of the American Rebellion. London: Richardson \& Urquhart, 1780.

. The Examination of Joseph Galloway, Esq; Late Speaker of the House of Assembly of Pennsylvania, Before the House of Commons, In a Committee of the American Papers, With Explanatory Notes. London: J. Wilkie, 1779.

. Letters from Cicero to Catiline the Second. With Corrections and Explanatory Notes. London: J. Bew, 1781.

Letters to a Nobleman, on the Conduct of the War in the Middle Colonies. London: J. Wilkie, 1779.

. Observations on the Fifth Article of the Treaty with America: And on the Necessity of appointing a Judicial Enquiry into the Merits and Losses of the American Loyalists. 1783. 
Galloway, Joseph. Plain Truth: Or a Letter to the Author of Dispassionate Thoughts on the American War. In Which the Principles and Arguments of that Author are refuted, and the Necessity of carrying on that War are clearly demonstrated. G. Wilkie, 1780.

. "Some Letters of Joseph Galloway." Pennsylvania Magazine of History and Biography vol. 21, no. 4 (1897).

Gilpin, Thomas ed. Exiles in Virginia with Observations on the Conduct of the Society of Friends during the Revolutionary War, Comprising the Official Papers of the Government Relating to that Period. 1777-1778. Philadelphia: Published for the Subscribers, 1848, Kessinger Legacy Reprint.

Goddard, William. The Partnership: Or the History of the Rise and Progress of the Pennsylvania Chronicle, \&c.: Wherein the Conduct of Joseph Galloway, Esq: Speaker of the Honourable House of Representatives of the Province of Pennsylvania, Mr. Thomas Wharton, sen. and their Man Benjamin Towne, my late partners, with my own, is properly delineated, and their Calumnies against me fully refuted. Philadelphia: William Goddard, 1770, LCP.

Graydon, Alexander. Memoirs of a Life Chiefly Passed in Pennsylvania, Within the Last Sixty Years. Edinburgh: William Blackwood \& T. Cadell, 1822.

Heinrichs, Johann. "Extracts from the Letter-Book of Captain Johann Heinrichs of the Hessian Jäger Corps, 1778-1780." Pennsylvania Magazine of History and Biography vol. 22 , no. 2, (1898).

Hunt, Isaac. The Case of Isaac Hunt, Esq. of Philadelphia. London, 1776, LCP.

In Council of Safety, Lancaster, $21^{\text {st }}$ October, 1777. Lancaster, PA: Francis Bailey, 1777. Early American Imprints, Evans 15529, LCP.

"Inventory of the Furniture and Goods of ... John Penn," May 15, 1788. Broadside. Philadelphia: Claypoole, 1788, Evans 21362, LCP.

Jefferson, Thomas. The Papers of Thomas Jefferson. Julian P. Boyd, ed. Princeton University Press, 1950.

Journals of the American Congress: From 1774 to 1788. In Four Volumes. Washington: Way \& Gideon, 1823. vols. 1, 2, 3.

Journals of the House of Representatives of the Commonwealth of Pennsylvania, Beginning the twenty-eight Day of November 1776, and Ending the second Day of October, 1781, with the Proceedings of the Several Committees and Conventions, Before and at the Commencement of the American Revolution. Philadelphia: John Dunlap, 1782. 
Journal of the Senate of the Commonwealth of Pennsylvania: Commenced at Harrisburg, On Tuesday, the seventh Day of January, in the Year of Our Lord One Thousand Eight Hundred and Forty-Six. And of the Commonwealth the Seventieth. Harrisburg: J. M. G. Lescure, 1846. vol. 1.

Journal of the Senate of the Commonwealth of Pennsylvania for the Session Begun at Harrisburg, on the $7^{\text {th }}$ Day of January, 1879. Harrisburg: Lane S. Hart, 1879.

Laws of the Commonwealth of Pennsylvania from the Fourteenth Day of October, One Thousand Seven Hundred, to the Twentieth Day of March, One Thousand Eight Hundred and Ten. Republished under the Authority of the Legislature. With Notes and References. Philadelphia: John Bioren, 1810. vol. 1, 2.

Lengel, Edward G., ed. The Papers of George Washington: Revolutionary War Series. Charlottesville: University of Virginia Press, 2003. vol. 13.

Madison, James. Notes of Debates in the Federal Convention of 1787 Reported by James Madison. New York: W. W. Norton \& Co., 1966.

Marshall, Christopher. Extracts from the Diary of Christopher Marshall, Kept in Philadelphia and Lancaster, During the American Revolution, 1774-1781. William Duane, ed. Albany, NY: Joel Munsell, 1877, Kessinger Legacy Reprint.

Minutes of the Second Session of the Ninth General Assembly of the Commonwealth of Pennsylvania. Evans 19162, LCP.

Minutes of the Seventh General Assembly of the Commonwealth of Pennsylvania, Which commenced at Philadelphia, on Monday the twenty-eighth Day of October, in the Year of our Lord One thousand seven hundred and eighty-two. Philadelphia: John Dunlap. Evans 17663, LCP.

Moore, Frank, ed. Diary of the American Revolution from Newspapers and Original Documents. New York: Charles Scribner, 1860. vol. 1.

Moore, John Bassett, ed. International Adjudications Ancient and Modern, History and Documents Together with Mediatorial Reports, Advisory Opinions, and the Decisions of Domestic Commissions, on International Claims. New York: Oxford University Press, 1931. Modern Series, vol. 3.

Morton, Robert. “The Diary of Robert Morton.” Pennsylvania Magazine of History and Biography vol. 1, no. 1 (1877).

Muhlenberg, Henry Melchior. The Notebook of a Colonial Clergyman, Theodore G. Tappert \& John W. Doberstein, eds. Minneapolis: Fortress Press, 1959. 
"Muster Roll of Captain Kearney's Company1st Battalion Pennsylvania Loyalists Commanded by Lt. Col. Allen" \& "Muster Roll of Captain Stephens Company 1st Battalion Pennsylvania Loyalists Commanded by Lt. Col. Allen," July 11, 1778. National Archives of Canada. RG 8, "C" Series, Vol. 1907, DLAR.

New American Bible, The. World Bible Publishers, 1987.

Paine, Thomas. The Crisis. New York: Peter Eckler Publishing Co., 1918.

Palmer, Gregory, ed. Biographical Sketches of Loyalists of the American Revolution. Westport, CT: Meckler Publishing, 1984.

Pemberton, James. “Memoirs of James Pemberton.” Friends Miscellany vol. 7, no. 2 (First Month, 1835).

Pemberton, John. "Brief Memoirs of the Life of John Pemberton, intended as an Introduction to a Journal of some parts of his Life and Travels." Friends Miscellany vol. 8, no. 2 (First Month, 1836).

Diary of John Pemberton, for the Years 1777 and 1778, Eli K. Price, ed. Philadelphia: Henry B. Ashmead, 1867.

. The Life and Travels of John Pemberton, A Minister of the Gospel of Christ. London: Charles Gilpin, 1844.

Penal Laws of Pennsylvania, The. Passed March 31, 1860. Harrisburg: A. Boyd Hamilton, State Printer, 1860.

Penn, John Esq. (Jr.). The Battle of Eddington; or British Liberty: A Tragedy. London: printed for Elmily, Faulder, Sewell, Owen and White, 1796, LCP.

Further Thoughts on the Present State of Public Opinion; Being a Continuation of a Timely Appeal to the Common Sense of the People of Great Britain in General, and of the Inhabitants of Buckinghamshire in Particular, on the Present Situation of Affairs. London: printed for Hatchard, 1800, LCP.

. Letters on the Drama. London: printed for Elmily, Faulder, Sewell, Owen and White, 1796, LCP.

Penney, Norman, ed. The Journal of George Fox Edited from the MSS. New York: Octagon Books, 1973.

Pennsylvania Archives, First Series. Selected and Arranged from Original Documents in the Office of the Secretary of the Commonwealth, Conformably to the Acts of the General Assembly, February 15, 1851 \& March 1, 1852. Samuel Hazard, ed. Philadelphia: Joseph Severns \& Co., 1853. vols. 3, 4, 5, 6, 7, 8, 9, 10, 11. 
Pennsylvania Archives, Second Series. William Henry Egle, ed. Harrisburg: E. K. Meyers, 1890. vols. 3, 14.

Pennsylvania Archives, Third Series. William Henry Egle, ed. Harrisburg: Clarence M. Busch, State Printer, 1896. vol. 10.

Pennsylvania Archives, Fourth Series. George Edward Reed, ed. Harrisburg: State of Pennsylvania, Wm. Stanley Ray, 1900. Papers of the Governors, vol. 3.

Pennsylvania Archives, Sixth Series. Thomas Lynch Montgomery, ed. Harrisburg: Harrisburg Publishing Company, State Printer, 1907. vols. 2, 12, 13.

Pennsylvania Archives, Eighth Series. Charles F. Hoban, ed. Votes of Assembly, vol. 8.

Penrose, Charles B. Argument of Charles B. Penrose, Esq., Before the Judicial Committee of the Senate, Relative to the Restitution of Confiscated Property of James Rankin. Philadelphia: William Y. Owen, 1851.

Philadelphia. Committee of Inspection, 1776. List of the Sub-Committees... February 26, 1776. Broadside, Philadelphia, 1776, LCP.

Proceedings Relative to Calling the Conventions of 1776 and 1790, The. Harrisburg: John S. Winstling, 1825.

Rawle, Anna. “A Loyalist's Account of Certain Occurrences in Philadelphia after Cornwallis's Surrender at Yorktown, Extracted from the Diary of Miss Anna Rawle, October 22 to October 26, 1781." Pennsylvania Magazine of History and Biography vol. 16, no. 1 (April, 1892).

Records of the Origin and Proceedings of the Outinian Society. London: Nicol, late Bulmer \& Co., 1822. vol. 1.

Roberts, Jonathan \& Philip Shriver Klein. "Notes and Documents: Memoirs of a Senator from Pennsylvania: Jonathan Roberts, 1771-1854." Pennsylvania Magazine of History and Biography vol. 61, no. 4 (October, 1937).

Rush, Benjamin. Considerations upon the Present Test-Law of Pennsylvania: Addressed to the Legislators and Freemen of the State. Philadelphia: Hall \& Sellers, 1784.

Sabine, Lorenzo. Biographical Sketches of Loyalists of the American Revolution, with an Historical Essay. Boston: Little, Brown, 1864; Kennikat Press Reprint. 2 vols.

Sansom, Hannah Callender. The Diary of Hannah Callender Sansom: Sense and Sensibility in the Age of the American Revolution. Susan E. Klepp and Karin Wulf, eds. Ithaca: Cornell University Press, 2010. 
Serle, Ambrose. The American Journal of Ambrose Serle. Edward H. Tatum, Jr., ed. San Marino, CA: The Huntington Library, 1940.

Smith, Paul H., ed. Letters of Delegates to Congress 1774-1789. Washington: Library of Congress, 1976. vols. 1, 6, 10.

Sparks, Jared, ed. The Life of George Washington, Commander-in-Chief of the American Armies, and First President of the United States, to which are added his Diaries and Speeches; and Various Miscellaneous Papers Relating to his Habits \& Opinions. London: Henry Colburn, 1839. vol. 2.

Statutes At Large of Pennsylvania from 1682 to 1801. James T. Mitchell \& Henry Flanders, eds. William Stanley Ray, State Printer of Pennsylvania, 1902. vols. 3, 7, 8, 9, $10,11,12,13,14,15,16$.

Stevens, B. F. Facsimiles of Manuscripts in European Archives Relating to America 1773-1783 With Descriptions, Editorial Notes, Collations, References and Translations. Wilmington, DE: Mellifont Press, 1970. vol. 24.

Taylor, Robert J., ed. The Susquehanna Company Papers. Ithaca: Cornell University Press. vol. 6.

Testimony of the People called Quakers, given forth by a Meeting of the Representatives of said People, in Pennsylvania and New-Jersey, held at Philadelphia the twenty-fourth Day of the first Month, 1775, The. Broadside [Philadelphia, 1775], Evans 14052, LCP.

Teucro Duce Nil Desperandum [Sire, do not despair]. Recruitment Broadside for the First Battalion of the Pennsylvania Loyalists. Evans 15351, LCP.

Tory Act, The. Published by Order of the Continental Congress, Philadelphia, January 2, 1776. Evans 15147, LCP.

Towne, Benjamin. To the Public, and particularly the kind Customers of the Pennsylvania Chronicle, \&c., LCP.

United States Continental Congress. The articles, published by Congress, of a treaty of amity and commerce, and of a treaty of alliance between the crown of France and these United States... Lancaster, PA: John Dunlap, 1778. Early American Imprints, First Series, Evans 16145, LCP.

Washington, George. By His Excellency George Washington, Esq; General, and Commander-in-Chief, of all the Forces of the United States of America. Proclamation, January 25, 1777. Evans 15632, LCP. 
Washington, George. Letters to Washington and accompanying papers. Stanislaus Murray Hamilton, ed. Boston: Houghton, Mifflin \& Co., 1898. vol. 4.

Westcott, Thompson ed. Names of Persons Who Took the Oath of Allegiance to the State of Pennsylvania, Between the Years 1777 and 1789, With a History of the 'Test Laws' of Pennsylvania. Philadelphia: John Campbell, 1865.

\section{DIGITAL SOURCES}

The Avalon Project, Lilian Goldman Law Library, Yale Law School (by chronology):

Charter of Connecticut, April 23, 1662.

http://avalon.law.yale.edu/17th_century/ct03.asp

Charter for the Province of Pennsylvania-1681.

http://avalon.law.yale.edu/17th_century/pa01.asp

Penn's Charter of Libertie, April 25, 1682.

http://avalon.law.yale.edu/17th_century/pa03.asp

Charter of Privileges Granted by William Penn, Esq. to the Inhabitants of Pennsylvania and Territories, October 28, 1701.

http://avalon.law.yale.edu/18th_century/pa07.asp

Constitution of Pennsylvania, September 28, 1776.

http://avalon.law.yale.edu/18th_century/pa08.asp

Treaty of Alliance between the United States and France, February 6, 1778.

http://avalon.law.yale.edu/18th_century/fr1788-2.asp

The Definitive Treaty of Peace, September 3, 1783.

http://avalon.law.yale.edu/18th_century/paris.asp

An Act to prohibit the carrying on the Slave Trade from the United States to any foreign place or country, March 22, 1794.

http://avalon.law.yale.edu/18th_century/s1001.asp

Treaty of Amity Commerce and Navigation, between His Britannick Majesty; and The United States of America, by Their President, with the advice and consent of Their Senate, November 19, 1794.

http://avalon.law.yale.edu/18th_century/jay.asp\#art6

An Act to Prohibit the Importation of Slaves into any Pace or Port Within the Jurisdiction of the United States, From and After the First Day of January, in the Year of our Lord One Thousand Eight Hundred and Eight, March 2, 1807. 2 Statutes 426. http://avalon.law.yale.edu/19th_century/s1004.asp 
The On-Line Institute for Advanced Loyalist Studies:

British Legion Biographical Sketches, Cavalry Officer. The On-Line Institute for Advanced Loyalist Studies.

http://www.royalprovincial.com/military/rhist/britlegn/blcav1.htm

General Court Martial of Martin McEvoy. Public Records Office, War Office. The OnLine Institute for Advanced Loyalist Studies.

http://www.royalprovincial.com/military /rhist/rcvol/rcvlet1.htm

History of the Provincial Corps of Pennsylvania Loyalists. Part 3, Philadelphia to

Pensacola. Part 4, War with Spain and the United Corps. Part 6, The Siege of Pensacola.

The On-Line Institute for Advanced Loyalist Studies.

http://www.royalprovincial.com/military/rhist/paloyal/pal3hist.htm

Roman Catholic Volunteers Approval for Corps, PRO 30/55/698. The On-Line Institute for Advanced Loyalist Studies.

http://www.royalprovincial.com/military/rhist/rcvol/rcvlet1.htm

Other Digital Sources:

A Cambridge Alumni Database. University of Cambridge.

http://venn.lib.cam.ac.uk

American Indian Treaties Portal. University of Nebraska-Lincoln.

http://treatiesportal.unl.edu/earlytreaties/treaty.00007.html

George Washington's Family Chart. Mount Vernon Ladies' Association.

https://web.archive.org/web/20110717064248/http://www.mountvernon.org/visit/plan/ind

ex.cfm/pid/348/

Joseph Pemberton (1747-1782). Ancestry.com.

https://www.ancestry.com/genealogy/records/joseph-pemberton_1553882

Joseph Price Diary. Lower Merion Historical Society.

http://www.lowermerionhistory.org/texts/price/

Loyalist Directory. United Empire Loyalists' of Canada.

http://www.uelac.org/Loyalist-Info/extras/Holder-Jacob/Holder-Jacob-biography.pdf

Manifesto and Proclamation of the Carlisle Peace Commission.

https://www.scribd.com/document/316810991/Manifesto-and-Proclamation-of-the-

Carlisle-Peace-Commission 
Papers of Benjamin Franklin. http://franklinpapers.org/franklin/framedVolumes.jsp

Pennsylvania County Formation. Pennsylvania Gene.

http://www.pagenweb.org/formation.html

Pennsylvania Historical and Museum Commission. Record Group 26, Records of the Department of State, Basic Records.

http://www.phmc.state.pa.us/portal/communities/documents/1776-1865/pennsylvaniaconstitution-1776.htm

Proclamation for Suppressing Rebellion and Sedition. Massachusetts Historical Society. https://www.masshist.org/revolution/doc-viewer.php?old=1\&mode=nav\&item id=858

Proclamation by Lord Howe. American Archives: Documents of the American Revolution Period, 1774-1776. Northern Illinois University Digital Collections and Collaborative Projects. http://amarch.lib.niu.edu/islandora/object/niuamarch\%3A101937

The Reading Times, June 13, 1884. https://www.findagrave.com/cgi-bin/fg.cgi?page=gr\&GRid=47242557

\section{SECONDARY SOURCES: MONOGRAPHS}

Allen, Thomas B. Tories: Fighting for the King in America's First Civil War. New York: Harper, 2010.

Allen, Thomas B. \& Todd W. Braisted. The Loyalist Corps: Americans in the Service of the King. Takoma Park, MD: FoxAcre Press 2011.

Armistead, Wilson. Anthony Benezet. From the Original Memoir. London: A. W. Bennett, 1859.

Baldwin, Ernest H. Joseph Galloway: Loyalist Politician. Philadelphia, 1902.

Banning, Lance. The Jeffersonian Persuasion: Evolution of a Party Ideology. Ithaca: Cornell University Press, 1978.

Barnett, Cleadie B. \& Elizabeth S. Sewell. Loyalist Families: A Loyalist Bi-Centennial Project (1783-1983) for the Fredericton Branch of the United Empire Loyalists' Association of Canada.

Bauman, Richard. For the Reputation of Truth: Politics, Religion, and Conflict among the Pennsylvania Quakers 1750-1800. Baltimore: Johns Hopkins Press, 1971. 
Bell, James B. A War of Religion: Dissenters, Anglicans and the American Revolution. New York: Palgrave Macmillan, 2008.

Benton, William Allen. Whig-Loyalism: An Aspect of Political Ideology in the American Revolutionary Era. Rutherford, NJ: Farleigh Dickinson University, 1969.

Bonomi, Patricia. Under the Cope of Heaven: Religion, Society, and Politics in Colonial America. New York: Oxford University Press, 2003.

Boyd, Julian P. Anglo-American Union: Joseph Galloway's Plans to Preserve the British Empire, 1774-1788. New York: Octagon Books, 1970; reprint of 1941 edition, University of Pennsylvania Press.

Boyd, Steven R., ed. The Whiskey Rebellion: Past and Present Perspectives. Westport, CT: Greenwood Press, 1985.

Brackenridge, H. M. History of the Western Insurrection in Western Pennsylvania, Commonly Called the Whiskey Insurrection. 1794. Pittsburgh: W. S. Haven, 1859.

Bradburn, Douglas. The Citizenship Revolution: Politics \& the Creation of the American Union 1774-1804. Charlottesville: University of Virginia Press, 2009.

Bronner, Edwin B. William Penn's “Holy Experiment.” New York: Columbia University Press, 1962.

Brooke, H. K. Annals of the Revolution: Or, A History of the Doans. Philadelphia: John B. Perry, 1843.

Brown, Wallace. The Good Americans: The Loyalists in the American Revolution. New York: William Morrow \& Co., 1969.

. The King's Friends: The Composition and Motives of the American Loyalist

Claims. Providence: Brown University Press, 1965.

Brunhouse, Robert L. The Counter-Revolution in Pennsylvania, 1776-1790. New York: Octagon Books, 1971; reprint of Pennsylvania Historical Commission's 1942 edition.

Burnett, Edmund Cody. The Continental Congress: A definitive history of the Continental Congress from its inception in 1774 to March, 1789. New York: W. W. Norton \& Co., 1964.

Burton, Clarence Munroe. John Connolly, A Tory of the Revolution. Proceedings of the American Antiquarian Society. Worcester, MA: The Davis Press, 1909. 
Bye, Arthur Edwin \& George MacReynolds, eds. The New Doane Book: Bucks County's Bandittories of the Revolution. Doylestown, PA: Bucks County Historical Society, 1952.

Calhoon, Robert McCluer. The Loyalists in Revolutionary America, 1760-1781. New York: Harcourt Brace Jovanovich, 1973.

Calhoon, Robert M., Timothy M. Barnes \& Robert S. Davis, eds. Tory Insurgents: The Loyalist Perception and Other Essays. Columbia: University of South Carolina Press, 2010.

Calhoon, Robert M., Timothy M. Barnes \& George A. Rawlyk, eds. Loyalists and Community in North America. Westport, CT: Greenwood Press, 1994.

Carp, Benjamin L. Rebels Rising: Cities and the American Revolution. New York: Oxford University Press, 2009.

Carey, Brycchan. From Peace to Freedom: Quaker Rhetoric and the Birth of American Antislavery, 1657-1761. New Haven: Yale University Press, 2012.

Carey, Brycchan \& Geoffrey Plank, eds. Quakers and Abolition. Urbana, IL: University of Illinois Press, 2014.

Chapin, Bradley. The American Law of Treason: Revolutionary and Early National Origins. Seattle: University of Washington Press, 1964.

Chartrand, René. American Loyalist Troops 1775-1784. Oxford, UK: Osprey Publishing, 2008.

Chopra, Ruma. Unnatural Rebellion: Loyalists in New York City during the Revolution. Charlottesville, VA: University of Virginia Press, 2011.

Coldham, Peter Wilson. American Loyalist Claims. National Genealogical Society, No. 45 .

Coleman, John M. Thomas McKean: Forgotten Leader of the Revolution. Rockaway, NJ: American Faculty Press, 1975.

Comly, John \& Isaac, eds. "Annals of the Pemberton family, with notes respecting some of their contemporaries." Friends Miscellany. vol. 7, no. 1, Fourth Month, 1835. Philadelphia: J. Richards, 1835.

Cooke, Jacob E. Tench Coxe and the Early Republic. Chapel Hill: University of North Carolina Press, 1978. 
Dellape, Kevin J. America's First Chaplain: The Life and Times of the Reverent Jacob Duché. Bethlehem, PA: Lehigh University Press, 2013.

Drake, Thomas E. Quakers and Slavery in America. Gloucester, MA: Yale University Press, 1950.

Dunn, Mary Maples. William Penn, Politics and Conscience. Princeton, N.J.: Princeton University Press, 1967.

Dunn, Dr. Mary, ed. Index to Pennsylvania's Colonial Records. Baltimore: Genealogical Publishing Co., 1992.

Durnbaugh, Donald F., ed. The Brethren in Colonial America: A Source Book on the Transplantation and Development of the Church of the Brethren in the Eighteenth Century. Elgin, IL: The Brethren Press, 1967.

Elkins, Stanley \& Eric McKitrick. The Age of Federalism. New York: Oxford University Press, 1993.

Ellis, Franklin \& Samuel Evans. History of Lancaster County, Pennsylvania, with Biographical Sketches of Many of its Pioneers and Prominent Men. Philadelphia: Everts \& Peck, 1883.

Ferling, John E. The Loyalist Mind: Joseph Galloway and the American Revolution. University Park, PA: The Pennsylvania State University Press, 1977.

Foster, Joseph S. In Pursuit of Equal Liberty: George Bryan and the Revolution in Pennsylvania. University Park, PA: The Pennsylvania State University Press, 1994.

Frantz, John B. \& William Pencak, eds. Beyond Philadelphia: The American Revolution in the Pennsylvania Hinterland. University Park, PA: The Pennsylvania State University Press, 2010.

Frazer, Persifor \& a Committee of the Society of the Alumni, eds. Biographical Catalogue of the Matriculates of the College [of Pennsylvania] Together with Lists of the Members of the College Faculty and the Trustees Officers and Recipients of Honorary Degrees, 1749-1893. Philadelphia: Society of the Alumni, 1894.

Gilbert, Alan. Black Patriots and Loyalists: Fighting for Emancipation in the War for Independence. Chicago: University of Chicago Press, 2012.

Gipson, Lawrence Henry. American Loyalist: Jared Ingersoll. New Haven: Yale University Press, 1971. 
Gough, John. A History of the People Called Quakers from their First Rise to the Present Time; Compiled from Authentic Records, and from the Writings of That People. Dublin: Robert Jackson, 1790.

Greene, Evarts B. \& Virginia D. Harrington, eds. American Population Before the Federal Census of 1790. Baltimore: Genealogical Publishing Co., 2006; reprint of 1932 Columbia University Press edition.

Hamilton, Kenneth Gardiner. John Ettwein and the Moravian Church during the Revolutionary Period. Bethlehem, PA: Times Publishing Co., 1940.

Hanna, William S. Benjamin Franklin and Pennsylvania Politics. Stanford University Press, 1964.

Hassler, Edward W. Old Westmoreland: A History of Western Pennsylvania during the Revolution. Cleveland: The Arthur H. Clark Company, 1900.

Hogg, Peter C. The African Slave Trade and its Suppression: A Classified and Annotated Bibliography of Books, Pamphlets and Periodical Articles. London: Routledge, 2013.

Holcomb, Julie L. Moral Commerce: Quakers and the Transatlantic Boycott of the Slave Labor Economy. Ithaca: Cornell University Press, 2016.

Holton, Woody. Forced Founders: Indians, Debtors, Slaves, \& the Making of the American Revolution in Virginia. Chapel Hill: University of North Carolina Press, 1999.

Horle, Craig W., Joseph S. Foster \& Laurie M. Wolfe, eds. Lawmaking and Legislators in Pennsylvania: A Biographical Dictionary. Harrisburg: Commonwealth of Pennsylvania, House of Representatives, 2005. vol. 3, 1757-1775: Allen-Kirkbride \& Knight-Yardley.

Hutson, James S. Pennsylvania Politics 1746-1770. Princeton University Press, 1972.

Ingle, H. Larry. First Among Friends: George Fox and the Creation of Quakerism. New York: Oxford University Press, 1994.

Jackson, John W. With the British Army in Philadelphia 1777-1778. San Rafael, CA: Presidio Press, 1979.

Jackson, Maurice. Let This Voice Be Heard: Anthony Benezet, Father of Atlantic Abolitionism. Philadelphia: University of Pennsylvania Press, 2009.

Jasanoff, Maya. Liberty's Exiles: American Loyalists in the Revolutionary World. New York: Alfred A. Knopf, 2011. 
Jones, Rufus M. The Quakers in the American Colonies. New York: Russell \& Russell, 1962.

Keith, Charles P. The Provincial Councillors of Pennsylvania Who Held Office Between 1733 and 1776, Who Were Some Time Chief Magistrates of the Province, and their Descendants. Philadelphia, 1883.

Kettner, James H. The Development of American Citizenship, 1608-1870. Chapel Hill: University of North Carolina Press, 1978.

Kistler, Ruth Moser. William Allen: Founder of Allentown, Colonial Jurist, Industrialist, and Loyalist. Allentown, PA: Lehigh County Historical Society, 1962.

Klein, Randolph Shipley. Portrait of an Early American Family: The Shippens of Pennsylvania Across Five Generations. Philadelphia: University of Pennsylvania Press, 1975.

Konkle, Burton Alva. Benjamin Chew 1722-1810. Philadelphia: University of Pennsylvania Press, 1932, Kessinger Legacy Reprint.

Lincoln, Charles Henry. The Revolutionary Movement in Pennsylvania 1760-1776.

Philadelphia: University of Pennsylvania, 1901.

Link, Eugene Perry. The Democratic-Republican Societies, 1790-1800. New York: Octagon Books, 1973.

Longenecker, Stephen L. The Christopher Sauers: Courageous Printers Who Defended Religious Freedom in Early America. Elgin, IL: The Brethren Press, 1981.

Mackesy, Piers. The War for America: 1775-1783. Cambridge: Harvard University Press, 1964.

Magee, Joan. Loyalist Mosaic: A Multi-Ethnic Heritage. Toronto: Dundurn Press, 1984.

Marietta, Jack D. The Reformation of American Quakerism, 1748-1783. Philadelphia: University of Pennsylvania Press, 1984.

Maxey, David W. Treason on Trial: The Case of John Roberts, Miller. Philadelphia: American Philosophical Society, 2011.

McCullough, David. 1776. New York: Simon and Schuster, 2005.

Mekeel, Arthur J. The Relation of the Quakers to the American Revolution. Washington, DC: University Press of America, 1979. 
Middlekauff, Robert. The Glorious Cause: The American Revolution, 1763-1789. New York: Oxford University Press, 2005.

Miller, Ken. Dangerous Guests: Enemy Captives and Revolutionary Communities during the War for Independence. Ithaca: Cornell University Press, 2014.

Miller, Richard G. Philadelphia - The Federalist City. Port Washington, NY: Kennikat Press, 1976.

Morgan, Edmund S. \& Helen M. Morgan. The Stamp Act Crisis: Prologue to Revolution. Chapel Hill: University of North Carolina Press, 1953.

Morris, Richard B. The Peace-Makers: The Great Powers \& American Independence. New York: Harper \& Row, 1965.

Nash, Gary B. The Unknown American Revolution: The Unruly Birth of Democracy and the Struggle to Create America. New York: Penguin Books 2005.

Nelson, William H. The American Tory. Boston: Beacon Press, 1964.

Newman, Richard \& James Mueller, eds. Antislavery and Abolition in Philadelphia: Emancipation and the Long Struggle for Racial Justice in the City of Brotherly Love. Baton Rouge: Louisiana State University Press, 2011.

Norton, Mary Beth. The British-Americans: The Loyalist Exiles in England 1774-1789. Boston: Little, Brown \& Company, 1972.

Onuf, Peter S. \& \& Leonard J. Sadosky. Jeffersonian America. Malden, MA: Blackwell Publishers, 2002.

O'Shaughnessy, Andrew Jackson. The Men Who Lost America: British Leadership, the American Revolution, and the Fate of the Empire. New Haven: Yale University Press, 2013.

Ousterhout, Anne M. A State Divided: Opposition in Pennsylvania to the American Revolution. Westport, CT: Greenwood Press, 1987.

The Most Learned Woman in America: A Life of Elizabeth Graeme Fergusson. University Park, PA: The Pennsylvania State University Press, 2004.

Pencak, William ed. Pennsylvania's Revolution. University Park, PA: The Pennsylvania State University Press, 2010.

Purcell, Edward, ed. Who Was Who in the American Revolution. New York: Facts on File, 1993. 
Richter, Daniel K. Facing East from Indian Country: A Native History of Early America. Cambridge: Harvard University Press, 2001.

Rogers, John Pugh. The Doan Outlaws or Bucks County's Cowboys in the Revolution. Doylestown, PA: Doylestown Publishing Co., 1897.

Rossignol, Marie-Jeanne \& Bertrand Van Ruymbeke, eds. The Atlantic World of Anthony Benezet (1713-1784): From French Reformation to North American Quaker Antislavery Activism. Leiden: Brill, 2016.

Rosswurm, Steven. Arms, Country and Class: The Philadelphia Militia and the "Lower Sort" during the American Revolution. New Brunswick: Rutgers University Press, 1987.

Ryerson, Egerton. The Loyalists of America and Their Times: From 1620 to 1816. New York: Haskell House Publishers, 1970; reprint of original 1880 edition.

Ryerson, Richard Alan. The Revolution Is Now Begun: The Radical Committees of Philadelphia, 1765-1776. Philadelphia: University of Pennsylvania Press, 1978.

Salinger, Sharon V. Taverns and Drinking in Early America. Baltimore: Johns Hopkins University Press, 2002.

Scharf, J. Thomas \& Thompson Westcott. History of Philadelphia, 1609-1884.

Philadelphia: L. H. Everts \& Co, 1884.

Sharpless, Isaac. A History of Quaker Government in Pennsylvania. 2 vols. Philadelphia: T. S. Leach \& Co., 1898-1899.

Shy, John. A People Numerous and Armed: Reflections on the Military Struggle for American Independence. New York: Oxford University Press, 1976.

Siebert, Wilbur H. The Loyalists of Pennsylvania. Columbus: Ohio State University, 1920.

Skemp, Sheila. Benjamin and William Franklin: Father and Son, Patriot and Loyalist. Boston: Bedford Books of St. Martin's Press, 1994.

Slaughter, Thomas P. The Whiskey Rebellion: Frontier Epilogue to the American Revolution. New York: Oxford University Press, 1986.

Smith, Paul H. Loyalists and Redcoats: A Study in British Revolutionary Policy. New York: W. W. Norton \& Company, 1964.

Soderlund, Jean. Quakers \& Slavery: A Divided Spirit. Princeton: Princeton University Press, 1985. 
Stern, Mark Abbott. David Franks: Colonial Merchant. University Park: Pennsylvania State University Press, 2010.

Taaffe, Stephen R. The Philadelphia Campaign, 1777-1778. Lawrence, KS: University Press of Kansas, 2003.

Taylor, Alan. The Divided Ground: Indians, Settlers, and the Northern Borderland of the American Revolution. New York: Vintage Books, 2006.

Thayer, Theodore. Israel Pemberton: King of the Quakers. Philadelphia: The Historical Society of Pennsylvania, 1943.

. Pennsylvania Politics and the Growth of Democracy 1740-1776.

Harrisburg, PA: Pennsylvania Historical and Museum Commission, 1953.

Thomas, Lawrence Buckley. The Thomas Book giving the Genealogies of Sir Rhys ap Thomas, K.G., the Thomas Family descended from him, and of some Allied Families. New York: Henry T. Thomas Co., 1896.

Thompson, Peter. Rum Punch \& Revolution: Taverngoing \& Public Life in EighteenthCentury Philadelphia. Philadelphia: University of Pennsylvania Press, 1999.

Tiedemann, Joseph S., Eugene R. Fingerhut \& Robert W. Venables, eds. The Other Loyalists: Ordinary People, Royalism, and the Revolution in the Middle Colonies, 17631787. Albany: State University of New York Press, 2009.

Treese, Lorett. The Storm Gathering: The Penn Family and the American Revolution. University Park, PA: The Pennsylvania State Press, 1992.

Tyler, Moses Coit. The Literary History of the American Revolution, 1763-1783. New York: G. P. Putnam's Sons, 1897.

Van Buskirk, Judith L. Generous Enemies: Patriots and Loyalists in Revolutionary New York. Philadelphia: University of Pennsylvania Press, 2002.

Van Tyne, Claude Halstead. The Loyalists in the American Revolution. New York: The Macmillan Company, 1902; Kessinger Legacy Reprint.

Virdin, Donald Odell. Pennsylvania Genealogies and Family Histories: A Bibliography of Books about Pennsylvania Families. Westminster, MD: Heritage Books, 2010.

Watson, John F. Annals of Philadelphia and Pennsylvania, in the Olden Time; Being a collection of Memoirs, Anecdote, and Incidents of the City and Inhabitants and of the earliest settlements of the Inland part of Pennsylvania, from the Days of the Founders. Washington DC: Ross \& Perry, 2003; reprint of the 1856 edition. 
Wharton, T. I. Esq., A Memoir of William Rawle, LL.D., Read at a meeting of the Council, held on the $22^{\text {nd }}$ day of February, 1837.

White, Richard. The Middle Ground: Indians, Empires, and Republics in the Great Lakes Region, 1650-1815. Cambridge, UK: Cambridge University Press, 2011.

\section{ARTICLES \& CHAPTERS}

Brobeck, Stephen. "Revolutionary Change in Colonial Philadelphia: The Brief Life of the Proprietary Gentry." William and Mary Quarterly vol. 33, no. 3 (July, 1976).

Brown, Richard. "The Disposition of Loyalists' Estates in Suffolk County, Massachusetts." The William and Mary Quarterly Third Series, vol. 21, no. 4 (October, 1964).

Calhoon, Robert M. "Civil, Revolutionary, or Partisan.” Tory Insurgents: The Loyalist Perception and Other Essays. University of South Carolina Press, 2010.

. "I Have Deduced Your Rights': Joseph Galloway's Concept of His Role, 1774-1775." Tory Insurgents: The Loyalist Perception and Other Essays. University of South Carolina Press, 2010.

. "Civil, Revolutionary, or Partisan: The Loyalists and the Nature of the War for Independence." Tory Insurgents: The Loyalist Perception and Other Essays. Robert M. Calhoon, Timothy M. Barnes, and Robert S. Davis, eds. Columbia: University of South Carolina Press, 2010.

"Catholic Loyalists of the American Revolution." The American Catholic Historical Researches. New Series, vol. 4, no. 4 (October, 1908).

Cohen, Norman S. "The Philadelphia Election Riot of 1742." Pennsylvania Magazine of History and Biography vol. 92, no. 3 (July, 1968).

Coleman, John M. "Joseph Galloway and the British Occupation of Philadelphia." Pennsylvania History vol. 30, no. 3 (July, 1963).

DeLancey, Edward F. “Chief Justice William Allen.” Pennsylvania Magazine of History and Biography vol. 1, no. 2 (1877).

Godfrey, Carlos E. "Muster Rolls of Three Troops of Loyalist Light Dragoons Raised in Pennsylvania1777-1778." Pennsylvania Magazine of History and Biography vol. 34, no. 1 (1910). 
Guy, Robert J., Jr. "William Thompson and the Pennsylvania Riflemen." Pennsylvania's Revolution. William Pencak, ed. University Park, PA: The Pennsylvania State University Press, 2010.

Ireland, Owen. "Bucks County." Beyond Philadelphia: The American Revolution in the Pennsylvania Hinterland. John B. Frantz \& William Pencak, eds. University Park, PA: The Pennsylvania State University Press, 2010.

Jenkins, Howard M. “The Family of William Penn.” Pennsylvania Magazine of History and Biography vol. 22, no. 1 (1898).

Keith, Charles P. "Andrew Allen.” Pennsylvania Magazine of History and Biography vol. 10, no. 4 (1887).

Kozuskanich, Nathan. “'Falling Under the Domination Totally of Presbyterians': The Paxton Riots and the Coming of the Revolution in Pennsylvania." Pennsylvania's

Revolution. William Pencak, ed. University Park, PA: The Pennsylvania State University Press, 2010.

Kyte, George W. "A Projected British Attack upon Philadelphia in 1781.” Pennsylvania Magazine of History and Biography vol. 76, no. 4 (October, 1952).

Lambert, Robert S. "The Confiscation of Loyalist Property in Georgia, 1782-1786." The William and Mary Quarterly Third Series, vol. 20, no. 1 (January, 1963).

Larson, Carlton F. W. "The Revolutionary American Jury: A Case Study of the 17781779 Philadelphia Treason Trials." Southern Methodist University Law Review vol. 61, no. 4 (2008).

Maas, David E. "The Massachusetts Loyalists and the Problem of Amnesty, 1775-1790." Loyalists and Community on North America. Robert M. Calhoon, Timothy M. Barnes and George A. Rawlyk, eds. Westport, CT: Greenwood Press, 1994.

MacGregor, Douglas. "Double Dishonor: Loyalists on the Middle Frontier." Pennsylvania's Revolution. William Pencak, ed. University Park, PA: The Pennsylvania State University, 2010.

MacGregor, Douglas. "The Ordeal of John Connolly: The Pursuit of Wealth through Loyalism." The Other Loyalists: Ordinary People, Royalism, and the Revolution in the Middle Colonies, 1763-1787. Joseph S. Tiedemann, Eugene R. Fingerhut, and Robert W. Venables, eds. Albany: State University of New York Press, 2009.

Messer, Peter C. "'A Species of Treason \& Not the Least Dangerous Kind': The Treason Trials of Abraham Carlisle and John Roberts." Pennsylvania Magazine of History and Biography vol. 123, no. 4 (October, 1999). 
Oaks, Robert F. "Philadelphians in Exile: The Problem of Loyalty during the American Revolution." Pennsylvania Magazine of History and Biography vol. 96, no. 3 (July, 1972).

Ousterhout, Anne M. "Frontier Vengeance: Connecticut Yankees vs. Pennamites in the Wyoming Valley." Pennsylvania History vol. 62, no. 3 (July, 1995).

Pencak, William. "Out of Many, One: Pennsylvania's Anglican Loyalist Clergy in the American Revolution." Pennsylvania's Revolution, William Pencak, ed. University Park, PA: The Pennsylvania State University Press, 2010.

Phelan, Thomas P. "Catholic Patriotism in Revolutionary Days." The Catholic Historical Review. New Series, vol. 1 (April 1921 to January 1922).

Potter, John E. "The Pennsylvania and Virginia Boundary Controversy.” Pennsylvania Magazine of History and Biography vol. 38, no. 4 (1914).

Powell, Jonathan. "Presbyterian Loyalists: A Chain of Interest in Philadelphia." Journal of Presbyterian History vol. 57, no. 2 (Summer, 1979).

"Roman Catholic Regiment of the American Revolution, The." The American Catholic Historical Researches. New Series vol. 8, no. 1 (January, 1912).

Smith, Paul H. "The American Loyalists: Notes on Their Organization and Numerical Strength." The William and Mary Quarterly Third Series vol. 25, No. 2 (April, 1968).

Stefon, Frederick J. "The Wyoming Valley.” Beyond Philadelphia: The American Revolution in the Pennsylvania Hinterland. John B. Frantz \& William Pencak, eds. University Park, PA: The Pennsylvania State University Press, 1998.

Thayer, Theodore. "The Pemberton Papers." Pennsylvania Magazine of History and Biography vol. 67, no. 3 (July, 1943).

Young, Henry J. "Treason and Its Punishment in Revolutionary Pennsylvania." Pennsylvania Magazine of History and Biography vol. 90, no. 3 (July, 1966).

Zeichner, Oscar. "The Rehabilitation of the Loyalists in Connecticut." The New England Quarterly vol. 11, no. 2 (June, 1938).

. "The Loyalist Problem in New York After the Revolution." New York

History vol. 21, no. 3 (July 1940). 


\section{DISSERTATIONS \& THESES}

Allen, Rolfe Lyman. "The Legislation for the Confiscation of British and Loyalist Property during the Revolutionary Era.” Ph.D. Dissertation, University of Maryland, 1937.

Brannon, Rebecca Nathan. "Reconciling the Revolution: Resolving Conflict and Rebuilding Community in the Wake of Civil War in South Carolina, 1775-1860." Ph.D. Dissertation, University of Michigan, 2007.

Brobeck, Stephen James. "Changes in the Composition and Structure of Philadelphia Elite Groups, 1756-1790.” Ph.D. Dissertation, University of Pennsylvania, 1972.

Cohen, Norman S. “William Allen: Chief Justice of Pennsylvania, 1704-1780.” Ph.D. Dissertation, University of California, Berkeley, 1966.

Coleman, Aaron N. "Loyalists in War, Americans in Peace: The Reintegration of the Loyalists, 1775-1800.” Ph.D. Dissertation, University of Kentucky, 2008.

High, John Walter, Jr. “The Philadelphia Loyalists, 1763-1783.” Ph.D. Dissertation, Temple University, 1974.

Jacobs, Roberta Tansman. “The Treaty and the Tories.” Ph.D. Dissertation, Cornell University, 1974.

Maas, David E. "The Return of the Massachusetts Loyalists.” Ph.D. Dissertation, University of Wisconsin, 1972.

O'Kane-Lipartito, Elisabeth. "Civilians and Society in the American Revolution and After, 1775-1830.” Ph.D. Dissertation, University of Houston, 1993.

Palfreyman, Brett. "Peace Process: The Reintegration of the Loyalists in PostRevolutionary America.” Ph.D. Dissertation, Binghamton University, 2014.

Young, Henry James. "The Treatment of the Loyalists in Pennsylvania." Ph.D. Dissertation, Johns Hopkins University, 1955. 
VITA

\section{RENÉ JOSÉ SILVA}

Born, Havana, Cuba

1972-1977

B.A., Communications

Seton Hall University

South Orange, New Jersey

1978-1981

$1981-1988$

1988-1996

1996-1999

1999-2001

2002-2007

2007-2011

2009-2011

2011-2018

Masters, International Administration

School for International Training

Brattleboro, Vermont

Director, Koubek Center

University of Miami, School of Continuing Studies

Coral Gables, Florida

Regional Director

Cuban American National Foundation

Miami, Florida

Director of Operations

Silva Case Management, Inc.

Miami, Florida

Vocational Training Manager

Vinnell Corporation/Job Corps

Homestead, Florida

Broker Associate

A. Craft, P. A. \& Fidelity Realty

Miami, Florida

Executive Director

Cuban American National Foundation

Miami, Florida

M. A., History

Florida International University

Miami, Florida

Doctoral Candidate \& Teaching Assistant

Florida International University

Miami, Florida 


\section{PUBLICATIONS AND PRESENTATIONS}

Silva, René J. "Reintegration of the Disaffected in Pennsylvania." Library Company of Philadelphia/Historical Society of Pennsylvania (June, 2017).

Silva, René J. "The Aftermath of Revolution in Pennsylvania.” Historical Society of Montgomery County, Pennsylvania (March, 2016).

Silva, René J. "In Defense of the King: Observations on Spanish American Royalism in the Era of Independence." Panoramas, Center for Latin American Studies, University of Pittsburgh (February 2015), web-based academic journal at http://www.panoramas.pitt.edu/content/defense-king-observations-spanish-americanroyalism-era-independence

Silva, René J. and Victor Uribe-Urán. "Spanish American Royalism in the Age of Revolution." Latin American Research Review: Journal of the Latin American Studies Association (LASA) Vol. 49, No. 1 (2014): 270-281.

Silva, René J. “Obraje y obreros en la construcción del Canal de Panamá.” Economía y Región, Cartagena de Indias, Colombia, vol. 7, no. 1 (June 2013): 231-238.

Silva, René J. "Race in the Spanish East Florida Rebellion of 1793-1795." Florida Conference of Historians, Sarasota, Florida (March, 2013).

Silva, René J. "Caught in the Middle: The Case of Free Black Abril in the Spanish East Florida Rebellion of 1795.” Florida International University, Department of History Graduate Students Association Atlantic History Conference (March, 2013).

Silva, René J. "Navigating the Seas of Uncertainty: Trade and International Politics in East Florida during the Second Spanish Period, 1784-1821.” Florida International University, Department of History Graduate Students Association Atlantic History Conference (March, 2012). 